UNIVERSIDADE DE SÃO PAULO (USP)

MUSEU DE ARQUEOLOGIA E ETNOLOGIA DA USP (MAE/USP)

PROGRAMA DE PÓS-GRADUAÇÃO EM ARQUEOLOGIA

\title{
ARQUEOLOGIA GUARANI NO LITORAL CENTRAL DE SANTA CATARINA
}

Isabela da Silva Müller

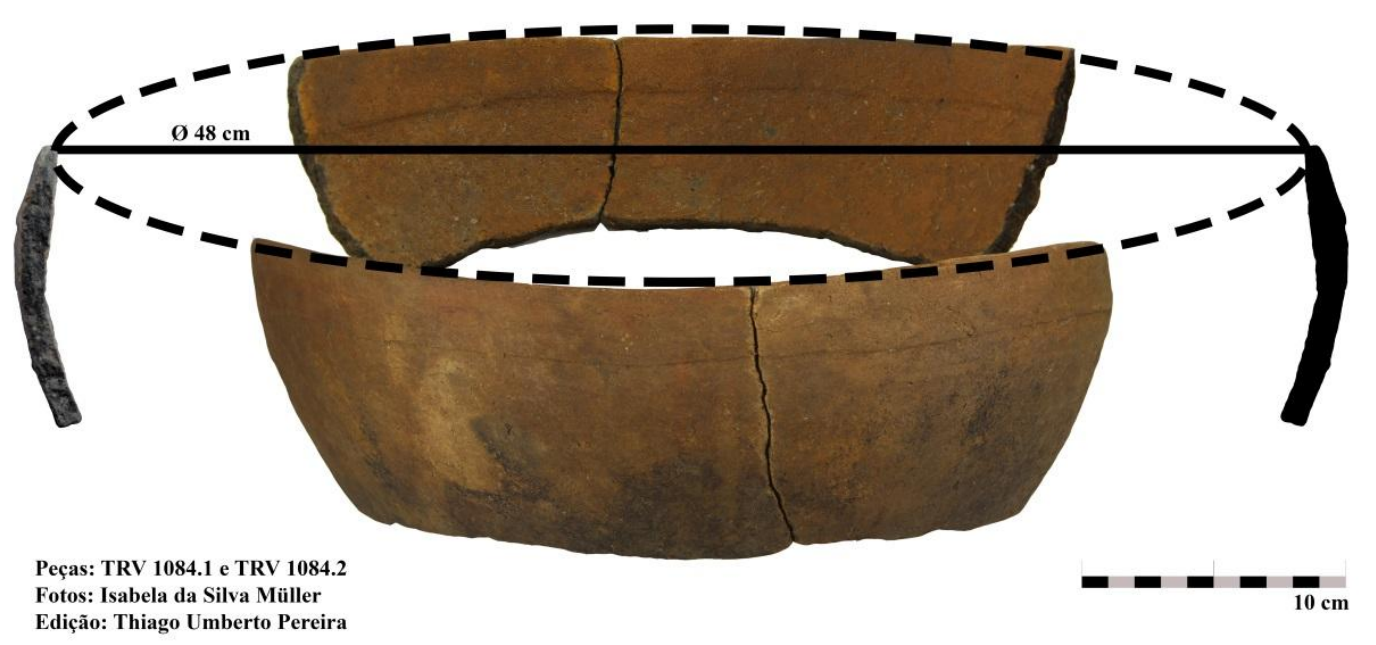

VERSÃO REVISADA

SÃO PAULO

JULHO DE 2019 
UNIVERSIDADE DE SÃO PAULO (USP)

MUSEU DE ARQUEOLOGIA E ETNOLOGIA DA USP (MAE/USP)

PROGRAMA DE PÓS-GRADUAÇÃO EM ARQUEOLOGIA

ARQUEOLOGIA GUARANI NO LITORAL CENTRAL DE SANTA CATARINA

Dissertação de Mestrado apresentada ao Programa de Pós-

Graduação em Arqueologia do Museu de Arqueologia e Etnologia da Universidade de São Paulo para a obtenção do título de mestra em Arqueologia.

Área de concentração: Arqueologia.

Orientação: Prof ${ }^{a}$ Dra. Ximena Suarez Villagran.

VERSÃO REVISADA

SÃO PAULO

JULHO DE 2019 


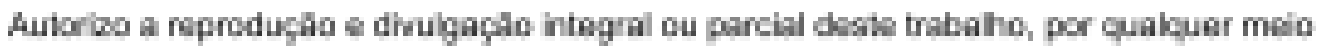

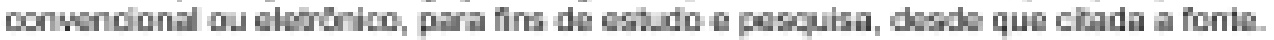

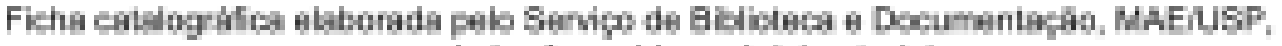

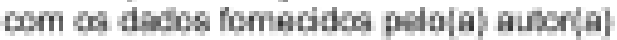

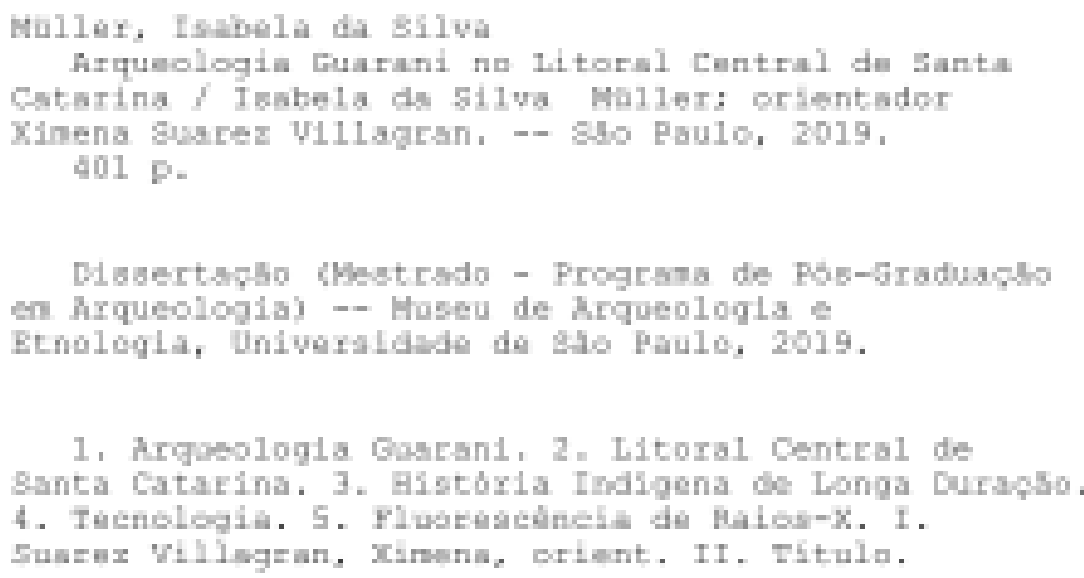




\section{AGRADECIMENTOS}

Agradeço à Fundação de Amparo à Pesquisa do Estado de São Paulo (FAPESP) (processo n²016/24682-1) pela concessão da bolsa de mestrado ao longo de um ano e três meses do curso, sem a qual este caminho teria sido mais árduo. Agradeço, igualmente, à FAPESP pela Bolsa Estágio de Pesquisa no Exterior (BEPE/FAPESP, sob processo $n^{\circ}$ 2017/21759-6), através da qual vivi uma incrível experiência no Museo de Ciencias Naturales de La Plata (Argentina).

Agradeço à Coordenação de Aperfeiçoamento de Pessoal de Nível Superior (Capes) pela concessão dos sete primeiros meses de bolsa de mestrado.

Agradeço à minha orientadora, Profa. Dra. Ximena S. Villagran, por ter aceitado o desafio e ter acreditado em mim. Pela orientação direta, assertiva, exigente e profissional. Aprendi muito com sua orientação.

Agradeço a Deus, que me guia e ilumina. Agradeço ao meu companheiro de vida, que sempre me incentiva e apoia com seu amor e vasto conhecimento e vivência em inteligência emocional, querendo me ver crescer, realizada e ser melhor que hoje. Agradeço ao meu pai e à minha mãe que sempre apoiaram e incentivaram meus estudos e escolhas, suportando financeiramente por muito tempo esse investimento. Afinal, os textos oficiais não dizem, mas a pesquisa e a ciência nesse país são financiados por pais, parceiros e familiares em boa e grande parte das situações. Agradeço à minha família, que se interessa em saber o que eu "tanto faço estudando na universidade" e busca compreender essa forma um tanto quanto diferente de trabalho.

À Profa. Márcia Rizzuto do Laboratório de Arqueometria na Física Nuclear (USP), pela paciência e super disposição e esforço (extracomunais) em me ensinar o passo a passo da realização das análises de XRF, das análises dos gráficos e interpretações. E, mesmo, pela paciência em me ensinar a mexer no excel! Aos seus colaboradores (como o Cauê), ao Cléber do LAMFI, à Silvia Cunha Lima pela conversa e disponibilidade.

Ao Prof. Dr. Mariano Bonomo, por ter me recebido em La Plata (AR) tão amigavelmente e com tanta atenção e boa vontade em discutir minha pesquisa. Por ter aberto a mim as pesquisas realizadas por sua equipe na UNLP e por tamanha 
generosidade. Ao Dr. Rodrigo Angrizani, pelas trocas de ideia e por ter me recebido tão atenciosamente no Centro de Investigaciones del CONICET em Diamante (AR).

À minha banca de qualificação, nas pessoas da Profa. Dra. Fabíola A. Silva e Profa. Dra. Milena Acha, cujos apontamentos e sugestões teóricas e formas de ver minha pesquisa foram imprescindíveis e valiosíssimas. Vocês foram muito importantes! A Francisco S. Noelli, por ter também contribuído com suas valiosas sugestões através da Fabíola.

À banca de defesa desta dissertação: Prof. Dr. Ângelo Alves Corrêa e Dr. Glauco Constantino Costa, pelas importantes sugestões de correções finais para a dissertação e sugestões de publicações futuras

Agradeço ao Prof. Dr. Lucas Bueno, pelos anos de parceria no LEIA/UFSC e por conceder o acesso ao material arqueológico do sítio Travessão do Rio Vermelho (TRV). Agradeço à Profa. Dra. Juliana S. Machado, com quem iniciei o aprendizado em análise cerâmica, e por estar aberta a ter discussões em torno do material e da pesquisa. Agradeço ao LEIA e aos seus integrantes!

Agradeço à Me. Luciane Z. Scherer por sempre abrir as portas e auxiliar em tudo e mais um pouco para que a pesquisa ocorresse muito bem nas dependências no laboratório de ArqueologiaArqueologia do MArquE/UFSC.

Agradeço ao MAE/USP, nas pessoas de Profa. Dra. Verônica Wesolowski e Hélio querido!! Agradeço ao MArquE, nas pessoas de Luciane Scherer, Ana Letícia Trivia, Dorothea Darella, Vanilde Gizoni e bolsistas. Ao Museo de Ciencia Naturales de la UNLP e ao Centro de Investigaciones de Diamante (CONICET) e seus colaboradores, pesquisadores e corpo docente, a cada um que me recebeu com seu valioso tempo e atenção!

À Ana, arquivologista do IPHAN/SC.

Ao Thiago Umberto Pereira, amigo e profissional responsável pela edição de todas as figuras contidas neste trabalho!

Às minhas amigas e amigos, Daniela, Kelly, Renata, Jordana, Fabiana, Juliana, Aline, Renato, Henrique, Marcony, Fabricio e demais colegas de mestrado (que mesmo que não tenhamos tido uma relação tão próxima, vocês fazem parte dessa 
trajetória). Nossa turma é incrível, passamos por tantas situações! Sou grata a cada um pelos aprendizados, parceria e por fazerem tanto por mim quando necessitei!

Aos amigos Daniela Freitas, Flávia, Gabi, Lucas Bond, Angela, PC, Leticia, Alejandra, Simón, que vêm me acompanhando há mais de 7 anos pela vida acadêmica e Arqueologia!

Ao Maurício, por sua consciência, por ter levado ao conhecimento de Luciane Scherer (MArquE) a descoberta do sítio arqueológico TRV. Agradeço a cada um que se dedicou à escavação do TRV.

A Walter Fernando Piazza (póstumo) pelo seu legado e à Profa. Maria de Fátima Piazza, pelo carinho de sempre.

A todos que passaram em algum momento durante a pesquisa e que contribuíram, embora não saibam exatamente, seja com uma provocação, uma crítica construtiva, um pensamento, uma sugestão. 


\section{RESUMO}

A dissertação Arqueologia Guarani no Litoral Central de Santa Catarina propõe a construção de uma história indígena Guarani de longa duração no litoral central catarinense a partir de uma Arqueologia do Lugar Guarani. Para isso, são analisadas duas coleções cerâmicas provenientes da Ilha de Santa Catarina (Florianópolis): a coleção Travessão do Rio Vermelho (TRV) (escavada entre os anos de 2013 e 2014 pela equipe do Laboratório de Estudos Interdisciplinares em ArqueologiaArqueologia LEIA/UFSC) e a coleção Lagoinha do Rio Tavares I (RT) (escavada nos anos 1965 e 1966, portanto, durante o PRONAPA, pelo Professor Doutor Walter Fernando Piazza). Essas coleções são analisadas conjugando a análise tecnológica e a arqueometria (por fluorescência de raios-x), ressaltando a importância da coordenação de diferentes métodos e da interdisciplinaridade na Arqueologia. A discussão e o objetivo são alcançados a partir das análises das coleções e dos lugares (sítios arqueológicos) e da interseção entre Arqueologia, História, Etnologia e Etnohistória. Nesse sentido, é verificado que as análises tecnológica e de fluorescência de raios-X se demonstraram complementares para a discussão dos processos de produção das vasilhas (tendo na composição da pasta o eixo elementar para essa interpretação) bem como possíveis usos das vasilhas. Foi possível tratar de escalas de produção, de um locus de manipulação de alimento da vida coletiva no teko'á e de um outro locus na periferia da aldeia relacionado à morte na cultura Guarani. Ao buscar as particularidades dentro da estrutura presente na cerâmica Guarani, foi evidenciada uma clara diferenciação entre as coleções em termos micro (material arqueológico em si) e macro (o material arqueológico e o lugar, o sítio arqueológico).

Palavras-chave: Arqueologia Guarani, Lugar, Tecnologia, Fluorescência de Raios-X, História, Etnologia, Etnohistória. 


\begin{abstract}
The mastering thesis Arqueologia Guarani no Litoral Central de Santa Catarina proposes the raising of a Guarani indigenous history in a long duration to the central coast of Santa Catarina from a Guarani Archaeology of Place. For this, they are analyzed two ceramic collections from Santa Catarina Island (Florianópolis): the Travessão do Rio Vermelho (TRV) collection (excavated between 2013 and 2014 by Laboratório de Estudos Interdisciplinares em Arqueologia - LEIA/UFSC) and Lagoinha do Rio Tavares I (RT) collection (this one excavated between 1965 and 1966 by PhD Walter Fernando Piazza during PRONAPA). These collections are analyzed coordinating a technology and an archaeometry (x-ray fluorescence) perspectives, so that it was possible to emphasize the importance of coordinating different methods and the interdisciplinary in archaeology. The discussion and the objective are reached by collections' and place's (archaeological sites') analysis and by the intersection among archaeology, history, ethnology and ethnohistory. Then, it is verified that the technological and the x-ray fluoresce analysis were complementary to the discussion on ceramic's production processes (as paste's composition was elementary on this comprehension) as well as on possible vessel's uses. It was possible to reach production scales, to argue about a locus of food manipulation inside the collective life in the teko'á and to argue about a locus related to the limits of the community associated to death on Guarani culture. Going through the particularities inside Guarani ceramic's structure, it was emphasized a clear defference between the analysed colections in micro (the archaeological material itself) and macro terms (the archaeological material and the place, the archaeological site).
\end{abstract}

Key-words: Guarani Archaeology, Place, Technology, X-Ray Fluorescence, History, Ethnology, Ethnohistory. 


\section{LISTA DE FIGURAS}

Figura 1. Mapa extraído da obra de Amílcar Mello (2005) contendo referências a lugares no litoral catarinense com nomenclaturas utilizadas pelos cronistas quinhentistas. Fonte: MELLO, 2005, P.50.

Figura 2.Mapa com rios principais na dinâmica da expansão Guarani. Fonte: BONOMO et.al., 2015. 55

Figura 3. Municípios que compõem a área da pesquisa de dissertação. Elaborado pela autora utilizando o software Google Earth.

Figura 4. Gráfico com datações absolutas para sítios arqueológicos Guarani no litoral catarinense. Elaborado por: Lucas Bond Reis em dezembro de 2015 para o Trabalho de Conclusão de Curso da autora (Müller, 2015).

Figura 5. Mapa contendo os sítios de ocupação Guarani na Ilha de Santa Catarina, Florianópolis. Elaborado por Lucas Bond Reis para o Trabalho de Conclusão de Curso da autora (MÜLLER, 2015). 74

Figura 6. Mapa com o Contexto Guarani no Litoral Central de Santa Catarina a partir de Bueno et. al. (2014), Noelli et.al. (2014), e pesquisa da autora nos Arquivos Físicos do IPHAN/SC e CNSA/IPHAN. Elaborado por Thiago Umberto Pereira. 82

Figura 7. Ficha de análise tecnológica utilizada nesta dissertação. 92

Figura 8. Imagem da bancada com o aparelho portátil de XRF, o computador com software relacionado, e o caderno de registros. Foto: autora.

Figura 9. Imagem com o aparelho realizando a medição de um dos padrões. Foto: autora.

Figura 10. Aparelho em outra configuração (sem o suporte vertical) realizando a medida do núcleo de um fragmento cerâmico. Foto: autora. 102

Figura 11. Exemplo de gráfico de áreas gerado pelo software WinQxas. 103

Figura 12. Superfície ampla escavada na área B1 do sítio TRV. Fonte: Florianópolis Arqueológica. Relatório Parcial, 2013. 105

Figura 13. Detalhe de estrutura de combustão na área B1 do sítio TRV. Fonte: Florianópolis Arqueológica. Relatório Parcial, 2013. 105

Figura 14.Croqui geral das intervenções na Área B do sítio adaptado da Fonte: Florianópolis Arqueológica. Relatório Parcial, 2013. Adaptado por Thiago Umberto 
Pereira, 2018. As unidades de escavação (quadras) analisadas estão apontadas em cor azul 107

Figura 15. Gráfico representando a natureza dos fragmentos analisados do sítio Travessão do Rio Vermelho (TRV) em porcentagem.

Figura 16. Gráfico representando os tipos de antiplástico encontrados na pasta cerâmica do sítio TRV em porcentagem. 118

Figura 17. Gráfico representando as formas de configuração do núcleo encontradas na pasta dos fragmentos do sítio TRV em porcentagem.

Figura 18. Gráfico representando a espessura dos fragmentos analisados do sítio TRV em porcentagem.

Figura 19. Relação entre os tratamentos plásticos de superfície encontrados e sua localização nas amostras do sítio TRV. Todos os tratamentos foram contabilizados, de acordo com o que foi encontrado em cada fragmento.

Figura 20.. Gráfico representando as formas de tratamento cromático de superfície e sua localização em cada fragmento cerâmico em porcentagem.

Figura 21. Faces externas dos fragmentos pertencentes ao Conjunto 1 identificado. Foto: autora. Edição: Thiago Umberto Pereira.

Figura 22. Faces internas dos fragmentos pertencentes ao Conjunto 1 identificado. Foto: autora. Edição: Thiago Umberto Pereira.

Figura 23. Faces externas dos fragmentos pertencentes ao Conjunto 2. Foto: autora. Edição: Thiago Umberto Pereira.

Figura 24. Faces internas dos fragmentos pertencentes ao Conjunto 2. Foto: autora. Edição: Thiago Umberto Pereira.

Figura 25. Faces externas dos fragmentos pertencentes ao Conjunto 3. Foto: autora. Edição: Thiago Umberto Pereira.

Figura 26. Faces internas dos fragmentos pertencentes ao Conjunto 3 . Foto: autora. Edição: Thiago Umberto Pereira. 130

Figura 27. Faces externas dos fragmentos pertencentes ao Conjunto 4. Foto: autora. Edição: Thiago Umberto Pereira.

Figura 28. Faces internas dos fragmentos pertencentes ao Conjunto 4. Foto: autora. Edição: Thiago Umberto Pereira.

Figura 29. Faces externas dos fragmentos pertencentes ao Conjunto 5. Foto: autora. Edição: Thiago Umberto Pereira. 
Figura 30. Faces internas dos fragmentos pertencentes ao Conjunto 5. Foto: autora. Edição: Thiago Umberto Pereira.

Figura 31. Faces externas dos fragmentos pertencentes ao Conjunto 6. Foto: autora. Edição: Thiago Umberto Pereira.

Figura 32. Faces internas dos fragmentos pertencentes ao Conjunto 6. Foto: autora. Edição: Thiago Umberto Pereira. 135

Figura 33. Detalhes das faces externas de fragmentos encontrados juntos durante a escavação com pintura preta na face interna e que compõem o conjunto 6. Foto: autora. Edição: Thiago Umberto Pereira.

Figura 34. Detalhes das faces interna de fragmentos encontrados juntos durante a escavação com pintura preta na face interna e que compõem o conjunto 6. Foto: autora. Edição: Thiago Umberto Pereira. 136

Figura 35. Faces externas dos fragmentos pertencentes ao Conjunto 7. Foto: autora. Edição: Thiago Umberto Pereira.

Figura 36. Faces externas dos fragmentos pertencentes ao Conjunto 7 . Foto: autora. Edição: Thiago Umberto Pereira.

Figura 37.. Faces externas dos fragmentos pertencentes ao Conjunto 8. Foto: autora. Edição: Thiago Umberto Pereira. 138

Figura 38. Faces internas dos fragmentos pertencentes ao Conjunto 8. Foto: autora. Edição: Thiago Umberto Pereira.

Figura 39.Espelhamento de borda da amostra TRV.368.3, com diâmetro projetado de 10 $\mathrm{cm}$, onde se observam ambas as faces do fragmento. 141

Figura 40. Espelhamento de borda da amostra TRV.344.1, com diâmetro projetado de $22 \mathrm{~cm}$, onde se observam ambas as faces do fragmento.

Figura 41. Espelhamento de borda das amostras TRV.1084.1 e TRV.1084.2 que se remontam, com diâmetro projetado de $48 \mathrm{~cm}$, onde se observam ambas as faces do fragmento. 142

Figura 42. Prancha contendo os resultados da análise de XRF dos núcleos dos fragmentos de TRV para os seguintes elementos químicos: silício ( $\mathrm{Si}$ ), alumínio (Al), fósforo $(\mathrm{P})$, enxofre $(\mathrm{S})$, potássio $(\mathrm{K})$, cálcio $(\mathrm{Ca})$, manganês $(\mathrm{Mn})$, ferro $(\mathrm{Fe})$, zinco (Zn) e estrôncio ( $\mathrm{Sr})$.

Figura 43. Prancha contendo os resultados da análise de XRF das faces interna e externa dos fragmentos de TRV para os seguintes elementos químicos: silício ( $\mathrm{Si}$ ), alumínio 
(Al), fósforo $(\mathrm{P})$, enxofre $(\mathrm{S})$, potássio $(\mathrm{K})$, cálcio $(\mathrm{Ca})$, manganês $(\mathrm{Mn})$, ferro $(\mathrm{Fe})$, zinco $(\mathrm{Zn})$ e estrôncio $(\mathrm{Sr})$. 150

Figura 44. Gráfico representando a natureza dos fragmentos cerâmicos analisados do sítio Lagoinha do Rio Tavares I (RT) em porcentagem.

Figura 45. Trempe/ytácuru identificada na coleção RT. Foto: autora. Edição: Thiago Umberto Pereira. 152

Figura 46. Gráfico representando a porcentagem de cada tipo de antiplástico presente nas pastas analisadas do sítio RT.

Figura 47. Detalhe da amostra RT.I.1.67.037 (face externa) em que observamos mineral A(quartzo) e caco moído.

Figura 48. Detalhe da amostra RT.I.1.67.039 (face externa) onde observa-se carvões como antiplástico (ponto pretos na imagem)

Figura 49. Gráfico representando as formas de configuração do núcleo encontradas nas amostras do sítio RT em porcentagem. 155

Figura 50. Gráfico representando a espessura dos fragmentos cerâmicos analisados do sítio RT em porcentagem.

Figura 51. Relação entre os tratamentos plásticos de superfície encontrados e sua localização nas amostras do sítio RT.

Figura 52. Detalhe de alisamento na face interna do fragmento RT.I.64.292. Foto: autora. Edição: Thiago Umberto Pereira. 160

Figura 53. Relação entre os tratamentos cromáticos de superfície encontrados e sua localização nas amostras do sítio RT.

Figura 54. Faces externas dos fragmentos pertencentes ao Conjunto 1. Foto: autora. Edição: Thiago Umberto Pereira.

Figura 55. Faces internas de fragmentos pertencentes ao Conjunto 1. Foto: autora. Edição: Thiago Umberto Pereira. 166

Figura 56. Faces externas dos fragmentos pertencentes ao Conjunto 2. Foto: autora. Edição: Thiago Umberto Pereira.

Figura 57. Faces externas dos fragmentos pertencentes ao Conjunto 2. Foto: autora. Edição: Thiago Umberto Pereira.

Figura 58. Faces internas dos fragmentos pertencentes ao Conjunto 2. Foto: autora. Edição: Thiago Umberto Pereira. 168

Figura 59. Faces externas dos fragmentos pertencentes ao Conjunto 3. Foto: autora. Edição: Thiago Umberto Pereira. 
Figura 60.Faces externas dos fragmentos pertencentes ao Conjunto 3. Foto: autora. Edição: Thiago Umberto Pereira.

Figura 61. Faces internas dos fragmentos pertencentes ao Conjunto 3. Foto: autora. Edição: Thiago Umberto Pereira. 170

Figura 62. Faces internas dos fragmentos pertencentes ao Conjunto 3. Foto: autora. Edição: Thiago Umberto Pereira. 170

Figura 63.aces externas dos fragmentos pertencentes ao Conjunto 4. Foto: autora. Edição: Thiago Umberto Pereira. 171

Figura 64. Faces externas dos fragmentos pertencentes ao Conjunto 4. Foto: autora. Edição: Thiago Umberto Pereira.

Figura 65. Faces internas dos fragmentos pertencentes ao Conjunto 4. Foto: autora. Edição: Thiago Umberto Pereira. 172

Figura 66. Faces internas dos fragmentos pertencentes ao Conjunto 4. Foto: autora. Edição: Thiago Umberto Pereira. 172

Figura 67. Faces externas dos fragmentos pertencentes ao Conjunto 5. Foto: autora. Edição: Thiago Umberto Pereira.

Figura 68. Faces internas dos fragmentos pertencentes ao Conjunto 5. Foto: autora. Edição: Thiago Umberto Pereira. 173

Figura 69. Faces externas dos fragmentos pertencentes ao Conjunto 6. Foto: autora. Edição: Thiago Umberto Pereira. 174

Figura 70. Faces externas dos fragmentos pertencentes ao Conjunto 7. Foto: autora. Edição: Thiago Umberto Pereira.

Figura 71. Faces externas dos fragmentos pertencentes ao Conjunto 7. Foto: autora. Edição: Thiago Umberto Pereira. 175

Figura 72. Faces internas dos fragmentos pertencentes ao Conjunto 7. Foto: autora. Edição: Thiago Umberto Pereira. 176

Figura 73. Faces internas dos fragmentos pertencentes ao Conjunto 7. Foto: autora. Edição: Thiago Umberto Pereira. 176

Figura 74. Faces externas dos fragmentos pertencentes ao Conjunto 8. Foto: autora. Edição: Thiago Umberto Pereira.

Figura 75. Faces externas dos fragmentos pertencentes ao Conjunto 8. Foto: autora. Edição: Thiago Umberto Pereira. 178

Figura 76. Faces internas dos fragmentos pertencentes ao Conjunto 8. Foto: autora. Edição: Thiago Umberto Pereira. 179 
Figura 77. Faces externas dos fragmentos pertencentes ao Conjunto 9. Foto: autora. Edição: Thiago Umberto Pereira.

Figura 78.Faces externas dos fragmentos pertencentes ao Conjunto 9. Foto: autora. Edição: Thiago Umberto Pereira.

Figura 79. Faces internas dos fragmentos pertencentes ao Conjunto 9. Foto: autora. Edição: Thiago Umberto Pereira.

Figura 80. Faces internas dos fragmentos pertencentes ao Conjunto 9. Foto: autora. Edição: Thiago Umberto Pereira. 181

Figura 81. Espelhamento de borda da amostra RT.I.1.64.037, com diâmetro projetado de $16 \mathrm{~cm}$, onde se observam ambas as faces do fragmento.

Figura 82. Espelhamento de borda da amostra RT.I.1.64.109, com diâmetro projetado de $20 \mathrm{~cm}$, onde se observam ambas as faces do fragmento.

Figura 83. Espelhamento da borda das amostras RT.I.1.64.232, RT.I.1.64.233 e RT.I.1.64.234 remontáveis, com diâmetro projetado de $54 \mathrm{~cm}$, onde se observam ambas as faces do fragmento. 185

Figura 84. Prancha contendo os resultados da análise de XRF dos núcleos dos fragmentos de RT para os seguintes elementos químicos: silício ( $\mathrm{Si}$ ), alumínio ( $\mathrm{Al}$ ), fósforo $(\mathrm{P})$, enxofre $(\mathrm{S})$, potássio $(\mathrm{K})$, cálcio $(\mathrm{Ca})$, manganês $(\mathrm{Mn})$, ferro $(\mathrm{Fe})$, zinco ( $\mathrm{Zn})$ e estrôncio $(\mathrm{Sr})$.

Figura 85. Prancha contendo os resultados da análise de XRF das faces interna e externa dos fragmentos de RT para os seguintes elementos químicos: silício (Si), alumínio (Al), fósforo $(\mathrm{P})$, enxofre $(\mathrm{S})$, potássio $(\mathrm{K})$, cálcio $(\mathrm{Ca})$, manganês $(\mathrm{Mn})$, ferro $(\mathrm{Fe})$, zinco $(\mathrm{Zn})$ e estrôncio $(\mathrm{Sr})$.

Figura 86. Gráfico representando a comparação entre os dois sítios arqueológicos estudados com relação à natureza das peças (em porcentagem).

Figura 87. Gráfico representando as formas de tratamento de superfície nos fragmentos analisados de ambos os sítios arqueológicos (em porcentagem). 200 Figura 88. Gráfico que representa as colorações das pastas dos fragmentos analisados dos sítio TRV e RT (em porcentagem). 203

Figura 89. Gráfico representando as marcas de uso encontradas em ambas as coleções analisadas (em porcentagem). 204 Figura 90. Gráfico representando a relação entre antiplástico e cor da pasta de ambos os sítios analisados (em porcentagem). 205 
Figura 91. Gráfico representando a relação entre as bordas e os tratamentos plásticos identificados em ambos os sítios (em porcentagem). 206

Figura 92. Gráfico representando as bordas analisadas e os tratamentos cromáticos associados a elas referente às coleções de ambos os sítios (em porcentagem). 207 Figura 93. Relação entre os tratamentos plásticos de superfície e as pastas encontrados nos fragmentos comparando os sítios arqueológicos TRV e RT. 210 Figura 94. Relação entre os tratamentos cromáticos de superfície e as pastas encontrados nos fragmentos comparando os sítios arqueológicos TRV e RT. 213 Figura 95. Relação entre as espessuras dos fragmentos e as pastas, comparando os sítios arqueológicos TRV e RT.

Figura 96. Gráfico com frequência dos diâmetros das bordas $(\mathrm{cm})$ encontradas nas coleções RT e TRV. 218

Figura 97. Gráfico em porcentagem com os conjuntos observados nas coleções RT e TRV. 222

Figura 98. Gráfico representando a área identificada do elemento químico silício no núcleo das amostras. As barras em azul correspondem ao sítio Lagoinha do Rio Tavares I e em laranja ao sítio Travessão do Rio Vermelho. 223 Figura 99. Gráfico representando a área identificada do elemento químico alumínio no núcleo das amostras. As barras em azul correspondem ao sítio Lagoinha do Rio Tavares I e em laranja ao sítio Travessão do Rio Vermelho. 224 Figura 100. Gráfico representando a área identificada do elemento químico fósforo no núcleo das amostras. As barras em azul correspondem ao sítio Lagoinha do Rio Tavares I e em laranja ao sítio Travessão do Rio Vermelho. 225 Figura 101. Gráfico representando a área identificada do elemento químico enxofre no núcleo das amostras. As barras em azul correspondem ao sítio Lagoinha do Rio Tavares I e em laranja ao sítio Travessão do Rio Vermelho. 226 Figura 102. Gráfico representando a área identificada do elemento químico potássio no núcleo das amostras. As barras em azul correspondem ao sítio Lagoinha do Rio Tavares I e em laranja ao sítio Travessão do Rio Vermelho. 226 Figura 103. Gráfico representando a área identificada do elemento químico cálcio no núcleo das amostras. As barras em azul correspondem ao sítio Lagoinha do Rio Tavares I e em laranja ao sítio Travessão do Rio Vermelho. 
Figura 104. Gráfico representando a área identificada do elemento químico manganês no núcleo das amostras. As barras em azul correspondem ao sítio Lagoinha do Rio Tavares I e em laranja ao sítio Travessão do Rio Vermelho. 228 Figura 105. Gráfico representando a área identificada do elemento químico ferro nas amostras. As barras em azul correspondem ao sítio Lagoinha do Rio Tavares I e em laranja ao sítio Travessão do Rio Vermelho. 229 Figura 106. Gráfico representando a área identificada do elemento químico zinco no núcleo das amostras. As barras em azul correspondem ao sítio Lagoinha do Rio Tavares I e em laranja ao sítio Travessão do Rio Vermelho. 231 Figura 107. Gráfico representando a área identificada do elemento químico estrôncio no núcleo das amostras. As barras em azul correspondem ao sítio Lagoinha do Rio Tavares I e em laranja ao sítio Travessão do Rio Vermelho. 232 Figura 108. Gráficos representando a área identificada do elemento químico silício nas faces internas (vermelho) e externas (verde) das amostras. As barras sólidas no gráfico inferior pertencem ao sítio Travessão do Rio vermelho e as barras no gráfico superior ao sítio Lagoinha do Rio Tavares I. 234 Figura 109. Gráficos representando a área identificada do elemento químico alumínio nas faces internas (vermelho) e externas (verde) das amostras. As barras sólidas no gráfico inferior pertencem ao sítio Travessão do Rio vermelho e as barras no gráfico superior ao sítio Lagoinha do Rio Tavares I. 235 Figura 110. Gráficos representando a área identificada do elemento químico fósforo nas faces internas (vermelho) e externas (verde) das amostras. As barras sólidas no gráfico inferior pertencem ao sítio Travessão do Rio vermelho e as barras no gráfico superior ao sitio Lagoinha do Rio Tavares I.

Figura 111. Gráficos representando a área identificada do elemento químico enxofre nas faces internas (vermelho) e externas (verde) das amostras. As barras sólidas no gráfico inferior pertencem ao sítio Travessão do Rio vermelho e as barras no gráfico superior ao sitio Lagoinha do Rio Tavares I. 238

Figura 112. Gráficos representando a área identificada do elemento químico potássio nas faces internas (vermelho) e externas (verde) das amostras. As barras sólidas no gráfico inferior pertencem ao sítio Travessão do Rio vermelho e as barras no gráfico superior ao sitio Lagoinha do Rio Tavares I.

Figura 113. Gráficos representando a área identificada do elemento químico cálcio nas faces internas (vermelho) e externas (verde) das amostras. As barras sólidas no gráfico 
inferior pertencem ao sítio Travessão do Rio vermelho e as barras no gráfico superior ao sitio Lagoinha do Rio Tavares I. 240

Figura 114. Gráficos representando a área identificada do elemento químico manganês nas faces internas (vermelho) e externas (verde) das amostras. As barras sólidas no gráfico inferior pertencem ao sítio Travessão do Rio vermelho e as barras no gráfico superior ao sitio Lagoinha do Rio Tavares I. 241

Figura 115. Gráficos representando a área identificada do elemento químico ferro nas faces internas (vermelho) e externas (verde) das amostras. As barras sólidas no gráfico inferior pertencem ao sítio Travessão do Rio vermelho e as barras no gráfico superior ao sitio Lagoinha do Rio Tavares I.

Figura 116. Gráficos representando a área identificada do elemento químico zinco nas faces internas (vermelho) e externas (verde) das amostras. As barras sólidas no gráfico inferior pertencem ao sítio Travessão do Rio vermelho e as barras no gráfico superior ao sitio Lagoinha do Rio Tavares I. 243

Figura 117. Gráficos representando a área identificada do elemento químico estrôncio nas faces das amostras. As barras sólidas no gráfico inferior pertencem ao sítio Travessão do Rio vermelho e as barras no gráfico superior ao sitio Lagoinha do Rio Tavares I. 


\section{LISTA DE TABELAS}

Tabela 1. Sítios arqueológicos Guarani com datação na região sul do litoral catarinense. Adaptada de Noelli, Milheira e Wagner (2014) e utilizada primeiramente em trabalho de conclusão de curso da autora (MÜLLER, 2015). Em Método, a sigla TL significa Termoluminescência, e C14 significa Carbono 14. 68

Tabela 2. Sítios arqueológicos na região central do litoral catarinense. Adaptado de Noelli, Milheira e Wagner (2014) e utilizada primeiramente em trabalho de conclusão de curso da autora (MÜLLER, 2015). Atualizada e corrigida para esta dissertação. Em Método, a sigla TL significa Termoluminescência, e ${ }^{14} \mathrm{C}$ significa Carbono 14. *A coordenada utilizada nesta tabela segue aquela publicada em Noelli et.al. (2014), mas nas tabelas seguintes, é utilizada e adotada neste trabalho a coordenada que a equipe do LEIA/UFSC corrigiu em campo, uma vez que o sítio Lagoinha do Rio Tavares I da Tabela 2 é o mesmo sítio Lagoinha do Rio Tavares I, cujo registro foi atualizado pelo LEIA/UFSC. **A coordenada foi verificada e não corresponde à localidade designada para o sítio arqueológico.

Tabela 3. Sítios arqueológicos Guarani na Ilha de Santa Catarina. Adaptado de Bueno et al (2014) para TCC da autora (MÜLLER, 2015) e atualizado e corrigido para esta dissertação. Em Método, a sigla TL significa Termoluminescência, e ${ }^{14} \mathrm{C}$ significa Carbono 14. Datum WGS84. *O sítio arqueológico Lagoinha do Rio Tavares I (nesta Tabela 3) é o mesmo sítio Lagoinha do Rio Tavares I da Tabela 2, referido com a sigla RT nesta dissertação. 73

Tabela 4.. Listagem de sítios arqueológicos Guarani feita a partir da pesquisa da autora nos arquivos físicos do IPHAN/SC. 76

Tabela 5. Listagem de sítios arqueológicos Guarani feita a partir de três levantamentos: o de Bueno et al (2014), o de Noelli, Milheira e Wagner (2014) e a partir da pesquisa realizada nos Arquivos Físicos do IPHAN/SC. Em Método, a sigla TL significa Termoluminescência, e ${ }^{14} \mathrm{C}$ significa Carbono 14. Datum WGS84. *Essas coordenadas estão demasiadamente distantes entre si quando plotadas no mapa da Figura 6; por isso, cada um dos quatro pontos desse registro foi considerado um ponto isolado de ocorrência de vestígios. 80 
Tabela 6. Descrição das unidades de escavação analisadas. A esquerda, coluna com a unidade a que se refere e área. A direita, descrição do que foi encontrado e coletado em cada unidade. 108

Tabela 7. Amostras das bordas da coleção TRV com seus respectivos diâmetros projetados $(\mathrm{cm})$ e porcentagens dos fragmentos $(\%)$. 140

Tabela 8. Amostras das bordas da coleção RT com seus respectivos diâmetros projetados $(\mathrm{cm})$ e porcentagens dos fragmentos $(\%)$. 184 


\section{SUMÁRIO}

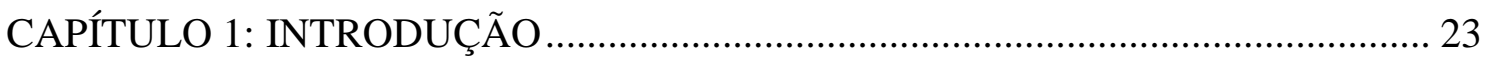

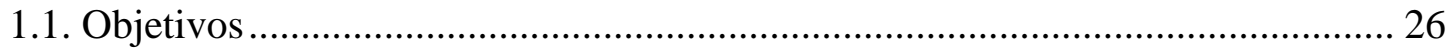

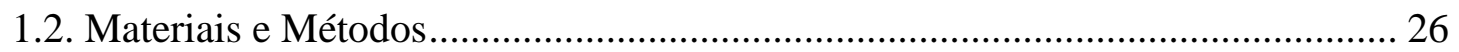

CAPÍTULO 2: ARQUEOLOGIA GUARANI........................................................ 30

2.1. Arqueologia Guarani como história indígena de longa duração.......................... 30

2.2. Arqueologia, Etnografia e Etnohistória na construção da história Guarani de

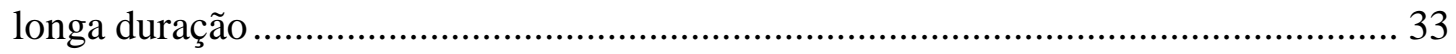

2.3. Etnografia e Etnohistória dos Guarani de Santa Catarina.................................... 37

2.4. Arqueologia Tupi e Arqueologia Guarani: origens e expansão.......................... 49

2.5. Por uma Arqueologia do Lugar Guarani............................................................ 56

CAPÍTULO 3: ARQUEOLOGIA GUARANI NO LITORAL CENTRAL

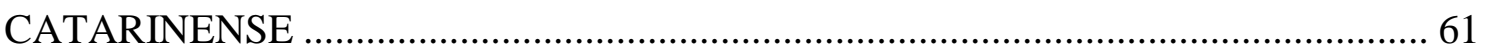

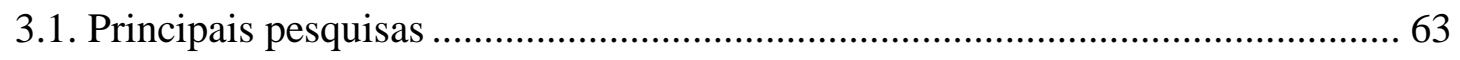

3.2. Ocupação Guarani no litoral central de Santa Catarina ....................................... 65

3.3. Levantamento de sítios arqueológicos Guarani no Acervo do IPHAN-SC......... 75

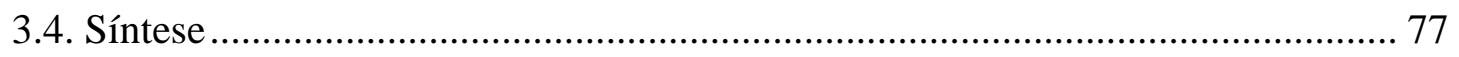

CAPÍTULO 4: MÉTODOS DE ANÁLISE DAS COLEÇÕES CERÂMICAS DOS

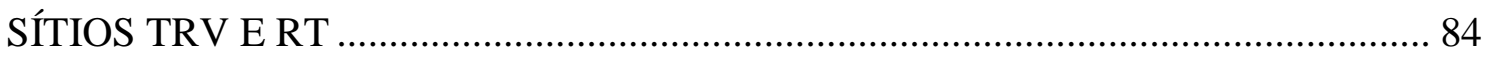

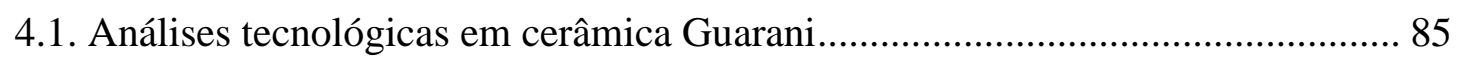

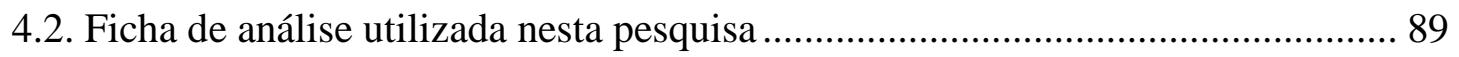

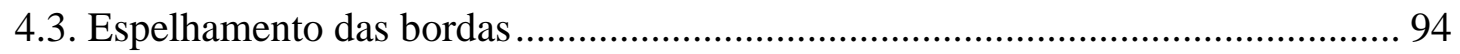

4.3. Arqueometria por fluorescência de raios-X (XRF) ........................................... 96

4.4. A coleção Travessão do Rio Vermelho (TRV) ................................................. 104

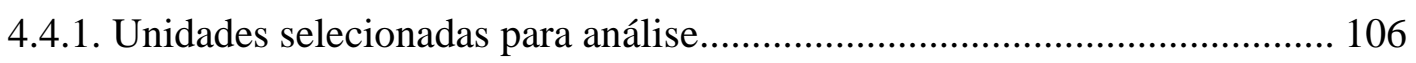

4.5. A coleção Lagoinha do Rio Tavares I (RT) .................................................... 109

4.5.1. Seleção dos fragmentos para análise ...................................................... 113

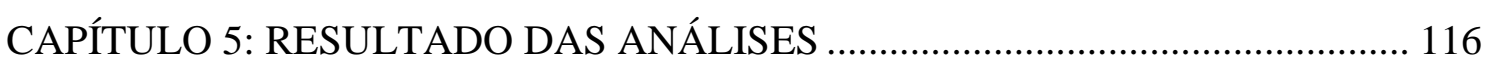

5.1. Análise macroscópica do Travessão do Rio Vermelho (TRV).......................... 116

5.1.1. Identificação de conjuntos/ agrupamentos .............................................. 125

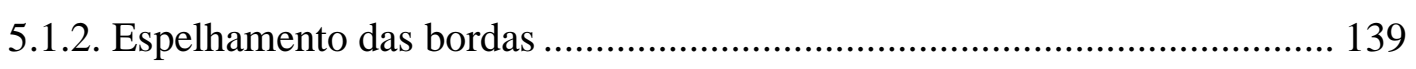

5.1.3. Análises arqueométricas por Fluorescência de Raios-X (XRF)................. 142

5.2. Análise macroscópica do Lagoinha do Rio Tavares I/ Rio Tavares (RT) .......... 151 
5.2.1. Identificação de conjuntos / agrupamentos ................................................ 165

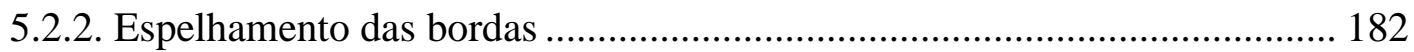

5.2.3. Análises arqueométricas por Fluorescência de Raios-X (XRF)................. 185

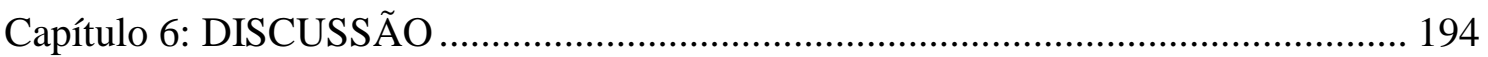

6.1. Comparação dos resultados da análise macroscópica de TRV e RT .................. 194

6.1.1. Natureza das peças .................................................................................. 194

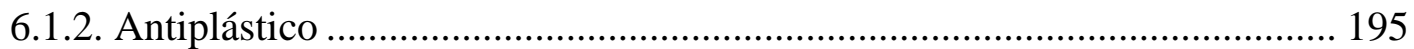

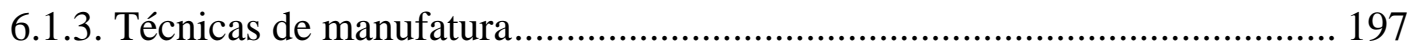

6.1.4. Configuração do núcleo (queima) ............................................................ 198

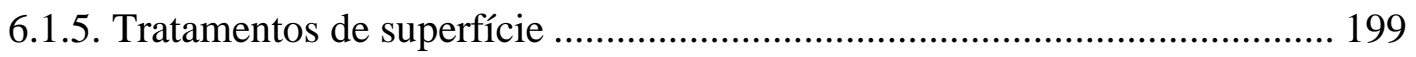

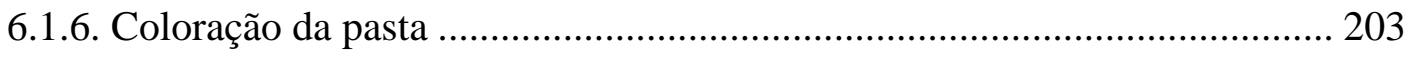

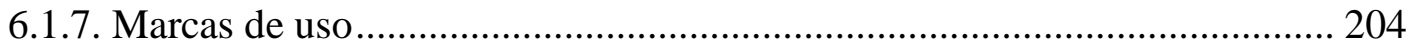

6.1.8. Relação antiplástico - coloração da pasta ................................................... 205

6.1.9. Relação bordas - tratamento de superfície.................................................. 206

6.1.10. Relação tratamento de superfície - coloração da pasta ............................ 207

6.1.11. Relação tratamento cromáticos de superfície - coloração da pasta .......... 211

6.1.12. Relação coloração da pasta - espessura das peças ..................................... 214

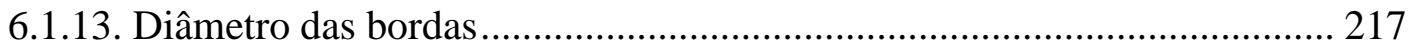

6.1.14. Relação diâmetro das bordas - espessura das bordas .............................. 218

6.1.15. Relação diâmetro das bordas - configuração dos núcleos (queima)......... 221

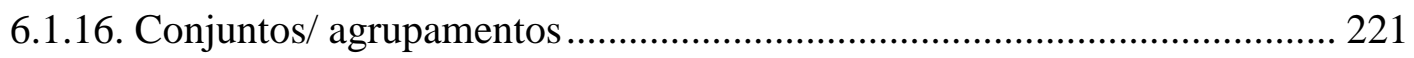

6.2. Análise arqueométrica por Fluorescência de Raios-X.................................... 222

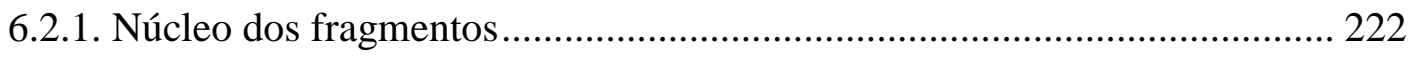

6.2.2. Faces interna e externa dos fragmentos.................................................. 233

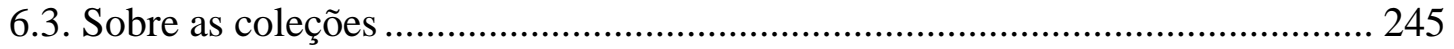

6.4. Sobre os Lugares e o contexto regional Guarani: Construindo uma Arqueologia

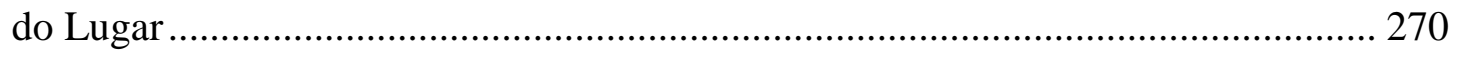

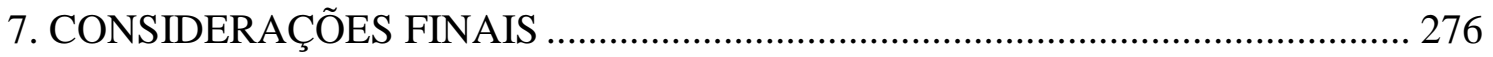

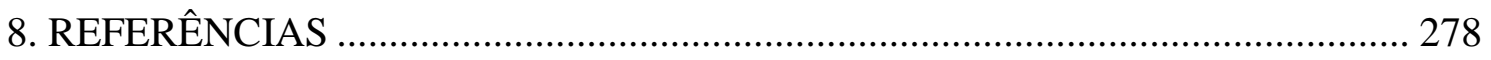

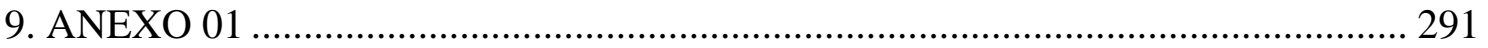

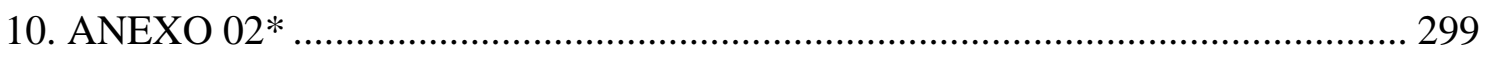

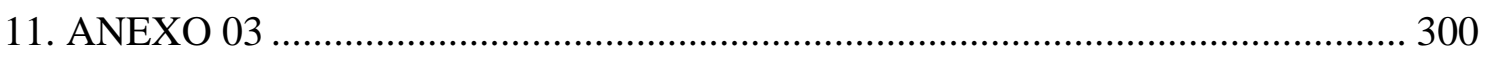

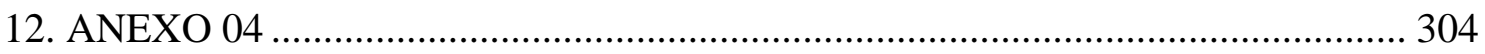

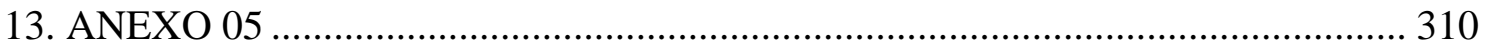




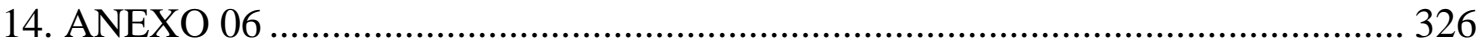

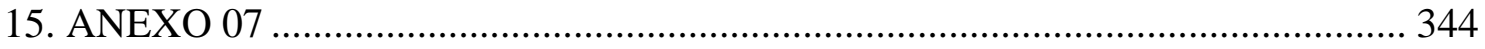

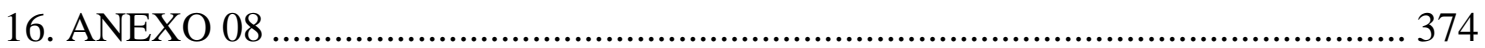

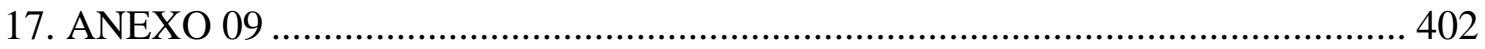




\section{CAPÍTULO 1: INTRODUÇÃO}

A dissertação de Mestrado Arqueologia Guarani no litoral central de Santa Catarina visa ampliar a discussão acerca da temática da Arqueologia Guarani no litoral central do estado de Santa Catarina, suas perspectivas e possibilidades. Esta proposta é inédita na região. Esse tema de pesquisa vem sendo abordado desde o ano de 2013 pelo Laboratório de Estudos Interdisciplinares em Arqueologia (LEIA/UFSC), através da análise e compreensão do sitio arqueológico denominado Travessão do Rio Vermelho (na localidade do Rio Vermelho, município de Florianópolis). Com ele, a autora desenvolveu iniciação científica e trabalho de conclusão de curso ${ }^{1}$, sob supervisão do Dr. Lucas Bueno e co-orientação da Dra. Juliana Salles Machado, e compreendeu a necessidade e importância da continuidade desse trabalho propondo uma história Guarani de longa duração no território localizado na região litorânea central do estado. O pressuposto que guia esta pesquisa compreende a Arqueologia enquanto história indígena de longa duração. Essa dissertação de mestrado, portanto, apresenta os resultados dos últimos anos de pesquisa nessa temática e considera que, apesar de tratarmos de uma Arqueologia Guarani, há necessidade de compreender a cultura como manutenção e transformação constante de estruturas, ou seja, com historicidade.

A problemática abordada se insere no panorama arqueológico do litoral do estado de Santa Catarina e na dinâmica regional do sul do país e da América do Sul no que tange a ocupação e expansão dos povos Guarani pré-coloniais, entendendo que a noção de expansão do território Guarani no período pré-contato europeu extrapolava as fronteiras atuais brasileiras. Portanto, propõe-se a compreensão da dinâmica de ocupação e organização desse espaço ao estudar contextualmente: 1) a localização e cronologia dos sítios arqueológicos identificados na região delimitada: Florianópolis / SC; 2) e análise tecnológica e arqueométrica da cultura material proveniente de dois desses sítios arqueológicos: Travessão do Rio Vermelho e Lagoinha do Rio Tavares I / Rio Tavares, município de Florianópolis / SC. Ao problematizar a presença e a história humana por trás desses vestígios e a produção escrita etnográfica do período do

\footnotetext{
${ }^{1}$ MÜLLER, Isabela da Silva. Arqueologia Guarani no Litoral Central de Santa Catarina: estudo de caso do sítio TRV. Trabalho de Conclusão de Curso de curso de Graduação em História. Universidade Federal de Santa Catarina: Florianópolis, 2015.
} 
chamado "contato europeu", pretende-se promover a reflexão e atuação políticas dos pesquisadores frente à chamada História Indígena.

Por meio de perspectiva que compreende a ciência da Arqueologia enquanto "história de longa duração" (e enquanto Ciência Humana) faz-se necessário pensar e articular diversas áreas do conhecimento, conforme já propunha Fernand Braudel (BRAUDEL, 1992, P.725). Tendo esse pressuposto, e compreendendo o estudo de Marshall Sahlins (SAHLINS, 1989) sobre estrutura e História, bem como a concepção e o conceito de lugar na Arqueologia (BOWSER, ZEDEÑO, 2009; WHITRIDGE, 2004), são buscadas continuidades e rupturas da dinâmica cultural na ocupação das populações Guarani na região destacada, o litoral central de Santa Catarina.

O conceito e a concepção de lugar e lugar significativo trazido para as pesquisas em Arqueologia Guarani possuem alto potencial, especialmente se trabalhados de forma inter e multidisciplinar, uma vez que eles consideram meios naturais e sociais (ZEDEÑO, BOWSER, 2009, P.1). O reconhecimento da existência do lugar e sua significância pelo indivíduo e o coletivo é o que define seu significado, evidencia sua trajetória histórica, explica suas conexões com outros lugares, e coloca sua articulação com a paisagem (ZEDEÑO, BOWSER, 2009, P.6). Uma vez que as evidências de ocupação Guarani pré-coloniais são os sítios arqueológicos, esses locus de atividades podem ser trabalhados de forma interdisciplinar a serem identificados os lugares significativos Guarani.

Nessa dinâmica, as evidências de ocupação Guarani se distribuem no Brasil desde o estado de Mato Grosso do Sul, a São Paulo, Paraná, Santa Catarina e Rio Grande do Sul; além dos vizinhos Paraguai (em sua região oriental), Argentina (em maior parte, na região nordeste desta) e Uruguai (NOELLI, 1999/2000). É importante destacar que esse mapeamento da distribuição dos sítios arqueológicos não se encontra completo, devido à falta de pesquisas em determinadas regiões e ao fato de muitos sítios arqueológicos terem sido bastante impactados ao longo de mais de quinhentos anos de presença europeia na região. Os sítios arqueológicos com ocupação Guarani do litoral catarinense apresentam as datações absolutas mais recentes. Em outra proposta de levantamento publicada em 2014 (NOELLI, MILHEIRA, WAGNER, 2014) podem-se extrair outras considerações acerca dos sítios no litoral catarinense: o litoral sul do estado ainda é aquele mais explorado nas pesquisas no que tange a temática Guarani e, 
no geral, as datações mais antigas encontram-se nesse; no litoral norte, o sítio arqueológico Poço Grande possui uma das datações mais recentes; o litoral central apresenta um conjunto relevante de sítios arqueológicos identificados nos municípios de Florianópolis, Palhoça e adjacências, mas estes foram alvo de pouquíssimos estudos sistemáticos.

Um olhar mais detalhado para a Ilha de Santa Catarina realizado pela equipe do LEIA/UFSC entre os anos de 2013 e 2015, sob a coordenação do Professor Doutor Lucas de Melo Reis Bueno em projeto denominado Florianópolis Arqueológica (BUENO, 2012), pode refinar o mapeamento desses sítios arqueológicos e confrontar a bibliografia vasta e a profusão de registros, feitos por muitos pesquisadores desde a década de 1850, e revisitar sítios arqueológicos. Apenas três dos sítios arqueológicos identificados com ocupação Guarani possuem datações absolutas: Porto do Rio Vermelho I (910 A.D. $/{ }^{14}$ C), Tapera $\left(1400+-70\right.$ A.D. $/{ }^{14}$ C4) e Travessão do Rio Vermelho (370 \pm 30 A.P. $/{ }^{14} \mathrm{C}$ e $290 \pm 30$ A.P. $\left./{ }^{14} \mathrm{C}\right)$. Não há publicações acerca da análise dos vestígios pertencentes a essa ocupação nos sítios elencados, a não ser para o sítio Lagoinha do Rio Tavares I / Rio Tavares (por Walter Fernando Piazza no ano de 1965), e sítio Travessão do Rio Vermelho (pesquisado nos anos de 2013 e 2014 pela equipe do LEIA, cujo material foi parcialmente analisado pela autora em trabalho de conclusão de curso no ano de 2015).

Assim, vê-se a partir desse panorama geral para o litoral central catarinense a necessidade de pesquisas que tragam melhor detalhamento para os contextos arqueológicos nessa região, que atualizem a Arqueologia Guarani no estado. Sabe-se que atualmente também é uma questão para a Arqueologia desenvolver estudos com relação às interações dos diferentes povos que habitaram um território. Nesse caso e no sul brasileiro, falamos da interação entre povos Guarani, Jê, caçadores-coletores e construtores dos sambaquis, e posteriormente europeus. Os Guarani são os povos mais estudados e conhecidos etnográfica e etnohistoricamente no Brasil, e a Arqueologia estuda os vestígios produzidos por eles, sendo ampla a produção de trabalhos em Arqueologia Guarani no país. Portanto, apesar dessa ampla produção, deve-se apostar nas questões que avancem o debate acerca dessa história indígena de longa duração, como: 1- análises tecnológicas aprofundadas; 2- busca de particularidades dentro da "estrutura" conhecida para a produção material cerâmica; 3- integração de diferentes métodos macro e microscópicos para as análises cerâmicas e sua interpretação. 


\subsection{Objetivos}

Tem-se como objetivo geral desta pesquisa: contribuir para a construção de uma história indígena Guarani de longa duração no sul do Brasil através das análises tecnológica e químicas de coleções cerâmicas Guarani provenientes de contextos arqueológicos localizados na Ilha de Santa Catarina. E, enquanto objetivos específicos: 1 - analisar as características dos sítios arqueológicos Travessão do Rio Vermelho (sigla TRV), e Lagoinha do Rio Tavares I / Rio Tavares (sigla RT), ocupados por grupos Guarani e localizados no litoral central de Santa Catarina, em relação a sua localização, cronologia e tecnologia; 2 - promover o confronto e interseção de interpretações em suas mais diversas formas, para a produção desse conhecimento histórico de longa duração.

\subsection{Materiais e Métodos}

Esta pesquisa trabalha com a articulação de diversas ciências e áreas (Arqueologia, História, Etnologia e Etnohistória) para a compreensão da ocupação Guarani no litoral central do estado de Santa Catarina. Enfatiza-se que para todas as coleções submetidas à análise tecnológica, buscar-se-á realizar a Arqueometria e aprofundar as discussões já existentes para distintas formas de análise, mas ainda brevemente utilizadas nessa temática para o Brasil. É realizado o estudo congregando três diferentes formas de coleções arqueológicas (com trajetórias distintas, produtos de diferentes momentos da história da Arqueologia no país).

Assim, esta pesquisa se baseia em três formas de análises: 1) documentais; 2) artefatuais (vestígios cerâmicos); 3) arqueométricas (Fluorescência de Raios-X). As coleções de vestígios cerâmicos analisadas foram escolhidas em função de serem coleções públicas e estarem disponibilizadas publicamente no Museu de Arqueologia e Etnologia Professor Oswaldo Rodrigues Cabral - MArquE/UFSC.

1) Fontes documentais:

- Relatos etnográficos de viajantes dos séculos XVI a XVIII que tratam da cultura Guarani no litoral central do estado, e que são retomadas por autores em formatos de fontes secundárias. São essas fontes secundárias: Silvio Coelho dos Santos (2004), Francisco Noelli (1993), Amílcar Mello (2005), Clóvis Brighenti (2012), Reinaldo Lohn 
(2004). Essas fontes contêm os relatos de: Hans Staden, Oviedo y Valés, Álvar Nuñez Cabeza de Vaca e Aleixo Garcia.

- Registros escritos da pesquisa arqueológica de Walter Fernando Piazza no sítio arqueológico Lagoinha do Rio Tavares I / Rio Tavares durante a vigência do Programa Nacional de Pesquisas Arqueológicas (PRONAPA) na década de 1960 e as publicações produzidas na década de 1970.

- Registros escritos produzidos sobre o sítio arqueológico Travessão do Rio Vermelho (TRV), em Florianópolis, pela equipe do LEIA/UFSC nos anos de 2013 e 2014, sob o Projeto "Florianópolis Arqueológica".

- Registros de processos de pesquisas arqueológicas localizados no Arquivo físico da Superintendência Regional do Instituto do Patrimônio Histórico e Artístico Nacional em Santa Catarina (IPHAN-SC).

2) Vestígios arqueológicos cerâmicos recuperados de escavações arqueológicas:

- Provenientes do sítio arqueológico Travessão do Rio Vermelho (TRV), e que atualmente, encontram-se salvaguardos no MArquE/UFSC.

- Análise dos vestígios materiais pré-coloniais provenientes da pesquisa realizada por Walter Fernando Piazza no sítio Lagoinha do Rio Tavares ILagoinha do Rio Tavares I / Rio Tavares (RT), salvaguardados no MarquE/UFSC.

Esses vestígios são analisados de forma a compreender os processos de produção inerentes nos artefatos que geraram as coleções, portanto, com uma influência da Arqueologia Comportamental de Schiffer e Skibo (SCHIFFER, 1995 [1972], 2010; SCHIFFER e SKIBO, 1995, 1997, 2001). Por meio da análise tecnológica (quantitativa e qualitativa), as coleções são discutidas, quando possível, por meio da cronologia e análise regional (levando em conta seus contextos). Por ser produção emblemática para a Arqueologia Brasileira no sul do país, a obra "Cerâmica Guarani", de Fernando La Salvia e José Proença Brochado (LA SALVIA, 1989), é utilizada como obra de confronto e/ou argumentação (dentre demais) para a análise cerâmica em andamento (MACHADO, 2005; 2005/2006), além das referências dos trabalhos de Shepard (SHEPARD, 1956), Orton et al (ORTON et al., 1993), Arnold (ARNOLD, 2000) e Chilton (CHILTON, 1998). 
3) Análises Arqueométricas:

- Além das análises de perspectiva tecnológica, os vestígios listados anteriormente foram selecionados e analisados sob perspectiva arqueométrica. A análise arqueométrica aprofunda e confronta as características identificadas durante a análise tecnológica para compreender os processos de produção dos artefatos. A técnica arqueométrica selecionada para complementar e confrontar a discussão é a Fluorescência de Raios-X (XRF). Essa técnica vai ao encontro da ampliação das discussões sobre o material, mesmo a nível macro-regional (pensando o sul do país) uma vez que o estudo arqueométrico em coleções cerâmicas Guarani mais conhecido foi realizado no ano de 2009 por Milheira e colaboradores (MILHEIRA, APPOLONI, PARREIRA, 2009).

Assim, este trabalho busca a análise e a reflexão sobre dois pilares: a análise de coleções e dos lugares (sítios arqueológicos) a partir de uma Arqueologia do Lugar para a construção dessa história indígena Guarani de longa duração no litoral central de $\underline{\text { Santa Catarina. }}$ O refinamento teórico-metodológico é um processo ao longo de toda a pesquisa, e também faz parte da proposta: de explorar as possibilidades dentro da temática em Arqueologia Guarani e buscar as particularidades perante a estrutura na cultura Guarani. Portanto, deve-se pensar e analisar os resultados a partir de como a Arqueologia, a Etnohistória e a Etnografia podem compor essa história Guarani possível na longa duração, enfatizando a relação entre as tecnologias estudadas e os lugares significativos Guarani no grande território pelo qual se movimentam essas populações.

Portanto, para dar conta da proposta, esta dissertação de mestrado encontrase dividida e apresentada da seguinte forma:

O Capítulo 1 trata desta introdução à pesquisa realizada. O Capítulo 2 apresenta brevemente o tema Arqueologia Guarani, discute as principais pesquisas no tema e traz as etnografias e etnohistórias feitas para os Guarani da região. O Capítulo 3 aborda a temática no litoral central de Santa Catarina, as principais pesquisas no litoral catarinense, o levantamento de sítios arqueológicos Guarani no Arquivo do IPHAN/SC. O Capítulo 4 apresenta as coleções analisadas (TRV e RT) e explora os métodos (análises macroscópicas e arqueométricas) e amostras dos materiais arqueológicos e sua seleção nesta pesquisa. O Capítulo 5 aborda os resultados das análises (macro e arqueométricas) do material cerâmico discutido no capítulo anterior. Por fim, no 
Capítulo 6 é realizada uma discussão comparando ambas as coleções em termos tecnológicos e em termos das análises de Fluorescência de Raios-X (XRF) sendo desenvolvida em cima de duas frentes: as coleções e os lugares, propondo a construção de uma Arqueologia do Lugar Guarani.. Então, no Capítulo 7 são apresentadas as considerações finais e, consequentemente, os anexos (contendo o glossário da ficha de análise cerâmica e o catálogo do material cerâmico analisado). 


\section{CAPÍTULO 2: ARQUEOLOGIA GUARANI}

Para lograr a realização e apresentação da pesquisa que busca a construção de uma história Guarani na longa duração no litoral central catarinense através do confronto entre Arqueologia, Etnologia e Etnohistória é importante ter em mente a fluidez que a cultura Guarani representa, apesar de sua característica prescritiva (NOELLI, 1993). O intuito aqui não é deixar estática a noção de Arqueologia Guarani e encaixar os objetos de estudo em um grande modelo fixo; mas, trata-se de compreender os modelos e propostas e avançar na discussão da temática buscando as particularidades para além da estrutura.

\subsection{Arqueologia Guarani como história indígena de longa duração}

Nesta pesquisa partimos da compreensão de que Arqueologia é uma ciência interdisciplinar e interpretativa, e se faz no presente. Ainda, se estreitarmos um pouco o foco de uma ampla temática de estudos apenas no Brasil, de formas de abordagens e métodos utilizados, especificamos aqui que este trabalho delimita Arqueologia como história indígena de longa duração (longue dureé) a partir das influências de Braudel e Sahlins (BRAUDEL, 1958; SAHLINS, 1989).

Corrêa (2014) nos relembra que o distanciamento entre a Arqueologia americana e História inicia-se no século XIX, evidenciado no Brasil pelo uso apenas da Etnografia no estudo da trajetória dos grupos indígenas (LANGEBAEK, 2005 apud CORRÊA, 2014, P.90). Isso, no Brasil, levou inexoravelmente a uma dissociação entre o registro arqueológico e as populações indígenas, como se estas últimas não tivessem história, principalmente antes do "contato" europeu. Essa situação voltou a mudar com o uso de métodos da História pela Antropologia e Arqueologia, além das discussões conceituais e teóricas. Nisso, houve a introdução do conceito de longue durée de Braudel, utilizado primeiramente por Lamberk-Karlovsky (1985) e em seguida por Hodder (2009) (CORRÊA, 2014, P.91). E, no Brasil, o conceito de longa duração tem sido aplicado nas pesquisas que buscam compreender o registro arqueológico como parte de um movimento chamado História Indígena, a partir da década de 1980 (CARNEIRO da CUNHA, 1992, P.92 apud CORRÊA, 2014). Noelli (NOELLI, 1993) 
foi o primeiro a usar essa noção braudeliana ao tratar do tema, Arqueologia Guarani, sendo um dos primeiro a trazer a longa duração. Assim, como já propunha Braudel (1958) na década de 1950 para a crise das ciências humanas, aqui se acredita que somente a interdisciplinaridade em Arqueologia pode construir o que chamamos dessa história indígena de longa duração. É imprescindível, todavia, esclarecer que a longa duração implica na dialética com a curta duração também, ou seja, da estrutura e fatos em constante discussão:

"A perspectiva de longa duração é fundamental para os estudos sobre continuidade/mudança e tradição/inovação (Hodder, 2009[1987]), visto que permite pensar a estrutura e ação, e avaliar essa relação como mais dialética e antagônica do que propriamente sistêmica" (CORRÊA, 2014, P.92).

O estudo do "registro arqueológico" (termo cunhado no processualismo) ou "materialidade" (termo utilizado no pós-processualismo e Arqueologias pós-coloniais) é bastante importante não somente aos profissionais da Arqueologia, mas como a uma grande diversidade de grupos em nossa sociedade, e por isso, vislumbramos discussões das mais amplas em torno do que o "material" representa e significa de formas plurais:

"Os artefatos, portanto, são vistos como constituídos de camadas de significados ou de histórias que podem ser diferentemente acessadas por diferentes indivíduos embebidos em diferentes redes e estratégias sociais" (SILVA \& NOELLI, 2017, p.p.56$57)$.

A partir dessas discussões, a Arqueologia contemporânea tem feito questionamentos acerca de qual história escreve, para quem serve e para que, seguindo um movimento das ciências humanas de modo geral. Sendo assim, o estudo dessa materialidade se faz de extrema importância na construção de uma história indígena Guarani de longa duração, buscando tornar visíveis caráteres históricos para os contextos contemporâneos das populações indígenas Guarani neste caso. Cabe ressaltar, contudo, que a Arqueologia, ou as Arqueologias, são plurais devido a distintas tradições e trajetórias de pesquisa dos países e regiões.

Mais plurais e heterogêneas são, então, as releituras realizadas de trabalhos e movimentos icônicos, o que é totalmente constante e dinâmico. Uma única pesquisa pode integrar releituras e apropriações de movimentos teóricos distintos, lembrando também que teoria e método são indissociáveis. Nesse ínterim, ao propor a construção 
de uma história indígena de longa duração, é proposta uma releitura histórico-cultural no sentido da forte influência de uma História Cultural e da longa duração no litoral central catarinense.

O estudo em Arqueologia Guarani com influências contemporâneas encontra-se inserido em um contexto maior, o da Arqueologia Tupi (SILVA \& NOELLI, 2017; CORRÊA, 2014). Os estudos em Arqueologia Tupi buscam aproximar Arqueologia e linguística por meio da interdisciplinaridade (e influência nos estudos de Brochado, por exemplo) na longa duração, estabelecendo identidades, fronteiras sociais e linguísticas do passado, negando as denominações "culturas arqueológicas" a partir de sua perspectiva essencialista e estática de cultura, como foram compreendidos e reproduzidos os estudos de Betty Meggers e Clifford Evans no Brasil. Ou seja, as críticas ao conceito de "culturas arqueológicas" se fizeram em relação às associações simplistas e diretas entre povo, língua e cultura material (SILVA \& NOELLI, 2017, p.56).

Nesses estudos em Arqueologia Tupi e Guarani, especificamente sobre a produção de artefatos, seus usos e distribuição no tempo-espaço, são usadas referências tais como as noções de habitus (BOURDIEU, 1977), de agência (GELL, 1998), de escolhas tecnológicas (LEMMONNIER, 1992) e de características de performance (SHIFFER e SKIBO, 1997). Neles, distintos autores definem a cultura material como um índice de etnicidade e mostram como a característica dos conjuntos artefatuais revelam diferentes expressões identitárias daqueles que os produziram e/ou utilizaram (SCHIFFER e SKIBO, 1997, P.56). Dessa forma, de acordo com Silva e Noelli (2017), ainda que se tenha cuidado ao procurar associar língua, povo e cultura material, não se pode simplesmente ignorar essa relação para determinadas populações e contextos socioculturais. Além disso, embora seja uma pesquisa árdua e complexa, não é impossível encontrar no registro os indicadores dessas relações e suas transformações no tempo. Não se pode negligenciar que há uma continuidade histórica entre populações do passado e as historicamente conhecidas, como demonstraram diversos pesquisadores no contexto brasileiro (como Wüst, 1991; Noelli, 1993; Heckenberger, 1996; Neves, 1998; Eremites de Oliveira, 2002), e seria por esse motivo que a interdisciplinaridade é fundamental e a cooperação entre Arqueologia e linguística é profícua - sendo este o caso Tupi (SILVA e NOELLI , 2017, P.59). 
Os autores Silva e Noelli afirmam que os casos Guarani e Tupinambá inauguraram um método que vem sendo testada no estudo de outros conjuntos cerâmicos atribuídos aos povos do tronco linguístico Tupi, partindo do pressuposto de que será possível identificar características tecnológicas comuns e funções homólogas, mas também variabilidade e variação nas cerâmicas dos falantes das outras línguas da família Tupi-Guarani e do tronco Tupi (SILVA e NOELLI, 2017, P.62).

Assim, a noção de cultura torna-se mais fluida nesses trabalhos em Arqueologia Tupi, como "ethos culturais" que possuem história, e relacionada à etnicidade. A etnicidade é, então, considerada como um processo reconhecido nos padrões observáveis da cultura material (HODDER, 1979 apud BONOMO et al.,2015), especialmente no caso Guarani, que aglomera muitos exemplos de dados arqueológicos, históricos, etnográficos, linguísticos, e antropológico-físicos. Os trabalhos, especialmente de Brochado (1984) e Noelli (1993), propõem a interdisciplinaridade acima de tudo (CORRÊA, 2014, P.27) e partem do pressuposto de que a pesquisa arqueológica parte da relação dialética entre passado/presente, sujeito/objeto (HODDER, 1988, 1991, 1992 apud CORRÊA, 2014, P.27). Da mesma forma, ao proporem uma história de longa duração, reforça-se que não se trata da proposta histórico-cultural nos termos de seu surgimento no século $\mathrm{XX}$, primeiramente pelo conceito de cultura não ser aquele normativo, tampouco da associação direta entre língua, povo e objeto, e menos ainda pelo caráter ininterrupto de história dessas populações e pela Arqueologia ser uma tributária da História.

\subsection{Arqueologia, Etnografia e Etnohistória na construção da história Guarani de longa duração}

A relação entre Arqueologia Tupi ou Guarani, Etnografia, Etnohistória, Linguística não é novidade. Os povos falantes de línguas Tupi-Guarani são muito bem conhecidos etnográfica e etnohistoricamente, e o confronto dessas diferentes produções com aquelas da Arqueologia se mostra extremamente profícuo e válido, sempre relembrando que não se trata de realizarmos uma associação direta entre língua e cultura material. E para pensar uma história indígena na longa duração, ou mesmo em 
prescritividade Guarani (NOELLI, 1993), essa relação e o confronto entre Arqueologia, Etnologia e Etnohistória deve ser realizado.

O que conhecemos inicialmente como Etnohistória surge como uma tendência com a Nova História, movimento na historiografia que questionou a supremacia da fonte escrita nos estudos bem como as abordagens tradicionais, e num momento em que História e Antropologia questionavam e disputavam o campo de abrangência de seus respectivos objetos de estudo (LAROQUE et al., 2015). Dentro desse campo de estudos amplo, encontra-se a história oral por exemplo. Ainda, há uma confusão no uso dos termos etnohistória e história indígena, que são designados para diversas pesquisas interdisciplinares que em sua maioria envolvem questões indígenas com abordagens históricas. A Etnohistória pode ser compreendida como disciplina acadêmica independente, segundo Cavalcante (CAVALCANTE, 2011), como compreensão e/ou representação própria dos povos indígenas acerca de sua história e do tempo (a citar FREITAS, 2004), como uma etno-ciência, ou como um método interdisciplinar. A Etnohistória, como método interdisciplinar que conjuga dados e métodos da antropologia, da história e da Arqueologia, seria o melhor caminho para compreender os povos de culturas não-ocidentais a partir de uma perspectiva histórica segundo o autor. Ainda, problematiza e analisa as documentações produzidas por indígenas e não indígenas, além de considerar a ruptura que o "contato europeu" causou nas Américas na dinâmica das populações indígenas (afetando a produção material inclusive). Nessa perspectiva, Cavalcante (2001) enfatiza também a importância e o diferencial recaem sobre as tradições orais e as fontes arqueológicas, além da linguística, que também tem se mostrado aliada nesse campo de pesquisa, pois os estudos de linguística histórica seriam capazes de apresentar diversos aspectos que dificilmente seriam acessados por outras vias (CAVALCANTE, 2001, P.359 apud CHAMORRO, 2009).

Acerca da diferenciação com a história indígena, e o uso das categorias éticas e êmicas (debate bastante conhecido nas ciências humanas), Eremites (2003) explora que é preciso ter clareza que a história indígena pode ser compreendida como a história que os cientistas sociais produzem acerca do transcurso sociocultural e histórico das populações nativas do continente americano, quer dizer, das representações que construímos sobre o outro, a nossa visão ética. Num segundo momento, a história indígena também poderia ser vista como a história narrada e interpretada segundo os 
próprios indígenas. Nesse segundo momento, a história indígena estaria ligada à ideia de ethos, ou seja, ao caráter sociocultural dos povos indígenas, e apresenta-se como um tipo de história êmica, aquela história que os próprios nativos americanos contam sobre si mesmos e sobre seus ancestrais. Esta visão êmica foi incorporada à ideia de etnohistória quando a tradição oral passou a ser considerada como uma importante fonte de pesquisa em muitos estudos realizados na América do Norte (EREMITES DE OLIVEIRA, 2003, p.2).

Sobre a problematização dos discursos observados nessas fontes, Bartomeu Meliá aponta para a questão das populações Guarani, grupos por ele estudados, sendo que apresenta um recurso que presume a análise da documentação a partir da cultura dos Guarani atuais, o que não se trata de buscar simples coincidências entre os Guarani "históricos" ou atuais, mas procurar categorias fundamentais para uma reestruturação semântica que seja autenticamente Guarani. Para ele, com os conhecimentos existentes da cultura Guarani atual, graças aos trabalhos de Nimuendajú, Cadogan e Schaden permitiriam apelar a esse recurso com seriedade (MELIÁ, 1997, p.100). Esse procedimento não seria de concordância unânime, muito pelo contrário. Carlos Fausto, por exemplo, aponta ser ingenuidade desconsiderar as rupturas que a conquista colonial representa para as culturas indígenas, ou imaginar que existiria correlação entre demografia e complexidade sociocultural ou sociopolítica, uma vez que cada cultura tem sua historicidade e a conquista causou grande ruptura na dinâmica desses povos. Fausto ainda apresentaria que as crônicas coloniais sobre os Tupi da costa apresentam uma inegável familiaridade com os Tupi atuais (FAUSTO, 1992, P.381 apud CAVALCANTE, 2011, P.360). Essa mesma familiaridade também poderia ser observada entre os Guarani atuais e a documentação história a seu respeito, ainda tratando do período posterior ao contato europeu. Tudo isso deveria, então, ser levado em conta com muita cautela. Uma das vantagens que as ciências humanas têm trazido para a produção atual encontra-se justamente na descentralização dos discursos, na valorização de múltiplas narrativas sobre o passado, ainda que os pesquisadores estejam inseridos e realizando ciência ocidental (sem nunca se distanciar desse esclarecimento). O que está em pauta aqui é não encaixar as culturas, mas conseguir visualizar a fluidez delas, especialmente a Guarani (usando o termo generalizador).

As etnografias já foram usadas no início do século XIX pelos arqueólogos, e agora estão sendo retomadas por questões éticas e de agenda, a chamada "virada 
etnográfica" (CASTAÑEDA, 2007, p.25). Embora muitas definições e usos das etnografias pelos profissionais não seja tão delimitada, Castañeda apresenta três formas gerais de uso: a etnografia arqueológica, a etnografia da Arqueologia e a Arqueologia etnográfica. Essas três formas seriam identificados e diferenciados de acordo com quatro critérios: a definição da agenda básica de pesquisa; a especificação do objeto de estudo; o papel da etnografia e sua relação com a Arqueologia; o propósito da pesquisa (CASTAÑEDA, 2007, P.28).

O uso mais conhecido das etnografias é aquele que Castañeda (2007) determina como "etnografia arqueológica", retomada na New Archaeology e na Arqueologia processual. Esse uso vê a etnografia como um método da Arqueologia, sendo o objeto de estudo, o passado. Ainda, o papel da etnografia seria ajudar na criação de "modelos" a partir de padrões contemporâneos observados que expliquem o registro arqueológico, promovendo teorias de médio alcance e criticando as analogias etnográficas realizadas anteriormente. Esse também foi o uso que mais sofreu críticas bem fundamentadas, como bem contextualizado em Politis (2002), justamente pelo fato de propor "leis gerais" para o registro arqueológico. Este autor também explora e apresenta de forma bastante clara como as Arqueologias que foram feitas com etnografias são bastante plurais (não havendo uma unidade na forma de desenvolvê-las), bem como o pós-processualismo prevê. Explora os trabalhos etnoarqueológicos na América do Sul, com destaque para o Brasil, e os apresenta como tendências distintas. Considera que, com relação à abordagem da obtenção e interpretação da informação, a tendência analítica teria um enfoque mais ético (HARRIS, 1980 apud POLITIS, 2002, P.75), enquanto que a hermenêutica se orientaria para a busca do êmico.

"Obviamente, los aspectos émic de los significados de las conductas son diffíciles de aceder, sobre todo teniendo en cuenta que los etnoarqueólogos no Suelen passar extensos períodos de campo a la manera de los estudios etnográficos clásicos. Sin embargo, esta dificultad no debe servir de excusa para intentar descifrar los códigos simbólicos contenidos en las conductas y en su dimensión material. Es posible abordar estos incluso con estadías no demasiado prolongadas si es que diseñan estrategias específicas para obtener este tipo de información (Frias, 1993; Habber, 2001; Politis; Saunders, 2002; Silva, 2000)" (POLITIS, 2002, p.75). 
Uma última tendência apresentada por Politis estaria representada por projetos no Brasil principalmente, que buscaria obter informações etnoarqueológicas para reconstruir processos históricos de grupos indígenas contemporâneos, representados por exemplo pelos trabalhos de: Heckenberger; Perterson; Neves, 1999; Wüst, 1998; Wüst; Barreto, 1999. Essa tendência buscaria compreender os processos de continuidade e mudança em contextos sociais específicos, mediante o uso complementário de informação etnográfica, etnohistórica e arqueológica. De alguma maneira essa forma de Arqueologia estaria ligada a uma "história indígena" (EREMITES de OLIVEIRA, 2001). O autor ainda vê que o potencial dessas investigações para a interpretação arqueológica é enorme (POLITIS, 2002, p.76).

No Brasil, segundo Silva (2012, p.30), com relação aos trabalhos de arqueólogos com coletivos indígenas, relacionam-se a pesquisas arqueológicas e etnoarqueológicas que visam à construção de uma história indígena de longa duração; com pesquisas etnoarqueológicas que tem como foco o entendimento da relação entre comportamento humano e cultura material com situações de demarcação, manutenção ou reivindicação de territórios tradicionais por parte dos coletivos indígenas; com a realização de empreendimentos que demandam trabalhos de Arqueologia preventiva e etnoArqueologia; ou com a esfera da Arqueologia pública. Portanto, podemos observar que a forma do uso das etnografias é plural e cada vez mais têm se diversificado de acordo com as questões científicas e políticas dos envolvidos. Ainda assim, o enfoque nesta breve explanação será dado a um determinado uso das etnografias e como se articula com a construção de uma história indígena de longa duração, como Silva menciona, e mais adiante, como se relaciona com uma etnohistória.

\subsection{Etnografia e Etnohistória dos Guarani de Santa Catarina}

Nesta pesquisa, por conseguinte, são confrontadas alguns relatos de viajantes produzidos sobre os Guarani especialmente no século XVI e estudos de cunho antropológico contemporâneos. Torna-se válida essa estratégia não como uma forma de admitir modelos a virem ser extrapolados para o passado, mas a serem considerados como mais um elemento na dinâmica de estudo das populações humanas. Se é válido e trata-se de uma das formas de se realizar o estudo sobre o passado e o material, há muito 
em que se avançar, uma vez que a ciência ocidental está em constante movimento, é reflexiva e deve sempre realizar sua autocrítica. É preciso explorar as possibilidades e limites de cada método na Arqueologia. São referências para se enredar a discussão sobre cultura Guarani: Montoya (MONTOYA, 1639) com seu Tesoro de la lengua guaraní, com o maior compilado sobre os Guarani; e Curt Nimuendajú com mapa no qual é visível a movimentação Guarani explorada pelos modelos de expansão Tupi e Guarani (Mapa etno-histórico de Curt Nimuendajú/IBGE, 1981); Bartomeu Meliá (MELIÁ, 1987) e John Manuel Monteiro (MONTEIRO, 1992), autores extremamente difundidos e respeitados nos estudos sobre os Guarani. Francisco Noelli (NOELLI, 1993), referência para a Arqueologia Guarani de forma interdisciplinar foi quem primeiro utilizou a noção de longa duração para a temática e em seu trabalho apresenta infinidade de dados de pesquisa etnohistórica para a compreensão do território Guarani; Silvio Coelho dos Santos (SANTOS, 2004), antropólogo que esteve dentre os indígenas catarinenses e deixou relatos sobre os Guarani; Reinaldo Lohn (LOHN, 2004), historiador, recuperou relatos de viajantes do século XVI na costa catarinense, dentre eles Hans Staden, Palmier de Gonneville, Álvar Nuñez Cabeza de Vaca, Aleixo Garcia; Amílcar de Mello (MELLO, 2005) que junto com Francisco Noelli, com extensa pesquisa, produziram a maior e mais extensa obra sobre os primeiros anos de contato dos europeus em Santa Catarina, trazendo o maior compilado de relatos como fontes primárias; Maria Dorothea Post Darella (DARELLA, 2004), antropóloga do MArquE que realizou seus estudos e trabalhos com os Guarani do estado, especialmente do litoral. E, por fim, Clóvis Brighenti (BRIGHENTI, 2012), historiador com temática de trabalho em História Indígena; e, por fim, Alguns desses autores já foram trabalhados pela autora em seu trabalho de conclusão de graduação (MÜLLER, 2015) e serão brevemente retomados; outros, são trazidos de forma inédita. Adiante, o enfoque será dado para a produção acerca dos Guarani no litoral catarinense, especificamente no litoral central.

Essa discussão também deve remeter a ampliar o debate acerca do compromisso atual do arqueólogo no Brasil no século XXI sobre considerar todos os interesses em torno do registro arqueológico / materialidade. Além disso, cabe a reflexão acerca de como falar em uma "cultura Guarani” não essencializada, mas tratando de um ethos cultural com continuidades na longue durée, através de uma perspectiva diacrônica (com o uso rigoroso, mas não pragmático das fontes). 
Amílcar Mello (2005) compôs obras bastante densas sobre o início do que se conhece tradicionalmente como história de Santa Catarina, no entanto, sua obra não é tão conhecida e mencionado na Academia e estudos tradicionais. É historiador com especialização em Etnolinguística e com Francisco Silva Noelli (2005) elaborou a perspectiva apresentada nos três volumes sob o título de Expedições: Santa Catarina na Era dos Descobrimentos Geográficos no ano de 2005 (MELLO, 2005). Nessa obra, Mello revisou e detalhou os dados publicados e nesses volumes explora com profundidade as ações europeias, portuguesas, espanholas e mesmo inglesas, no território catarinense.

Vale lembrar que desde os anos 1500 se resumiram basicamente no projeto das Coroas portuguesa e espanhola de conhecer os territórios americanos e explorar suas riquezas, até que é iniciado o projeto de colonização do território português. Além disso, o território português, segundo o Tratado de Tordesilhas (1494), tinha seu limite com o território espanhol em Laguna (litoral sul do estado). É comum nos registros dos cronistas do século XVI haver sempre a referência a três pontos distintos no litoral catarinense, locais de ancoragem e passagem dos navegadores: ilha de São Francisco do Sul (litoral norte), a Ilha dos Patos ou Ilha de Santa Catarina (Florianópolis atualmente), e Laguna ou Viaça (PERRONE-MOISES, 1992; MELLO, 2005). Ainda, a região no litoral central compreendida pela baía de Garopaba (não se conhece exatamente em qual ponto) era conhecida por Baía dos Patos (MELLO, 2005, P.53). É possível observar melhor essas informações no mapa formulado por Mello a partir das crônicas que levantou do mapa formulado e reproduzido a seguir (Figura 7). Nota-se, com especial atenção a região litorânea central, compreendida entre a Baía de Tijucas e Imbituba, alvo deste estudo de mestrado. Nela, ainda há referências da própria Baía de Tijucas (atual Tijucas) ou Baía das Seis Ilhas (MELLO, 2005, P.53), da Armação da Piedade (atual Governador Celso Ramos), Canasvieiras, Estreito, Baía Sul (atuais Florianópolis, sendo esta última remetida à grande região de água compreendida entre Florianópolis, São José, Palhoça, Paulo Lopes e Garopaba), Massiambu (atual Palhoça), Caieira da Barra do Sul (atual Florianópolis), Praia da Pinheira (Palhoça), Ilha do Coral (atual Paulo Lopes), Garopaba e Imbituba sob suas diversas denominações. Destaque para, além da região da Ilha de Santa Catarina (com referência aos indígenas), mas também a Massiambu, região conhecida atualmente pelos sítios arqueológicos Guarani e por concentrar umas das terras indígenas Guarani da região, a T.I. Massiambu (região 
do município de Palhoça, a sul de Florianópolis, e identificada no mapa da Figura 6, página 81). Dessa região também provêm registros de ancoragem dos europeus e exploração dos recursos para adentrarem o interior e os rios da bacia do Cubatão, seguindo viagem. Dentre esses registros, estão os de Richard Madox (MELLO, 2005, P.32). Importantíssimo também é enfatizar que os Guarani no litoral catarinense eram referidos por esses cronistas como carijós, assim também conhecidos no Mapa etnohistórico de Curt Nimuendajú/IBGE (1981) de Curt Nimuendajú.

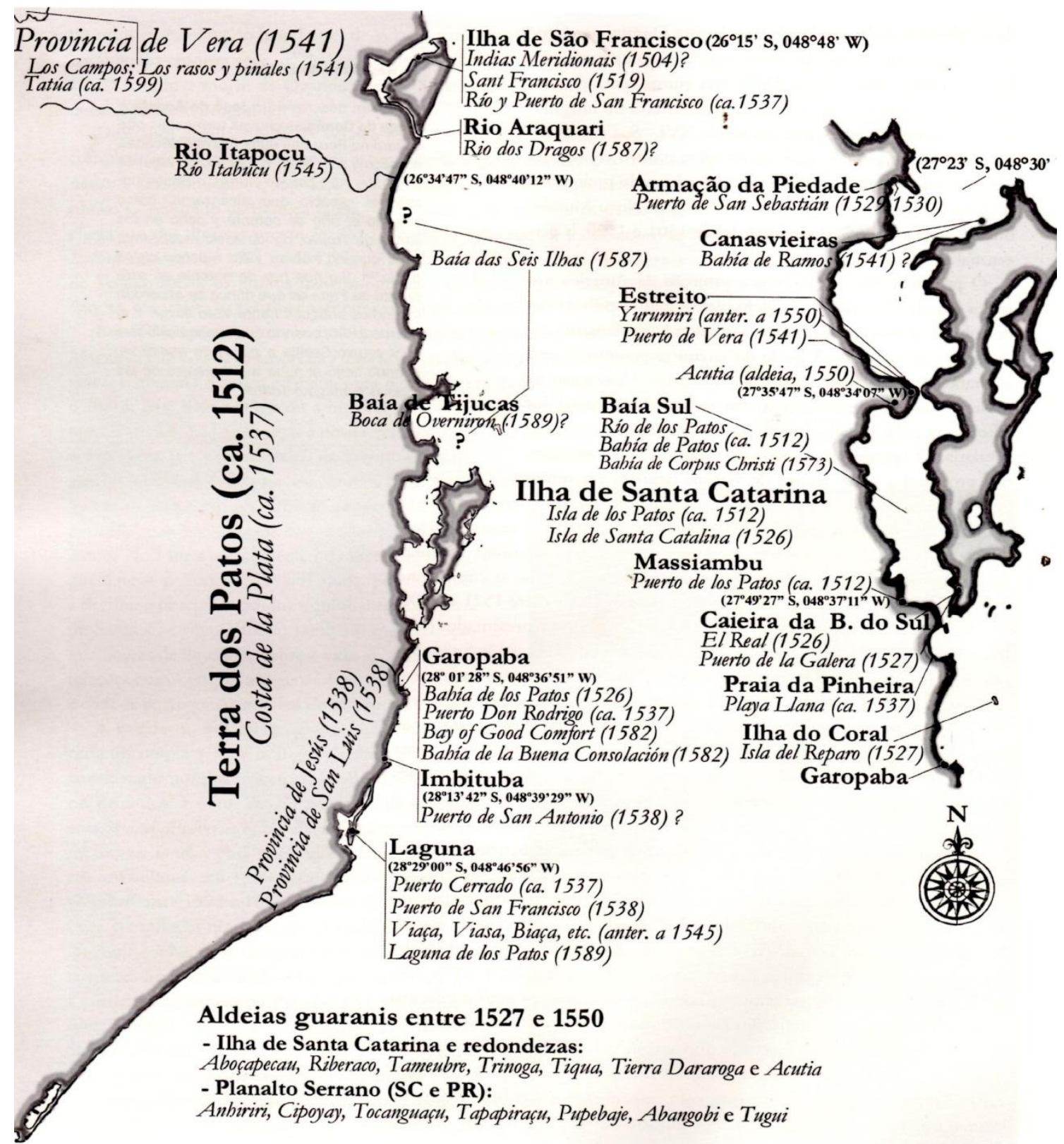

Figura 1. Mapa extraído da obra de Amílcar Mello (2005) contendo referências a lugares no litoral catarinense com nomenclaturas utilizadas pelos cronistas quinhentistas. Fonte: MELLO, 2005, P.50. 
O autor também traz cronistas que estiveram em território da colônia por diversos motivos, que passaram em Santa Catarina ou não, e mesmo que escreveram sobre o estado não tendo estado nele. São os cronistas, uns mais conhecidos na literatura, outros não tanto em uma lista extensa e que, em sua maior parte, estiveram em expedições que percorriam o litoral brasileiro e buscavam o Rio da Prata (atrás de riquezas) e, por isso, estiveram na Ilha de Santa Catarina (Florianópolis atual) para abastecimento das expedições para adentrarem o interior: Binot Paulmier de Gonneville, Antonio de Herrera y Tordesilla, Martín Fernández de Enciso, Henrique Montes, Dom Rodrigo de Acuña, Francisco Dávilla, Martín Mendez, Sebastião Caboto, Luiz Ramírez, Alonso de Santa Cruz, Roger Barlow, Hernando Ribera, Diego Garcia de Moguer, Pero Lopes de Sousa, Ulrich Schmidl, Alonso de Chaves, Fr. Bernaldo de Armenta, Francisco López de Gómara, Juan de Araoz, Pedro Dorantes, Alvar Núnez Cabeza de Vaca, Pero Hernández, Juan Sánchez de Vizcaya, Pedro de Fuentes, Gonzalo F. de Oviedo y Valdés, Pe. Manuel da Nóbrega, Martim de Brás Árias, Juan de Salazar de Espinosa, Hans Staden, Theodore de Bry, Juan Salmerón de Heredia, Fr. André Thevet, Jaime Rasquín, Andrés Martinez, Juan López de Velasco, Francisco Ortiz de Vergara, Hernando de Montalvo, Martín del Barco Centenera, Peter Carder, Edward Fenton, Luke Ward, Richard Madox, Fr. Juan Pascual de Rivadaneira, João Pinto, Pedro Sarmiento de Gamboa, Pe. Fernão Cardim, Gabriel Soares de Sousa, Pero Rodrigues, Anthony Knivet, Richard Hakluyt, Diego Rodríguez Valdés y de la Banda, Ruy Días de Guzmán. Alguns deles também são trazidos e mais conhecidos através das obras de Berger e Perrone-Moises (BERGER org.,1996; PERRONE-MOISES, 1992), como Binot Paulmier de Gonneville. Destes, destacam-se:

- Henrique Montes, português tripulante da caravela da expedição espanhola de João Dias de Solis ao Rio da Prata naufragou na ilha de Santa Catarina em 1516. Escreveu Relación (1527), documento contábil em que descreveu os artigos europeus que trocou com os índios carijós por alimentos e materiais para a construção de uma galera e do arraial que abrigou os homens de Caboto na ilha de Santa Catarina durante quase quatro meses no verão de 1526-1527. (MELLO, 2005, P.p.22, 92).

- Alvar Núñez Cabeza de Vaca: um dos personagens mais conhecidos do Novo Mundo, Cabeza de Vaca após certo período de muitas aventuras na América, regressou à Espanha em 1537 e retornou à América com o cargo de primeiro 
governador oficial da ilha de Santa Catarina e adelantado da província do Rio da Prata. Na Relación general (1545) narrou episódios ocorridos desde sua saída da Europa, a sua permanência de meio ano em Santa Catarina, as viagens pelo interior do continente e as intrigas políticas de que fora alvo. Junto dele também esteve Francisco Ortiz de Vergara, que apontou vantagens de a armada em que estava invernar na ilha de Santa Catarina e no Viaça, terra de índios amigos, farta comida e madeira (MELLO, 2005, P.p.26, 30, 244).

- Hans Staden: bastante conhecido e difundido nas etnografias, alemão, visitou em dois momentos o Brasil, e tripulou a expedição dos Sanabria (1550). Segundo Mello,

"Logo que chegou à ilha de Santa Catarina, protagonizou uma cena cômica. Fingindo-se cativo dos carijós que tinha acabado de contatar, Staden foi com eles até a sua nau, que aguardava notícias ancorada na baía. A bordo, sem saber o que estava acontecendo, os marujos 'caíram no trote' do espirituoso aventureiro. Brincadeiras à parte, esse episódio foi uma espécie de prenúncio do que posteriormente lhe aconteceria no litoral norte paulista, quando quase foi devorado pelos tupinambás e tamoios. Deixou, em seu livro Verdadeira história e descrição de um país de selvagens nus, ferozes e canibais, situado no novo mundo América... (1557), um interessantíssimo relato das suas aventuras" (MELLO, 2005, P.28).

Theodore De Bry posteriormente fez as famosas xilogravuras conhecidas a partir dos registros de Staden e que acompanham essa publicação.

- Francisco López de Gómara, foi secretário de Hernán Cortés e autor de Historia general de las Índias (1554) e incluiu informações sobre o porto dos Patos e explica tal nome por no local haver muitos patos pretos sem penas e com bico de corvo. Ainda, “(...) consultando a correspondência enviada do litoral catarinense pelo frei Bernaldo de Armenta, Gómara esclarece também o motivo pelo qual os carijós do lugar facilmente abraçaram a fé católica: antes deles, um índio chamado Etiguara anunciara a vinda dos religiosos para predicar-lhes." (MELLO, 2005, P.p.25, 230).

- Gonzalo de Oviedo y Valdés: polémico cronista-mor da Espanha, escreveu Historia general y natural de las Indias, islas y Tierra Firme del Mar Océano. Nunca esteve em Santa Catarina, mas na edição da obra de 1557, fez a primeira menção às Lagoas da Conceição e do Peri da Ilha de Santa Catarina: “[...] há 
duas lagoas nesta ilha, uma delas salobre de água do mar, e a outra doce, nas quais há muitas pescarias". Foi ele, segundo Mello, que também citou as cinco aldeias carijós existentes: Riberaco, Tíqua, Tameubre, Trinoga e Aboçapeau (MELLO, 2005, P.p.27, 282).

- Diego Rodríguez Valdés y de la Banda: na Relación, escrita de Buenos Aires em 1599, fazendo menção a dois barcos enviados do Rio de Janeiro ao sul do país para resgatar canhões pertencentes a uma das naus da armada de Diego Flores de Valdés naufragada na Ilha de Santa Catarina. A missão teria sido bem acolhida pelos carijós da Ilha segundo o relato, sendo que os indígenas estavam alarmados pelas falsas notícias espalhadas por um grupo de portugueses de São Vicente que diziam que em breve apareceriam espanhóis inimigos para roubálos e escravizá-los (MELLO, 2005, P.p.34, 556).

- Martín del Barco Centenera: foi um dos principais cronistas da expedição do adelantado Juan Ortiz de Zárate ao Rio da Prata e escreveu o poema épico ou crônica rimada chamada Argentina y conquista del Río de la Plata, com otros acaecimientos de los Reynos del Perú, Tucumán, y Estado del Brasil (1601). Nele, registra a situação por qual passaram na rima "Santa Catarina, ilha sem ventura, de tantos espanhóis sepultura". Segundo Mello, "a ilha outrora tão generosa, estava despovoada de seus tradicionais amigos carijós, que haviam se refugiado no interior e em Laguna para fugir dos assaltos portugueses e de seus aliados tupiniquins" (MELLO, 2005, P.p.31, 360).

Posteriormente, Boiteux (1912) deve ter retomado os excertos de Oviedo y Valdés, sendo trazido por autores como a antropóloga Darrella (2004) (MÜLLER, 2015):

"Da estada de Sebastião Caboto, na década de 1520, foram citadas as aldeias Riberacô, Tiguá, Tameubre, Trinoga e Abeçapecaú na Ilha de Santa Catarina (Boiteux, 1912:119). Duas décadas após, o viajante alemão Hans Staden anotou que os índios Guarani estavam abandonando a Ilha, assim como a área continental, onde se situava a aldeia Acutia. Ambas, Ilha e aldeia foram por ele desenhadas quando dessa estada, (...)". (DARELLA, 2004, P.131).

Do excerto anterior, podemos observar registros de nomes e localização dada pelos viajantes das aldeias Guarani ou "Carijó" em Florianópolis. Valendo-se, também, de Boiteux (1912), os arqueólogos Teresa Fossari (2004) e Inácio Schmitz 
(1959) referem-se à mesma passagem para identificar a localização das aldeias citadas pelos viajantes com a localização dos sítios arqueológicos com ocupação Guarani conhecidos hoje - regiões nordeste, leste e sul da Ilha de Florianópolis no geral (MÜLLER, 2015). Esses são dados a serem trabalhado juntamente àqueles dos registros materiais. Nesse mesmo mapa reproduzido anteriormente, Mello traz outra aldeia Guarani conhecida entre 1527 e 1550 para o litoral central, além daquelas citadas anteriormente: Acutia (MELLO, 2005, P.50). Esta última, Acutia, é descrita e xilografada no livro de Hans Staden mencionado e se trataria de aldeia carijó localizada no continente, próxima ao estreito que este faz com a ilha de Santa Catarina:

"Em 1550, quando o alemão Staden a visitou, um de seus habitantes era um basco de Bilbao chamado Juan Ferdinando, encarregado pelos espanhóis de plantar mandioca para abastecer as suas frotas. Acutia (provavelmente Cutia, roedor do gênero Dasyprocta) é a única aldeia carijó de Santa Catarina representada pictograficamente no século XVI.” (MELLO, 2005, P.53).

Mello realizou, ainda, um levantamento sobre a toponímia quinhentista de Santa Catarina realizada por Lucas Alexandre Boiteaux (já mencionado acima), em trabalho de Boiteaux intitulado Toponomástica da costa catarinense no século XVI (apresentado em 1916). Nesse levantamento, confronta as informações produzidas por Boiteaux com sua pesquisa histórica, elucidando alguns nomes (MELLO, 2005, P.52), como:

- Aboçapecau: segundo descrição de Oviedo y Valdés (1557), Mello registra:

"Aldeia Guarani-carijó situada na ilha de Santa Catarina ou imediações. Boiteaux tenta uma explicação etimológica decompondo a palavra Aboçapecau (...) A expressão resultante seria então y mybyasa i'peka y, i.e., 'barra do porto do rio dos patos'. Para Boiteaux, o atual Massiambu, localizado no continente diante da ponta sul da ilha de Santa Catarina, seria assim chamado em virtude do y mvyasa i'peka y. Oviedo, que situa Aboçapecau na ilha, diz que a aldeia era 'cercada de paliçada, com seus torreões a intervalos, devido aos tupis que estão na terra do rei de Portugal, que são índios inimigos seus. As paredes das casas são de paliçada espessa e embarradas, com suas seteiras, porque são frecheiros; e os tetos ou telhados estão cobertos de cascas de árvores, e o comprimento destas moradias ou casas é de sessenta, oitenta e cem passos”. (MELLO, 2005, P.58)

Interessante observar nesse registro o tom da posse das terras ao reino português, ignorando a presença ancestral indígena no território. Também, há uma breve 
descrição de aspectos das habitações indígenas e paliçadas presentes na aldeia Guarani, ainda que seja levantada a dúvida de onde, de fato, se encontra a aldeia: no continente ou na ilha de Santa Catarina. Ainda, importante sublinhar as grandes habitações mencionadas que, muitas vezes, não aparecem como grandes em outros relatos, como já discutido por Milheira em sua tese de doutorado (MILHEIRA, 2010). Isso, devido ao já desmantelamento ocasionado às populações indígenas com o avanço do contato europeu.

- Riberaco: segundo descrição de Oviedo y Valdés (1557):

"Aldeia carijó na ilha de Santa Catarina ou adjacências. Seria Riberaco uma corruptela de Ribeirão?” (MELLO, 2005, P.59).

- Tameubre, Tiqua e Trinoga: também segundo Oviedo y Valdés (1557), são consideradas todas aldeias carijó na ilha de Santa Catarina ou adjacências, sem etimologia (MELLO, 2005, P.p.61.62).

- Jurumerim, Schirmerein, Yurumiri, Jurumirim: segundo depoimento de Martim de Brás Árias (1549), relato de Hans Staden (1557), descrições de Juan López de Velasco (1574) e Martín del Barco Centenera (1602):

"Esse era o nome dado pelos Guaranis ao estreito existente entre a ilha de Santa Catarina e o continente. Seu significado é composto pelas palavras Guaranis Yuyu (boca) e miri (pequena)" (MELLO, 2005, P.62).

Portanto, observamos que esses breves registros possuem relatos considerados, segundo as ciências humanas contemporâneas, bastante unilaterais e eurocêntricos (típicos da forma de discurso empregada, do contexto vivido pelos autores e do tipo de escrita), mas que nos apontam certas referências com relação aos Guarani que viviam no litoral central catarinense, mais especificamente em Florianópolis rebatizada de Ilha dos Patos para Ilha de Santa Catarina por Sebastião Caboto (MELLO, 2005, 23).

Muitos desses registros, especialmente aqueles de Álvar Núñez Cabeza de Vaca são retomados por historiadores da região, como ocorre em Brighenti (BRIGHENTI, 2012, P.7). Sobre Cabeza de Vaca, afirma que os Guarani litorâneos ou "carijós" mantinham comunicação com os demais Guarani que ocupavam os atuais estados do Rio Grande do Sul, Paraná e São Paulo, e os países Paraguai, Argentina e Bolívia. O navegador Álvar Nuñez Cabeza de Vaca ao ser nomeado governador do Paraguai, desembarcou na Ilha de Santa Catarina, em 1541, e teria seguido pelo caminho do Peabiru até Assunção (Paraguai), guiado pelos Guarani. Durante o percurso, 
Cabeza de Vaca registrou a fartura de alimentos que encontrava nas aldeias por onde passava sua comitiva de mais de 200 pessoas que desde o litoral até Assunção a população Guarani falava uma só língua. Seriam eles lavradores de milho, de mandioca duas vezes ao ano, criavam galinhas e patos, possuíam papagaios e ocupavam uma grande extensão e falavam uma só língua. Apenas no ano de 1528 aparecem com o emprego de "Guarani", nome dado por europeus, na carta de Luiz Ramires (MELLO, 2005;P.7; MÜLLER, 2015'.

Posteriormente, para a região da Ilha, esses registros estariam mais relacionados aos movimentos de conhecimento do território Português, e a preocupação inicial em ocupá-lo (a fim de evitar ocupação espanhola) e maior controle da região do Prata. Então, o contato com bandeirantes, no geral paulistas e caboclos (LOHN, 2004, P.29), também gerou registros. Da mesma forma, os registros são encontrados nos documentos e relatos militares, a partir de uma colonização intencional da coroa portuguesa a fim de guarnecer a Ilha contra inimigos. Uma colonização mais efetiva veio apenas com a tentativa de trazer as famílias açorianas para o litoral. Esse "Caminho do Peabiru" que tanto aparece na literatura sobre os Guarani de uma forma geral e é retomado nos relatos quando se trata de Santa Catarina O Imaginário acerca do Caminho para o Pacífico, da "Terra da Cocanha" que tantos viajantes perseguiram é fortalecida pela associação em muitos momentos realizada pelas interpretações dos relatos e teóricos com a busca pela "Terra sem Mal" pelos indígenas Guarani. Posteriormente, o caminho pelo interior de Santa Catarina com destino a Lages também fora auxiliado por meio das frentes indígenas (LOHN, 2004, P.52; MÜLLER, 2015).

Outro relato bastante comum na literatura histórica é o de Aleixo Garcia após ter sucedido à expedição pela costa brasileira e tendo alcançado o Rio da Prata, na expedição de 1515 quando partiu da Espanha e atingiu quatro meses após o Rio da Prata novamente. Teve um contato malsucedido com indígenas, foi morto e a expedição malogrou (SANTOS, 2004, P.17; MÜLLER, 2015):

“[...] Os sobreviventes desta aventura regressaram para a Espanha. Ao passar pela Ilha de Santa Catarina, um de seus navios naufragou. Da tripulação deste barco, onze homens salvaram-se, juntando-se aos indígenas que habitavam a Ilha. Foram esses sobreviventes os primeiros habitantes europeus da terra catarinense. Foram eles que fizeram as primeiras incursões pelo sertão. Um deles, chamado Aleixo Garcia, ajudados pelos indígenas que habitavam a Ilha, fez uma longa incursão para o 
interior, acabando por atingir a região onde hoje se situa o Paraguai. Isto no ano de 1524." (SANTOS, 2004, P.17).

A antropóloga Darella (DARELLA, 2004; MÜLLER, 2015) apresenta relatos de Boiteux (1912) sobre Taunay explicitando que em 1576 já não havia mais indígenas, tendo esses se retirado para Viaça (Laguna). Além disso:

"Informações de que não havia mais ocupação Guarani na Ilha de Santa Catarina no século XVII, quando do estabelecimento de Francisco Dias Velho e seu propósito de povoação, são comuns e se apóiam em documentos como o apresentado por Pauli (1987:59 apud Fossari, 2004:151): 'A ausência de índio, que já vinha desaparecendo da costa catarinense desde tempos anteriores a 1600, facultava a ocupação relativamente pacífica das terras, sobretudo das ilhas. Uma carta enviada pelo espanhol Juan Ortiz de Zarate, em 29 de março de 1576, revela que o despovoamento indígena começara pela Ilha de Santa Catarina. Em 1635 o missionário Inácio Sequeira declara a Ilha totalmente deserta.'.” (DARELLA, 2004, P.131)

Clovis Brighenti traz em seus estudos que a estratégia adotada pelos Guarani com o não indígena não fora o de confronto. Auxiliaram com alimentos, caminhos e nominaram os lugares e as coisas. Foram disputados pelos escravocratas e Jesuítas nos séculos XVI e XVII. A população do litoral catarinense foi praticamente extinta, e ao perceberem que os não indígenas não eram confiáveis, optaram pelo distanciamento; se faziam invisíveis, preferiram as matas e as migrações como forma de permanecer Guarani. A partir da década de 1970, com a crescente devastação da floresta atlântica, foram violentamente atingidos, segundo ele, aumentando as migrações e os acampamentos nas margens das rodovias (BRIGHENTI, 2012, P.9; MÜLLER, 2015).

De toda forma, esses registros mencionam a preferência dos europeus em alguns momentos em se estabelecer temporariamente no norte da Ilha ou em Massiambu (parte continental); mencionam a fartura de recursos da Ilha, provenientes da terra e das lagoas e laguna, além do mar; os muitos naufrágios ocorridos na região e estada dos europeus por longos períodos para reabastecimento; mencionam a interação por muitas vezes "pacífica" dos indígenas com os portugueses, ora não tanto com os espanhóis; as alianças realizadas com os indígenas; também mencionam "fuga" para o continente por parte dessas populações. Sobre essa fuga para o continente e interior, há muito que problematizar, e o sítio arqueológico TRV nos auxilia nisso. Uma delas é a navegação utilizada por eles entre as ilhas e território litorâneo (para além do tradicional e 
conhecido uso dos rios) e pouco se conhece sobre esse tema na Arqueologia por motivos de conservação dos materiais; e outra é a discussão se essas fugas ocorreram de fato ou não. Como ocorreu a relação entre os Guarani da Ilha e os europeus? Mesmo havendo esses poucos registros escritos que descrevem a pontual interação entre esses povos distintos, compreende-se que essa relação foi bem mais profunda do que a forma que é descrita, houve descendentes dessas relações, e as disputas de poder foram mais complexas. O Guarani foi, por muitas vezes, tratado como aliado, gentil, passivo e pacífico nesses registros. O Guarani também possui a característica de "Guaranizar", ou seja, abranger o diferente sem deixar sua essência (NOELLI, 1993). Como isso pode ter agido na interação com os europeus? Quais foram as estratégias adotadas por eles? Sabe-se que essas populações sempre foram agentes que também compuseram a história do território, agentes na longa duração dessas histórias possíveis. Sabe-se, também, que a conquista causou impacto muito grande na dinâmica das diversas populações indígenas habitantes do território brasileiro, e isso é evidente nos relatos observados. Mesmo assim, conseguimos enxergar a agência desses povos e a dinâmica que os fazem ser Guarani através dos séculos? A Arqueologia pode dar pistas e ajudar a compor essa história no confronto com diferentes fontes.

Darella (DARELLA, 2004, P.p.50-53), trabalhando nas terras indígenas no litoral do estado especificamente com os Mbya, traz o que é o território para o Guarani. Esse território seria um território existencial singularizado, ligando o modo de ser Guarani ao modo de como os Guarani vivem seu espaço geográfico. Não há fronteiras impeditivas para os Mbya em seu movimento. Cita Pacheco de Oliveira (1998) ao mencionar que os povos indígenas possuem fronteiras territoriais bem mais fluidas, que oscilam regularmente em função de variações demográficas, expedições guerreiras ou movimentos migratórios de vários tipos. Além disso, o movimento na vida Guarani dá forma e significado ao território. A vivência, interpretação e reelaboração de mundo formulam o território e por ele são formulados. E, com isso, seria consensual na bibliografia Guarani a importância do parentesco como eixo de transmissão e intercâmbio de conhecimento e memória, bem como de vivência cultural no território, no qual se inserem os deslocamentos e as ocupações.

$\mathrm{Na}$ região de Massiambu (município de Palhoça), trazida nos relatos trabalhados aqui (onde há a presença carijó/Guarani), há uma concentração de sítios arqueológicos observada no mapa da Figura 6, além daqueles presentes no Parque 
Estadual da Serra do Tabuleiro. Essa região também concentra atualmente três territórios indígenas Guarani. São eles: T.I. Morro dos Cavalos, a T.I Massiambu e a T.I Cambirela (FUNAI, 2012), também expostos no mapa da Figura 6 (página 81). Ou seja, até hoje, essas populações se movimentam e mantêm territórios na região, mesmo diante da invisibilização que sofrem perante o restante da sociedade e perante política do Estado nada favorável para com elas. Na Ilha de Santa Catarina, a mesma região (sul) que os relatos mencionam haver as grandes aldeias indígenas no século XVI, também é a mesma que concentra a maior parte dos sítios arqueológicos Guarani da Ilha, dentre eles, um também em estudo nesta dissertação (Lagoinha do Rio Tavares I).

Nos concentramos, pois nesta pesquisa com os vestígios materiais adiante problematizados, a compreender os Guarani "pré-coloniais" na região de estudo sem, contudo, deixar de se ter em mente o período do contato europeu e o primeiro século de interação entre esses povos (que os relatos quinhentistas nos propiciam). Os vestígios materiais estudados, como serão vistos adiante, não possuem marcas desse contato, ainda assim, compreende-se aqui que as fronteiras culturais são muito mais fluidas do que se costuma determinar, como propôs Darella. Imagina-se alguma forma de interação e ação indígena Guarani frente ao contato quinhentista e problematizado através do sítio arqueológico Travessão do Rio Vermelho. Para os séculos seguintes, de efetiva colonização europeia (séculos XVIII e XIX), ressalta-se a pesquisa de Angela Salvador (SALVADOR, 2017), que buscou nos vestígios materiais e nos registros escritos (cronistas e documentos oficiais) as marcas indígenas na sociedade colonial da Ilha de Santa Catarina. Para os séculos XVIII e XIX, outros cronistas são citados e conhecidos, como François Frézier, John Mawe, Duperrey e G.H. von Lagsdorff (PALMA DE HARO, 1979).

\subsection{Arqueologia Tupi e Arqueologia Guarani: origens e expansão}

Existem aproximadamente 6000 sítios arqueológicos Tupi (abrangendo os falantes de línguas Tupi-Guarani) registrados no Brasil, Argentina, Paraguai, Uruguai e Bolívia, com 643 datações que abrangem o período de 4.500 A.P até depois da chegada dos europeus nas Américas (SILVA \& NOELLI, 2017, p.63; CORRÊA, 2017). Os autores Silva \& Noelli (2017) e Corrêa (2017) mencionam que essas últimas 
informações estão em um banco de dados que vem sendo constituído ao longo de anos por Brochado (1984), Noelli (1999-2000; 2004), Corrêa e Samia (2006), Corrêa (2009; 2014) e Bonomo et.al. (2014) e obteve últimas atualizações e revisões com Silva e Noelli e com Corrêa (2017). Dentro os sítios Tupi, existem 1177 sítios arqueológicos Guarani com 248 datações radiocarbônicas (BONOMO et al., p.4).

Os estudos em Arqueologia Guarani concentram-se no período cronológico após a diferenciação das populações de línguas Tupi-Guarani do tronco Tupi, que teria ocorrido por volta de 2500 (RODRIGUES, 1964) a 3000 anos atrás segundo pesquisas recentes (SILVA \& NOELLI, 2017). Cabe destacar, a partir do é dito por esses últimos autores que a Arqueologia Guarani em nenhum momento pode se deslocar do contexto geral de estudos Tupi, afinal, o que se busca de forma geral com essas pesquisas é justamente compreender a dinâmica por detrás do objeto, dos padrões, dos modelos, das "fronteiras" já estabelecidas, compreender a dinâmica das populações falantes do mesmo tronco linguístico, e com as demais, a relação do "micro" com o "macro" em distintos aspectos.

Ao falar em uma Arqueologia Guarani logo se pressupõe a associação com os falantes Tupi-Guarani atuais, os Guarani distribuídos por diversos estados do Brasil Mato Grosso do Sul, São Paulo, Paraná, Santa Catarina e Rio Grande do Sul-, e demais países da América do Sul - Paraguai, Argentina, Uruguai, além do Brasil (BONOMO et al., 2015; MÜLLER, 2015). Portanto, apesar de um processo bastante drástico, como o contato europeu nos anos de 1500 e as subsequentes violências aplicadas por essa nova sociedade e forças oficiais, é compreendida uma continuidade com relação aos falantes das línguas Tupi-Guarani anteriores ao contato, por exemplo, uma história de aproximadamente três mil anos suportada através do registro material (Arqueologia) e da Linguística (BROCHADO, 1984; NOELLI, 1993; SILVA e NOELLI, 2017).

Podemos observar que no Brasil e América do Sul de forma geral, a associação entre Arqueologia e Linguística na compreensão do que seriam os elementos Tupi e o Guarani ao longo do tempo apresentou-se forte desde o século XIX e seu legado permaneceu até a contemporaneidade (e está presente nesta pesquisa). Alguns autores já se debruçaram rigorosamente para retomar o histórico e a crítica a essa trajetória, como: Noelli (1993), Silva \& Noelli (2017), Bonomo e colaboradores (2014), Dias (2012) e Corrêa (2014). Observa-se que as sínteses sobre Arqueologia Tupi são 
caracterizadas por uma diversidade de abordagens teóricas que encontra paralelo com o próprio histórico de estruturação da disciplina no país (DIAS, 2012, p.121). Recomenda-se, aqui, o trabalho de Corrêa (2014) como aquele mais atualizado e que propõe uma releitura da expansão Tupi pela América do Sul.

Nessa linha de raciocínio, Silva e Noelli (2017) enfatizam que a Arqueologia, assim como outras ciências sociais, busca compreender a relação entre cultura material, língua e etnicidade. Os/as arqueólogos/as têm se empenhado em explicar as causas e o significado da variabilidade e da padronização artefatual encontradas no registro arqueológico e um de seus objetivos seria procurar responder se elas podem ser bons indicadores para se compreender as identidades e fronteiras sociais e linguísticas no passado (SILVA \& NOELLI, 2017, p. 55). Para Dias (2012), a Arqueologia Tupi foi fortemente influenciada por modelos Amazônicos, e tem sido marcada pela oposição entre propostas interpretativas que enfatizam seu caráter performativo (enfoque histórico-cultural) ou seu caráter prescritivo (enfoque históricodireto) (LINO, 2009, P.23 apud DIAS, 2012, P.121).

Como trabalho consequente desse período e de grande impacto para todas pesquisas subsequentes, encontramos aquele de Francisco Noelli, cujo modelo aponta para uma identidade prescritiva Guarani no sul brasileiro proveniente de tal dispersão. A pesquisa de Noelli trata-se de um modelo de território Guarani. Para Dias, os trabalhos de Noelli (1993) e Soares (1997) marcaram o início de um processo de ruptura radical com as interpretações tradicionais ao integrarem à interpretação arqueológica modelos sobre territorialidade e mobilidade Guarani, fortemente embasados em uma extensa revisão da bibliografia dos cronistas do século XVI e XIX. A densidade, variabilidade e profundidade temporal do registro arqueológico Guarani passaram a ser entendidos em função de estratégias de manejo dos recursos da floresta subtropical, que ordenados por complexas redes sócio-políticas, ofereceriam ocupações de longa duração (DIAS, 2012, p.130).

O método léxico-estatístico glotocronológico sugeriu que a diferenciação do Tronco Tupi teria iniciado mais de cinco mil anos atrás, isto é, antes de 3000 a.C.; enquanto que a separação da própria família Tupi-Guarani teria começado antes de 2500 anos atrás, isto é, 500 a.C., e não recentemente como se pensava (SILVA \& NOELLI, 2017). Estas datações são muito mais antigas do que imaginavam os 
etnólogos que propuseram uma expansão rápida e próxima da chegada dos europeus. Assim, os Tupi já estariam dispersos pelo Brasil há 1900 anos em áreas muito distantes entre si e dos centros de origem propostos (NOELLI, 1993). Parte da expansão geográfica das cerâmicas policrômicas, exceto na região andina e nos Llanos da Venezuela e para além, deveria ser correlacionada com a expansão dos Tupi a partir da Amazônia Central (NOELLI, 1993). Com tais informações, combinadas com aquelas datações radiocarbônicas produzidas com o Programa Nacional de Pesquisas Arqueológicas (PRONAPA) (1965-1971) - e utilizando algumas das categorias por ele produzidas -, Noelli (1993) afirma que os ancestrais dos Guarani passaram para a drenagem do Paraguai e se espalharam pelo sistema fluvial Paraná-Paraguai-Uruguai, pela costa atlântica adjacente e as bacias dos rios costeiros, onde foram encontrados pelos europeus. Isso, após um ramo da cerâmica da subtradição Guarita ter sido levado para fora da Amazônia por novas migrações, devendo ter subido para o sul pelo Madeira-Guaporé. Datações radiocarbônicas ao redor de 200 a.C. para o início desta transformação são sugeridas pelo fato que ca. A.D. 100-200 a cerâmica da subtradição Guarani já se encontrava espalhada desde o alto Paranapanema até o médio Jacuí (NOELLI, 1993, p.74).

Analisando dados etnográficos sobre os Tupi e seu contato com o europeu, e as semelhanças e diferenças entre Guarani e Tupinambá, Noelli conclui sobre o funcionamento do modelo geral construído para explicar os padrões arqueológicos e etnográficos demonstrados pela distribuição das populações indígenas na América do Sul tropical. Para ele, é necessário postular um lento e constante aumento da população na Amazônia Central, o qual alimentava a contínua expansão, primeiro dos falantes Aruak, depois dos falantes Tupi, Karib e outros grupos (LATHRAP, 1962, 1970, 1977; BROCHADO e LATHRAP, 1980; BROCHADO, 1981 apud NOELLI, 1993, P.74). Isso tudo quer dizer que a ocorrência de desequilíbrios demográficos entre estas diferentes culturas é crucial para a expansão.

Dessa forma, Noelli (1993) reafirma que o motor das expansões Tupi fora a pressão demográfica causada pelo lento e contínuo aumento da população e devido ao eficiente aproveitamento dos recursos do ambiente - no caso, as extensas várzeas fluviais amazônicas. A esse fenômeno, Brochado (1984) havia se referido como “enxameamento", retomado por Noelli. Estas várzeas, exploradas pelo sistema indígena de cultivo e manejo ambiental, eram capazes de sustentar apenas densidades 
relativamente baixas de habitantes, em relação à área de apropriação que necessitavam. A competição pelos recursos limitados teria forçado as comunidades a se afastarem, buscando sempre, porém, o mesmo nicho ecológico - os ricos solos aluviais, fáceis de trabalhar e que produziam o máximo com o mínimo de esforço. As condições de constrangimento das várzeas e a própria disposição dos rios, tornou estes movimentos lineares, levando a que eventualmente certos ramos das migrações saíssem da área amazônica, invadindo o resto da América do Sul por diversos caminhos. (NOELLI, 1993, p.79).

Mas, e os Guarani e sua expansão? Onde se inserem nessa expansão Tupi, sendo os Guarani falantes do tronco Tupi? Bonomo e colaboradores (2014) também exploraram as propostas de Brochado $(1984,1989)$ e Noelli (1993) ao propor o uso e produção de dados através de um Sistema de Informação Geográfico (SIG/GIS) para compor essa história de longa duração na dispersão e expansão Guarani pela América do Sul (BONOMO et al.,2015). Em cima dos dados densamente compilados, foram formados os seguintes layers utilizados no SIG: Digital Elevation Model (DEM), Dispersion Routes Model (DRM), e o Temporal Visualization Model (TVM). No entanto, esse número de sítios arqueológicos cresce, e sabemos da complexidade de se realizar tal levantamento e de haver um levantamento completo, uma vez que dependem fortemente da classificação dada pelos arqueólogos aos sítios arqueológicos e vestígios encontrados, da divulgação dos trabalhos realizados, da localização da maior parte das pesquisas e do impacto ao longo de mais de quinhentos anos de história, uma questão de amostragem. A concentração desses vestígios está identificada, segundo o referido trabalho, nas regiões adjacentes do rio Guaíba, posteriormente no Alto Uruguai, Alto Paraná e então na costa atlântica e Lagoa dos Patos. Faltam pesquisas no Paraguai especialmente e no estado de Mato Grosso do Sul em fronteira com aquele mesmo país a fim de aprofundar estudos sobre a origem da dispersão Guarani. Compreende-se, também o movimento de expansão Guarani (não mais migração), em poucas palavras, como partindo das regiões mais ao norte em direção ao sul dos países e ao litoral brasileiro, com evidente concentração ao longo dos grandes rios (MÜLLER, 2015).

Os modelos gerados por Bonomo et.al. (2014) para a dispersão Guarani coincidem com as propostas de Brochado (1989) para os Tupi e Noelli $(1993,1998)$ de forma geral, ainda que haja algumas divergências com relação às rotas que essas populações Guarani seguiram e suas cronologias. Os resultados obtidos nesse estudo 
(BONOMO et. al.,2015) suportam a ideia de Brochado (1989) e Noelli (1998) de que o fenômeno consistiu em uma expansão populacional e não migração. E, ainda retomando, ambos os autores seguiram Lathrap (1956) e propuseram que o crescimento contínuo demográfico devido a agricultura tenha causado fissões nas vilas e subsequentes buscas por novas terras a cultivar na periferia dos domínios. Haveria, então, um sistema Guarani de conexões de vilas interconectadas por alianças políticas, econômicas e sociais; além disso, essa divisão em vilas proporcionou o domínio além das terras sem deixa-las. Isso significa arqueologicamente que independentemente de datas antigas, também é possível obter datas recentes num mesmo local. Esse movimento corresponderia mais a expansão das fronteiras que a migração de um local a outro (ondas migratórias) (BONOMO et al.,2015, p.p.14-15).

Percebe-se, ainda, que as datações mais antigas encontram-se nas regiões de Mato Grosso do Sul, São Paulo, Paraná, Rio Grande do Sul e Argentina, lembrando novamente que este não é um panorama amplo, uma vez que há poucas datações para os sítios, conforme visto, e de o Paraguai, por exemplo, não apresentar nenhuma delas até então. São os sítios: Lagoa 1 (MS/Brasil), Acampamento 3 (SP/Brasil), João Batista (PR/Brasil), Fazenda Dona Carlota (PR/Brasil), Emilio Kieffer (RS/Brasil) e San Miguel II (Corrientes/Argentina). São datas que se encontram entre 2010+-75 e 1700+230 A.P, ou seja, no período de 0 a 300 A.D (BONOMO et. al.2015, P.5). Por exemplo, espera-se que as datas mais antigas para o estado de Santa Catarina estejam em sua região oeste, mas há algumas delas contemporâneas no litoral, para o qual novamente, falta-nos detalhamento (MÜLLER, 2015). Segundo esse mesmo trabalho de Bonomo et.al. (2014), durante os primeiros três séculos de nossa era, a evidência mais antiga aparece na Bacia do Rio da Prata, e então com a confluência dos rios Paraná e Iguaçu. Entre 300 e 1.000 A.D (contando com 25 sítios e 35 datações) se observa momento de estabilidade, com a permanência de áreas ocupadas e poucos dispersões para novas áreas nos primeiros quatro séculos. E há um aumento nas áreas já ocupadas na confluência dos rios Paraná e Iguaçu, na bacia do Ivaí, no rio Uruguai e na média bacia do rio Jacuí. As novas áreas estão restritas aos pontos mais ao sul, e finalmente ao fim desse milênio, começaria a ocupação da costa atlântica. Entre 1.000 e 1.780 A.D (contando com 198 datações absolutas para 117 sítios arqueológicos e com cinco sítios com material de origem europeia), a ocupação cresce nas áreas já ocupadas, e então, aumentam significativamente as datas para as regiões dos rios Paraná e Iguaçu, a bacia 
do Paranapanema, o rio Ivaí, a bacia do rio Jacuí, o Alto Uruguai, a costa atlântica de Santa Catarina e Rio Grande do Sul e a parte norte da província de Corrientes na Argentina. Novas áreas são ocupadas nesse período: a costa norte de Santa Catarina (com os sítios Poço Grande e Tapera); o rio Miranda (tributário do Paraguai); o alto Uruguai em direção ao rio Pelotas; rio Iguaçu; Lagoa dos Patos; bacia Camaquã; bacia do rio Cebollatí; o médio e baixo Uruguai; o delta do Paraná; e o Rio da Prata.

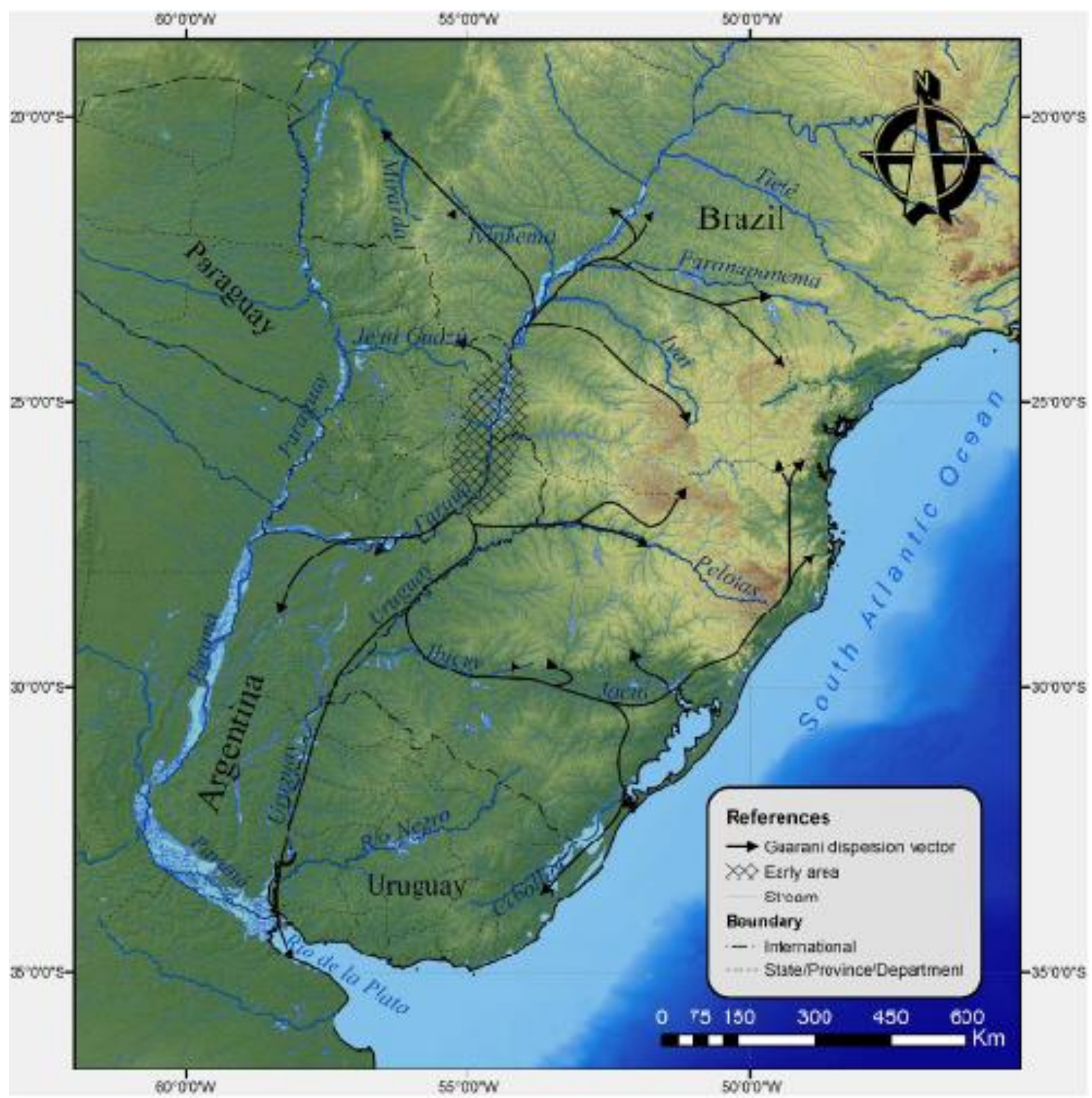

Figura 2. Mapa com rios principais na dinâmica da expansão Guarani. Fonte: BONOMO et.al., 2015.

Por fim, de 1.000 A.D em diante, com a crescente densidade de sítios em todas as áreas ocupadas, também é possível observar pulsos de dispersão em todas as direções: observa-se movimento a oeste e leste do rio Miranda, para a costa Atlântica do Brasil e Uruguai; em um segundo momento, para as galerias de florestas e os baixos cursos dos rios Paraná e Uruguai e nos braços do rio da Prata. Essa dinâmica de 
mobilidade foi, então, transformada drasticamente no começo no século XVI (NOELLI, 2004), coincidindo com aquelas causadas pela conquista e colonização luso-hispânica (BONOMO et al.,2015, P.p.11-13). Todo esse breve panorama, ainda nos remete a pensar e buscar compreender a interação ocorrida entre os Guarani e os demais grupos humanos. Essas observações sobre o trabalho de Bonomo et.al. (2014) já tinham sido trazidas pela autora (MÜLLER, 2015) em trabalho de conclusão de curso.

\subsection{Por uma Arqueologia do Lugar Guarani}

Bowser (BOWSER, 2004) afirma que a habilidade de compreender múltiplas perspectivas na Arqueologia dos lugares é crítico para a prática da Arqueologia hoje em dia; e, como arqueólogos/as, o nosso próprio senso de lugar na ciência e na sociedade está em processo de reconstrução, como as fronteiras da prática arqueológica global está a ser inclusive em construção para múltiplas vozes, incluindo indígenas, minorias étnicas e outros públicos cujos passados estão representados. Retoma Peter Whitridge (WHITRIDGE, 2002, P.1) que observa que a noção de 'lugar', de lugar significativo, assume um discurso marcado e não precisa estar atrelado à Arqueologia da paisagem. Recentes contribuições de Bradley (1998, 2000), Ingold (1993), Tilley (1994) e outros (como ASMORE, 2002; JOYCE \& FILLESPIE, 2000; MESKELL, 2003; ROBIN \& ROTHSCHILD, 2002; e ZEDEÑO, 1997), segundo Bowser, marcam a emergência da 'Arqueologia do lugar', localizada parcialmente na Arqueologia da paisagem, no entanto, mais preocupada em compreender em como as pessoas comunicam e dão sentimento ao seu redor cultural e físico em múltiplas escalas.

Os/as arqueólogos/as engajados com os desafios de compreender os significados sociais e culturais de lugares arqueológicos estão comprometidos/as por razões que vão de puramente intelectuais, a práticas, a convicções morais e éticas. Ainda, todas as abordagens para tais significados requerem considerações da experiência subjetiva, um conceito que estremece as bases do inquérito arqueológico científico. Por consequência, como manter o rigor teórico e metodológico e a base empírica arqueológica enquanto adicionamos múltiplos significados e perspectivas na arena da prática política? Isso é algo que Bowser (2004) questiona e para isso, autores têm focado no uso de dados arqueológicos e etnoarqueológicos para compreender os 
significados sociais e culturais dos lugares e as manifestações materiais de tais significados. Os autores, segundo ela, têm partido dos caminhos de como pessoas dão significado ao seu universo cultural e físico e identificam abordagens teóricas e metodológicas para a análise arqueológica.

Peter Whitridge afirma que:

"With the emergence of a landscape archaeology focused on practical, meaningful, and sociopolitical aspects of people's relationship to the natural and built environment, place has increasingly acquired a specialized sense opposed to space, as the local and the meaningful are opposed to the universal and the objective". (WHITRIDGE, 2004, P.213)

Lugar é compreendido pelo autor (WHITRIDGE, 2004, P.214) como o efeito de um movimento geral do pensamento e a prática que imbrica no real e no representativo de complexos e heterogêneos níveis de sítios. O investimento de locais particulares com significado (place-making) seria um processo social e cognitivo onipresente. Um lugar pode ser pensado como um imaginário especializado, um nexo de significados imaginários no lugar de sua intersecção com o real:

"The notion of imaginaries opened up by this rethinking of place usefully orients us to hybrid past realities constituted by historically emergent networks of representations, embodied practices, and things.” (WHITRIDGE, 2004 P.214)

Segundo o autor, os lugares são significantes não simplesmente neles mesmos, mas como os lugares de conexão entre o real para um espaço de circulação de significados socialmente inteligíveis, nos quais entidades que são incomensuráveis com respeito a materialidades - paisagens, casas, corpos e coisas - facilmente exportam propriedades na forma de atributos conceituais e associações simbólicas (WHITRIDGE, 2004, P.240). Zedeño e Bowser (2009) afirmam que Basso (1996) demonstra a intrínseca rede de conexões que existe entre identidade, trajetória, memória, e noções de terra natal. Lugar, na visão dele, seria onde história, tanto humana quanto outra, acontece e onde o conhecimento adquirido vivendo a história reside.

De acordo com Agnew (AGNEW, 1987 apud ZEDEÑO, BOWSER, 2009, P.1), um lugar é a conjuntura onde meio ambiente, pessoas e significado convergem em múltiplas escalas e, no processo, criam um registro da presença do comportamento humano, da percepção e cognição. O registro material da presença humana em um lugar 
é, de fato, tema da Arqueologia; os significados econômico, social, político e simbólico uma vez inscritos em locais na paisagem devem emergir no processo de reconstrução e interpretação dos passados das pessoas a partir do registro arqueológico.

Ainda que a Arqueologia do lugar seja de interesse atual, não é novo na profissão, uma vez que Lewis Binford foi o pioneiro moderno no reconhecimento do poder e do potencial desse conceito. E, no artigo "The archaeology of Place", Binford argumenta que:

"until we turn our serious attention to the design of reliable methods for monitoring past conditions of interest, we will never be able to address interesting questions through the investigation of archaeological remains.... We must turn our analytical attention to the role of different places in the organization of past systems [1982:28-29]" (ZEDEÑO, BOWSER, 2009, P.1)

Ainda que a ecologia humana e a geografia cultural tenham tido um grande impacto na teoria antropológica desde a década de 1930 (com Steward, 1955; Steward e Seltzer, 1938; e Wedel, 1941, 1953), segundo as autoras, o positivismo que acompanhou a advento da Nova Arqueologia (ou New Archaeology) inicialmente contornou inúmeros aspectos da dinâmica humana-natureza para criar um visível registro material (Binford, 1962). Estudos em paisagem e lugar voltaram a ter popularidade como resultado da geografia humanística de Cosgrove (Cosgrove e Daniels, 1988), Jackson (1984), Pred (1984) e Tuan (1977), dentre outros, e esses conceitos rapidamente apareceram na literatura antropológica da América do Norte, Austrália e Europa. O trabalho influenciador de Basso (1996) combinou os princípios da etnosemântica com abordagens geográficas de lugar. E então, ao longo de definições e trabalhos, foram expandindo e relendo a temática e abordagem e pesquisadores contemporâneos têm aberto cada vez mais o tema para agendas políticas e intelectuais. Além disso, lugares particulares contêm elementos para a compreensão de mundos sociais construídos, mantidos e modificados por aqueles que uma vez os habitaram. Isso pode ser alcançado através de investigações biográficas, topográficas, geopolíticas, ideológicas, cosmológicas e aspectos mnemônicos do lugar construído e continuamente com o desenvolvimento de trabalhos entre lugares e entre lugares e paisagens mais amplas. Após Lewis Binford (1982), tem sido um trabalho lento, segundo elas (ZEDEÑO, BOWSER, 2009, P.4) integrar, desenvolver e operacionalizar método 
arqueológico com entendimentos teóricos de lugares significativos para viabilizar cada vez mais sua aplicação:

"In archaeology of place, as Bowser (2004) defines it, is one that focuses on the ways in which people impart meaning - both symbolically and through action - to their cultural and physical surroundings at multiple scales and on the material forms theses meanings may take. Its premise is simple: people create places through behavioral interactions with nature and the supernatural; they recognize their experiences by developing spatial referents for their actions through material modification and verbal and metaphoric inscription. On the basis of theses cognitive processes, people develop senses of place and attachments to place that motivate, structure, and transform their interactions with the material world in patterned ways (...). Thus, the scrutiny of archaeological places as geographic or architectural referents of human behavior, perception, cognition, and history has the potential to reveal an untold wealth of cultural and social information" (ZEDEÑO, BOWSER, 2009, P.5).

Então, uma Arqueologia do lugar deve considerar meios naturais e modificados (ou meio construído / built environment), o que é uma Arqueologia das relações históricas das pessoas com a natureza. Mais recentemente, agência e materialidade deram à Arqueologia do lugar um foco mais fresco ao trazer esses esforços à percepção, prática e memória. Os lugares e paisagens apresentam multi níveis; cada nível representa uma forma particular de experiência e cognição (ZEDEÑO, BOWSER, 2009, P.1).

Sobre a diferença entre lugar e espaço, Whitridge esclarece:

"In an increasingly common usage that first crystallized in phenomenological geography, space is taken to refer to the universal, abstract, quantifiable quality of spatial extension, especially as conceived and developed by objectifying sciences like physics or urban planning or, for that matter, archaeology. Place, on the other hand, is taken to refer to a qualitative, historically emergent, experientially grounded mode of inhabiting or dwelling in the world that invests particular locations with personal and collective significance. Tilley (1994) employs such a dichotomous characterization as the foundational premise of a new phenomenological landscape archaeology." (WHITRIDGE, 2004, P.214).

E, o que é um lugar significativo? Conforme Zedeño e Bowser (2009, P.6), lugar é um locus discreto de comportamento, materiais e memória. Um local significativo é um produto das interações entre as pessoas com a natureza e o 
sobrenatural, bem como um com o outro. O reconhecimento da existência do lugar e sua significância pelo indivíduo e o coletivo é o que define seu significado, evidencia sua trajetória histórica, explica suas conexões com outros lugares, e coloca sua articulação com a paisagem mais ampla tacita ou explicitamente.

Portanto, será buscado trabalhar com os conceitos de lugar e lugar significativo a partir dos os objetos de estudo desta pesquisa e contribuir na construção dessa Arqueologia Guarani de longa duração na região. 


\section{CAPÍTULO 3: ARQUEOLOGIA GUARANI NO LITORAL CENTRAL CATARINENSE}

O litoral central aqui é delimitado como a faixa de municípios compreendidos entre Porto Belo e Garopaba, sendo o total de nove municípios: Porto Belo, Tijucas, Governador Celso Ramos, Biguaçu, São José, Florianópolis, Palhoça, Paulo Lopes, Garopaba. A área de pesquisa do Parque Estadual da Serra do Tabuleiro que abrange, dentre outros municípios, partes dos municípios de Palhoça e Florianópolis não foi alvo de aprofundamento nesta pesquisa por hora. Os municípios que fazem parte do litoral central estão demonstrados na Figura 3: 


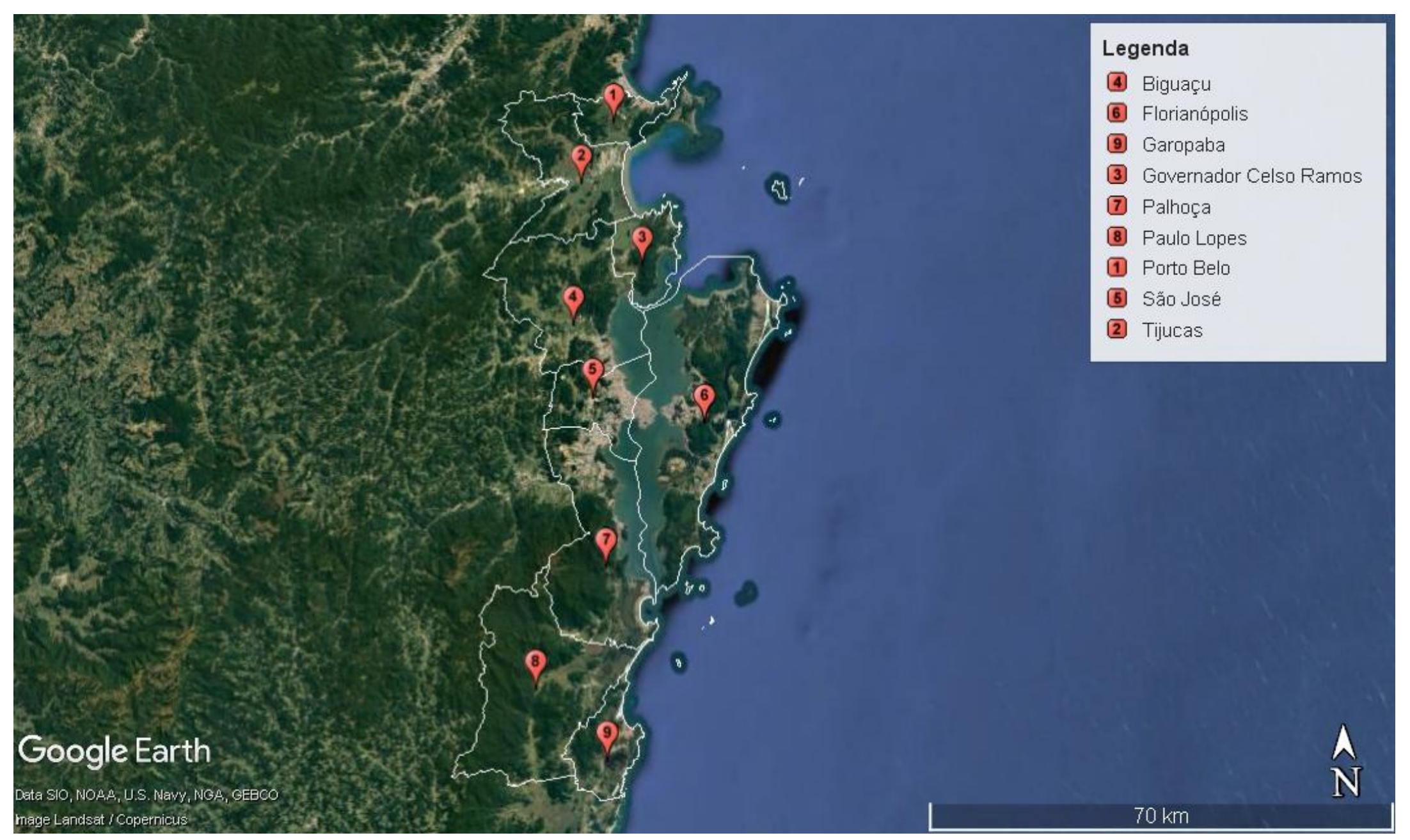

Figura 3. Municípios que compõem a área da pesquisa de dissertação. Elaborado pela autora utilizando o software Google Earth. 
Neste tópico são retomados os trabalhos mais representativos na Arqueologia realizados até o momento no litoral catarinense, área de estudo deste trabalho (BANDEIRA, 2004; LINO, 2007; MILHEIRA, 2010, por exemplo). O panorama de pesquisas arqueológicas do litoral central é enfatizado, congregando também as primeiras pesquisas realizadas por Walter Fernando Piazza (PIAZZA, 1965, 1967) e Pe. João Alfredo Rohr (SCHMITZ, 1959), no início do período que se chamou de "a institucionalização da Arqueologia no Brasil" (FERREIRA, 1999), além de Maria José Reis e Alroino Eble (EBLE e REIS, 1976). Além disso, estão sendo explorados, pela autora nesta dissertação, os levantamentos mais atualizados realizados nas publicações, como em Noelli e colaboradores (NOELLI, MILHEIRA, WAGNER, 2014). Esse trabalho, apesar de considerar o litoral central com fronteiras sociopolíticas atuais, leva em conta um estudo sobre território e paisagem que pode extrapolar as mesmas.

\subsection{Principais pesquisas}

Destacam-se no litoral de Santa Catarina as seguintes pesquisas:

A pesquisa de doutorado de Rafael Guedes Milheira (MILHEIRA, 2010), intitulada Arqueologia Guarani no litoral sul-catarinense: história e território, buscou compor um modelo regional de ocupação Guarani no litoral de Jaguaruna, sul de Santa Catarina, enfatizando a compreensão dos processos histórico-culturais que compõem o sistema de assentamento. Sua pesquisa foi consequência de um trabalho vinculado à Arqueologia empresarial, na qual levantou 17 sítios arqueológicos e realizou intervenções em sub-superfície em sete deles. Por meio de abordagem intra / inter-sítio, articulou questões sobre os espaços habitacionais e problemas regionais que englobam diferentes estratégias de assentamentos dos grupos Guarani na paisagem e suas articulações. Os temas abordados pelo autor versam sobre organização social, economia regional, função de sítio, território e estratégias de assentamento. Articulou dados arqueológicos, etnohistóricos e etnográficos, buscando um estudo que propõe compor uma narrativa sobre a história de longa duração, além de tratar de aspectos de abandono do território de domínio Guarani, em parte, pela violência indígena realizada e descrita na literatura histórica do Brasil Colônia. Trabalha, ainda, pensando sobre o processo de 
expansão desse grupo no sul brasileiro em uma dinâmica de diferentes vias de acesso da serra ao litoral sul (MÜLLER, 2015).

A tese de Dione da Rocha Bandeira (BANDEIRA, 2004), denominada Ceramistas pre-coloniais da Baia da Babitonga, SC : Arqueologia e etnicidade, foi desenvolvida litoral norte do estado com sítios arqueológicos classificados anteriormente como referentes às tradições arqueológicas taquara-itararé e tupiGuarani, são eles: Itacoara, Bupeva II e Poço Grande. A autora trabalhou com o conceito de etnicidade, e enfatizou elementos como os vestígios faunísticos e o ambiente de inserção dos sítios arqueológicos. A autora buscou produzir informações para cada sítio com cerâmica, apontando similaridades e diferenças, com o intuito de realizar um estudo regional e comparar sua área de pesquisa com outros contextos arqueológicos e grupos indígenas, para ao final propor uma Etnohistória para a região (MÜLLER, 2015).

Ainda, na região do litoral sul do estado, na Bacia do Rio Araranguá, Jaisson Teixeira Lino (LINO, 2007), em dissertação de mestrado intitulada Arqueologia Guarani na Bacia Hidrográfica do Rio Araranguá, Santa Catarina, também se valeu de dados arqueológicos e etnohistóricos, propondo um modelo de mobilidade e área de domínio - para pensar a história de longa duração Guarani na área. Contradizendo (baseado em Rogge, 1996) o modelo standard formulado por Betty Meggers ("fatores limitantes”), utiliza dados relativos ao ambiente disponíveis para a área, além de estudos etnográficos, e o estudo de três coleções cerâmicas escavadas durante a vigência de um projeto de Arqueologia de contrato. Sua análise cerâmica buscou desenvolver o perfil tecnológico e a funcionalidade das vasilhas. Lino teve assim como objeto de pesquisa, o sistema de assentamento e a cultura material proveniente de vinte sítios arqueológicos Guarani na região (MÜLLER, 2015).A partir da síntese de pesquisas realizadas, podemos observar os esforços para procurar desenvolver histórias de longa duração para diversas regiões catarinenses. A região litorânea central merece estudos detalhados de forma contextual. Podemos destacar pesquisadores que atuaram fortemente no litoral central, e cujas pesquisas se tornaram emblemáticas para o conhecimento dos contextos Guarani. As primeiras pesquisas foram realizadas pelo Pe. João Alfredo Rohr (SCHMITZ, 1959), um jesuíta, estudioso e arqueólogo amador, e que atuou em todo o estado catarinense, inclusive junto ao Serviço do Patrimônio Histórico e Artístico Nacional (o SPHAN) contra a destruição dos sítios arqueológicos no estado; e pelo 
Prof. Walter Fernando Piazza (PIAZZA, 1965, 1967), professor de História da UFSC, realizando as pesquisas no âmbito do PRONAPA. Outros nomes fortes para a região foram Maria José Reis e Alroino Eble (EBLE e REIS, 1976), principalmente com relação ao relatório de impacto social produzido por eles na área do Parque Estadual da Serra do Tabuleiro (constante, em sua maior parte, na região que denominamos aqui como litoral central). Reis e Eble identificaram sítios arqueológicos e os elencaram conforme as características que observaram, atribuindo "tipos", embora não tenham relacionado à ocupações humanas.

A princípio, e baseados nas referências existentes para os sítios arqueológicos de ocupação Guarani, sugerimos que provavelmente muitos daqueles sítios identificados por Reis e Eble (1976) como "mancha preta" são referentes à ocupação Guarani na região. A listagem desses sítios foi elaborada pela autora a partir do relatório, e encontra-se em anexo (ANEXO 01). No entanto, é difícil afirmar tal correlação, pois faltam pesquisas na área que retomem a localização desses sítios e a realização de atividades sistemáticas no contexto. Recentemente, a graduanda em História (UFSC) e pesquisadora do LEIA/UFSC, Victoria Scabora realizou pesquisa na área, propondo mapeamento dos sítios a partir da listagem feita e disponibilizada em anexo e dos registros de Reis e Eble (1976), e analisando uma coleção cerâmica na região, tendo registrado tudo em relatório publicado em janeiro de 2019 (SCABORA, 2019). Esta dissertação, por hora, não aprofundou a discussão sobre essa região (ainda que ela abranja partes dos municípios de Palhoça e Florianópolis, localizados no litoral central), por isso os sítios identificados por Reis e Eble (sem coordenadas geográficas) não estão sendo considerados no mapeamento feito e apresentado adiante. E, mais recentemente o LEIA/UFSC, sob supervisão do Dr. Lucas Bueno desenvolveu um projeto de recadastramento e levantamento de todos os sítios arqueológicos na Ilha de Santa Catarina em convênio com a superintendência regional do IPHAN no estado. O projeto denominado Florianópolis Arqueológica (BUENO et.al., 2012, 2014) ocorreu entre os anos de 2012 e 2015, e contou com as escavações arqueológicas de três sítios arqueológicos, sendo um deles de ocupação Guarani, o sítio TRV, cuja coleção cerâmica é analisada nesta dissertação.

\subsection{Ocupação Guarani no litoral central de Santa Catarina}


Com relação aos levantamentos mais recentes, temos aquele realizado por Noelli, Milheira e Wagner (2014). Para o litoral catarinense de forma geral, esse levantamento consta 200 sítios arqueológicos identificados, sendo apenas 15 com datações absolutas, como observado no gráfico a seguir. As duas datações radiocarbônicas vindas do sítio Travessão do Rio Vermelho (em Florianópolis) ainda não havia sido incluídas nesse trabalho. Assim, tem-se que o litoral sul do estado ainda é aquele mais explorado nas pesquisas no que tange a temática Guarani. No geral, as datações mais antigas encontram-se nessa região - aquelas mais antigas são encontradas

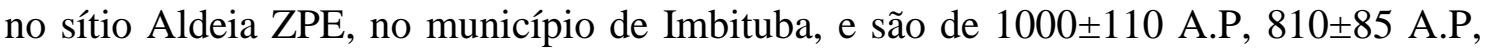

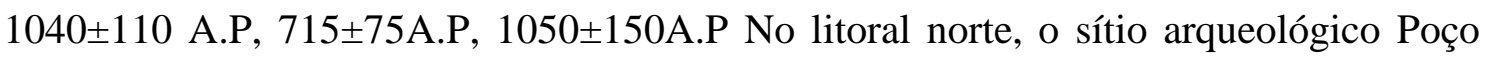
Grande possui uma das datações mais recentes, ou seja, 340 35 A.P/TL (NOELLI, MILHEIRA, WAGNER, 2014, P.p.205-255). O litoral central apresenta um conjunto relevante de sítios arqueológicos identificados nos municípios de Florianópolis e Palhoça e adjacências, mas estes foram alvo de pouquíssimos estudos sistemáticos.

É importante pontuar que esse aspecto e amostragem que os levantamentos possuem são bastante condicionados a uma menor ou maior urbanização das áreas, aos objetos de pesquisas dos cientistas, a áreas de empreendimento de grande porte, dentre outros fatores. Portanto, não refletem um real panorama de concentração dos sítios, mas um panorama possível para o momento de pesquisa que se vive. Com todas as datações conhecidas para o litoral catarinense, baseado nos trabalhos de Noelli, Milheira e Wagner (2014) e Bueno et al. (2014) (dados da Tabela 4), foi elaborado o seguinte gráfico (Figura 4): 


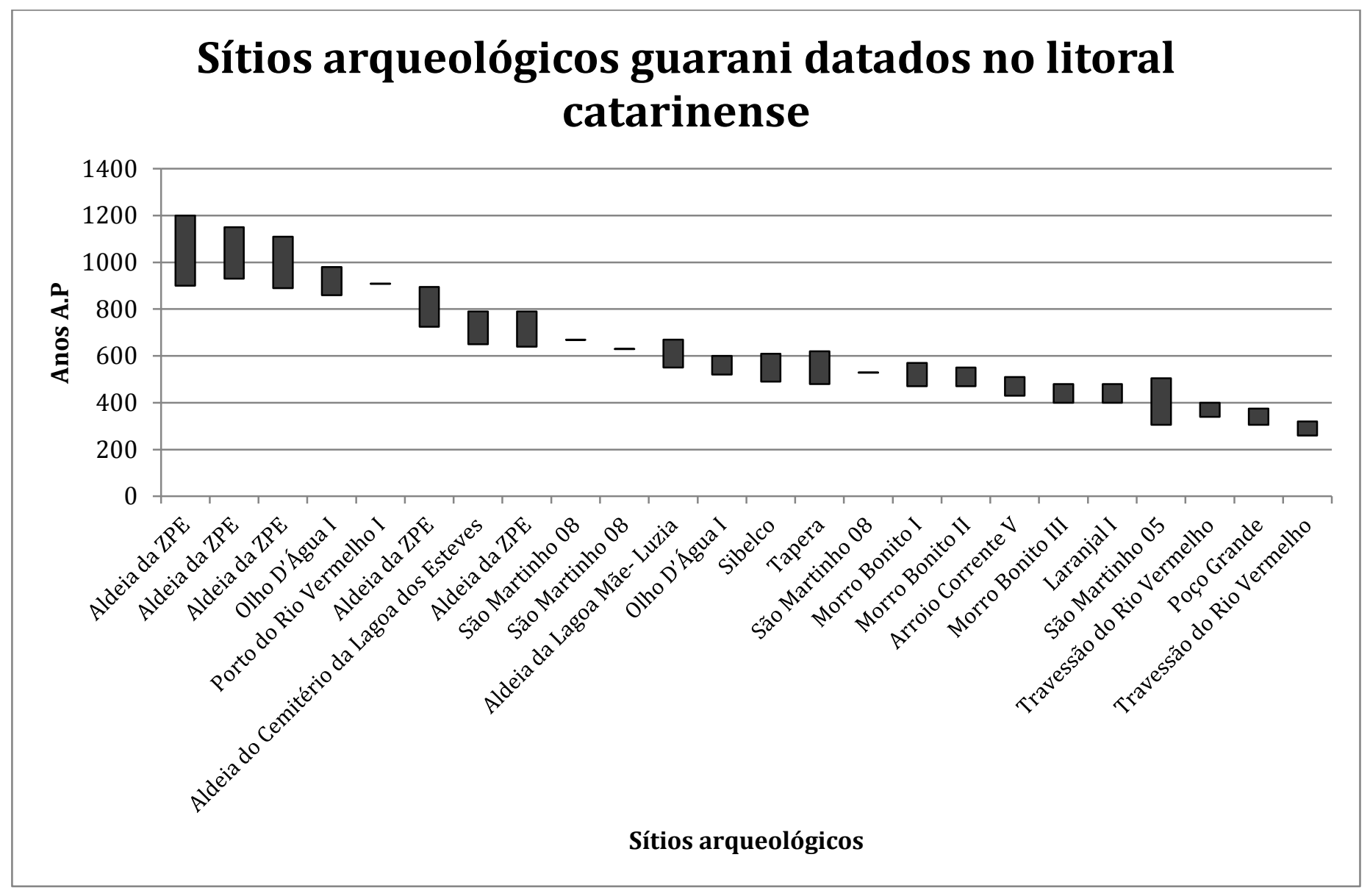

Figura 4. Gráfico com datações absolutas para sítios arqueológicos Guarani no litoral catarinense. Elaborado por: Lucas Bond Reis em dezembro de 2015 para o Trabalho de Conclusão de Curso da autora (Müller, 2015). 
Sobre os sítios arqueológicos Guarani com datações no litoral sul catarinense especificamente (Tabela 1), temos:

\begin{tabular}{|c|c|c|c|c|}
\hline Município & Nome & $\begin{array}{c}\text { Coordenada } \\
\text { UTM } \\
\end{array}$ & Sigla & Datação/Método \\
\hline Araranguá & $\begin{array}{l}\text { Aldeia da } \\
\text { Lagoa Mãe- } \\
\text { Luzia }\end{array}$ & $\begin{array}{c}\text { 22J } 663557 \\
6805711\end{array}$ & ARA010 & $610 \pm 60$ A.P./ TL \\
\hline Içara & $\begin{array}{l}\text { Aldeia do } \\
\text { Cemitério da } \\
\text { Lagoa dos } \\
\text { Esteves }\end{array}$ & $\begin{array}{c}22 \mathrm{~J} 665644 \\
6807591\end{array}$ & IÇA009 & 720 \pm 70 A.P. $/ \mathrm{TL}$ \\
\hline Imbituba & $\begin{array}{l}\text { Aldeia da } \\
\text { ZPE }\end{array}$ & $\begin{array}{c}\text { 22J } 726040 \\
6876650\end{array}$ & IMA023 & $\begin{array}{c}\text { 1000 } \pm 110 \text { A.P } \\
810 \pm 85 \text { A.P, } \\
1040 \pm 110 \text { A.P } \\
\text { 715 } \pm 75 \text { A.P } \\
1050 \pm 150 \text { A.P } \\
\text { /TL }\end{array}$ \\
\hline Jaguaruna & $\begin{array}{c}\text { Morro } \\
\text { Bonito I }\end{array}$ & $\begin{array}{c}\text { 22J } 699077 \\
6833937\end{array}$ & JUU01 & $520 \pm 50$ A.P $/{ }^{14} \mathrm{C}$ \\
\hline Jaguaruna & $\begin{array}{c}\text { Morro } \\
\text { Bonito II }\end{array}$ & $\begin{array}{c}22 \mathrm{~J} 697129 \\
6833686\end{array}$ & JUU02 & $510 \pm 40$ A.P $/ 1^{14} \mathrm{C}$ \\
\hline Jaguaruna & $\begin{array}{c}\text { Morro } \\
\text { Bonito III }\end{array}$ & $\begin{array}{c}22 \mathrm{~J} 696340 \\
6833244 \\
\end{array}$ & JUU03 & $440 \pm 40$ A.P $/{ }^{14} \mathrm{C}$ \\
\hline Jaguaruna & Laranjal I & $\begin{array}{c}22 \mathrm{~J} 701597 \\
6832366\end{array}$ & JUU37 & $440 \pm 40$ A.P $/{ }^{14} \mathrm{C}$ \\
\hline Jaguaruna & $\begin{array}{c}\text { Arroio } \\
\text { Corrente V }\end{array}$ & $\begin{array}{c}\text { 22J } 691901 \\
6825308\end{array}$ & $\mathrm{~s} / \mathrm{d}$ & $470 \pm 40$ A.P $/{ }^{14} \mathrm{C}$ \\
\hline Jaguaruna & $\begin{array}{c}\text { Olho } \\
\text { D’Água I }\end{array}$ & $\begin{array}{c}\text { 22J } 675956 \\
6813757\end{array}$ & $\mathrm{~s} / \mathrm{d}$ & $\begin{array}{c}560 \pm 40 \text { A.P } \\
920 \pm 60 \text { A.P } /{ }^{14} \mathrm{C}\end{array}$ \\
\hline Jaguaruna & Sibelco & $\begin{array}{c}\text { 22J } 695611 \\
6832335 \\
\end{array}$ & s/d & $550 \pm 60$ A.P $/{ }^{14} \mathrm{C}$ \\
\hline Joinville & Poço Grande & $\begin{array}{c}\text { 22J } 0714993 \\
7073270\end{array}$ & s/d & $340 \pm 35$ A.P/TL \\
\hline $\begin{array}{c}\text { São } \\
\text { Martinho }\end{array}$ & $\begin{array}{c}\text { São } \\
\text { Martinho 05 }\end{array}$ & $\begin{array}{c}22 \mathrm{~J} 699264 \\
6886618\end{array}$ & SM 05 & 505-305 A.P $/{ }^{14} \mathrm{C}$ \\
\hline $\begin{array}{c}\text { São } \\
\text { Martinho }\end{array}$ & $\begin{array}{c}\text { São } \\
\text { Martinho } 08\end{array}$ & $\begin{array}{c}\text { 22J } 699365 \\
6886511\end{array}$ & SM 08 & $\begin{array}{c}1280 \text { A.D, } 1320 \\
\text { A.D, } 1420 \\
\text { A.D } /{ }^{14} \mathrm{C}\end{array}$ \\
\hline
\end{tabular}

Tabela 1. Sítios arqueológicos Guarani com datação na região sul do litoral catarinense. Adaptada de Noelli, Milheira e Wagner (2014) e utilizada primeiramente em trabalho de conclusão de curso da autora (MÜLLER, 2015). Em Método, a sigla TL significa Termoluminescência, e C14 significa Carbono 14.

Já no litoral central do estado, que é nosso enfoque nesse momento, os sítios estão concentrados, em sua maior parte, na Ilha de Santa Catarina ou Florianópolis, sendo que a parte continental dessa área carece de mais estudos acadêmicos. Compreende-se enquanto a região do litoral central do estado, então, a faixa entre os municípios de Porto Belo e Garopaba, abaixo da barra do Itapocu ou enseada da Barra Velha. Esses municípios considerados limite da área de estudo foram 
abrangidos aqui por estarem sempre fora das demais pesquisas que estudam os litorais norte e sul, ainda que geograficamente eles já não estejam na área central. Além disso, o município de Garopaba se apresenta muito mais próximo do que se considera litoral central, por formar baía (baía sul) juntos dos municípios de Paulo Lopes, Palhoça e Florianópolis. Seguem os sítios arqueológicos apresentando vestígios da presença Guarani nessa região segundo o mesmo trabalho de Noelli e colaboradores (2014) na Tabela 2: 


\begin{tabular}{|c|c|c|c|c|}
\hline Município & Nome & $\begin{array}{c}\text { Coordenadas } \\
\text { UTM }\end{array}$ & Sigla & Datação/Método \\
\hline Florianópolis & $\begin{array}{c}\text { Florianópolis } \\
39\end{array}$ & $\mathrm{~s} / \mathrm{d}$ & $\begin{array}{l}\text { FLN } \\
004\end{array}$ & $\mathrm{~s} / \mathrm{d}$ \\
\hline Florianópolis & $\begin{array}{c}\text { Florianópolis } \\
40\end{array}$ & $\mathrm{~s} / \mathrm{d}$ & $\begin{array}{l}\text { FLN } \\
062\end{array}$ & $\mathrm{~s} / \mathrm{d}$ \\
\hline Florianópolis & $\begin{array}{l}\text { Dunas do } \\
\text { Pântano do } \\
\text { Sul I }\end{array}$ & $\begin{array}{c}22 \mathrm{~J} \\
745023 / 6924780\end{array}$ & $\begin{array}{l}\text { FLN } \\
062\end{array}$ & $\mathrm{~s} / \mathrm{d}$ \\
\hline Florianópolis & $\begin{array}{l}\text { Florianópolis } \\
44\end{array}$ & $\mathrm{~s} / \mathrm{d}$ & $\begin{array}{l}\text { FLN } \\
063\end{array}$ & s/d \\
\hline Florianópolis & $\begin{array}{l}\text { Dunas do } \\
\text { Pântano do } \\
\text { Sul II }\end{array}$ & $\begin{array}{c}22 \mathrm{~J} \\
745053 / 6924754\end{array}$ & $\begin{array}{c}\text { FLN } \\
063\end{array}$ & s/d \\
\hline Florianópolis & $\begin{array}{l}\text { Dunas do } \\
\text { Pântano do } \\
\text { Sul III }\end{array}$ & $\begin{array}{c}\text { 22J } \\
744827 / 6924784\end{array}$ & $\begin{array}{c}\text { FLN } \\
064\end{array}$ & $\mathrm{~s} / \mathrm{d}$ \\
\hline Florianópolis & $\begin{array}{l}\text { Dunas do } \\
\text { Pântano do } \\
\text { Sul IV }\end{array}$ & $\begin{array}{c}\text { 22J } \\
745299 / 6924707\end{array}$ & $\begin{array}{c}\text { FLN } \\
065\end{array}$ & s/d \\
\hline Florianópolis & $\begin{array}{c}\text { Ponta da } \\
\text { Caiacanga- } \\
\text { Açu / } \\
\text { Florianópolis } \\
41\end{array}$ & $\begin{array}{c}\text { 22J } \\
738182 / 6926640\end{array}$ & $\begin{array}{l}\text { FLN } \\
066\end{array}$ & $\mathrm{~s} / \mathrm{d}$ \\
\hline Florianópolis & $\begin{array}{c}\text { Lagoinha do } \\
\text { Rio } \\
\text { Tavares* / } \\
\text { Florianópolis } \\
42\end{array}$ & $\begin{array}{c}22 J \\
7423308 / 6956038\end{array}$ & $\begin{array}{c}\text { FLN } \\
067\end{array}$ & s/d \\
\hline Florianópolis & $\begin{array}{c}\text { Dunas da } \\
\text { Lagoa da } \\
\text { Conceição / } \\
\text { Florianópolis } \\
43\end{array}$ & $\mathrm{~s} / \mathrm{d}$ & $\begin{array}{c}\text { FLN } \\
068\end{array}$ & s/d \\
\hline Florianópolis & Rendeiras & $\begin{array}{c}\text { 22J } \\
750549 / 6943743\end{array}$ & $\begin{array}{l}\text { FLN } \\
069\end{array}$ & $\mathrm{~s} / \mathrm{d}$ \\
\hline Florianópolis & Base Aérea & $\mathrm{s} / \mathrm{d}$ & $\begin{array}{c}\text { SC- } \\
\text { LF-01 }\end{array}$ & $\mathrm{s} / \mathrm{d}$ \\
\hline Florianópolis & Tapera & $\begin{array}{c}22 \mathrm{~J} \\
739918 / 6934533\end{array}$ & $\begin{array}{c}\text { SC- } \\
\text { LF-02 } \\
\text { / FLN } \\
058 \\
\end{array}$ & $\begin{array}{c}1400 \pm 70 \text { A.D./ } \\
{ }^{14} \mathrm{C}\end{array}$ \\
\hline Florianópolis & $\begin{array}{l}\text { Rua das } \\
\text { Garças, } \\
\text { Campeche }\end{array}$ & $\begin{array}{c}22 \mathrm{~J} \\
746843 / 6934710\end{array}$ & $\mathrm{~s} / \mathrm{d}$ & $\mathrm{s} / \mathrm{d}$ \\
\hline Florianópolis & $\begin{array}{l}\text { Costeira do } \\
\text { Pirajubaé }\end{array}$ & $\begin{array}{c}22 \mathrm{~J} \\
744057 / 6940470\end{array}$ & $\mathrm{~s} / \mathrm{d}$ & $\mathrm{s} / \mathrm{d}$ \\
\hline Florianópolis & $\begin{array}{l}\text { Ponta da } \\
\text { Caiacanga- } \\
\text { Açu }\end{array}$ & $\begin{array}{c}22 \mathrm{~J} \\
738182 / 6926640\end{array}$ & $\mathrm{~s} / \mathrm{d}$ & $\mathrm{s} / \mathrm{d}$ \\
\hline Florianópolis & Rio do Meio & $\mathrm{s} / \mathrm{d}$ & $\mathrm{s} / \mathrm{d}$ & $\mathrm{s} / \mathrm{d}$ \\
\hline
\end{tabular}




\begin{tabular}{|c|c|c|c|c|}
\hline Florianópolis & $\begin{array}{l}\text { Dunas do } \\
\text { Pântano do } \\
\text { Sul V }\end{array}$ & $\begin{array}{c}22 \mathrm{~J} \\
744823 / 6924872\end{array}$ & $\mathrm{~s} / \mathrm{d}$ & $\mathrm{s} / \mathrm{d}$ \\
\hline Florianópolis & Valda 1 & $\mathrm{~s} / \mathrm{d}$ & $\mathrm{s} / \mathrm{d}$ & $\mathrm{s} / \mathrm{d}$ \\
\hline Florianópolis & $\begin{array}{l}\text { Povoado do } \\
\text { Campeche }\end{array}$ & $\begin{array}{c}22 \mathrm{~J} \\
562790 / 6640402 * *\end{array}$ & $\mathrm{~s} / \mathrm{d}$ & $\mathrm{s} / \mathrm{d}$ \\
\hline Florianópolis & $\begin{array}{l}\text { Pântano do } \\
\text { Sul II }\end{array}$ & $\begin{array}{c}22 \mathrm{~J} \\
745372 / 6924565\end{array}$ & $\mathrm{~s} / \mathrm{d}$ & $\mathrm{s} / \mathrm{d}$ \\
\hline Florianópolis & Lagoinha & $\begin{array}{c}\text { 22J } \\
748616 / 6938503\end{array}$ & $\mathrm{~s} / \mathrm{d}$ & $\mathrm{s} / \mathrm{d}$ \\
\hline Florianópolis & $\begin{array}{l}\text { Florianópolis } \\
44\end{array}$ & $\mathrm{~s} / \mathrm{d}$ & $\mathrm{s} / \mathrm{d}$ & $\mathrm{s} / \mathrm{d}$ \\
\hline Florianópolis & Naufragados & $\begin{array}{c}22 \mathrm{~J} \\
739868 / 6919008 \\
\end{array}$ & s/d & $\mathrm{s} / \mathrm{d}$ \\
\hline Florianópolis & $\begin{array}{l}\text { Porto do Rio } \\
\text { Vermelho } 1\end{array}$ & $\begin{array}{c}22 \mathrm{~J} \\
754385 / 6953086\end{array}$ & $\begin{array}{c}\text { SC- } \\
\text { PRV- } \\
01\end{array}$ & 910 A.D. $/{ }^{14} \mathrm{C}$ \\
\hline Garopaba & $\begin{array}{l}\text { Aldeia da } \\
\text { Praia da } \\
\text { Ferrugem }\end{array}$ & $\mathrm{s} / \mathrm{d}$ & - & $\mathrm{s} / \mathrm{d}$ \\
\hline Garopaba & $\begin{array}{c}\text { Aldeia da } \\
\text { Praia do Rosa }\end{array}$ & $\mathrm{s} / \mathrm{d}$ & - & $\mathrm{s} / \mathrm{d}$ \\
\hline Garopaba & $\begin{array}{c}\text { Praia da } \\
\text { Gamboa } 2\end{array}$ & $\mathrm{~s} / \mathrm{d}$ & $\begin{array}{c}\text { GRB } \\
002\end{array}$ & $\mathrm{~s} / \mathrm{d}$ \\
\hline Garopaba & Garopaba 3 & $\mathrm{~s} / \mathrm{d}$ & $\begin{array}{c}\text { GRB } \\
003\end{array}$ & $\mathrm{~s} / \mathrm{d}$ \\
\hline Garopaba & Praia do Rosa & s/d & - & $\mathrm{s} / \mathrm{d}$ \\
\hline $\begin{array}{l}\text { Governador } \\
\text { Celso Ramos }\end{array}$ & $\begin{array}{l}\text { Armação da } \\
\text { Piedade }\end{array}$ & $\mathrm{s} / \mathrm{d}$ & - & $\mathrm{s} / \mathrm{d}$ \\
\hline Palhoça & $\begin{array}{c}\text { Sabino J. } \\
\text { Silveira }\end{array}$ & $\mathrm{s} / \mathrm{d}$ & $\begin{array}{c}\text { SC- } \\
\text { PEST- } \\
04\end{array}$ & $\mathrm{~s} / \mathrm{d}$ \\
\hline Palhoça & $\begin{array}{l}\text { Nestor M. } \\
\text { Matos }\end{array}$ & $\mathrm{s} / \mathrm{d}$ & $\begin{array}{c}\text { SC- } \\
\text { PEST- } \\
08 \\
\end{array}$ & $\mathrm{~s} / \mathrm{d}$ \\
\hline Palhoça & $\begin{array}{l}\text { Saturnino A. } \\
\text { Santos }\end{array}$ & $\mathrm{s} / \mathrm{d}$ & $\begin{array}{c}\text { SC- } \\
\text { PEST- } \\
11\end{array}$ & $\mathrm{~s} / \mathrm{d}$ \\
\hline Palhoça & $\begin{array}{l}\text { Nestor C. } \\
\text { Santos }\end{array}$ & $\mathrm{s} / \mathrm{d}$ & $\begin{array}{c}\text { SC- } \\
\text { PEST- } \\
16\end{array}$ & $\mathrm{~s} / \mathrm{d}$ \\
\hline Palhoça & Praia de Fora & $\mathrm{s} / \mathrm{d}$ & $\begin{array}{c}\text { SC- } \\
\text { PEST- } \\
24\end{array}$ & $\mathrm{~s} / \mathrm{d}$ \\
\hline Palhoça & $\begin{array}{c}\text { Posto } \\
\text { Massiambu }\end{array}$ & $\mathrm{s} / \mathrm{d}$ & - & $\mathrm{s} / \mathrm{d}$ \\
\hline Palhoça & Três Barras & $\mathrm{s} / \mathrm{d}$ & s/d & $\mathrm{s} / \mathrm{d}$ \\
\hline Palhoça & Aviãozinho & $\begin{array}{c}22 \mathrm{~J} \\
733382 / 6920104\end{array}$ & $\mathrm{~s} / \mathrm{d}$ & $\mathrm{s} / \mathrm{d}$ \\
\hline Palhoça & Faz. S. Inês & $\begin{array}{c}22 \mathrm{~J} \\
733216 / 6919925\end{array}$ & $\mathrm{~s} / \mathrm{d}$ & $\mathrm{s} / \mathrm{d}$ \\
\hline Palhoça & Praia da & $\mathrm{s} / \mathrm{d}$ & PAC & $\mathrm{s} / \mathrm{d}$ \\
\hline
\end{tabular}




\begin{tabular}{|c|c|c|c|c|}
\hline & Pinheira II & & 004 & \\
\hline Palhoça & Maciambu I & 22J & $\mathrm{s} / \mathrm{d}$ & $\mathrm{s} / \mathrm{d}$ \\
& & $733120 / 6918236$ & & \\
\hline Paulo Lopes & $\begin{array}{c}\text { Ildefonso } \\
\text { Vieira }\end{array}$ & $\mathrm{s} / \mathrm{d}$ & SC- & $\mathrm{s} / \mathrm{d}$ \\
& & & $\begin{array}{c}\text { PEST- } \\
06\end{array}$ & \\
\hline Paulo Lopes & - (Localidade & $\mathrm{s} / \mathrm{d}$ & SC- & $\mathrm{s} / \mathrm{d}$ \\
& $\begin{array}{c}\text { de Dunas da } \\
\text { Gamboa) }\end{array}$ & & PEST- & \\
& Amadeu A. & $\mathrm{s} / \mathrm{d}$ & SC- & $\mathrm{s} / \mathrm{d}$ \\
& Moisés & & PEST- & \\
& & & 17 & \\
\hline Paulo Lopes & Vitauro & $\mathrm{s} / \mathrm{d}$ & SC- & $\mathrm{s} / \mathrm{d}$ \\
& Lopes & & PEST- & \\
& & & 21 & \\
\hline Paulo Lopes & Manuel F. & s/d & SC- & $\mathrm{s} / \mathrm{d}$ \\
& Pereira & & PEST- & \\
& & & 22 & \\
\hline Paulo Lopes & Paulo Lopes & $\mathrm{s} / \mathrm{d}$ & SC- & $\mathrm{s} / \mathrm{d}$ \\
& & & PEST- & \\
& & & 23 & \\
\hline
\end{tabular}

Tabela 2. Sítios arqueológicos na região central do litoral catarinense. Adaptado de Noelli, Milheira e Wagner (2014) e utilizada primeiramente em trabalho de conclusão de curso da autora (MÜLLER, 2015). Atualizada e corrigida para esta dissertação. Em Método, a sigla TL significa Termoluminescência, e ${ }^{14} \mathrm{C}$ significa Carbono 14. *A coordenada utilizada nesta tabela segue aquela publicada em Noelli et.al. (2014), mas nas tabelas seguintes, é utilizada e adotada neste trabalho a coordenada que a equipe do LEIA/UFSC corrigiu em campo, uma vez que o sítio Lagoinha do Rio Tavares da Tabela 2 é o mesmo sítio Lagoinha do Rio Tavares I, cujo registro foi atualizado pelo LEIA/UFSC. **A coordenada foi verificada e não corresponde à localidade designada para o sítio arqueológico.

Este levantamento (Tabela 2) pode dar uma noção geral da quantidade de sítios arqueológicos no litoral central e onde estão distribuídos. Podemos observar, além daqueles na cidade de Florianópolis, alguns em Paulo Lopes, Palhoça, Garopaba e Governador Celso Ramos. No entanto, para a região da Ilha de Santa Catarina, com um olhar mais detalhado, podemos refinar essa busca, confrontar bibliografia vasta e a profusão de registros feitos por muitos pesquisadores desde a década de 1850, e revisitar sítios arqueológicos. Foi o que a equipe do LEIA/UFSC realizou entre os anos de 2012 e 2015, sob a coordenação do Professor Doutor Lucas de Melo Reis Bueno em projeto denominado Florianópolis Arqueológica (BUENO, 2012). Analisando a reunião de sítios arqueológicos com ocupação Guarani desse levantamento, compreende-se a importância e necessidade do olhar debruçado e contextualizado, pois cada região apresenta suas particularidades geográficas, de produção científica, de trajetória na Arqueologia, dentre outras áreas, para a área de pesquisa. A seguir, então, o resultado 
para os sítios arqueológicos na Ilha de Florianópolis que contêm vestígios Guarani na Tabela 3:

\begin{tabular}{|c|c|c|c|c|}
\hline Município & Nome & $\begin{array}{l}\text { Coordenada } \\
\text { UTM }\end{array}$ & Sigla & Datação/Método \\
\hline Florianópolis & $\begin{array}{l}\text { Costeira do } \\
\text { Pirajubaé }\end{array}$ & $\begin{array}{c}\text { 22J 744651,26 } \\
6939545,376\end{array}$ & CPJ & $\mathrm{s} / \mathrm{d}$ \\
\hline Florianópolis & $\begin{array}{l}\text { Dunas da } \\
\text { Joaquina }\end{array}$ & $\begin{array}{c}\text { 22J } 751639 \\
6941536\end{array}$ & $\mathrm{~s} / \mathrm{d}$ & $\mathrm{s} / \mathrm{d}$ \\
\hline Florianópolis & $\begin{array}{c}\text { Dunas da Lagoa } \\
\text { VI }\end{array}$ & $\begin{array}{c}\text { 22J } 751288,141 \\
6943382,145\end{array}$ & $\mathrm{~s} / \mathrm{d}$ & $\mathrm{s} / \mathrm{d}$ \\
\hline Florianópolis & $\begin{array}{c}\text { Dunas do } \\
\text { Pântano do Sul I }\end{array}$ & $\begin{array}{c}\text { 22J 745114,673 } \\
6924686,193\end{array}$ & $\mathrm{~s} / \mathrm{d}$ & $\mathrm{s} / \mathrm{d}$ \\
\hline Florianópolis & $\begin{array}{c}\text { Dunas do } \\
\text { Pântano do Sul } \\
\text { II }\end{array}$ & $\begin{array}{c}\text { 22J } 745041,255 \\
6924729,789\end{array}$ & $\mathrm{~s} / \mathrm{d}$ & $\mathrm{s} / \mathrm{d}$ \\
\hline Florianópolis & $\begin{array}{c}\text { Dunas do } \\
\text { Pântano do Sul } \\
\text { V }\end{array}$ & $\begin{array}{c}22 \mathrm{~J} 745052,325 \\
6924633,153\end{array}$ & $\begin{array}{l}- \\
\text { s/d }\end{array}$ & $\mathrm{s} / \mathrm{d}$ \\
\hline Florianópolis & $\begin{array}{l}\text { Estação Florestal } \\
\text { IV }\end{array}$ & $\begin{array}{c}\text { 22J 753656,88 } \\
6952326,07\end{array}$ & $\mathrm{~s} / \mathrm{d}$ & $\mathrm{s} / \mathrm{d}$ \\
\hline Florianópolis & Lagoa do Peri I & $\begin{array}{c}\text { 22J 744787,535 } \\
6930226,963\end{array}$ & $\mathrm{~s} / \mathrm{d}$ & $\mathrm{s} / \mathrm{d}$ \\
\hline Florianópolis & Lagoa do Peri II & $\begin{array}{c}\text { 22J 745214,261 } \\
6930135,176\end{array}$ & $\mathrm{~s} / \mathrm{d}$ & $\mathrm{s} / \mathrm{d}$ \\
\hline Florianópolis & $\begin{array}{c}\text { Lagoinha do } \\
\text { Rio Tavares I* }\end{array}$ & $\begin{array}{c}22 J 749250 \\
6938525 \\
\end{array}$ & s/d & s/d \\
\hline Florianópolis & $\begin{array}{l}\text { Lagoinha do Rio } \\
\text { Tavares I II }\end{array}$ & $\begin{array}{c}\text { 22J 748655,681 } \\
6937814,973\end{array}$ & s/d & $\mathrm{s} / \mathrm{d}$ \\
\hline Florianópolis & Naufragados II & $\begin{array}{c}\text { 22J } 740205,125 \\
6918806\end{array}$ & NFG 2 & $\mathrm{~s} / \mathrm{d}$ \\
\hline Florianópolis & $\begin{array}{c}\text { Ponta da } \\
\text { Caiacanga-Açu I }\end{array}$ & $\begin{array}{c}\text { 22J } 738906 \\
6926707 \\
\end{array}$ & PCG 1 & $\mathrm{~s} / \mathrm{d}$ \\
\hline Florianópolis & $\begin{array}{c}\text { Porto do Rio } \\
\text { Vermelho I }\end{array}$ & $\begin{array}{c}\text { 22J } 754433 \\
6953082\end{array}$ & $\mathrm{~s} / \mathrm{d}$ & 910 A.P. ${ }^{14} \mathrm{C}$ \\
\hline Florianópolis & Tapera & $\begin{array}{c}\text { 22J 739674,392 } \\
6935046,207\end{array}$ & TAP & $1400 \pm 70$ A.D. $/{ }^{14} \mathrm{C}$ \\
\hline Florianópolis & $\begin{array}{l}\text { Travessão do } \\
\text { Rio Vermelho }\end{array}$ & $\begin{array}{c}22 J 756372 \\
6957075 \text { WGS } 84\end{array}$ & TRV & $\begin{array}{l}290 \pm 30 \text { A.P; } \\
370 \pm 30 \text { A.P. }\end{array}$ \\
\hline Florianópolis & Valda I & $\begin{array}{c}\text { 22J } 756502 \\
6960293 \\
\end{array}$ & VLD & $\mathrm{s} / \mathrm{d}$ \\
\hline
\end{tabular}

Tabela 3. Sítios arqueológicos Guarani na Ilha de Santa Catarina. Adaptado de Bueno et al (2014) para

TCC da autora (MÜLLER, 2015) e atualizado e corrigido para esta dissertação. Em Método, a sigla TL significa Termoluminescência, e ${ }^{14} \mathrm{C}$ significa Carbono 14. Datum WGS84. *O sítio arqueológico Lagoinha do Rio Tavares I (nesta Tabela 3) é o mesmo sítio Lagoinha do Rio Tavares da Tabela 2, referido com a sigla RT nesta dissertação. 


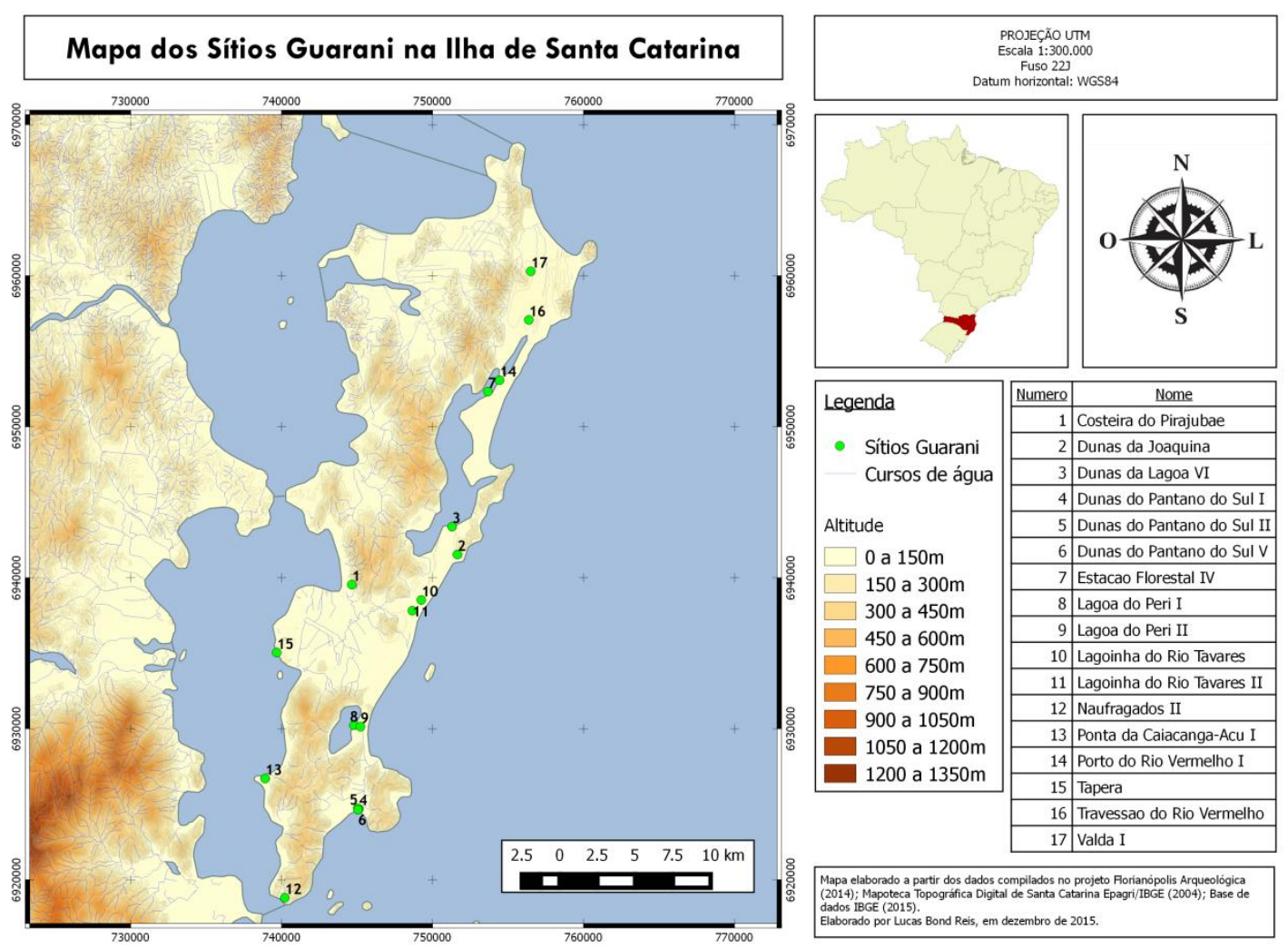

Figura 5. Mapa contendo os sítios de ocupação Guarani na Ilha de Santa Catarina, Florianópolis. Elaborado por Lucas Bond Reis para o Trabalho de Conclusão de Curso da autora (MÜLLER, 2015).

No mapa da Figura 5 observa-se a localização dos sítios listados na Tabela 3. Apenas três desses sítios arqueológicos possuem datações da presença Guarani: Porto do Rio Vermelho I (910 A.D. $/{ }^{14}$ C), Tapera $\left(1400 \pm 70\right.$ A.D. $/{ }^{14}$ C) e Travessão do Rio Vermelho (370 \pm 30 A.P. $/{ }^{14} \mathrm{C}$ e $290 \pm 30$ A.P $\left./{ }^{14} \mathrm{C}\right)$.

A partir das Tabelas 2 e 3, observa-se que existem 40 sítios arqueológicos para a região delimitada como litoral central, sendo 17 em Florianópolis (ou seja, 23 sítios na parte continental e 17 na Ilha de Florianópolis). Esse cálculo é feito considerando somente os sítios da parte continental descritos na Tabela 2 e os sítios em Florianópolis elencados na Tabela 3. Porém, há apenas quatro datações absolutas na região de três sítios arqueológicos em Florianópolis (região da ilha). Essa disparidade entre número de sítios e datas sugere que há muito em que se percorrer em termos de pesquisa arqueológica na região. Nesses levantamentos, observa-se que não há sítios nos municípios de Biguaçu, Porto Belo e Tijucas. Há, ainda, questões emblemáticas a serem discutidas de forma mais aprofundada teórico-metodologicamente, como quando determinar um sítio com essa ocupação. Apenas e tão somente pela presença da cerâmica de tradição tupiGuarani? Os sítios líticos Guarani sem cerâmica estão sendo 
identificados? Infelizmente, ainda não, e o material lítico ainda é pouco explorado. Como esses sítios podem estar relacionados contextualmente? Muito provável que através de sistemas de assentamento que, somente, com métodos adequados de campo poderão ser identificados. Esses são apenas alguns questionamentos que só poderão ser resolvidos com o trabalho sistemático e contextual, não constante nesta pesquisa de mestrado, mas cujo questionamento merece destaque. Ainda, algumas confusões devem ser desfeitas com o encaminhamento da pesquisa, como a nomenclatura e identificação correta daquele que é o sítio Rio Tavares ou Lagoinha do Rio Tavares I e que será alvo dessa pesquisa de mestrado.

Observamos que o sítio arqueológico Travessão do Rio Vermelho, também

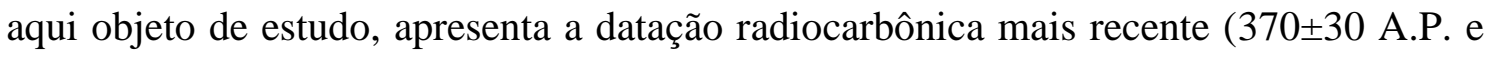
$290 \pm 30$ A.P) dentre os demais (Porto do Rio Vermelho I e Tapera). Interessante que este é o único sítio datado que contem apenas uma ocupação (Guarani). Os demais, Porto do Rio Vermelho I e Tapera, são sítios conchíferos que em algumas de suas camadas apresentaram material cerâmico Guarani - cujos contextos também devem ser pesquisados mais a fundo. Além disso, observa-se que a ocupação do TRV é praticamente contemporânea aquela de Poço Grande, no litoral norte do estado, ou seja, bastante recentes para o panorama geral de dispersão Guarani no sul da América do Sul. Todavia, o levantamento realizado pela autora entre os anos de 2016 e 2017 nos arquivos do IPHAN/SC deve provocar maiores questionamentos com relação a esse panorama regional.

\subsection{Levantamento de sítios arqueológicos Guarani no Acervo do IPHAN-SC}

A pesquisa nos arquivos físicos da Superintendência Regional do IPHAN em Santa Catarina envolveu todos os trabalhos de Arqueologia Guarani no litoral central delimitado aqui, tanto acadêmicas quanto em trabalhos de Arqueologia empresarial realizados no final da década de 1990 e início dos anos 2000. Em números gerais, 248 processos foram analisados (contendo, cada, um relatório ou mais), o que permitiu detectar 12 sítios no litoral central, 10 dos quais não foram publicados em outros meios de divulgação. Problemáticas com relação ao tema e abordagem das pesquisas devem ser discutidos, assim como a não publicação de muitos dos resultados das pesquisas. Outro tema relevante é entender o que os profissionais têm considerado como sítio Guarani em suas pesquisas que, no geral, implica no reconhecimento de 
fragmentos cerâmicos da tradição tupiGuarani e tão somente (a cerâmica ainda permanece como "fóssil-guia").

A pesquisa realizada nos arquivos físicos do IPHAN/SC permitiu identificar 12 sítios arqueológicos, listados na Tabela 4:

\begin{tabular}{|c|c|c|c|c|}
\hline Município & Nome & Coordenada & Sigla & Referências \\
\hline Florianópolis & $\begin{array}{c}\text { Lagoinha do } \\
\text { Rio Tavares / } \\
\text { Aldeia Guarani. }\end{array}$ & $\begin{array}{c}\text { UTM } \\
\text { E0749102/N6938687, } \\
\text { E0749081/N6938614, } \\
\text { E0749295/N6938553, } \\
\text { E079237/N6938476 }\end{array}$ & - & SILVA, 2004. \\
\hline Florianópolis & $\begin{array}{l}\text { Marinas do } \\
\text { Campeche }\end{array}$ & $\begin{array}{c}\text { UTM E746105 } \\
\text { N6935207 }\end{array}$ & - & SILVA, 2000. \\
\hline Florianópolis & $\begin{array}{l}\text { Marinas do } \\
\text { Campeche II }\end{array}$ & $\begin{array}{l}\text { UTM E0746225 } \\
\text { N6935281 }\end{array}$ & - & SILVA, 2005. \\
\hline $\begin{array}{l}\text { Governador } \\
\text { Celso Ramos }\end{array}$ & Praia do Sissial & - & - & SILVA, 2007. \\
\hline Palhoça & - & $\begin{array}{c}\text { UTM 737820 } \\
6913356,737820 \\
6913424,737834 \\
6913486,737948 \\
6913425 .\end{array}$ & - & IPHAN/SC \\
\hline Palhoça & Engenho & $\begin{array}{l}\text { UTM } 725456 \\
6907855\end{array}$ & - & FARIAS, 2009. \\
\hline Palhoça & KM 265 & $\begin{array}{l}\text { UTM } 722920 \\
6865345\end{array}$ & - & BASTOS, 2006. \\
\hline Palhoça & Nova Brasília & $\begin{array}{l}\text { UTM } 725736 \\
6907855\end{array}$ & - & BASTOS, 2006. \\
\hline Palhoça & $\begin{array}{l}\text { Areal I, SC } \\
\text { Areal I }\end{array}$ & $\begin{array}{c}\text { UTM 22J } 0729257 \\
6912722\end{array}$ & - & $\begin{array}{c}\text { SCHWENGBER, } \\
2013 .\end{array}$ \\
\hline Palhoça & - & $\begin{array}{l}\text { UTM E0725733 } \\
\text { N6876064 }\end{array}$ & - & SILVA, 2005. \\
\hline Palhoça & $\begin{array}{l}\text { Cerâmico de } \\
\text { Massiambu }\end{array}$ & $\begin{array}{c}\text { UTM } 733120 \\
6918236\end{array}$ & - & BASTOS, 2006. \\
\hline Garopaba & $\begin{array}{l}\text { Aldeia da Praia } \\
\text { da Ferrugem }\end{array}$ & $\begin{array}{c}\text { UTM } 2804560 \\
4837447\end{array}$ & - & DE MASI 2001. \\
\hline
\end{tabular}

Tabela 4.. Listagem de sítios arqueológicos Guarani feita a partir da pesquisa da autora nos arquivos físicos do IPHAN/SC.

Os 12 sítios apresentados na Tabela 4 são aqueles identificados dentre o total de 248 processos arquivados no IPHAN/SC e que se referem a "sítios arqueológicos Guarani”, embora por vezes não contenham ficha de registro de sítio ou 
mais nenhuma informação adicional, e não se saiba se foram registrados como sítio arqueológico no CNSA/IPHAN. Observa-se que não há registros de sítios Guarani nos municípios de São José, Biguaçu e Porto Belo, ainda que haja processos provenientes de pesquisa nesses municípios.

Alguns problemas foram detectados durante a pesquisa no acervo do IPHAN-SC:

1 - Sítios arqueológicos identificados com um nome vieram a ser pesquisados por pesquisadores distintos mais adiante e tiveram nome alterado e só então a ficha de cadastro de sítio arqueológico padrão do IPHAN preenchida. Isso gera a duplicidade na informação que só vem a ser solucionada com o mapeamento, uma vez que, muitas vezes, as informações e características descritas nos documentos são insuficientes para a diferenciação dos sítios.

2 - Ambiguidade nas fichas de cadastro de sítios arqueológicos Guarani, descritos como aldeia ou habitação sem, muitas vezes, ocorrer a delimitação e intervenções em subsuperfície dos sítios adequados para tais inferências, sem reflexões e bibliografias adequados para tais determinações ou, ao menos, sem explicitá-las.

3 - Muitos sítios arqueológicos são mencionados nos relatórios sem, contudo, mencionar de onde provem o primeiro registro ou referência.

4 - Falta de informação complementar que caracterize os sítios arqueológicos identificados e mesmo a falta de nome para alguns sítios.

Sobre o sítio arqueológico Lagoinha do Rio Tavares na Tabela 4, acredita-se corresponder ao mesmo Lagoinha do Rio Tavares I contido no levantamento de Bueno et al. (2015) e analisado nesta dissertação.

\subsection{Síntese}

A Tabela 5 reúne os sítios revelados nos levantamentos bibliográficos produzidos por Bueno et al (2014), Noelli, Milheira e Wagner (2014) e os sítios identificados na pesquisa dos arquivos do IPHAN/SC apresentados nas Tabelas 2, 3 e 4. Foram desfeitas as duplicidades e elucidadas as dúvidas com relação a nomenclatura, à 
coordenadas corretas e pertencimentos aos municípios ao colocá-los no mapa, totalizando 48 sítios arqueológicos Guarani conhecidos para o litoral central de SC:

\begin{tabular}{|c|c|c|c|c|c|}
\hline Município & Nome & Coordenada & Sigla & Datação/Método & Referências \\
\hline Florianópolis & $\begin{array}{l}\text { Costeira do } \\
\text { Pirajubaé }\end{array}$ & $\begin{array}{c}\text { 22J 744651,26 } \\
\text { 6939545,376 } \\
\text { WGS } 84\end{array}$ & CPJ & $\mathrm{s} / \mathrm{d}$ & $\begin{array}{l}\text { Bueno et al } \\
\text { (2014); Noelli } \\
\text { et al. (2014) }\end{array}$ \\
\hline Florianópolis & $\begin{array}{c}\text { Dunas da } \\
\text { Joaquina }\end{array}$ & $\begin{array}{c}\text { 22J } 751639 \\
6941536 \text { WGS } \\
84\end{array}$ & $\mathrm{~s} / \mathrm{d}$ & $\mathrm{s} / \mathrm{d}$ & $\begin{array}{l}\text { Bueno et al } \\
\text { (2014); Noelli } \\
\text { et al. (2014) }\end{array}$ \\
\hline Florianópolis & $\begin{array}{l}\text { Dunas da } \\
\text { Lagoa VI }\end{array}$ & $\begin{array}{c}\text { 22J 751288,141 } \\
6943382,145 \\
\text { WGS } 84\end{array}$ & $\mathrm{~s} / \mathrm{d}$ & $\mathrm{s} / \mathrm{d}$ & $\begin{array}{l}\text { Bueno et al } \\
\text { (2014); Noelli } \\
\text { et al. (2014) }\end{array}$ \\
\hline Florianópolis & $\begin{array}{l}\text { Dunas do } \\
\text { Pântano do } \\
\text { Sul I }\end{array}$ & $\begin{array}{c}\text { 22J 745114,673 } \\
\text { 6924686,193 } \\
\text { WGS } 84\end{array}$ & $\mathrm{~s} / \mathrm{d}$ & $\mathrm{s} / \mathrm{d}$ & $\begin{array}{l}\text { Bueno et al } \\
\text { (2014); Noelli } \\
\text { et al. (2014) }\end{array}$ \\
\hline Florianópolis & $\begin{array}{l}\text { Dunas do } \\
\text { Pântano do } \\
\text { Sul II }\end{array}$ & $\begin{array}{c}22 \mathrm{~J} 745041,255 \\
6924729,789 \\
\text { WGS } 84\end{array}$ & $\mathrm{~s} / \mathrm{d}$ & $\mathrm{s} / \mathrm{d}$ & $\begin{array}{l}\text { Bueno et al } \\
\text { (2014); Noelli } \\
\text { et al. (2014) }\end{array}$ \\
\hline Florianópolis & $\begin{array}{l}\text { Dunas do } \\
\text { Pântano do } \\
\text { Sul V }\end{array}$ & $\begin{array}{c}\text { 22J } 745052,325 \\
6924633,153 \\
\text { WGS } 84\end{array}$ & $\mathrm{~s} / \mathrm{d}$ & $\mathrm{s} / \mathrm{d}$ & $\begin{array}{l}\text { Bueno et al } \\
\text { (2014); Noelli } \\
\text { et al. (2014) }\end{array}$ \\
\hline Florianópolis & $\begin{array}{c}\text { Estação } \\
\text { Florestal IV }\end{array}$ & $\begin{array}{c}\text { 22J 753656,88 } \\
6952326,07 \\
\text { WGS } 84\end{array}$ & $\mathrm{~s} / \mathrm{d}$ & $\mathrm{s} / \mathrm{d}$ & $\begin{array}{l}\text { Bueno et al } \\
\text { (2014); Noelli } \\
\text { et al. (2014) }\end{array}$ \\
\hline Florianópolis & $\begin{array}{l}\text { Lagoa do } \\
\text { Peri I }\end{array}$ & $\begin{array}{c}\text { 22J 744787,535 } \\
\text { 6930226,963 } \\
\text { WGS } 84\end{array}$ & $\mathrm{~s} / \mathrm{d}$ & $\mathrm{s} / \mathrm{d}$ & $\begin{array}{l}\text { Bueno et al } \\
\text { (2014); Noelli } \\
\text { et al. (2014) }\end{array}$ \\
\hline Florianópolis & $\begin{array}{l}\text { Lagoa do } \\
\text { Peri II }\end{array}$ & $\begin{array}{c}\text { 22J 745214,261 } \\
\text { 6930135,176 } \\
\text { WGS } 84\end{array}$ & $\mathrm{~s} / \mathrm{d}$ & $\mathrm{s} / \mathrm{d}$ & $\begin{array}{l}\text { Bueno et al } \\
\text { (2014); Noelli } \\
\text { et al. (2014) }\end{array}$ \\
\hline $\begin{array}{c}\text { Florianópoli } \\
\text { s }\end{array}$ & $\begin{array}{c}\text { Lagoinha } \\
\text { do Rio } \\
\text { Tavares I / } \\
\text { Lagoinha } \\
\text { do Rio } \\
\text { Tavares }\end{array}$ & $\begin{array}{c}22 J 749250 \\
6938525 \text { WGS } \\
84\end{array}$ & s/d & s/d & $\begin{array}{l}\text { Bueno et al } \\
\text { (2014); Noelli } \\
\text { et al. (2014) }\end{array}$ \\
\hline Florianópolis & $\begin{array}{c}\text { Lagoinha do } \\
\text { Rio Tavares } \\
\text { II }\end{array}$ & $\begin{array}{c}\text { 22J 748655,681 } \\
\text { 6937814,973 } \\
\text { WGS } 84\end{array}$ & $\mathrm{~s} / \mathrm{d}$ & $\mathrm{s} / \mathrm{d}$ & $\begin{array}{l}\text { Bueno et al } \\
\text { (2014) }\end{array}$ \\
\hline Florianópolis & $\begin{array}{l}\text { Naufragados } \\
\text { II }\end{array}$ & $\begin{array}{c}\text { 22J 740205,125 } \\
6918806 \text { WGS } \\
84\end{array}$ & NFG 2 & $\mathrm{~s} / \mathrm{d}$ & $\begin{array}{l}\text { Bueno et al } \\
\text { (2014); Noelli } \\
\text { et al. (2014) }\end{array}$ \\
\hline Florianópolis & $\begin{array}{l}\text { Ponta da } \\
\text { Caiacanga- } \\
\text { Açu I } \\
\end{array}$ & $\begin{array}{c}\text { 22J } 738906 \\
6926707 \text { WGS } \\
84 \\
\end{array}$ & PCG 1 & $\mathrm{~s} / \mathrm{d}$ & $\begin{array}{l}\text { Bueno et al } \\
\text { (2014); Noelli } \\
\text { et al. (2014) }\end{array}$ \\
\hline Florianópolis & $\begin{array}{c}\text { Porto do } \\
\text { Rio } \\
\text { Vermelho I } \\
\end{array}$ & $\begin{array}{c}\text { 22J } 754433 \\
6953082 \text { WGS } \\
84 \\
\end{array}$ & & 910 A.P. ${ }^{14} \mathrm{C}$ & $\begin{array}{l}\text { Bueno et al } \\
\text { (2014); Noelli } \\
\text { et al. (2014) }\end{array}$ \\
\hline Florianópolis & Tapera & $\begin{array}{c}22 \mathrm{~J} 739674,392 \\
6935046,207 \\
\text { WGS } 84\end{array}$ & TAP & $\begin{array}{l}1400 \pm 70 \\
\text { A.D. } /{ }^{14} \mathrm{C}\end{array}$ & $\begin{array}{l}\text { Bueno et al } \\
\text { (2014); Noelli } \\
\text { et al. (2014) }\end{array}$ \\
\hline Florianópoli & Travessão & 22J 756372 & TRV & $290 \pm 30$ A.P; & Bueno et al \\
\hline
\end{tabular}




\begin{tabular}{|c|c|c|c|c|c|}
\hline $\mathbf{S}$ & $\begin{array}{c}\text { do Rio } \\
\text { Vermelho } \\
\end{array}$ & $\begin{array}{c}6957075 \text { WGS } \\
84 \\
\end{array}$ & & 370 \pm 30 A.P. & (2014) \\
\hline Florianópolis & Valda I & $\begin{array}{c}\text { 22J } 756502 \\
6960293 \text { WGS } \\
84\end{array}$ & VLD & $\mathrm{s} / \mathrm{d}$ & $\begin{array}{l}\text { Bueno et al } \\
\text { (2014); Noelli } \\
\text { et al. (2014) }\end{array}$ \\
\hline Florianópolis & $\begin{array}{l}\text { Marinas do } \\
\text { Campeche }\end{array}$ & $\begin{array}{l}\text { UTM E746105 } \\
\text { N6935207 }\end{array}$ & - & - & $\begin{array}{c}\text { Arquivo } \\
\text { IPHAN/SC }\end{array}$ \\
\hline Florianópolis & $\begin{array}{l}\text { Marinas do } \\
\text { Campeche } \\
\text { II }\end{array}$ & $\begin{array}{c}\text { UTM E0746225 } \\
\text { N6935281 }\end{array}$ & - & - & $\begin{array}{l}\text { Arquivo } \\
\text { IPHAN/SC }\end{array}$ \\
\hline Garopaba & $\begin{array}{l}\text { Aldeia da } \\
\text { Praia da } \\
\text { Ferrugem }\end{array}$ & - & $\mathrm{s} / \mathrm{d}$ & $\mathrm{s} / \mathrm{d}$ & $\begin{array}{c}\text { Noelli et. al., } \\
2014 \text { / } \\
\text { Arquivo } \\
\text { IPHAN/SC }\end{array}$ \\
\hline Garopaba & $\begin{array}{l}\text { Aldeia da } \\
\text { Praia do } \\
\text { Rosa }\end{array}$ & $\mathrm{s} / \mathrm{d}$ & $\mathrm{s} / \mathrm{d}$ & $\mathrm{s} / \mathrm{d}$ & $\begin{array}{l}\text { Noelli et. al., } \\
2014\end{array}$ \\
\hline Garopaba & $\begin{array}{c}\text { Praia da } \\
\text { Gamboa } 2\end{array}$ & $\mathrm{~s} / \mathrm{d}$ & $\begin{array}{l}\text { GRB } \\
002\end{array}$ & $\mathrm{~s} / \mathrm{d}$ & $\begin{array}{l}\text { Noelli et. al., } \\
2014\end{array}$ \\
\hline Garopaba & Garopaba 3 & $\mathrm{~s} / \mathrm{d}$ & $\begin{array}{c}\text { GRB } \\
003\end{array}$ & $\mathrm{~s} / \mathrm{d}$ & $\begin{array}{c}\text { Noelli et. al., } \\
2014\end{array}$ \\
\hline Garopaba & $\begin{array}{c}\text { Praia do } \\
\text { Rosa }\end{array}$ & $\mathrm{s} / \mathrm{d}$ & $\mathrm{s} / \mathrm{d}$ & s/d & $\begin{array}{l}\text { Noelli et. al., } \\
2014\end{array}$ \\
\hline $\begin{array}{l}\text { Governador } \\
\text { Celso Ramos }\end{array}$ & $\begin{array}{l}\text { Armação da } \\
\text { Piedade }\end{array}$ & $\mathrm{s} / \mathrm{d}$ & $\mathrm{s} / \mathrm{d}$ & $\mathrm{s} / \mathrm{d}$ & $\begin{array}{c}\text { Noelli et. al., } \\
2014\end{array}$ \\
\hline $\begin{array}{c}\text { Governador } \\
\text { Celso Ramos }\end{array}$ & $\begin{array}{c}\text { Praia do } \\
\text { Sissial }\end{array}$ & $\mathrm{s} / \mathrm{d}$ & - & - & $\begin{array}{c}\text { Arquivo } \\
\text { IPHAN/SC }\end{array}$ \\
\hline Palhoça & $\begin{array}{l}\text { Sabino J. } \\
\text { Silveira }\end{array}$ & $\mathrm{s} / \mathrm{d}$ & $\begin{array}{l}\text { SC- } \\
\text { PEST- } \\
04\end{array}$ & $\mathrm{~s} / \mathrm{d}$ & $\begin{array}{l}\text { Noelli et. al., } \\
2014\end{array}$ \\
\hline Palhoça & $\begin{array}{l}\text { Nestor M. } \\
\text { Matos }\end{array}$ & $\mathrm{s} / \mathrm{d}$ & $\begin{array}{c}\text { SC- } \\
\text { PEST- } \\
08\end{array}$ & $\mathrm{~s} / \mathrm{d}$ & $\begin{array}{c}\text { Noelli et. al., } \\
2014\end{array}$ \\
\hline Palhoça & $\begin{array}{l}\text { Saturnino } \\
\text { A. Santos }\end{array}$ & $\mathrm{s} / \mathrm{d}$ & $\begin{array}{c}\text { SC- } \\
\text { PEST- } \\
11 \\
\end{array}$ & $\mathrm{~s} / \mathrm{d}$ & $\begin{array}{c}\text { Noelli et. al., } \\
2014\end{array}$ \\
\hline Palhoça & $\begin{array}{l}\text { Nestor C. } \\
\text { Santos }\end{array}$ & $\mathrm{s} / \mathrm{d}$ & $\begin{array}{c}\text { SC- } \\
\text { PEST- } \\
16\end{array}$ & $\mathrm{~s} / \mathrm{d}$ & $\begin{array}{c}\text { Noelli et. al., } \\
2014\end{array}$ \\
\hline Palhoça & $\begin{array}{l}\text { Praia de } \\
\text { Fora }\end{array}$ & s/d & $\begin{array}{c}\text { SC- } \\
\text { PEST- } \\
24\end{array}$ & $\mathrm{~s} / \mathrm{d}$ & $\begin{array}{c}\text { Noelli et. al., } \\
2014\end{array}$ \\
\hline Palhoça & $\begin{array}{c}\text { Posto } \\
\text { Massiambu }\end{array}$ & $\mathrm{s} / \mathrm{d}$ & $\mathrm{s} / \mathrm{d}$ & $\mathrm{s} / \mathrm{d}$ & $\begin{array}{c}\text { Noelli et. al., } \\
2014\end{array}$ \\
\hline Palhoça & Três Barras & $\begin{array}{c}\text { UTM } 0730593 \\
6911509\end{array}$ & $\mathrm{~s} / \mathrm{d}$ & $\mathrm{s} / \mathrm{d}$ & $\begin{array}{c}\text { Noelli et. al., } \\
2014 \text { / } \\
\text { Arquivo } \\
\text { IPHAN/SC }\end{array}$ \\
\hline Palhoça & Aviãozinho & $\begin{array}{c}22 \mathrm{~J} \\
733382 / 6920104 \\
\end{array}$ & $\mathrm{~s} / \mathrm{d}$ & s/d & $\begin{array}{c}\text { Noelli et. al., } \\
2014 \\
\end{array}$ \\
\hline Palhoça & Faz. S. Inês & $\begin{array}{c}22 \mathrm{~J} \\
733216 / 6919925 \\
\end{array}$ & $\mathrm{~s} / \mathrm{d}$ & $\mathrm{s} / \mathrm{d}$ & $\begin{array}{c}\text { Noelli et. al., } \\
2014\end{array}$ \\
\hline Palhoça & $\begin{array}{c}\text { Praia da } \\
\text { Pinheira II }\end{array}$ & $\mathrm{s} / \mathrm{d}$ & $\begin{array}{c}\text { PAC } \\
004\end{array}$ & $\mathrm{~s} / \mathrm{d}$ & $\begin{array}{c}\text { Noelli et. al., } \\
2014\end{array}$ \\
\hline
\end{tabular}




\begin{tabular}{|c|c|c|c|c|c|}
\hline Palhoça & Maciambu I & $\begin{array}{c}22 \mathrm{~J} \\
733120 / 6918236 \\
\end{array}$ & $\mathrm{~s} / \mathrm{d}$ & $\mathrm{s} / \mathrm{d}$ & $\begin{array}{l}\text { Noelli et. al., } \\
2014\end{array}$ \\
\hline Palhoça & - & $\begin{array}{c}\text { UTM } 737820 \\
6913356, \\
737820 \\
6913424 \\
737834 \\
6913486, \\
737948 \\
6913425 .^{*}\end{array}$ & - & - & $\begin{array}{c}\text { Arquivo } \\
\text { IPHAN/SC }\end{array}$ \\
\hline Palhoça & Engenho & $\begin{array}{c}\text { UTM } 725456 \\
6907855\end{array}$ & - & - & $\begin{array}{c}\text { Arquivo } \\
\text { IPHAN/SC }\end{array}$ \\
\hline Palhoça & $\begin{array}{c}\text { Nova } \\
\text { Brasília }\end{array}$ & $\begin{array}{c}\text { UTM } 725736 \\
6907855\end{array}$ & - & - & $\begin{array}{c}\text { Arquivo } \\
\text { IPHAN/SC }\end{array}$ \\
\hline Palhoça & $\begin{array}{c}\text { Areal I, SC } \\
\text { Areal I }\end{array}$ & $\begin{array}{l}\text { UTM 22J } \\
0729257 \\
6912722\end{array}$ & - & - & $\begin{array}{c}\text { Arquivo } \\
\text { IPHAN/SC / } \\
\text { CNSA } \\
\text { IPHAN }\end{array}$ \\
\hline Palhoça & $\begin{array}{c}\text { Cerâmico de } \\
\text { Massiambu }\end{array}$ & $\begin{array}{c}\text { UTM } 733120 \\
6918236\end{array}$ & - & - & $\begin{array}{c}\text { Arquivo } \\
\text { IPHAN/SC }\end{array}$ \\
\hline Paulo Lopes & $\begin{array}{l}\text { Ildefonso } \\
\text { Vieira }\end{array}$ & $\mathrm{s} / \mathrm{d}$ & $\begin{array}{c}\text { SC- } \\
\text { PEST- } \\
06\end{array}$ & $\mathrm{~s} / \mathrm{d}$ & $\begin{array}{l}\text { Noelli et. al., } \\
2014\end{array}$ \\
\hline Paulo Lopes & $\begin{array}{c}- \\
\text { (Localidade } \\
\text { de Dunas da } \\
\text { Gamboa) }\end{array}$ & $\mathrm{s} / \mathrm{d}$ & $\begin{array}{c}\text { SC- } \\
\text { PEST- } \\
07\end{array}$ & $\mathrm{~s} / \mathrm{d}$ & $\begin{array}{l}\text { Noelli et. al., } \\
2014\end{array}$ \\
\hline Paulo Lopes & $\begin{array}{l}\text { Amadeu A. } \\
\text { Moisés }\end{array}$ & $\mathrm{s} / \mathrm{d}$ & $\begin{array}{c}\text { SC- } \\
\text { PEST- } \\
17\end{array}$ & $\mathrm{~s} / \mathrm{d}$ & $\begin{array}{l}\text { Noelli et. al., } \\
2014\end{array}$ \\
\hline Paulo Lopes & $\begin{array}{l}\text { Vitauro } \\
\text { Lopes }\end{array}$ & $\mathrm{s} / \mathrm{d}$ & $\begin{array}{c}\text { SC- } \\
\text { PEST- } \\
21\end{array}$ & $\mathrm{~s} / \mathrm{d}$ & $\begin{array}{l}\text { Noelli et. al., } \\
2014\end{array}$ \\
\hline Paulo Lopes & $\begin{array}{l}\text { Manuel F. } \\
\text { Pereira }\end{array}$ & $\mathrm{s} / \mathrm{d}$ & $\begin{array}{c}\text { SC- } \\
\text { PEST- } \\
22\end{array}$ & $\mathrm{~s} / \mathrm{d}$ & $\begin{array}{l}\text { Noelli et. al., } \\
2014\end{array}$ \\
\hline Paulo Lopes & Paulo Lopes & $\mathrm{s} / \mathrm{d}$ & $\begin{array}{c}\text { SC- } \\
\text { PEST- } \\
23\end{array}$ & $\mathrm{~s} / \mathrm{d}$ & $\begin{array}{l}\text { Noelli et. al., } \\
2014\end{array}$ \\
\hline
\end{tabular}

Tabela 5. Listagem de sítios arqueológicos Guarani feita a partir de três levantamentos: o de Bueno et al (2014), o de Noelli, Milheira e Wagner (2014) e a partir da pesquisa realizada nos Arquivos Físicos do IPHAN/SC. Em Método, a sigla TL significa Termoluminescência, e ${ }^{14} \mathrm{C}$ significa Carbono 14. Datum WGS84. *Essas coordenadas estão demasiadamente distantes entre si quando plotadas no mapa da Figura 6; por isso, cada um dos quatro pontos desse registro foi considerado um ponto isolado de ocorrência de vestígios.

Além dos registros mais formais como esses analisados, há relatos e escritos sobre outros achados de cerâmica Guarani ao longo da região pesquisada, que não constituíram em si sítios arqueológicos, ou foram descritos como sítios arqueológicos 
com outro tipo de ocupação contendo recorrência/elemento Guarani. Este é o caso de registro manuscrito encontrado nas dependências do MArquE e disponibilizado pela arqueóloga Me. Luciane Zanenga Scherer, sobre cachimbo encontrado junto a esqueleto no sítio arqueológico sambaqui SC LF 39 Praia Lessa no ano de 1976 em Florianópolis. $\mathrm{Na}$ ocasião, a equipe do Museu Universitário da UFSC (agora MArquE) foi ao local realizar um "salvamento" em função da demolição de um rancho que deixou à mostra esqueleto. Foram encontrados, também, alguns fragmentos de cerâmica, raspadores e um machado semi-polido. Outras evidências cerâmicas Guarani também foram encontradas nas ruas do bairro Rio Vermelho, mesma localidade do sítio TRV analisado neste trabalho, e já mencionadas no trabalho de conclusão de curso da autora (MÜLLER, 2015).

A partir da Tabela 5, e tendo em mãos o levantamento final do contexto Guarani registrado na área de pesquisa, foi desenvolvido o mapa da Figura 6 (com os sítios que possuem coordenadas apenas). Atenção para as coleções dos sítios arqueológicos que aqui são analisadas (TRV no nordeste da Ilha de Santa Catarina com a datação mais recente para o litoral e RT no sul) e para as concentrações de sítios arqueológicos no sul da Ilha (Florianópolis) e na parte sul do litoral central (concentração em Palhoça). Esta última concentração se deve, também, a uma questão amostral visto que há mais processos de Arqueologia empresarial derivados de obras na região (facilitando encontrar esses sítios). Mesmo assim, conforme será visto no tópico a seguir, etnograficamente essa mesma região concentrava a presença de indígenas no século XVI, assim como a região do sul da Ilha de Santa Catarina. 


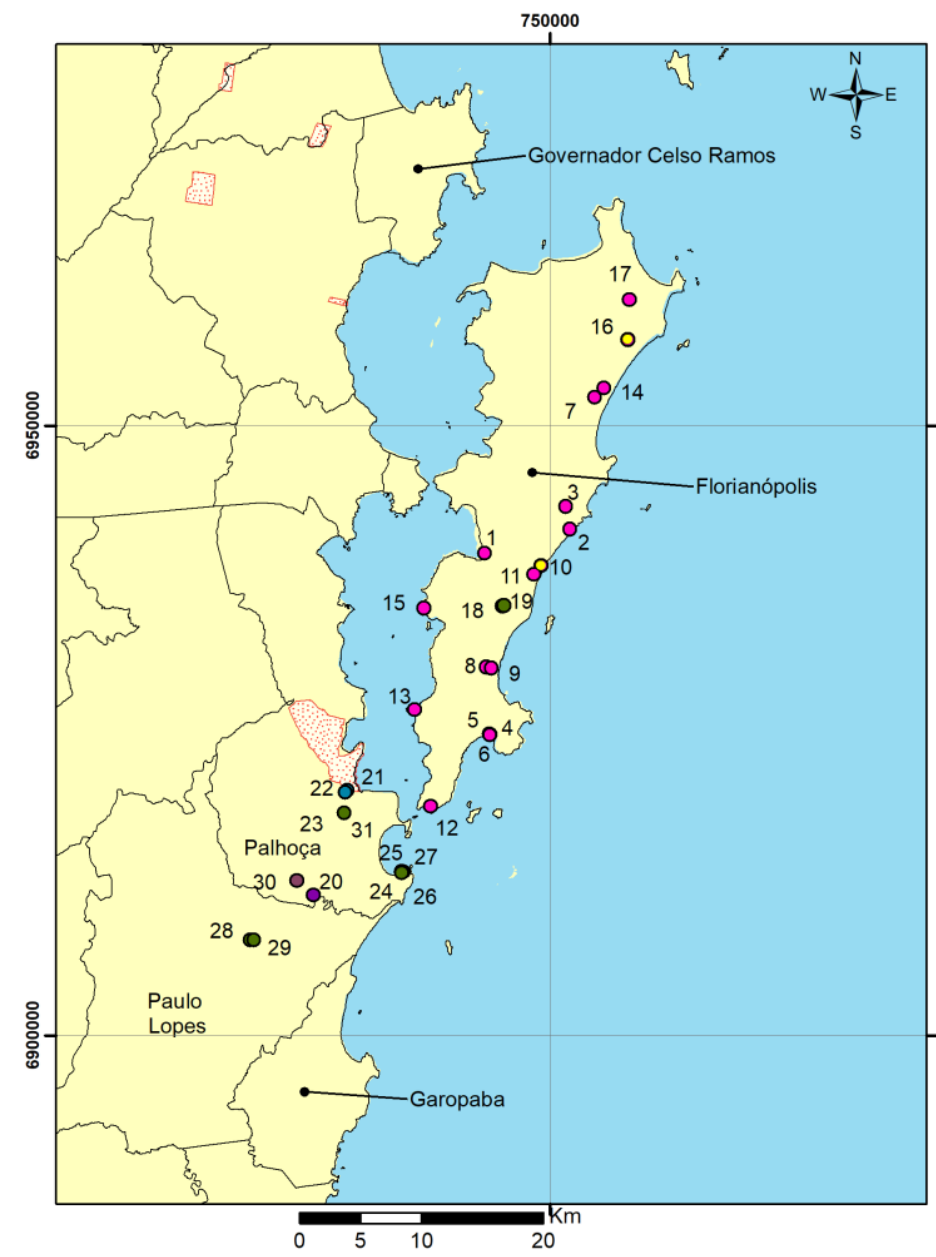

\section{Contexto Guarani Nomes dos Sítios}

Legenda $\quad 001$ - Costeira do Pirajubaé

Sítios Guaranis com coordenadas $\quad 0003$ - Dunas da Lagoa VI

Sítios Analisados 004 - Dunas do Pântano do Sul 1

C 005 - Dunas do Pântano do Sul II

Terras Indigenas 006 - Dunas do Pântano do Sul V

Levantamento $\quad 0007$ - Estação Florestal IV

O Arquivo IPHAN/SC 0008 - Lagoa do Peri I

O Arquivo IPHAN/SC / CNSA IPHAN

- Lagoinha do Rio Tavares

O Bueno et al (2014) O 012 - Naufragados II

○ Noelli et. al., 2014 ○ 013 - Ponta da Caiacanga-Açul

Noelli et. al. 2014 / Arquivo IPHAN/SC 014 - Porto do Rio Vermelho I

- 015 - Tapera

○ 016 - Travessão do Rio Vermelho

- 017 - Valda I

- 018 - Marinas do Campeche

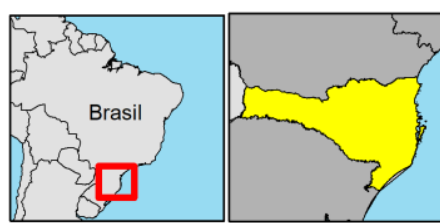

019 - Marinas do Campeche II

- 020 - Três Barras

- 021 - Aviãozinho

- 023 - Maciambu

- 024 - Sem Nome

- 025 - Sem Nome

Dados Técnicos:

- 026 - Sem Nome

o/Sistema de Coordenad

Bases SRTMMUFRGS, Limite de Estados/

- 027 - Sem Nome

- 028 - Engenho

- 029 - Nova Brasilia

- 030 - Areal I, SC Areal I

Responsável Mapa: Thiago Umberto Pereir

- 031 - Cerâmico de Massiambu

Figura 6. Mapa com o Contexto Guarani no Litoral Central de Santa Catarina a partir de Bueno et. al. (2014), Noelli et.al. (2014), e pesquisa de Isabela da Silva Müller nos Arquivos Físicos do IPHAN/SC e CNSA/IPHAN. Elaborado por Thiago Umberto Pereira. 
Observa-se no mapa da Figura 6, ainda, que buscou-se não somente identificar as evidências arqueológicas Guarani, mas o contexto atual Guarani explicitado pelas terras indígenas (T.Is) Massiambu, Morro dos Cavalos e Cambirela em Palhoça e M’biguaçu, Mymba Roka, Itanhaé e Amâncio em Biguaçu (FUNAI, 2012) tradicionalmente conhecidas pela literatura das ciências humanas para a região. No entanto, o shapefile utilizado da FUNAI (atualização de novembro de 2018) contem as T.Is Canelinha (Tijucas/São João Batista), Amaral/Tekoá Kuriy (Biguaçu), Molho da Palha (Briguaçu/Tijucas), M’biguaçu (Biguaçu) e Morro dos Cavalos (Palhoça). Há que se ter em mente que, apesar de terem suas terras demarcadas ou estarem em demarcação, os Guarani não estão exclusivamente nessas TIs, senão que estão em constante movimento pelo território da região em destaque e demais territórios na América do Sul: em constante movimento, conforme Darella (2014) ressaltou em seu trabalho.

Nota-se apenas que os pontos de números 024 a 027 no mapa correspondem a um único registro identificado na pesquisa nos Arquivos do IPHAN/SC e que não possui nome ou outra identificação a não ser o município onde se encontra (Palhoça) e quatro pontos de coordenadas (UTM 737820 6913356, 737820 6913424, 737834 6913486, 737948 6913425) (Tabela 5). Esses pontos muito provavelmente têm algum problema no seu registro visto que, quando plotados, formam um polígono com pontos demasiadamente distantes entre si. Por isso, optou-se por registrá-lo como quatro pontos.

Os resultados da pesquisa nos Arquivos do IPHAN/SC foram positivas em termos de resultados no levantamento de sítios não identificados por levantamentos anteriores, como observamos com o sítio Marinas do Campeche e Marinas do Campeche II. Os sítios arqueológicos no município de Palhoça sem nome e os sítios arqueológicos do Parque Estadual da Serra do Tabuleiro também são importantes evidências e colocam questões a serem solucionadas em breve com trabalhos de campo e métodos adequados para solucionar seus registros e atualizá-los no banco de dados geral do panorama Tupi na América do Sul. 


\section{CAPÍTULO 4: MÉTODOS DE ANÁLISE DAS COLEÇÕES CERÂMICAS DOS SÍTIOS TRV E RT}

Este capítulo apresenta o material arqueológico estudado, problematiza o contexto de formação das coleções e dá inicio à discussão sobre como as análises macroscópicas e arqueométricas serão interpretadas teoricamente. Apresenta-se, também, os métodos de estudo das coleções. Nesse ínterim, é possível aprofundar a discussão mencionando o contexto do qual provem o material a ser estudado aqui, possuindo basicamente material arqueológico cerâmico e suas documentações escritas e fotográficas quando existentes: 1) a coleção Travessão do Rio Vermelho (TRV); 2) a coleção Lagoinha do Rio Tavares I (RT).

Ambas as coleções estão salvaguardadas pelo MArquE/UFSC, sendo a primeira coleção proveniente de pesquisa de campo da qual a autora participou entre os anos de 2013 e 2014, e a segunda proveniente de pesquisa da década de 1960. Além de terem sido desenvolvidas em contextos distintos, com questionamentos distintos, os procedimentos em campo foram diferentes, bem como em laboratório. A coleção TRV foi triada, manuseada (com luvas de vinil sem talco) e higienizada somente por uma pessoa (a autora desta pesquisa), sendo a maior parte do material higienizado a seco (para não inviabilizar análises microscópicas futuras) e numerado com a menor interferência possível. A coleção RT, já parte do acervo do MArquE desde a década de 1960, já havia passado por higienização (acredita-se que com água), manuseio desconhecido e numeração com material branco (crê-se que corretivo escolar). Também não se conhece o momento em que esse trabalho de laboratório foi realizado: se na presença do arqueólogo Walter Fernando Piazza ou posteriormente, por profissionais da instituição. Foi realizada a triagem do material cerâmico pela autora.

Em ambas, foi realizada a triagem do material cerâmico e sua seleção para análise (ver tópicos 4.4.1 e 4.5.1), uma vez que as coleções não foram analisadas em sua totalidade. Os materiais não-cerâmicos foram registrados, a proposta era não negligenciá-los nas análises; portanto, o intuito era realizar uma triagem e pré-análise dos mesmos (no material lítico, conchífero, carbonífero, remanescentes ósseos humanos, e o produto da flotação do sedimento coletado em campo). Porém, não foi possível proceder a tais atividades, especialmente à análise macroscópica do material 
lítico Guarani presente em ambas as coleções pela Dra. Alejandra Mataresse, visto que o MArquE fechou as portas a atendimento externo após o incêndio e desastre ocorrido com o Museu Nacional da Universidade Federal do Rio de Janeiro (UFRJ). Isso, em função de reivindicações de melhoras e adequações estruturais para os prédios que abrigam a instituição. Ainda, repentinamente, o museu reabriu o acesso a pesquisadores de forma coordenada na data de 07 de novembro de 2018 em acordo com a reitoria da universidade.

\subsection{Análises tecnológicas em cerâmica Guarani}

La Salvia \& Brochado publicaram no ano de 1989 um livro emblemático para a Arqueologia Guarani e análises cerâmicas que, mesmo se tratando de cerâmica Guarani, é conhecido por grande parte daqueles que trabalham com materiais cerâmicos: Cerâmica Guarani (LA SALVIA \& BROCHADO, 1989). Brochado ficou bastante conhecido na Arqueologia brasileira por ter feito parte do PRONAPA e tê-lo abandonado, trilhando um caminho referência para muitas gerações posteriores. Nesse trabalho, os autores fizeram um compilado e classificaram milhares de fragmentos analisados (acredita-se que a maior análise já realizada de material cerâmico Guarani) e, lançaram referências para todas as análises que seguiram posteriormente, independente da orientação teórica do pesquisador:

“Até agora [até o final da década de 1980] no Brasil a cerâmica arqueológica tem sido estudada primeiramente como um meio de organizar sequências seriadas para estabelecer cronologias e só recentemente Brochado (1980) tentou estabelecer distinções culturalmente significativas e reconstruir a dieta do grupo Guarani. (...) Em alguns raros casos foram estudadas as características das argilas utilizadas na pasta (Goulart, 1982: 12 -119)(...)”. (LA SALVIA \& BROCHADO, 1989, P.5)

Essa mudança na forma de se projetar e realizar a pesquisa arqueológica, refletida nas análises cerâmicas, mudou consideravelmente a partir da década de 1980 com o trabalho de Brochado e demais gerações que seguiram com influências processuais e, mais recentemente, com a pluralidade de formas e fazeres arqueológicos também com ambas influências processual (que passou por autorreflexão) e pósprocessual, surgem também não comumente trabalhos plurais na forma com que são 
configurados teórica e metodologicamente. Atualmente, as pesquisas não têm mais se encaixado em uma forma ou outra: são feitas releituras de diversas influências das escolas na Arqueologia e tem se proposto novas abordagens.

La Salvia \& Brochado enfatizam que sendo a cerâmica um elemento tecnológico determinante de um comportamento, a proposta seria ver o homem e amulher que desenvolvem uma tecnologia como satisfação de suas necessidades e inserido dentro de um contexto ecológico onde nichos ocorreriam, com características geológicas, pedológicas e vegetais diferentes, determinando comportamentos distintos dentro de uma mesma tradição cultural. Segundo eles, as inovações poderiam ser de ordem ambiental ou por contato, o que seria em alguns casos motivos insuficientes para serem criadas modificações culturais mas, simplesmente, tecnológicas (LA SALVIA \& BROCHADO, 1989, P.5). Essa última afirmação dos autores ressalta uma ideia que eles já propunham a ser trabalhada, dado o contexto das pesquisas em que desenvolveram seu trabalho, e que permanece até atualmente com suas adaptações por grande parte das pesquisas em Arqueologia Guarani no sul brasileiro. Apesar de, para aquele momento, Brochado ter quebrado muitos paradigmas da Arqueologia com viés históricoculturalista, essa proposta ainda se encontra na perspectiva teórica da tecnologia como mediadora da relação ser humano - meio ambiente. Essa visão se contrapõe àquela da tecnologia como construção social.

"A visão tradicional de tecnologia, dominante no cenário arqueológico e antropológico ainda atualmente, pauta-se em uma perspectiva adaptativista, na qual a tecnologia assume o papel de mediadora entre o homem e o meio, uma resposta a questões ambientais relacionadas a problemas básicos de sobrevivência. Tal perspectiva deixa transparecer uma visão extremamente positivista, que pressupõe níveis de respostas que vão de ineficientes a óptimas. Nessa visão não há a possibilidade de escolhas sociais ou simbólicas no decorrer do processo, uma vez que apenas as soluções óptimas, pensadas a partir de razões de custo-benefício e risco, seriam aceitas e reproduzidas (Bamforth 1986; Fitzbugh 2001). Apesar de restritiva essa abordagem gerou inúmeros modelos interpretativos, amplamente utilizados na Arqueologia." (MACHADO, 2007, P.64)

E, nesta pesquisa de mestrado, será buscado enfocar na visão da tecnologia como construção social baseado na pesquisa de Machado (MACHADO, 2005, 2005- 
2006, 2007). Nessa perspectiva, a tecnologia passa a ser percebida como construção social inspirada no estudo das técnicas corporais de Mauss:

“(...) com seus trabalhos passa-se a perceber o papel condicionante da cultura nos movimentos humanos e, por consequência, na criação e uso de seus instrumentos. Mauss (1991) mostra que 'O corpo é o primeiro instrumento do homem e o mais natural'. Suas ideias aliadas aos trabalhos de LeroiGourham (1945) inspiraram os trabalhos posteriores da chamada Antropologia da Tecnologia, difundida por Lemonnier (1986, 1992). Segundo Mauss (1991), as técnicas corporais fundamentam a tecnologia; o uso do corpo não é natural, como uma determinação biológica, e sim cultural, as técnicas corporais são aprendizados culturais, condicionamentos culturais do corpo. Para Lemonnier (1986:1992), se as técnicas corporais são aprendidas, então os gestos técnicos também são culturalmente definidos; o corpo passa a ser entendido como ferramenta inicial, que é diferente entre os grupos e pessoas." (MACHADO, 2007, P.65)

Segundo Machado (MACHADO, 2007, P.65), além de Lemonnier, LeroiGourham também teria observado o corpo humano como instrumento técnico do ser humano; e a importância desses três autores (Leroi-Gourham em 1945, Mauss em 1991 e Lemonnier em 1986 e 1992) deve-se ao caráter comparativo dos trabalhos, pois ao descrever e comparar a mesma técnica em distintos períodos e locais, indicam como estas podem ser diferentes, ou seja, possibilidades de variações isocrésticas. Observa-se, também, que os conceitos de tecnologia adotados por diferentes pesquisadores a partir da aproximação com uma antropologia estariam diretamente relacionados às noções de cultura:

"Para Schiffer e Skibo (1992), ênfase é dada no comportamento dos indivíduos com relação aos artefatos ao longo de toda sua vida útil. Segundo esses autores: '(...) tecnologia é um corpus de artefatos, comportamentos e conhecimentos para a criação e utilização de produtos, que é transmitido entre as gerações' (Schiffer e Skibo 1992:44). Desse modo, são analisadas as atividades nas quais as interações sociais acontecem, é a chamada 'Arqueologia comportamental'” (MACHADO, 2007, P.66).

Gaspar (GASPAR, 2014) citando Silva (SILVA, 2000, P.21 apud GASPAR, 2014, P.30) define tecnologia como o conjunto de artefatos, comportamentos e conhecimentos empregados pelo ser humanona transformação e utilização do mundo material. Importante, também, mencionar que a tecnologia encontra-se em um contexto 
cultural mais amplo: os sistemas tecnológicos que, por sua vez, são compostos por conjuntos técnicos. Dentre as etapas dessa cadeia operatória, os agentes realizam uma série de escolhas e combinações de escolhas (que caracterizam os conjuntos técnicos e os sistemas tecnológicos). Porém, essas escolhas são sempre culturais e podem ser motivadas por razões práticas, adaptativas e/ou simbólicas, ou pela combinação de diversas razões (MACHADO, 2007, P.67).

Cadeias operatórias também poderiam ser compreendidas como sequências de operações para a realização da transformação da matéria em artefato (MACHADO, 2005-2006, P.90 apud PFAFFENBERGER, 2001). As diferentes cadeias operatórias não necessariamente significam diferenças culturais, mas podem estar relacionadas às performances. As características de performance são as características do produto final que, por sua vez, são definidas por cada propriedade dos materiais e cada técnica utilizada para a produção de uma vasilha cerâmica (GASPAR, 2014, P.34):

“(...) uma característica de performance é a capacidade, competência ou habilidade que pode ser exercida por um determinado artefato em uma performance, sendo comportamentalmente relevante em uma interação específica." (SCHIFFER, 2010, P.90 apud GASPAR, 2014, P.30)

Schiffer e Skibo propõem que para compreender a relação entre as escolhas feitas e as performances das vasilhas (sendo performance, é possível observar os resultados desta inter-relação a partir do princípio de correlatos. Os correlatos seriam princípios gerais que regeriam determinadas tecnologias, que eram dominados pelos artesãos através dos processos de tentativa e erro realizados durante suas experimentações (MACHADO, 2007, P.68). E sobre continuidade e mudança em termos tecnológicos? É bastante difícil identificar mudanças dentro de um sistema tecnológico e, não necessariamente, a mudança implicaria em mudança de tradição/estilo tecnológica. Para Ingold, só se poderia compreender a formação e manutenção da tecnologia através do envolvimento entre o artesão, suas ferramentas e matérias-primas em um ambiente (INGOLD, 2001 apud MACHADO, 2007, P.70). Já as mudanças (adoção de novas tecnologias) podem ocorrer de diversas formas e em diferentes esferas do processo produtivo, por razões que nem sempre são econômicas, racionais/científicas ou previsíveis, mas sempre são culturalmente significativas. Para Sahlins, a cultura deve ser compreendida de forma dinâmica, com constante mudança cultural, ou seja, um processo dialético entre continuidade e mudança. Para ele, o evento 
em si não causaria ruptura, pois há uma transformação de elementos que vão se reestruturando; a inovação seria um processo construído aos poucos (SAHLINS, 1986 apud MACHADO, 2007, P.72). Para Schiffer e Skibo, as mudanças seriam fenômenos de longa duração e deveria ser buscado entendê-las a partir das características de performance; compreendem dessa forma as mudanças nos sistemas tecnológicos e a variabilidade artefatual, uma vez que enquanto está inserido num contexto sistêmico, ele está mudando (a mudança seria parte integrante da história de vida e cadeia comportamental dos artefatos) (SCHIFFER, SKIBO, 1992, 1997 apud MACHADO, 2007, P.72).

\subsection{Ficha de análise utilizada nesta pesquisa}

Após essa breve explanação de conceitos-chave para compreender a discussão em tecnologia, é importante enfatizar que a ficha de análise na qual se baseou Machado e na qual a ficha desta pesquisa de mestrado está majoritariamente embasada, tem como referências as etapas da cadeia operatória (Leroi-Gourham em 1971) para compreender características de performance (Schiffer e Skibo em 1992 e 1997). E, para compreender as atividades sistemáticas envolvidas na produção cerâmica, para compreender a cadeia operatória da produção cerâmica, é necessário observar:

"(...) escolha das fontes de matéria-prima, tanto de argila como de antiplásticos e pigmentos, coleta e processamento dessas matérias-primas, inclusão de antiplásticos na argila, manufatura de sua estrutura através das técnicas de roletagem, moldagem e/ou modelagem, alisamento e outros tratamentos de superfície (como a autilização de técnicas impermeabilizantes), secagem e utilização de técnicas decorativas (plásticas ou pintadas) antes ou depois do processo de queima." (MACHADO, 2005-2006, P.89).

Aqui, buscou-se por uma análise de atributos, que vai ao encontro dos objetivos propostos e discussão realizada em torno das coleções e dos lugares Guarani, uma vez que envolve uma comparação descritiva de características do artefato (LAVIN, 1986:3 apud CHILTON, 1998), como tempero/antiplástico ou tipo de argila, ou tratamento de superfície. Segundo Chilton (1998), vasilhas podem compartilhar alguns atributos, mas não outros. No método de análise utilizado por ela, uma análise de 
atributos de escolha tecnológica, o intuito é buscar pela variação e covariação através dos objetos - não exatamente entre grupos de objetos. Um importante componente para essa análise é que as vasilhas, ao invés de fragmentos individuais, são as unidades de análise. Por esse motivo, perseguir as análises de bordas e bases é produtivo (e uma meta futura para este trabalho). Chilton diz que o uso de vasilhas como unidades de análise é muito importante na interpretação do comportamento humano porque eram como as unidades mais comuns de significado nas sociedades pré-históricas (CARR, 1993; SKIBO et al., 1989a apud CHILTON, 1998, P.146). Nessa análise ela define um atributo como um aspecto ou variável da vasilha cerâmica, como tratamento de superfície, cor, tipo de inclusão e forma. Assim, cada atributo tem um número infinito de possíveis valores. Assim, ao invés de encaixar os fragmentos em determinadas categorias, cada fragmento pode apresentar como resultado uma infinidade de possibilidades de classificação. Essa definição se diferencia da de Cowgill (1982), Rouse (1960, 1964), e de Petersen e Sanger (1991), que definem um atributo como um estado específico de uma variável - não a variável em si mesma. (P.146). Essa forma de conduzir as análises possibilita que a fluidez e as particularidades das culturas, nesse caso, Guarani sejam exploradas.

Por fim, uma reflexão que Silva et.al. (2004) levantam para a importância das análises tecnológicas para a busca das particularidades culturais, o que é almejado nessa dissertação para os Guarani presentes no litoral central catarinense, especialmente na Ilha de Santa Catarina:

"Neste processo de interação do homem com o seu meio natural, a tecnologia atua como um mecanismo de intermediação a partir do qual é definido o modo como os homens irão organizar os meios materiais e os conhecimentos para explorar os recursos naturais e transformá-los em produtos culturais. Neste sentido, os sistemas tecnológicos não devem se entendidos, no contexto arqueológico, exclusivamente como índices de adaptabilidade. Devido à dimensão social e simbólica que possuem, os mesmos devem ser também entendidos e investigados como um meio de expressão cultural. Assim, os estudos sobre artefatos cerâmicos que levem em consideração a totalidade dos seus elementos constitutivos podem gerar um maior refinamento interpretativo tanto do ponto de vista tipológico como das características de performance desses artefatos e, consequentemente, transformar nossas concepções sobre as tradições arqueológicas. Os exemplos de cerâmica Tupi (...) evidenciaram que dentre estes diferentes conjuntos há diferenças e semelhanças regionais no 
que se refere às escolhas tecnológicas. Isso nos faz pensar que uma tradição tecnológica de longa duração como é chamada 'tradição tupiGuarani' poderia ser entendida como sendo o resultado de performances culturais diferenciadas, ao longo do tempo e do espaço, no que se refere às escolhas tecnológicas e que seu entendimento implicaria necessariamente na realização de estudos regionais comparativos e na percepção das expressões particulares e convergentes destas diferentes populações" (SILVA et.al., 2004, P.60).

Uma vez que há a necessidade em se utilizar categorias na ficha de análise, o desafio se encontra, então, em compreender a dinâmica no processo de produção. Assim, pensando nessa sequência, a ficha de análise macroscópica aqui utilizada também segue etapas do processo de produção do material cerâmico, como é possível observar abaixo na Figura 7.

A ficha usada nesta pesquisa foi formada a partir da ficha de análise cerâmica do LEIA/UFSC, com influência no trabalho de Machado (MACHADO, 2005) e La Salvia \& Brochado (LA SALVIA \& BROCHADO, 1989)². A mesma foi adaptada para esta pesquisa após banca de qualificação, estágio realizado no exterior pela BEPE/FAPESP sob supervisão de Dr. Mariano Bonomo, e questionamentos e demandas surgidas ao longo das análises. A ficha encontra-se descrita e esmiuçada no GLOSSÁRIO (ANEXO 05), parte final da dissertação, onde também consta o processo pela qual passou até chegar a sua versão final. Essa ficha encontra-se registrada a seguir. Importante enfatizar que as fichas de análise são plurais e formadas de acordo com os questionamentos de cada pesquisa e de acordo com o que o material analisado oferece. Aqui, o intuito é compreender o processo de produção das vasilhas cerâmicas encontradas em ambos os sítios através das análises tecnológica e por fluorescência de raios-X.

\footnotetext{
${ }^{2}$ Essa ficha inicial foi testada em análise piloto com o material sem referência (fragmentos cerâmicos recolhidos por moradores) do sítio TRV durante iniciação científica desenvolvida na graduação pela autora.
} 


\section{A FICHA DE ANÁLISE CERÂMICA}

1. Sítio

2. PN - dígito

3. Localização (unidade de escavação)

4. Nível Estratigráfico

5. Natureza da Peça

1 - borda

2 - base

3 - parede

4 - inflexão

5 - alça

6 - cachimbo/petangua

7 - decoração

8 - reforço

9 - bolota de argila ou trempe ytácuru

6. Antiplástico

1 - cariapé

2 - caco moido

3 - mineral A (areia grossa)

4 - mineral B (areia média)

5 - mineral C (areia fina)

6 - óxido de ferro

7 - argila

8 - carvão

7. Técnica de Manufatura

1 - roletado / acordelado

2 - modelado

3 - moldado

4 - torneado

8. Configuração do Núcleo (indicativo de queima)

1 - (oxidante)

2 - (oxidante interna e externa, e redutora no núcleo)

3 - (redutora)

4 - (oxidante interna/redutora externa)

5 - (redutora interna/oxidante externa) 6 -

9. Coloração da Face Externa

10. Coloração da Face Interna

11. Espessura da Peça (mm)

12. Forma do Lábio
1- plano
2 - arredondado
3 - apontado
4 - biselado

13. Espessura do Lábio

14. Diâmetro da Borda $(\mathrm{cm})$

15. Porcentagem da Borda (\%)

16. Forma da Borda

1 - restritivo

2 - irrestritivo

3 - vertical

4 - ponto de inflexão
17. Forma da Base

$$
\begin{aligned}
& 1 \text { - plano } \\
& 2 \text { - côncava } \\
& 3 \text { - convexa } \\
& 4 \text { - reforçada }
\end{aligned}
$$

18. Tratamento Plástico de Superficie

1 - alisamento

2 - polimento

3 - corrugado

4 - digitado

5 - ungulado

6 - inciso

7 - escovado

8 - acanalado

9 - estampado

10 - ponteado

11 - nodulado

12 - exciso

19. Localização do Tratamento Plástico

1 - face interna

2 - face externa

3 - lábio

4 - face interna e externa

20. Tratamento Cromático de Superfície

1- monocrômico (pintura)

2 - bicrômico (engobo+pint / pint-pint/ engobotengobo)

3 - policrômico (engob+pint+pint/3pints)

4 - engobo vermelho

5 - engobo branco

6- enegrecimento e/ou brunidura

7-resina

21. Localização do Tratamento Cromático

1 - face interna

2 - face externa

3- lảbio

4 - faces interna e externa

22. Pasta

1 - branca

2 - laranja A (alaranjado)

3 - laranja B (avermelhado)

4 - laranja C (tom de marrom)

5 - cinza preta

23. Marca de Uso

1 - fuligem

2 - reciclagem

3 - desgaste acentuado

4 - fermentação

24. Atribuição Etnohistórica (não foi atribuida nessa fase da pesquisa)

25. Conjunto Atribuído (pode já ser observável ou não)

26. Observações

Figura 7. Ficha de análise tecnológica utilizada nesta dissertação. 
Sendo assim, é possível observar que a ficha utilizada inicia com categorias de identificação da peça (1. Sítio, 2. PN - dígito, 3. Localização (unidade de escavação), 4. Nível Estratigráfico, 5. Natureza da Peça), depois passa pela preparação de matéria-prima (6. Antiplástico). Aqui, abre-se uma observação de que a argila não foi observada e não se encontra nesse momento da análise, uma vez que o que temos acesso e analisamos é à pasta como produto final (21. Pasta) (essa observação e sugestão foi realizada pela Profa. Dra. Fabíola Silva na banca de qualificação deste trabalho). Então, segue-se às técnicas de manufatura (7. Técnica de Manufatura), passa por indicativos de queima (8. Configuração do Núcleo, 9. Coloração da Face Externa, 10. Coloração da Face Interna), mais medidas e observações sobre formas (11. Espessura da Peça em mm, 12. Forma do Lábio, 13. Espessura do Lábio, 14. Diâmetro da Borda em cm, 15. Porcentagem da Borda (\%), 16. Forma da Borda, 17. Forma da Base), tratamentos de superfície (18. Tratamento Plástico de Superfície, 19. Localização do Tratamento Plástico, 20. Tratamento Cromático de Superfície, 21. Localização do Tratamento Cromático), passa pela observação da pasta (22. Pasta), uso (23. Marca de Uso), classificação (dentro de categorias etnohistóricas e conjuntos: 24. Atribuição Etnohistórica - não foi atribuída nessa fase da pesquisa-, 25.Conjunto Atribuído - pode já ser observável ou não) e demais observações (26. Observações). A base dessa sequência de atributos foi também utilizada por Gaspar (GARPAR, 2014, P.p.42-43).

Faz-se um grifo de que nessa ficha trabalhada os acabamentos de superfície e decoração são tratados dentro de uma categoria apenas, Tratamento de Superfície, compreendendo que ambas são formas de trabalhar a superfície das vasilhas sem realizar distinção entre. Assim como o atributo 23.Atribuição Etnohistórica nesta fase da pesquisa não foi explorada exaustivamente. Ainda, para padronizar as colorações de que trata a ficha (, cada fragmento foi relacionado a uma correspondência na tabela Munsell Soil Color Charts que, por consequência, foi relacionado às cores de pasta:

- Pasta branca: os correspondentes na tabela Munsell são 7.5YR 8/1 white, 7.5YR 5/1 gray, 7.5YR 6/1 gray, 7.5YR 6/.2 pinkish gray, 7.5YR 6/3 light brown, 7.5YR 6/6 reddish yellow, 7.5YR 7/1 light gray, 7.5YR 7/2 pinkish gray, 7.5YR 7/3 pink, 7.5YR 7/4 pink, 7.5YR 8/2 pinkish white, 7.5YR 8/3 pink, 7.5YR 6/1 pink. 
- Pasta laranja A: 2.5YR 5/5 red, 5YR 4/6 yellowish red, 5YR 5/6 yellowish red, 7.5YR 4/2 brown, 7.5YR 4/3 brown, 7.5YR 4/6 strong brown, 7.5YR 6/3 light brown, 7.5YR 6/4 light brown, 7.5YR 6/6 reddish yellow..

- Pasta laranja B (tom avermelhado): 2.5YR 4/6 red, 5YR 3/3 dark reddish brown, 5YR 4/4 reddish brown, 5YR 4/6 yellowish red, 5YR 5/4 reddish brown, 5YR 5/6 yellowish red, 7.5YR 4/4 brown, 7.5YR 4/6 strong brown, 7.5YR 5/4 brown, 7.5YR 5/8 yellowish red.

- Pasta laranja C (tom de marrom): 5YR 5/6 yellowish, 5YR 5/8 yellowish red, 7.5YR 2.5/1 black, 7.5YR 3/1 very dark gray, 7.5YR 3/2 dark brown, 7.5YR 3/3 dark brown, 7.5YR 4/1 dark gray, 7.5YR 4/2 brown, 7.5YR 4/3 brown, 7.5YR 4/4 brown, 7.5YR 4/6 strong brown, 7.5YR 5/3 brown, 7.5YR 5/4 brown, 7.5YR 5/6 strong brown, 7.5YR 6/2 pink, 7.5YR 6/3 light brown, 7.5YR 6/4 light brown, 7.5YR 7/3 pink, 7.5YR 3/4 dark brown, 7.5YR 4/1 dark gray, 7.5YR 5/2 brown, 7.5YR 6/6 reddish yellow, 10YR 7/2 light gray, 10YR 7/3 pale yellow, 10YR 7/4 pale yellow.

- Pasta cinza/preta: 7.5YR 3/1 very dark gray, 7.5YR 5/1 gray e 7.5YR 4/1 dark gray.

Demais observações no já referido glossário da ficha ao final deste trabalho (ANEXO 05).

\subsection{Espelhamento das bordas}

Foi realizado o espelhamento das bordas nesta dissertação, mas não sua projeção da vasilha inteira a partir das mesmas conforme é comum nos trabalhos de análise cerâmica. Isso devido a acreditar que para que a projeção seja feita de uma forma melhor embasada, deve-se ter como referência todas as vasilhas inteiras conhecidas arqueológica e etnograficamente para, então, obtermos formas "padrões" e então, podermos extrapolar para os fragmentos de borda. As formas conhecidas/existentes e já bem difundidas são muito importantes como um primeiro passo para pensarmos essas vasilhas completas. Ainda assim, há trabalhos referência e bastante representativos da temática cerâmica Guarani ao propor a reconstrução gráfica dos recipientes cerâmicos inteiros a partir dos fragmentos. São eles os trabalhos de Brochado, Monticelli e Neumann (BROCHADO, MONTICELLI \& NEUMANN, 1990), Brochado e Monticelli (BROCHADO \& MONTICELLI, 1994), Jacobus 
(JACOBUS, 1994) e mais recentemente a extensa pesquisa de Corrêa (CORRÊA, 2014) com apontamentos sobre algumas formas de vasilhas Guarani.

Entretanto, uma vez que se busca nesta pesquisa as particularidades em meio à estrutura Guarani, foi optado por realizar os espelhamentos das peças a partir do diâmetro provável calculado através das bordas presentes nas coleções (atributo 14. Diâmetro da borda em $\mathrm{cm}$ ) e do posicionamento correto das bordas, utilizando o ábaco, que também, mesmo sendo feita de forma totalmente cuidadosa, tratam-se de aproximações. Por exemplo, a confiabilidade das projeções de diâmetro das bordas implica diretamente nos espelhamentos feitos e, por sua vez, é determinada pelo atributo 15. Porcentagem da borda (\%). Quanto menor a porcentagem, menos o diâmetro projetado é confiável e o contrário também é válido. Os espelhamentos projetam apenas os lados contrários das bordas analisadas em posição aproximada àquela em que estariam se vislumbrássemos uma vasilha inteira apoiada em superfície plana. Ao visualizar o trecho da borda projetada no seu lado contrário e a circunferência que essa gera, é possível ter dimensão mais visual de como a vasilha iniciava (pelas bordas) e propor formas totais a elas. Ao visualizar parte da forma que essa vasilha deveria ter, auxilia na compreensão de quais tipos (atrelados às categorias etnohistóricas) e dimensões os mesmos. Nesse momento, essa informação foi essencial para a visualização das dimensões das vasilhas que, associado aos dados de espessura, puderam gerar novos dados às interpretações feitas sobre o conjunto cerâmico de cada sítio arqueológico.

Esses "espelhamentos", conforme serão tratados aqui, foram desenvolvidos de forma a adiantar a etapa de se realizar o desenho a mão dos materiais em papéis branco e vegetal para depois serem digitalizados e trabalhados em softwares como CorelDraw, o que é comum no meio da Arqueologia brasileira. Foi utilizado, ao invés do procedimento descrito anteriormente, um procedimento conhecido e executado para esses casos pela equipe de Arqueologia do Museo de Ciencias Naturales de la Universidad Nacional de La Plata, especificamente ensinado pela doutoranda Canela Castro $^{3}$. Consiste nas seguintes etapas:

\footnotetext{
${ }^{3}$ Essas técnicas e outros métodos utilizados para a Arqueologia vieram a ser conhecidos durante estágio realizado pela autora no Museo de Ciencias Naturales de la UNLP (La Plata) em abril de 2018, sob supervisão estrangeira do pesquisador do CONICET Dr, Mariano Bonomo. Esse estágio ocorreu através da Bolsa Estágio de Pesquisa no Exterior (BEPE/FAPESP), processo n²017/21759-6.
} 
- Cada fragmento de borda/base é fotografado com fundo de cor bastante contrastante com a cor da peça (neste caso, azul). Não pode esquecer de fotografar a escala junto. Deve haver fotografias de distintas posições: corte transversal, face interna e face externa. Especificamente para as bordas, elas devem ser fotografadas transversalmente como se fossem ser desenhadas para a projeção total da vasilha, na posição provável em que se localizavam na vasilha completa. Essa etapa foi realizada pela autora;

- A edição dessas imagens, então, deve ocorrer com o uso do software Photoshop, uma vez que para esse uso esse software se torna mais prático esse procedimento. Para o espelhamento, são utilizadas mais as seguintes informações obtidas durante a análise tecnológica de forma macroscópica: o provável diâmetro da borda e a porcentagem o fragmento representa no todo da circunferência. Então, no software com essas últimas informações, é possível desenhar uma circunferência provável da vasilha e espelhar esse fragmento em duas ou três dimensões. Esta etapa de edição foi testada e produzida pelo arqueólogo e profissional Thiago Umberto Pereira.

Assim, esses espelhamentos estão disponibilizados no CATÁLOGO DE VESTÍGIOS CERÂMICOS ao final desta dissertação (ANEXO 06) ${ }^{4}$. A intenção desse catálogo é proporcionar imagens em quantidade e boa qualidade para comparação com materiais cerâmicos diversos de outros trabalhos. Buscou-se tal contribuição e espera-se que a iniciativa possa ser difundida e aprimorada

\subsection{Arqueometria por fluorescência de raios-X (XRF)}

As análises arqueométricas são imprescindíveis na discussão sobre análise cerâmica e seus resultados/ interpretações e são necessárias na interdisciplinaridade, no confronto e forma de olhar o material. Nesse confronto, percebemos como nossas escolhas são subjetivas a todo momento durante as pesquisas. Ainda assim, são necessários alguns parâmetros mais objetivos. Há diversas técnicas de análises destrutivas, não-destrutivas e semidestrutivas que se enquadram sob a denominação de

\footnotetext{
${ }^{4}$ Vale enfatizar que esses espelhamentos são representações bidimensionais, portanto, nesse momento não intentam ser tridimensionais.
} 
“arqueométricas". Porém, antes de avançar, é necessário definir esse campo. A Arqueometria é uma área de pesquisa interdisciplinar que envolve o uso de métodos científicos físico-químicos a fim de responder a questões específicas para o conhecimento dos objetos produzidos por diferentes sociedades, e permitir revelar e identificar os materiais e tecnologias utilizados no passado e, também, para obter parâmetros mais embasados para a preservação e conservação do patrimônio cultural (RIZZUTTO, 2015, P.67). Por isso, muitas vezes são remetidas como "análises físicoquímicas". Elas existem desde o século XIX e foram intensificadas durante o processualismo na Arqueologia, momento no qual foi buscado um status de caráter mais "científico" nas disciplinas exatas e da terra em contraposição com as demais ciências humanas (que ocupavam majoritariamente o cenário nas discussões na área).

Nessa pesquisa de mestrado, dentro de um rol bastante extenso de técnicas arqueométricas, a forma de análise escolhida foi a Fluorescência por Raios-X (XRF), devido aos questionamentos que surgiram durante a pesquisa no geral e durante a análise macroscópica do material explicitados a seguir. $\mathrm{Na}$ análise macroscópica os atributos observados são feitos a olho nu, no máximo com o auxílio de uma lupa de mão. Portanto, a escolha do XRF se deu em função da necessidade sentida em se caracterizar quimicamente tudo que era inorgânico e que se observava de maneira genérica macroscopicamente; em função da necessidade de confrontar as características de cor da pasta, pintura, engobo que eram observadas macroscopicamente e, mesmo, pensar em proveniências distintas da matéria-prima para a fabricação das cerâmicas presentes nos dois sítios arqueológicos. O XRF é uma técnica que pode explorar essas questões de uma forma geral e é largamente utilizada no estudo do patrimônio material e proporciona um bom confronto para as análises prévias macroscopicamente; ele realiza um diagnóstico das coleções de maneira elementar (para elementos inorgânicos) e, então, havendo necessidade de se aprofundar em uma ou outra questão mais específica, determinar outras técnicas para solucioná-las. É importante salientar que nenhum dos dois tipos de análise, macroscópicas e arqueométricas, se sobressai uma a outra. Ambas são complementares. E para construir uma interpretação final de análise cerâmica menos tendenciosa é que se buscou confrontar diferentes tipos de análise.

"A XRF é capaz de detectar e quantificar as concentrações químicas dos elementos presentes na amostra analisada, pois a radiação de fluorescência que é emitida proveniente de cada átomo é característica da espécie química, ou seja, não existe 
similaridade entre as radiações de radiofrequência emitidas por diferentes átomos da Tabela Periódica. Além disso, a XRF também pode fornecer a informação sobre a localização superficial de onde o elemento emissor se encontra na amostra de maneira bastante precisa em termos de análises quantitativas. Assim, a técnica de XRF pode ser usada para quantificar a concentração dos elementos presentes na amostra analisada de forma eficaz, sem contaminá-la ou descaracterizá-la." (NASCIMENTO-DIAS, OLIVEIRA, DOS ANJOS, 2017)

Portanto, observamos que se trata de uma análise quali-quantitativa, nãodestrutiva em boa parte das situações (dependendo do equipamento utilizado), eficaz, segura e que tem se tornado bastante difundida no meio do patrimônio cultural e, na Arqueologia, tem crescido o número de parcerias com laboratórios de física e química para a sua realização, especialmente com materiais cerâmicos. Além disso, a técnica do XRF permite identificar aspectos da tecnologia de produção das vasilhas estudadas, aspectos esses sobre: a seleção e preparo da matéria-prima e o modo de construção do recipiente cerâmico (SILVA et al., 2004). Em estudo realizado por Silva et.al. (2004) em cerâmicas Tupi amazônicas e provenientes do sul do país, por exemplo, foi evidenciado que dentre os diferentes conjuntos há diferenças e semelhanças regionais no que se refere às escolhas tecnológicas. Isso sugeriria que uma tradição tecnológica de longa duração como a chamada "tradição tupiGuarani" poderia ser compreendida como sendo o resultado de performances culturais diferenciadas, ao longo do tempo e espaço no que se refere às escolhas tecnológicas, e que seu entendimento implicaria necessariamente na realização de estudos regionais comparativos e na percepção das expressões particulares e convergentes dessas populações (SILVA et al., 2004, P.60). E nesse intuito também reside o propósito das análises aqui propostas para o contexto regional do litoral central catarinense, o estudo da longa duração com suas particularidades, mudanças e continuidades.

Outro estudo através do método XRF se mostrou bastante profícuo na discussão dos contextos Guarani. Esse estudo foi realizado por Milheira, Appoloni e Parreira (2009) buscando identificar uma chamada "crosta escura" presente na superfície dos fragmentos arqueológicos ao redor do sistema lagunar da Laguna dos Patos (RS). Permitiu não somente identificar os elementos químicos componentes da "crosta preta", mas também possibilitou avançar na discussão dos processo pósdeposicionais naturais que atuam sobre os materiais arqueológicos no litoral (MILHEIRA, APPOLONI, PARREIRA, 2009, P.362). Uma terceira análise com XRF 
mais recente é aquela realizada por Carbonera e Appoloni (CARBONERA, APPOLONI, 2017) em vestígios cerâmicos Guarani no alto Uruguai buscando conhecer a composição do material pictórico, ou seja, as tintas utilizadas no tratamento cromático das vasilhas.

Se possuirmos essa diversidade de dados produzidos por meio de diversos métodos, será possível ampliar as discussões em torno dos contextos Guarani em nível micro e macro-regional, uma vez que há muitos métodos de natureza físico-química a serem aplicados dependendo dos questionamentos feitos às pesquisas. Para as análises arqueométricas é recomendada a associação de no mínimo duas técnicas, pois para cada uma há um grau de abrangência, de medição e especificidade. Também é recomendado evitar análises desnecessárias - há que se ter bem claro o que se quer medir. O manuseio do material desde o momento da escavação arqueológica até o laboratório deve ser cuidado, além de levar em conta as técnicas de caracterização e datação desses materiais para que não se inviabilizem análises posteriores. Para algumas técnicas, destrutivas e micro-destrutivas, certamente haverá que se pesar o potencial informativo da medição para a discussão no conhecimento que pode ser gerado com tal uso - no geral, não se utiliza essas técnicas em objetos tidos como "únicos" (STUART, 2007). Aqui, foi escolhida uma forma de análise que gerou bons resultados e provocadores para as próximas pesquisas a serem desenvolvidas. $\mathrm{O}$ equipamento utilizado para as análises de XRF possibilitou que se tornasse uma análise não destrutiva, portanto, os materiais não sofreram dano algum. Importante sublinhar que as análises não diferenciam processos tafonômicos da produção do objeto por exemplo, por isso realizar análises prévias, como conhecer o máximo possível as trajetórias dos objetos e coleções faz-se necessário; lembrando ainda que todo tipo de coleção é potente para o conhecimento sendo ela proveniente de pesquisas recentes ou há muito tempo salvaguardadas em museus. Trata-se apenas de realizar as perguntas corretas e usar o método mais apropriado aos contextos.

Por fim, essa análise com XRF foi realizada em parceria com a Professora do Instituto de Física USP, Departamento de Física Nuclear, Dra. Márcia de Almeida Rizzutto, e especificamente no laboratório Núcleo de Apoio a Pesquisa Física Aplicada ao Estudo do Patrimônio Artístico e Histórico - NAP-FAEPAH ${ }^{5}$. Os questionamentos

\footnotetext{
${ }^{5}$ Para o transporte das peças do Museu de Arqueologia e Etnologia Professor Oswaldo Rodrigues Cabral (MArquE/UFSC) ao NAP-FAEPAH foi requerido ao Instituto do Patrimônio Histórico e Artístico
} 
que surgiram para a escolha do XRF se concentraram em compreender o processo de produção das vasilhas Guarani (conforme proposta de análise geral), especificamente em: compreender se as mesmas características observáveis a olho nu nos conjuntos formados tinham correspondência físico-quimica; determinar a composição da pasta; identificar a composição do antiplástico presente na pasta; e reconhecer a ação dos processos pós-deposicionais no material. Sobre a temperatura de queima, não foi possível determiná-la nesta etapa da pesquisa (ainda assim, é possível através de FTIR e difração de raios-x por exemplo) para confrontar. A composição do antiplástico presente na pasta foi determinada através do XRF e complementado com análise em lupa (observado no Glossário da ficha de análise quantitativa). Já, com relação aos demais questionamentos, foram satisfeitos em sua maior parte, especialmente com relação à composição da pasta. E serão abordados adiante.

Foram selecionadas 14 amostras de cada sítio arqueológico estudado para realização das análises arqueométricas, totalizando 28 fragmentos (cujas imagens das amostras estão no ANEXO 07). Os fragmentos foram escolhidos ao final da etapa das análises macroscópicas e são representativos dos conjuntos identificados em cada sítio. Outros foram escolhidos para representar características específicas, como engobo, tratamento de superfície, ou uma possível ação pós-deposicional nas superfícies. Os conjuntos 1 a 8 do material analisado do sítio TRV foram amostrados. Para o sítio Rio Tavares, os conjuntos amostrados foram 1, 2, 3, 6 e 7. Vale destacar que as amostras foram limpas a seco. As medidas foram realizadas com voltagem de $30 \mathrm{KV}$, i de 20 micro A. A interpretação das mesmas seguiu no mês de agosto (2018). Vale ressaltar que cada etapa foi realizada pela autora sob a orientação constante da Profa. Márcia Rizzutto, desde o manuseio do equipamento às interpretações das análises geradas.

Foram medidos seis pontos ao todo em cada fragmento cerâmico: dois pontos na face interna; dois pontos na face externa; e dois pontos no núcleo. De acordo com alguma especificidade macrovisual pontual foram selecionados os pontos nas faces interna e externa a serem medidos. Antes de realizar as medidas foram medidos padrões de calibração do instrumento, tais como: ar; chumbo $(\mathrm{Pb})$; sedimento (Buffallo River); e argila (sítio Saracuruna - IPT 32). Os dois últimos padrões servem para transformar

Nacional (IPHAN) uma solicitação de movimentação de bens arqueológicos para análise em território nacional (de acordo com a Portaria do IPHAN de $\mathrm{n}^{\circ} 195$, de 18 de maio de 2016) realizada pela arqueóloga responsável pelo MArquE, Me. Luciane Zanenga Scherer, e tendo sido aprovada sob Processo $\mathrm{N}^{\circ} 01510.000475 / 2018-46$. 
em porcentagem às quantificações geradas pelo equipamento (correspondentes a área de cada pico). As Figuras 8, 9 e 10 mostram diferentes de momentos do processo de medição das amostras com XRF.

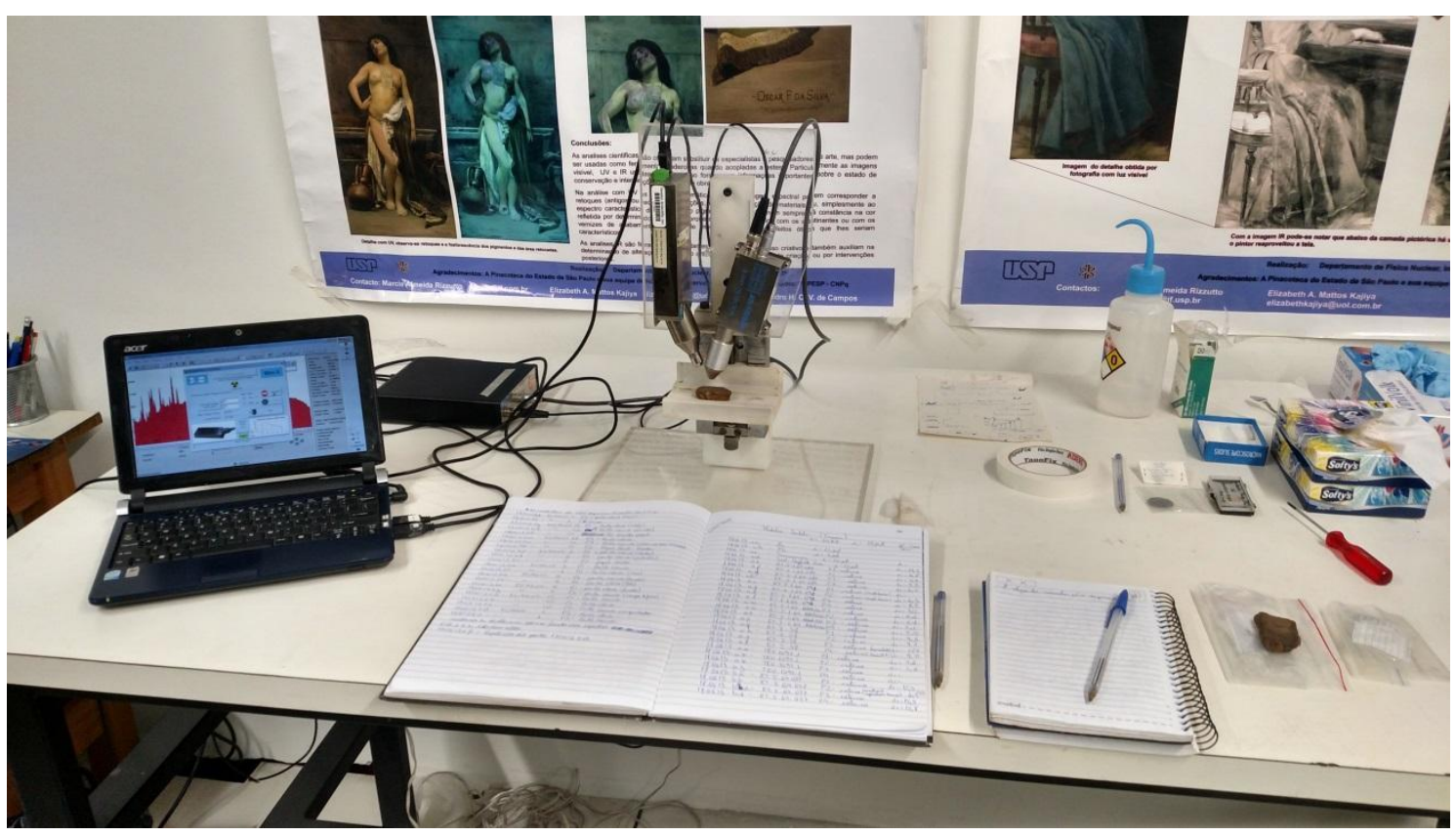

Figura 8. Imagem da bancada com o aparelho portátil de XRF, o computador com software relacionado, e o caderno de registros. Foto: Isabela da Silva Müller.

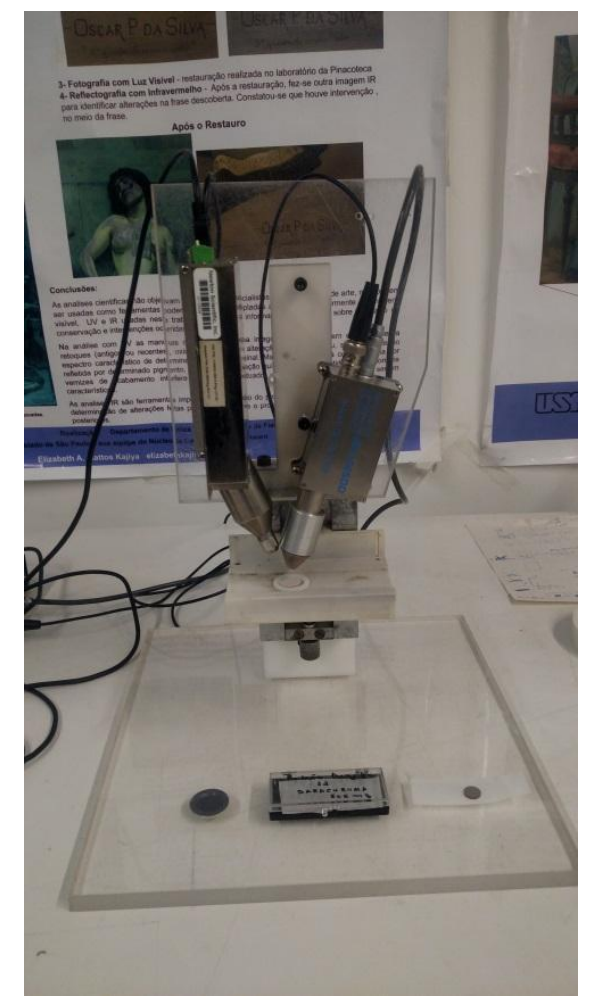

Figura 9. Imagem com o aparelho realizando a medição de um dos padrões. Foto: Isabela da Silva Müller. 


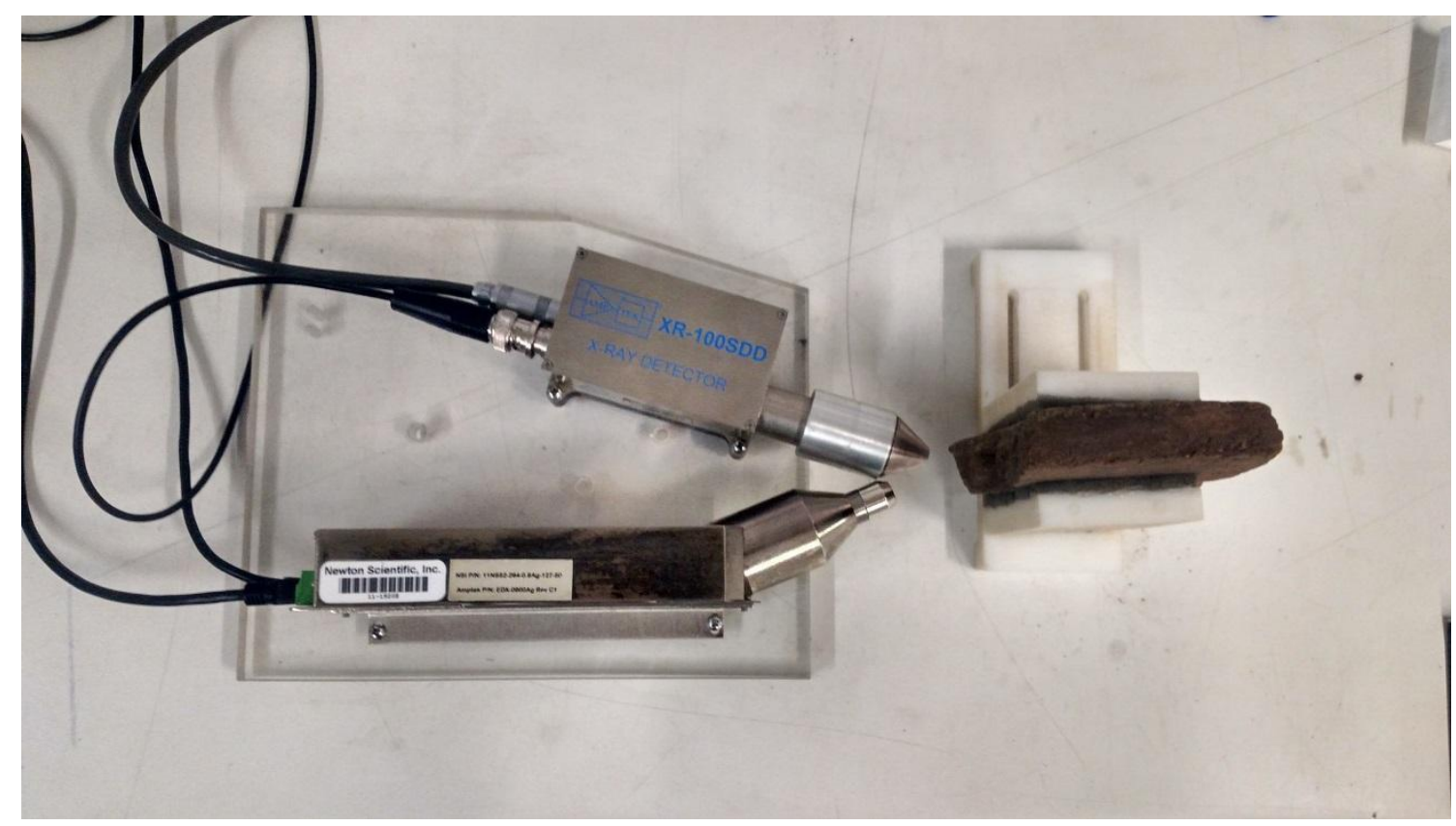

Figura 10. Aparelho em outra configuração (sem o suporte vertical) realizando a medida do núcleo de um fragmento cerâmico. Foto: Isabela da Silva Müller.

Após seleção das amostras e medição das mesmas em laboratório, o terceiro momento envolveu o tratamento dos dados gerados e sua análise. A conversão dos dados gerados pelo equipamento foi feita com os softwares GraphViewm, WinQxas, e Qxasreader para gerar gráficos com os picos de área identificados em cada ponto medido (Figura 11). Para cada ponto de análise, foi feita a identificação do elemento químico observado e, posteriormente, essas informações foram transformadas em quantificações de áreas em tabelas de Excel. Foram identificados 25 elementos químicos para cada ponto medido. Cada dado foi analisado individualmente e em conjunto para sua interpretação. Após a análise foi definido que o resultado das medições nos seis pontos por fragmento poderiam ser trabalhados como média, devido à constância na medida do Argônio (Ar). A medida do argônio foi importante para obter o parâmetro de que todas as medidas estiveram constantes e podem ser comparáveis diretamente, isso porque há argônio entre o tubo do equipamento e a peça; e uma vez que a distância entre o tubo e a peça aumenta, o resultado da medida dos elementos químicos presentes no material diminui porque o valor do argônio é maior; e uma vez que essa distância diminui, o resultado da medida aumenta uma vez que o valor do argônio é menor. Por isso, a importância de se buscar manter uma distância constante entre o tubo e a peça, e o argônio revela essa se ocorreu alguma mudança nessas medidas. 


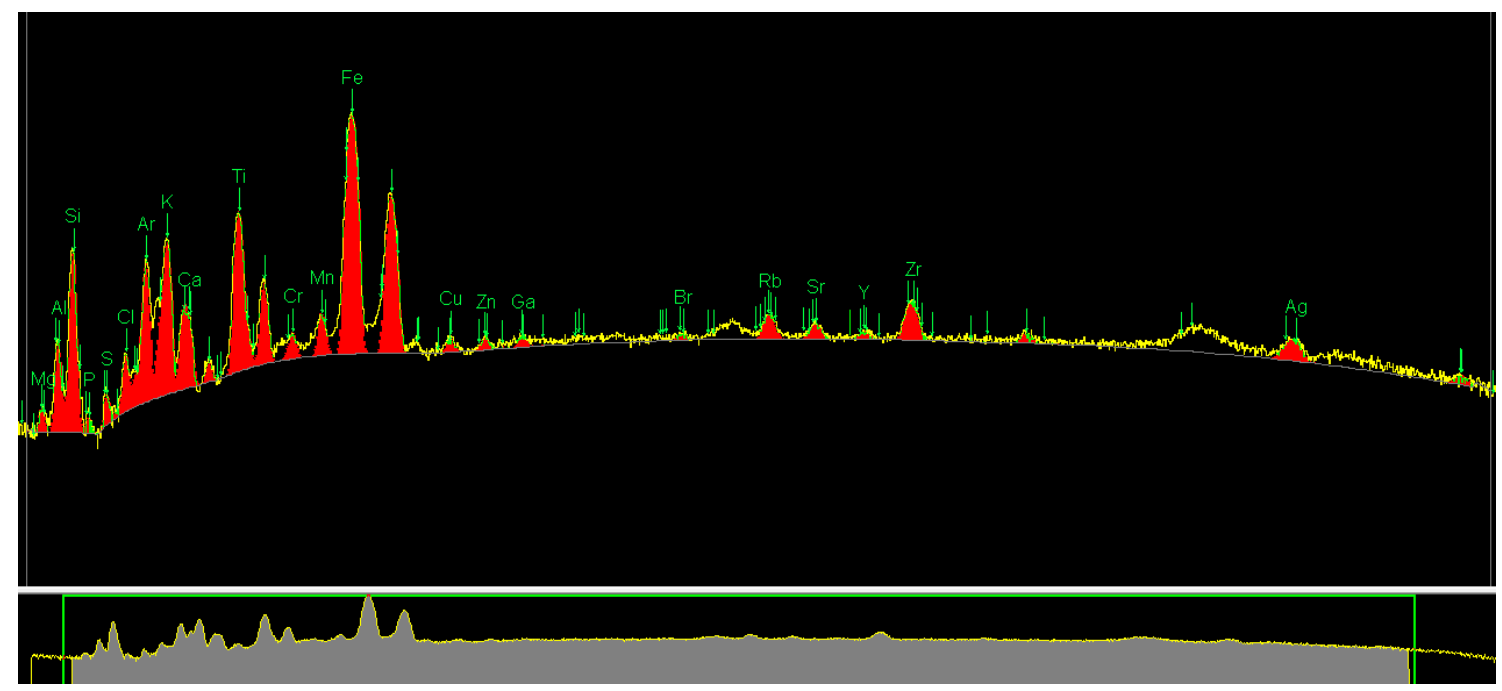

Figura 11. Exemplo de gráfico de áreas gerado pelo software WinQxas.

Por exemplo, os dois pontos medidos em cada parte da cerâmica (face interna e externa, respectivamente) foram transformados em um apenas através da média aritmética entre eles. Em casos específicos, foi utilizado um dos dois pontos em detrimento de algum problema com a segunda medição. Para esse tipo de situação, em que só se pode utilizar um dos dois pontos, e para que houvesse um detalhamento maior é que a medida dos seis pontos ao total se mostrou bastante eficaz. Importante salientar que as informações nos gráficos correspondentes à concentração de cada elemento químico correspondem às medidas de área de pico e não de porcentagem total. Isso significa que, as medidas em área podem ser comparadas dentro de cada elemento químico apenas. Por exemplo, é possível dizer que uma amostra $\mathrm{X}$ tem mais ferro $(\mathrm{Fe})$ que a amostra $\mathrm{Y}$, mas usando os valores de área de pico não é possível dizer que a amostra $\mathrm{X}$ contem mais ferro $(\mathrm{Fe})$ que cálcio $(\mathrm{Ca})$ que a amostra Y. Quando falamos em "pico" é importante ressaltar que isso se refere à apresentação no gráfico, não à sua concentração. Além disso, esses gráficos geraram planilhas de dados com os valores (de área, não de concentração) no software Excel. Dessas, foram gerados os gráficos que serão discutidos nos resultados dessa dissertação. As tabelas com os dados brutos do Excel encontram-se no ANEXO 08.

Dos 25 elementos químicos identificados, três foram pouco expressivos (bário -Ba-, chumbo - $\mathrm{Pb}$-, e níquel $-\mathrm{Ni}$ ), um deles que nos serve como referência das medidas (argônio, Ar, presente entre o tubo de irradiação e o material arqueológico no momento da medida das amostras), e a prata ( $\mathrm{Ag}$ ) referente ao tubo de prata do 
equipamento. As medidas são apresentadas nos gráficos de áreas de forma qualitativa e foram divididas em faces interna, externa, e núcleo da pasta.

\subsection{A coleção Travessão do Rio Vermelho (TRV)}

A coleção Travessão do Rio Vermelho (TRV) é proveniente de sítio arqueológico de mesmo nome localizado no bairro Rio Vermelho, região nordeste da Ilha de Santa Catarina (ficha de cadastro de sítio em ANEXO 03, produzida pela equipe do Florianópolis Arqueológica - ficha não disponível do CNSA/IPHAN). Parte do sítio (ainda não totalmente delimitado) foi trabalhado pela equipe do LEIA/ UFSC, sob coordenação do Prof. Dr. Lucas Bueno, entre os anos de 2013 e 2014 (Portaria N.37 de 19 de agosto de 2013. Processo 01510.001749/2013-18). O sítio não era conhecido até um morador ter identificado os fragmentos cerâmicos no local e procurado o setor de Arqueologia do MArquE/UFSC na pessoa da arqueóloga Me. Luciane Zanenga Scherer. Em seguida, a equipe do LEIA iniciou a pesquisa no sítio. Com relação à pesquisa realizada em campo, que resultou em intervenções de superfície e subsuperfície, procurou-se trabalhar com a evidenciação do que se chama "superfície ampla" (Figuras 12 e 13), totalizando $28 \mathrm{~m}^{2}$ de área escavada. Assim, pode-se identificar possíveis áreas de atividade no piso de ocupação do sítio arqueológico. 


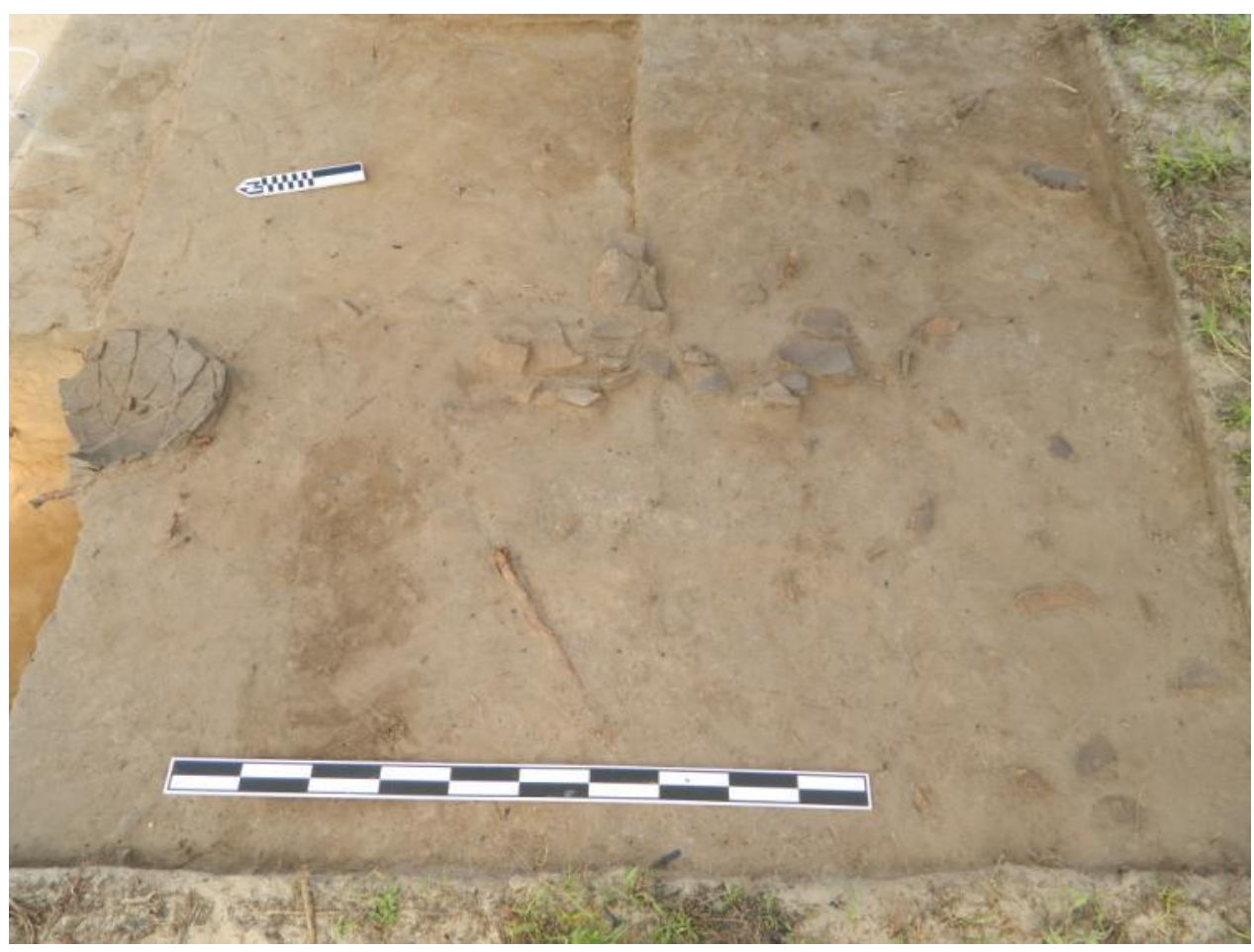

Figura 12. Superfície ampla escavada na área B1 do sítio TRV. Fonte: Florianópolis Arqueológica. Relatório Parcial, 2013.

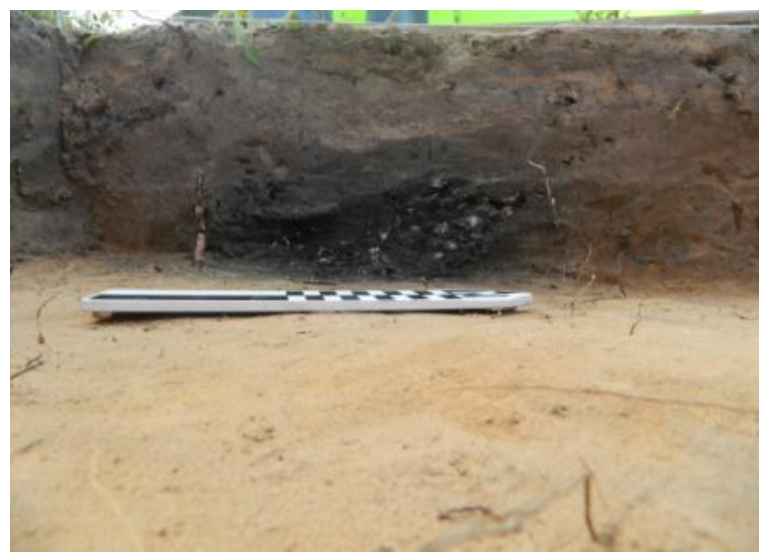

Figura 13. Detalhe de estrutura de combustão na área B1 do sítio TRV. Fonte: Florianópolis Arqueológica. Relatório Parcial, 2013.

Além do material cerâmico pré-colonial, foram coletadas durante a escavação amostras de madeira carbonizada e conchas provenientes de possíveis fogueiras para análise radiocarbônica, análise antracológica e identificação de espécie das conchas por meio de parcerias com demais laboratórios e setores da universidade. Foram coletadas, ainda, pequenas amostras de material lítico. O sítio foi datado a partir de amostras de carvão proveniente de duas possíveis estruturas de combustão, com 


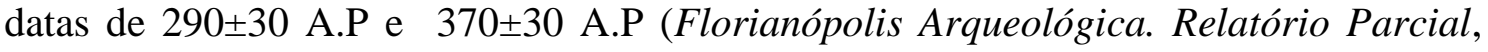
2013) (ANEXO 02), período da chegada dos europeus na região.

\subsubsection{Unidades selecionadas para análise}

O sítio TRV é unicomponencial, ou seja, possui um único pacote de ocupação, com sedimento preto de textura arenosa. A escavação foi realizada por níveis artificiais de $10 \mathrm{~cm}$. O sítio não foi delimitado na ocasião, mas duas áreas foram identificadas: A e B. Na área A foi realizada coleta de superfície. Na área B, foram realizadas: coleta de superfície, tradagens e aberturas de áreas amplas de escavação identificadas como B1, B2 (a maior delas, onde foram foi concentrado um maior esforço devido à profusão de material) e B3.

As unidades de escavação cujos fragmentos cerâmicos foram analisados nesta pesquisa estão localizadas nas áreas B1 (uma quadra) e B2 (três quadras). Na Figura 14 é possível observar as quadras selecionadas para análise (em azul).

- A unidade de escavação N141W128 foi escolhida por representar a maior concentração de material cerâmico escavado no setor B2;

- as unidades N120W132 e N118W131 também possuem alta concentração de material arqueológico cerâmico e estão associados à primeira possível estrutura de combustão encontrada e datada;

- a unidade N120W127 foi selecionada em função de estar localizada em outra extremidade do setor de escavação B1 e também associado a uma segunda possível estrutura de combustão.

O material arqueológico cerâmico foi analisado nas dependências do MArquE/UFSC, local que contem o seu endosso institucional. Todo o material cerâmico foi pesado e contabilizado. 


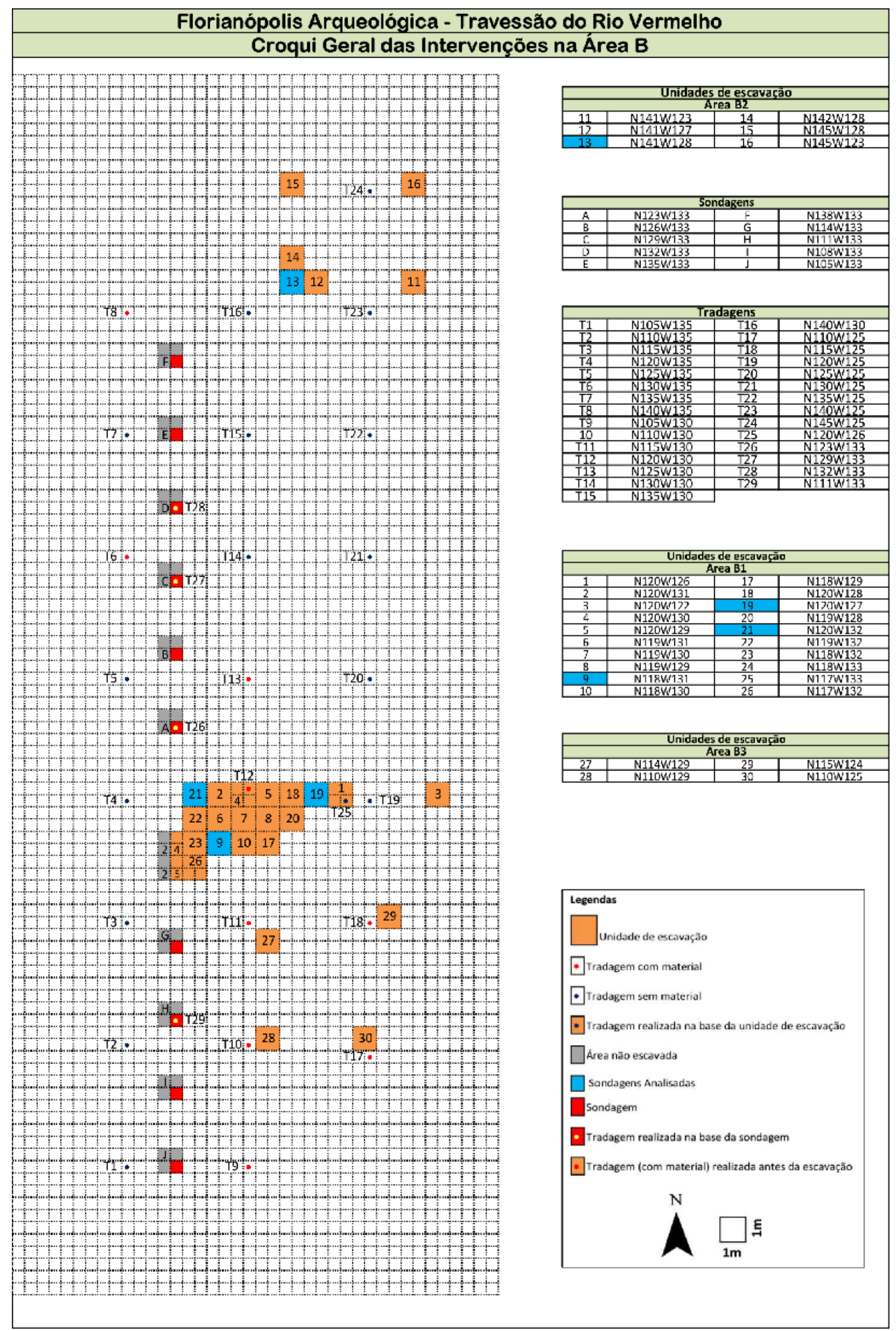

Figura 14.Croqui geral das intervenções na Área B do sítio adaptado da Fonte: Florianópolis Arqueológica. Relatório Parcial, 2013. Adaptado por Thiago Umberto Pereira, 2018. As unidades de escavação (quadras) analisadas estão apontadas em cor azul 
Na Tabela 6, são descritas as unidades de escavação cujos materiais cerâmicos foram analisados:

\begin{tabular}{|c|c|}
\hline \multicolumn{2}{|c|}{ TRV: DESCRIÇÃO DAS UNIDADES DE ESCAVAÇÃO ANALISADAS } \\
\hline $\begin{array}{l}\text { Unidade de } \\
\text { escavação e } \\
\text { área }\end{array}$ & Descrição \\
\hline$\frac{\text { N118W131 (área }}{\text { B1) }}$ & $\begin{array}{l}\text { Foi coletado, além de material cerâmico, carvão (em coletas individuais), lítico e } \\
\text { conchas, sendo que a maior quantidade do material coletado estava em seu segundo } \\
\text { nível (de } 20 \text { a } 30 \mathrm{~cm} \text { ), e essa quantidade diminuiu ao avançar dos níveis até a } \\
\text { escavação da quadra finalizar nos dois níveis estéreis, de números } 4 \text { e } 5 \text {. }\end{array}$ \\
\hline$\frac{\text { N120W127 (área }}{\text { B1) }}$ & $\begin{array}{l}\text { Foram visualizados e coletados sedimento, conchas, cerâmica e carvão. Também } \\
\text { ao longo do segundo nível (de } 20 \text { a } 30 \mathrm{~cm} \text { ), como na unidade anterior, foi } \\
\text { identificada uma mancha escura (de coloração } 7.5 \mathrm{YR} 4 / 4 \text { brown) e uma possível } \\
\text { estrutura de combustão de onde foram retiradas amostras de carvão para datação e } \\
\text { de onde provem uma das datações do sítio, além de que foram feitas coletas de } \\
\text { sedimento dessa mesma estrutura para flotação. Foi encontrada a maior parte dos } \\
\text { vestígios também no segundo nível. Foram feitos croquis intermediários dos níveis. } \\
\text { Nos níveis subsequentes, a estrutura de combustão aos poucos desapareceu sendo } \\
\text { que no quarto nível, já se encontrava em sua base (mais compactada) e foram } \\
\text { coletados da mesma o sedimento, conchas, cerâmica, carvão (para datação). Não } \\
\text { foram encontrados outros vestígios fora da estrutura nesse nível. }\end{array}$ \\
\hline $\begin{array}{l}\text { N120W132 (área } \\
\text { B1, a mais } \\
\text { próxima a } \\
\text { N118W131) }\end{array}$ & $\begin{array}{l}\text { Foram coletados cerâmica e carvão; do segundo nível também foi coletada a maior } \\
\text { quantidade do material. A escavação dessa unidade não continuou para níveis mais } \\
\text { profundos devido à concentração dos esforços da equipe na abertura das áreas } \\
\text { amplas no segundo nível (aquele que mais apresentou material). }\end{array}$ \\
\hline $\begin{array}{l}\text { N141W128 (área } \\
\text { B2, distante } 20 \\
\text { metros da área } \\
\text { B1), }\end{array}$ & $\begin{array}{l}\text { Foram coletados carvão, material lítico e cerâmico. Do primeiro nível (de } 10 \text { a } \\
\text { 20cm) não ocorreu coleta de material; o segundo nível contava com a maior } \\
\text { presença de materiais. A quadra foi perturbada nos níveis mais superficiais por } \\
\text { tábuas de madeira, provavelmente de construções antigas e, além disso, ocorreu } \\
\text { uma deposição sedimentar um pouco variável com relação à área B1, uma vez que } \\
\text { aqui, a maior parte dos materiais e demais elementos (como sedimento mais } \\
\text { escurecido) aparece no terceiro nível (um pequeno aterro para a suposta construção } \\
\text { provavelmente), mas que trataria da mesma camada natural observada nas demais } \\
\text { unidades de escavação. No terceiro nível também foi feita uma coleta de carvão } \\
\text { para datação. Croquis intermediários junto às demais unidades a seu redor foram } \\
\text { produzidos. A unidade de escavação foi explorada até o sexto nível contendo neste } \\
\text { apenas carvão. }\end{array}$ \\
\hline
\end{tabular}

Tabela 6. Descrição das unidades de escavação analisadas. A esquerda, coluna com a unidade a que se refere e área. A direita, descrição do que foi encontrado e coletado em cada unidade.

Conforme visto na Tabela 6, a maior concentração de material encontra-se no segundo nível, de 20 a $30 \mathrm{~cm}$, sendo que na unidade onde foi encontrada a estrutura 
de combustão mencionada (uma vez que outras duas também foram identificadas em áreas distintas da escavação), a mesma seguiu até níveis mais baixos.

O sítio arqueológico não possui a "mancha escura" pela qual muitos dos sítios Guarani foram/são identificados (é muito comum encontrar na literatura arqueológica, manchas escuras elipsoidais em superfície associadas a sítios de ocupação Guarani). No TRV, não há "manchas escuras" elipsoidais em superfície, tampouco em subsuperfície. No entanto, está presente o sedimento de coloração escura (castanho escuro, preto) (ver Figura 13) característico de sítios de ocupação humana.

\subsection{A coleção Lagoinha do Rio Tavares I (RT)}

O material da coleção Lagoinha do Rio Tavares I encontra-se salvaguardado no MArquE/UFSC. Este sítio foi alvo de breve estudo durante a vigência do PRONAPA, com atividades coordenadas por Walter Fernando Piazza no ano de 1964 (PIAZZA, 1965, 1966, 1967) e posteriormente, não foi mais estudado de forma a ter um interesse científico mais aprofundado. Possui também constante reprodução através de outras duas denominações: Lagoinha do Rio Tavares ou Rio Tavares (sob a sigla RT), ou ainda, pela sigla FLN 067, confusão que ajudou a ser desfeita no andamento da pesquisa produzida pelo LEIA/UFSC (ficha de cadastro do sítio em ANEXO 04). O nome Rio Tavares provem da denominação do próprio Piazza em sua publicação (1965) ao se remeter ao sítio como "o sítio arqueológico do Rio Tavares (RT - 1.64)" (PIAZZA, 1965, P.53). Inclusive “RT.I.1.64.\#\#” é a numeração que cada fragmento cerâmico recebeu na curadoria feita pelo museu, e aqui a sigla RT é usada constantemente para nos referirmos ao esse sítio por causa do seu material ser numerado dessa forma. "Lagoinha do Rio Tavares" é como a documentação institucional do MArquE se refere ao sítio e como encontra-se seu cadastro no Cadastro Nacional de Sítios Arqueológicos (CNSA/IPHAN); porém, sabemos que esse cadastro não se encontra atualizado em sua disponibilização pública. A sigla "FLN 067" é aquela contida junto à ficha de cadastro no próprio CNSA, cujo responsável pelo registro fora Pr. João Alfredo Rohr no ano de 1971. A equipe do projeto Florianópolis Arqueológica também elucidou a questão, inclusive perante outros sítios cadastrados como Rio Tavares I, Rio Tavares II, Rio Tavares III e Rio Tavares IV, todos sambaquis. A equipe 
atualizou a ficha de cadastro anteriormente mencionada com nova nomenclatura "Lagoinha do Rio Tavares I" (ANEXO 04). Nesta dissertação, será usada a nomenclatura Lagoinha do Rio Tavares I e a sigla RT para nos referirmos a ele.

Trata-se de um sítio cerâmico Guarani. Encontra-se em área privativa residencial, já bem destruído, na localidade do Campeche ou Lagoinha do Rio Tavares. O sítio se encontra sobre planície flúvio-aluvial a $320 \mathrm{~m}$ da Lagoinha do Rio Tavares (com o Rio Tavares sendo o mais próximo do mesmo) na bacia do Morro das Pedras. A equipe do LEIA, na pessoa de Pedro Cesco Litwin, registrou, também, um novo sítio arqueológico cerâmico Guarani muito próximo deste: Lagoinha do Rio Tavares II.

Há ainda, uma determinada irresolução se o sítio Lagoinha do Rio Tavares I pesquisado por Piazza é o mesmo sítio de trabalho de pesquisa arqueológica empresarial realizada pelo arqueólogo Osvaldo Paulino Silva no início dos anos 2000, uma vez que não há menção de Piazza no relatório disponibilizado pelo Arquivo do IPHAN sobre essa pesquisa empresarial, mas características são muito similares à localização do sítio em questão e podem fazer parte de uma mesma área ocupada. Portanto, iremos tratar nesse momento apenas da pesquisa realizada na década de 1960.

Piazza realizou intervenções no sítio arqueológico Lagoinha do Rio Tavares I (PIAZZA, 1965, 1967) e destinou todos os vestígios frutos dessas intervenções (ao longo do estado) ao antigo Museu de Antropologia da UFSC (hoje, MarquE/UFSC). Suas intervenções nos sítios foram marcadas pelos métodos utilizados no PRONAPA que incluem a abertura de algumas unidades de escavação de $1 \mathrm{~m}^{2}$ em cada sítio arqueológico, buscando compor um panorama geral da Arqueologia no país (DIAS, 1995). Porém, nessa escavação, Piazza adotou métodos diferentes, como a abertura de trincheiras de -escavação. Apesar de não ser claro em sua publicação (PIAZZA, 1965, P.p.57-58), Piazza menciona que nas primeiras trincheiras, estudou uma área de $32 \mathrm{~m}^{2}$. Num segundo momento de escavação de trincheiras, o mesmo não menciona as dimensões de suas intervenções.

Em sua publicação, Piazza discorre sobre o ambiente "pré-histórico" da Ilha de Santa Catarina para situar o sítio em questão, localizado em uma das regiões lagunares em processo de sedimentação, no distrito da Lagoa, e a 500m do oceano Atlântico (PIAZZA, 1965, P.55). Naquela década, 
"Partindo da estrada municipal, contorna-se a lagoa do Mato de Dentro, até sua ponta sul, numa extensão de $1 \mathrm{~km}$. É proprietário do terreno o Sr. Venâncio Bernardino das Chagas, residente no Porto do Rio Tavares. / Trata-se de uma elevação arenosa, cujo 'datum' foi fixado a $2,73 \mathrm{~m}$ de altura do nível de um caminho vicinal (assinalado no plano), e que deve estar, aproximadamente, a 3 ou $4 \mathrm{~m}$ acima do nível atual do mar. O sítio abrange uma superfície irregular, cujo ponto extremo Norte está a $35 \mathrm{~m}$ do 'datum' e o ponto Sul a $78 \mathrm{~m}$; os extremos Leste e Oeste, respectivamente, a $48 \mathrm{~m}$ e $49 \mathrm{~m}$. Teríamos assim, grosso modo, uma superfície de $10.767 \mathrm{~m}^{2}$ para a zona arqueológica. / O monte arenoso está atualmente coberto, em parte, por uma vegetação arbustiva rala e, em parte, por uma pequena cultura de mandioca" (PIAZZA, 1965, P.55).

O pesquisador explica a já conhecida presença de muitos sambaquis na região e alerta para a presença de fragmentos cerâmicos encontrados em terrenos que margeiam a estrada e ladeiam o Rio Tavares (que também teria ali sua nascente). Menciona, também, que veio a conhecimento do mesmo através de outro pesquisador já muito conhecido na região, o Pe. João Alfredo Rohr SJ, quando este realizou prospecções em sambaquis situados na região:

“Durante um curso de 'Introdução' à cerâmica pré-histórica do Brasil', ministrado pela Faculdade de Filosofia, Ciências e Letras da Universidade de Santa Catarina, pelo Prof. Oldemar Blasi, do Museu Paranaense, acompanhou-nos o Pe. Rohr, juntamente com aquele professor, ao sítio em questão. Nessa ocasião (15 de abril de 1964), coletaram-se alguns cacos de superfície: 4 de cerâmica lisa, 1 de cerâmica pintada (traços vermelhos sobre engobo amarelo) e 2 de cerâmica corrugada. Ficamos de, na primeira ocasião, realizar, com nossos alunos, uma prospecção que definisse, em termos científicos e definitivos, a natureza do sítio e servisse para levantar alguns problemas acercada cultura dos homens que ali viveram." (PIAZZA, 1965, P.57)

Mais adiante, descreve as intervenções realizadas no sítio e os materiais coletados: cerâmico, lítico e ósseo, conforme contexto das pesquisas do período; não há, nesse caso, coleta de sedimento, por exemplo, ou coletas de amostras específicas destinadas a análises microscópicas:

"O trabalho foi efetuado em três dias - 22, 23 e 28 de maio de 1964 quando se procedeu ao levantamento topográfico e à escavação sistemática de uma 'trincheira-teste', para conhecimento das condições gerais da estratigrafia. Pesquisou-se numa superfície de 32 $\mathrm{m}^{2}$, alcançando-se em todos os setores escavados profundidades variáveis de 50 a $60 \mathrm{~cm}$, de acordo com a posição do solo arqueológico. / Dos trabalhos realizados resultou boa quantidade de 
material cerâmico (264 cacos). / Voltou-se em 1965, à área, para proceder-se a uma amostragem. Realizaram-se, então (26 de junho), três cortes: A, B e C (...), que apresentaram uma pobreza arqueológica digna de nota: 24 cacos no corte A, 13 no corte B e 133 no corte C (destes, 19 formam uma urna corrugada, descrita adiante, e outros 25 formam um vaso de boca ampliada, lábios redondos e verticais, bojo semi-globular e base côncava). / Dividido o sítio em setores e dada a exiguidade do tempo de que se dispunha em 1964, exploraram-se apenas 8 deles, que se encontravam na parte mais elevada. $\mathrm{Na}$ 'trincheira-teste', aberta no setor F1, desceu-se até uma profundidade de $90 \mathrm{~cm}$. / Da prospecção estratigráfica resultou o estabelecimento de três extratos (...): o primeiro, superficial (camada húmica), de areia com vegetação arbustiva esparsa, alcançando, por vezes, a profundida de $30 \mathrm{~cm}$ [em seu croqui, descreve a camada como tendo de 0 a $25 \mathrm{~cm}$ a partir da superfície]; o segundo, de areia escura, variando do cinza pardo para o prêto (camada arqueológica), onde predominavam os cacos de cerâmica e onde, também, apareceram uns poucos coquinhos carbonizados e algum material lítico associado; a espessura variava de 10 a $20 \mathrm{~cm}$ [no desenho de perfil, descreve essa camada como de 25 a $50 \mathrm{~cm}$ a partir da superfície]; no terceiro extrato, de areia amarela, pouco ou nada foi coletado; serviu de local de enterramento de uma urna (?), cujo achamento será relatado à parte [no perfil desenhado, descreve a camada de 50 a $90 \mathrm{~cm}$ e mais a partir da superfície]." (PIAZZA, 1965, P.p.58-59).

Sendo assim, a camada arqueológica que descreve Piazza segue praticamente o mesmo contexto encontrado no sítio TRV, como um único pacote, variando apenas em alguns centímetros, de acordo com a deposição de sedimento das regiões em que se encontram os sítios. Não se tem conhecimento de nenhuma amostra de carvão datada dessa etapa de escavação. Por isso, torna-se difícil associá-lo à contemporaneidade da ocupação no sítio TRV ou não. No entanto, as informações que o pesquisador nos dá são bastante detalhadas em comparação àquelas de outras pesquisas realizadas pelo PRONAPA. A coleção foi pré-analisada entre 1964 e 1965 para compor a publicação e foram utilizadas categorias como: "cerâmica simples", "cerâmica decorada", "fina", "grossa", "pintada", "mal cozida", "bem cozida", "erodida", "vermelho sem amarelo", “engóbio vermelho", “engóbio branco", “corrugada", "ungulada" (PIAZZA, 1965, P.p.61-72), e com essas categorias foi feita a classificação.

Assim, Piazza (PIAZZA, 1965, P.p.61-72) dividiu os fragmentos cerâmicos em: Lagoa Simples (36 fragmentos), Lagoa Pintada (187 fragmentos), Lagoinha Corrugada (190 fragmentos), e Lagoinha Ungulada (21 fragmentos), segundo características de pasta (método de manufatura, antiplástico, textura, cor, queima), decoração e forma (borda, espessura, base, perfil). Ainda, foram coletadas duas "urnas" 
(assim denomina Piazza) com primeiros fragmentos surgindo na camada húmica e finalizando aos $90 \mathrm{~cm}$; e sobre o fragmento enterrado em maior profundidade foi encontrado um lítico polido, de basalto, segundo Piazza (PIAZZA, 1965, P.p.70, 74-75), e alguns fragmentos de ossos longos (PIAZZA, 1965, P.70). Rapidamente, Piazza lista os materiais líticos encontrados associados à cerâmica como: um "fragmento de machado ou batedor polido", um "furador ou batedor" e "dois alisadores" (PIAZZA, 1965, P.p.70). Os materiais líticos não foram objeto de uma análise nesta dissertação, mas ressalta-se sua grande contribuição nos estudos em Arqueologia Guarani e, especialmente, da necessidade de bons contextos documentados de associação entre materiais lítico e cerâmico para a compreensão de questões relacionadas ao lítico na cultura Guarani pré-colonial. Piazza (PIAZZA, 1965, P.72) menciona, também, uma segunda "urna" e um terceiro "vaso", esses não identificados na instituição até o momento dessa pesquisa de mestrado:

"Na abertura dos cortes, em 1965, deparamos, novamente, com uma urna, desta feita inteira, até o momento de ser retirada. / Trata-se de uma urna totalmente corrugada, encontrada no corte $\mathrm{C}$, cuja boca estava a $60 \mathrm{~cm}$ de profundidade, completamente coberta de cacos cerâmicos de outros tipos (...), cujo faturamento consubstanciou-se em 19 cacos. As dimensões são as seguintes: altura: $58,5 \mathrm{~cm}$; diâmetro de boca: $54 \mathrm{~cm}$; diâmetro do bojo: $60 \mathrm{~cm}$. A base é côncava e, portanto, fica-se impossilitado de reconstituir suas dimensões. A forma é assimétrica, de acordo com a perspectiva. / Também em 1965, no corte C, encontraram-se 25 cacos de cerâmica corrugada (12 eram bordas), que estavam sobre a boca da urna acima referida e que, posteriormente, em laboratório, foram recolados. Era um vaso de boca ampliada(...): diâmetro da boca: $47 \mathrm{~cm}$; altura da peça: $18 \mathrm{~cm}$. Êste vaso apresenta-se, internamente, com engóbio branco. Na borda, cerca de 15 a $20 \mathrm{~mm}$ abaixo do lábio (...)" (PIAZZA, 1965, P.72).

\subsubsection{Seleção dos fragmentos para análise}

O material arqueológico escolhido para este trabalho foram os vestígios cerâmicos. Estes foram sub-amostrados, assim como realizado na coleção TRV, mas não utilizando os mesmos critérios, senão um princípio em comum: o mesmo número de fragmentos analisados na coleção TRV seria o mesmo número de fragmentos

analisados na coleção RT. Inicialmente, o intuito era selecionar de três a quatro quadras/unidades de escavação em áreas diferentes do sítio para as análises tecnológicas de forma qualitativa e quantitativa para a geração de dados a serem comparados com a coleção do TRV. No entanto, isso não foi possível por causa da perda de informações 
entre o material e a documentação primária escrita (artigo publicado por Piazza em separata no ano de 1965). Ainda que a documentação primária escrita contenha certo detalhamento das quadras e mencione de onde provêm os conjuntos de materiais cerâmicos, não foi possível relacionar essas informações ao material. A numeração feita nas peças não se conecta a nenhuma informação escrita. É possível que, ou estejam perdidas as documentações de laboratório, ou mesmo que ao realizar a numeração das peças (na década de 1960 ou posteriormente, uma vez que não há o registro de quando foi realizada) não se tivesse levado essa relação em consideração. Ainda assim, não se sabe também quando a numeração das peças foi realizada, se na década de 1960 junto à escavação, ou posteriormente. Esse tipo de questões são típicas de coleções que estão há um bom tempo nas instituições e de coleções que provêm de contextos mais distantes temporalmente de pesquisas. Ainda assim, estes não são empecilhos para empreendermos na construção de um discurso sobre o passado através delas.

Sobre alcances e limitações na pesquisa de coleções depositadas em museus, há que se ter em mente, primeiramente, sendo coleções do século passado ou apenas de uma década atrás, cada uma possui seu contexto de produção, questionamentos e objetivos específicos orientadores para sua formação; assim, muitas vezes o material da coleção analisado hoje pode não apresentar elementos que correspondam a perguntas atuais. Por isso, é necessário conhecer seus alcances e limitações; e conhecer quais questionamentos podem ser trabalhados com eles. Bonomo, Capdepont e Matarrese (BONOMO et.al., 2009) realizaram estudo amplo e invejável, publicado sob o título de Alcances en el estudio de colecciones. Los materiales arqueológicos del delta del Río Paraná depositados em el Museo de La Plata (Argentina). Segundo eles, as coleções fazem parte do patrimônio cultural e não devem ser excluídas, a priori, dos projetos de investigação (BONOMO et.al., 2009, P. 70). Nesse trabalho, os autores iniciam estudos na área do delta do rio Paraná a partir das coleções depositadas no Museo de La Plata, desenvolvidas entre o final do século XIX e o início do século XX que abrangem materiais líticos, ósseos, cerâmicos e metais. Segundo eles, no geral as coleções trazem um grande potencial de informação em escala ampla sobre a distribuição geográfica dos sítios, a presença de objetos arqueológicos pouco frequentes na atualidade, a base regional de recursos líticos e a tecnologia óssea, cerâmica e lítica. E, no que diz respeito ao material cerâmico, os autores obtiveram sucesso ao começar a reconstruir as técnicas de fabricação, decoração e os potenciais de uso dos recipientes cerâmicos. $\mathrm{Na}$ área 
estudada pelos autores, é proposta uma confluência de diferentes etnias como falantes de línguas Tupi-Guarani, Chaná e Chanátimbú, que junto às diferenças temporais e funcionais poderia ter causado a variabilidade constatada nas análises. Ou seja, utilizando o exemplo bem sucedido de análises de coleções em museus como realizado por Bonomo et.al. (2009), desafio semelhante pode ser imposto a coleções de contextos brasileiros, como a coleção RT. Isso porque possuem alto potencial de análise tecnomorfológica, sendo a análise tecnológica priorizada nesta dissertação.

Foi decidido que para comparar as coleções, haveria de ser analisado o mesmo número de fragmentos nas coleções dos sítios TRV e RT. Foram também priorizadas as bordas e bases da coleção RT para poder extrair informações singulares dessas partes das vasilhas, como o possível diâmetro da vasilha formado pelo fragmento analisado, informação somente possível através da análise da borda. Logo, foram analisadas todas as bordas (49 fragmentos) e bases (2 fragmentos) e o restante dos fragmentos constituiu-se de paredes. A seleção das paredes das vasilhas foi feita da seguinte forma: foram selecionados aleatoriamente dois fragmentos de cada embalagem cerâmica até alcançar o número de 165 fragmentos ao total. Assim, considera-se que foi alcançada uma forma mais objetiva e que contemplou a maior parte da variabilidade existente na coleção. 


\section{CAPÍTULO 5: RESULTADO DAS ANÁLISES}

\subsection{Análise macroscópica do Travessão do Rio Vermelho (TRV)}

Todos os fragmentos cerâmicos acima de $2 \mathrm{~cm}$ recuperados das quatro unidades escolhidas foram analisados, contabilizando um total de $\mathbf{1 6 5}$ fragmentos (posteriormente, na próxima coleção, o mesmo número de fragmentos foi adotado para a comparação das mesmas). Com relação à natureza das peças, foram observados: 12 bordas (7,28\% da coleção); 1 base (0,61\%); e 152 fragmentos de parede (92,12\%). Essa divisão, mais esmiuçada encontra-se na Figura 15 em porcentagem/concentração. O gráfico apresenta as categorias (borda, base, parede, borda com inflexão e parede com inflexão) conforme a ficha de análise foi produzida, portanto as totalidades de bordas e paredes estão divididas com as categorias borda com inflexão e parede com inflexão. Importante fazer essa distinção ao pensar não apenas em fragmentos, mas nas vasilhas formadas pelos fragmentos. Ao manter essas divisões, é possível vislumbrar e refletir sobre as formas dos recipientes ainda que não seja possível defini-los. Assim, no gráfico da Figura 13 se observa a predominância de paredes na coleção TRV, sendo os fragmentos com inflexão em quantidade praticamente insignificante perante o total. A ficha de análise possuía nove categorias referente à natureza da peça, no entanto, no material analisado não foi encontrado nenhuma alça (possível para material cerâmico Guarani evidenciando o contato europeu), cachimbo (ou petanguá), ou nenhuma forma de decoração (como apliques, comuns nas cerâmicas Tupi amazônicas), reforço (encontrado na coleção RT e que será explorado adiante) ou bolota de argila e trempelytácuru.

O que foi analisado da coleção TRV será tratado como dados específicos das unidades selecionadas. Ainda, os gráficos seguem a sequência de atributos observados na ficha de análise apresentada que, por sua vez, segue a lógica de pensar tecnologicamente o processo de produção de uma vasilha. 


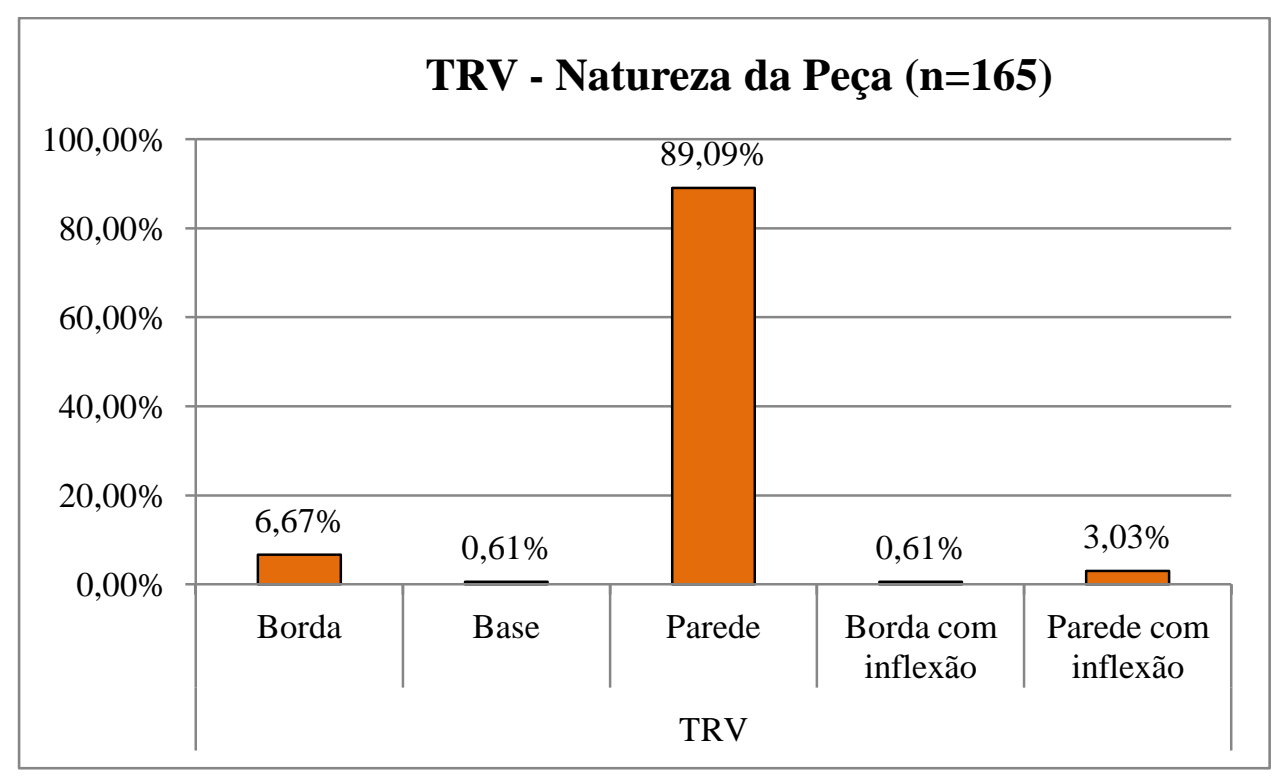

Figura 15. Gráfico representando a natureza dos fragmentos analisados do sítio Travessão do Rio Vermelho (TRV) em porcentagem.

Das quatro unidades de escavação analisadas, $12.12 \%$ do material pertence à unidade N120W127 (área B1), 15.76\% pertence à unidade N120W132 (área B1), 7.27\% pertence à unidade N141W128 (área B2), e 64.85\% do material cerâmico é pertencente à unidade N118W131 (setor B1). Portanto, a unidade N118W131 concentra a maior parte do material analisado.

Observamos na coleção a presença do antiplástico intencional adicionado à argila para a confecção da pasta cerâmica (Figura 16). Ao observar os antiplásticos presentes nas pastas, tem-se em mente que a própria argila utilizada para a formação das vasilhas continha impurezas e minerais, e estes são considerados antiplásticos visto que antiplástico é tudo aquilo que não é plástico. Portanto, para ocorrer uma separação em categorias de antiplástico, tendo sido acrescentado de forma intencional ou não, foi observada sua quantidade. E, neste trabalho, sempre que for utilizado o termo antiplástico, entenderá que estejamos falando sobre o antiplástico intencional. Portanto, se o óxido de ferro, por exemplo, foi observado isoladamente, não foi considerado como antiplástico. Se o óxido foi observado em quantidade (a partir de $30 \%$ da área da pasta em que é observado) foi considerado como antiplástico. Assim ocorreu da mesma forma a classificação para os demais tipos encontrados. Esse procedimento é padrão para a identificação dessa categoria (antiplástico) de forma geral, como observado em Machado (2005). A ficha de análise cerâmica continha as 
categorias cariapé, caco moído, mineral $A$, mineral $B$, mineral $C$, óxido de ferro, argila e carvão. Na coleção TRV não foi encontrado cariapé, cauixi, nem argila e praticamente $75 \%$ dos fragmentos analisados possuem todos os tamanhos de minerais A, B e C identificados como antiplástico (sendo, $92.68 \%$ de uso do antiplástico mineral em toda a coleção). Os tamanhos dos antiplásticos minerais foram identificados pelas categorias mineral A (grosso - 2 a $3 \mathrm{~mm}$ ), mineral B (médio - 1 a 1,5mm) e mineral C (fino menor que 1mm) (Observar no ANEXO 05, Glossário da Ficha de Análise Cerâmica ao final desta dissertação para melhor compreensão dos tamanhos dos antiplásticos). Há pouquíssimas amostras com caco moído como antiplástico, carvão ou óxidos de ferro (ao todo, representam $7.32 \%$ da coleção) e estes sempre aparecem associados ao antiplástico mineral independente de seu tamanho:

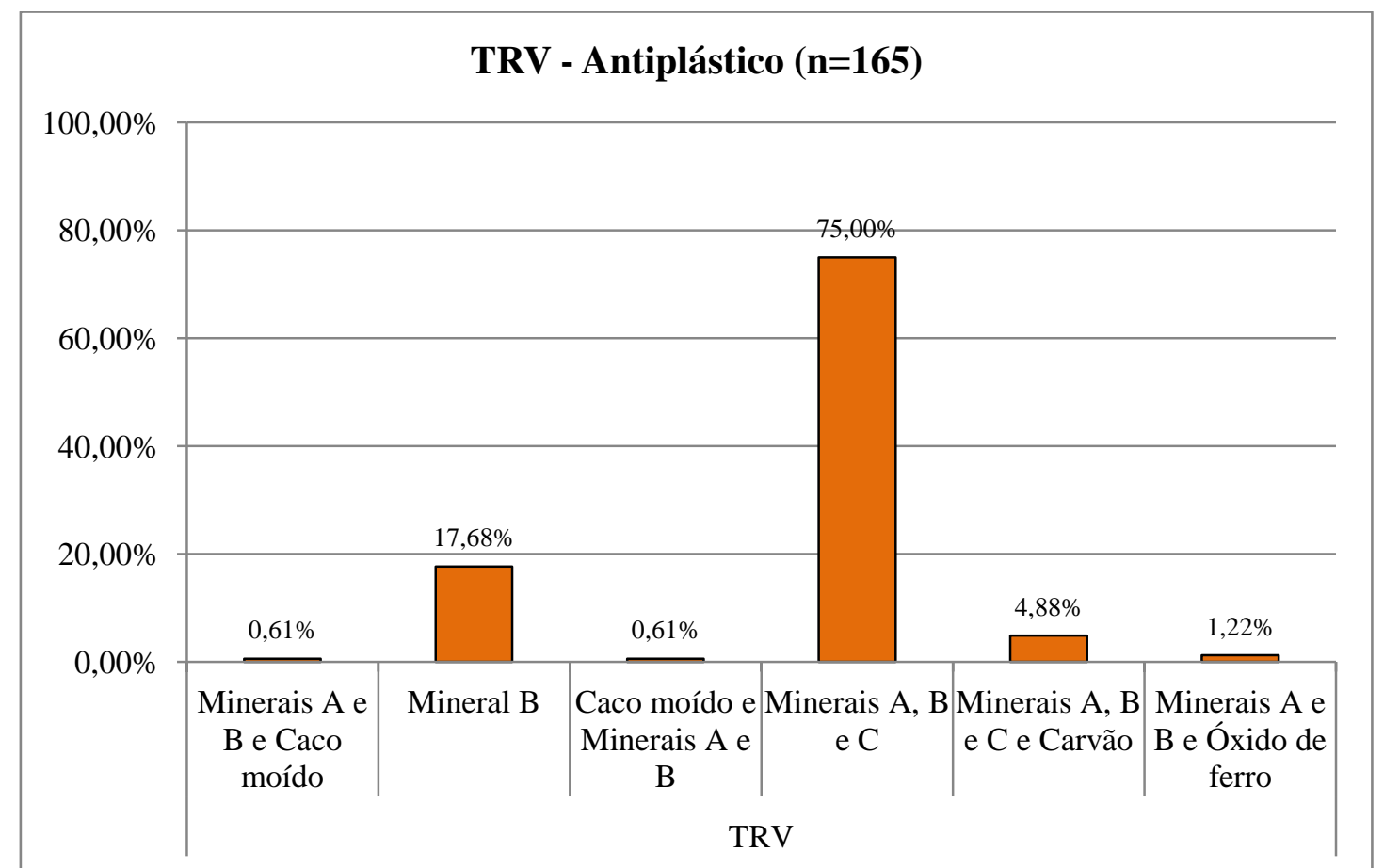

Figura 16. Gráfico representando os tipos de antiplástico encontrados na pasta cerâmica do sítio TRV em porcentagem.

Sobre as técnicas de manufatura utilizadas, apenas uma única base identificada é feita com a técnica de moldagem, enquanto que o restante de toda a coleção se apresentada como roletada/acordelada (LA SALVIA \& BROCHADO, 1989).

As configurações de núcleo (indicativo de queima) (Figura 17) seguiram a classificação de Rye (RYE, 1981, P.116 apud GASPAR, 2014). Entre parênteses na legenda do gráfico, foi enfatizado o correspondente da classificação de Rye (dada em 
números) segundo a referência principal da ficha de análise utilizada aqui (MACHADO, 2005). Um total de $49.7 \%$ da coleção possui queima 5 (redutora internamente e oxidante externamente), seguida da de número 3 (redutora, com 24.85\%), e na sequência, as queimas de número 1 (20\%, oxidante), número 2 (3.64\%, oxidante interna e externamente e redutora no núcleo) e número 4 (1.21\%, oxida na parte interna e redutora externamente). A queima de número 6 não foi identificada. Esses dados refletem ao ambiente de queima utilizado para um dos processos de produção da vasilha cerâmica e, através deles, é possível observar se a queima ocorreu em ambiente com oxigênio em quantidade homogênea (redutora) através do uso de fornos ou ambientes mais controlados, ou queima com quantidade variável de oxigênio (oxidante) geralmente ao ar livre e não tão controlada. Importante enfatizar, também, que a análise por fragmentos pode não refletir o que ocorreu de forma completa na vasilha, porém, com os dados totais observados em conjunto pode-se obter uma noção geral de que o ambiente de queima mais utilizado foi a oxidante. Com os dados obtidos, compreendese que, no geral, o ambiente não proporcionou queimas homogêneas, favorecendo um cozimento maior nas partes externas das vasilhas, diferente da pasta em sua parte interna. $\mathrm{O}$ dado com o resultado refere-se a uma amostra totalmente degradada que não possuía a metade externa de sua pasta, impossibilitando conhecer com exatidão a configuração de seu núcleo.

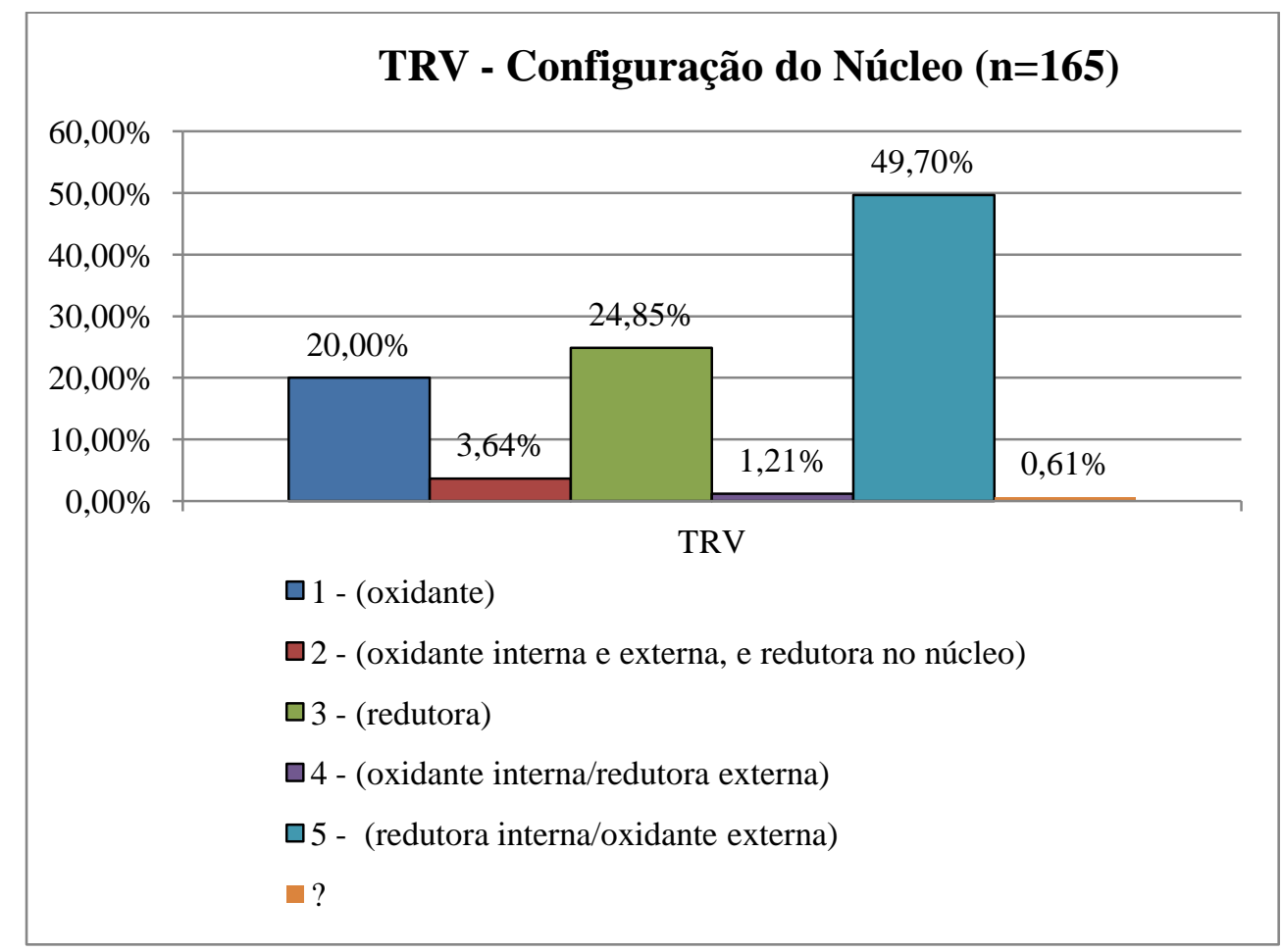


Figura 17. Gráfico representando as formas de configuração do núcleo encontradas na pasta dos fragmentos do sítio TRV em porcentagem.

Com relação à espessuras das paredes das peças $(\mathbf{m m})$, há uma predominância de peças de 6 a 11 milímetros, especificamente de $7 \mathrm{~mm}$. No entanto, esse dado é muito variável e não se mostrou tão produtivo no sentido de pensar os conjuntos cerâmicos (Figura 18). Com essa informação é possível refletir sobre as dimensões das vasilhas, associado às demais técnicas de manufatura (e que será trabalhado mais adiante):

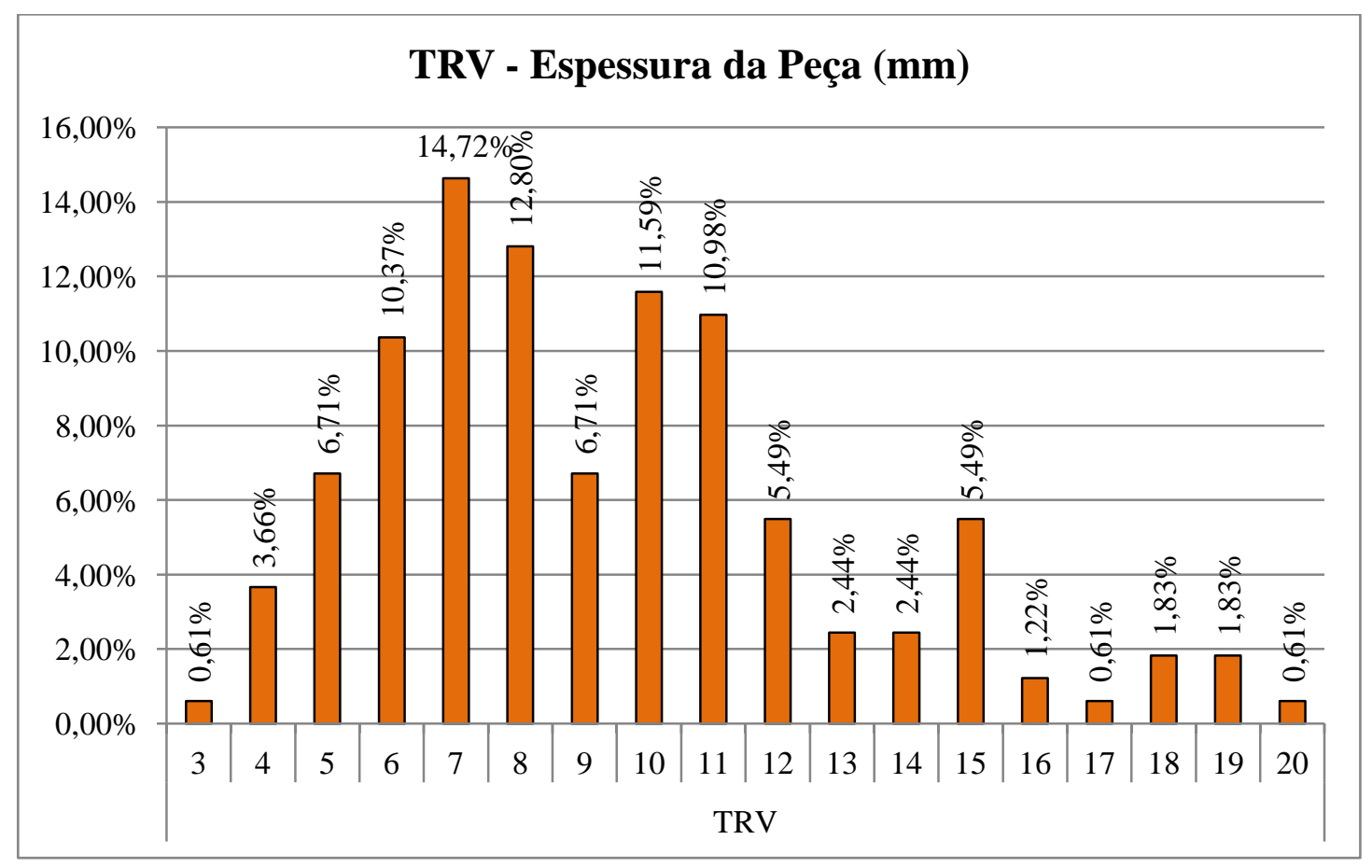

Figura 18. Gráfico representando a espessura dos fragmentos analisados do sítio TRV em porcentagem. Os valores do eixo $\mathrm{X}$ correspondem à espessura em milímetros $(\mathrm{mm})$.

Na Figura 19 conta-se com os gráficos sobre a relação entre os tratamentos plásticos e suas localizações nos fragmentos. A relação refere-se a 164 fragmentos, visto que um deles estava demais erodido e danificado impossibilitando observar qualquer tipo de tratamento de superfície. Os gráficos estão divididos por tratamento plástico no fragmento. Observamos que todas as peças foram compreendidas como possuindo algum tipo de alisamento, mesmo que tenha sido feito para receber outro tratamento em outra etapa de sua produção. Então, o alisamento apenas variaria com relação à localização na peça e em sua associação com outro tratamento plástico: 


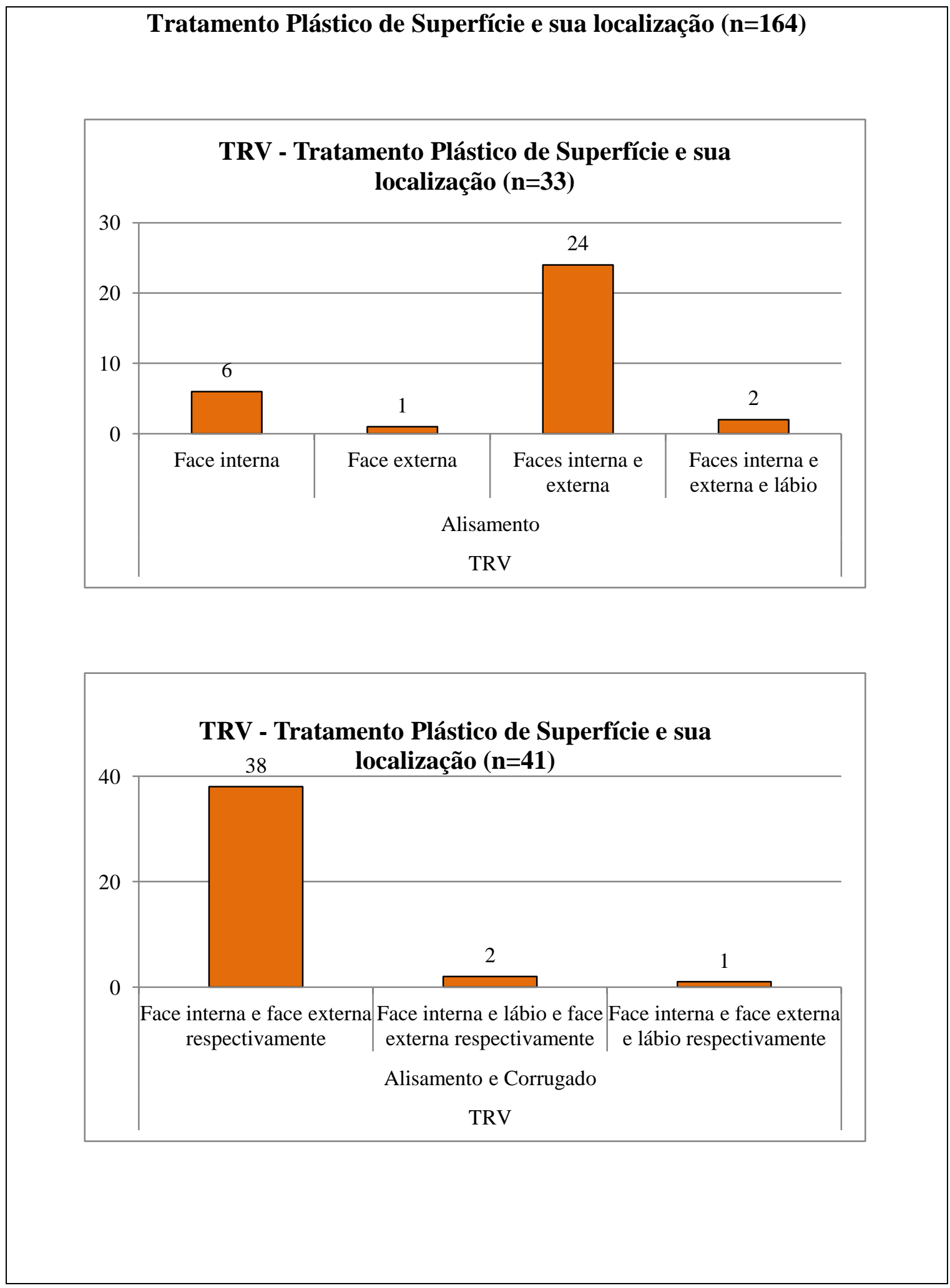



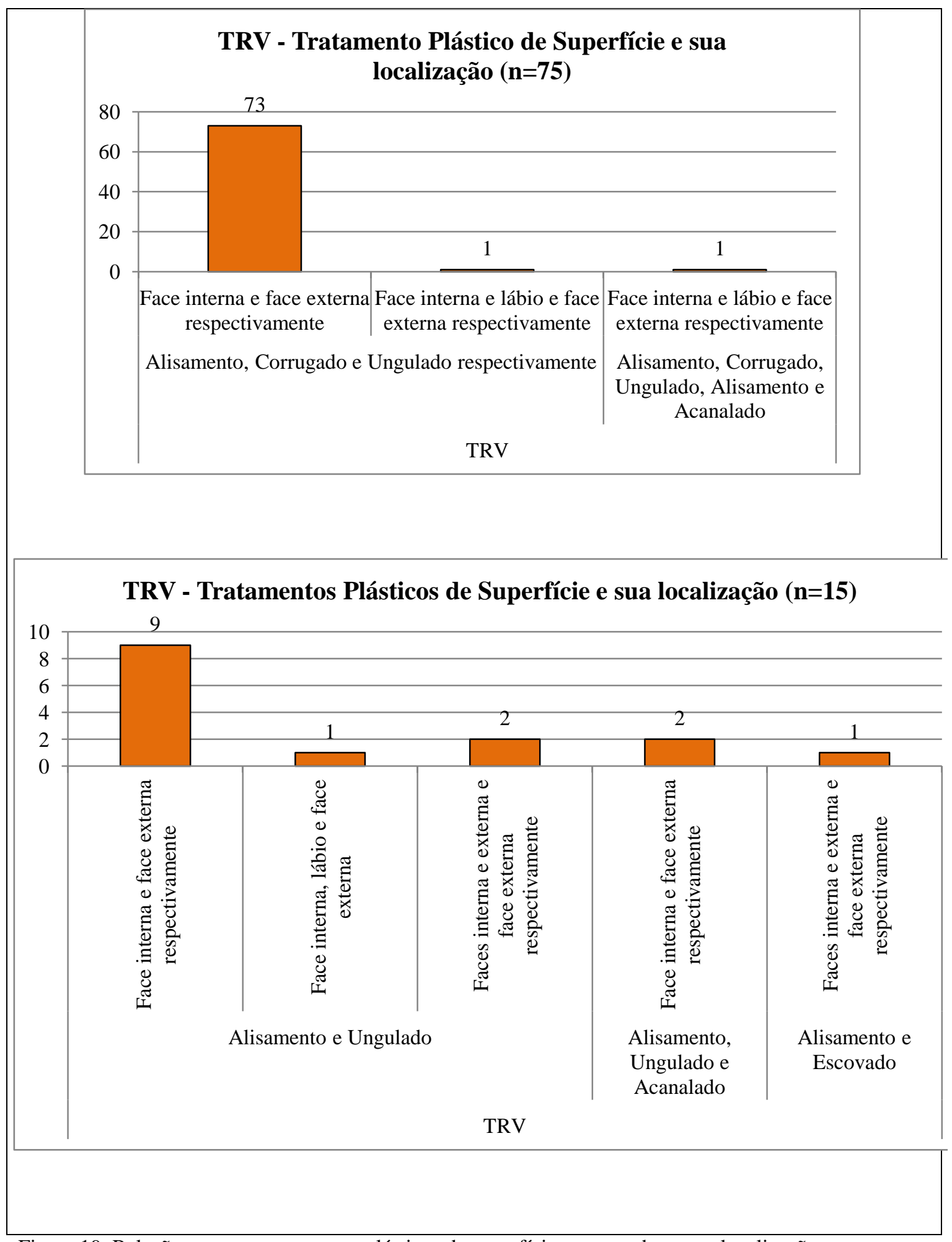

Figura 19. Relação entre os tratamentos plásticos de superfície encontrados e sua localização nas amostras do sítio TRV. Todos os tratamentos foram contabilizados, de acordo com o que foi encontrado em cada fragmento.

Os gráficos mostram que das 33 peças contendo apenas alisamento como tratamento plástico de superfície, 6 o possuem na face interna, 1 na face externa, $24 \mathrm{em}$ ambas as faces e 2 em ambas as faces e lábio (nesse caso, trata-se de duas bordas). Das 
41 peças que possuem os tratamentos alisamento e corrugado ao mesmo tempo (este último marcante da cultura material cerâmica Guarani), 38 possuem o alisamento nas faces internas e o corrugado nas faces externas; 2 fragmentos (de bordas) possuem o alisamento nas faces internas e lábios e o corrugado em suas faces externas; e 1 fragmento (de borda) possui alisamento na face interna e o corrugado na face externa e lábio. Essa última informação de o lábio da peça conter um tratamento plástico para além do alisamento não é comum em ambas as coleções.

Observa-se, também, que 75 fragmentos possuem os tratamentos alisamento, corrugado e ungulado associados. Desses, 73 têm o alisamento nas faces internas e os tratamentos corrugado e ungulado nas faces internas da mesma peça. Apenas 1 dos 75 fragmentos (borda) possui o alisamento na face interna e lábio e, os tratamentos corrugado e ungulado na face externa. Um dos 75 fragmentos (borda) também possui o alisamento na face interna e lábio e, o corrugado, ungulado, alisamento e acanalado associados na face externa. Importante esclarecer sobre a alta presença das peças unguladas: boa parte do tratamento corrugado possui marcas de unhas, isso quer dizer que, ao utilizar os dedos para realizar esse tratamento, a marca das unhas das artesãs permaneceram evidenciadas também. Ou seja, sempre que o ungulado aparecer junto ao corrugado, quer dizer que foi identificada ao final do gesto da artesã ao realizar o corrugado, a marca de sua unha. $\mathrm{O}$ mesmo não ocorreu no bloco anterior como é possível observar.

De 14 fragmentos, 12 possuem os tratamentos alisamento e ungulado associados (sem a presença do corrugado): 9 com o alisamento em suas faces internas e o ungulado em suas faces externas; 1 (borda) com o alisamento na face interna e lábio e o ungulado em sua face externa, e 2 fragmentos com alisamento em ambas as faces sendo que o ungulado se apresenta em suas faces externas. Desses 15 fragmentos, 2 ainda possuem o alisamento (nas faces internas), ungulado e acanalado (nas faces externas) associados. E, por fim, 1 possui o alisamento e escovado associados, sendo o alisamento em ambas as faces e o escovado também na face externa junto ao alisamento; aliás, este fragmento escovado é o único com esse tipo de decoração na coleção, pois, como observado, os tratamentos predominantes aparecem como o alisamento, o corrugado e o ungulado associados. Além disso, importante enfatizar que o alisamento está sempre presente na face interna em graus distintos. 
A relação entre tratamento plástico de superfície e espessura dos fragmentos (que vai de 3 a $20 \mathrm{~mm}$ ) apresenta uma variação bem grande. Embora não tenha se apresentado excelente na compreensão da coleção analisada, podemos extrair mais algumas importantes informações observando-as perante o todo, como: $7.32 \%$ dos fragmentos apresenta alisamento, corrugado e ungulado ao mesmo tempo com $7 \mathrm{~mm}$ de espessura, seguido de $6.10 \%$ do mesmo tratamento, mas em peças de $11 \mathrm{~mm}$.

Já na Figura 20 é possível visualizar a relação entre tratamento cromático dos fragmentos analisados e a suas localizações na peça, tendo em vista que 30 fragmentos da amostra apresentaram tratamento cromático, o que representa um universo bem menor que aquele que contem fragmentos com tratamento plástico de superfície:

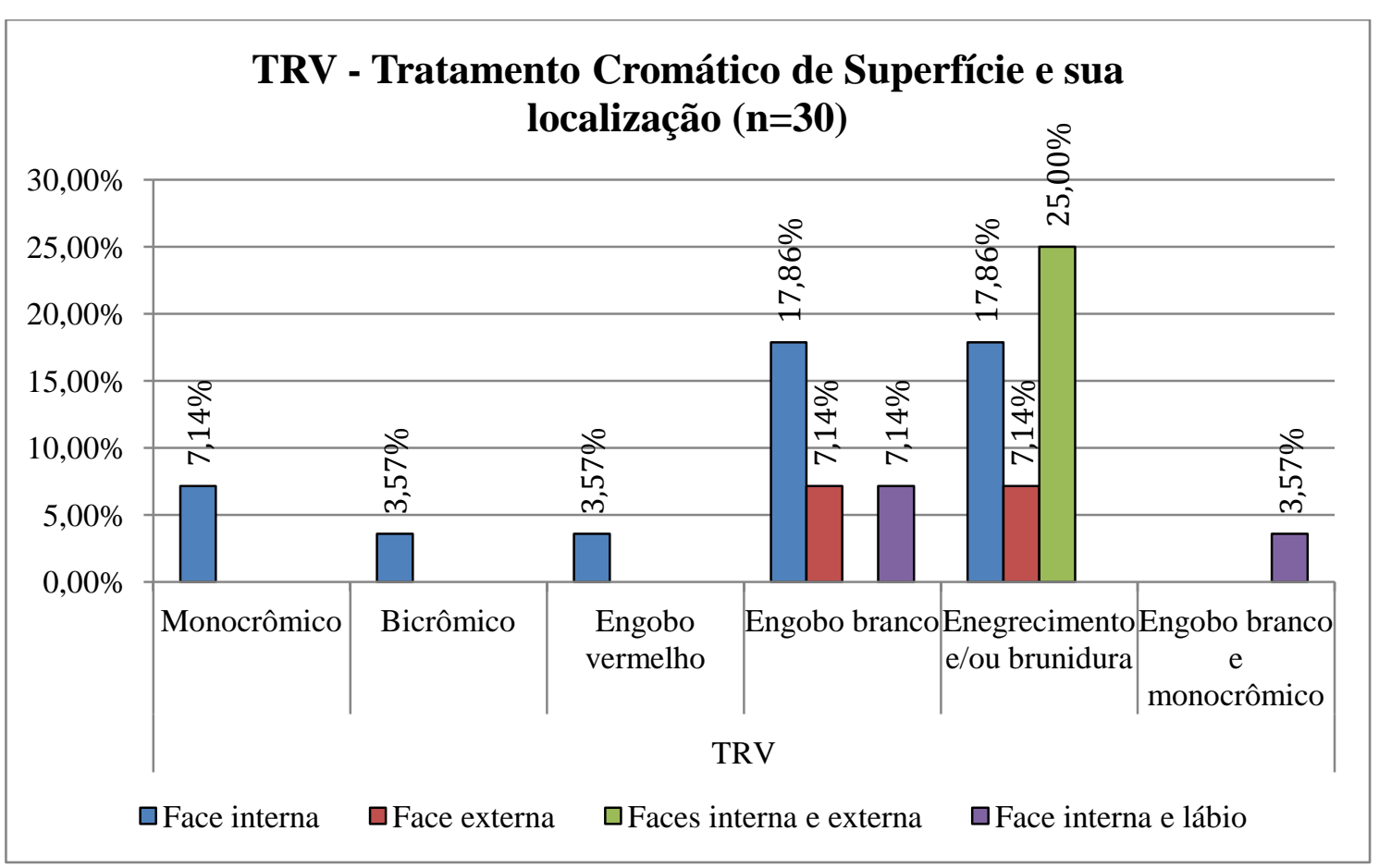

Figura 20.. Gráfico representando as formas de tratamento cromático de superfície e sua localização em cada fragmento cerâmico em porcentagem.

Observamos que $50 \%$ dos fragmentos possuem enegrecimento e/ou brunidura em diferentes localizações: $25 \%$ em ambas as faces, $17.86 \%$ somente nas faces internas dos fragmentos, $7.14 \%$ somente nas faces externas. No entanto, há uma variabilidade grande de técnicas decorativas presentes: monocrômica (composta somente por pintura), bicrômica (engobo e pintura ou duas pinturas distintas), engobo vermelho, engobo branco, e o próprio enegrecimento, especialmente nas faces internas 
dos fragmentos. Além disso, a decoração monocrômica é responsável por apenas $7.14 \%$ dos 30 fragmentos (nas faces internas), a bicrômica por 3.57\% (nas faces internas), o engobo vermelho responsável por apenas $3.57 \%$ nas faces internas assim como o tratamento bicrômico, o engobo branco e o tratamento monocrômico juntos também apareceram em apenas $3.57 \%$ dos fragmentos; e, por fim, o engobo branco foi o segundo tratamento mais observado (após o enegrecimento/brunidura), responsável ao todo por $32.14 \%$ dos fragmentos (sendo $17.86 \%$ somente nas faces internas).

Por fim, sobre as colorações/cores das pastas, foram identificadas cinco tonalidades ao longo das análises, identificadas como: branca, laranja A, laranja B, laranja $\mathrm{C}$ e cinza/preta. Vale destacar que para determinar essa atribuição totalmente subjetiva, foram observadas não somente a coloração das faces das amostras, mas o padrão de queima dos núcleos, uma vez que a queima impacta diretamente naquilo que se observa no processo final. Na coleção TRV, foram encontradas apenas as quatro primeiras colorações de pasta.

Sendo assim, 66.67\% dos fragmentos se mostraram com a pasta laranja C, predominante na coleção e que irá diferenciar substancialmente da coleção RT, seguido da pasta laranja B (18.79\%), pasta laranja A (13.33\%), e da pasta branca $(0.61 \%)$.

Sobre as formas das bordas e bases: foram 12 bordas identificadas na coleção, $66.67 \%$ delas são irrestritivas e $33.33 \%$ são restritivas (a borda com inflexão presente na coleção também se apresentou como restritiva). E, a única base encontrada nessa amostragem foi identificada como plana.

\subsubsection{Identificação de conjuntos/ agrupamentos}

Uma outra etapa bastante importante dessa análise macroscópica é a observação de conjunto / agrupamentos cerâmicos com características similares. Alguns autores trabalham a noção de conjunto como sendo tipos, ou mesmo fases de tradições. Aqui os conjuntos foram formados pelo agrupamento de características semelhantes visualmente, especialmente cor da pasta e tratamento de superfície. Esses conjuntos podem ou não se equivaler a fragmentos de uma mesma vasilha, e podem também vir a fazer parte de uma mesma categoria etnohistórica de artefatos conhecidos (não se trata de uma regra), e nos servem para organizar a variabilidade observada a partir de 
características marcantes, e não engessar em categorias os artefatos. Essa forma de agrupar vai ao encontro do que Chilton (1998) propõe para uma análise que deve buscar a variabilidade de técnicas e tratamentos de superfície e lida com a avaliação de vasilhas enquanto olha fragmentos.

Esses agrupamentos seguem uma lógica subjetiva, e foram formados após a análise de cada fragmento (podendo essa etapa ter ocorrido na forma inversa). A intenção em se formar esses conjuntos é aproximá-los, dentro da grande variabilidade em que se apresentam para, junto com todo o conhecimento produzido, buscar identificar fragmentos das mesmas vasilhas ou da mesma categoria de vasilhas: yapepó (panelas para cozinhar), cambuchí (jarras para bebidas em geral, especialmente bebidas fermentadas alcoólicas), ñaetá/ñaeá (caçarolas para cozinhar), cambuchí caguãba (tigelas para beber), ñamõpu/ñamypiu (pratos para assar beiju) e ñaembé/teembirú (pratos para comer) - (LA SALVIA \& BROCHADO, 1989; BROCHADO \& MONTICELLI, 1994; NEUMANN, 2011), além de suas diversidades e variabilidades. Novamente, é importante enfatizar que, dentro dos padrões Guarani, busca-se as particularidades dos grupos.

Dessa forma, foram identificados oito conjuntos / agrupamentos, descritos a seguir tendo como eixos de agrupamento principais as cores das pastas, o tipo de tratamento de superfície que leva cada fragmento e sua espessura, uma vez que esses dois atributos visuais se mostraram mais destacados para realizar tal diferenciação. Ou seja, as diferenças e semelhanças entre os fragmentos são mais evidentes ao observar os dois atributos citados (cor da pasta e tratamento de superfície). É possível observar que, mesmo que a pasta predominante na coleção seja a laranja $\mathrm{C}$, diferenciam-se nos tratamentos de superfície observáveis.

CONJUNTO 1: esse conjunto apresenta fragmentos com a predominância de pasta laranja C (laranja em tom de marrom), e fragmentos com tratamentos plásticos corrugados e ungulados. A espessura dos fragmentos varia de 5 a $19 \mathrm{~mm}$ (Figuras $21 \mathrm{e}$ 22). 


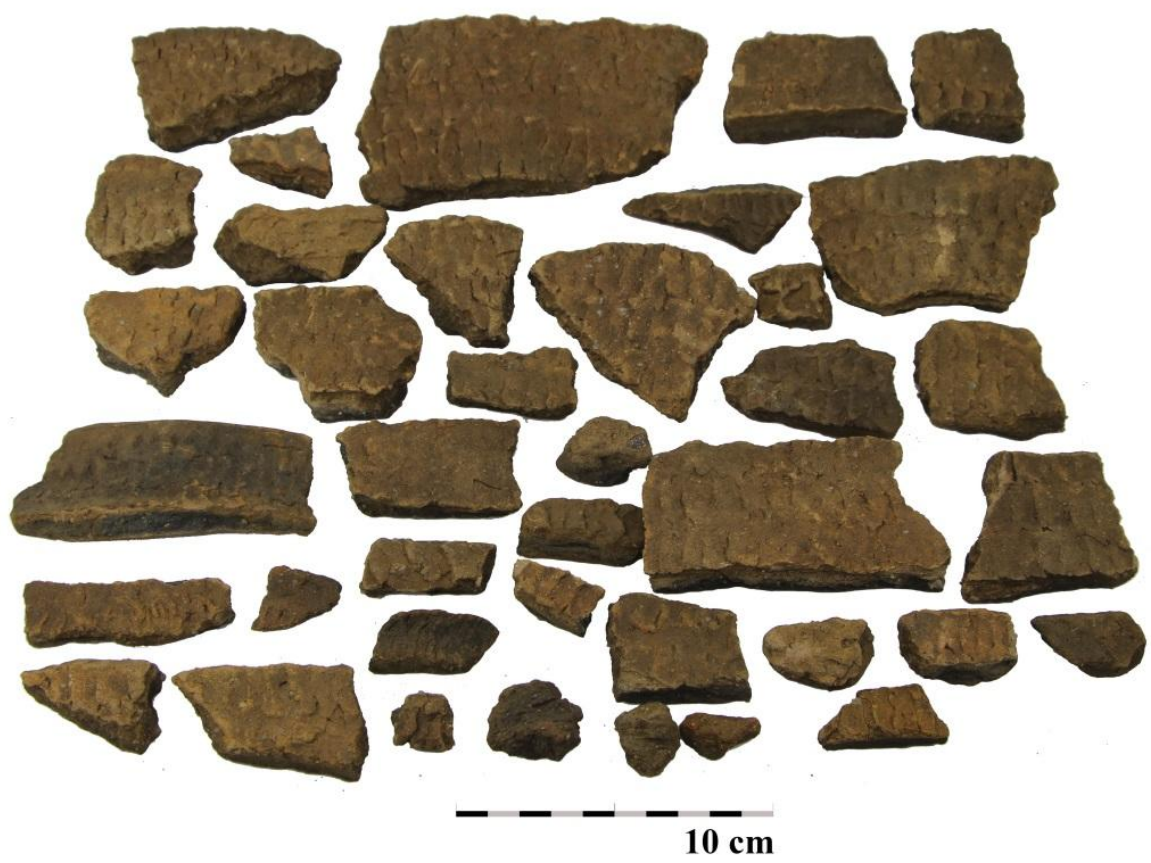

Figura 21. Faces externas dos fragmentos pertencentes ao Conjunto 1 identificado. Foto: Isabela da Silva Müller. Edição: Thiago Umberto Pereira.

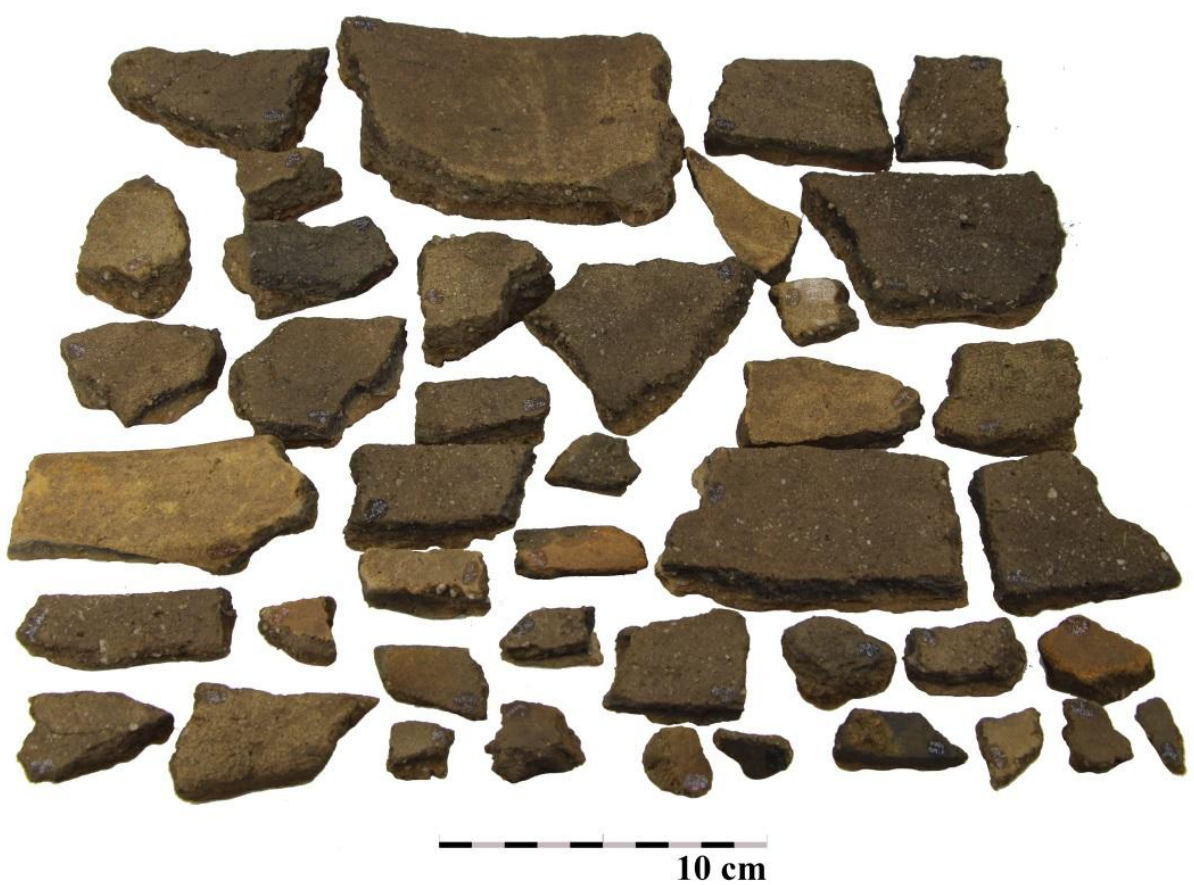

Figura 22. Faces internas dos fragmentos pertencentes ao Conjunto 1 identificado. Foto: Isabela da Silva Müller. Edição: Thiago Umberto Pereira. 
CONJUNTO 2: esse conjunto de fragmentos agrupáveis apresentou também pasta laranja C (laranja em tom de marrom) (pasta predominante em toda a coleção), com tratamentos plásticos corrugados com ungulados, e somente ungulados, com espessuras de 6 a $15 \mathrm{~mm}$ (Figuras 23 e 24).

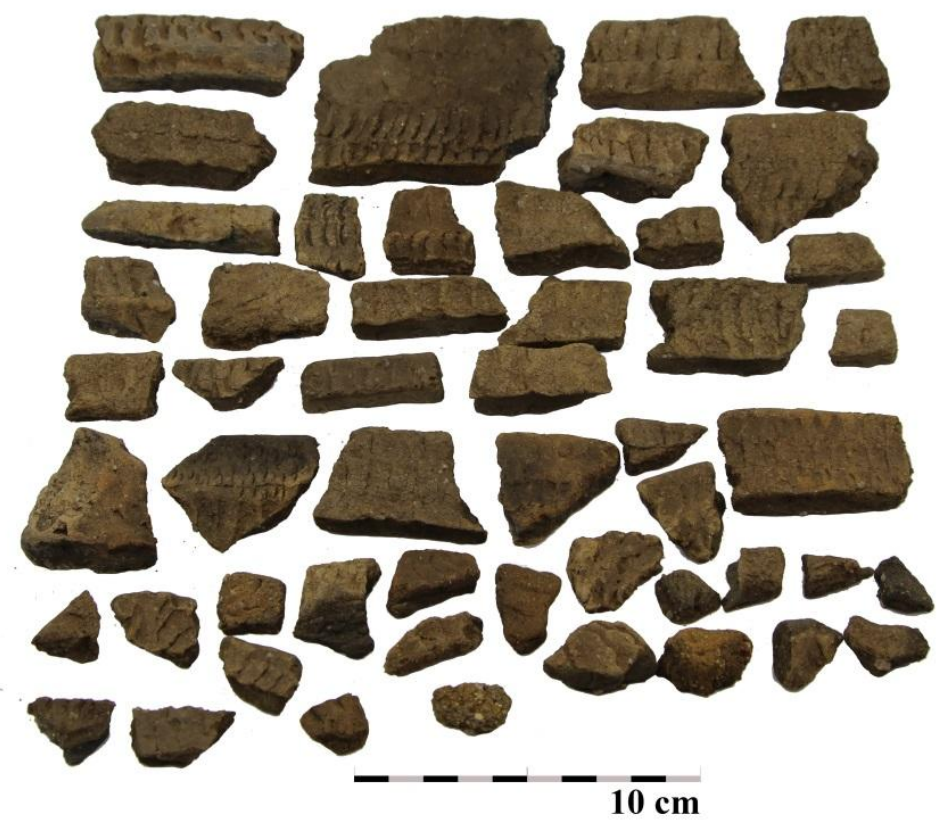

Figura 23. Faces externas dos fragmentos pertencentes ao Conjunto 2. Foto: Isabela da Silva Müller. Edição: Thiago Umberto Pereira. 


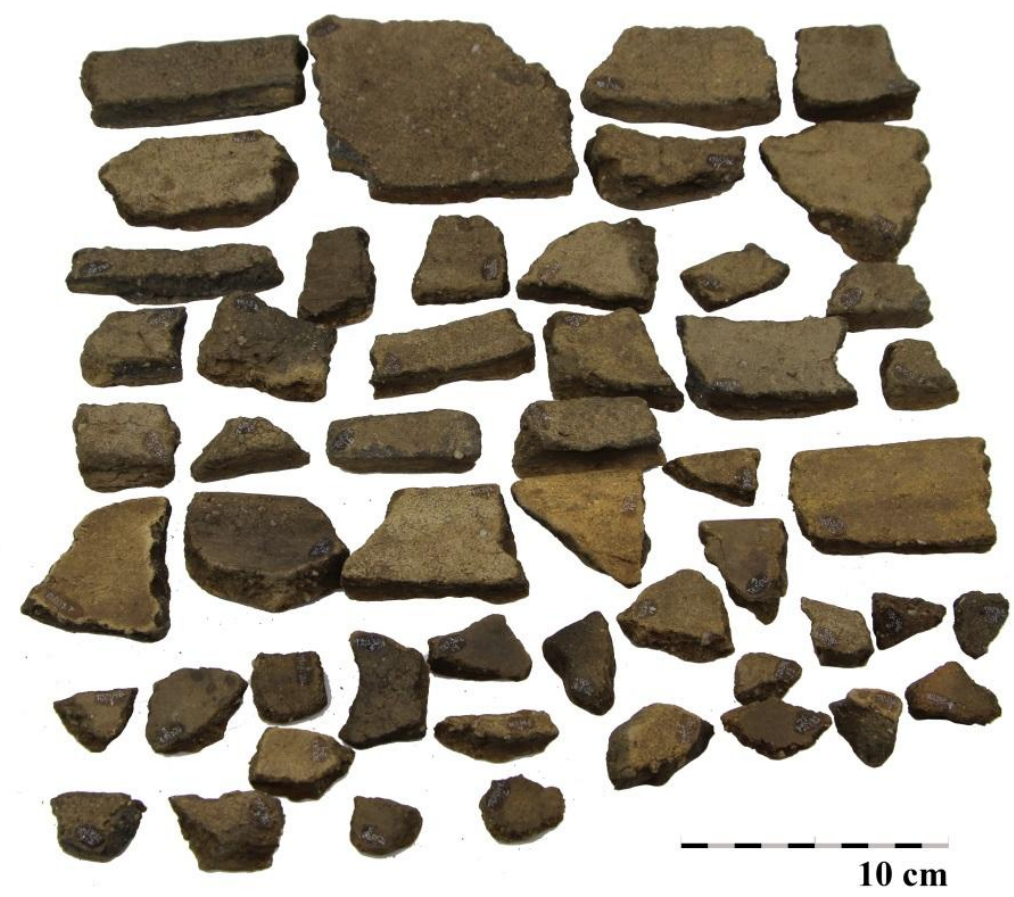

Figura 24. Faces internas dos fragmentos pertencentes ao Conjunto 2. Foto: Isabela da Silva Müller. Edição: Thiago Umberto Pereira.

CONJUNTO 3: esse conjunto é composto por fragmentos de pastas laranja A e B (laranja em tom de vermelho), com tratamentos plásticos corrugados, ungulados e corrugados com marcas de unhas e de espessuras que variam de 3 a $20 \mathrm{~mm}$ (Figuras 25 e 26): 


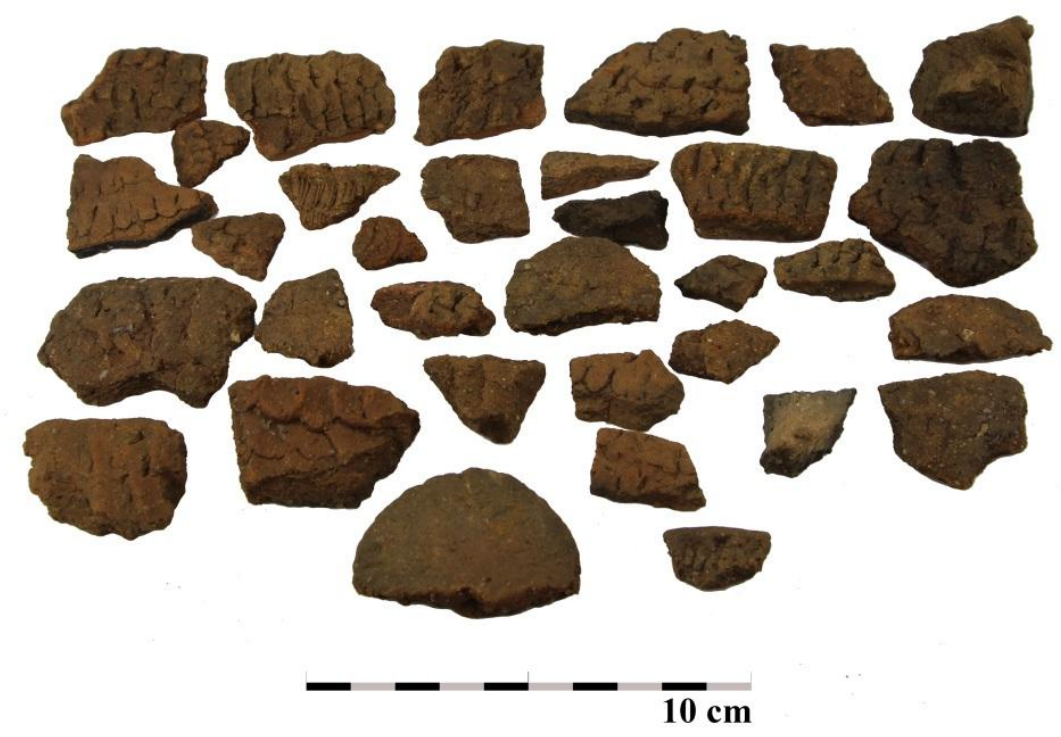

Figura 25. Faces externas dos fragmentos pertencentes ao Conjunto 3. Foto: Isabela da Silva Müller. Edição: Thiago Umberto Pereira.

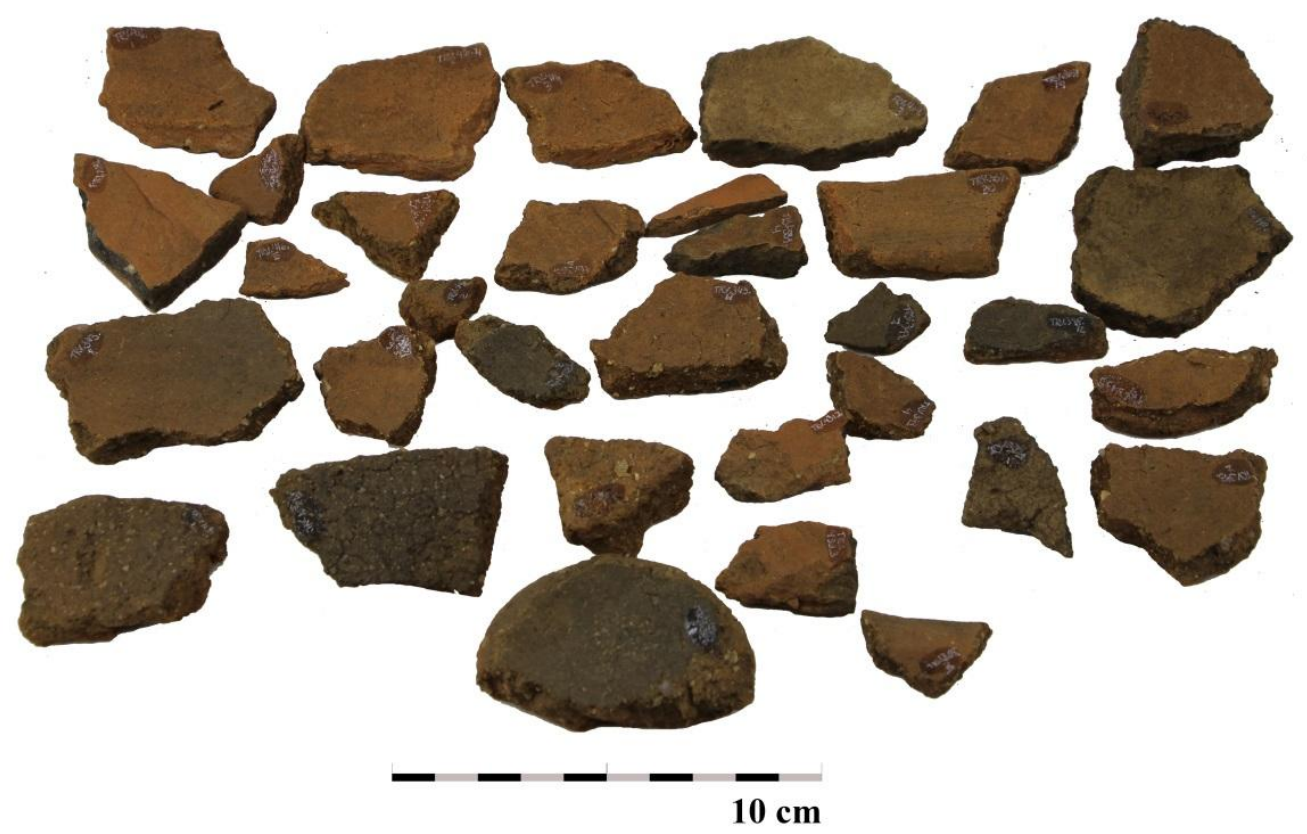

Figura 26. Faces internas dos fragmentos pertencentes ao Conjunto 3 . Foto: Isabela da Silva Müller. Edição: Thiago Umberto Pereira. 
CONJUNTO 4: composto por fragmentos de pastas laranja A (laranja) e B (laranja em tom de vermelho), alisados. Os fragmentos possuem espessura de 6 a $13 \mathrm{~mm}$ (Figuras 27 e 28):

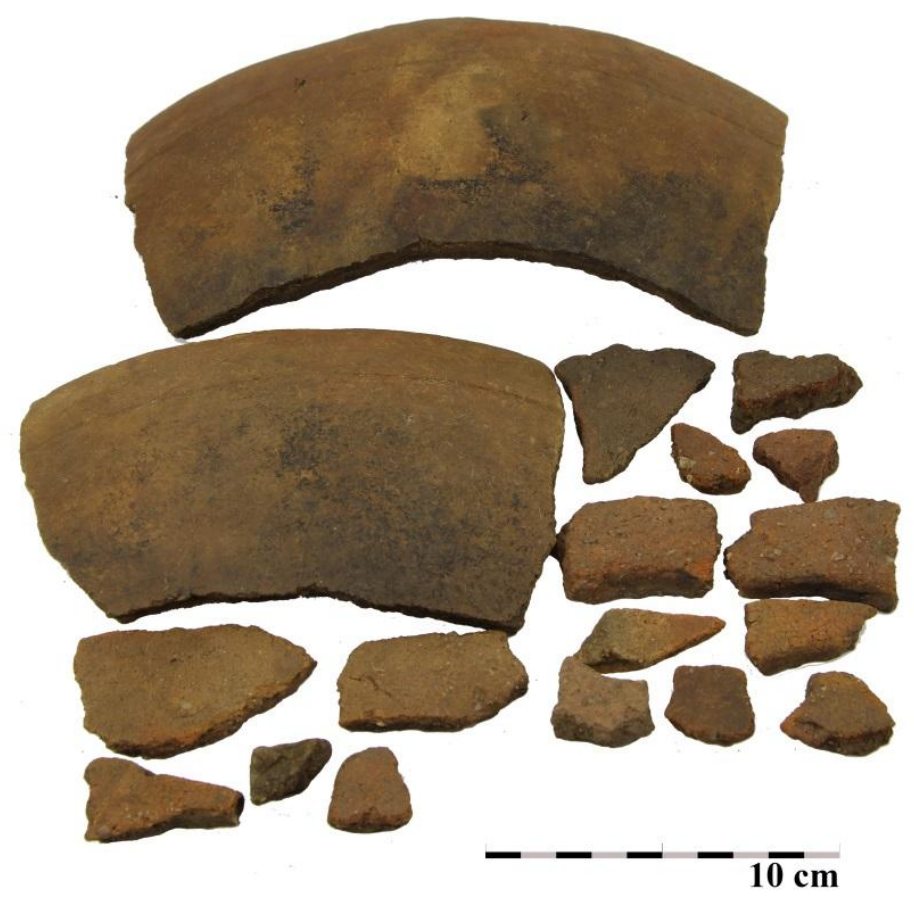

Figura 27. Faces externas dos fragmentos pertencentes ao Conjunto 4. Foto: Isabela da Silva Müller. Edição: Thiago Umberto Pereira. 


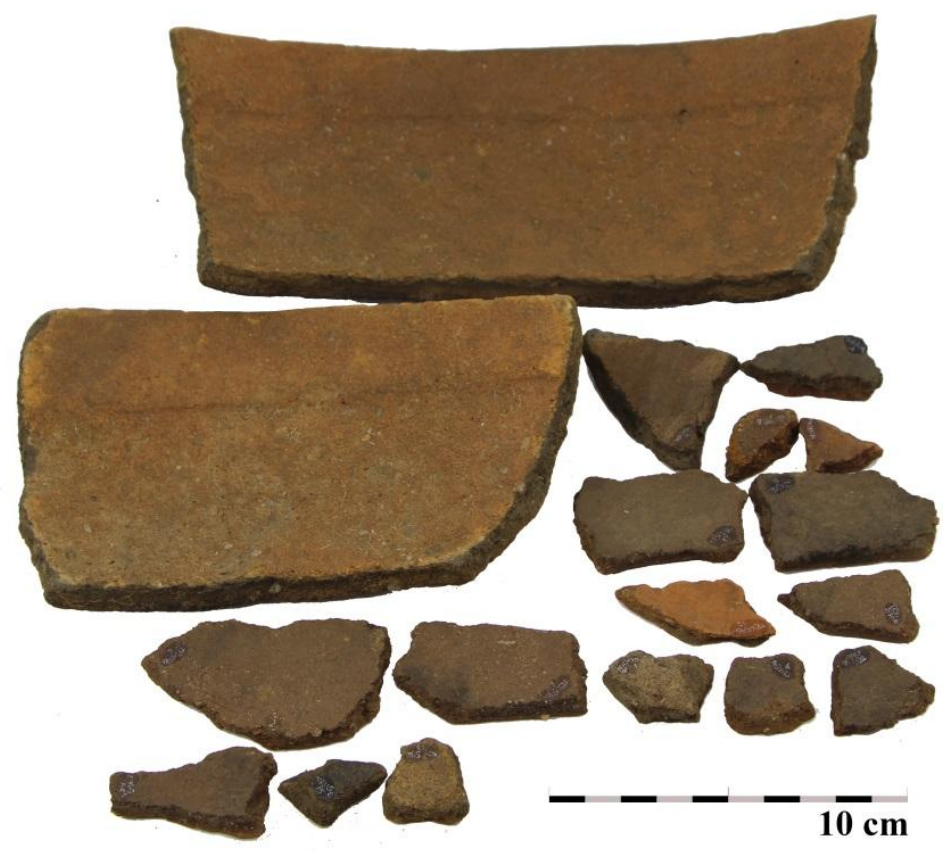

Figura 28. Faces internas dos fragmentos pertencentes ao Conjunto 4. Foto: Isabela da Silva Müller. Edição: Thiago Umberto Pereira.

CONJUNTO 5: composto por fragmentos de pastas laranja A (laranja) e B (laranja em tom de vermelho), alisados, de $18 \mathrm{~mm}$ de espessura (dois fragmentos apenas) nas figuras 19 e 30. Apesar de ser composto por dois fragmentos apenas, esses únicos fragmentos se diferenciam macroscopicamente de forma muito claramente dentro da amostragem separada para análise. 


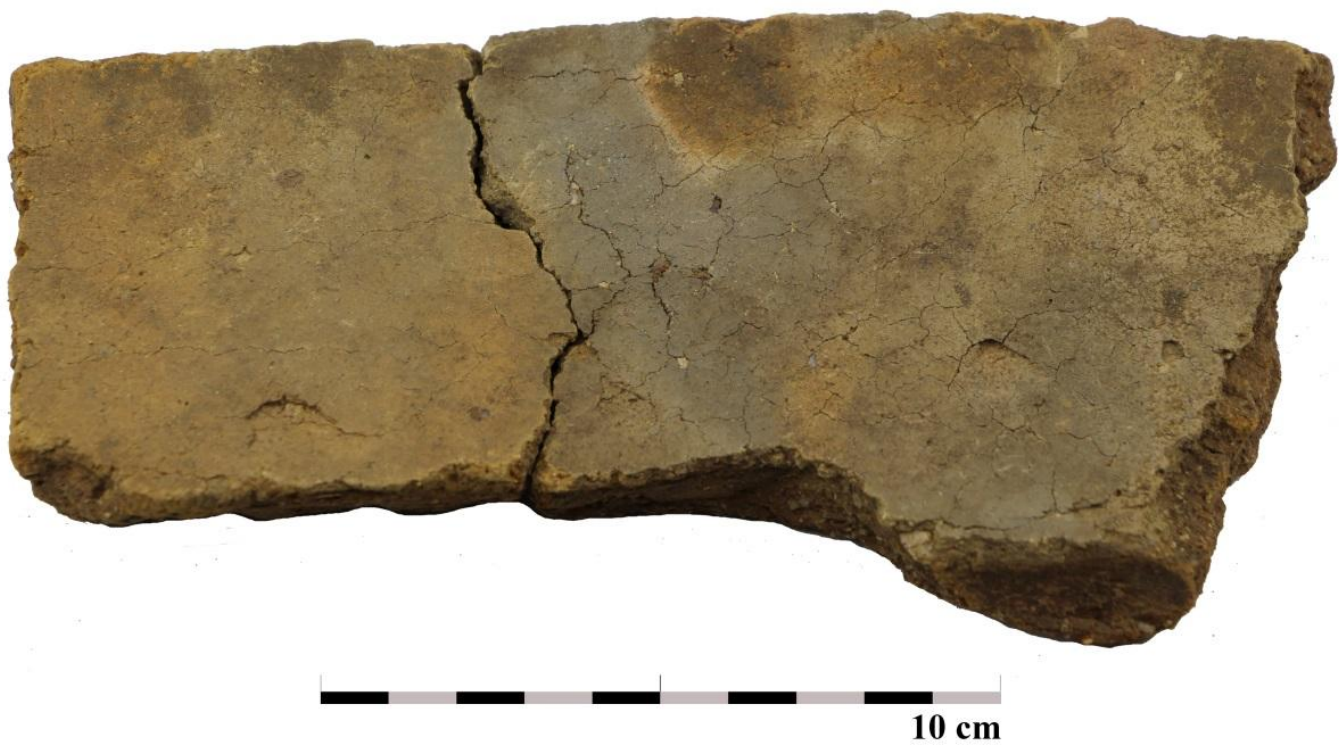

Figura 29. Faces externas dos fragmentos pertencentes ao Conjunto 5. Foto: Isabela da Silva Müller. Edição: Thiago Umberto Pereira.

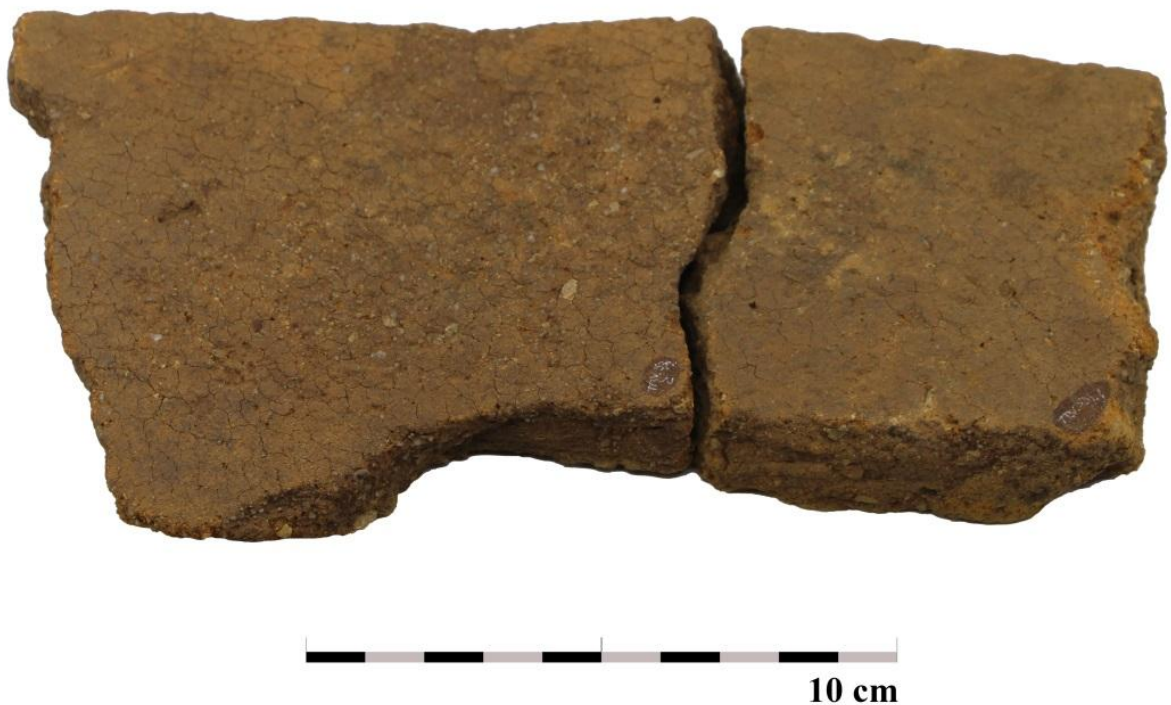

Figura 30. Faces internas dos fragmentos pertencentes ao Conjunto 5. Foto: Isabela da Silva Müller. Edição: Thiago Umberto Pereira. 
CONJUNTO 6: composto por fragmentos de pastas laranja $C$ (laranja em tom de marrom), ungulados, corrugados, sendo alguns fragmentos com pintura preta nas faces internas e alguns pequenos alisados. Possuem de 4 a $11 \mathrm{~mm}$ de espessura (Figuras 31 a 34) Os fragmentos das Figuras 31 e 32 fazem parte de uma mesma vasilha e foram encontrados na escavação como um só, mas como fragmentação. Durante a retirada, não houve jeito de mantê-los unidos. São esses fragmentos que contem a pintura preta nas faces internas.

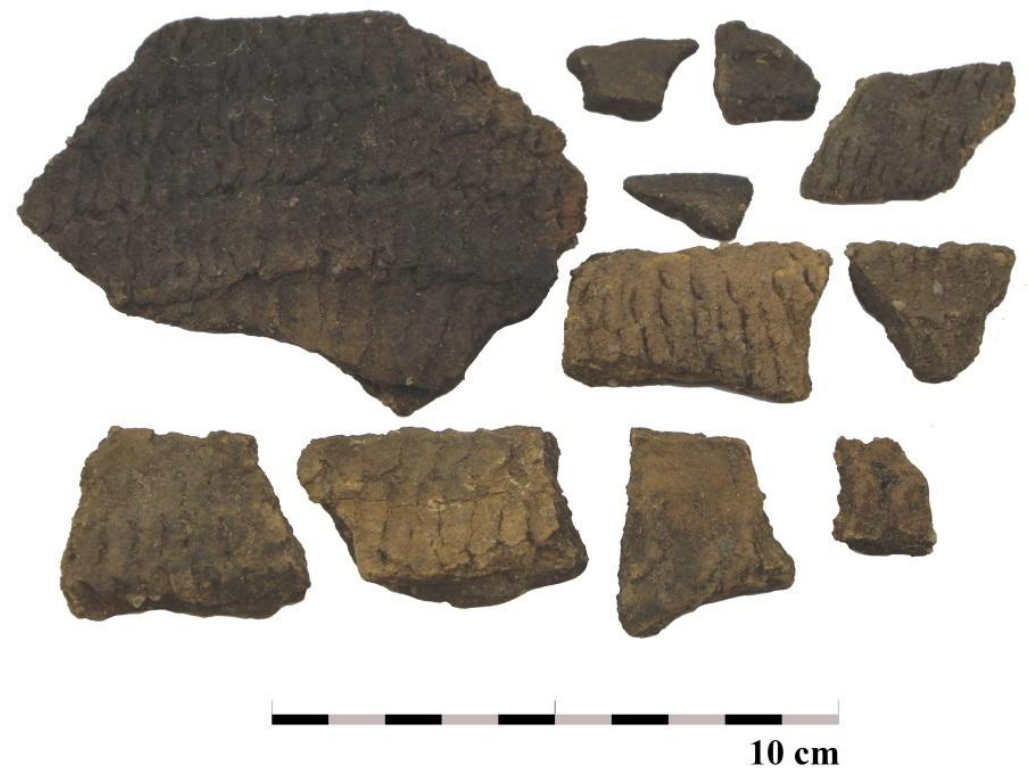

Figura 31. Faces externas dos fragmentos pertencentes ao Conjunto 6. Foto: Isabela da Silva Müller. Edição: Thiago Umberto Pereira. 


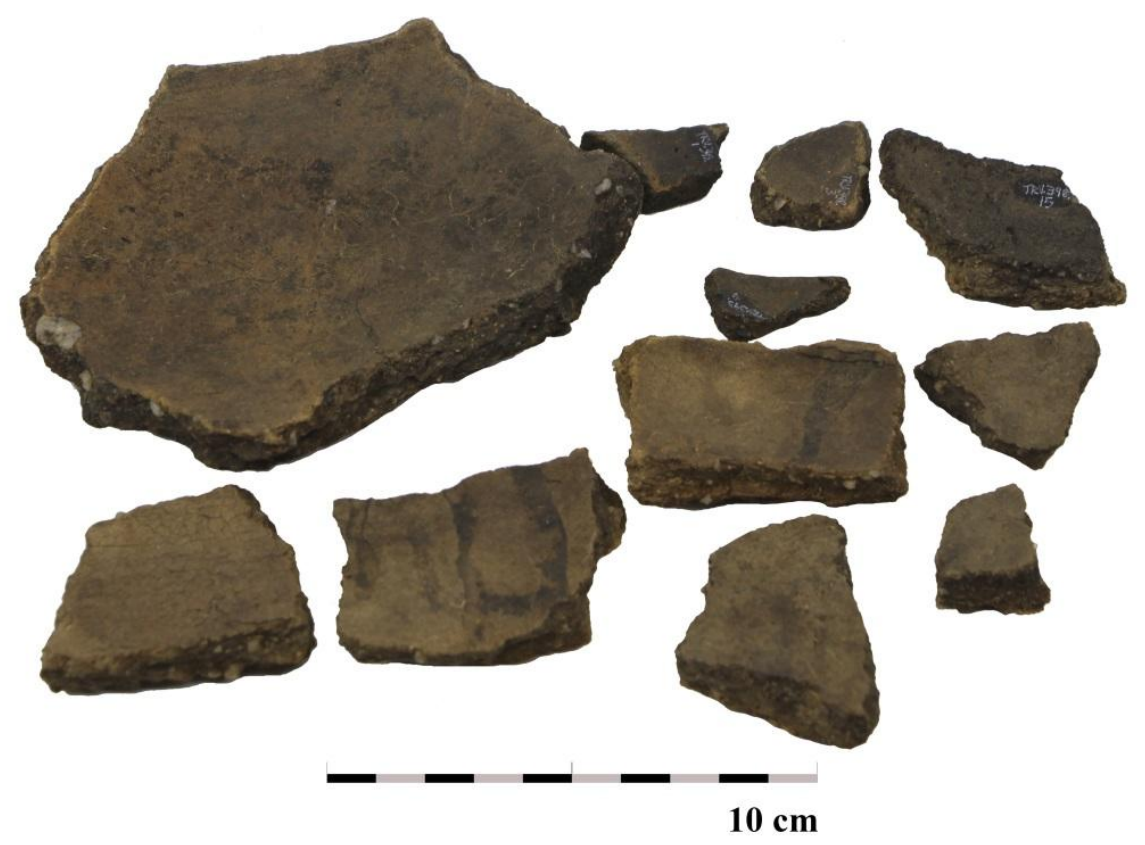

Figura 32. Faces internas dos fragmentos pertencentes ao Conjunto 6. Foto: Isabela da Silva Müller. Edição: Thiago Umberto Pereira.

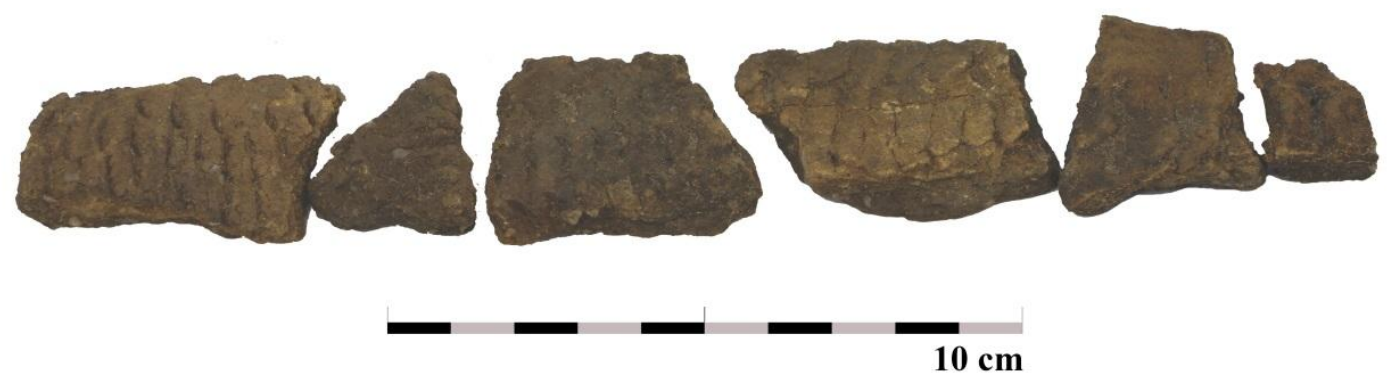

Figura 33. Detalhes das faces externas de fragmentos encontrados juntos durante a escavação com pintura preta na face interna e que compõem o conjunto 6. Foto: Isabela da Silva Müller. Edição: Thiago Umberto Pereira. 


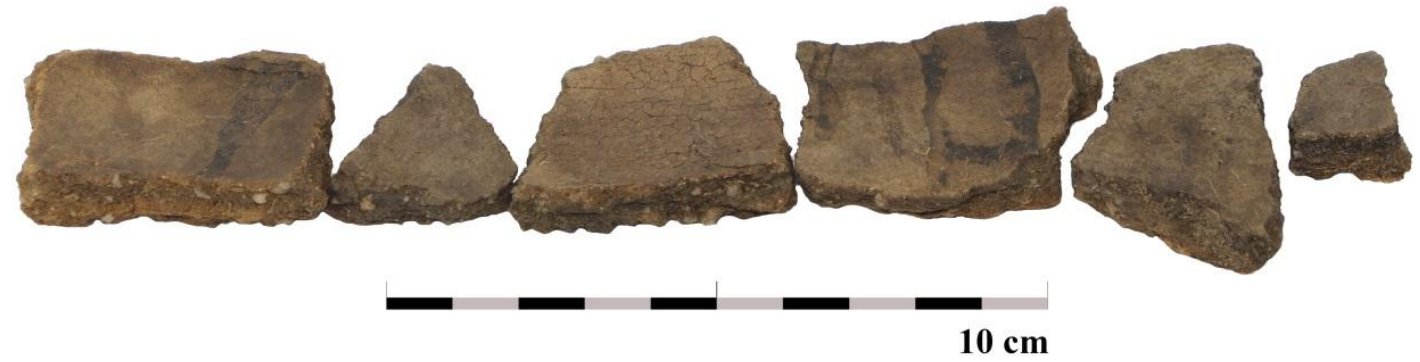

Figura 34. Detalhes das faces interna de fragmentos encontrados juntos durante a escavação com pintura preta na face interna e que compõem o conjunto 6. Foto: Isabela da Silva Müller. Edição: Thiago Umberto Pereira.

CONJUNTO 7: composto por fragmentos de pasta branca (únicos dois fragmentos encontrados) e com tratamento plástico alisado, de 6 a $8 \mathrm{~mm}$ de espessura (Figuras 33 e $34)$. 


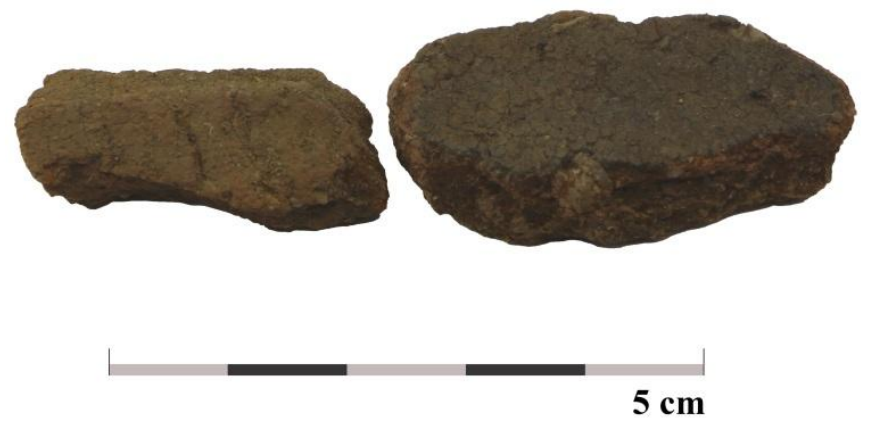

Figura 35. Faces externas dos fragmentos pertencentes ao Conjunto 7. Foto: Isabela da Silva Müller. Edição: Thiago Umberto Pereira.

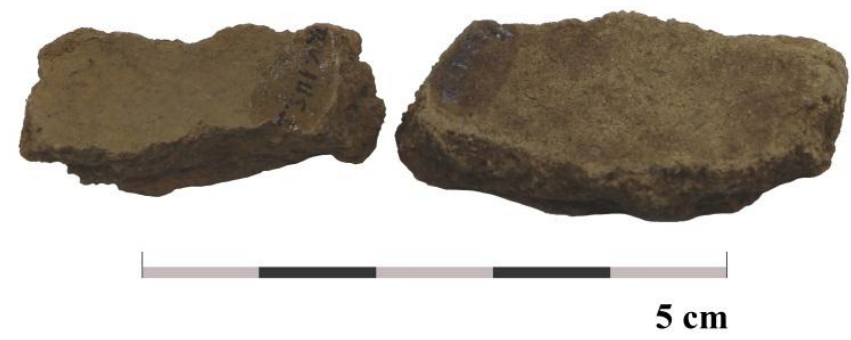

Figura 36. Faces externas dos fragmentos pertencentes ao Conjunto 7 . Foto: Isabela da Silva Müller. Edição: Thiago Umberto Pereira. 
CONJUNTO 8 (AVULSOS): composto de fragmentos que não se encaixaram nos conjuntos anteriores, mas que muito provavelmente possuem seus pares no restante do sítio arqueológico. Possuem de 6 a 8 mm de espessura (Figura 37 e 38). É formado, como é possível observar nas imagens, por um fragmento não identificado como fragmento de uma vasilha, mas contem argila e uma quantidade extraordinária de antiplástico mineral, quantidade não observada em nenhum material cerâmico. Composta, também, por fragmento com engobo vermelho e branco associados, outro fragmento com engobo branco e pintura vermelha em sua face interna, e um último com engobo branco e tratamento plástico ungulado na face externa.

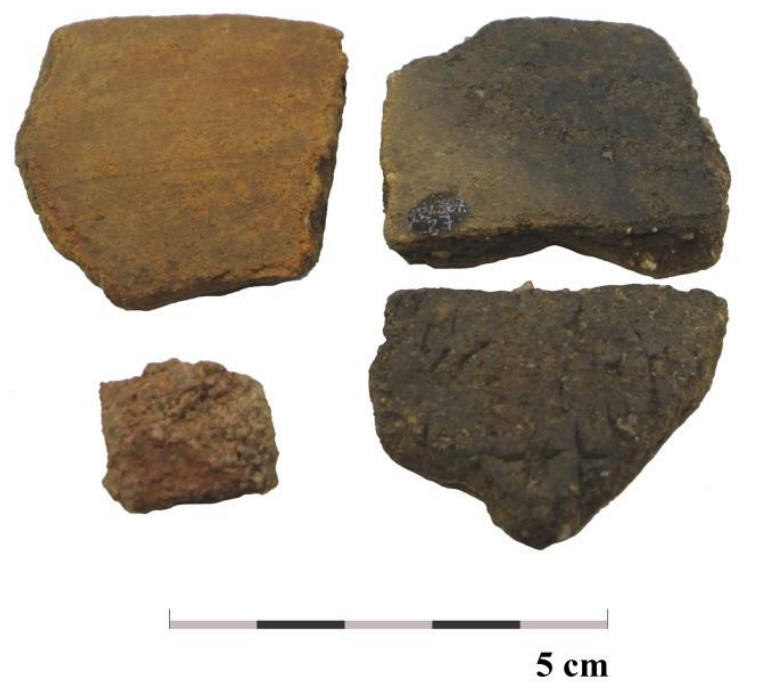

Figura 37. Faces externas dos fragmentos pertencentes ao Conjunto 8. Foto: Isabela da Silva Müller. Edição: Thiago Umberto Pereira. 


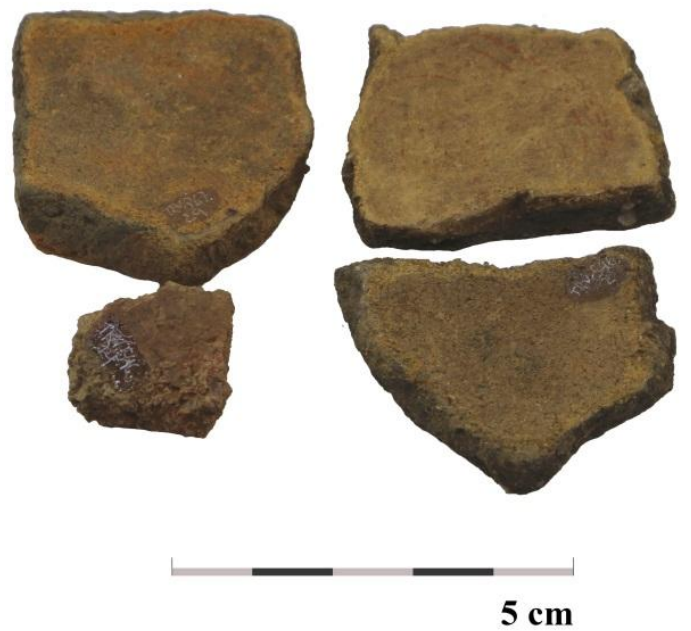

Figura 38. Faces internas dos fragmentos pertencentes ao Conjunto 8. Foto: Isabela da Silva Müller. Edição: Thiago Umberto Pereira.

\subsubsection{Espelhamento das bordas}

Nesta coleção, foram observáveis diâmetros de 10 a 48 cm (Tabela 7), portanto, uma variedade grande de vasilhas pequenas a grandes. Uma nova etapa com novo fôlego será necessária para mapear e buscar todas as formas completas existentes no sul da América do Sul (trabalho já desenvolvido, inclusive, por Corrêa em 2014 para tese de doutorado) e a partir de então, realizar as projeções das vasilhas inteiras a partir dos fragmentos das bordas. 


\begin{tabular}{|c|c|c|}
\hline \multicolumn{2}{|c|}{ TRV: Diâmetros Projetados das Bordas (cm) e Porcentagens das Bordas (\%) } \\
\hline Amostra & $\begin{array}{c}\text { 14. Diâmetro da Borda (cm) } \\
\text { (diâmetro de abertura) }\end{array}$ & 15. Porcentagem da Borda (\%) \\
\hline TRV.343.4 & 11 & 7 \\
\hline TRV.373.6 & 17 & 8 \\
\hline TRV.414.1 & 34 & 4,5 \\
\hline TRV.344.1 & 22 & 8 \\
\hline TRV.368.2 & 20 & 4 \\
\hline TRV.368.3 & 10 & 4 \\
\hline TRV.367.18 & 30 & 6,5 \\
\hline TRV.367.26 & 24 & 2 \\
\hline TRV.367.13 & 30 & 11 \\
\hline TRV.339.7 & & \\
\hline TRV.1084.1 & & \\
\hline TRV.1084.2 & & \\
\hline & & \\
\hline & & \\
\hline
\end{tabular}

Tabela 7. Amostras das bordas da coleção TRV com seus respectivos diâmetros projetados (cm) e porcentagens dos fragmentos $(\%)$.

Assim, todos os espelhamentos estão disponibilizados no CATÁLOGO DE VESTÍGIOS CERÂMICOS (ANEXO 06) ao final desta dissertação conforme já mencionado. A intenção desse catálogo é proporcionar imagens em quantidade e boa qualidade para a comparação com materiais cerâmicos diversos de outros trabalhos. Buscou-se tal contribuição e espera-se que a iniciativa possa ser difundida e aprimorada.

Nas Figuras 39 a 41, são apresentados os espelhamentos de três bordas com diâmetros distintos para a coleção TRV: 


\section{$\varnothing 10 \mathrm{~cm}$}

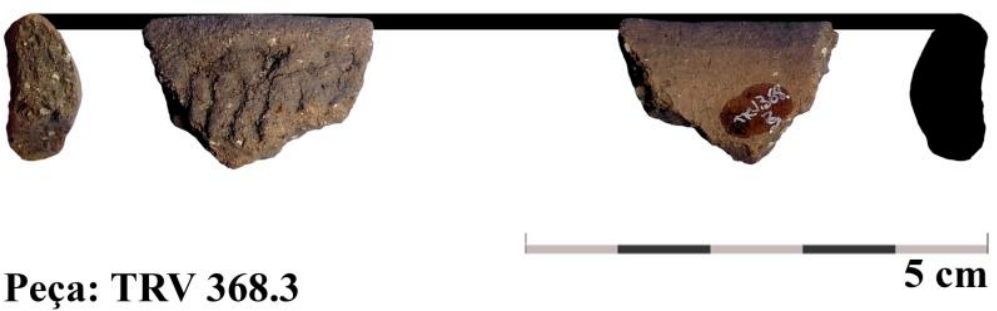

Fotos: Isabela da Silva Müller

Edição: Thiago Umberto Pereira

Figura 39.Espelhamento de borda da amostra TRV.368.3, com diâmetro projetado de $10 \mathrm{~cm}$, onde se observam ambas as faces do fragmento. Foto: Isabela da Silva Müller. Edição: Thiago Umberto Pereira.

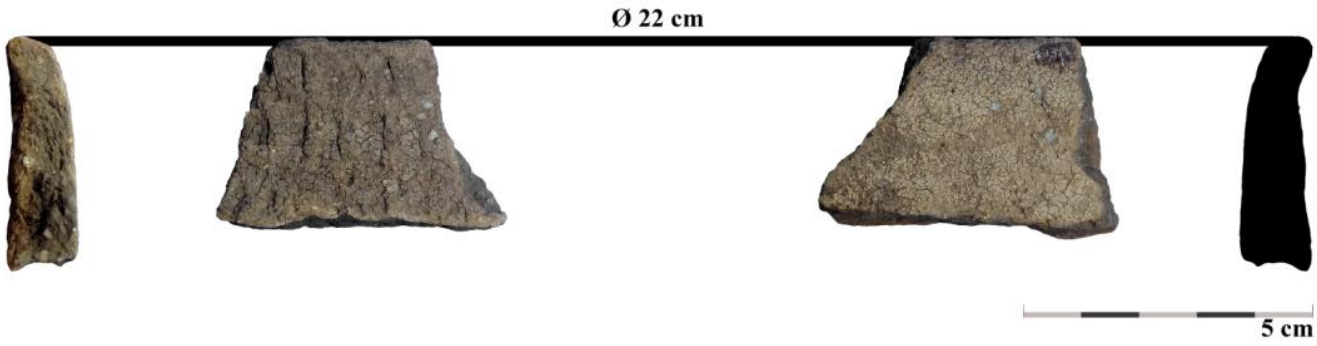

Peça: TRV 344.1

Fotos: Isabela da Silva Müller

Edição: Thiago Umberto Pereira

Figura 40. Espelhamento de borda da amostra TRV.344.1, com diâmetro projetado de $22 \mathrm{~cm}$, onde se observam ambas as faces do fragmento. Foto: Isabela da Silva Müller. Edição: Thiago Umberto Pereira. 


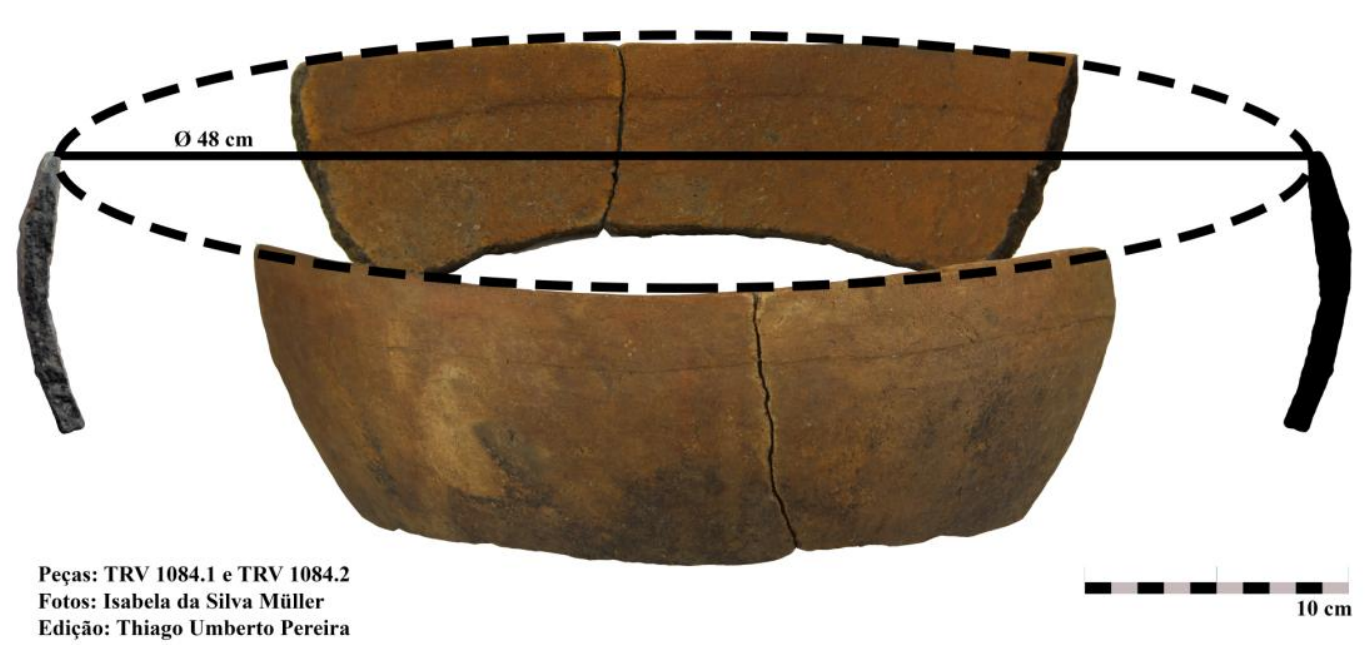

Figura 41. Espelhamento de borda das amostras TRV.1084.1 e TRV.1084.2 que se remontam, com diâmetro projetado de $48 \mathrm{~cm}$, onde se observam ambas as faces do fragmento. Foto: Isabela da Silva Müller. Edição: Thiago Umberto Pereira.

Os espelhamentos dessas bordas auxiliam na visualização da circunferência da vasilha e, somados aos dados de espessuras dos fragmentos bem como de tratamentos de superfície, ajudam a compor a interpretação final da coleção no sítio arqueológico.

\subsubsection{Análises arqueométricas por Fluorescência de Raios-X $(X R F)$}

Os resultados das análises de XRF para a coleção TRV estão divididos em duas pranchas: a primeira corresponde às análises dos núcleos dos fragmentos (Figura 42) e a segunda (Figura 43) das faces interna e externa dos fragmentos. Essa divisão em pranchas facilita a observação dos resultados gerados de diferentes partes das amostras. Na segunda prancha (Figura 43), onde estão discriminadas cada amostra analisada, nota-se que há dois valores para cada amostra: aquele identificado com a letra "I" refere-se à medida da face interna e a amostra identificada pela letra "E" refere-se a sua medida de face externa. 


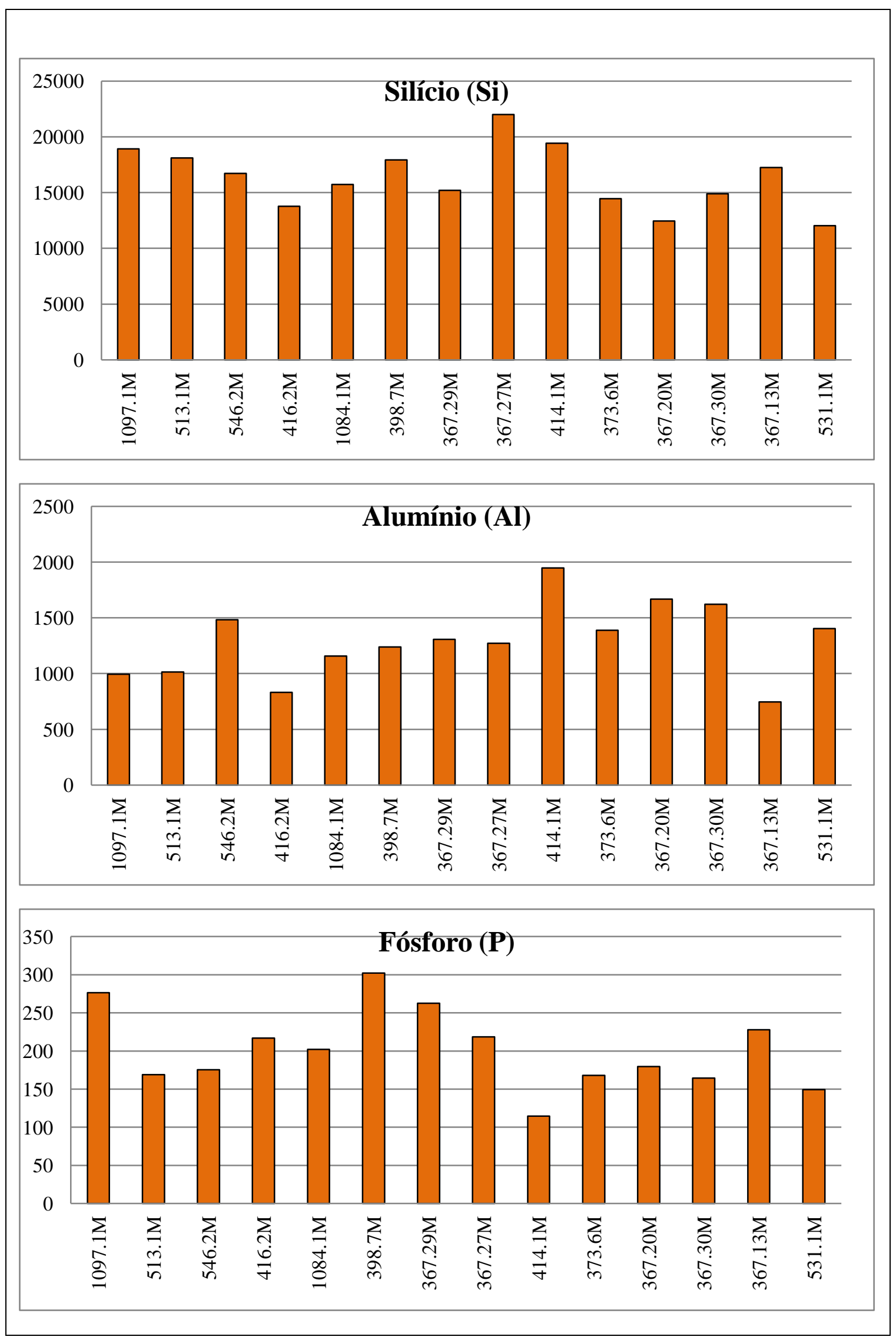



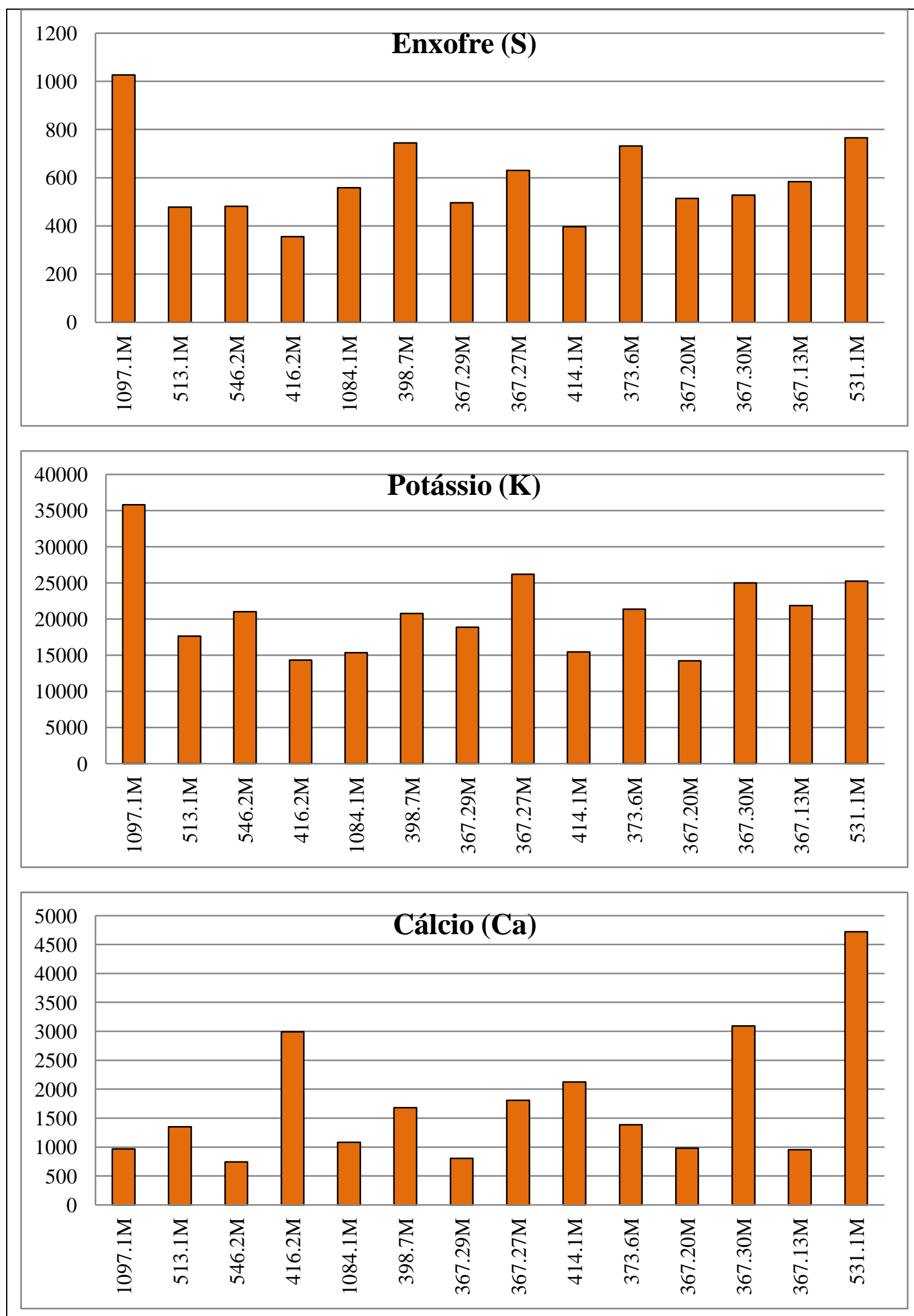

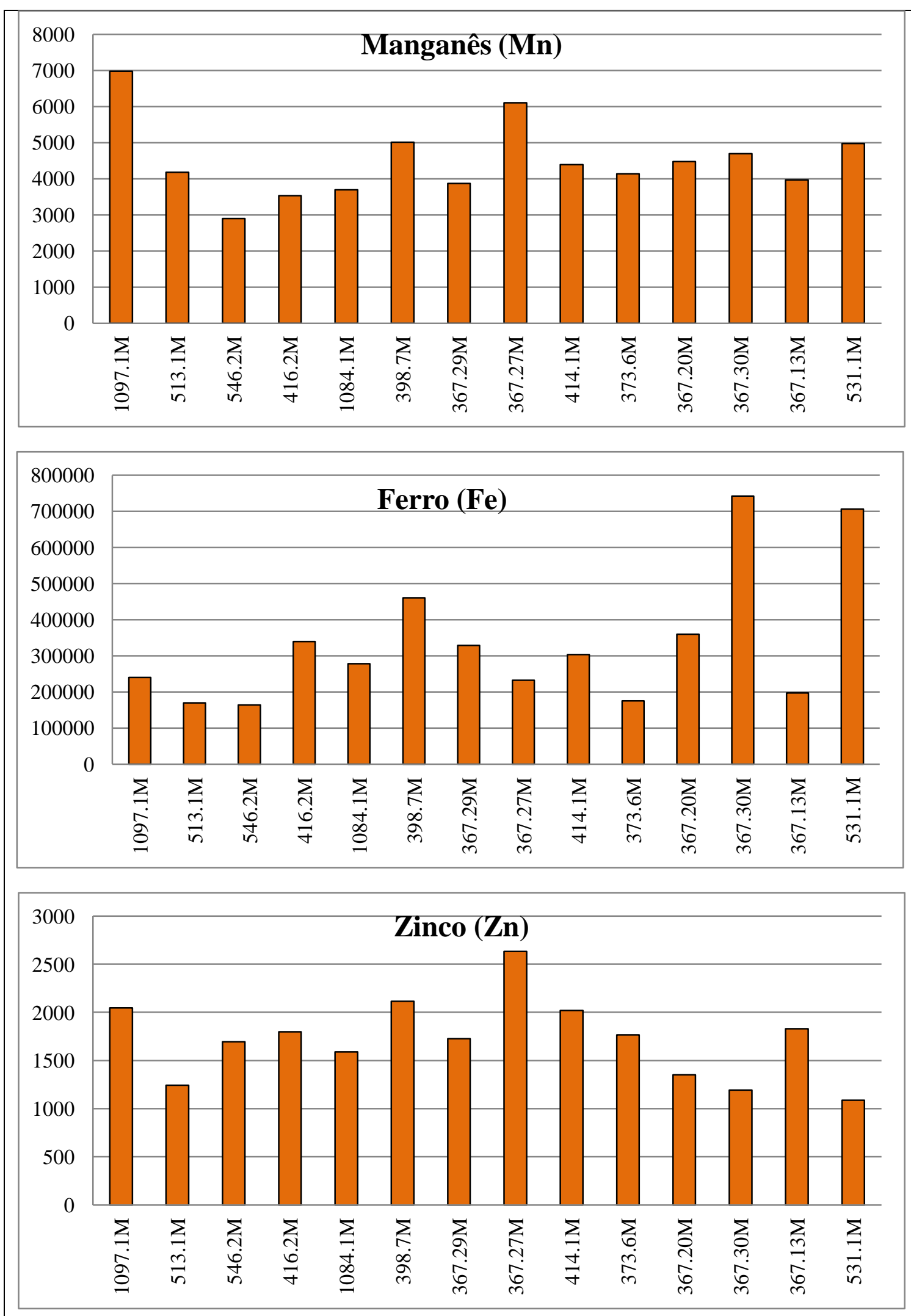


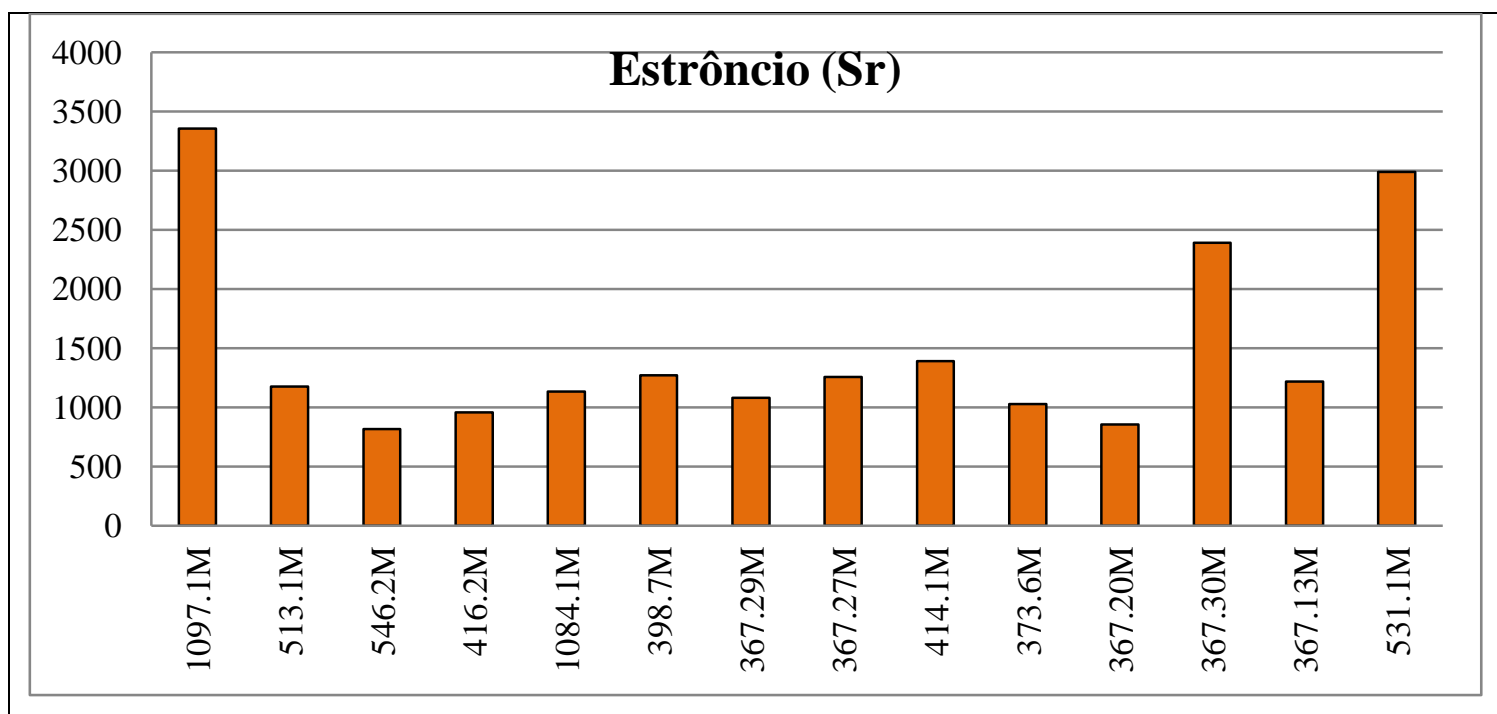

Figura 42. Prancha contendo os resultados da análise de XRF dos núcleos dos fragmentos de TRV para os seguintes elementos químicos: silício $(\mathrm{Si})$, alumínio $(\mathrm{Al})$, fósforo $(\mathrm{P})$, enxofre $(\mathrm{S})$, potássio $(\mathrm{K})$, cálcio $(\mathrm{Ca})$, manganês $(\mathrm{Mn})$, ferro $(\mathrm{Fe})$, zinco $(\mathrm{Zn})$ e estrôncio $(\mathrm{Sr})$. 


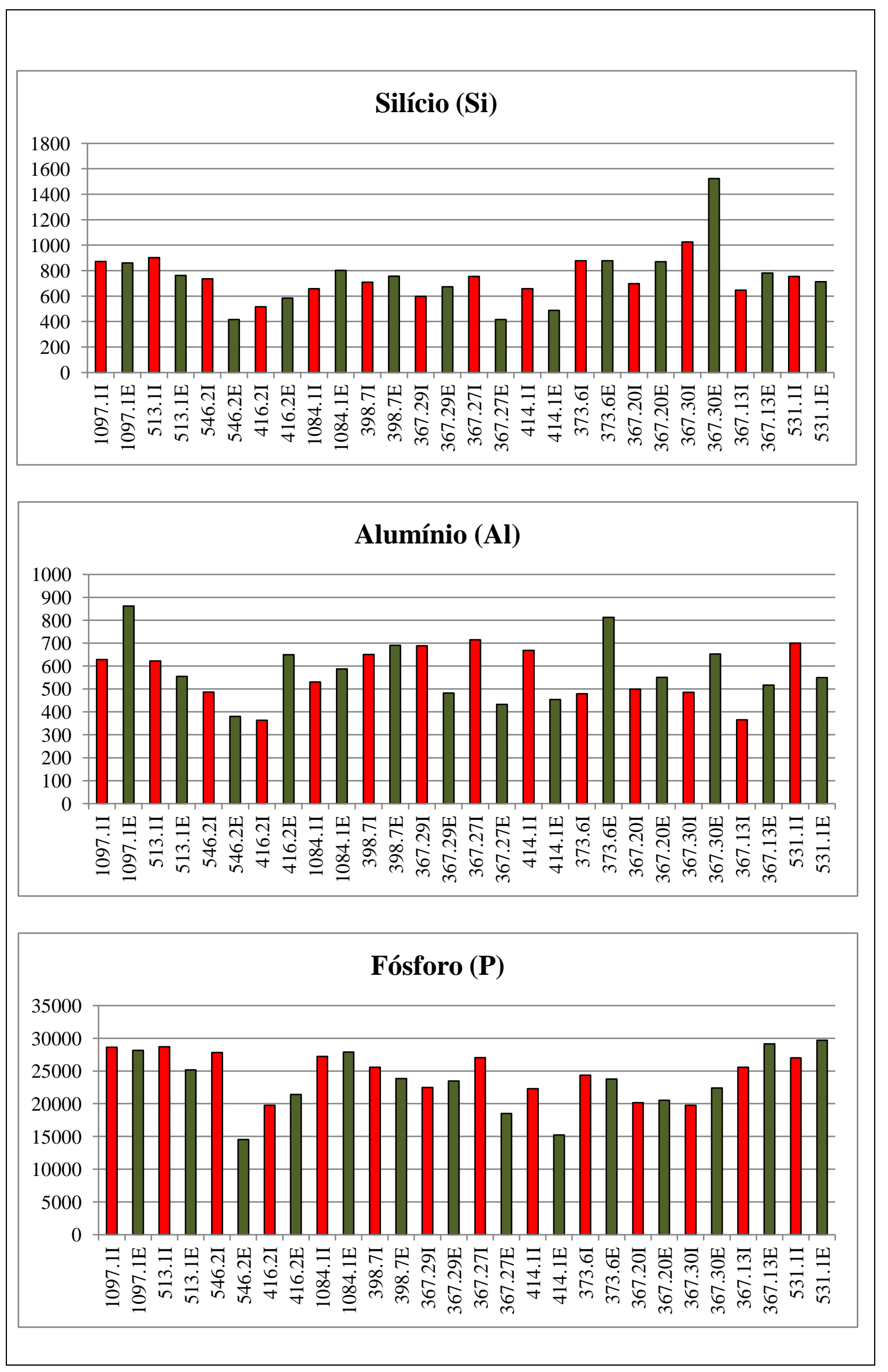



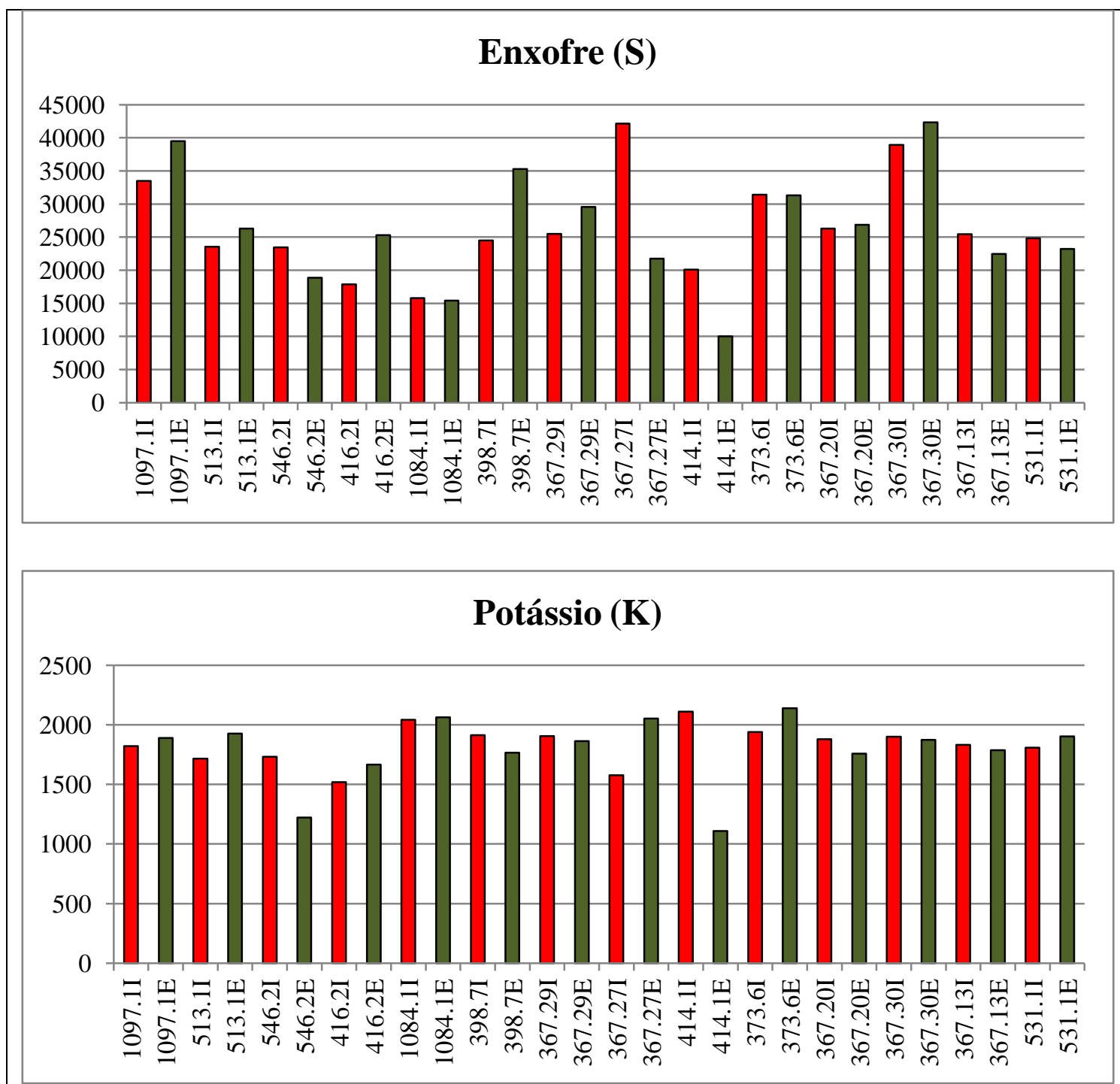

\section{Cálcio (Ca)}

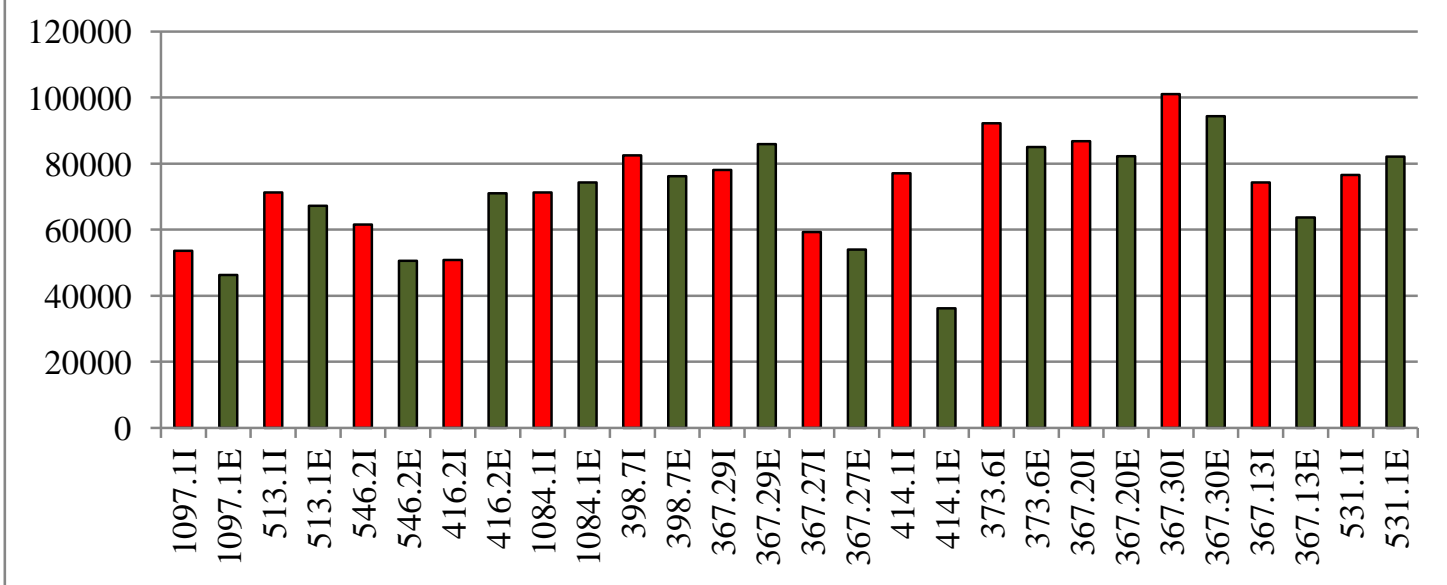




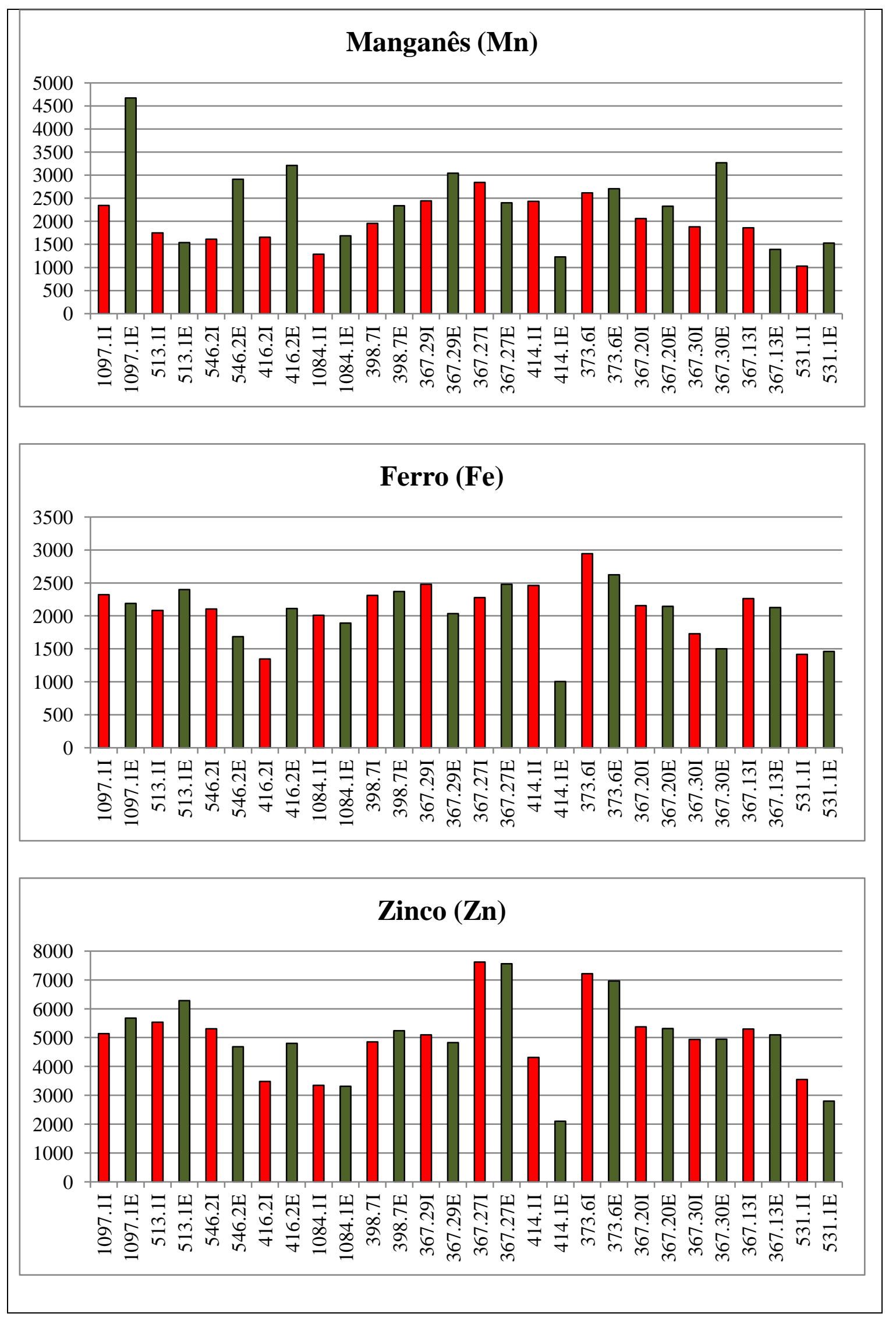




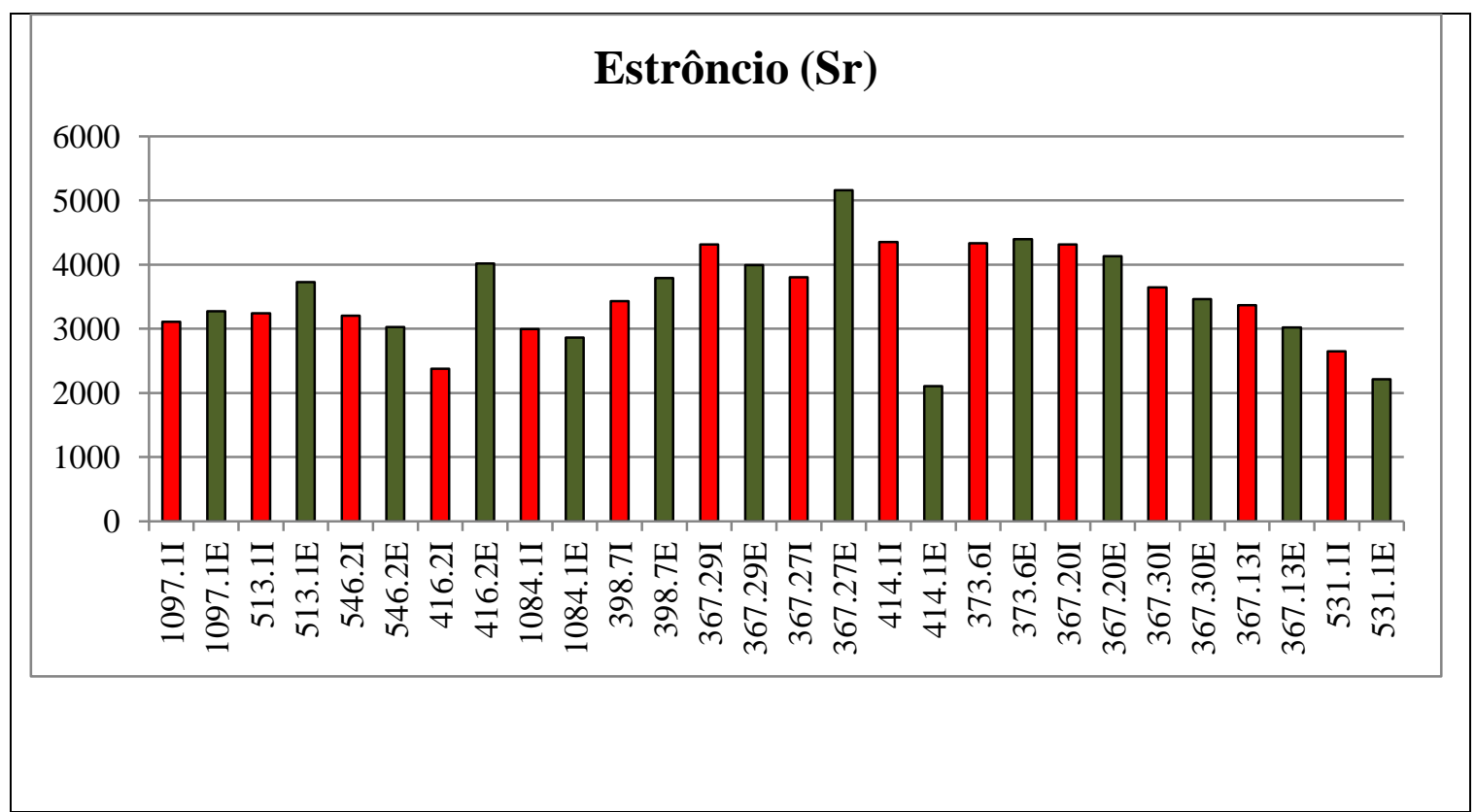

Figura 43. Prancha contendo os resultados da análise de XRF das faces interna e externa dos fragmentos de TRV para os seguintes elementos químicos: silício ( $\mathrm{Si}$ ), alumínio (Al), fósforo $(\mathrm{P})$, enxofre $(\mathrm{S})$, potássio $(\mathrm{K})$, cálcio $(\mathrm{Ca})$, manganês $(\mathrm{Mn})$, ferro $(\mathrm{Fe})$, zinco $(\mathrm{Zn})$ e estrôncio $(\mathrm{Sr})$.

A proposta desta dissertação é realizar a comparação entre ambas as coleções e, os gráficos gerados pelas análises de XRF, fazem mais sentido e dizem mais quando são comparadas ambas as coleções. Apesar de que os valores apresentados nos gráficos são aqueles em área e não em concentração, como já explicado na apresentação do método, podemos fazer algumas considerações sobre as medidas da coleção TRV ao compararmos os núcleos dos fragmentos e suas faces. São as considerações:

No núcleo dos fragmentos é identificada uma quantidade muito maior de silício ( $\mathrm{Si}$ ) e alumínio ( $\mathrm{Al}$ ) que em suas faces interna e externa, atestando a predominância desses elementos na pasta cerâmica, visto que esta é um aluminossilicato (SHEPARD, 1956, P.6). O potássio (K), o ferro (Fe) são mais abundantes nos núcleos dos fragmentos e de forma heterogênea. $\mathrm{O}$ fósforo $(\mathrm{P})$, o enxofre $(\mathrm{S})$, o cálcio $(\mathrm{Ca})$, o titânio (Ti), o zinco ( $\mathrm{Zn})$ e o estrôncio $(\mathrm{Sr})$, por sua vez, apresentam-se de forma contrária: quantidade muito mais elevada nas faces (sem distinção entre faces interna ou externa) que nos núcleos. O manganês $(\mathrm{Mn})$ encontra-se em quantidades semelhantes tanto nos núcleos quanto nas faces dos fragmentos, mas de forma mais homogênea nos núcleos.

Assim, a um primeiro momento é possível avaliar que aqueles elementos mais evidentes nas faces podem estar vinculados a tratamentos de superfície dadas às 
vasilhas, aos seus usos e manuseios e ao caráter pós-deposicional; e aqueles elementos mais abundantes nos núcleos podem estão vinculados às fontes de matérias-primas (argila e antiplástico). Mas, essa discussão será aprofundada mais adiante, ao compararmos ambas as coleções.

\subsection{Análise macroscópica do Lagoinha do Rio Tavares I/ Rio Tavares (RT)}

Dos 165 fragmentos analisados na coleção RT, observamos com relação à natureza das peças que $63.25 \%$ dos fragmentos analisados constituiu-se de paredes, alto número assim como na coleção do sítio TRV (Figura 44). Aqui, como na coleção TRV, não foram identificadas alças, cachimbos, decoração ou bolota de argila (itens presentes na ficha de análise). Porém, claramente há mais bordas e bases nesta amostragem que na amostragem da coleção TRV, um número bastante díspar: trata-se de 47 bordas e duas bases em RT (total de $29.51 \%$ da coleção) e 12 bordas e 1 base (7.89\% da coleção) em TRV. Ainda, foi encontrada uma peça bastante peculiar: a trempe/ytácuru (Figura 45), a qual é forte indício de materiais utilizados no processo de produção das vasilhas ou de seu uso. Geralmente, a trempe é um pedaço de argila cozida manuseado de forma a apoiar as vasilhas na queima ou no uso. Esta contem marcas dos negativos de tratamentos plásticos de outras vasilhas, tendo sido cozida enquanto apoiava vasilha ao fogo. Os espelhamentos das bordas estão disponibilizados no CATÁLOGO DE VESTÍGIOS CERÂMICOS no ANEXO 06 (estes utilizando a técnica descrita passo a passo anteriormente). Nesta coleção, também foi observado maior número de fragmentos (bordas ou não) com pontos de inflexão (diferente da coleção TRV), além de estarem em dimensões maiores que a outra coleção. Isso significa que, o processo de fragmentação no RT não foi tão intenso quanto no TRV. 


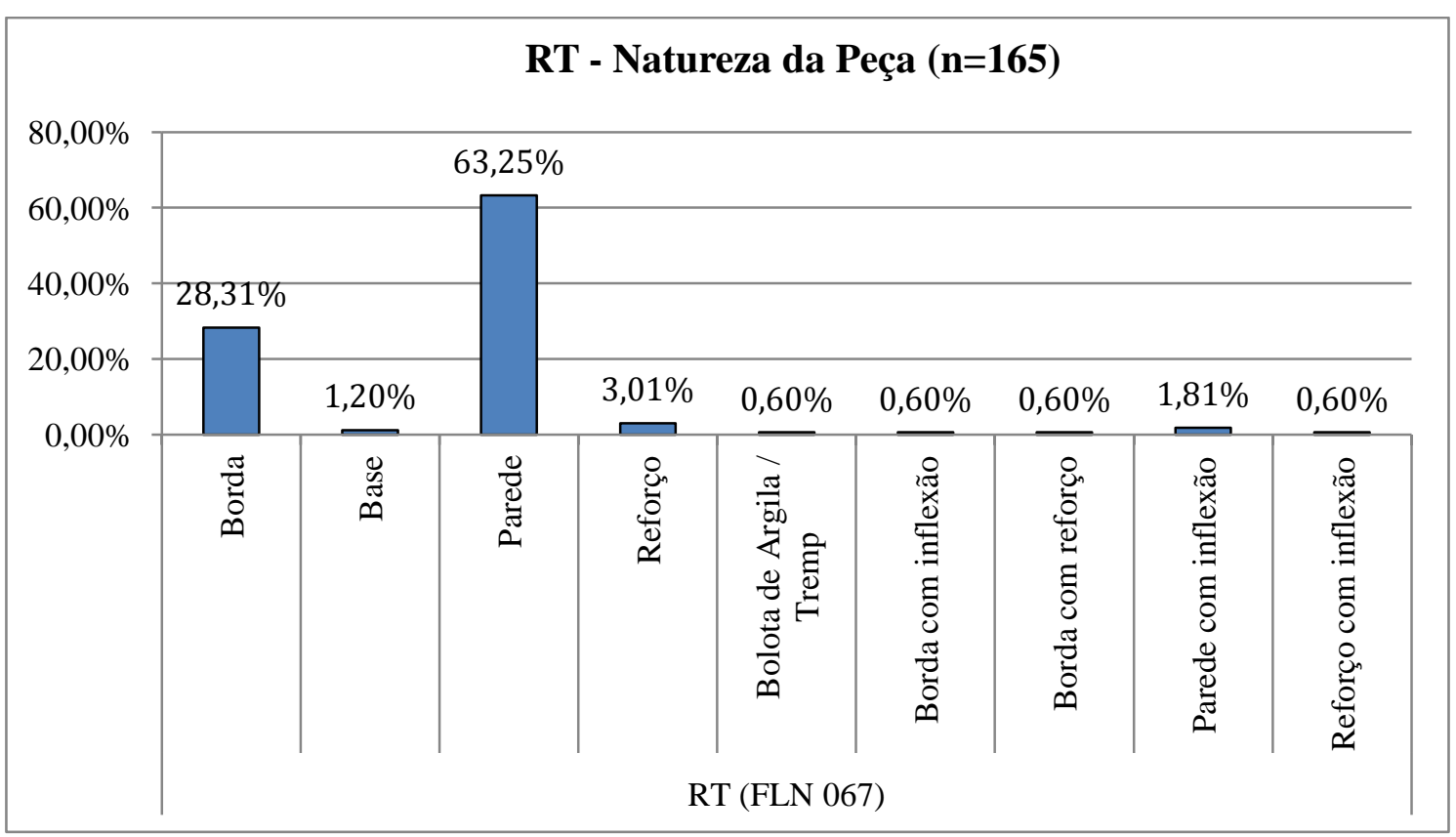

Figura 44. Gráfico representando a natureza dos fragmentos cerâmicos analisados do sítio Lagoinha do Rio Tavares I (RT) em porcentagem.

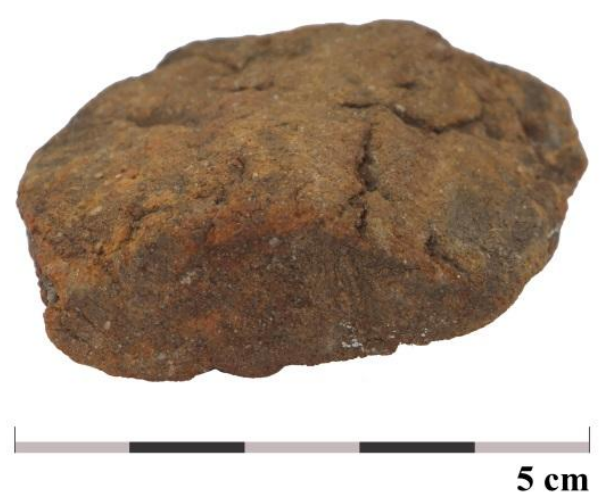

Figura 45. Trempe/ytácuru identificada na coleção RT. Foto: Isabela da Silva Müller. Edição: Thiago Umberto Pereira.

Com relação ao antiplástico presente na pasta cerâmica, encontramos os distintos tamanhos de minerais ao mesmo tempo (em $85.54 \%$ dos fragmentos, sendo 
$53.61 \%$ de minerais $\mathrm{A}, \mathrm{B}$ e $\mathrm{C}$ e $31,93 \%$ de minerais $\mathrm{B}$ ), minerais e caco moído na concentração de $13.86 \%$ (mais que na coleção TRV), e $0.60 \%$ de antiplástico mineral com carvão (a menor porcentagem) (Figura 46). As categorias apresentadas no gráfico são aquelas visualizadas na coleção RT, portanto há fragmentos apenas com mineral B e outros com caco moído e minerais A e B. A maior parte dos fragmentos apresenta minerais $\mathrm{A}, \mathrm{B}$ e $\mathrm{C}$ ao mesmo tempo; há também aqueles com caco moído e mineral $\mathrm{B}$; e, em menor número, aqueles com minerais $\mathrm{A}, \mathrm{B}$ e $\mathrm{C}$ e carvão. A coleção RT não apresentou antiplásticos de cariapé, caiuixi, óxidos de ferro e argila.

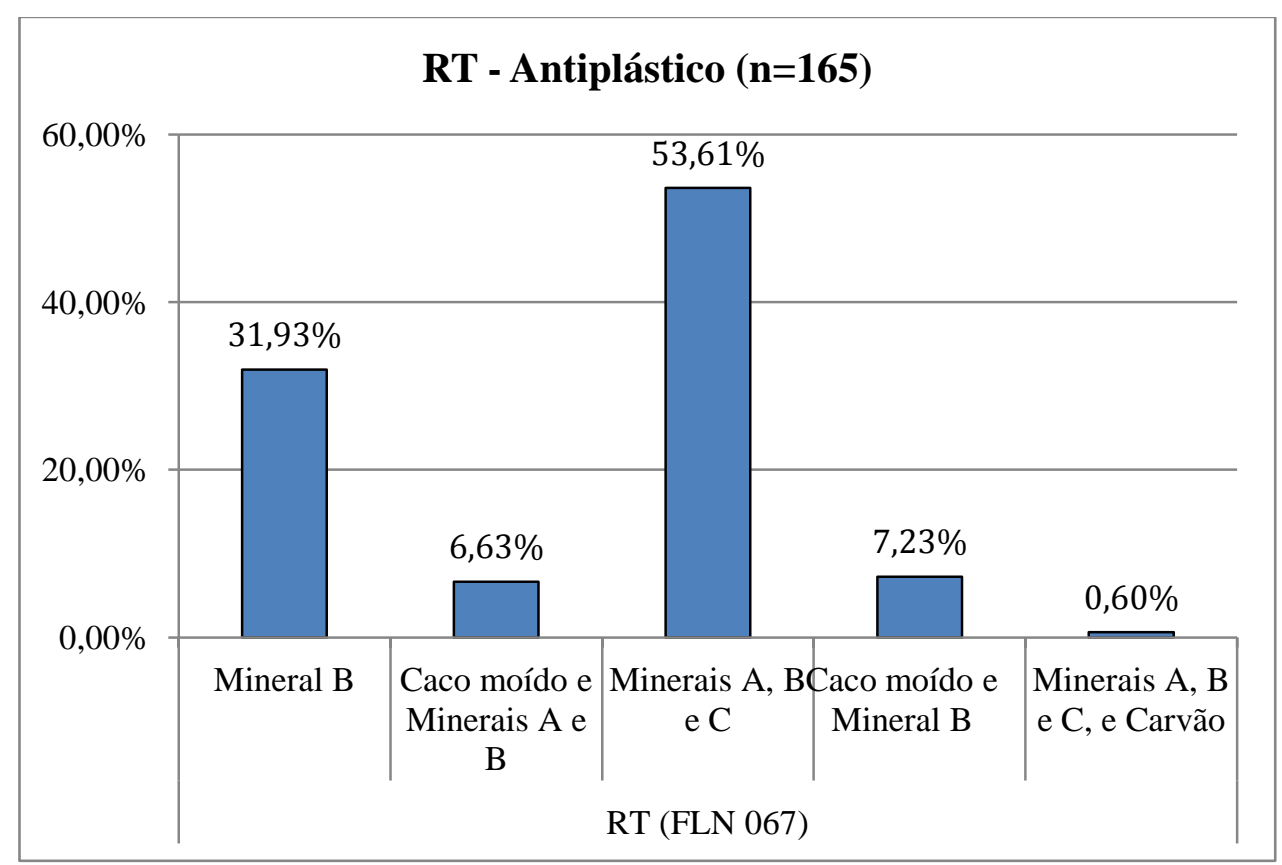

Figura 46. Gráfico representando a porcentagem de cada tipo de antiplástico presente nas pastas analisadas do sítio RT.

Sobre exemplos de alguns desses antiplásticos (caco moído, mineral, e carvão), encontramos nas amostras RT.I.1.67.037 e RT.I.1.67.039 (Figuras 47 e 48): 


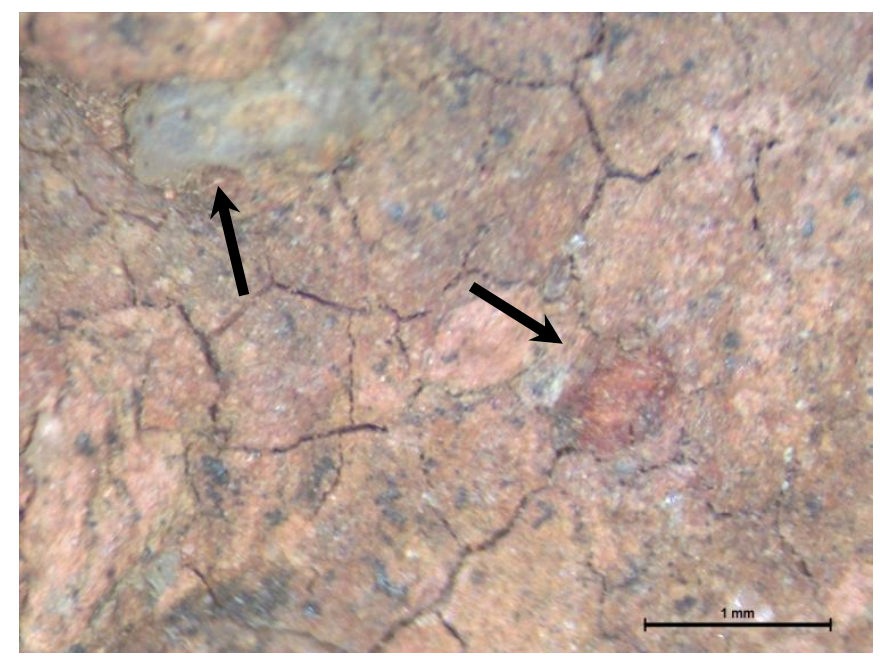

Figura 47. Detalhe da amostra RT.I.1.67.037 (face externa) em que observamos mineral A(quartzo) e caco moído.

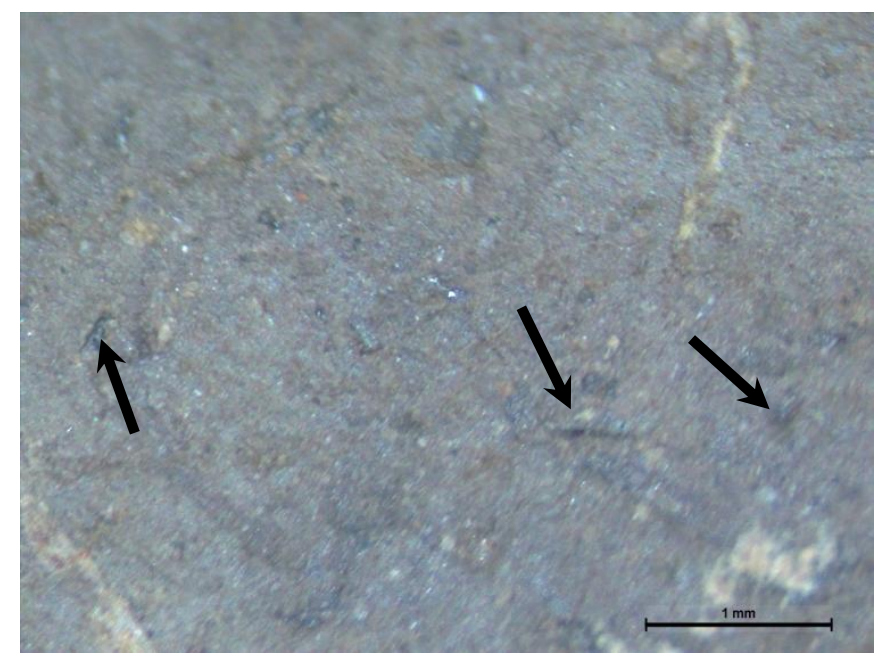

Figura 48. Detalhe da amostra RT.I.1.67.039 (face externa) onde observa-se carvões como antiplástico (ponto pretos na imagem).

Sobre as técnicas de manufatura identificadas, $98.19 \%$ da coleção é composta por peças roletadas ou acordeladas, sendo apenas um fragmento modelado ( $0.60 \%$ dos fragmentos) e dois (as bases) moldados (referente a 1.2\%). Da mesma forma como na coleção TRV, não foi identificada peça alguma torneada (portanto, com influência colonial).

Observamos na Figura 49 as configurações dos núcleos (como indicativos de queima), sendo que a porcentagem das queimas 1 (correspondente à oxidante) e 2 (correspondente à redutora) são bastante similares $(42.12 \%$ para queima oxidante e $43.37 \%$ para a queima redutora). Portanto há praticamente um equilíbrio e 
predominância nessa coleção entre as queimas oxidante e redutora, diferente da coleção TRV em que predomina a queima de número 5 (redutora internamente e oxidante externamente). A queima 5 observa-se em $13.25 \%$ dos fragmentos analisados e, por último, a queima de número 2 (oxidante interna e externamente, e redutora no núcleo) com $1.20 \%$ dos fragmentos. Isso tudo quer dizer que há um equilíbrio de queimas homogêneas em diferentes graus, ou oxidantes ou totalmente redutoras. Importante mencionar novamente que essa classificação numérica seguiu aquela de Rye (RYE, 1981, P.116 apud GASPAR, 2014). Não foram encontradas as queimas 4 e 6.

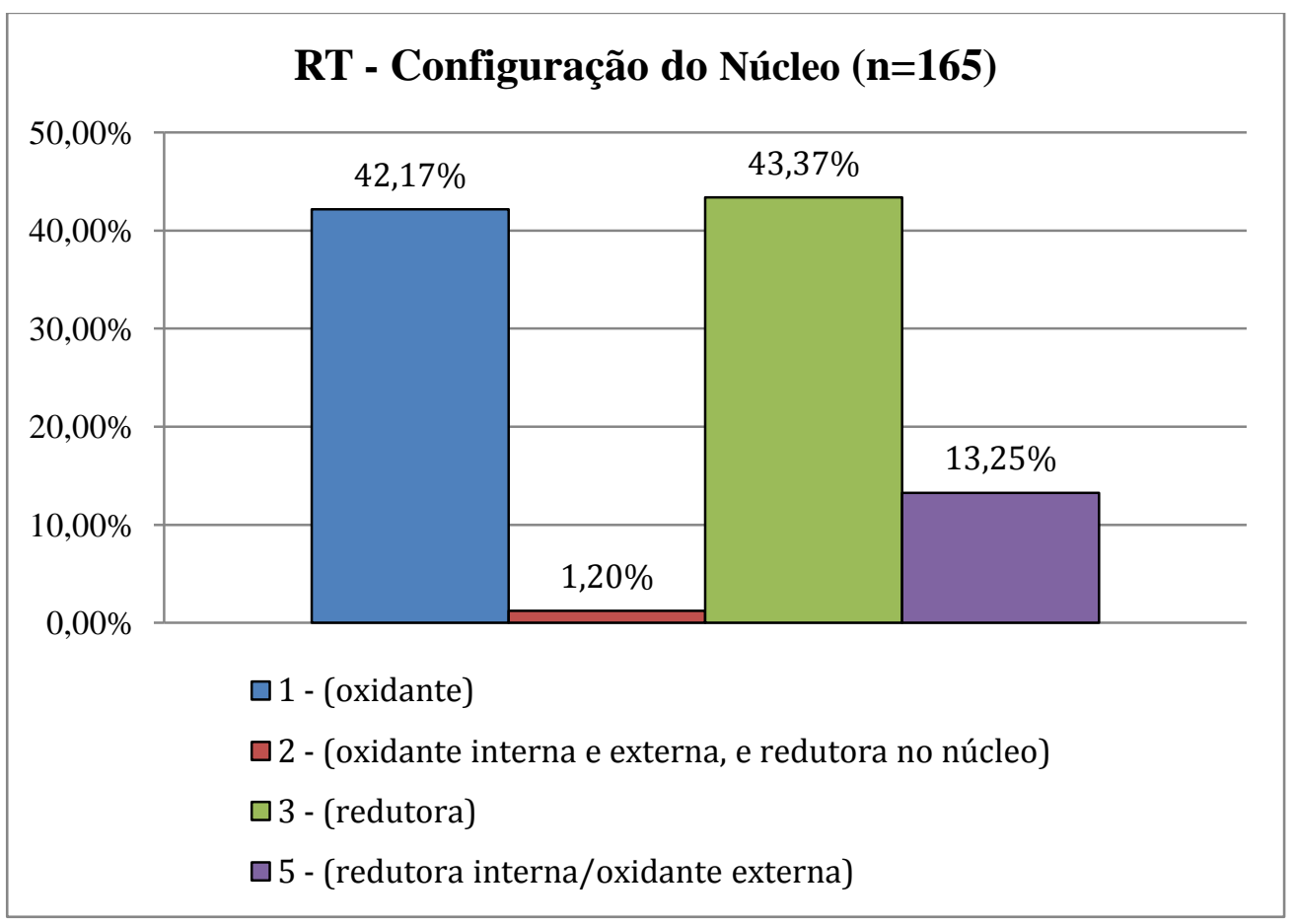

Figura 49. Gráfico representando as formas de configuração do núcleo encontradas nas amostras do sítio RT em porcentagem.

Já com relação às espessuras das paredes das peças $(\mathbf{m m})$, há também uma grande variabilidade. Foi constatado que $12.05 \%$ dos fragmentos possui $7 \mathrm{~mm}$. Em seguida, há $9.64 \%$ dos fragmentos com $8 \mathrm{~mm}$ e $9.04 \%$ com $13 \mathrm{~mm}$; enquanto que menos de $1 \%$ dos fragmentos possui $1 \mathrm{~mm}$ e menos de $1 \%$ possui $23 \mathrm{~mm}$, sendo que a escala abrange de 1 a 23 mm (Figura 50): 


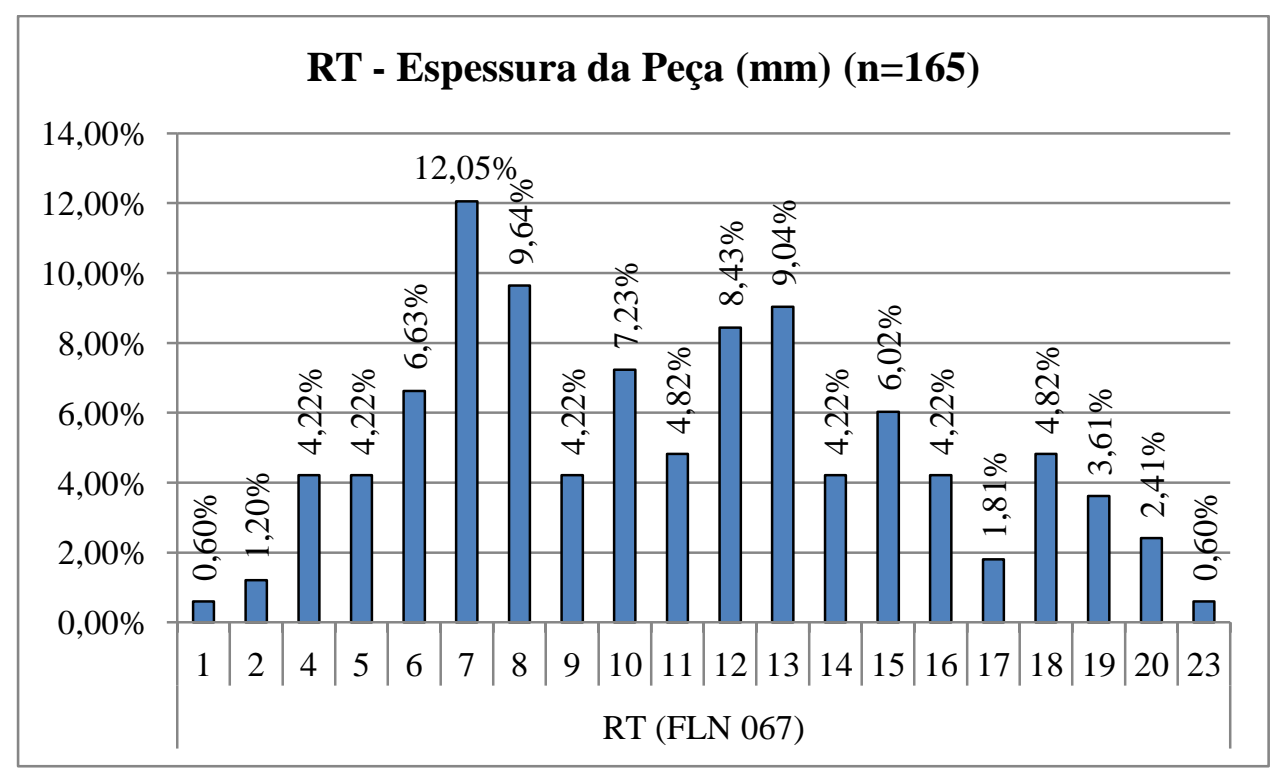

Figura 50. Gráfico representando a espessura dos fragmentos cerâmicos analisados do sítio RT em porcentagem.

Foi feita, também, a relação entre as formas das bordas $(\mathbf{m m})$ e espessuras dos lábios (mm). Mas, com o intuito de se identificar correlações como de acordo com a forma do lábio, uma espessura de lábio específica, essa relação se mostrou pouco profícua visualmente. Ainda assim, foi possível observar que $95.88 \%$ das bordas são simples (ou seja, sem inflexão ou reforço), e 4.12\% (isso quer dizer 2 fragmentos) referem-se a bordas com inflexão ou com reforço. Além de as espessuras dos lábios em todas as bordas variarem de $1 \mathrm{a} 18 \mathrm{~mm}$ e de a maior parte dos lábios serem planos ou arredondados em bordas sem inflexão ou reforço, a maior parte das bordas de lábios planos possui espessuras de $4 \mathrm{~mm}$ (10.2\% dos fragmentos) e $9 \mathrm{~mm}(8.16 \%)$. Entre os lábios arredondados, $10.2 \%$ possui $4 \mathrm{~mm}$ e $8.16 \%$ possui $8.16 \%$; os lábios apontados possuem bem fina espessura (de 1 a $3 \mathrm{~mm}$ ) e apenas um lábio biselado foi identificado (correspondendo a $2.04 \%$ do total de fragmentos), com $10 \mathrm{~mm}$, em uma borda com inflexão; e apenas um lábio plano foi identificado (correspondendo a 2.04\% do total de fragmentos) em uma borda com reforço com $18 \mathrm{~mm}$ de espessura. Portanto, as espessuras variam bastante dentro das formas de lábio identificadas.

Aparentemente, também não há relação direta entre espessura da peça (mm) e espessura do lábio $(\mathbf{m m})$. Porém, mesmo essas relações não tão válidas são importantes para compreendermos as coleções e determinadas características relacionadas ou não no modo de produção das vasilhas. Por exemplo, ainda foi possível 
apreender que as espessuras dos fragmentos variaram de 4 a $23 \mathrm{~mm}$, e as espessuras dos lábios, de 1 a $18 \mathrm{~mm}$, ou seja, as espessuras dos lábios são sempre menores que da peça como um todo. Cada fragmento apresentou uma medida para cada espessura da peça associada à espessura do fragmento, ou seja, observamos a singularidade de cada parte que compõe as vasilhas e a variedade de espessuras presentes na coleção. Ou mesmo, poderíamos observar essa relação como a irregularidade em milímetros dos artefatos produzidos, uma vez que a parede de uma vasilha não se mantem com espessura milimetricamente constante em toda sua extensão. No entanto, há algumas medidas que se repetem em baixa frequência: $8.16 \%$ das bordas possuem $6 \mathrm{~mm}$ de espessura com 4 mm de lábio; $4.08 \%$ das bordas possuem $7 \mathrm{~mm}$ de espessura com $2 \mathrm{~mm}$ de lábio; $6.12 \%$ das bordas possui $7 \mathrm{~mm}$ de espessura com $4 \mathrm{~mm}$ de lábio; $6.12 \%$ das bordas possui 9 $\mathrm{mm}$ de espessura com $7 \mathrm{~mm}$ de lábio; $4.08 \%$ das bordas possui $13 \mathrm{~mm}$ de espessura com $9 \mathrm{~mm}$ de lábio; e $4.08 \%$ possui $19 \mathrm{~mm}$ de espessura com $9 \mathrm{~mm}$ de lábio. Mesmo assim, esses últimos dados são irrisórios e reforçam que não foi possível correlacionar de maneira mais profunda a espessura da peça com a espessura do lábio na coleção.

Da mesma forma ocorreu com a relação entre a espessura do lábio $(\mathbf{m m}) \mathbf{e}$ o diâmetro das bordas (cm). Foi possível observar que, de modo geral, mas não exclusivo, quanto maior a espessura do lábio na borda, maior o diâmetro da peça. Mas essa informação não é regra e não pode ser extrapolada para o conjunto inteiro. Além disso, a maior parte dos fragmentos (6.12\% dos fragmentos de borda, número ínfimo) possui $10 \mathrm{~mm}$ de lábio para um diâmetro projetado de $56 \mathrm{~cm}$. O restante dos fragmentos de bordas possuem entre 1 e 2 fragmentos no máximo para cada espessura e diâmetro relacionado. Ou seja, não é possível extrapolar qualquer relação para todo um conjunto.

Referente aos tratamentos plásticos de superfície e suas localizações nos fragmentos (Figura 51), praticamente todos se apresentaram alisados. Isso porque, mesmo com um tratamento cromático, previamente foi feito um alisamento no fragmento para receber a pintura, ou o engobo por exemplo. 


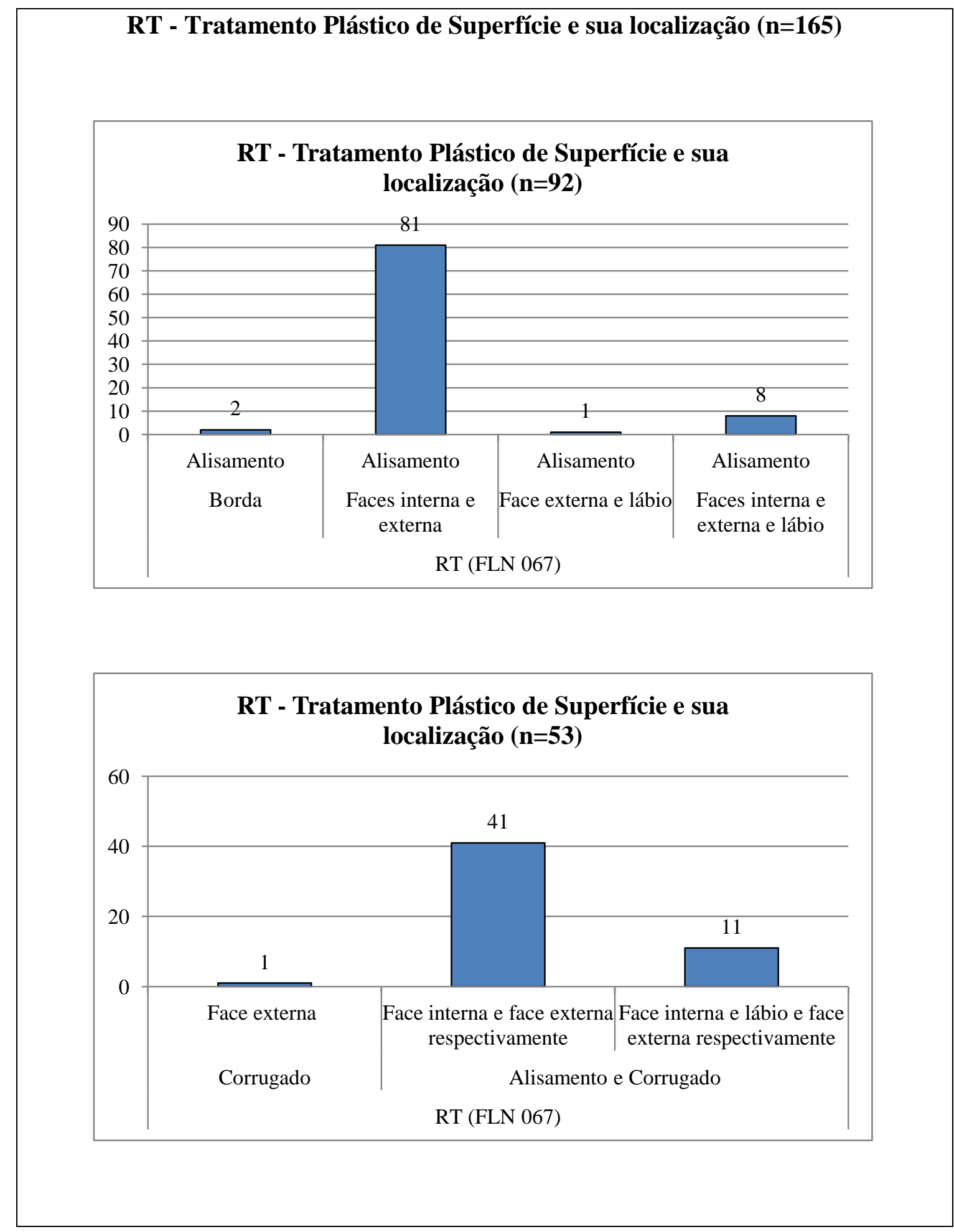




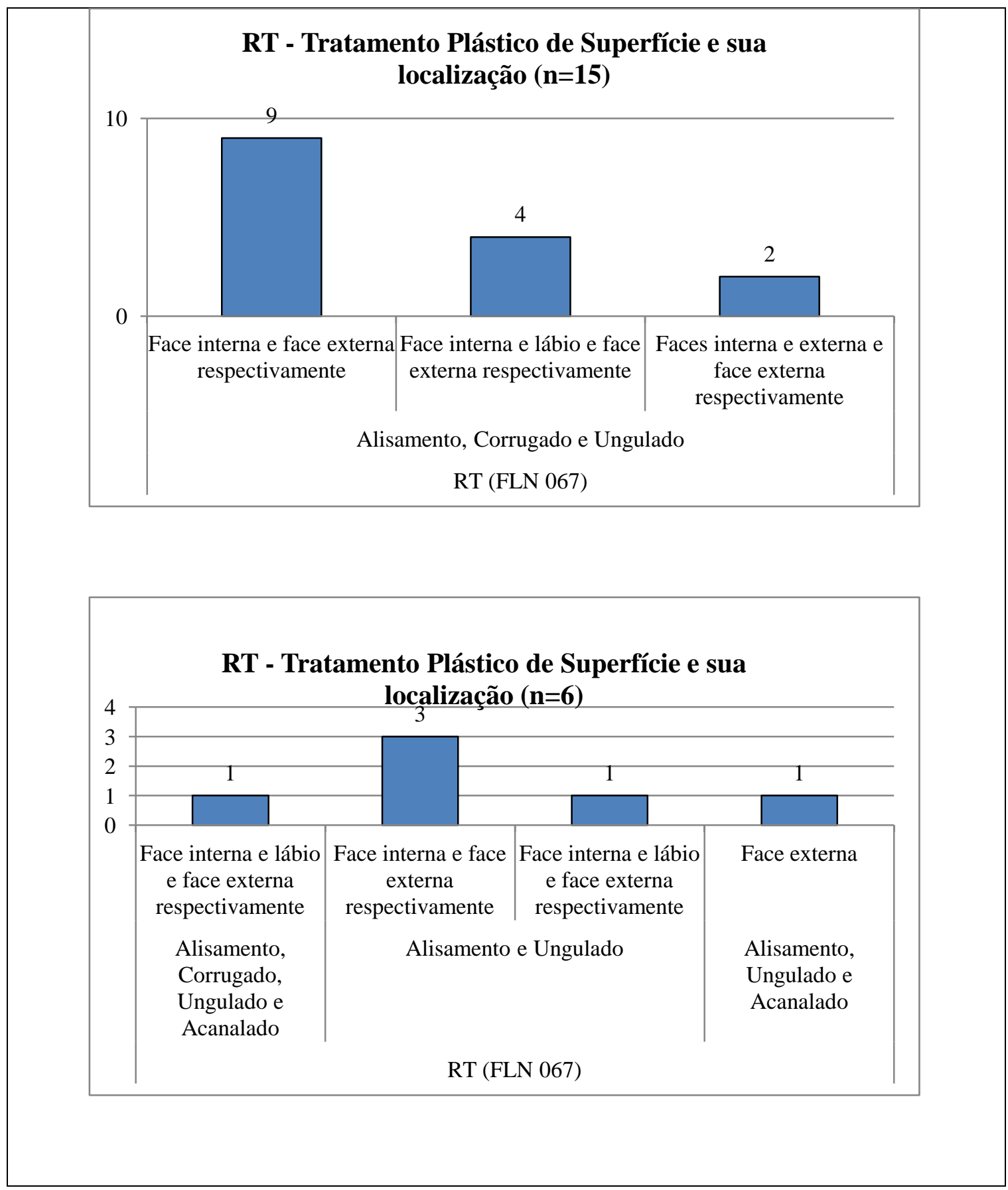

Figura 51. Relação entre os tratamentos plásticos de superfície encontrados e sua localização nas amostras do sítio RT.

Portanto, no total de 165 fragmentos, encontram-se os seguintes tratamentos: alisamento, corrugado, ungulado e acanalado. Eles estão isolados ou associados. Assim, 92 são alisados de alguma forma, sendo 81 alisados em ambas as faces, 2 apenas nas bordas, 1 alisado na face interna e lábio (borda), e 8 em ambas as faces e lábio (bordas). Desse total, 53 possuem o corrugado, sendo: apenas 1 fragmento somente com corrugado, 41 com o alisamento nas faces internas e corrugado nas faces 
externas; e 11 com alisamento nas faces internas e lábios e corrugado nas faces externas. Ainda, um número menor, de 15 fragmentos, possui a associação entre alisamento, corrugado e ungulado: 9 possuem as faces internas alisadas e as externas corrugadas e unguladas; 4 possuem as faces internas e lábios alisados e as faces externas corrugadas e unguladas; e 2 com ambas as faces alisadas e parte das faces externas corrugadas e unguladas ao mesmo tempo. E, por fim, temos que 1 fragmento possui tratamento alisado internamente e no lábio e corrugado, ungulado e acanalado externamente; 3 possuem alisamento internamente e ungulado externamente; 1 possui alisamento internamento e ungulado na face externa; e 1 possui alisamento, ungulado e acanalado na face externa ao mesmo tempo. O corrugado sempre aparece nas faces externas (na coleção TRV da mesma forma), mas não ocorre o mesmo para o tratamento cromático, ora na face interna, ora na face externa. Observa-se, a seguir, detalhe (na seta) das marcas de alisamento horizontal bastante evidente visualmente de um fragmentos cerâmico da coleção (Figura 52):

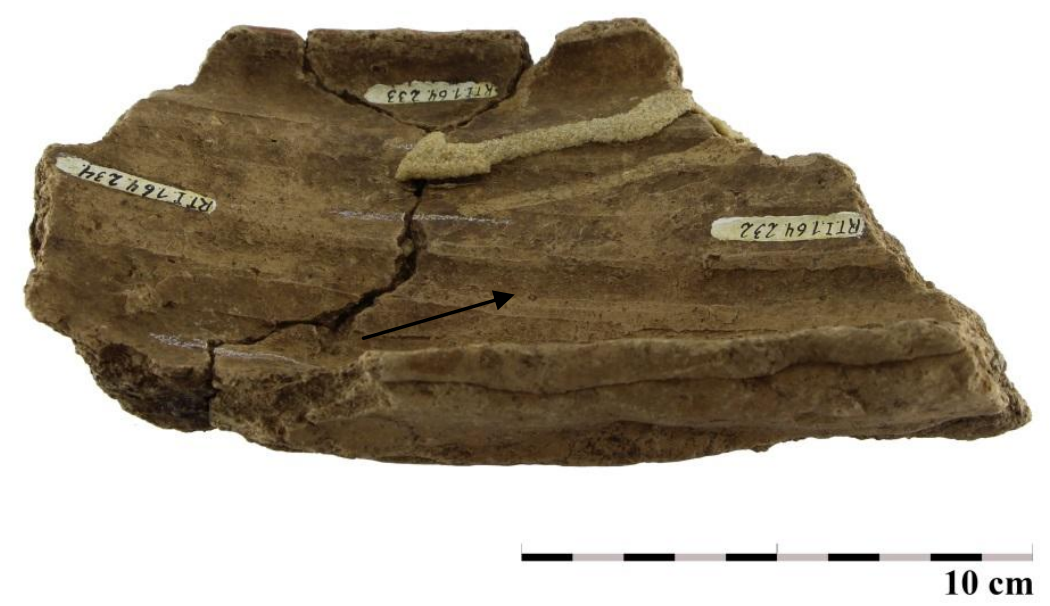

Figura 52. Detalhe de alisamento na face interna do fragmento RT.I.64.292. Foto: Isabela da Silva Müller. Edição: Thiago Umberto Pereira.

Dos 165 fragmentos analisados, 102 possuem tratamentos cromáticos, número bastante elevado e que diferencia altamente esta coleção da coleção TRV (são 
31 fragmentos apenas com esse tratamento). O engobo branco é o tratamento mais encontrado na coleção (Figura 53). Observa-se, então, os tratamentos cromáticos de superfície e suas localizações:

RT - Tratamento Cromático de Superfície $(n=102)$
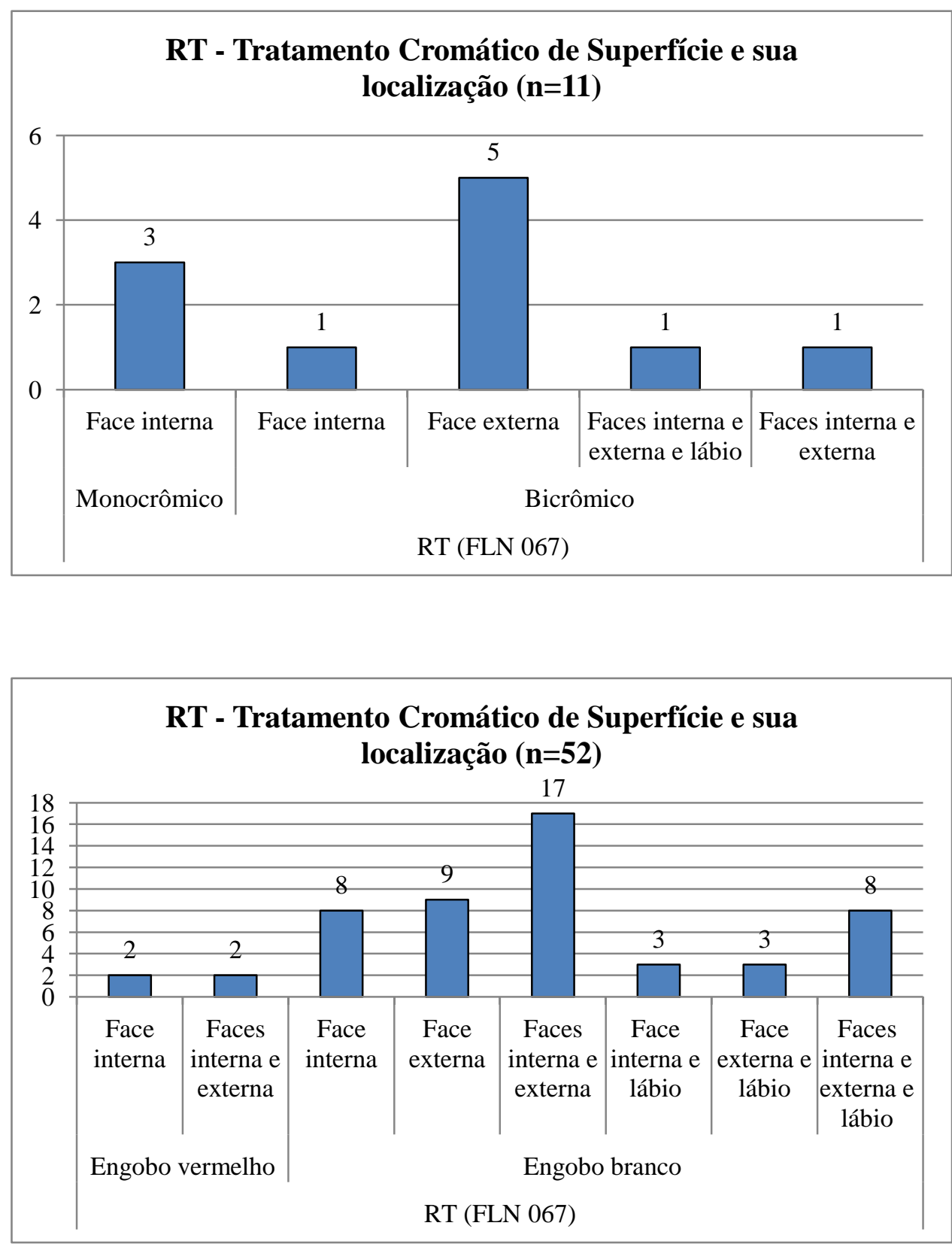


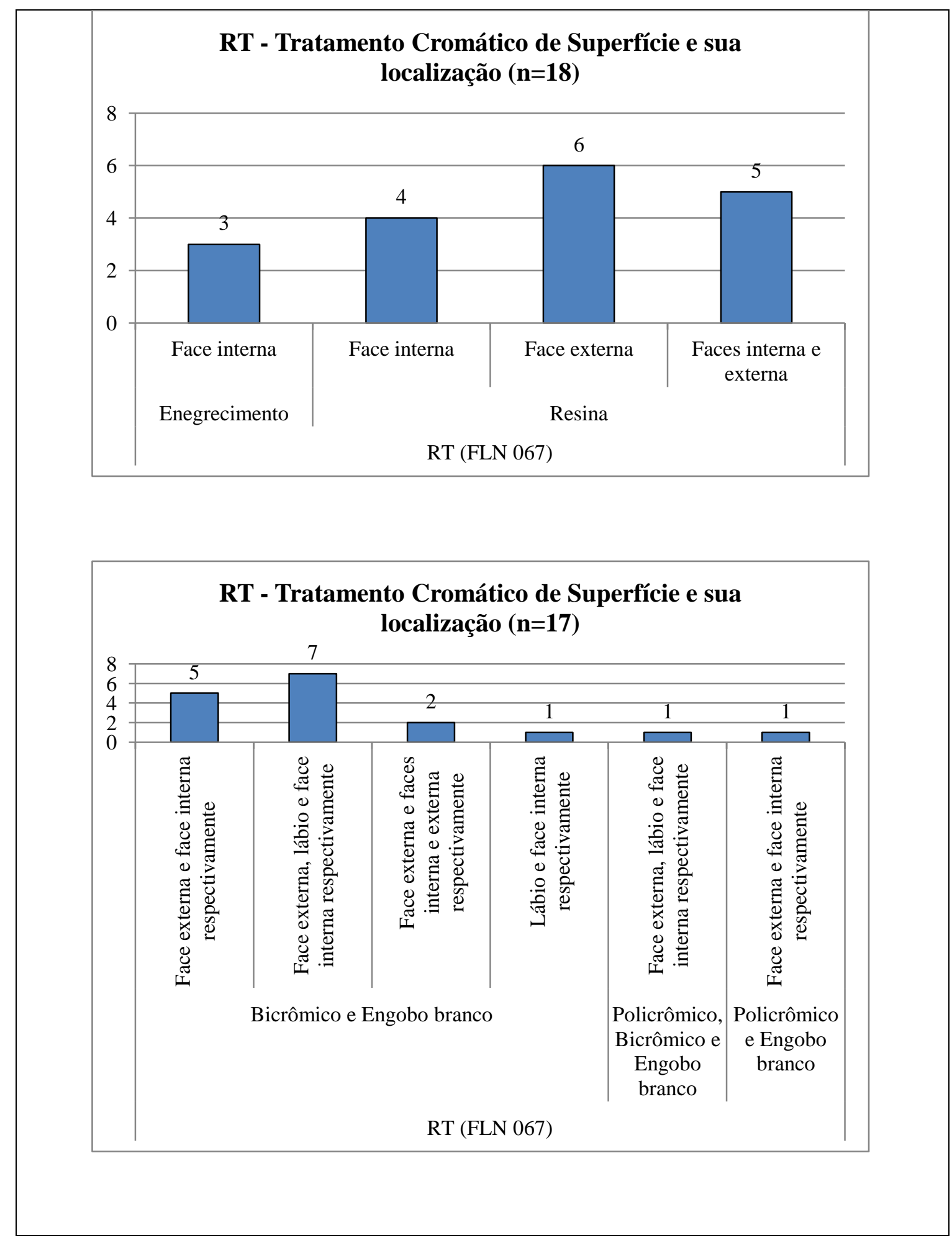




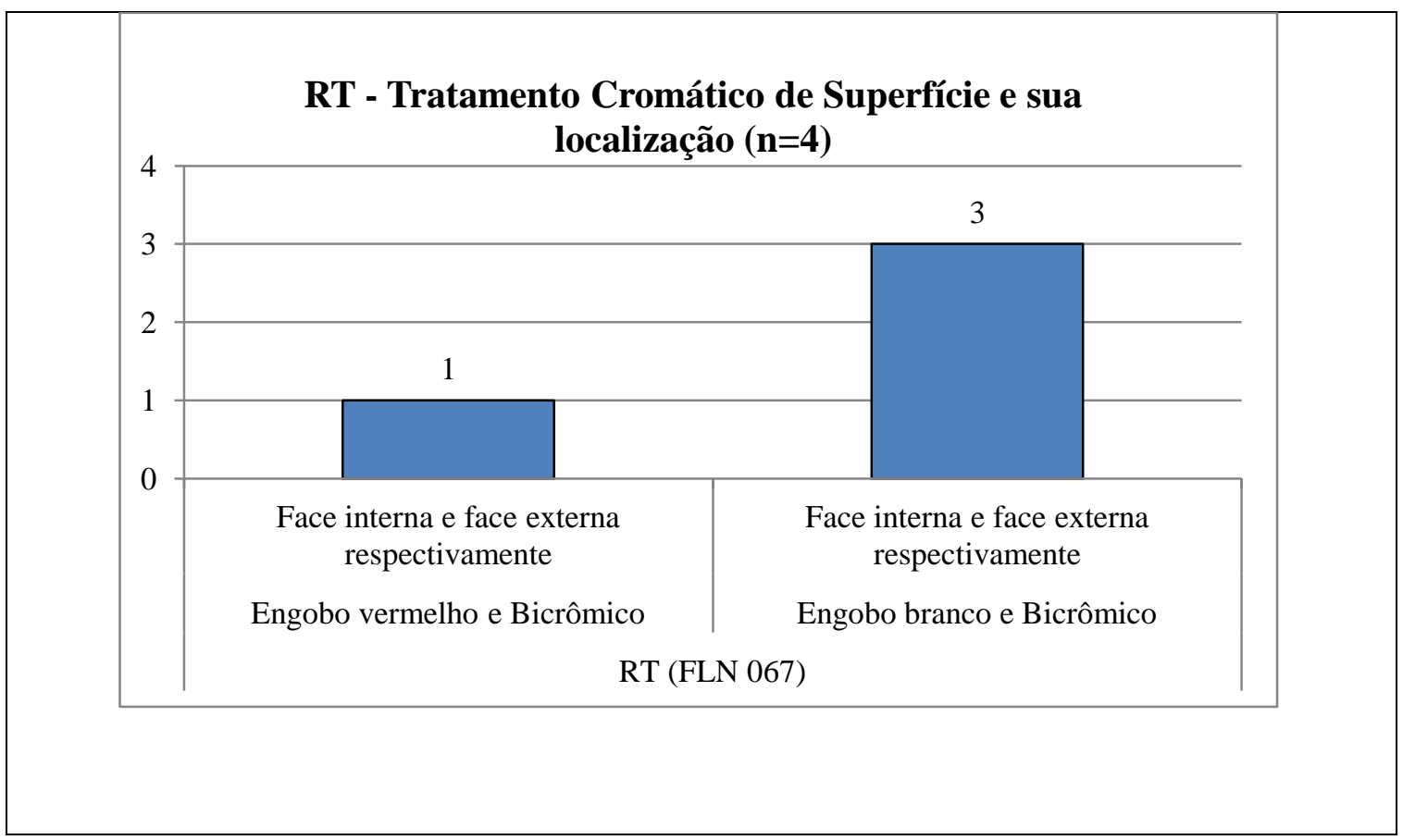

Figura 53. Relação entre os tratamentos cromáticos de superfície encontrados e sua localização nas amostras do sítio RT.

De acordo com os gráficos observados, o tratamento cromático mais evidente numericamente são os engobos vermelho e branco isolados (52 fragmentos). Mas, se forem contabilizadas as peças com engobo e alguma pintura associados (monocrômica ou bicrômica), esse número chega a 73, mais que cinquenta por cento de todos os tratamentos cromáticos observados. Assim, 3 fragmentos apenas possuem tratamento monocromático apenas (pintura) nas faces internas, e 8 possuem tratamento bicrômico (pintura com pintura ou engobo com pintura), sendo que destes 8: 1 possui o tratamento bicrômico na face interna; 5 nas faces externas; 1 em ambas as faces e lábio (neste caso, uma borda); e 1 em ambas as faces. Com relação aos fragmentos com engobo somente, 4 possuem somente engobo vermelho (sendo 2 nas faces internas e 2 em ambas as faces). Com engobo branco somente, são 48 fragmentos, sendo 8 nas faces internas, 9 nas faces externas, $17 \mathrm{em}$ ambas as faces, 3 nas faces internas e lábios, 3 nas faces externas e lábios, e 8 em ambas as faces e lábios. Apenas três fragmentos apresentaram enegrecimento na face interna: nota-se que estes provavelmente não se tratam de casos de enegrecimento (como tratamento intencional); tratam de um escurecimento ocorrido de acordo com o uso das vasilhas em virtude da presença de matéria orgânica internamente. Para aprofundar nesse tipo de marcas de uso, é necessário um estudo mais aprofundado e específico de uso das vasilhas. Ainda, 15 
fragmentos aparentam ter algum tipo de resina: 4 nas faces internas, 6 nas faces externas e 5 em ambas as faces. Sobre a categoria "resina", esta não foi aprofundada nem foi possível determiná-la nas análises arqueométricas (devido às resinas serem substâncias prioritariamente orgânicas e neste trabalho não ter sido utilizado método algum de identificação de elementos orgânicos). Porém, foi atribuída a ela alteração cromática observada nas superfícies dos fragmentos de aspecto craquelado.

Sobre a associação entre tratamentos mono, bi ou policrômicos e engobos, obteve-se: 15 fragmentos com tratamento bicrômico e engobo branco, sendo 5 com tratamento bicrômico nas faces externas e engobo branco nas faces internas, $7 \mathrm{com}$ tratamento bicrômico nas faces externas e lábios e engobo branco nas faces internas, 2 com bicrômico externamente e engobo branco em ambas as faces, 1 bicrômico no lábio e engobo branco internamente. Um (1) fragmento possui Tratamento policrômico externamente, bicrômico no lábio e engobo branco internamente, e 1 possui tratamento policrômico na face externa e engobo branco internamente. Um (1) fragmento possui engobo vermelho internamente e tratamento bicrômico externamente e 3 possuem engobo branco internamente e tratamento bicrômico externamente. É importante também destacar que grande parte dos engobos brancos (predominantes) estão nas faces internas dos fragmentos.

Foram elaboradas mais duas formas de relação: os tratamentos plásticos vs. espessuras da peças (mm) e os tratamentos cromáticos vs. espessuras das peças (mm), entretanto não foram estabelecidas conclusões de correlações para esses atributos. Ou seja, por exemplo, o tratamento plástico corrugado ocorre nos fragmentos de menor a maior espessura e não somente em uma determinada faixa de espessura; assim como o engobo branco também nas mais diversas espessuras encontradas. A faixa de espessura das peças com tratamento plástico é de 1 a $23 \mathrm{~mm}$ (e a espessura mais recorrente é a de $7 \mathrm{~mm}, 6.63 \%$, em fragmentos corrugados) e a faixa de espessura dos fragmentos com tratamento cromático é entre 2 e $23 \mathrm{~mm}$ (e a espessura mais recorrente é a de $6 \mathrm{~mm}, 5.88 \%$, em fragmentos com engobo branco). Ou seja, assim como na coleção TRV, não há diferença em termos de espessuras entre os tratamentos plásticos e cromáticos.

Com relação à coloração/cor das peças, a identificação seguiu da mesma forma que para a coleção TRV. Na coleção RT foram identificadas as cinco cores 
presentes na ficha, que possuem seus correspondentes na tabela Munsell (ver páginas 92 e 93).

Ao contrário da coleção TRV, aqui a maior porcentagem foi verificada com a pasta branca (59.64\%), seguida da laranja C (21.69\%), da laranja A (11.45\%), da laranja B (6.02\%), e da cinza/preta (com 1.20\%).

Referente às formas das bordas e bases, $32.65 \%$ das bordas se apresentam como restritivas (bordas com inflexão estão entre aquelas restritivas), $42.86 \%$ se apresentam como irrestritivas (a borda com reforço também se encontra sob essa classificação), e $24.49 \%$ são verticais. Aqui, a maior porcentagem também está nas bordas irrestritivas, assim como na coleção TRV, no entanto em RT (49) há mais bordas que em TRV (12). As bases identificadas (2 fragmentos) são planas, também como na coleção TRV.

\subsubsection{Identificação de conjuntos / agrupamentos}

Foram identificados nove conjuntos cerâmicos para o sítio Lagoinha do Rio Tavares I/ Rio Tavares na análise macroscópica. Novamente, os conjuntos foram formados tendo como eixos de agrupamento principais as cores das pastas, o tipo de tratamento de superfície e espessura de cada fragmento.

CONJUNTO 1: esse conjunto é composto por fragmentos de pasta branca ou laranja C (laranja em tom de marrom) com engobo branco (em sua maior parte) como tratamento cromático de superfície e, por vezes, pintura vermelha sobre engobo; as espessuras das peças variam de 1 a $23 \mathrm{~mm}$ (trata-se de um conjunto bastante abrangente com relação a este último atributo) (Figuras 54 e 55): 


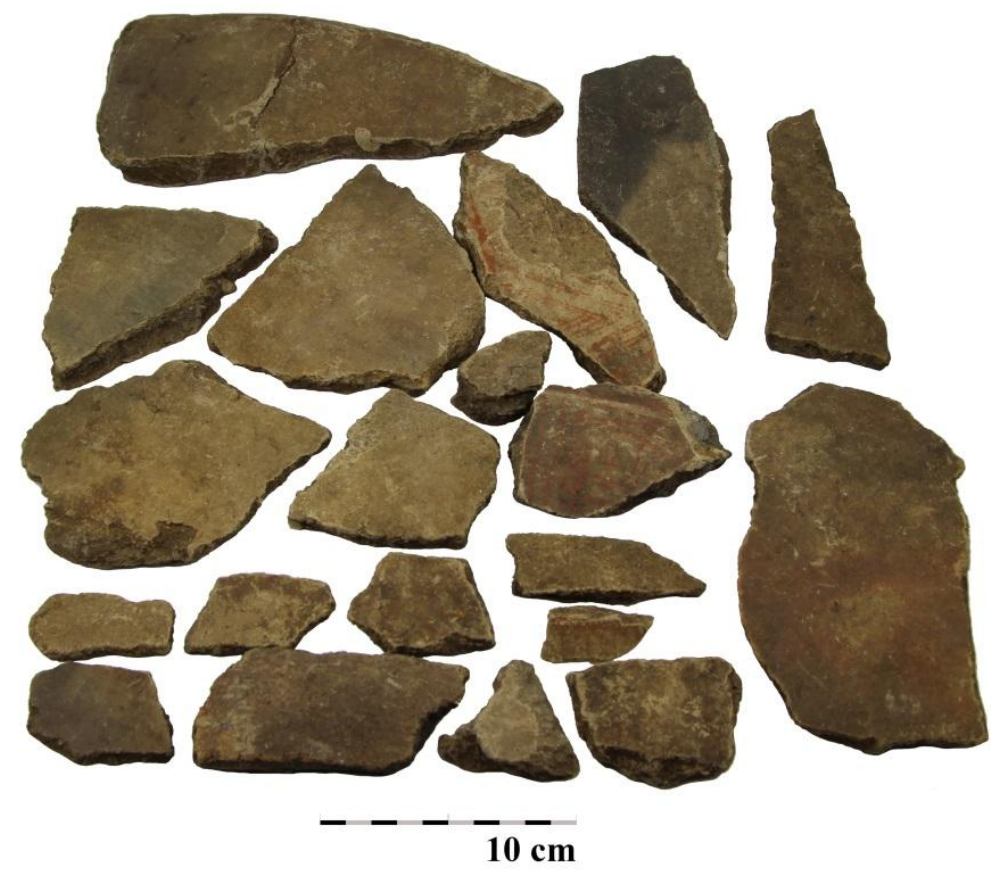

Figura 54. Faces externas dos fragmentos pertencentes ao Conjunto 1. Foto: Isabela da Silva Müller. Edição: Thiago Umberto Pereira.

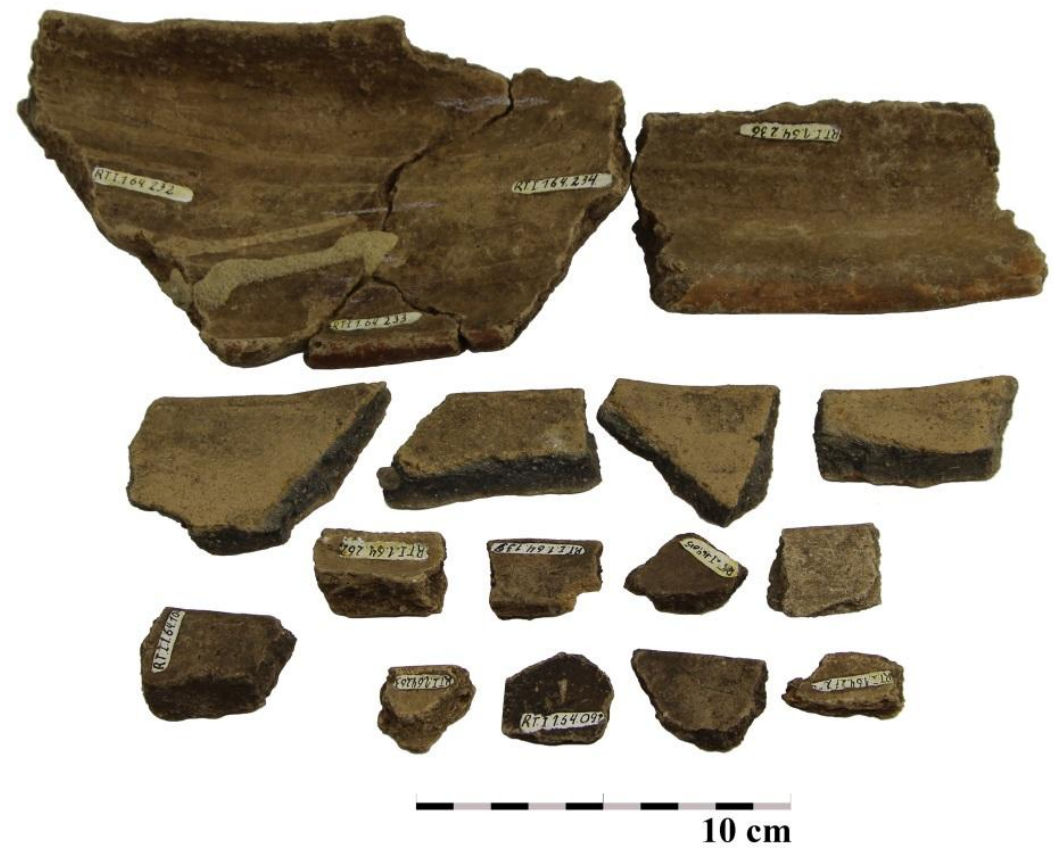

Figura 55. Faces internas de fragmentos pertencentes ao Conjunto 1. Foto: Isabela da Silva Müller. Edição: Thiago Umberto Pereira. 
CONJUNTO 2: composto por fragmentos de pasta branca ou laranja C (laranja em tom de marrom), com tratamento plástico corrugado (corrugados distintos) nas faces externas (corrugado sempre nas faces externas) e, por vezes, engobo nas faces internas como tratamento cromático; as espessuras das peças variam de 4 a 18 mm (Figuras 56, 57 e 58$)$ :

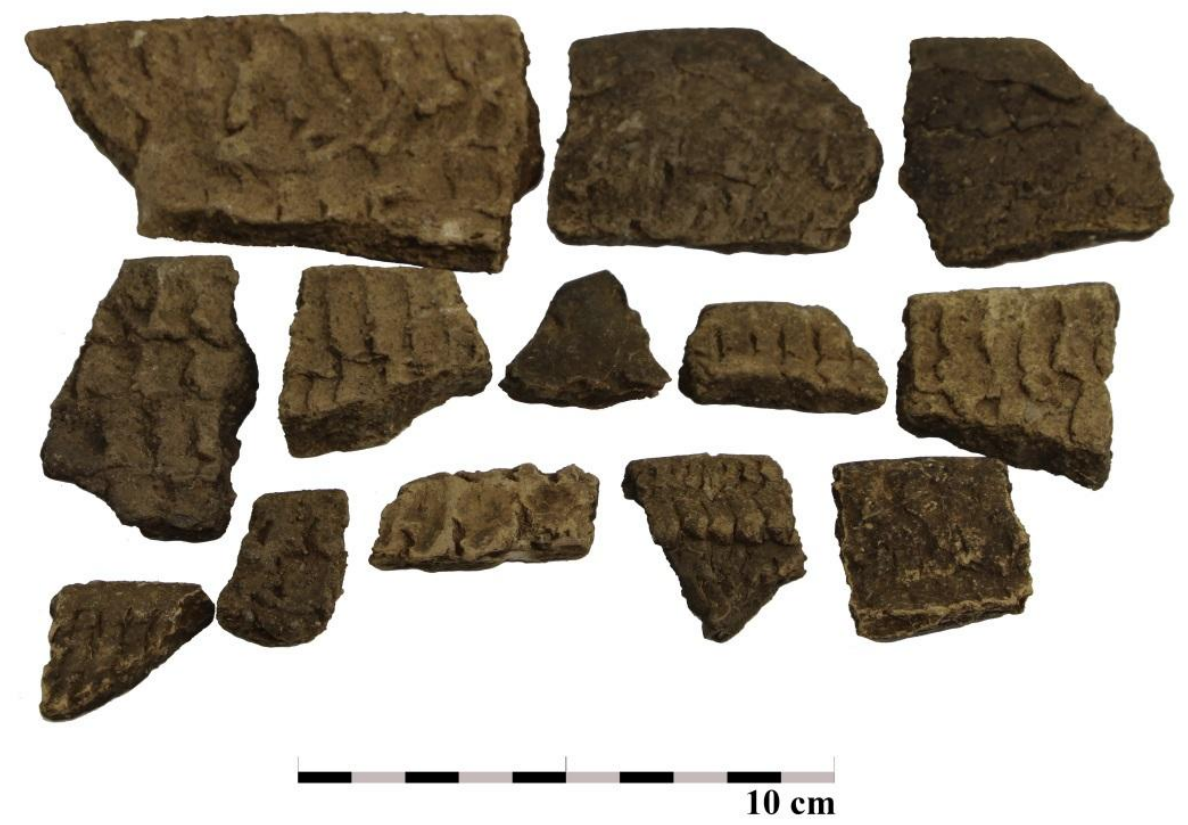

Figura 56. Faces externas dos fragmentos pertencentes ao Conjunto 2. Foto: Isabela da Silva Müller. Edição: Thiago Umberto Pereira. 


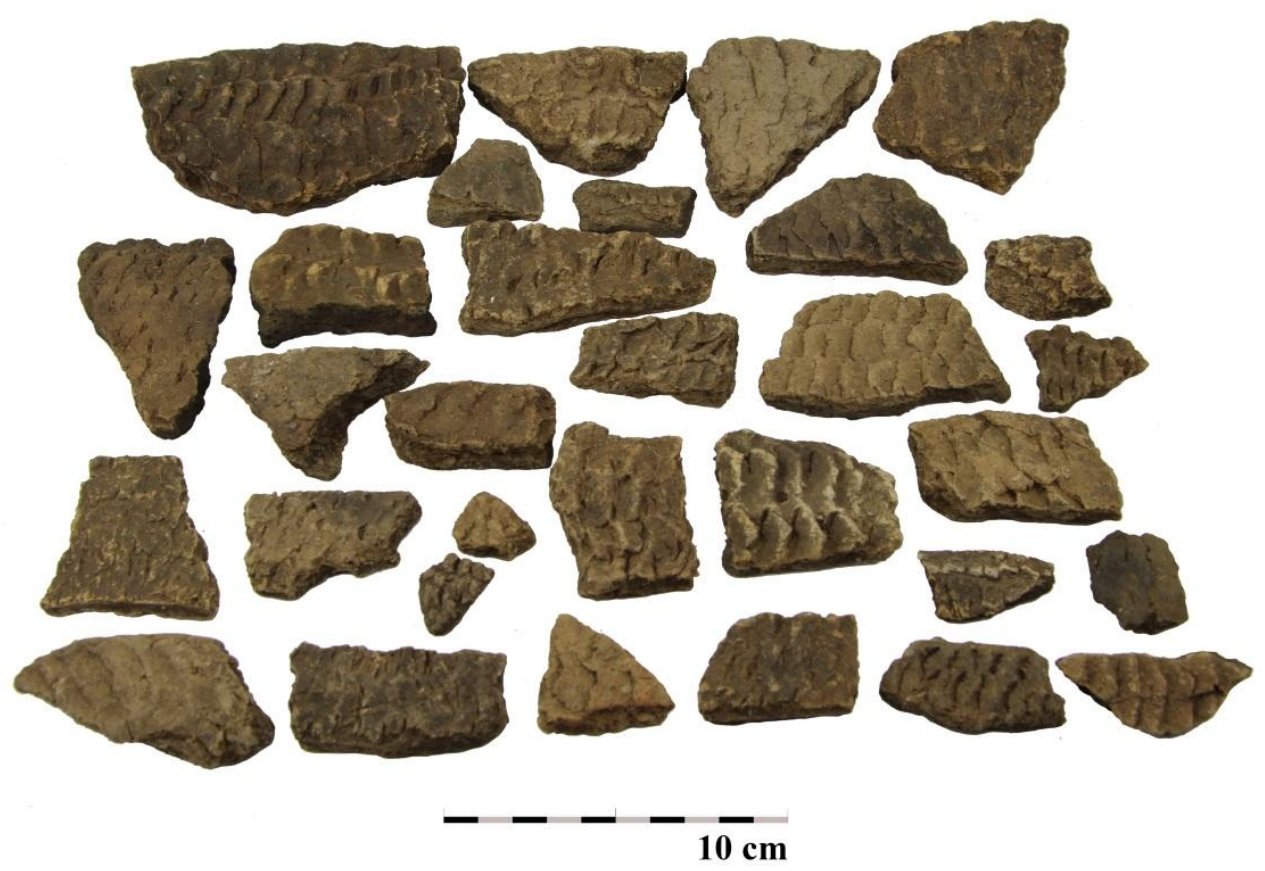

Figura 57. Faces externas dos fragmentos pertencentes ao Conjunto 2. Foto: Isabela da Silva Müller. Edição: Thiago Umberto Pereira.

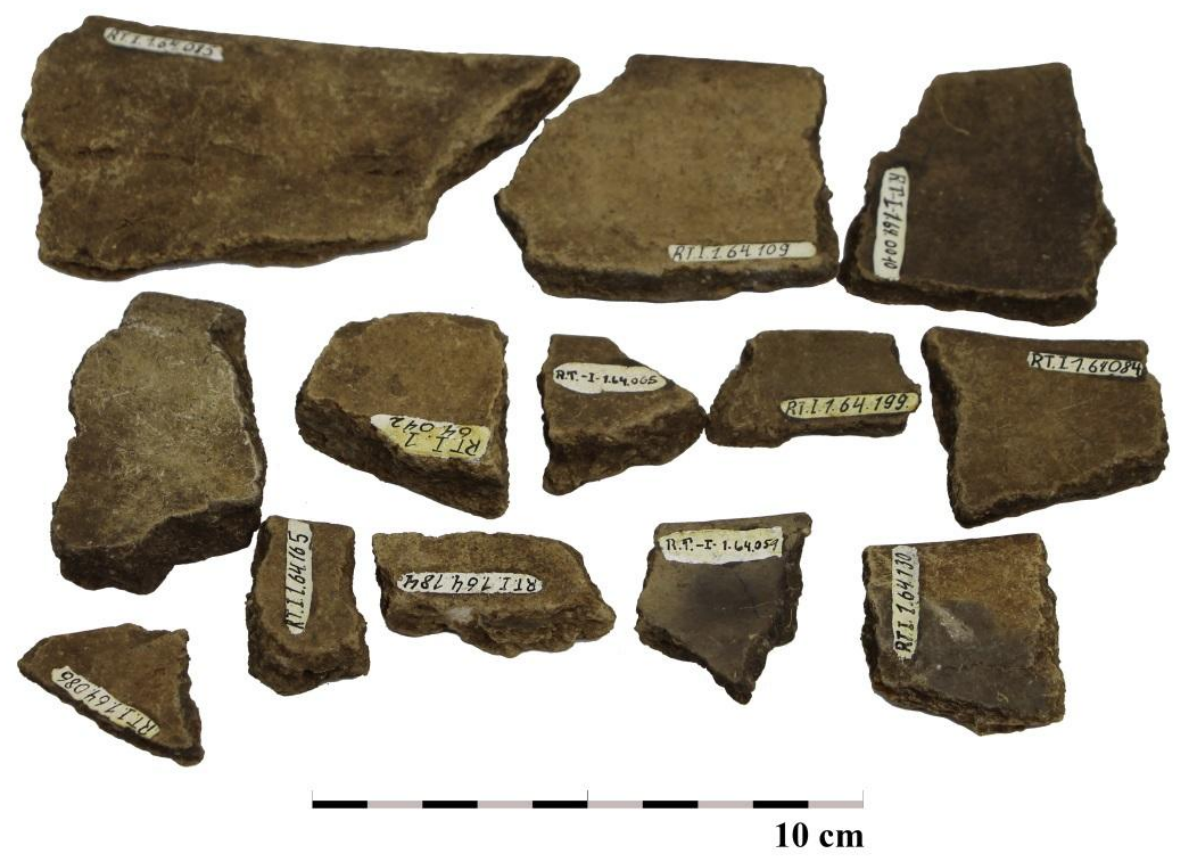

Figura 58. Faces internas dos fragmentos pertencentes ao Conjunto 2. Foto: Isabela da Silva Müller. Edição: Thiago Umberto Pereira. 
CONJUNTO 3: composto por fragmentos de pasta laranja A ou B, alisados (tratamento plástico de superfície), e alguns com leves corrugados e ungulados (não tão bem evidenciados); as espessuras estão entre 4 e 15 mm (Figuras 59, 60, 61 e 62):

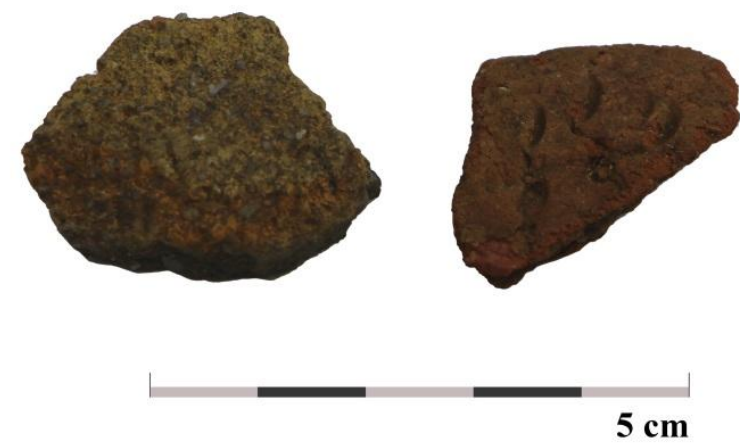

Figura 59. Faces externas dos fragmentos pertencentes ao Conjunto 3. Foto: Isabela da Silva Müller. Edição: Thiago Umberto Pereira.

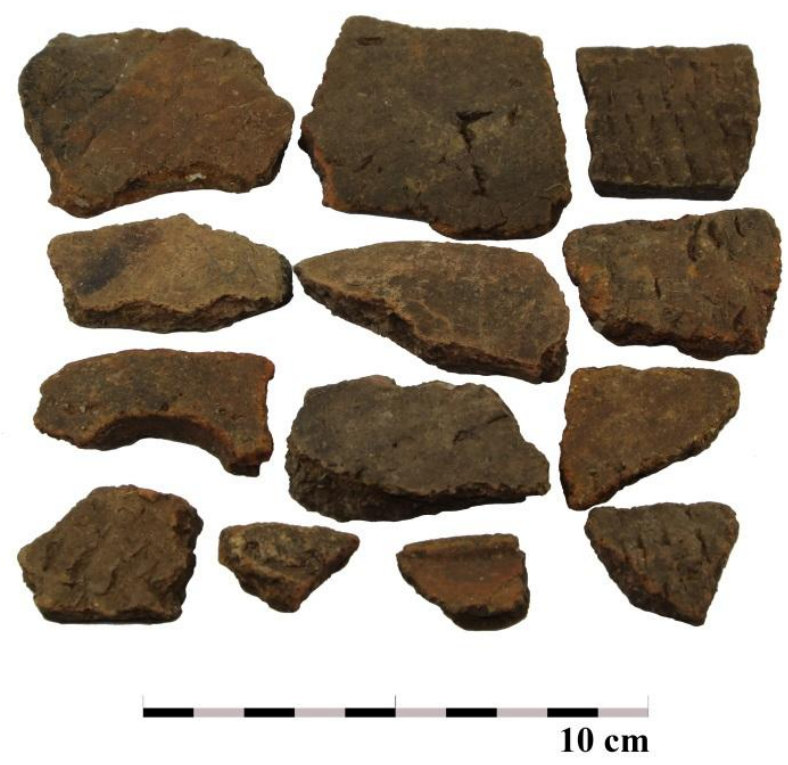

Figura 60.Faces externas dos fragmentos pertencentes ao Conjunto 3. Foto: Isabela da Silva Müller. Edição: Thiago Umberto Pereira. 


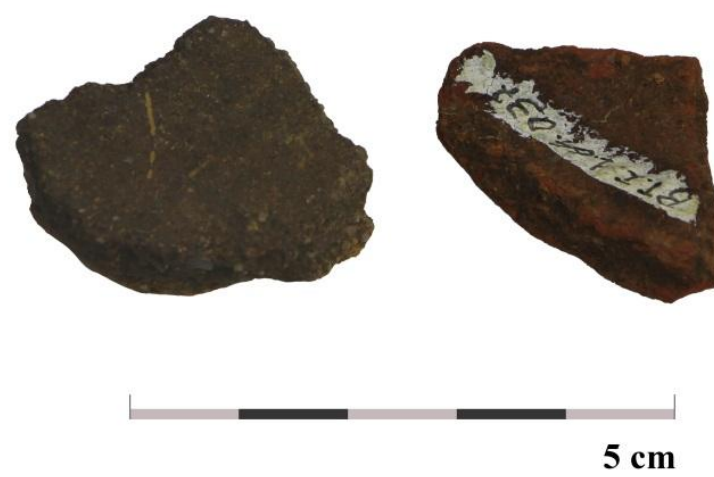

Figura 61. Faces internas dos fragmentos pertencentes ao Conjunto 3. Foto: Isabela da Silva Müller. Edição: Thiago Umberto Pereira.

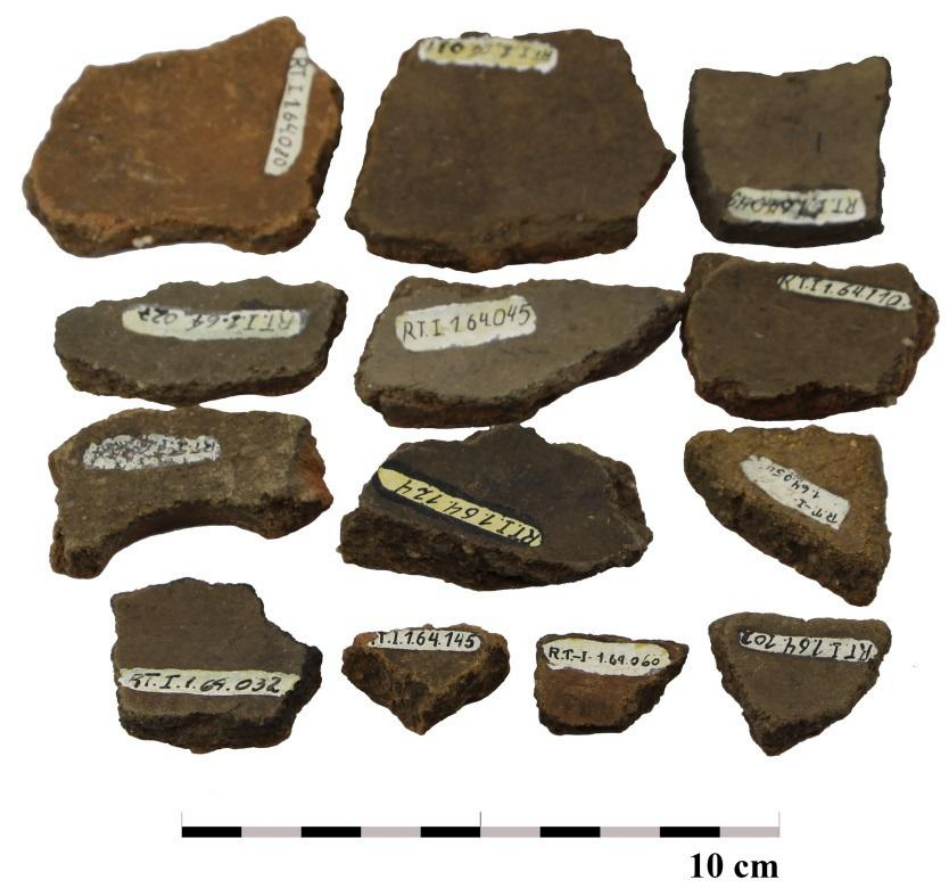

Figura 62. Faces internas dos fragmentos pertencentes ao Conjunto 3. Foto: Isabela da Silva Müller. Edição: Thiago Umberto Pereira. 
CONJUNTO 4: composto por fragmentos de pastas laranja A e B corrugados e mais espessas (de 8 a $14 \mathrm{~mm}$ ) que os fragmentos dos conjuntos anteriores (Figuras 63 a 66):

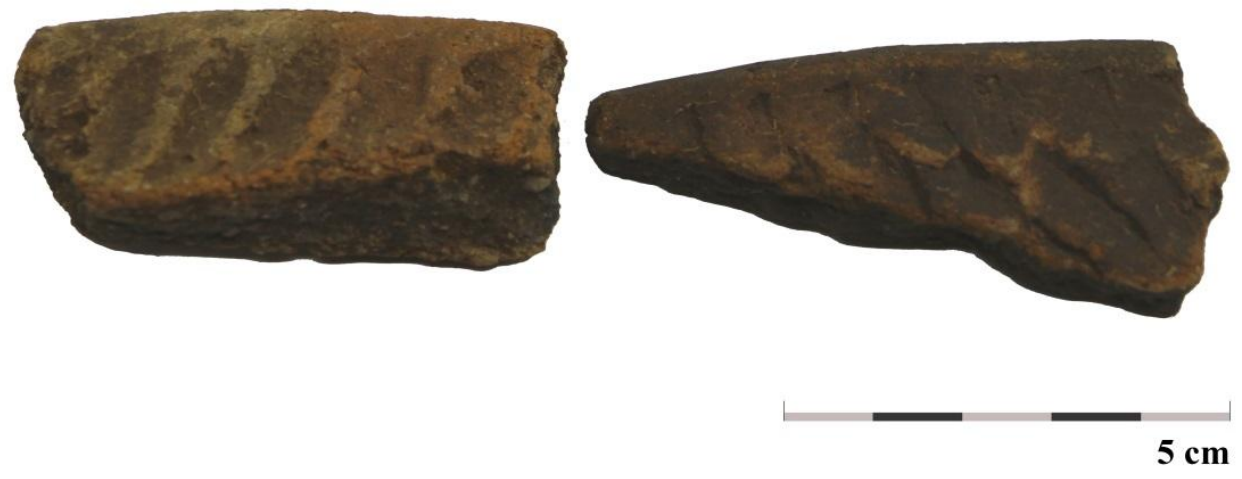

Figura 63.aces externas dos fragmentos pertencentes ao Conjunto 4. Foto: Isabela da Silva Müller. Edição: Thiago Umberto Pereira.

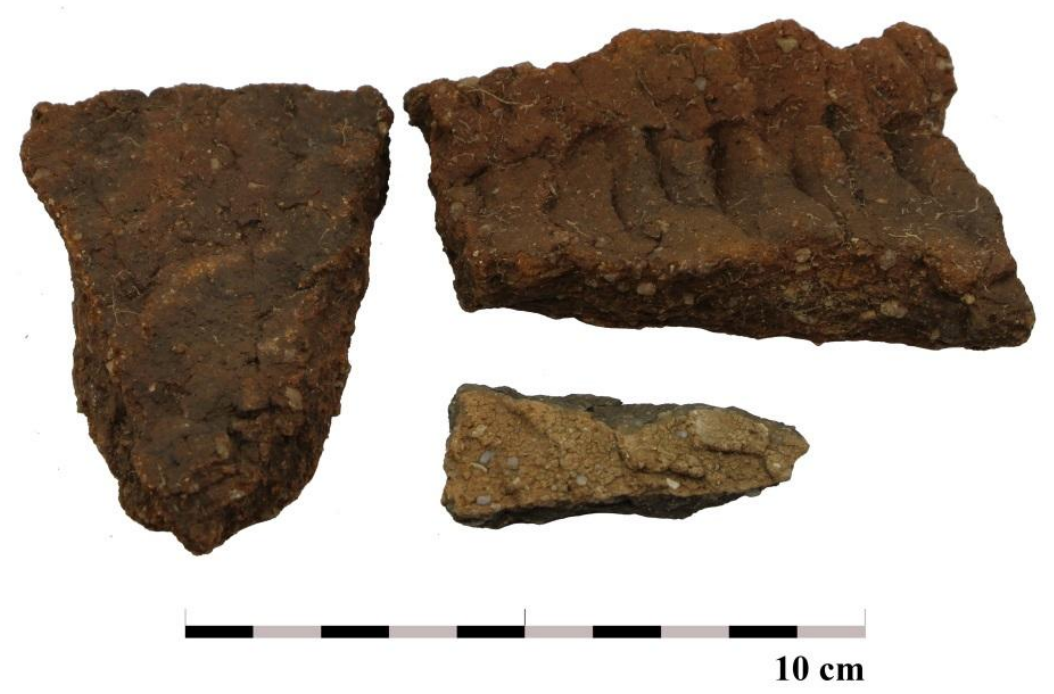

Figura 64. Faces externas dos fragmentos pertencentes ao Conjunto 4. Foto: Isabela da Silva Müller. Edição: Thiago Umberto Pereira. 

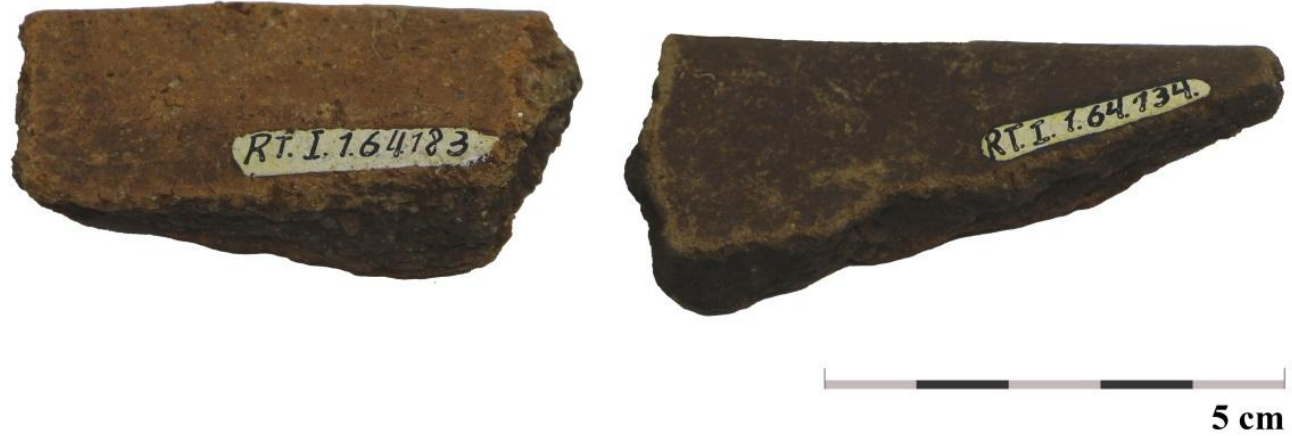

Figura 65. Faces internas dos fragmentos pertencentes ao Conjunto 4. Foto: Isabela da Silva Müller. Edição: Thiago Umberto Pereira.

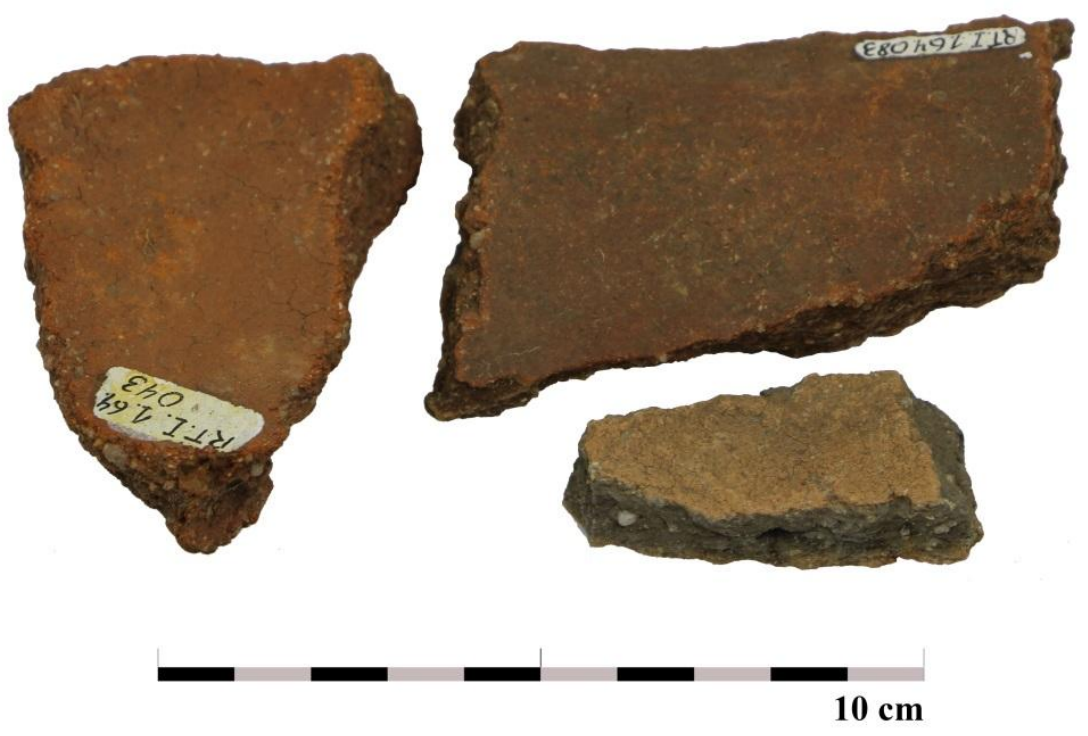

Figura 66. Faces internas dos fragmentos pertencentes ao Conjunto 4. Foto: Isabela da Silva Müller. Edição: Thiago Umberto Pereira. 
CONJUNTO 5: composto por fragmentos de pastas laranja B e C alisados; as $\begin{array}{llllllll}\text { espessuras } & \text { variam } & \text { de } & 15 & \mathrm{~mm} & \text { (Figuras } & 67 & \text { e }\end{array}$

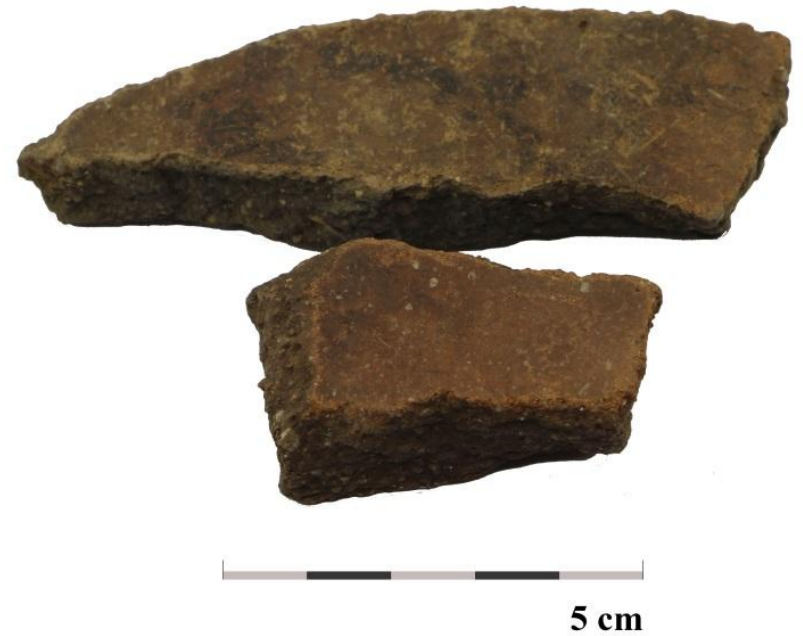

Figura 67. Faces externas dos fragmentos pertencentes ao Conjunto 5. Foto: Isabela da Silva Müller. Edição: Thiago Umberto Pereira.

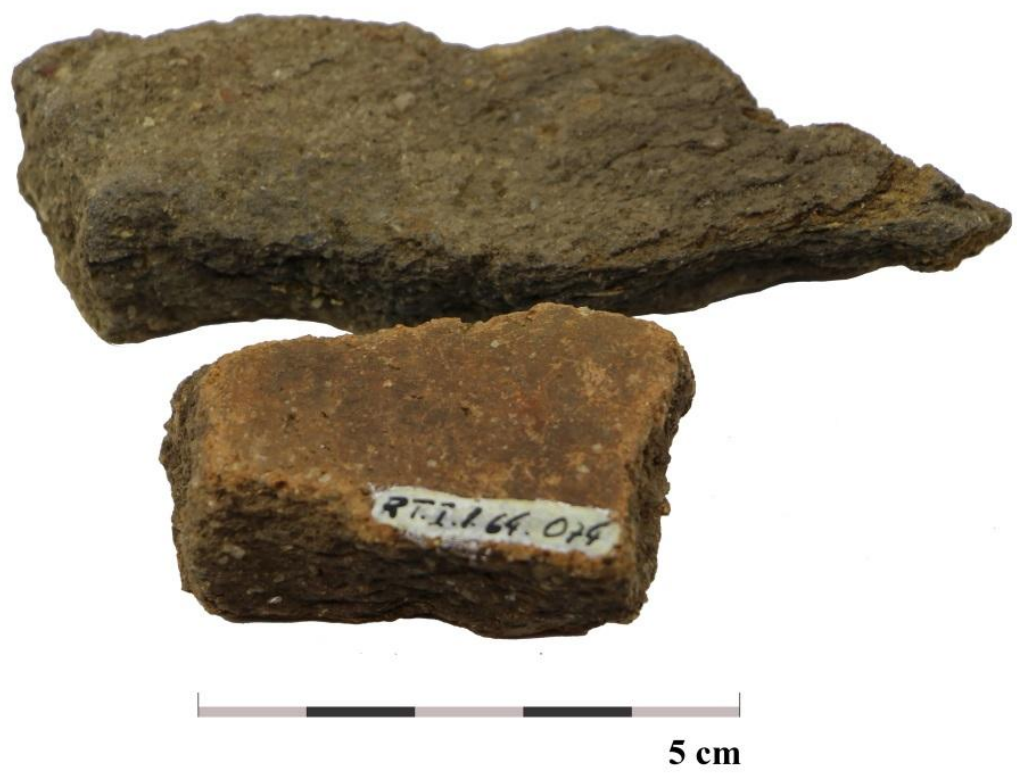

Figura 68. Faces internas dos fragmentos pertencentes ao Conjunto 5. Foto: Isabela da Silva Müller. Edição: Thiago Umberto Pereira. 
CONJUNTO 6: composto por fragmentos de pasta laranja A corrugados; as espessuras variam de 9 a $20 \mathrm{~mm}$ (Figura 67):

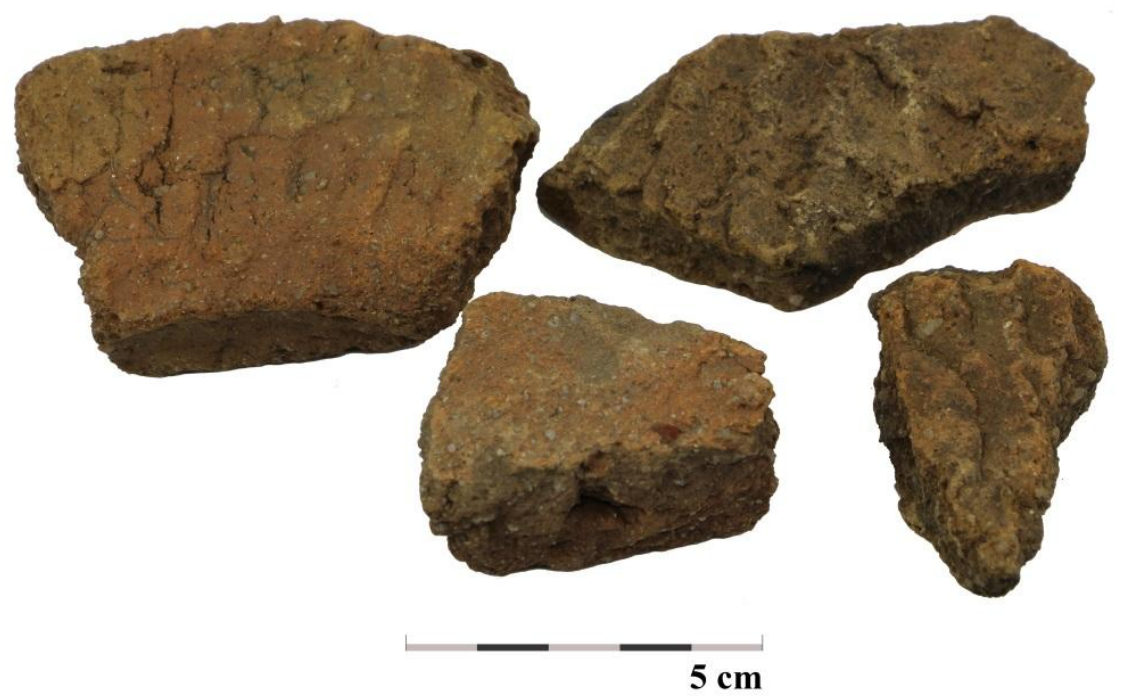

Figura 69. Faces externas dos fragmentos pertencentes ao Conjunto 6. Foto: Isabela da Silva Müller. Edição: Thiago Umberto Pereira.

CONJUNTO 7: composto por fragmentos de pastas laranja $\mathrm{C}$ e cinza/preto alisados, corrugados, ungulados (como tratamentos plásticos de superfície); suas espessuras variam de 4 a $19 \mathrm{~mm}$ (Figuras 70, 71, 72 e 73): 

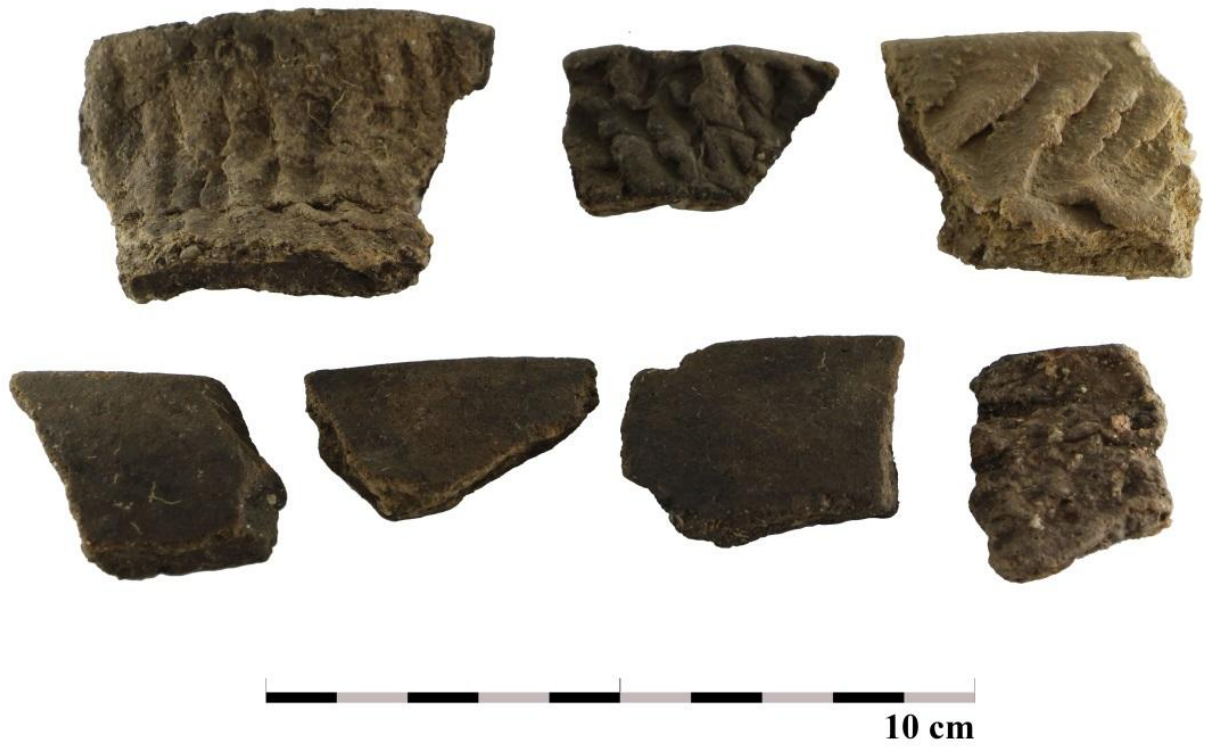

Figura 70. Faces externas dos fragmentos pertencentes ao Conjunto 7. Foto: Isabela da Silva Müller. Edição: Thiago Umberto Pereira.

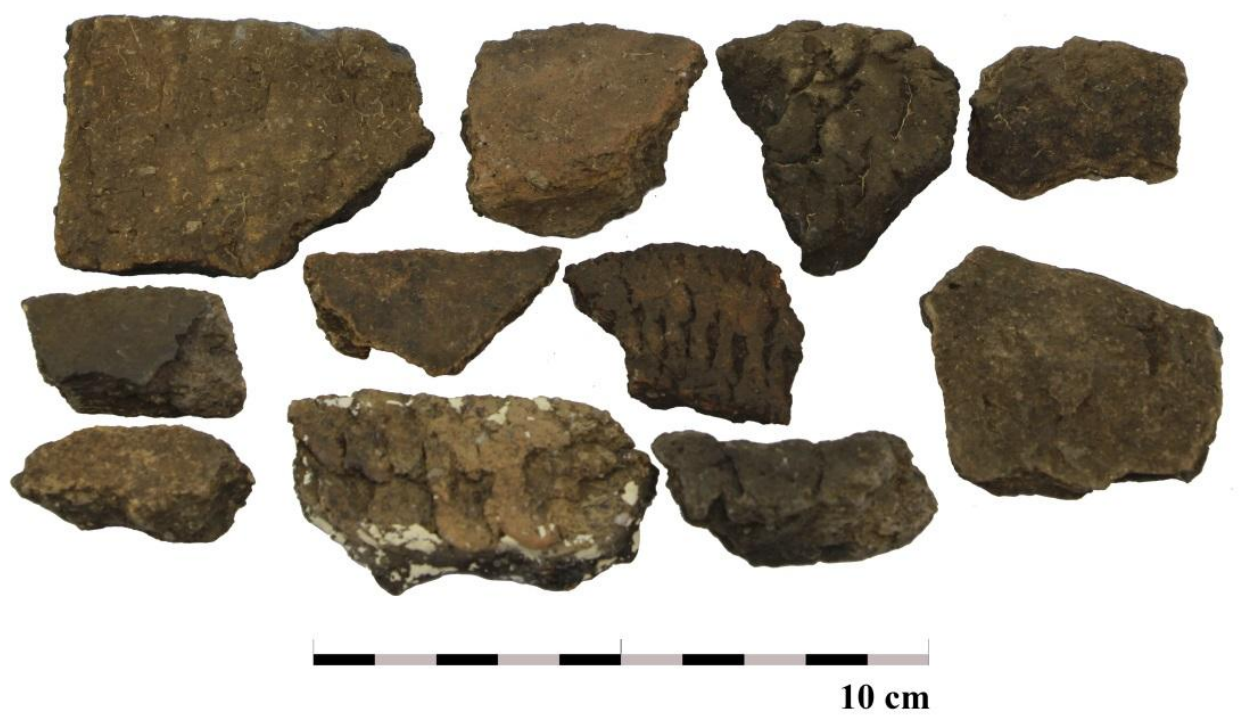

Figura 71. Faces externas dos fragmentos pertencentes ao Conjunto 7. Foto: Isabela da Silva Müller. Edição: Thiago Umberto Pereira. 


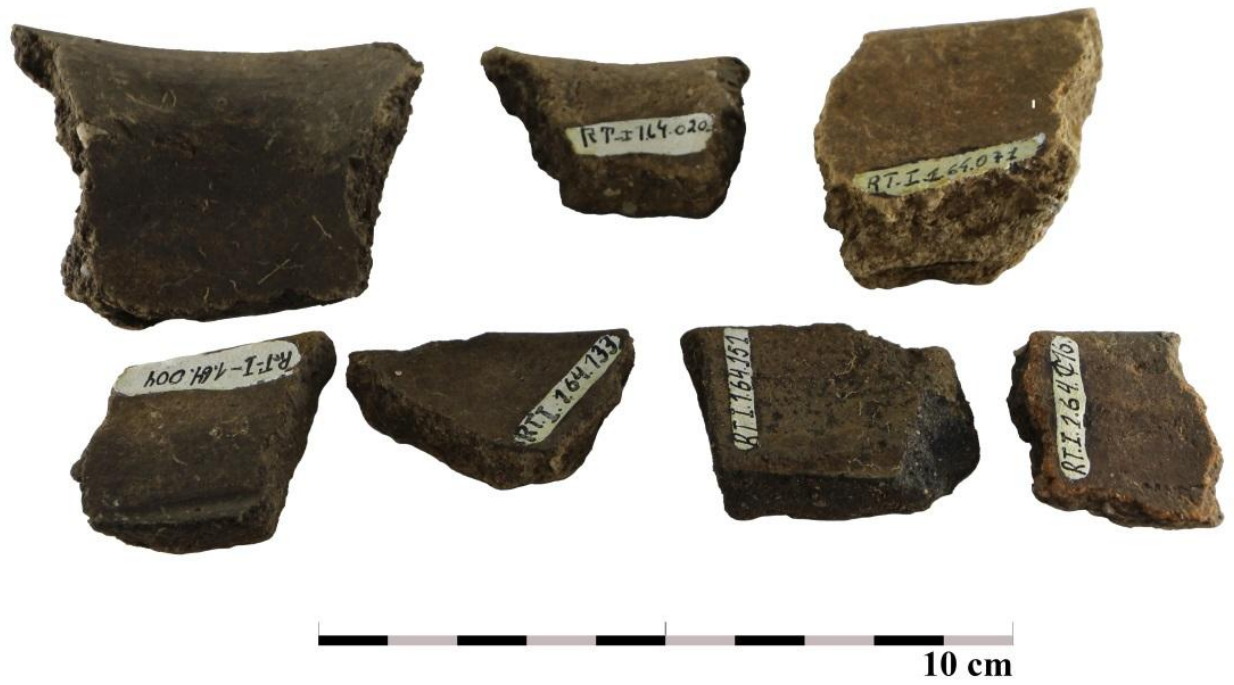

Figura 72. Faces internas dos fragmentos pertencentes ao Conjunto 7. Foto: Isabela da Silva Müller. Edição: Thiago Umberto Pereira.

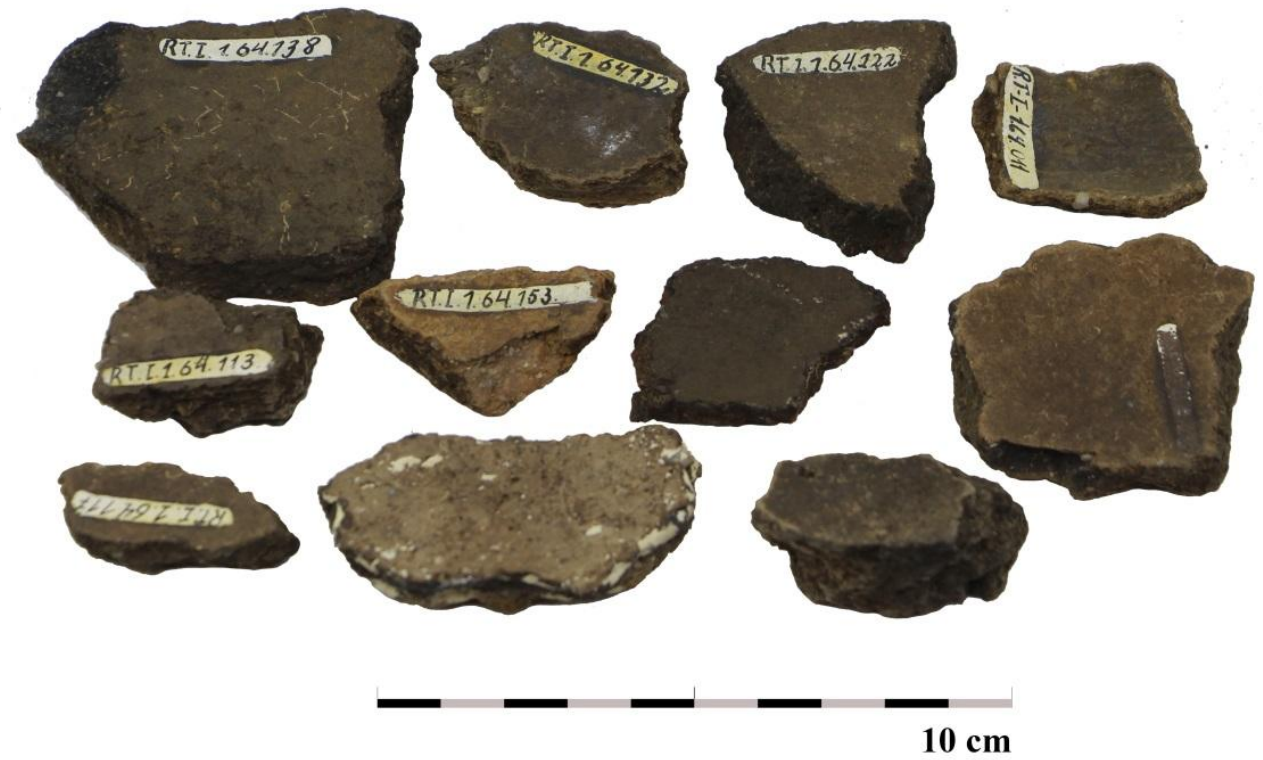

Figura 73. Faces internas dos fragmentos pertencentes ao Conjunto 7. Foto: Isabela da Silva Müller. Edição: Thiago Umberto Pereira. 
CONJUNTO 8: trata-se de um conjunto bastante homogêneo, de fragmentos de pasta branca ou laranja $\mathrm{C}$, por vezes com engobo branco mas com aspecto diferente do conjunto 1 (devido a ações pós-deposicionais). Possuem espessuras de 6 a $19 \mathrm{~mm}$ (Figuras 74, 75 e 76):

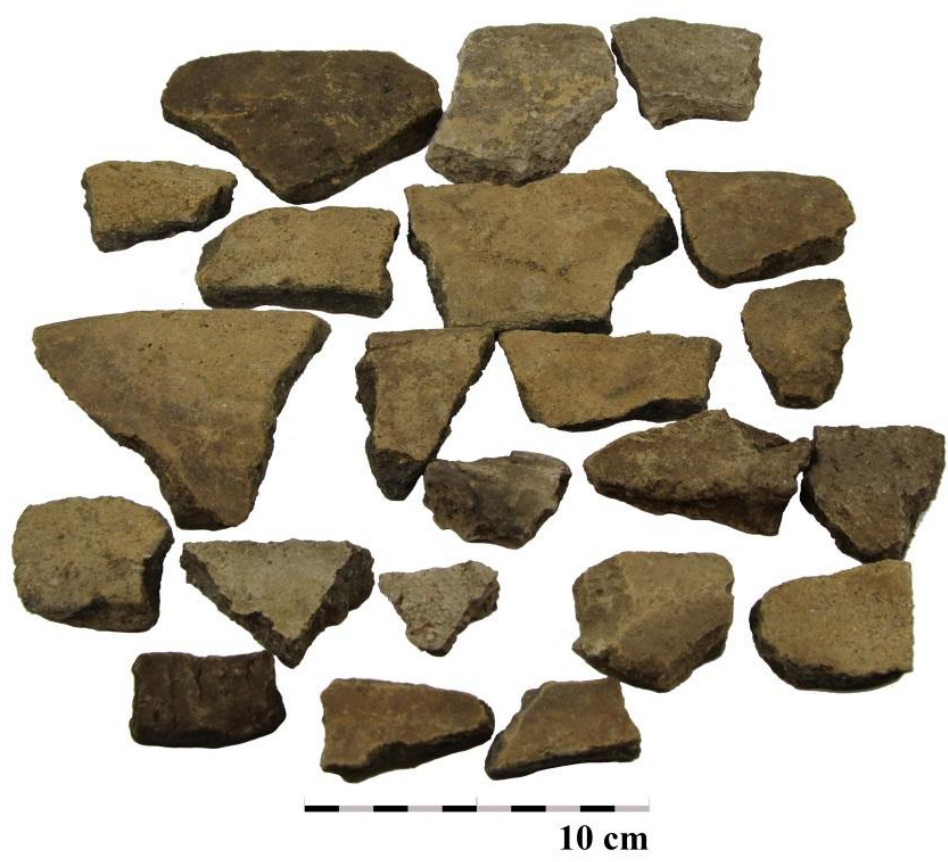

Figura 74. Faces externas dos fragmentos pertencentes ao Conjunto 8. Foto: Isabela da Silva Müller. Edição: Thiago Umberto Pereira. 


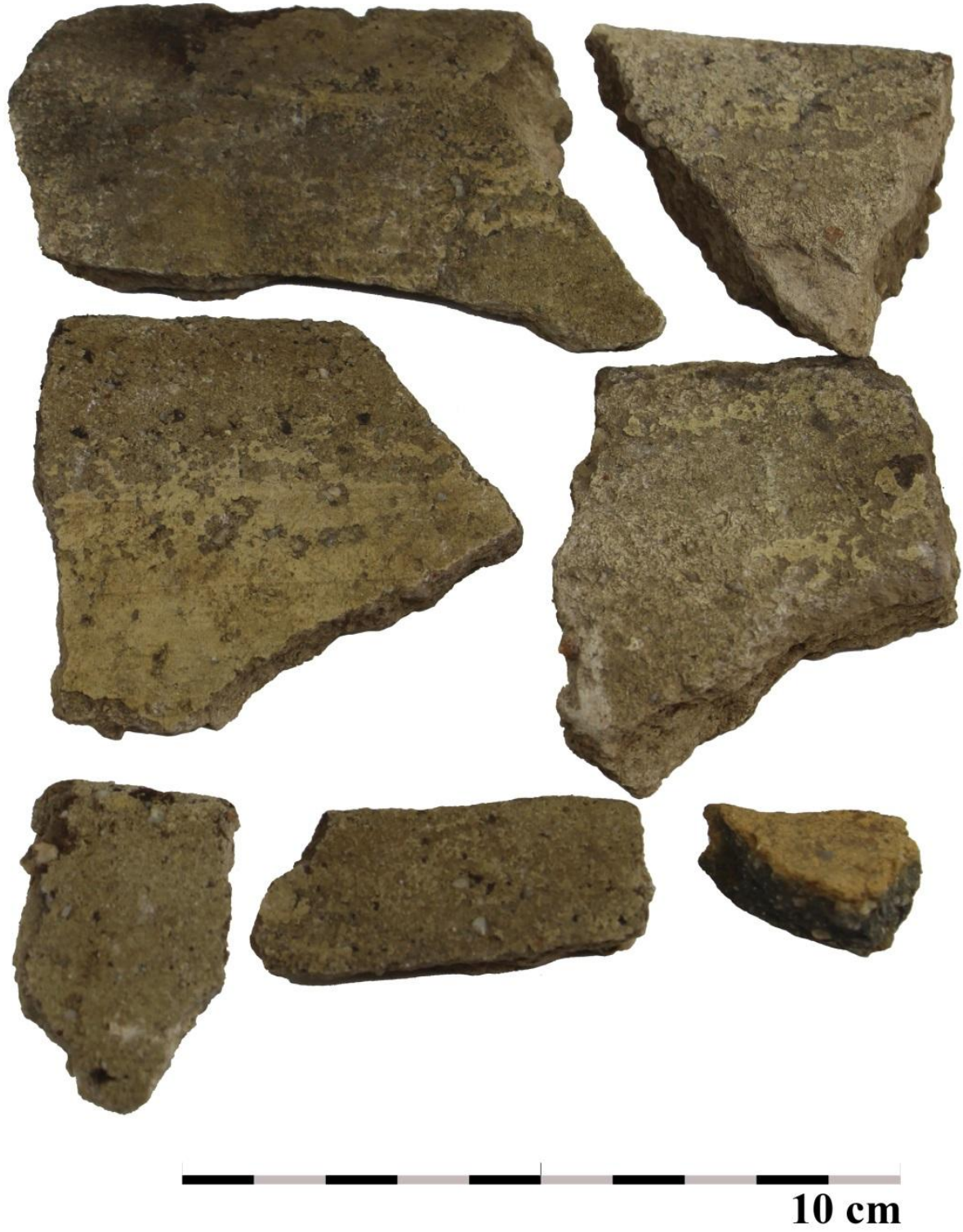

Figura 75. Faces externas dos fragmentos pertencentes ao Conjunto 8. Foto: Isabela da Silva Müller. Edição: Thiago Umberto Pereira. 


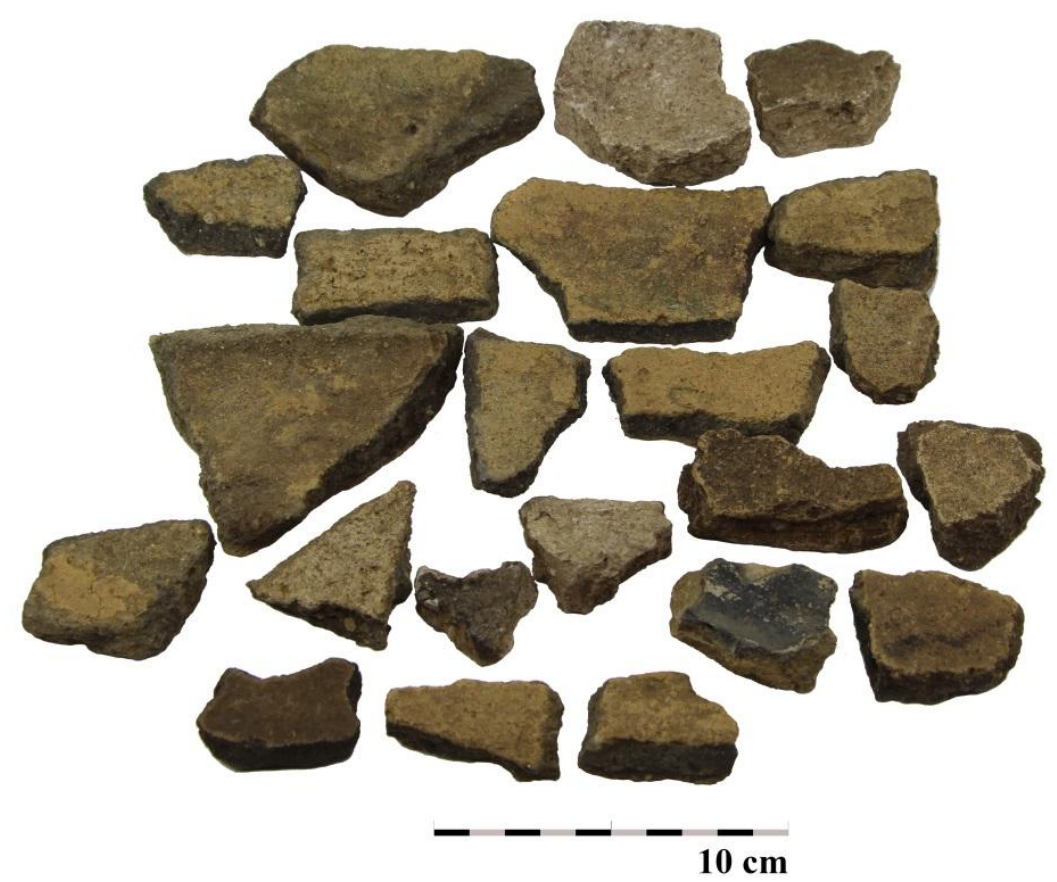

Figura 76. Faces internas dos fragmentos pertencentes ao Conjunto 8. Foto: Isabela da Silva Müller. Edição: Thiago Umberto Pereira.

CONJUNTO 9: composto por fragmentos não agrupáveis nos conjuntos anteriores, de 4 a 20mm de espessura (Figuras 77 a 80). Composto por dois fragmentos, sendo um deles com engobo vermelho e outro não se trata propriamente dito de um fragmento, mas de uma peça comum em sítios arqueológicos que remetem a locais de produção de vasilhas (ou mesmo de seu uso): a trempe/ytácuru. Trata-se de uma peça feita de argila (sem antiplástico) que foi moldada e ficou marcada em negativo pela peça que apoiou durante a manufatura de uma vasilha. 

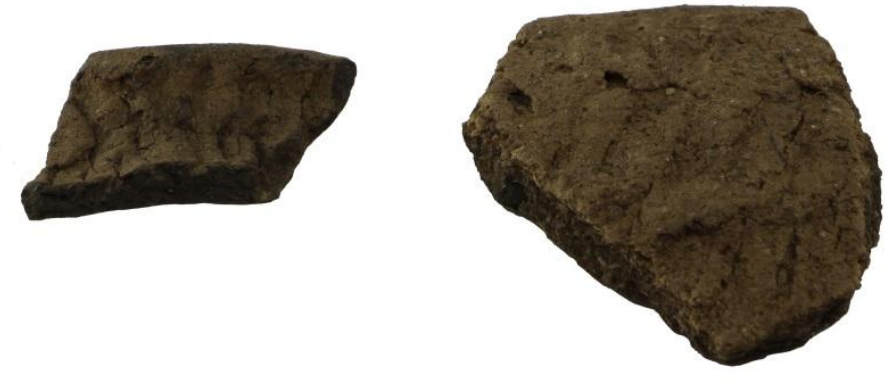

$5 \mathrm{~cm}$

Figura 77. Faces externas dos fragmentos pertencentes ao Conjunto 9. Foto: Isabela da Silva Müller. Edição: Thiago Umberto Pereira.

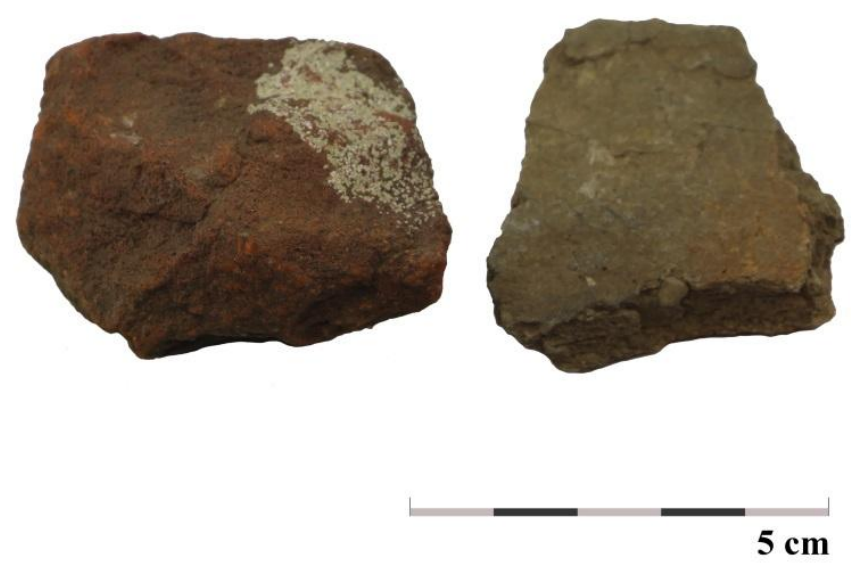

Figura 78.Faces externas dos fragmentos pertencentes ao Conjunto 9. Foto: Isabela da Silva Müller. Edição: Thiago Umberto Pereira. 

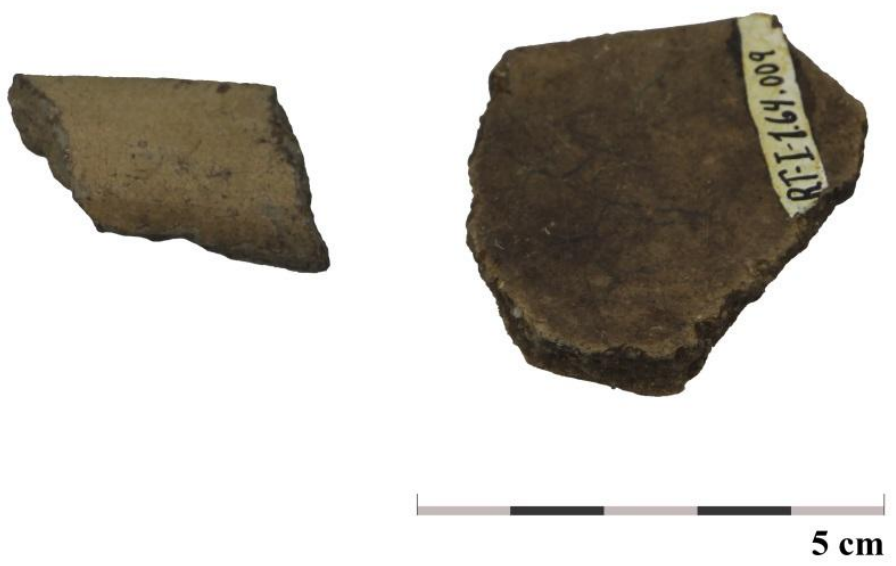

Figura 79. Faces internas dos fragmentos pertencentes ao Conjunto 9. Foto: Isabela da Silva Müller. Edição: Thiago Umberto Pereira.

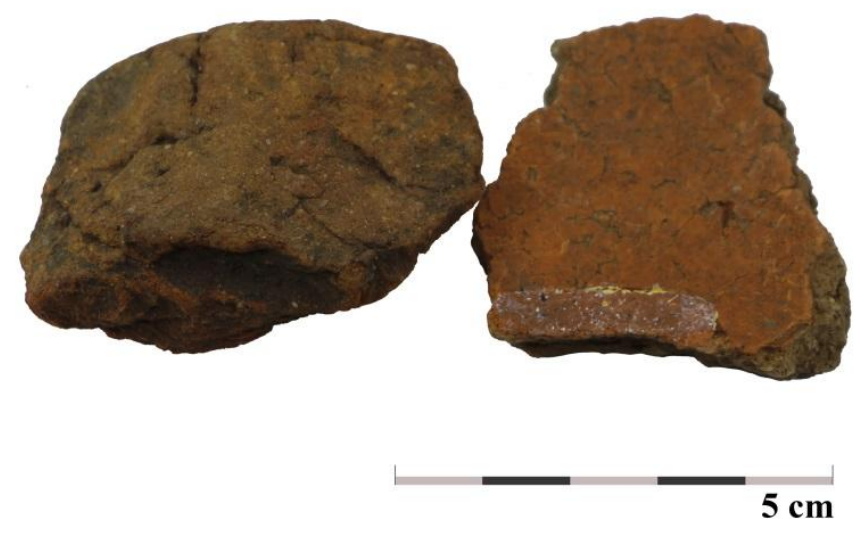

Figura 80. Faces internas dos fragmentos pertencentes ao Conjunto 9. Foto: Isabela da Silva Müller. Edição: Thiago Umberto Pereira. 


\subsubsection{Espelhamento das bordas}

A coleção RT possui mais bordas que a coleção TRV e, por consequência, foram gerados mais espelhamentos a partir das bordas de RT. Na Tabela 8 é possível observar os diâmetros projetados a partir das bordas da coleção (diâmetro de abertura das vasilhas) e as porcentagens das mesmas.

\begin{tabular}{|c|c|c|}
\hline \multicolumn{3}{|c|}{ TRV: Diâmetros Projetados das Bordas (cm) e Porcentagens das Bordas (\%) } \\
\hline Amostra & $\begin{array}{l}\text { 14. Diâmetro da Borda (cm) } \\
\text { (diâmetro de abertura) }\end{array}$ & 15. Porcentagem da Borda $(\%)$ \\
\hline RT.I.1.64.037 & 16 & 4 \\
\hline RT.I.1.64.047 & 20 & 3,5 \\
\hline RT.I.1.64.019 & 20 & 8 \\
\hline RT.I.1.64.141 & 20 & 3 \\
\hline RT.I.1.64.236 & 56 & 6,5 \\
\hline RT.I.1.64.130 & 19 & 6 \\
\hline RT.I.1.64.109 & 20 & 7 \\
\hline RT.I.1.64.085 & 56 & 6 \\
\hline RT.I.1.64.092 & 16 & 3 \\
\hline RT.I.1.64.084 & 22 & 6 \\
\hline RT.I.1.64.059 & 22 & 5 \\
\hline RT.I.1.64.134 & 54 & 4 \\
\hline 5.1 & 50 & 1,5 \\
\hline RT.I.1.64.009 & 42 & 2,5 \\
\hline RT.I.1.64.071 & 52 & 2,5 \\
\hline RT.I.1.64.199 & 44 & 2 \\
\hline RT.I.1.64.232/233/234 & 54 & 5 \\
\hline
\end{tabular}




\begin{tabular}{|c|c|c|}
\hline 4.1 & 40 & 4 \\
\hline 4.2 & 40 & 4,5 \\
\hline 4.3 & 50 & 1,5 \\
\hline 6.1 & 52 & 2,5 \\
\hline $9 . .1$ & 56 & 4 \\
\hline RT.I.1.64.262 & 54 & 2 \\
\hline RT.I.1.64.263 & 54 & 1,5 \\
\hline RT.I.1.64.272 & 54 & 1,5 \\
\hline RT.I.1.64.104 & 56 & 2 \\
\hline RT.I.1.64.139 & 40 & 2,5 \\
\hline 3.1 & 56 & 2,5 \\
\hline 7.1 & 54 & 2 \\
\hline 2.1 & 46 & 2 \\
\hline RT.I.1.64.116 & 20 & 3,5 \\
\hline 8.1 & 22 & 4,5 \\
\hline RT.I.1.64.010 & 40 & 2 \\
\hline RT.I.1.64.133 & 26 & 3 \\
\hline RT.I.1.64.004 & 22 & 4,7 \\
\hline RT.I.1.64.065 & 36 & 1 \\
\hline RT.I.1.64.020 & 20 & 6 \\
\hline RT.I.1.64.151 & 36 & 2,5 \\
\hline 1.1 & 20 & 10 \\
\hline RT.I.1.64.165 & 32 & 3 \\
\hline RT.I.1.64.183 & 32 & 6 \\
\hline RT.I.1.64.184 & 32 & 4 \\
\hline
\end{tabular}




\begin{tabular}{|c|c|c|}
\hline RT.I.1.64.042 & 42 & 2 \\
\hline A.1 & 48 & 3 \\
\hline A.2 & 48 & 2,5 \\
\hline B.1 & 56 & 4,5 \\
\hline C.1 & 56 & 3 \\
\hline C.2 & 56 & 3 \\
\hline RT.I.1.64.086 & 22 & \\
\hline
\end{tabular}

Tabela 8. Amostras das bordas da coleção RT com seus respectivos diâmetros projetados (cm) e porcentagens dos fragmentos (\%). Nota-se que as amostras que não iniciam com a sigla "RT.I.1" não estavam enumeradas, sendo a autora responsável por uma identificação provisória, que foi retirada das peças assim que finalizou sua análise.

Nas Figuras 81 a 83, será possível observar três espelhamentos com diâmetros distintos. Todos os espelhamentos estão no CATÁLOGO DE VESTÍGIOS CERÂMICOS (ANEXO 06).

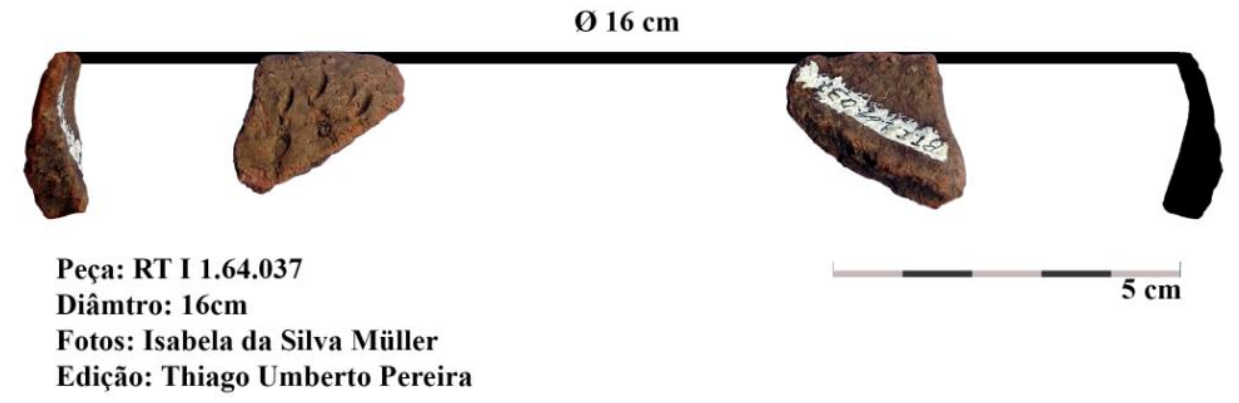

Figura 81. Espelhamento de borda da amostra RT.I.1.64.037, com diâmetro projetado de $16 \mathrm{~cm}$, onde se observam ambas as faces do fragmento. Foto: Isabela da Silva Müller. Edição: Thiago Umberto Pereira. 


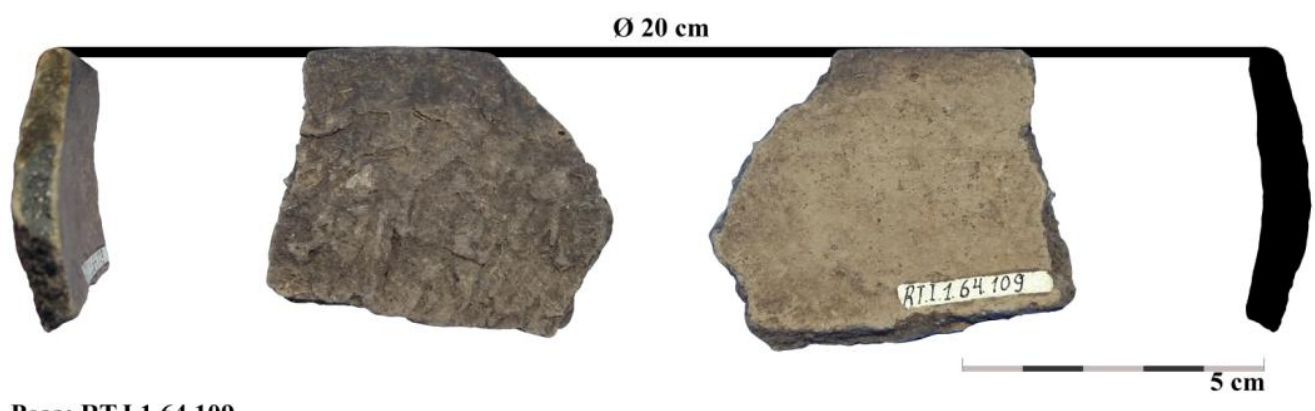

Peça: RT.I.1.64.109

Fotos: Isabela da Silva Müller

Edição: Thiago Umberto Pereira

Figura 82. Espelhamento de borda da amostra RT.I.1.64.109, com diâmetro projetado de $20 \mathrm{~cm}$, onde se observam ambas as faces do fragmento. Foto: Isabela da Silva Müller. Edição: Thiago Umberto Pereira.

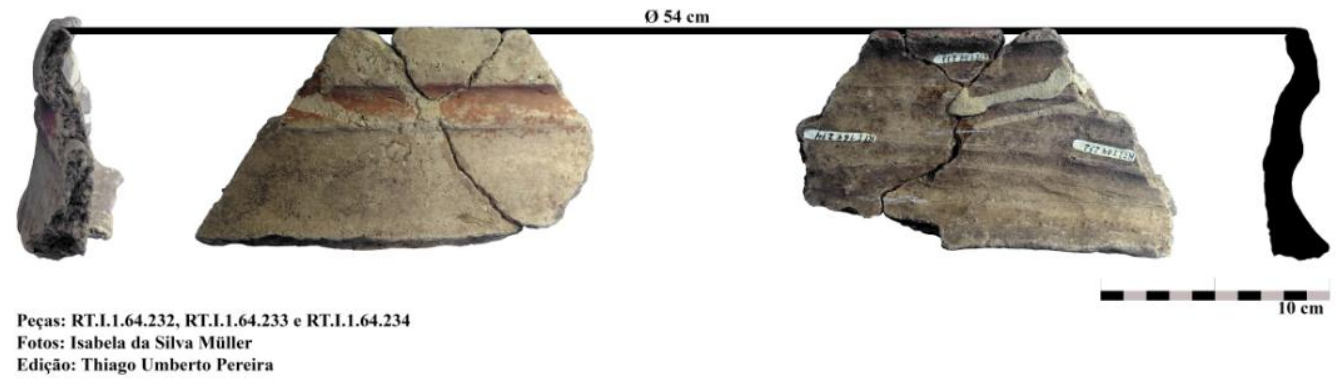

Figura 83. Espelhamento da borda das amostras RT.I.1.64.232, RT.I.1.64.233 e RT.I.1.64.234 remontáveis, com diâmetro projetado de $54 \mathrm{~cm}$, onde se observam ambas as faces do fragmento. Foto: Isabela da Silva Müller. Edição: Thiago Umberto Pereira.

\subsubsection{Análises arqueométricas por Fluorescência de Raios-X (XRF)}

Os resultados das análises de XRF para a coleção RT também estão divididos em duas pranchas: a primeira corresponde às análises dos núcleos dos fragmentos (Figura 84) e a segunda (Figura 85), das faces interna e externa dos fragmentos. Na segunda prancha (Figura 85), onde está discriminada cada amostra analisada, nota-se que há dois valores para cada amostra: aquele identificado com a letra "I" refere-se à medida da face interna e a amostra identificada pela letra "E" refere-se a sua medida de face externa. 


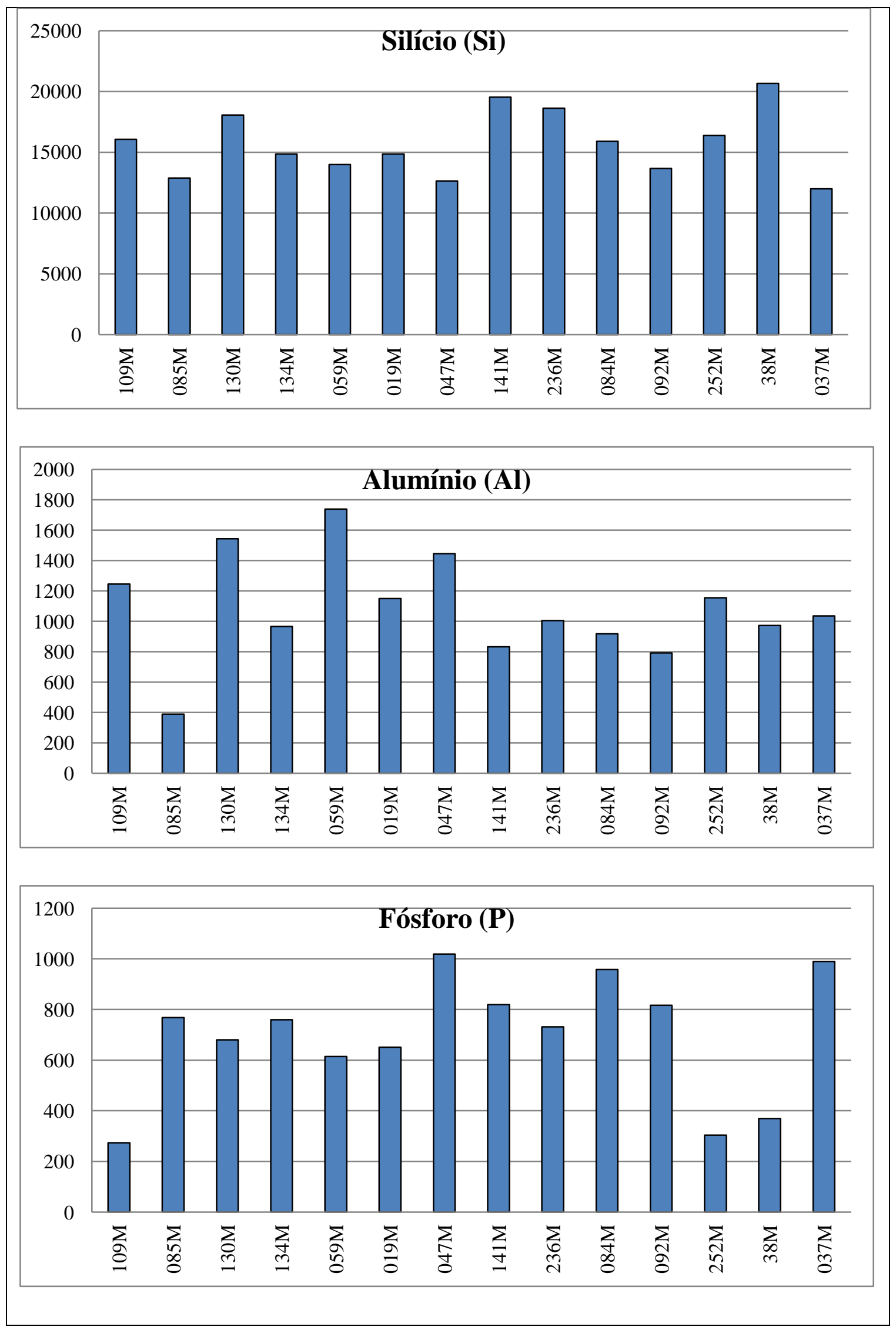




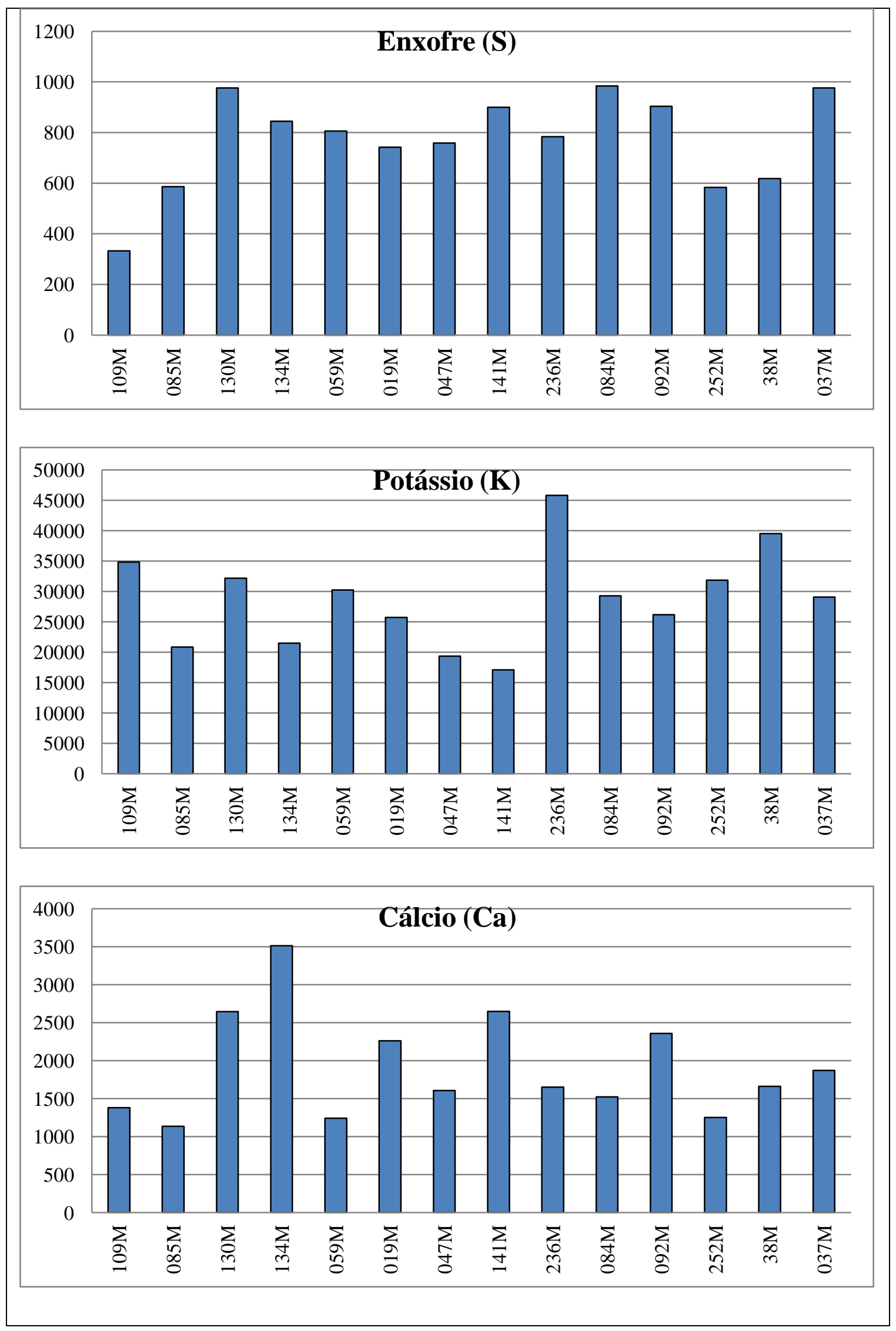




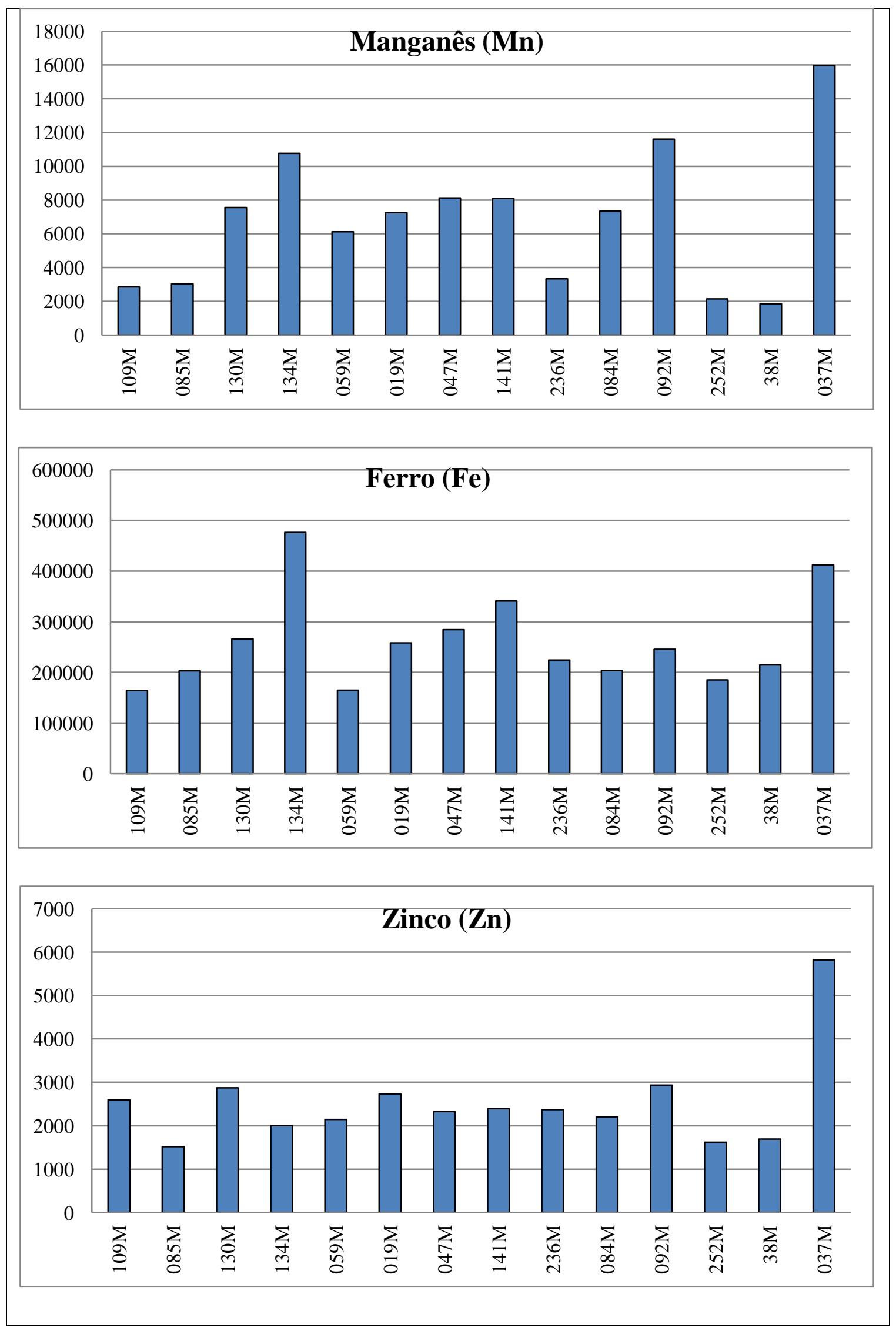




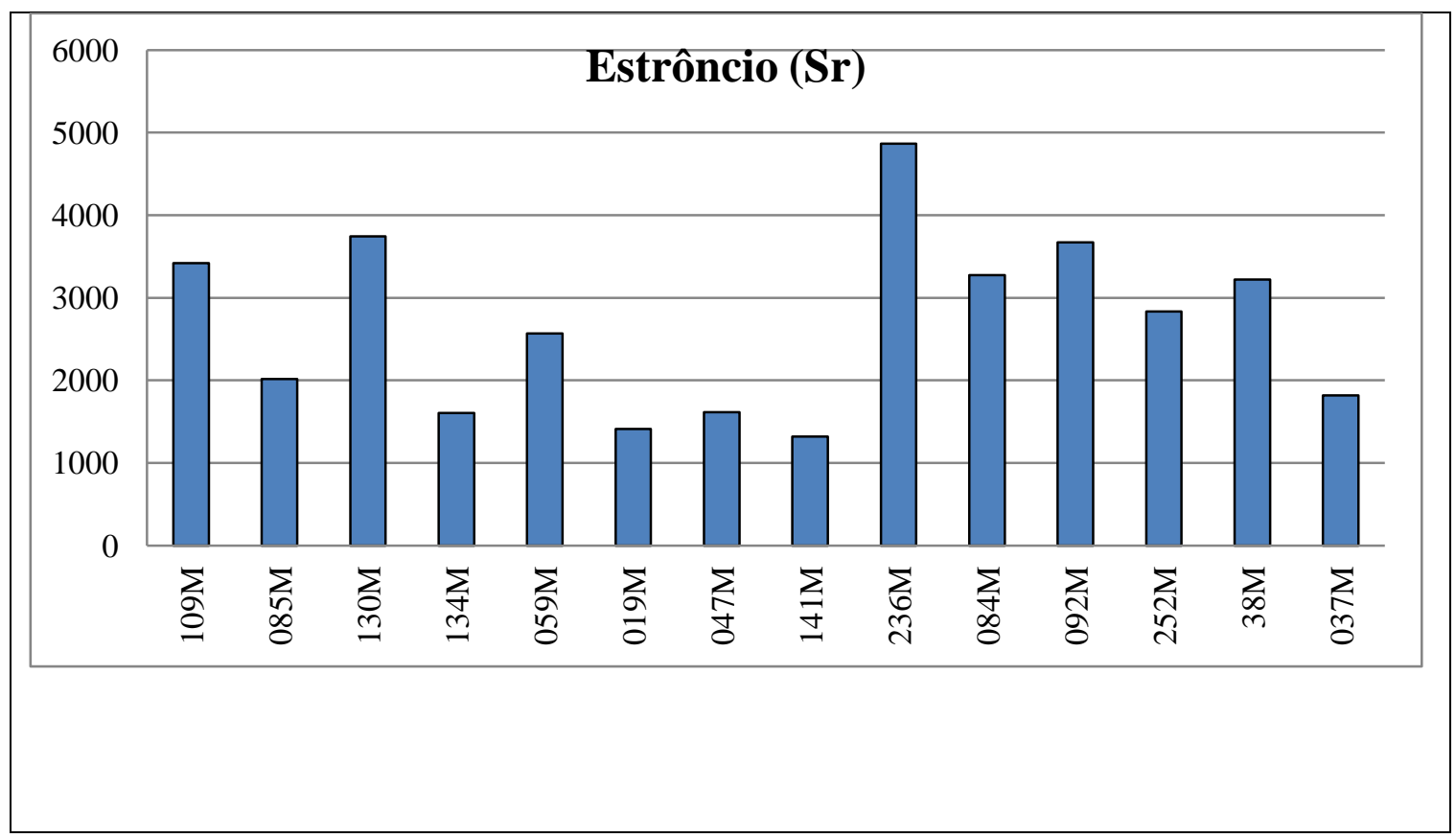

Figura 84. Prancha contendo os resultados da análise de XRF dos núcleos dos fragmentos de RT para os seguintes elementos químicos: silício $(\mathrm{Si})$, alumínio $(\mathrm{Al})$, fósforo $(\mathrm{P})$, enxofre $(\mathrm{S})$, potássio $(\mathrm{K})$, cálcio $(\mathrm{Ca})$, manganês $(\mathrm{Mn})$, ferro $(\mathrm{Fe})$, zinco $(\mathrm{Zn})$ e estrôncio $(\mathrm{Sr})$. 


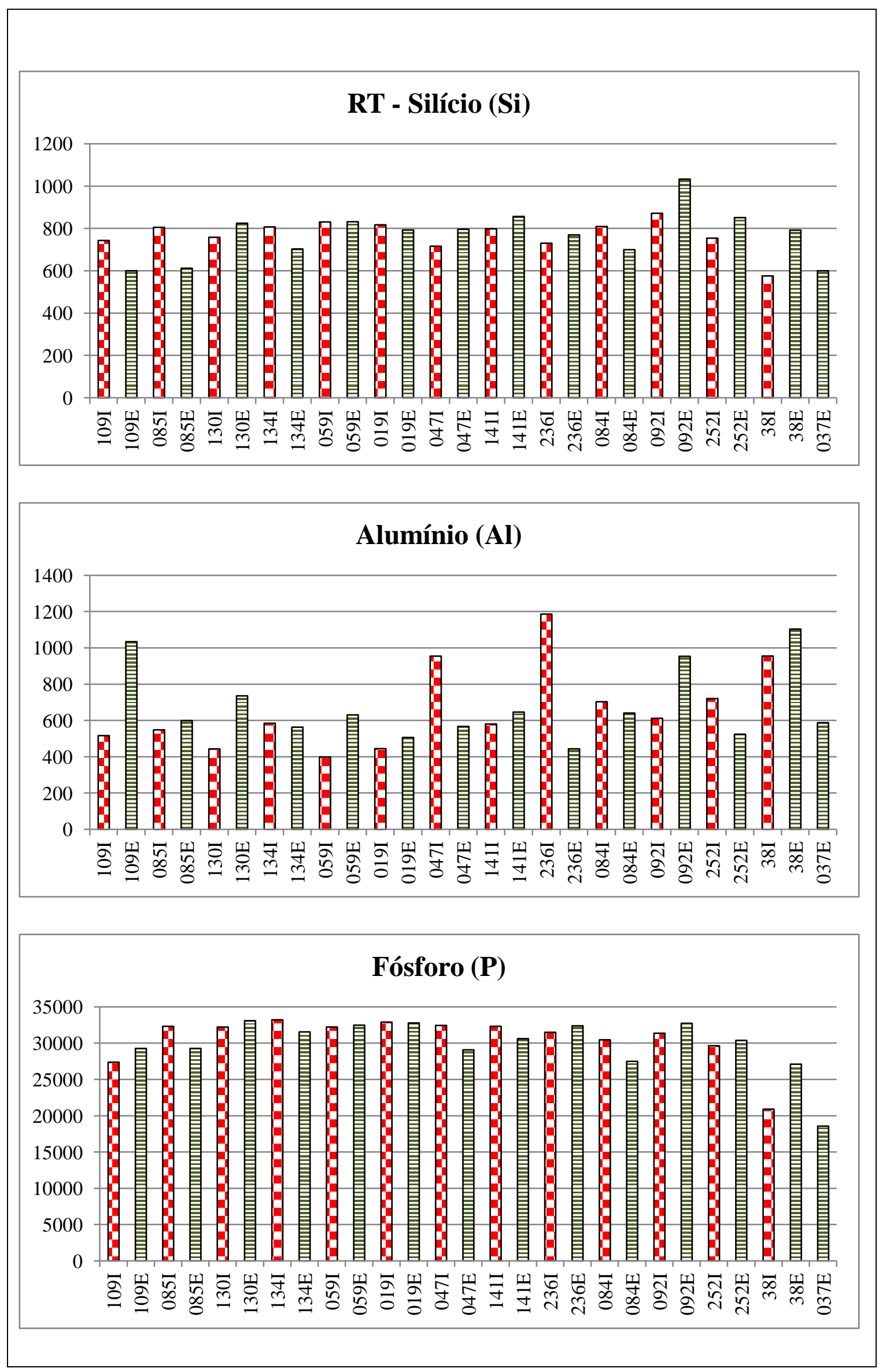




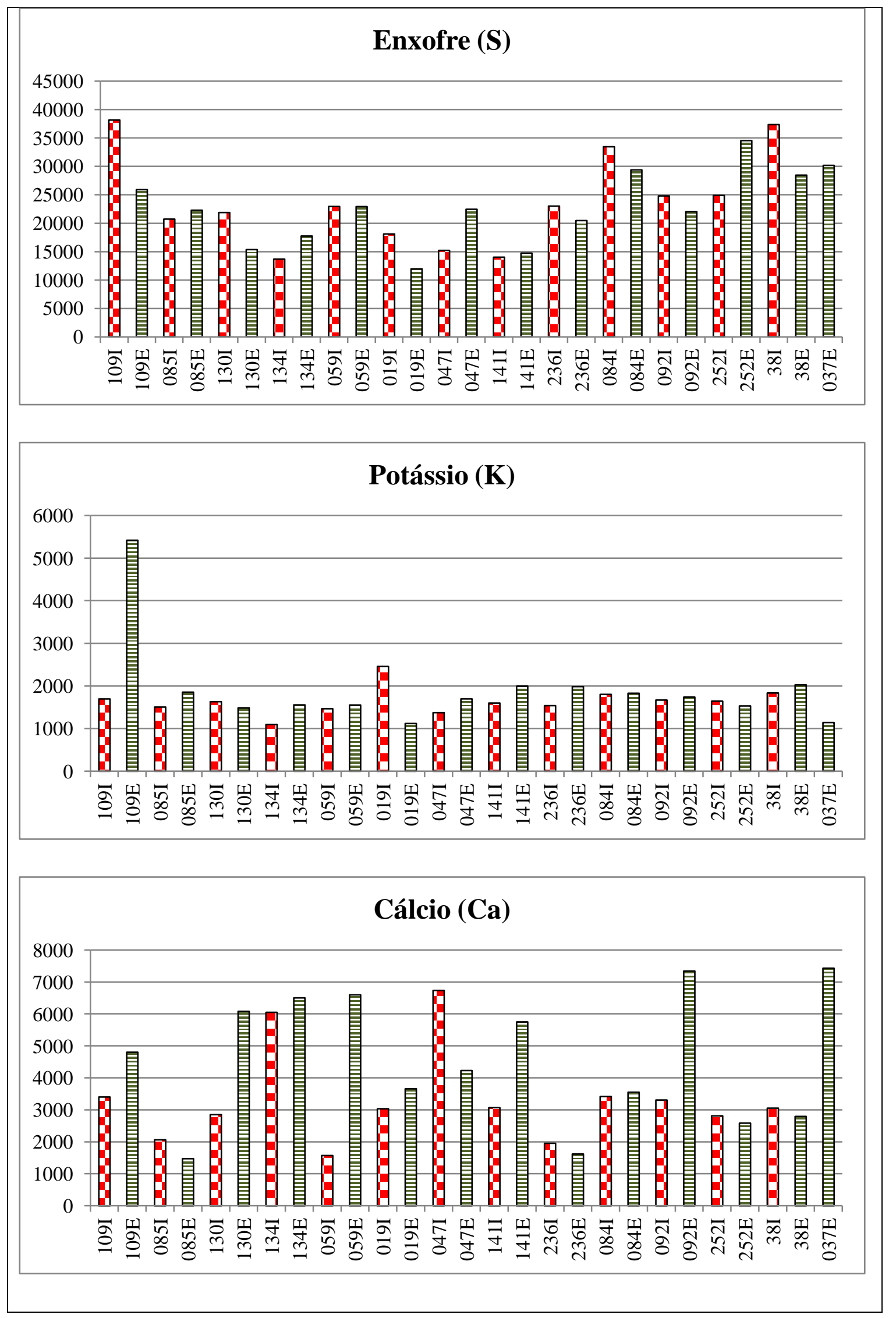




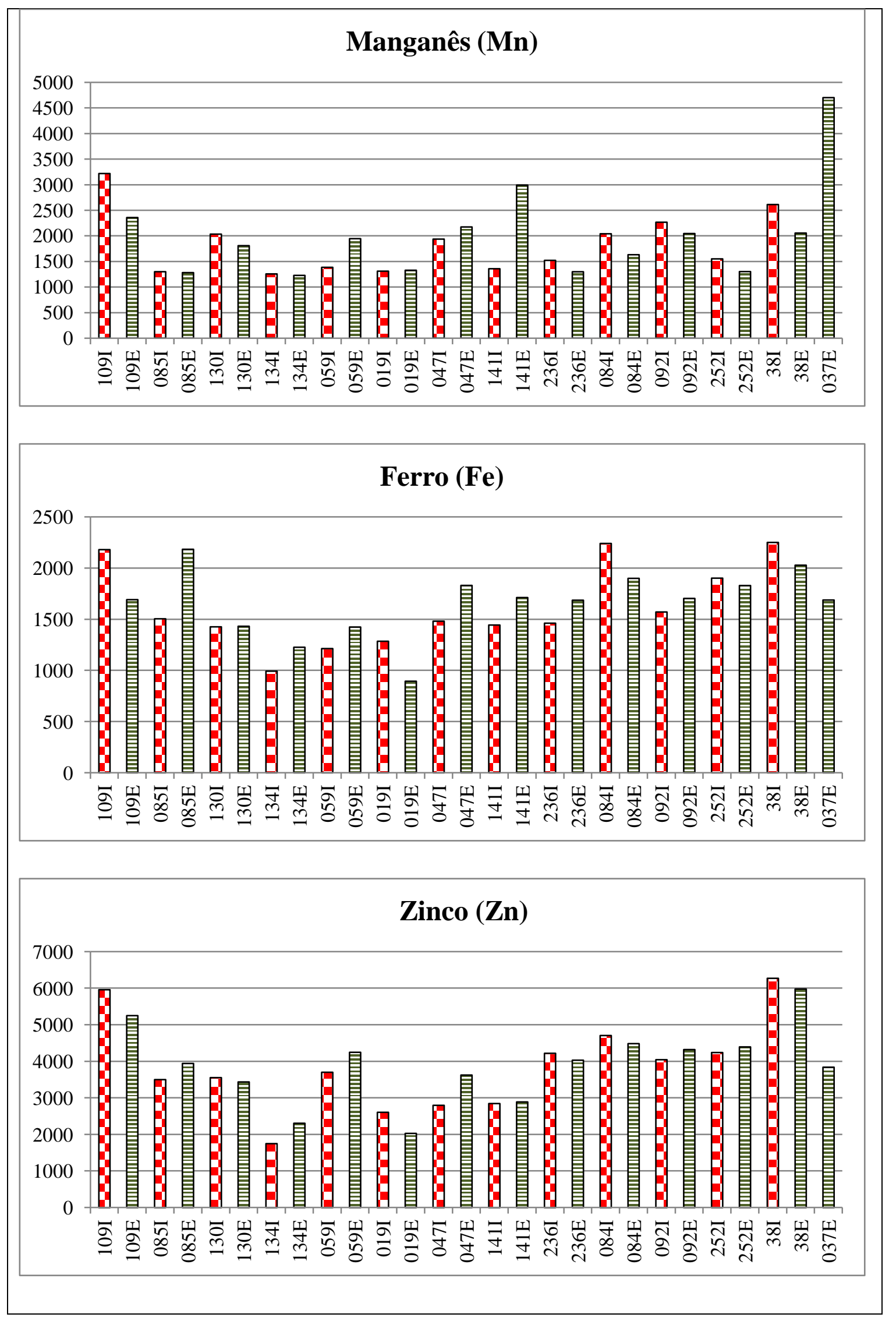




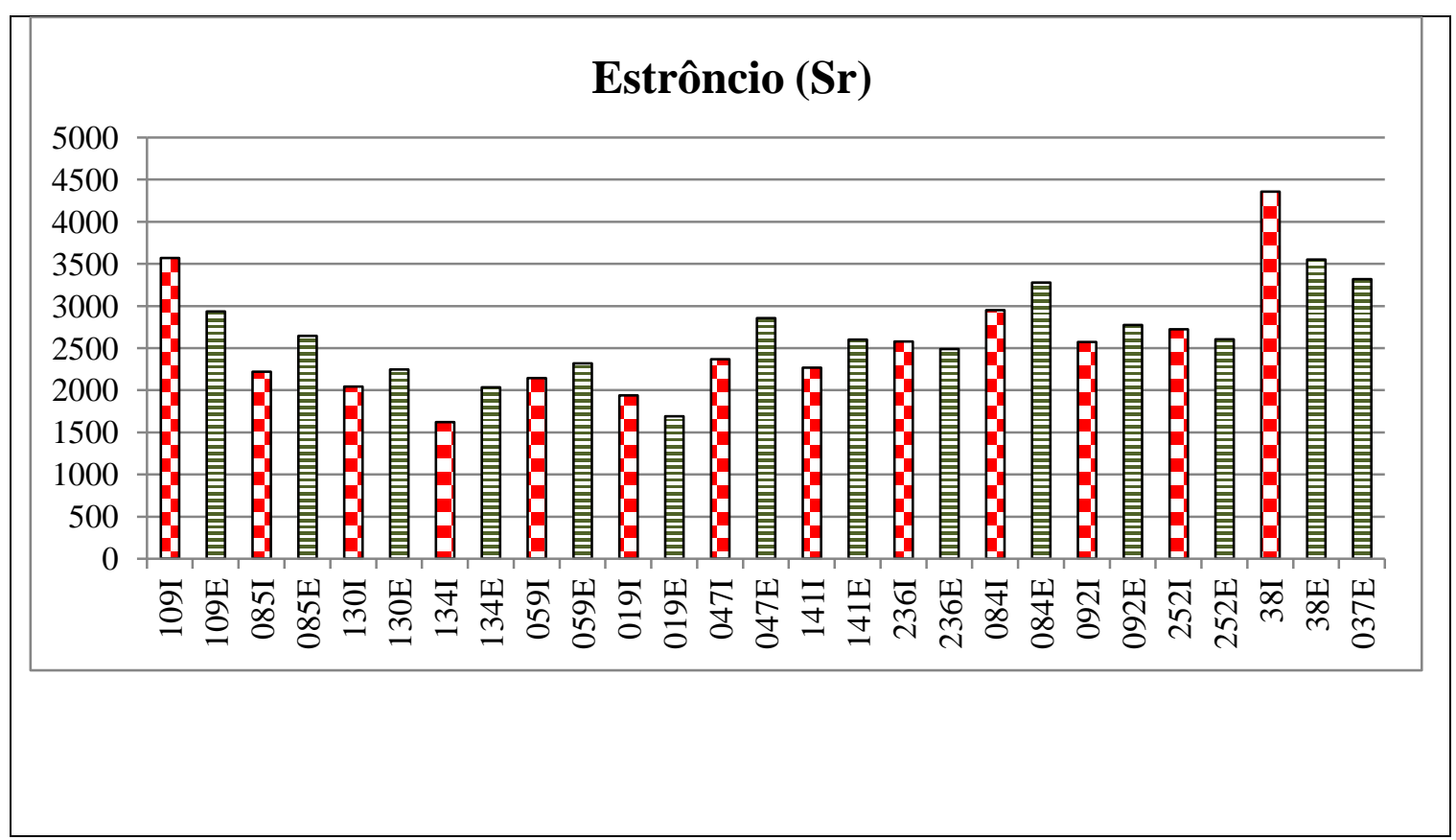

Figura 85. Prancha contendo os resultados da análise de XRF das faces interna e externa dos fragmentos de RT para os seguintes elementos químicos: silício ( $\mathrm{Si}$ ), alumínio (Al), fósforo $(\mathrm{P})$, enxofre (S), potássio $(\mathrm{K})$, cálcio $(\mathrm{Ca})$, manganês $(\mathrm{Mn})$, ferro $(\mathrm{Fe})$, zinco $(\mathrm{Zn})$ e estrôncio $(\mathrm{Sr})$.

Assim como na coleção TRV, os valores de silício (Si) e alumínio (Al) são muito maiores nos núcleos que nas faces, ou seja, são a base da pasta cerâmica. Há mais potássio $(\mathrm{K})$ e ferro $(\mathrm{Fe})$ nos núcleos dos fragmentos que em suas faces. Chama a atenção a alta quantidade de fósforo $(\mathrm{P})$ nas faces dos fragmentos em comparação aos núcleos, assim como de enxofre $(\mathrm{S})$, cálcio $(\mathrm{Ca})$ e manganês $(\mathrm{Mn})$. Os valores de zinco ( $\mathrm{Zn})$ e estrôncio $(\mathrm{Sr})$ são bem similares tanto nos núcleos quanto nas faces. 


\section{CAPÍTULO 6: DISCUSSÃo}

\subsection{Comparação dos resultados da análise macroscópica de TRV e RT}

Algumas relações e considerações puderam ser estabelecidas ao comparar as duas coleções analisadas de forma macroscópica, e serão descritas a seguir com discussão baseada na bibliografia especializada.

\subsubsection{Natureza das peças}

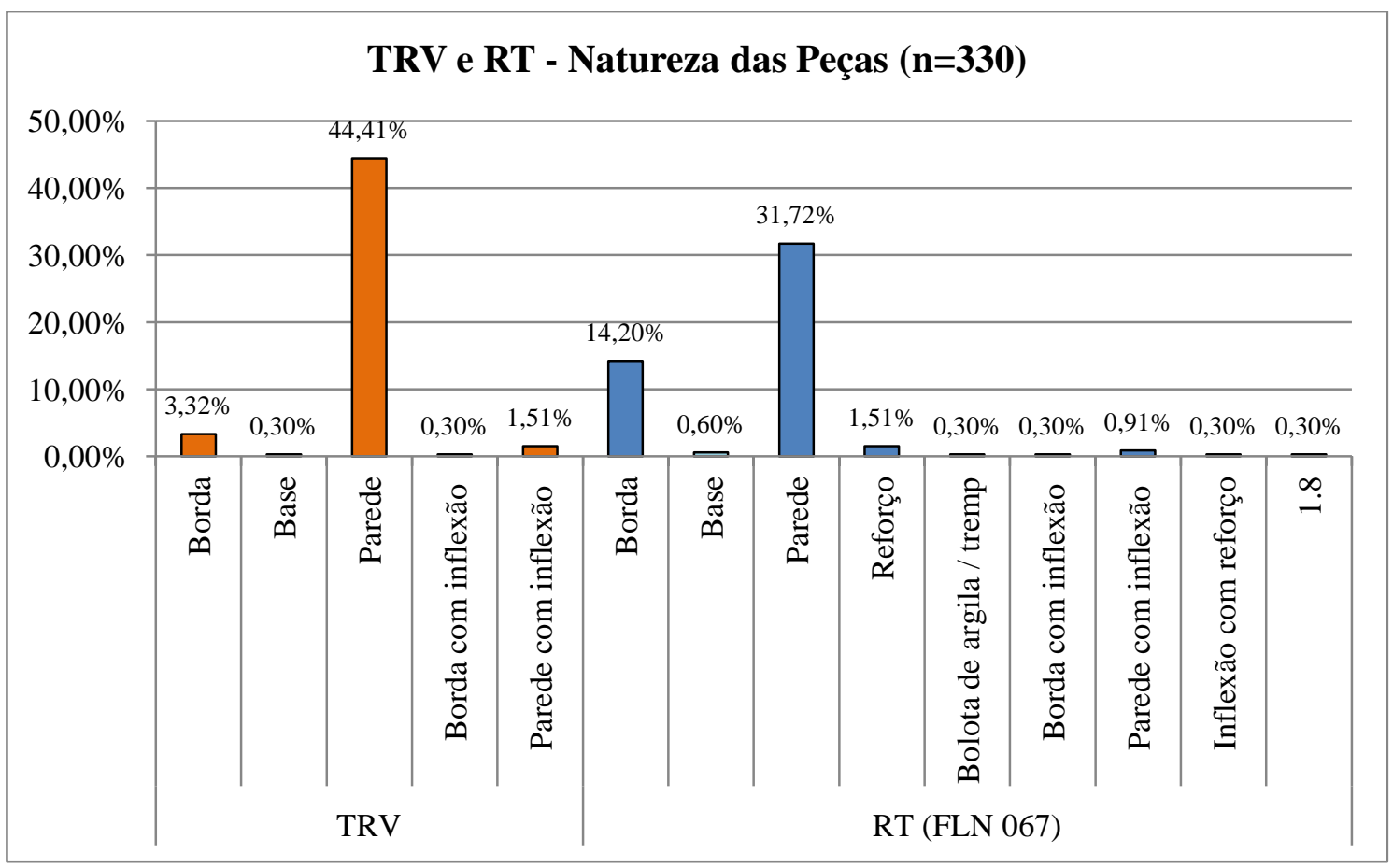

Figura 86. Gráfico representando a comparação entre os dois sítios arqueológicos estudados com relação à natureza das peças (em porcentagem).

Conforme o atributo natureza das peças e o que é observado na Figura 86, há uma porcentagem maior de fragmentos de paredes na coleção TRV que aqueles em RT, uma vez que a coleção RT possui muito mais bordas analisadas (14.20\%) que a coleção TRV (3.32\%). Também é possível observar uma variabilidade maior com relação a essa categoria na coleção RT: há trempe/ytácuru (Noelli, 1993, P.234), bordas 
e paredes com inflexão (além de fragmentos maiores em comparação às duas coleções), e reforços não observados na coleção TRV. Mesmo assim, importante reforçar que não foram encontrados elementos que caracterizassem alguma influência colonial no material cerâmico (como alças e, mesmo, com relação à técnica de manufatura, como o torneado). Ou seja, o predomínio de paredes em ambas as coleções trata-se de uma questão puramente amostral no sentido de que não foram selecionadas apenas bordas e bases para este estudo, além de que a área de parede de uma vasilha é muito maior numa vasilha que a área de bordas e bases em grande parte dos recipientes cerâmicos (a não ser que estes sejam assadores, por exemplo, e então teriam uma área muito maior de base e borda). Ao observar a presença de bordas e paredes com inflexão e reforços na coleção RT, isso pressupõe que a mesma possui vasilhas de tamanhos maiores, comparados a TRV, pois esses recursos e estruturas como inflexão e reforços são utilizados para uma maior sustentação da massa da vasilha.

\subsubsection{Antiplástico}

Sobre o antiplástico encontrado nas coleções, predominou o antiplástico mineral em seus diversos tamanhos e em abundância. Carvão, caco moído e óxido de ferro foram observados em menores quantidades. O caco moído como antiplástico também é referido como chamote em muitas bibliografias especialmente no sul brasileiro, denominação que provêm em parte da referência de la Salvia e Brochado (LA SALVIA \& BROCHADO, 1989, P.16). Em RT não foi observado cariapé, caiuixi, óxidos de ferro e argila; e em TRV, não foi observado cariapé, caiuixi, e argila. Importante ressaltar que, segundo Rye (RYE, 1981, P.26 apud MACHADO, 20052006, P.91), após a busca da matéria-prima em sua fonte (argila), segue-se ao preparo da argila: retirando inclusões grosseiras e com o acréscimo do antiplástico à argila ainda úmida. O termo antiplástico seria, então, utilizado num sentido genérico para indicar quaisquer inclusões contidas na pasta, podendo vir de origens indeterminadas. Quando tais inclusões são intencionais, a escolha do antiplástico é fundamental já que materiais específicos estão normalmente correlacionados a funções específicas. Isto porque as propriedades físicas inerentes a determinados antiplásticos é que vão permitir ou não o exercício de determinadas funções ao produto final. Mas, o que provocariam na pasta? 
Segundo a autora, os antiplásticos, em geral, têm a finalidade de reter a umidade da argila, tornando seu processo de secagem mais lento e estável, diminuindo o risco de a vasilha rachar, comum durante o processo. Além disso, eles tendem a diminuir a plasticidade, facilitando a seu manuseio em formas distintas.

Também remetido como tempero, o antiplástico representa escolhas tanto naturais como culturais no processo de produção das vasilhas e é possível compreender se seu uso com determinada argila foi funcional ou não testando quimicamente a plasticidade dessa argila e a eficácia ou não de determinado antiplástico nesse contexto (MACHADO, 2005-2006, P.93) e, além disso, é importante observar os tratamentos de superfície e escolha do antiplástico (como observou Machado em seu trabalho de 2005). Nesta dissertação, não foi encontrada relação direta entre essas duas variáveis. Ainda assim, nota-se que o maior uso ocorreu com o antiplástico mineral em diferentes tamanhos; quanto maior o tamanho do antiplástico e sua quantidade na argila, maior a probabilidade de quebra da vasilha (um correlato proposto por Schiffer e Skibo em SHIFFER \& SKIBO, 1992, P.61); porém os antiplásticos minerais em tamanho grande (mineral A) aparecem em ambas as coleções associados sempre aos antiplásticos minerais $\mathrm{B}$ e/ou $\mathrm{C}$ (tamanhos médio e pequeno) e em muito menor quantidade que estes últimos. Considerando isso, acredita-se que ocorriam quebras em função da presença desse antiplástico, mas não de forma extensiva (observando o padrão de quebra das vasilhas: em sua maior parte na junção dos roletes e não necessariamente em áreas de maior concentração de antiplástico mineral A).

Parece haver um certo equilíbrio na quantidade de antiplástico na pasta (novamente, se demasiado o uso do antiplástico, as quebras são muito mais frequentes, sendo vasilhas que não poderiam ser transportadas frequentemente). Segundo Schiffer e Skibo (SCHIFFER \& SKIBO, 1992, P.52), há correlatos para o uso do tempero mineral, sendo eles: provocam alta resistência a choques térmicos e possuem maior condutividade térmica (aumento da capacidade de transferir calor), com maior capacidade de aquecimento, ou seja, são excelentes para vasilhas que vão ao fogo cozinhar alimentos. Porém, o tempero mineral diminui a resistência ao impacto (conforme dito anteriormente) e diminui a resistência de materiais ainda não queimados. O antiplástico de caco moído (ou chamote) também diminuiria a resistência de materiais ainda não queimados. Ainda, segundo os autores, referente à capacidade de resfriamento (que seria a diminuição da temperatura pela evaporação), existe uma maior 
permeabilidade do antiplástico de areia (mineral) do que do orgânico, ou seja, uma permeabilidade suficiente. Portanto, o antiplástico pode ressaltar características térmicas, força mecânica e a porosidade das vasilhas (ORTON et al., 1993; CHILTON, 1998; SKIBO, 1992; GASPAR, 2014).

Dessa forma, em ambas as coleções observa-se o recorrente uso das mesmas categorias de antiplástico (minerais e caco moído em menor quantidade), algo que geralmente se espera de acordo com a bibliografia cerâmica Guarani (LA SALVIA \& BROCHADO, 1989). O óxido de ferro e o carvão aparecem em pouquíssimas porcentagens na coleção TRV. Mas, ainda que seja em pouca quantidade, são importantes para registrar a variabilidade que refletem: variabilidade de fontes de matéria-prima. Os minerais (A, B e C) são os mais utilizados nas coleções e acredita-se que um dos motivos de isso ocorrer seja a abundância de fontes dessa matéria-prima ao redor dos sítios arqueológicos: ambos estão localizados em depósitos arenosos. Essa observação também não exclui a compreensão de intenção de uso das vasilhas pelas ceramistas: as que possuem muitos antiplásticos minerais (principalmente mineral $\mathrm{A}$ ) tendem a quebrar mais facilmente, mas esse padrão de quebra devido ao antiplástico mineral não foi observado, e isso quer dizer que q quantidade de antiplástico mineral utilizada foi bastante compatível com a intenção de seu uso - utilizar as vasilhas ao fogo (pois têm boa capacidade de condutividade térmica e resistência a choques térmicos). Ainda assim, tendem a ser mais frágeis que os potes de antiplástico orgânico (não observados nesta análise). Ou seja, a partir do antiplástico estudado pode-se compreender que não se tratavam de vasilhas que seriam muito transportados (essa informação pode ser complementada com a avaliação dos diâmetros das vasilhas).

\subsubsection{Técnicas de manufatura}

Com relação às técnicas de manufatura, ambas as coleções são formadas prioritariamente através da técnica roletada/acordelada, a não ser pelas bases (moldadas). Segundo Machado (MACHADO, 2005-2006, P.100), o moldado consiste em prensar a argila ainda plástica diretamente entre as mãos produzindo formas discoidais planas. $\mathrm{O}$ acordelado, normalmente aplicado à construção da própria estrutura da vasilha, e consiste na sobreposição de roletes de argila. Em seu trabalho, também 
utilizou a definição de Shepard (1965, P.57) que também seguimos aqui, uma definição inclusiva que se refere tanto ao posicionamento espiralado dos roletes como a sucessão de anéis. A técnica roletada/acordelada é bastante comum para a cerâmica Guarani (LA SALVIA \& BROCHADO, 1989), observada nos fragmentos de borda e parede, sendo as bases moldadas. É ela que possibilita a estruturação de vasilhas pequenas a grandes. Nenhuma base roletada foi encontrada, também possível ainda que rara segundo bibliografia especializada.

\subsubsection{Configuração do núcleo (queima)}

Sobre as configurações de núcleo (indicativo de queima), observamos ao analisar cada coleção anteriormente que se diferem bastante, sendo em TRV predominantes as queimas 5 (redutora internamente e oxidante externamente com $49.7 \%$ dos fragmentos) e em seguida a queima 3 (redutora, com $24.85 \%$ dos fragmentos) segundo a classificação de Rye (RYE, 1981, P.116). A queima de número 6 não foi identificada na coleção TRV. Já na coleção RT, a predominância é da queima 1 (correspondente à oxidante) e 2 (correspondente à redutora), com $42.12 \%$ para queima 1 e $43.37 \%$ para a queima 2. Não foram encontradas as queimas 4 e 6 em RT. Portanto, observa-se que as coleções possuem padrões de queima bem distintos. Apesar de um fragmento não representar uma vasilha como um todo, as porcentagens encontradas são bastante claras e diferenciadoras: houve um ambiente de queima mais redutor (não homogêneo) em TRV e em RT há um equilíbrio entre queimas oxidantes e redutoras, portanto, entre ambientes de queima oxidantes e redutores. Isso significa que as vasilhas em TRV e RT não tiveram queimas homogêneas, tendo sido essas, muito provavelmente à céu aberto, sem o total controle do oxigênio na queima de todas as peças, tendo sido queimadas amontoadas.

Sobre os indicativos de queima (observação de configuração do núcleo e colorações das faces interna e externa), pode-se dizer que determinam também a coloração final da pasta e, por isso o atributo de cor da pasta está atrelado especialmente às colorações das faces conforme há explicitado. A cor da pasta que observamos está associada, então, à argila captada (e suas características físico-químicas) e com a queima da vasilha (além da qualidade e quantidade de antiplástico e posicionamento das 
vasilhas na fogueira). Ainda, sobre o processo de queima, é importante enfatizar que se inicia apenas quando a vasilha está completamente seca, se não, a vaporização da água durante o processo de aquecimento e sua pressão podem vir a quebrar o vaso; e é apenas através do processo de queima que a argila passa a possuir as características conhecidas da cerâmica, como a dureza, a porosidade e a estabilidade (MACHADO, 2005-2006, P.106). Segundo Shepard (SHEPARD, 1965, P.74), é possível dividir em três partes distintas o processo da queima das vasilhas cerâmicas: 1) o período de desidratação, 2) o período de oxidação (partículas carbonáceas são queimadas e somem da argila e o ferro e outros componentes são oxidados) e 3) o período de vitrificação (os componentes da cerâmica se integram adquirindo maciez). A obtenção de coloração uniforme depende da proteção da vasilha do contato direto com o fogo. O controle da temperatura ocorre por meio do tipo de combustível, do forno e do ambiente/atmosfera que circunda as vasilhas. O controle deste último é feito através da quantidade de ar disponível para queimar a quantidade de combustível disposta no forno: uma quantidade insuficiente de oxigênio produz condições redutoras; se o ar for suficiente ao combustível, há um efeito neutro; e, se houver excesso de oxigênio, haverá resultados oxidantes (MACHADO, 2005-2006, P.106) ${ }^{6}$.

Também, segundo literaturas etnográficas sobre sociedades ceramistas tradicionais, a queima a céu aberto resulta finais mais oxidantes; ainda assim, segundo Machado (Idem, P.106 citando Silva em comunicação pessoal), trabalhos etnoarqueológicos e de experimentação demonstraram a existência de microambientes em processos de queima a céu aberto resultando em ambientes tanto oxidantes como redutores.

\subsubsection{Tratamentos de superfície}

Já sobre os tratamentos de superfície, a maior parte do tratamento cromático está na coleção RT; no entanto, ambas as coleções possuem praticamente o

\footnotetext{
${ }^{6}$ Aliás, abre-se um parêntesis aqui para mencionar que para além da observação macroscópica, é possível conhecer com maior exatidão a temperatura de queima do vasilhame através do uso da técnica de micro raman, técnica que vem sendo cada vez mais utilizada (que neste momento não foi possível ser utilizada).
} 
mesmo número de fragmentos com tratamento plástico devido ao tratamento corrugado em muitas peças com engobo branco em RT (Figura 87):

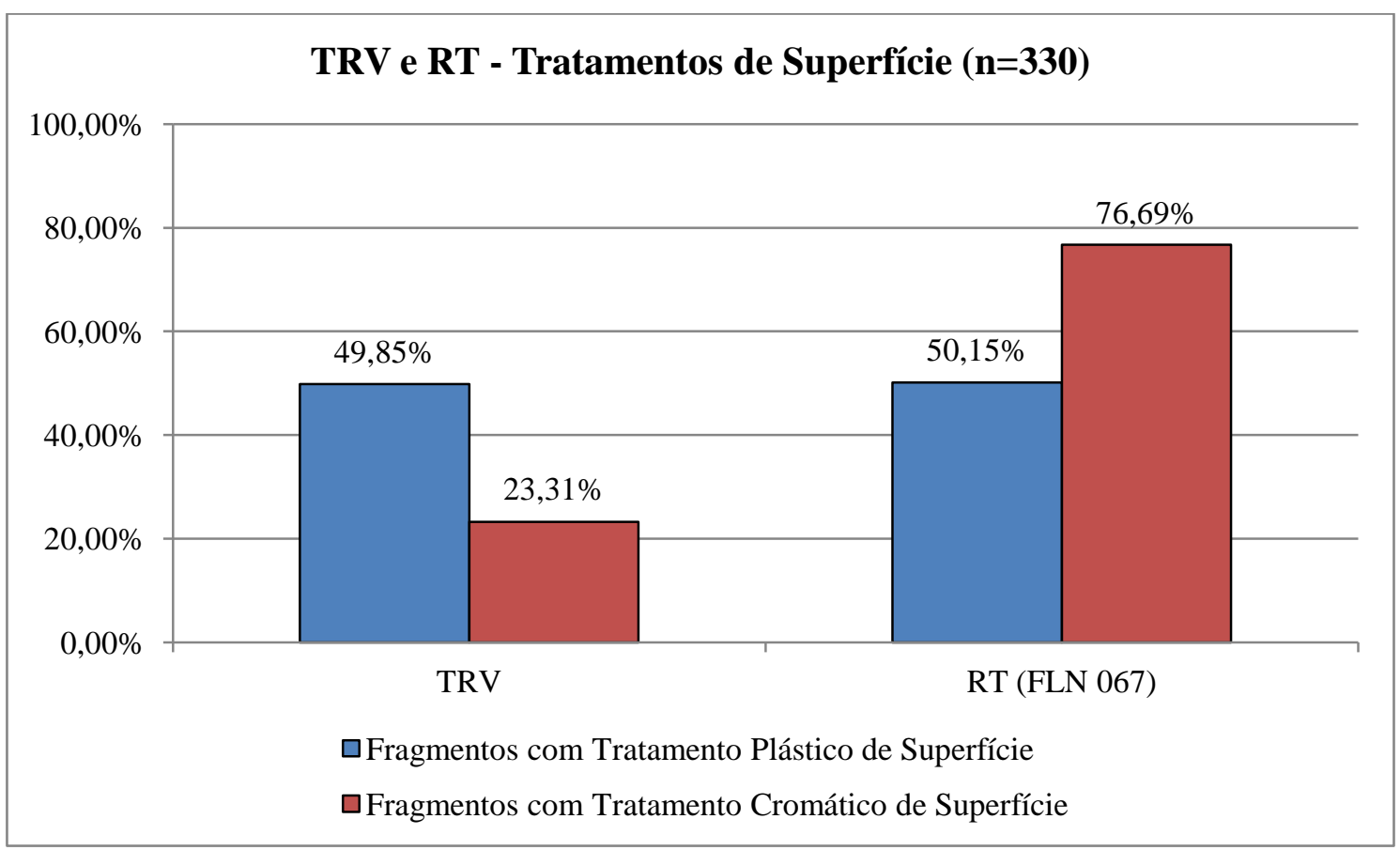

Figura 87. Gráfico representando as formas de tratamento de superfície nos fragmentos analisados de ambos os sítios arqueológicos (em porcentagem).

Aqui, não foi feita distinção entre acabamento de superfície e tratamento plástico de superfície ou tratamento cromático de superfície. Foram tratados como tratamento plástico e tratamento cromático de superfície, especialmente não havendo distinção entre acabamento de superfície e tratamento plástico de superfície (que segue uma lógica funcional). Na literatura cerâmica em geral, diz-se que após o formato geral da vasilha pronta, o ceramista segue aos tratamentos de superfície que podem ser tanto sobre a argila úmida ou seca (ou acabamento). Fariam parte do "acabamento" o alisamento, o enegrecimento e o polimento segundo Rye (RYE, 1981, P.40), a aplicação de resinas e em alguns casos o engobo (SHEPARD, 1965, P.67 apud RYE, 1981, P.104). O alisamento, ainda segundo Machado (2008-2009), pode ocorrer com as mãos ou com instrumentos como coquinhos, cabaças ou material lítico. Nesta pesquisa, não foram identificados materiais líticos associados ao alisamento no sítio TRV e, no sítio RT, essa associação tornou-se difícil de definir. Mas, observou-se que todo o alisamento realizado segue o sentido horizontal dos roletes. Com plantas é possível valer-se do enegrecimento ao carbonizarem em contato com calor excessivo em processo de queima da peça primária ou secundária 
O polimento é feito através de procedimentos semelhantes ao do alisamento, porém, sobre superfícies secas e com a utilização de instrumentos arredondados, como um seixo. Aqui não foi identificado o polimento como tratamento de superfície. Partes polidas dos fragmentos (e, respectivamente, das vasilhas) foram vislumbradas, mas acredita-se que em função do apoio das vasilhas no solo ou algum outro suporte possivelmente.

Todos os atributos analisados buscam evidenciar o modo de fazer por trás do resultado final; nesse sentido, os tratamentos plásticos identificados e usados na ficha possuem também uma compreensão no seu modo de fazer que o distinguem uns dos outros. As referências utilizadas neste trabalho seguem La Salvia \& Brochado (LA SALVIA \& BROCHADO, 1989, P.P.35-36). Nele, são descritas as formas de se fazer cada um deles, como o corrugado que tem por definição nos autores "tem como expressão decorativa a dobra - é a ação lateral do dedo sobre a superfície cerâmica, pressionando uma parte da argila, por arraste, e formando uma crista de forma semilunar como resultado do acúmulo da argila arrastada" (LA SALVIA \& BROCHADO, 1989, P.35).

Na bibliografia de Arqueologia Guarani (especialmente em La Salvia \& Brochado 1989) também é comum encontrar a barbotina, sendo sua definição naqueles autores "um revestimento superficial de argila mais refinada, aplicado à cerâmica antes da queima". Ela se diferenciaria do "banho", compreendido aqui como engobo, por seu refinamento, visto que o banho seria um refinamento maior da argila, um "revestimento superficial, delgado, proveniente de um caldo ou nata de argila em suspensão na água, aplicado à superfície cerâmica antes da queima" (LA SALVIA \& BROCHADO, 1989, P.p.16-17). No entanto, nas análises macroscópicas e arqueométricas aqui realizadas não foi possível fazer uma distinção entre ambos, sendo qualquer camada fina de argila aplicada à superfície antes da queima denominada como engobo.

Sobre as tintas utilizadas nos tratamentos cromáticos, La Salvia e Brochado (LA SALVIA \& BROCHADO, 1989, P.97) afirmam ser vegetais o negro, o preto, o vermelho e o amarelo; sendo que as tintas minerais seriam o branco, o vermelho e o ocre. O negro seria extraído do jenipapo, o preto do murici (várias espécies do gênero Byrsonima, da família das Malpighiaceas); o vermelho e amarelo seriam extraídos do urucu (do Tupi, de $u r u$ 'ku, vermelho), fruto do urucuzeiro (da família das bixáceas) 
(todas vegetais). Já com relação às tintas minerais, o amarelo ser ia extraído do taguá ou tauá (do Tupi ta'wa= argila amarela), extraída do xisto argiloso ou da argila aluvional colorida por óxido de ferro; o vermelho do piranga (do Tupi pi'rag = vermelho, encarnado), barro vermelho; e o branco, por fim, seria extraído da tabatinga (do Tupi tagua'tingua ou tawa'tîga = barro branco), argila sedimentar, mole e com alto teor de matéria orgânica.

Como já explicado, não foi utilizada a definição de Rye (1981) que não inclui nessa etapa o engobo, como faz Shepard (1965). Em muitos casos, segundo Machado (2005-2006), o uso do engobo se dá como um acabamento funcional da superfície do vaso com o objetivo de impermeabilizá-lo. Como Técnicas decorativas, plástica e pintada: o modelado permitiria a mais liberdade de explorar representações.

Ainda, segundo Chilton (CHILTON, 1998, P.154), os tratamentos de superfície podem afetar profundamente a performance de uma vasilha (Schiffer et al., 1994). Por exemplo, uma superfície áspera pode aumentar a resistência ao choque térmico e reduzir o lascamento térmico (Schiffer et al., 1994). Uma superfície áspera também provê uma firmeza (Rice 1987:232) e pode aumentar a absorção do calor e a evaporação de líquidos (Charlton 1969; Herron 1986). Assim, os tratamentos de superfície não são escolhidos automaticamente; uma ceramista faz escolhas dentre inúmeras possibilidades de acordo com vários critérios pessoais, sociais e tecnológicos.

Dessa forma, ao observarmos uma diferença entre as coleções, pode-se estabelecer que: em TRV, o uso de tratamentos de superfície plásticos ásperos (como o corrugado e o ungulado) favorece o uso das vasilhas ao fogo (aumentando a resistência ao choque térmico e reduzindo o lascamento térmico), tendo sido projetadas muito provavelmente para esse uso ao fogo. Somado a isso, a interpretação sobre os antiplásticos nessa coleção corrobora esse dado. Na coleção RT, apesar de termos observado o uso das mesmas categorias de antiplástico, há o predomínio do tratamento cromático, sendo o engobo predominante. Esse tipo de tratamento, geralmente, não é utilizado em vasilhas que vão ao fogo, mas são utilizados para servir e mesmo armazenar bebidas (uma vez que a camada de engobo ajuda a fechar os poros da vasilha cerâmico). Portanto, grande parte das vasilhas em RT foi utilizada para servir e armazenar. 


\subsubsection{Coloração da pasta}

Com relação às colorações/cores das pastas (derivada da fonte de argila utilizada e da queima das vasilhas), a coleção TRV possui maior parte de fragmentos com pasta de cor laranja $\mathrm{C}$, enquanto que na coleção RT, a maioria dos fragmentos possui cor branca (Figura 88). Essa distinção é muito visível se colocarmos ambas as coleções lado a lado; trata-se de produtos bastante distintos, ainda que as mesmas técnicas sejam utilizada em ambas e que todas elas sejam reconhecidamente Guarani. Essa diferença claramente remete a buscar as possíveis fontes de matéria-prima (argila) na área de estudo, o litoral central catarinense (mais especificamente, a ilha de Florianópolis), conforme as análises de XRF também apontam, apesar do conhecimento e forte difusão na literatura arqueológica de que esta categoria é resultado de ambos os fatores: queima das vasilhas durante sua produção; e cor/propriedades da argila enquanto matéria-prima. Ou seja, neste ponto as análises aqui realizadas reforçam a necessidade de se conhecer a composição físico-química das fontes de argila das pastas que são analisadas e reforçam a existência de uma variabilidade nas fontes de matériaprima utilizadas.

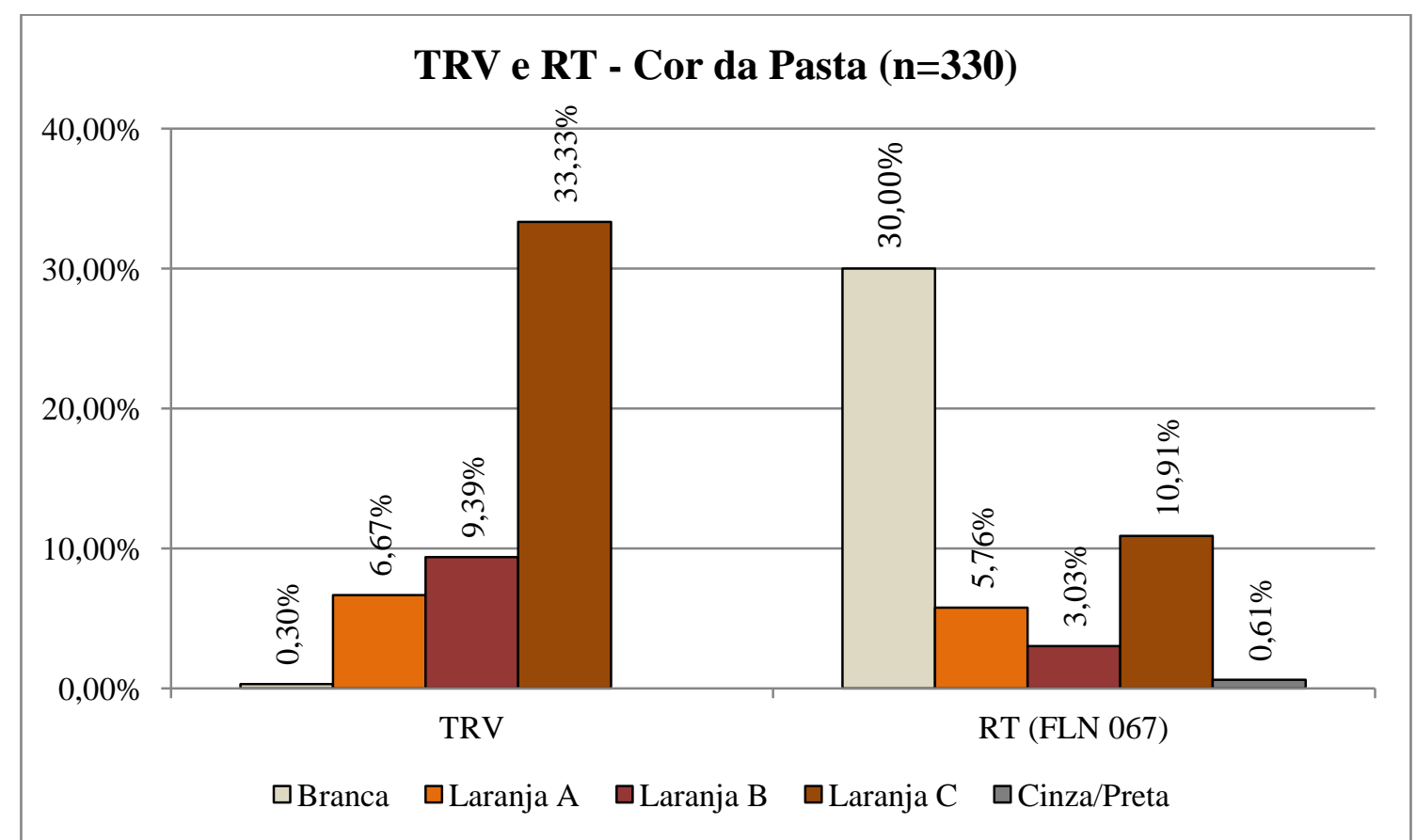

Figura 88. Gráfico que representa as colorações das pastas dos fragmentos analisados dos sítio TRV e RT (em porcentagem). 


\subsubsection{Marcas de uso}

Sobre as marcas de uso identificadas, em RT foi vislumbrado mais o desgaste acentuado em virtude do conjunto 8 especialmente, uma vez que apresentou um desgaste bastante diverso do restante da coleção. Isso pode ser devido a algum setor escavado ter sofrido processos pós-deposicionais distintos do restante da área escavada. Ainda assim, não é possível afirmar visto que não foi possível relacionar esse conjunto de fragmentos a um determinado setor da escavação devido à falta de documentação. Na coleção TRV, as marcas de fuligem foram dominantes (Figura 89):

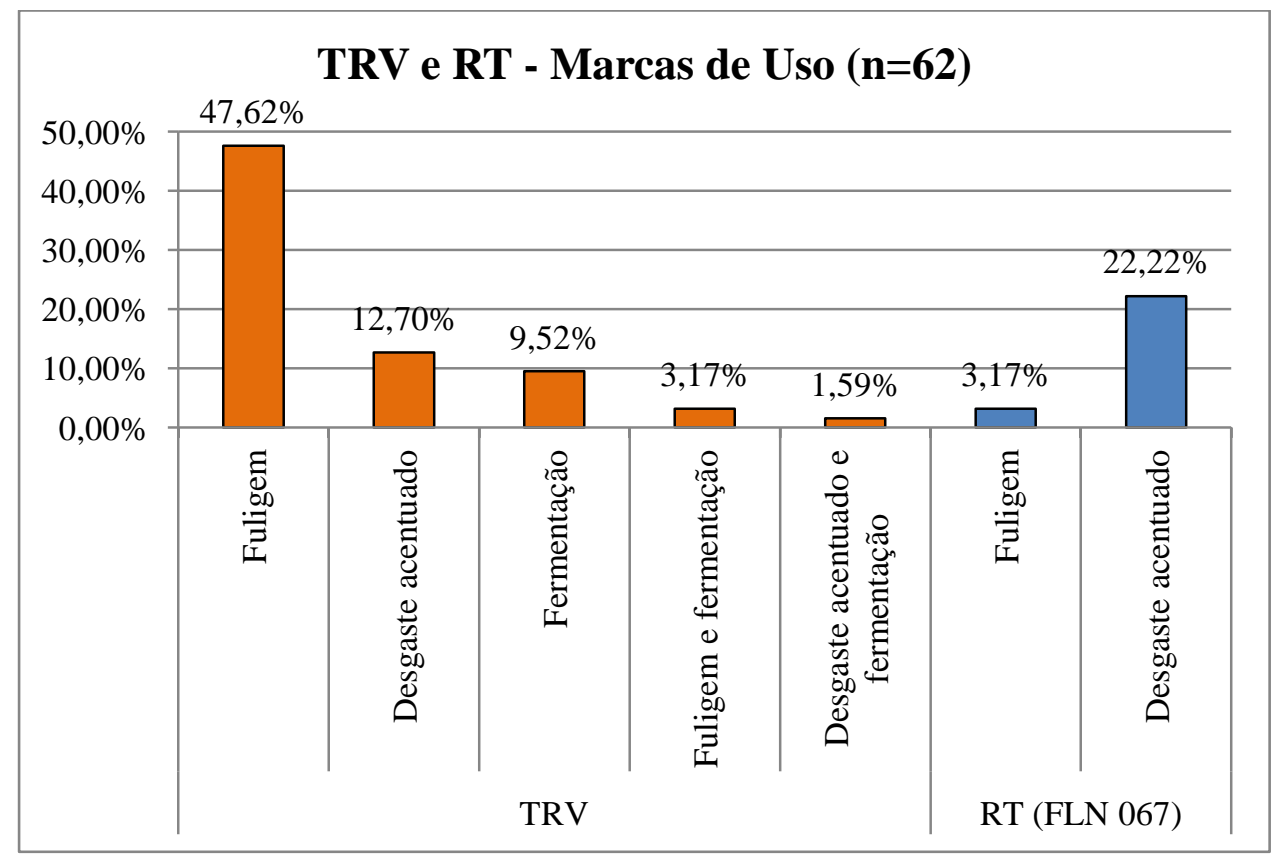

Figura 89. Gráfico representando as marcas de uso encontradas em ambas as coleções analisadas (em porcentagem).

É importante frisar que, nesta análise, não foi o intuito realizar um estudo exaustivo das marcas de uso e das marcas deixadas nas vasilhas por questões tafonômicas e aspectos pós-deposicionais que atuaram nos depósitos arqueológicos. No entanto, enfatiza-se a relevância desse tipo de estudo para uma melhor compreensão das funções desses materiais que indiretamente são analisados e compreendendo os depósitos nos quais estiveram inseridos, complementando e compondo a compreensão dos sítios arqueológicos estudados. Um bom exemplo de um trabalho de caráter metodológico com marcas de uso em cerâmica Guarani no sul brasileiro é aquele 
intitulado Distribuição das marcas de uso e especificidades funcionais para a cerâmica Guarani pré-colonial de Mariana Araújo Neumann (NEUMANN, 2011). Nele, a autora conjugou o método de análise "use-alteration" com a observação das características de cada categoria funcional, ou seja, yapepó, cambuchí, ñaetá, cambuchí caguaba e tembirú.

\subsubsection{Relação antiplástico - coloração da pasta}

Sobre a relação entre antiplástico e a coloração/cor da pasta em ambas as coleções, foi possível observar que, na coleção RT, a maior parte dos fragmentos de pasta laranja $\mathrm{C}$ possui antiplásticos minerais, enquanto que na coleção TRV a argila branca é aquela que contem a maior parte dos antiplásticos minerais (Figura 90). Porém, esse dado não é tão revelador, visto que já foi descrito anteriormente que há a predominância das cor branca na coleção RT e da cor laranja C na coleção TRV, e em ambas, os antiplásticos minerais predominam. O que essa relação nos revela é que não houve escolhas específicas de antiplásticos para determinadas cores de pastas.

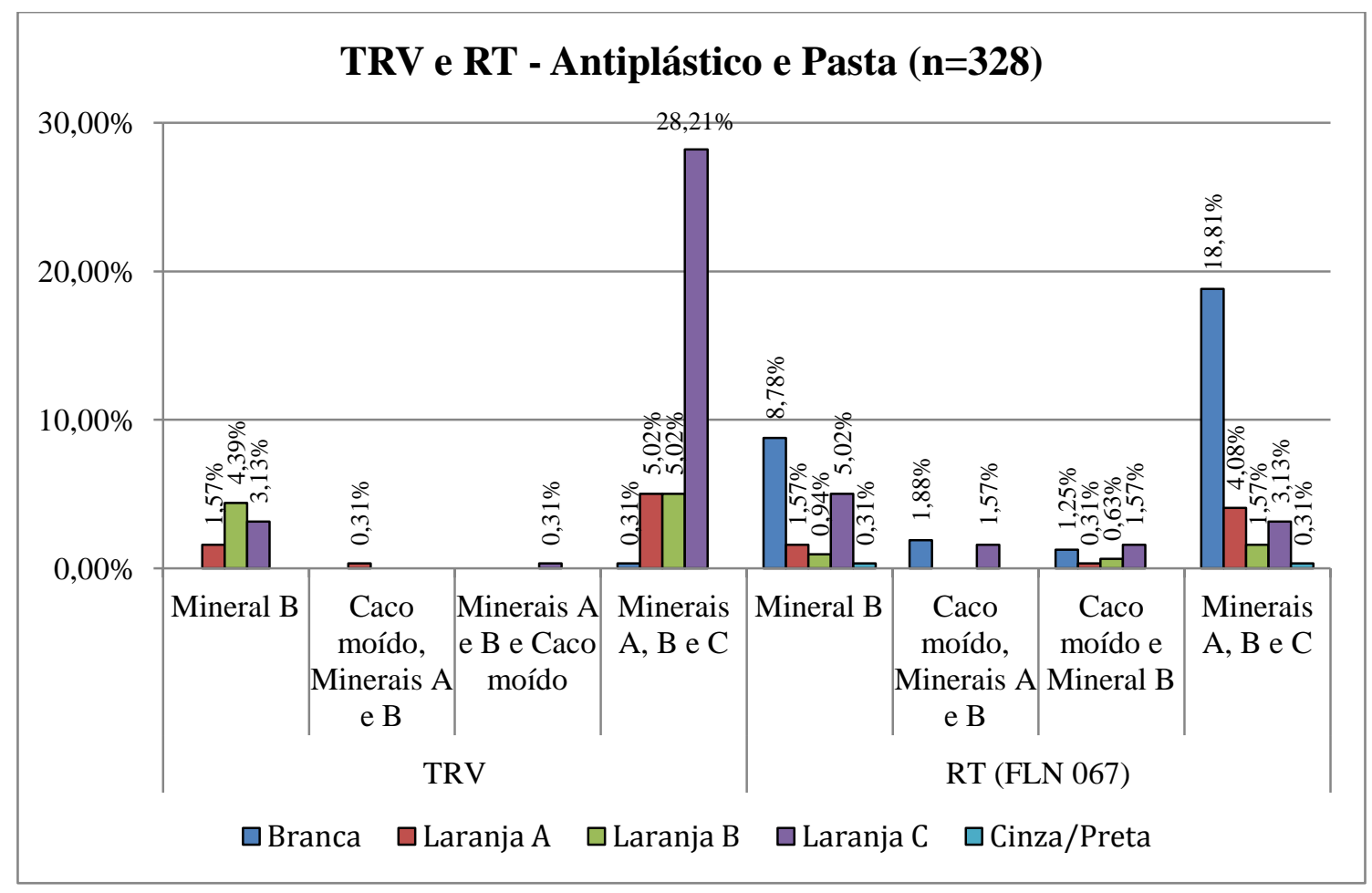

Figura 90. Gráfico representando a relação entre antiplástico e cor da pasta de ambos os sítios analisados (em porcentagem). 


\subsubsection{Relação bordas - tratamento de superfície}

Com relação às bordas e os tratamentos de superfície, a maior parte das bordas em RT possui alisamento, enquanto que em TRV há alisamento interno com corrugado e ungulado externo (Figura 91), o que, novamente, enfatiza a predominância do tratamento cromático em RT (seguido do alisamento), e do tratamento plástico (seja ele, alisado, corrugado ou ungulado) em TRV. Esses dados revelam, também, que foram analisadas bordas das mesmas vasilhas ou de vasilhas das mesmas categorias e características que as paredes analisadas.

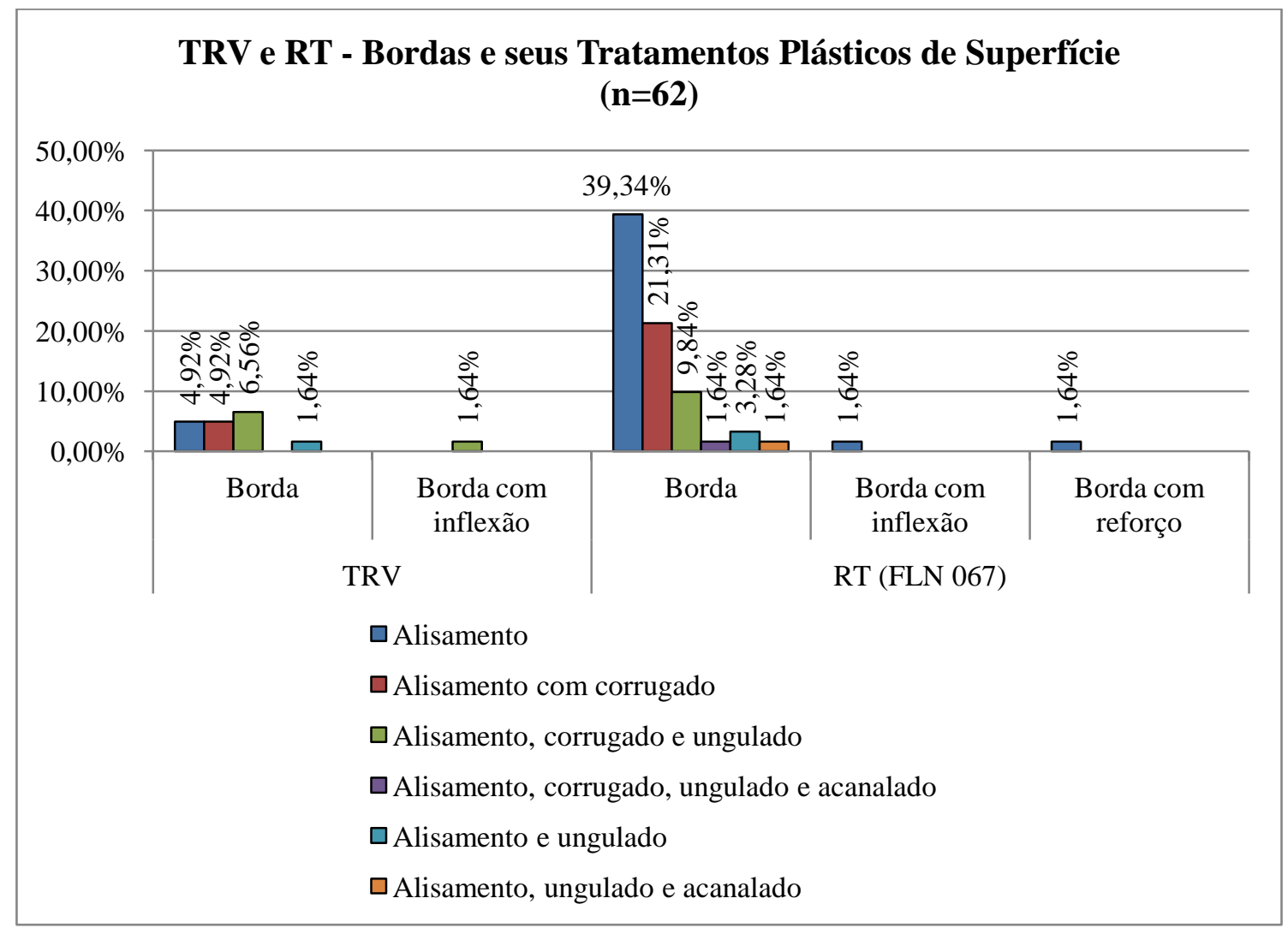

Figura 91. Gráfico representando a relação entre as bordas e os tratamentos plásticos identificados em ambos os sítios (em porcentagem).

Como já observado anteriormente, o engobo branco sobre alisamento predominou nas bordas da coleção RT (da mesma forma que nas paredes), enquanto que o engobo branco e o engobo vermelho com pintura predominaram em TRV quando aparecem (Figura 92). Isso significa as bordas com tratamento cromático analisadas em RT correspondem as mesmas vasilhas das paredes e bases analisadas ou da mesma categoria; já as bordas com tratamento cromático na coleção TRV demonstram que a 
coleção não apresentou somente vasilhas que vão ao fogo, mas vasilhas de servir e armazenar (mesmo que em porcentagem ínfima em relação ao restante da coleção).

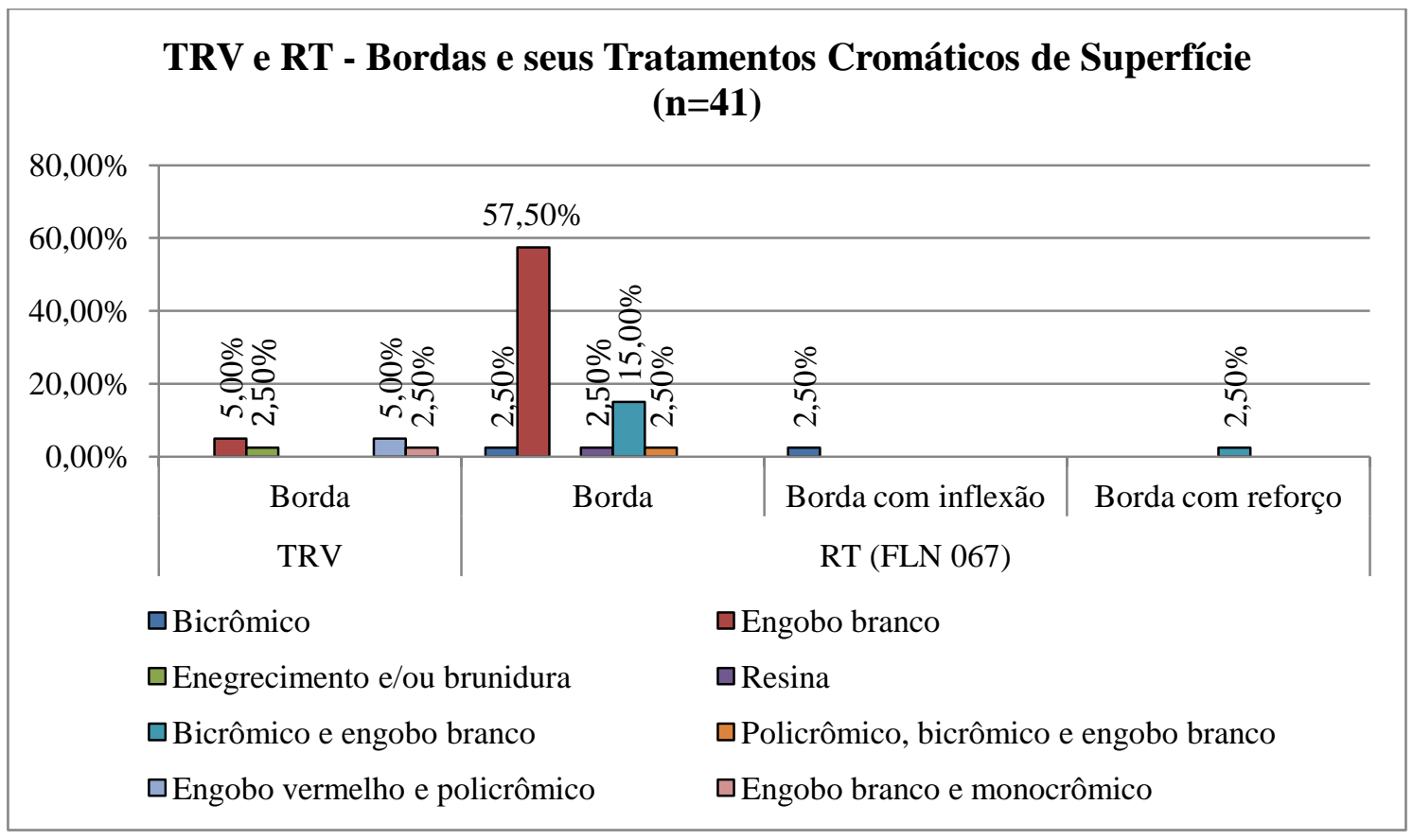

Figura 92. Gráfico representando as bordas analisadas e os tratamentos cromáticos associados a elas referente às coleções de ambos os sítios (em porcentagem).

\subsubsection{Relação tratamento de superfície - coloração da pasta}

Observa-se na Figura 93 uma síntese com relação aos tratamentos de superfície de ambas as coleções e a cor de suas pastas, onde a pasta laranja $\mathrm{C}$ junto com os tratamentos alisado, corrugado e ungulado predomina na coleção TRV, diferente na coleções RT, na qual predomina a pasta branca e o alisamento: 


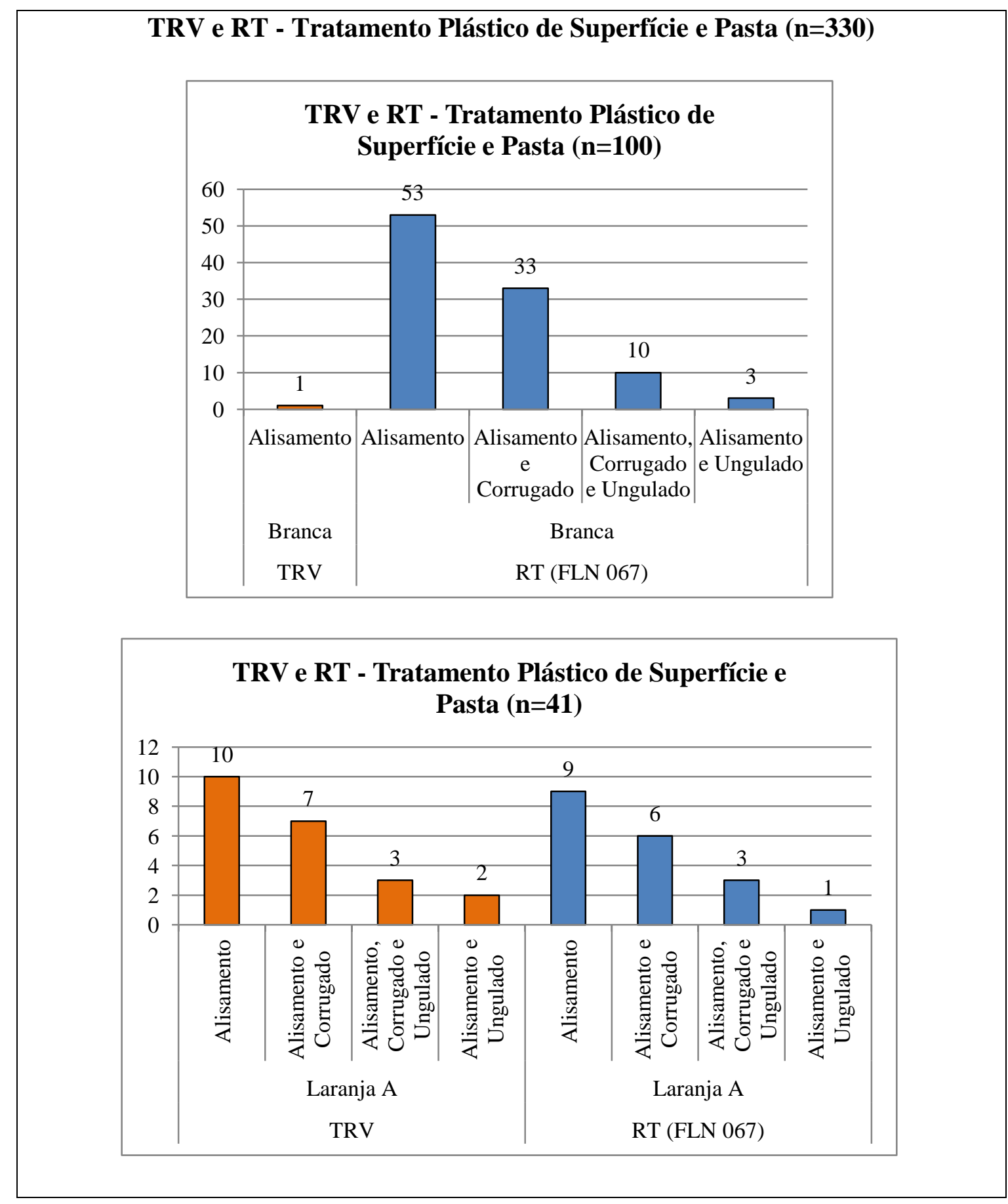




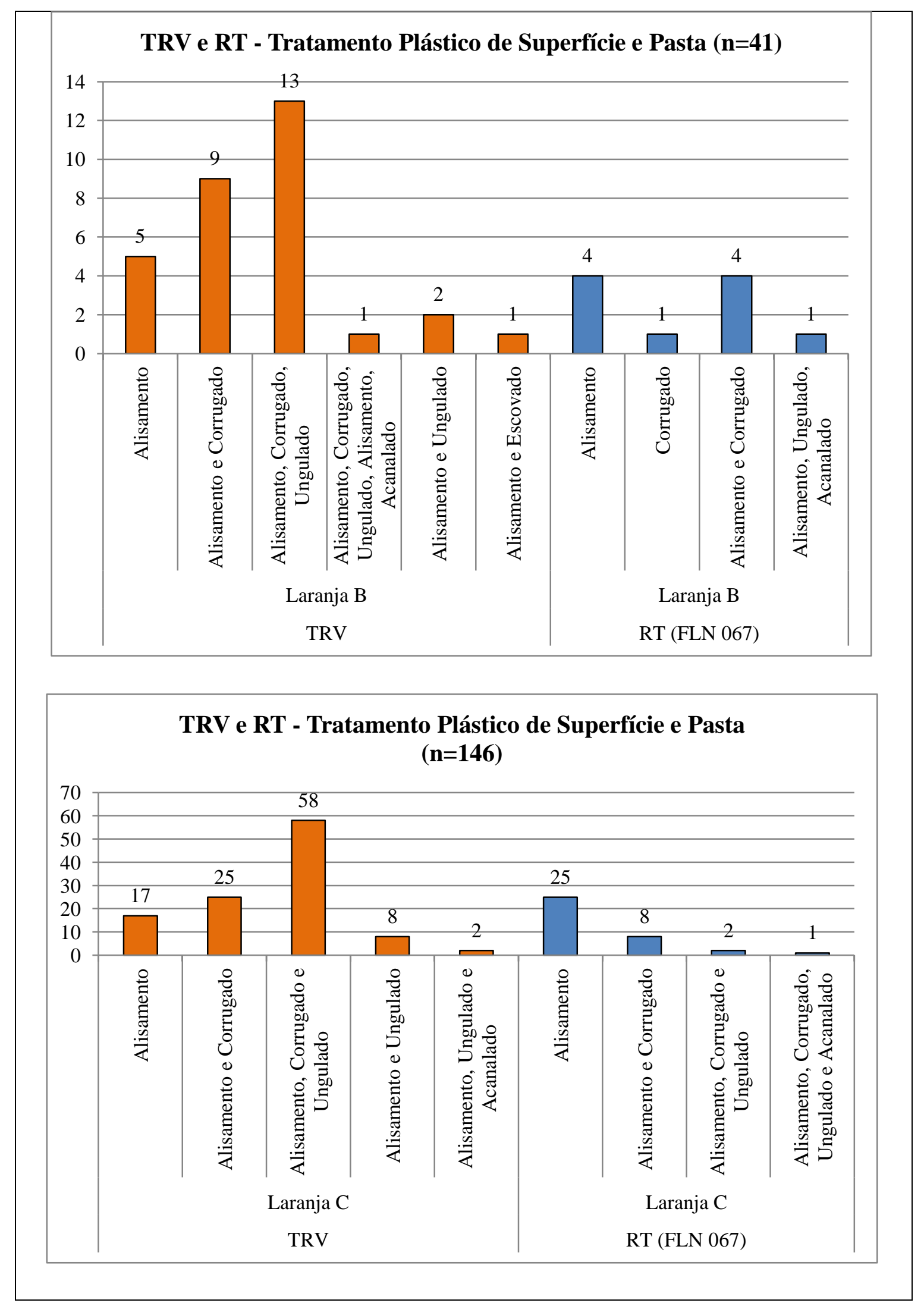




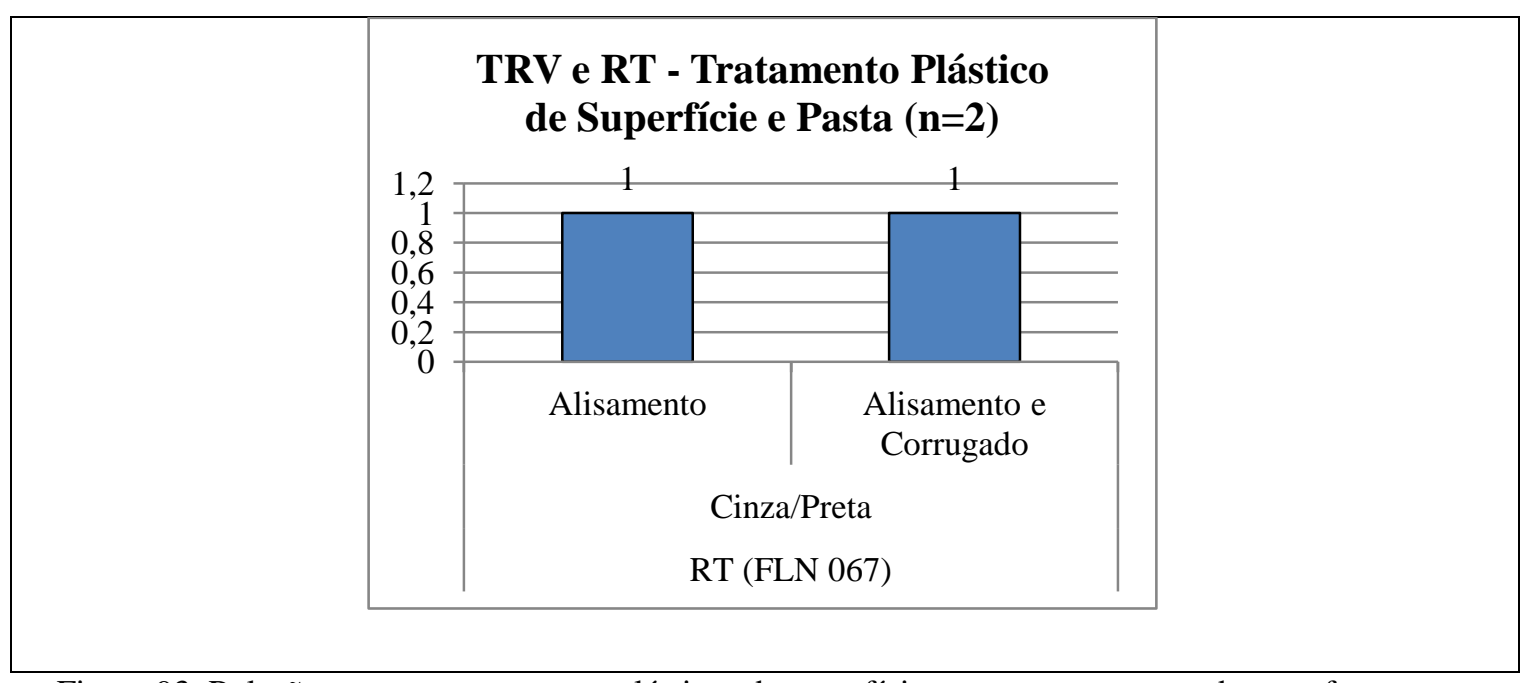

Figura 93. Relação entre os tratamentos plásticos de superfície e as pastas encontrados nos fragmentos comparando os sítios arqueológicos TRV e RT.

A pasta branca existe em 100 das 330 peças analisadas e, na coleção RT, é bastante abundante (especialmente com o alisamento, são 53 fragmentos). A pasta laranja A tem 41 dos fragmentos dentro do total de peças e em quantidades bastante similares entre ambas as coleções ( 22 em TRV e 19 em RT), e em ambas se encontra mais em fragmentos alisados. A pasta laranja B possui, assim como a laranja A, 41 dos fragmentos, sendo $31 \mathrm{em} \mathrm{TRV} \mathrm{e} 10 \mathrm{em} \mathrm{RT}$. Em TRV é mais recorrente em peças com a associação entre alisamento, corrugado e ungulado, mas também ocorre nesses tratamentos isolados e mesmo com acanalado e escovado. Aliás, os acanalados e escovados somente apareceram nas pastas laranja B e C. A pasta laranja C possui a maior representatividade dentre as demais (são 146 de 330 peças) devido especialmente à sua presença na coleção TRV (são 110 fragmentos, portanto, mais que a pasta branca em RT). A pasta cinza/preta é praticamente inexpressiva entre as coleções (são 2 fragmentos em ambas).

Isso tudo significa que, além da variabilidade de pastas existente nas coleções, há a predominância já conhecida da pasta laranja C na coleção TRV e da pasta branca na coleção RT, mas todas as pastas foram encontradas em ambas as coleções. A pasta laranja C é escolhida em TRV para levar a maior parte dos tratamentos alisado, corrugado e ungulado, sendo vasilhas de uso ao fogo; e a pasta branca é escolhida para levar o alisamento que dá base ao tratamento cromático na coleção RT, sendo em sua maior parte vasilhas para servir e armazenar. Os tratamentos de superfície identificados nas pastas laranja C (em TRV) e branca (em RT) também estão nas demais pastas, ou 
seja, não há uma diferenciação de tipos de vasilhas para determinada cor de pasta dentro de cada coleção; mas há essa diferenciação entre as coleções. Mas, o que os dados do parágrafo anterior revelam são, também, as particularidades encontradas nas evidências de menor quantidade: tratamentos plásticos mais raros, como o acanalado e o escovado aparecem em uma pasta específica, a laranja B, pouco encontrada nas coleções.

\subsubsection{Relação tratamento cromáticos de superfície - coloração da pasta}

Os gráficos da Figura 94 reiteram a relação de cada contexto entre os tratamentos cromáticos de superfície e a cor da pasta nas coleções. Novamente, como o número de fragmentos com tratamento cromático não é igual àqueles com tratamento plástico, foram observadas nos gráficos as 162 peças:

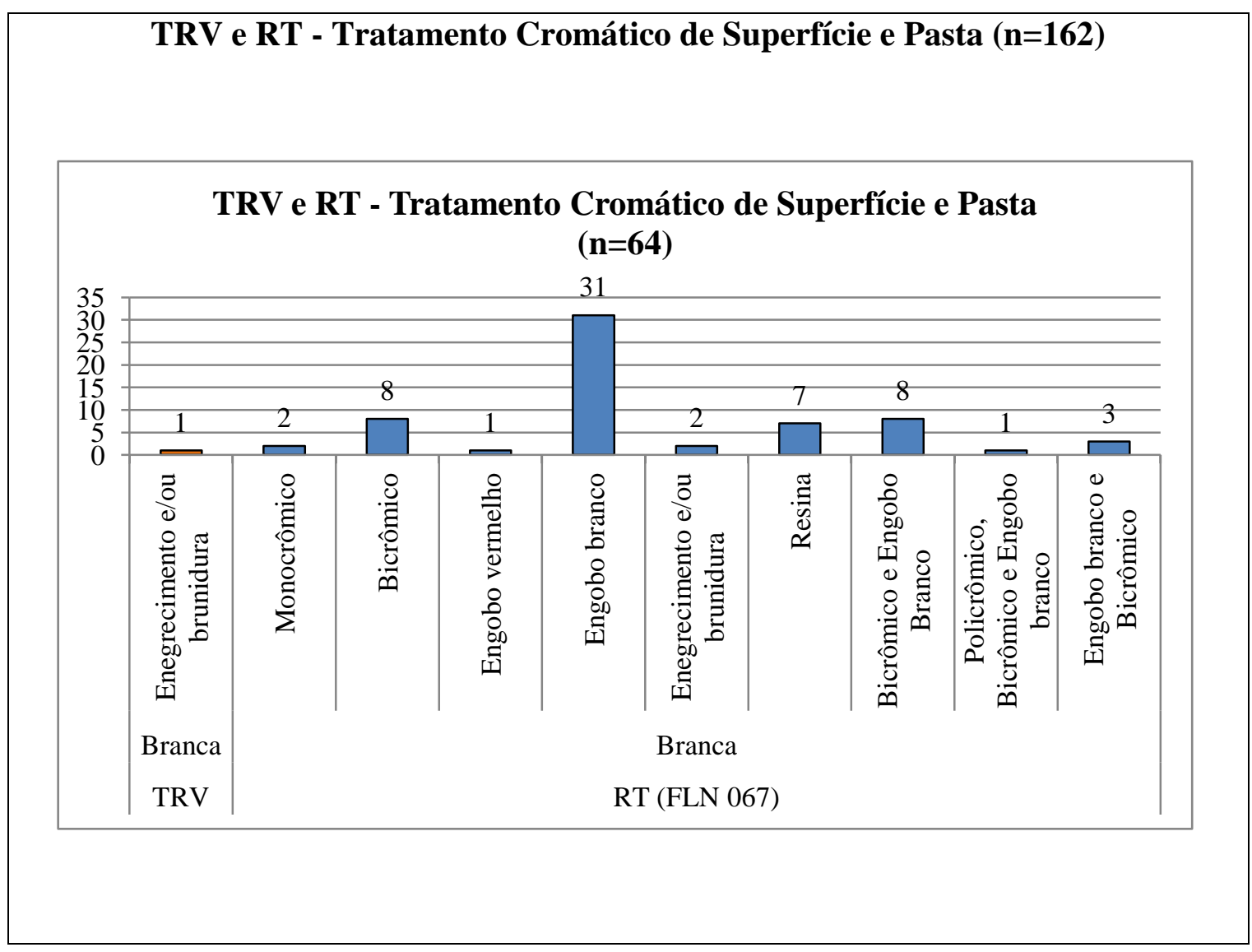




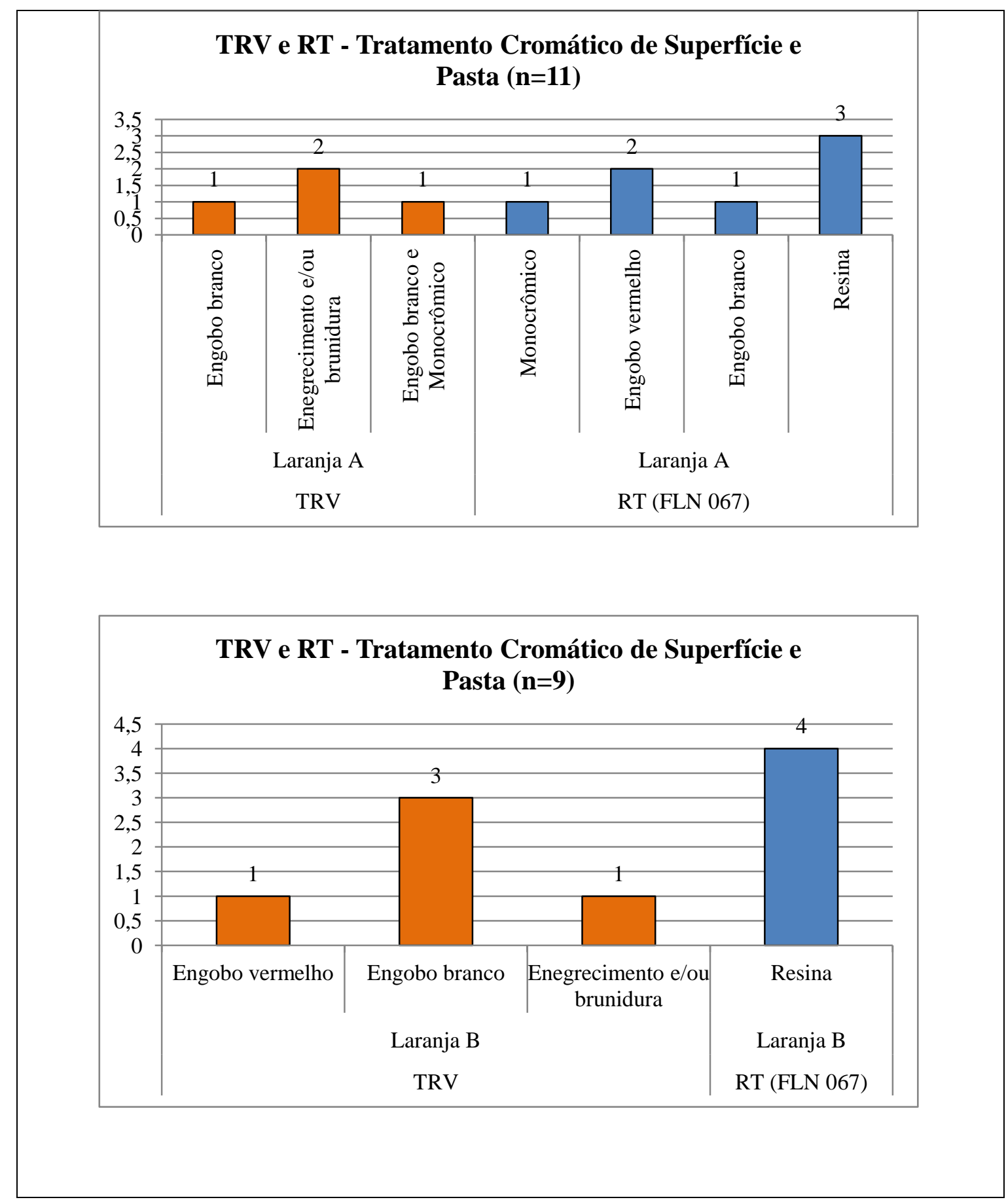




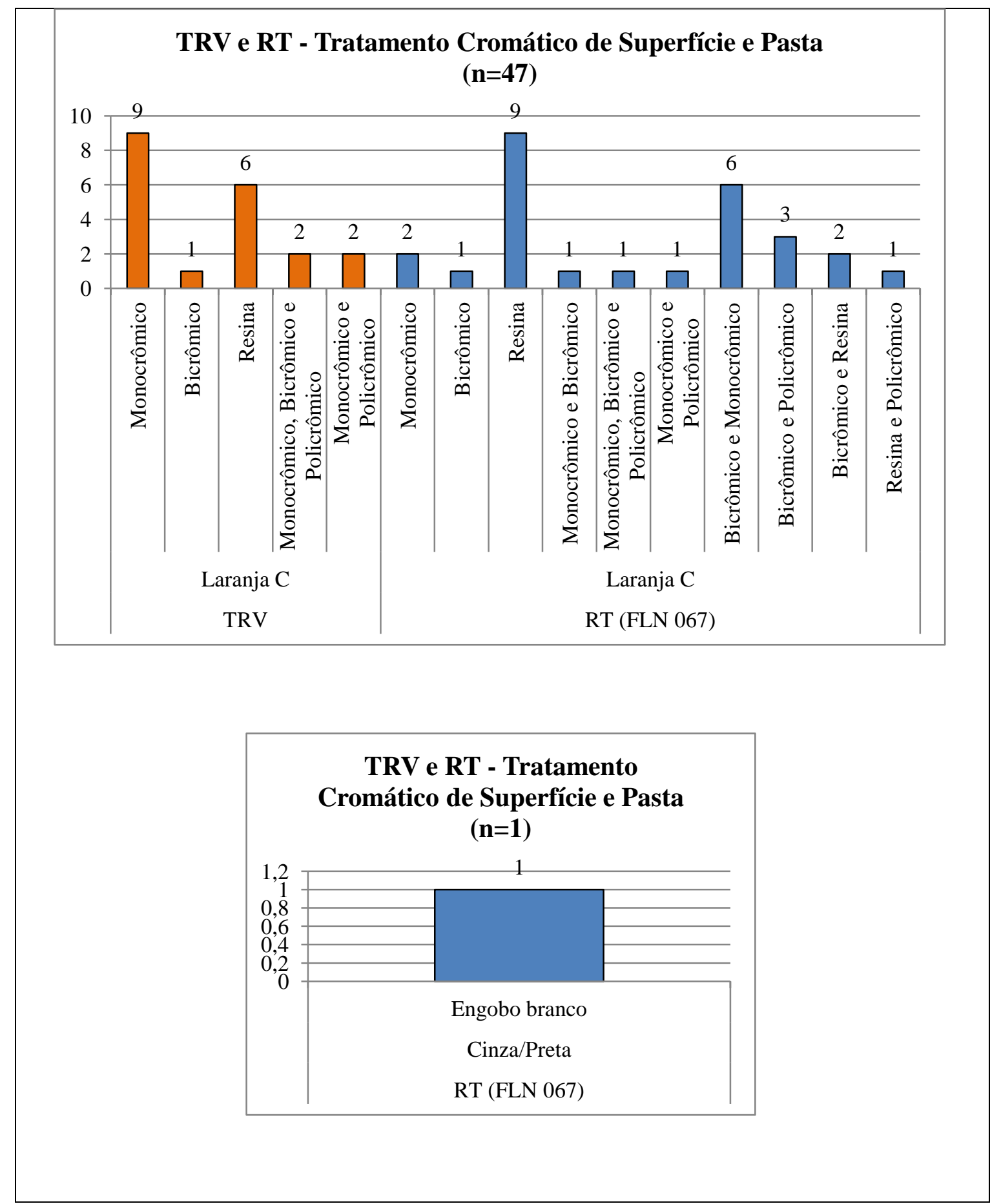

Figura 94. Relação entre os tratamentos cromáticos de superfície e as pastas encontrados nos fragmentos comparando os sítios arqueológicos TRV e RT.

A pasta branca na coleção RT é a mais comum, especialmente se associada aos tratamentos cromáticos (são 63 fragmentos), sendo 31 apenas com engobo branco. A coleção TRV apresenta um fragmento nessa modalidade, identificado com enegrecimento/brunidura. A pasta laranja A apresenta-se com mais tratamentos cromáticos em RT, ainda que as diferenças entre as coleções sejam ínfimas nesse caso 
(são 11 fragmentos, sendo 7 em RT e 4 em TRV). Observa-se, ainda, que resina apareceu RT em fragmentos de pastas laranja A, B e C somente. A resina apareceu em TRV somente na pasta laranja C. Pouca diferença numérica também é observada entre os tratamentos cromáticos em pasta laranja B (são 5 em TRV e 4 em RT). A pasta laranja $\mathrm{C}$ com tratamento cromático também ocorre praticamente em similaridade em ambas as coleções, sendo que a monocromia é mais abundante em TRV e a resina em RT. E somente uma amostra em RT apresentou tratamento cromático (engobo branco) na pasta de cor cinza/preta. Importante pontuar nos gráficos que, na maior parte dos casos, o engobo não serve de base à pinturas posteriores, ou por uma questão pósdeposicional, as pinturas não puderam ser identificadas atualmente.

Isso tudo significa que, além de já estar claro que a coleção RT possui mais fragmentos com tratamento cromático (sendo o engobo branco em grande profusão, nas pastas branca e laranja C), existe variabilidade de tratamentos cromáticos em ambas as coleções; ou seja, se os tratamentos cromáticos estão relacionados a vasilhas que, no geral, não vão ao fogo (LANDA, 1995, P.48), temos em ambas as coleções vasilhas para servir e armazenar. Não ocorrem padrões nas escolhas das pastas com determinados tratamentos cromáticos entre as coleções.

\subsubsection{Relação coloração da pasta-espessura das peças}

É possível observar uma relação entre usos de cores de pastas diferentes e as espessuras das peças $(\mathbf{m m})$. Nas pastas laranja $\mathrm{C}$ os fragmentos corrugados e ungulados estão em maior quantidade em espessuras médias na coleção TRV, assim como as pastas brancas com alisamento estão em maior quantidade nas mesmas espessuras na coleção RT (Figura 95). 

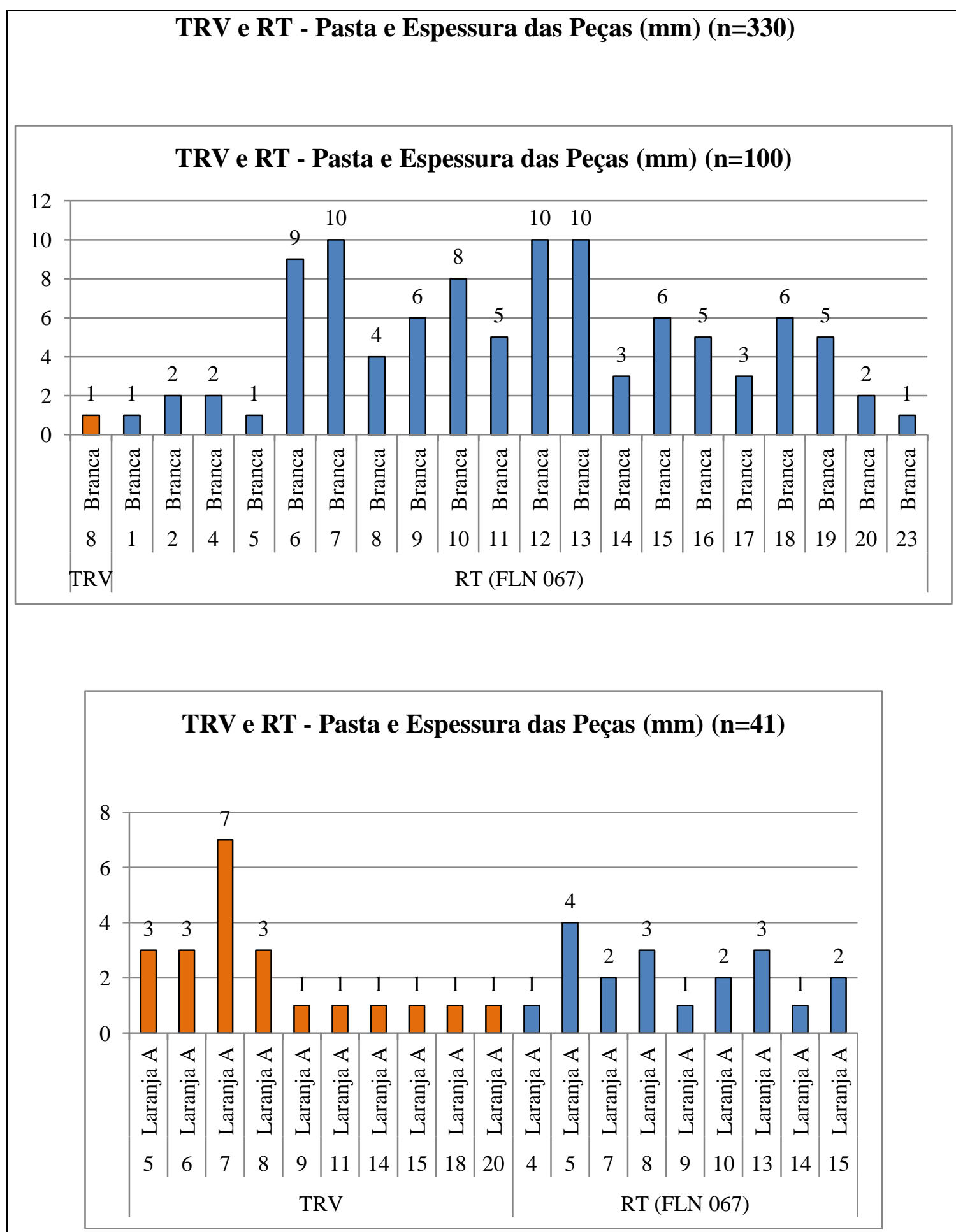

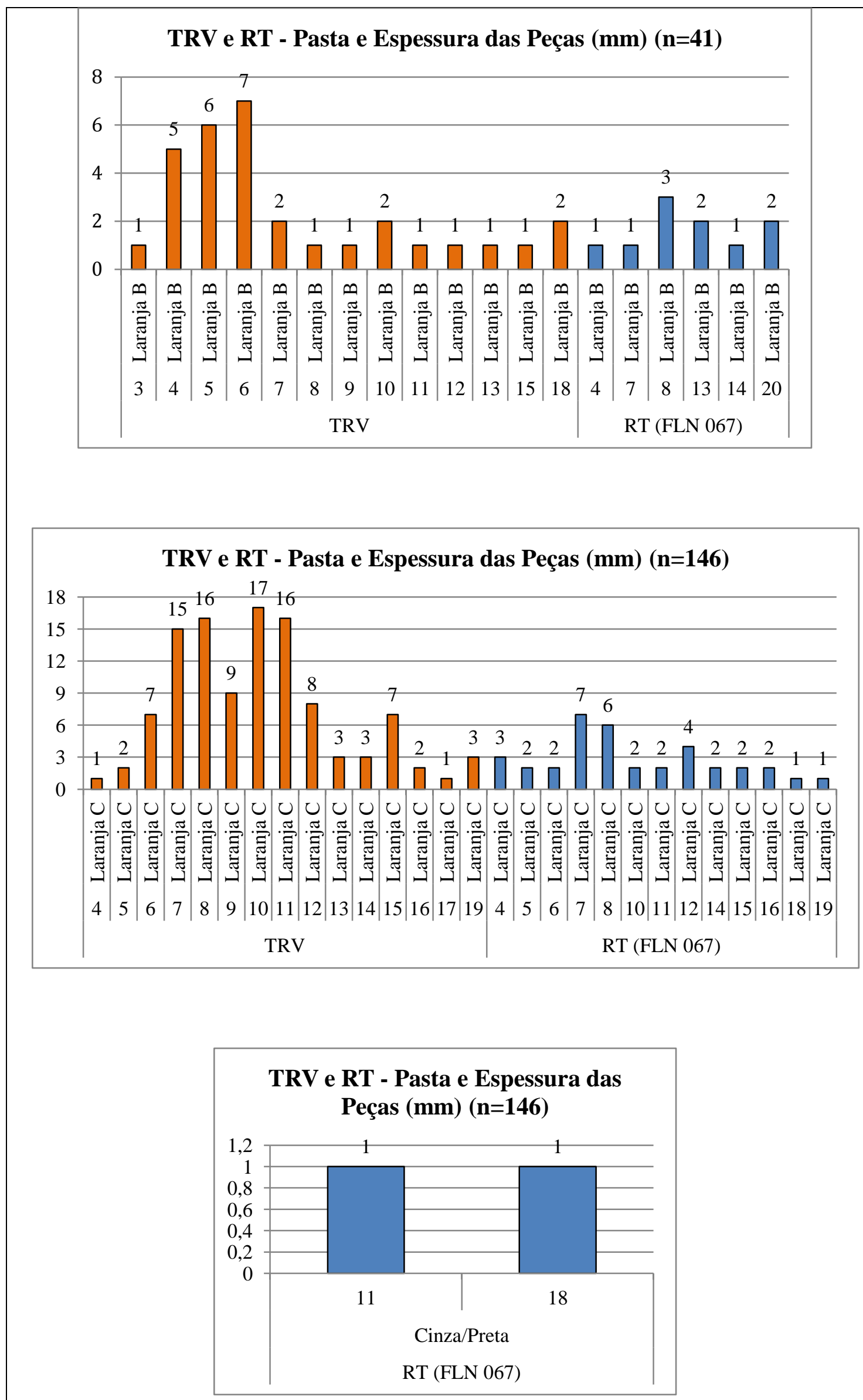
Figura 95. Relação entre as espessuras dos fragmentos e as pastas, comparando os sítios arqueológicos TRV e RT.

Há um número maior de fragmentos de espessuras de 6, 7, 12 e $13 \mathrm{~mm}$ com pasta branca. Na pasta laranja A, encontra-se 7 fragmentos com $7 \mathrm{~mm}$ (a maior recorrência observada). Na pasta laranja $\mathrm{B}$, há uma recorrência em 4, 5 e $6 \mathrm{~mm}$ na coleção TRV. Na pasta laranja C, há recorrências novamente na coleção TRV em 7, 8, 10 e $11 \mathrm{~mm}$. E na pasta cinza/preta apenas dois fragmentos foram identificados nas coleções (de 11 e $18 \mathrm{~mm}$ ). Ainda assim, essas relações se mostraram pouco satisfatórias, e apenas reforçam o que já vem sendo observado na análise das coleções: a faixa de 6 a $18 \mathrm{~mm}$ para coleção RT mais evidente em pastas branca, e uma faixa de 6 a $15 \mathrm{~mm}$ na coleção TRV mais evidente em pasta laranja C (TRV), sendo que a pasta laranja $\mathrm{C}$ em TRV apresenta todas as faixas de espessura (da menor à maior) e a pasta branca apresenta todas as faixas de espessura em RT. Isso quer dizer que, em sua grande parte, as vasilhas possuem a mesma faixa de espessura e não há uma relação direta entre espessura da peça e escolha da pasta pelos ceramistas Guarani que produziram ambas as coleções (mesmo que as espessuras menores - de até $7 \mathrm{~mm}$ - tenham aparecido em ambas as coleções em pastas de pouca evidenciação).

\subsubsection{Diâmetro das bordas}

Com relação ao diâmetro das bordas (cm) (Figura 96) projetado por meio do ábaco, há uma faixa maior de diâmetros na coleção RT (entre 16 e 56 cm) em comparação com a coleção TRV (10 a $48 \mathrm{~cm})$, ou seja, aparentemente há vasilhas de boca mais ampla na coleção RT. Esse resultado está relacionado diretamente com a amostragem obtida. Há algumas medidas que se repetem com maior frequência: $11.48 \%$ dos fragmentos apontam para diâmetro de $20 \mathrm{~cm}, 9.84 \%$ apontam para diâmetro de 54 cm e $13.11 \%$ apontam para diâmetro de $56 \mathrm{~cm}$ (coleção RT) e 22 e $48 \mathrm{~cm}$ aparecem com $3.28 \%$ cada na coleção TRV. Ou seja, é possível afirmar que há vasilhas mais amplas e, por isso, maiores em RT que em TRV, ainda que seja pouca a diferença, uma vez que existe uma premissa de relação direta entre diâmetro da borda e tamanho da vasilha projetada, porém, que deve ser testada com cautela. Isso é discutido de forma um pouco mais aprofundada no tópico 6.1.14. 


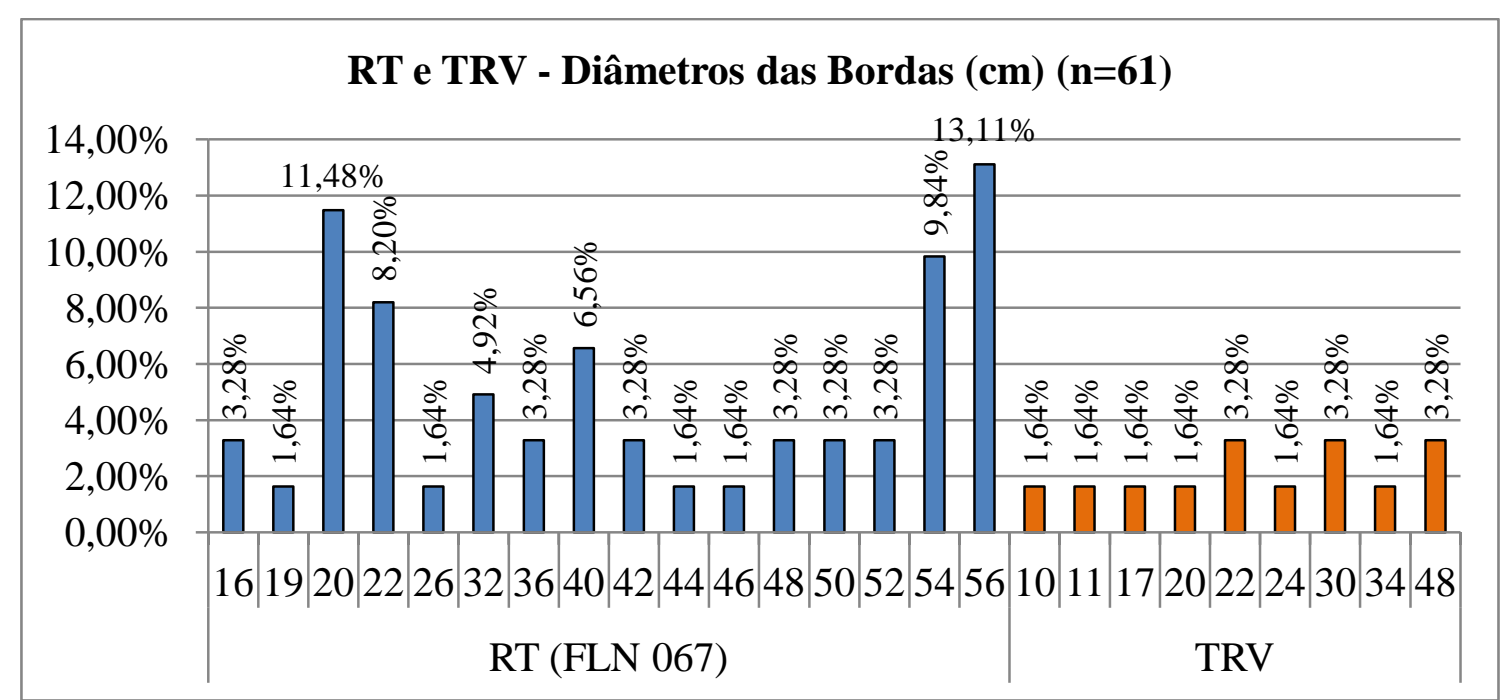

Figura 96. Gráfico com frequência dos diâmetros das bordas $(\mathrm{cm})$ encontradas nas coleções RT e TRV.

Ainda assim, essas informações sobre os diâmetros das bordas projetados deve ter em conta a porcentagem a que se refere o fragmento dentro uma vasilha (também observado através do ábaco). Assim, as bordas em RT sugerem responder de $1 \%$ a $10 \%$ das vasilhas, e em TRV de $2 \%$ a $17 \%$; sendo mais recorrente em RT os fragmentos que se referem a $2 \%, 2.5 \%$ e $3 \%$ (11.4\% dos fragmentos de borda) da vasilha e $1.5 \%, 4 \%$ e $6 \%$ (8.2\% dos fragmentos). Em TRV, foi mais comum o fragmento correspondente a $4 \%$ das vasilhas $(6.56 \%$ dos fragmentos de borda analisados). Isso revela que, então, as porcentagens de fragmentos de bordas são bastante pequenos para arriscar projeções de diâmetro exatas, mas que aquelas que foram obtidas na pesquisa podem e devem ser levadas em conta com cautela.

\subsubsection{Relação diâmetro das bordas - espessura das bordas}

Pensando nas dimensões possíveis das vasilhas inteiras com as informações de diâmetros das bordas (cm) (correspondente ao diâmetro de abertura das vasilhas) e espessuras (mm) das mesmas, é evidente que essas categorias possuem uma relação, e, no geral, quanto maior o diâmetro projetado, maior a espessura do fragmento. Milheira (MILHEIRA, 2010), em sua tese de doutorado que analisou o território Guarani no litoral sul catarinense, pode realizar um compilado bastante denso com relação a informações e interpretações intra e inter sítios das pesquisas realizadas em Arqueologia 
Guarani no sul do país até então, e seu trabalho é referência para os que seguem. Segundo esse autor (MILHEIRA, 2013, P.216), em artigo derivado de pesquisa, afirma que não se deve ler as espessuras dos fragmentos como indicadores diretos de que as espessuras medidas representam vasilhas inteiras, ou seja: não se pode pensar numa relação direta da paredes finas e vasilhas finas como consequência, ou espessuras grossas, consequentemente vasilhas grossas. Os gráficos indicando variação desses dados sugerem uma variação tipológica na coleção, que deve ser pensada junto ao estudo de projeção das vasilhas. A variação encontrada por ele nas coleções que analisou seria típica de coleções provenientes de aldeias, onde todos os tipos de vasilhas de diferentes funções são identificados.

Na coleção TRV, a variação da espessura e diâmetro das bordas (correspondente ao diâmetro de abertura das vasilhas) também demonstra diferentes funções. Ainda que neste trabalho de mestrado as projeções das vasilhas não tenham sido efetivadas em função de uma escolha metodológica, os dados obtidos de espessura dos fragmentos e diâmetro projetado somados à visualização dos espelhamentos dão bom avanço nesse sentido, não prejudicando essa interpretação, muito pelo contrário: auxiliam na interpretação das dimensões das vasilhas inteiras e não encerram ideias de formas estáticas para as vasilhas completos. Da mesma forma, essas duas categorias foram observadas e sistematizadas por Milheira (MILHEIRA, 2008) em outro artigo derivado de sua tese, em que considerou em suas análises que espessuras entre 12 e 36 $\mathrm{cm}$ de diâmetro com espessuras de 8 a $10 \mathrm{~mm}$ seriam correspondentes a vasilhas pequenas e médias; entre 12 e $50 \mathrm{~cm}$ de diâmetro e 10 e $12 \mathrm{~mm}$ de espessura seriam vasilhas pequenas a grandes; diâmetros de 20 a $56 \mathrm{~cm}$ com paredes de 10 a $22 \mathrm{~mm}$ seriam correspondentes a vasilhas médias e grandes; e diâmetros de 20 a 28 cm seriam correspondentes a vasilhas médias.

Portanto, a partir desses estudos foram pautadas a interpretação feita aqui sobre o tamanho das vasilhas nas coleções TRV e RT. A coleção TRV possuiria em sua maior parte, seguindo as bases dadas por Milheira, vasilhas pequenas a médias (com diâmetros de 10 a $48 \mathrm{~cm}$, predominando 22 e $48 \mathrm{~cm}$, com espessuras de 6 a $15 \mathrm{~mm}$ ), e em RT predominaria vasilhas médias a grandes (com diâmetros de 16 a $56 \mathrm{~cm}$, com maior ênfase em diâmetros de 20, 54 e $56 \mathrm{~cm}$ e espessuras de 6 a $18 \mathrm{~mm}$ ). 
A espessura das paredes das vasilhas está relacionada diretamente com a capacidade de aquecimento: paredes finas refletem alta capacidade de aquecimento e baixa resistência ao impacto; paredes grossas refletem alta resistência ao impacto e baixa capacidade de aquecimento (SCHIFFER E SKIBO, 1992, P.52). Esses dados podem ser pensados também sobre a questão da mobilidade dos objetos: se possuem baixa resistência ao impacto, pouco provável que sejam muito transportáveis e o contrário também é verdadeiro.

Ou seja, se temos vasilhas pequenas a médias com diâmetros de 10 a $48 \mathrm{~cm}$, predominando 22 e $48 \mathrm{~cm}$, com espessuras de 6 a $15 \mathrm{~mm}$ em TRV, essas vasilhas possuem alta capacidade de aquecimento (somado ao antiplástico mineral) e de baixa a média resistência ao impacto (ainda que o antiplástico mineral esteja em medida equilibrada para não favorecer quebras). Somado a isso, vimos que o tratamento de superfície plástico mais rugoso também favorece a capacidade de aquecimento das vasilhas, sendo predominante na coleção TRV. Esta seria, então, uma coleção excelente para ir ao fogo, mas de baixa a média resistência ao impacto (apesar das vasilhas pequenas e fáceis de manusear), não podendo ter sido transportada muito.

Em contrapartida, em RT predominam vasilhas médias a grandes com diâmetros de 16 a $56 \mathrm{~cm}$, com maior ênfase em diâmetros de 20, 54 e $56 \mathrm{~cm}$ e espessuras de 6 a $18 \mathrm{~mm}$, ou seja, com menor capacidade de aquecimento e alta resistência ao impacto apesar de possuir antiplástico mineral que favorece a quebra. Esse mesmo antiplástico mineral, como vimos no tópico 6.1.2, favorece a condutividade térmica (a capacidade de aquecimento), então, em RT apesar de a espessura desfavorecer sua capacidade de aquecimento, ela é contrabalanceada com os antiplásticos minerais presentes na pasta, e ainda possui resistência ao impacto. Ao ser resistente ao impacto, pode ser movida mais que a coleção TRV, mas tendo em conta o tamanho das vasilhas (médios a grandes), dificilmente eram transportados em longas distâncias. O tratamento de superfície cromático (mais evidente em RT) diminui a porosidade das vasilhas e favorece sua capacidade de armazenamento, mas diminui sua capacidade de ir ao fogo. Então, a coleção RT estaria mais propensa a não ser transportada constantemente e melhor utilizada para servir e armazenar alimentos/produtos. 
Ambas as coleções demonstram que as ceramistas possuíam um grande domínio empírico sobre a produção cerâmico segundo seu uso final dada a forma como foram conjugadas as características físico-químicas dos materiais utilizados e sua performance final.

\subsubsection{Relação diâmetro das bordas - configuração dos núcleos (queima)}

Sobre uma possível relação que pudesse ser estabelecida entre diâmetro das bordas (cm) (diâmetro de abertura das vasilhas) e configuração dos núcleos, as bordas em RT possuem as queimas 1, 3 e 5, e as bordas em TRV possuem as queimas 2, 3 e 5. Porém, não foi possível estabelecer mais nenhuma relação aprofundada com esses dois atributos juntos. Por fim, uma última relação que foi buscada e testada foi aquela entre a configuração dos núcleos e as cores das pastas. Mas na qual não foi encontrada relação alguma válida. Isso significa que a escolha do tipo de queima a ser realizado nas vasilhas independeu da coloração das pastas (e mesmo das argilas utilizadas). Ainda assim, essa relação não invalida o conhecimento de que a coloração da pasta, ou seja, coloração final que observamos na vasilha seja devido aos dois fatores: indicativos de queima e matéria-prima (argila e antiplástico).

\subsubsection{Conjuntos/ agrupamentos}

Os conjuntos observados (Figura 97) em cada coleção (9 na coleção RT e 8 na coleção TRV) também revelam considerações levantadas ao longo das análises e observadas a partir dos gráficos trabalhados até então, uma vez que esses conjuntos são formados pela similaridade entre cor de pasta, tratamentos de superfície e espessuras das peças. Observa-se que a maior parte das peças em ambos os conjuntos se encontra nos conjuntos 1 e 2 de cada coleção, e foram agrupados assim propositalmente, e são conjuntos que congregam espessuras medianas, tratamentos plásticos e cromáticos mais frequentes na coleção de modo geral e apresentam as cores de pasta predominantes em cada coleção. 


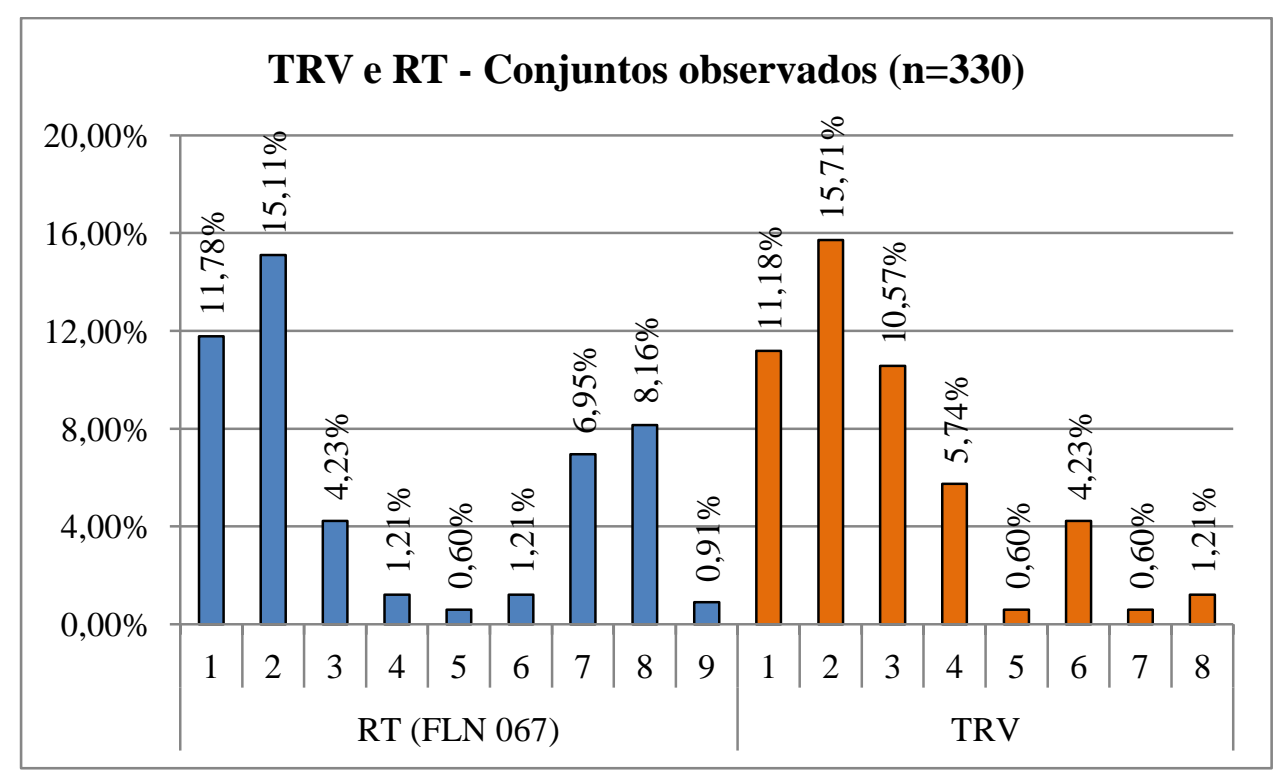

Figura 97. Gráfico em porcentagem com os conjuntos observados nas coleções RT e TRV.

\subsection{Análise arqueométrica por Fluorescência de Raios-X}

\subsubsection{Núcleo dos fragmentos}

Nas Figuras 98 a 107 apresentam-se os histogramas com os valores de área do pico calculado para cada elementos selecionado nos núcleos das pastas. As medidas apresentadas são as do silício ( $\mathrm{Si}$ ), alumínio (Al), fósforo $(\mathrm{P})$, enxofre $(\mathrm{S})$, potássio $(\mathrm{K})$, cálcio $(\mathrm{Ca})$, manganês $(\mathrm{Mn})$, ferro $(\mathrm{Fe})$, zinco $(\mathrm{Zn})$ e estrôncio $(\mathrm{Sr})$, uma vez que sua interpretação é mais direta e prática de discutirmos com as análises macroscópicas posteriormente. Imagens de todas as amostras selecionadas para a análise de XRF estão no CATÁLOGO DE VESTÍGIOS CERÂMICOS (ANEXO 07). 


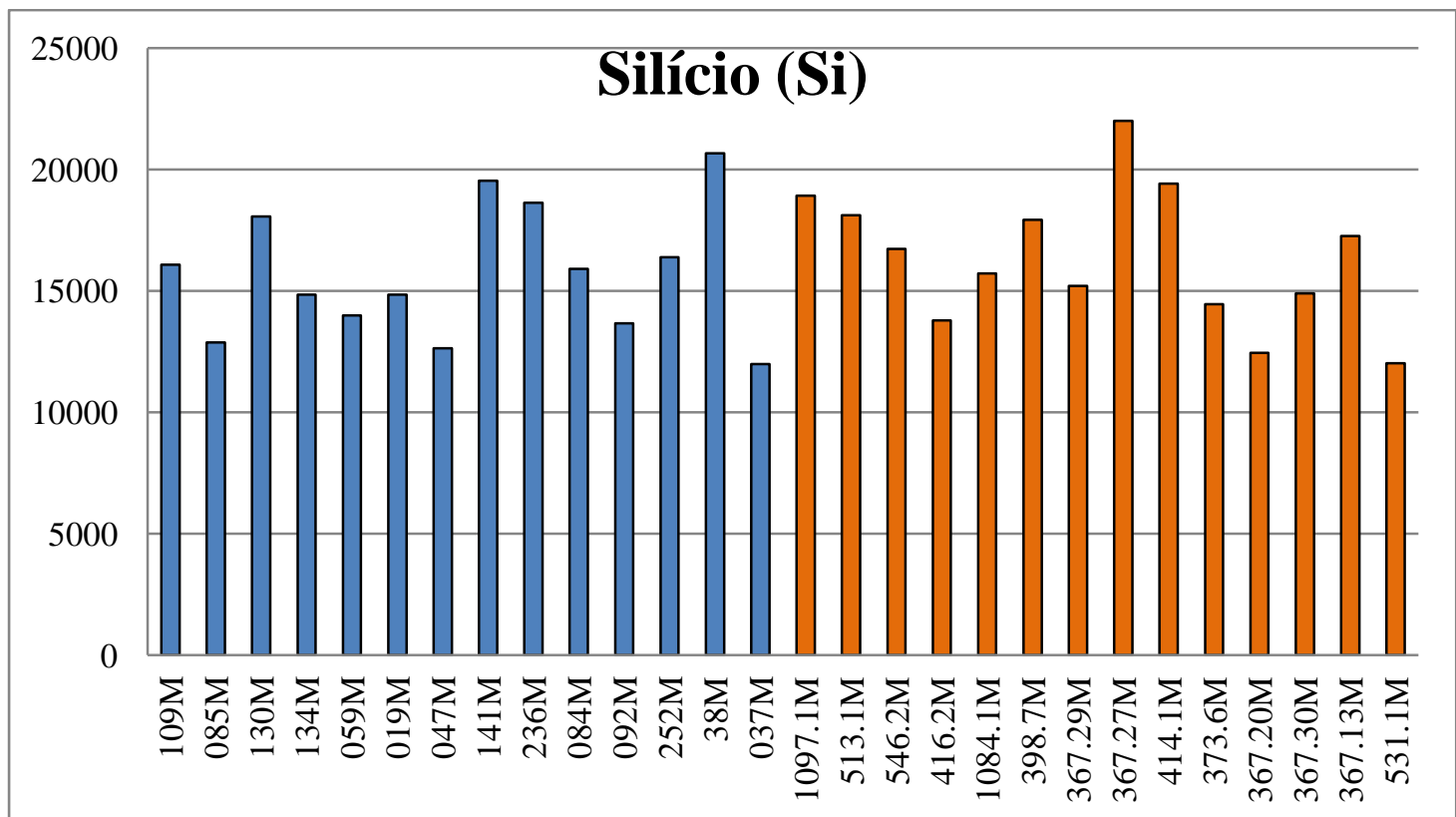

Figura 98. Gráfico representando a área calculada do pico para o elemento químico silício no núcleo das amostras. As barras em azul correspondem ao sítio Lagoinha do Rio Tavares I e em laranja ao sítio Travessão do Rio Vermelho.

O silício ( $\mathrm{Si}$ ) (Figura 98) encontra-se presente em todas as amostras em abundância (por ser a base das argilas, que são aluminossilicatos) e talvez em algumas mais que em outras devido a alguma ação pós-deposicional. As amostras foram higienizadas a seco e algumas impurezas podem ter restado nos materiais, ou seja, sedimento do depósito em que estava implantado o sítio arqueológico e que foi capturado na análise de raios-x. Tanto o alumínio quanto o silício se comportam de forma distinta nas faces dos materiais. 


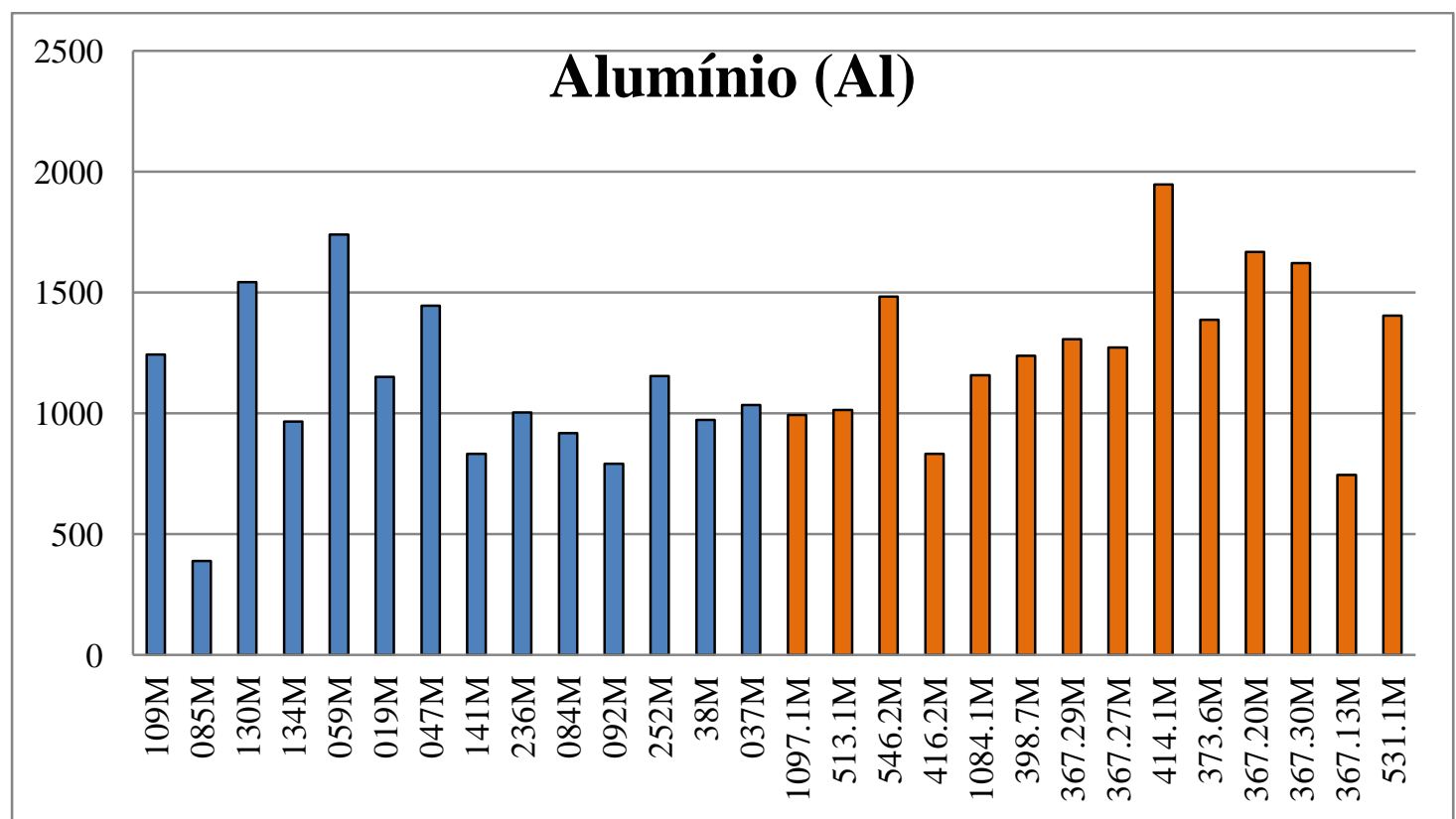

Figura 99. Gráfico representando a área calculada do pico para o elemento químico alumínio no núcleo das amostras. As barras em azul correspondem ao sítio Lagoinha do Rio Tavares I e em laranja ao sítio Travessão do Rio Vermelho.

Como é possível observar na Figura 99, o elemento químico alumínio (Al) não se apresentou como um bom visualizador de agrupamentos no gráfico, uma vez que se encontra presente na composição da argila junto ao silício (Si) (SHEPARD, 1956, P.6). De acordo com a fonte de matéria-prima e diferentes tipos de argila, as concentrações de alumínio e silício variam. Aparece em todas as amostras de forma heterogênea, ou seja, demonstra variabilidade, assim como o silício, mas não permite agrupar amostras.

Além de $\mathrm{Al}$ e $\mathrm{Si}$, as argilas apresentam mais elementos em concentrações menores que $\mathrm{Al}$ e $\mathrm{Si}$, e esses elementos serão exploradas na sequência. A variação de outros elementos se deve aos traços geológicos existentes nas fontes de matérias-primas (formação da matéria-prima utilizada para a pasta), aos usos das vasilhas (que deixam resquícios físico-químicos) e ações pós-deposicionais que atuaram sobre os vestígios.

O fósforo (Figura 100) também foi encontrado nas medidas, mas em quantidades muito superiores nas faces dos fragmentos (como visto na apresentação dos resultados para cada sítio arqueológico). Nos núcleos, ficou bastante evidente a separação em dois grupos, praticamente distinguindo as amostras entre ambos os sítios, a não ser por três exceções no agrupamento de amostras referente ao sítio RT. O fósforo ocorre em grande quantidade, por exemplo, na cerâmica arqueológica da Amazônia (em formato de fosfatos de alumínio) e na terra preta antropogênica (TPA) da Amazônia e 
está relacionado ao material orgânico. Uma hipótese é a de que os fosfatos se formam nos vasos cerâmicos durante o cozimento/seu uso, com o fósforo provindo de alimentos, como Duma (DUMA, 1972, P.128) propôs de acordo com modelos também experimentais que o fósforo na forma de fosfato estaria relacionado ao uso das vasilhas, que teriam enriquecido de fósforo de acordo com as substâncias orgânicas que um dia as vasilhas contiveram.

Posteriormente, Dunnell e Hunt (DUNNELL \& HUNT, 1990), utilizando a fluorescência de raios-X indicaram que os níveis de fósforo não eram devidos necessariamente aos conteúdos orgânicos das vasilhas. Eles demonstraram que o fósforo deverá ser avaliado num conjunto, levando em consideração a composição das matériasprimas, o uso das vasilhas e a interação com o ambiente deposicional e sua mudança de composição. Por isso, para haver uma definição melhor da origem do fósforo, se é devida ao uso da vasilha ou se faz parte da argila ou de aspectos pós-deposicionais, é necessário ocorrerem análises do sedimento do sítio arqueológico e da argila proveniente de possíveis fontes de matéria-prima para que seja possível uma inferência mais assertiva. De qualquer forma, o fósforo encontra-se presente nos núcleos dos fragmentos, portanto, na pasta, ainda que em menor quantidade que o fósforo das faces. Ou seja, pode-se dizer que ele está presente na matéria-prima das vasilhas. Já o alto teor de fósforo das faces pode ser tanto em decorrência do uso quanto de ações pósdeposicionais (será explorado mais adiante).

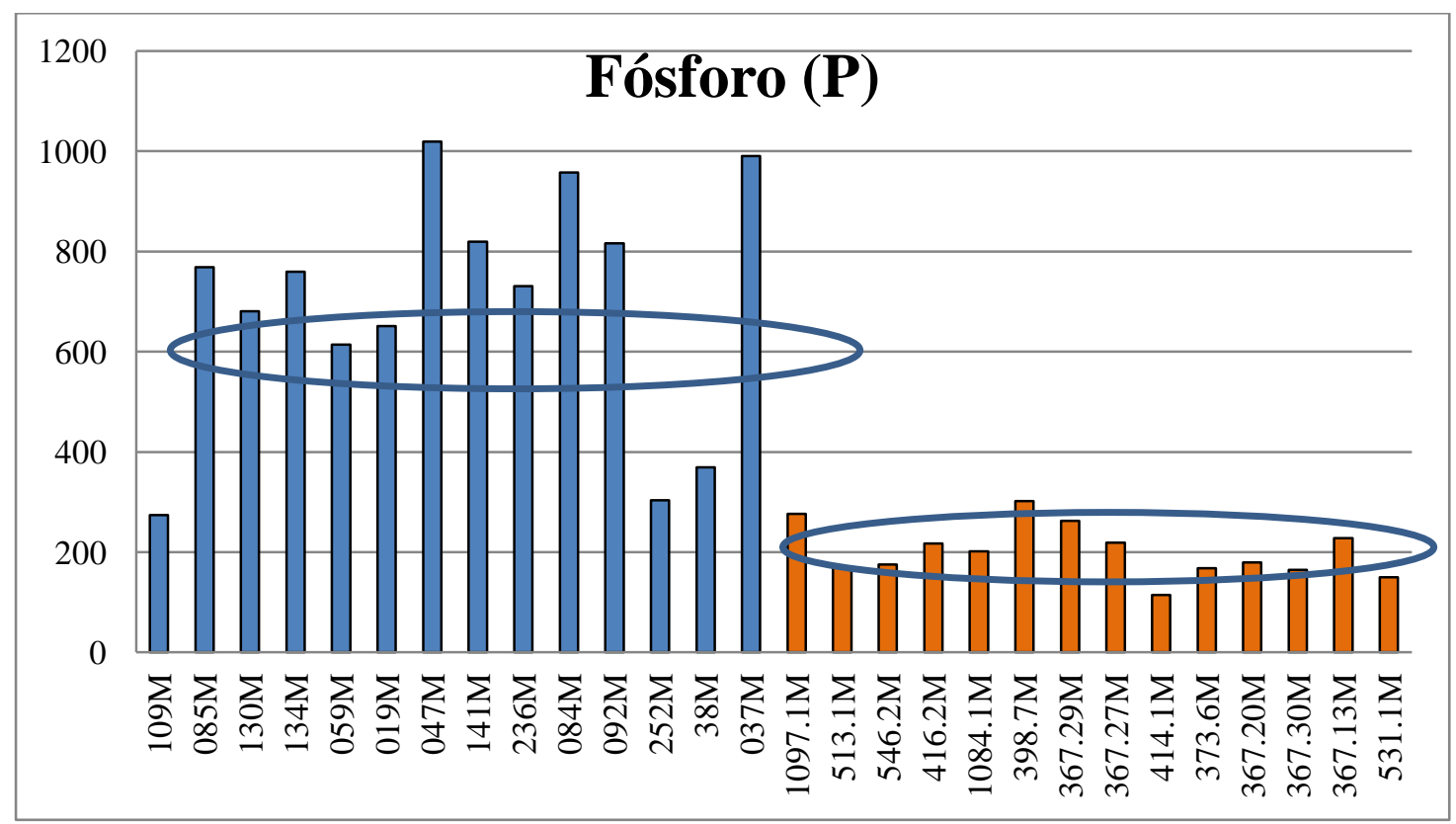

Figura 100. Gráfico representando a área calculada do pico para o elemento químico fósforo no núcleo 
das amostras. As barras em azul correspondem ao sítio Lagoinha do Rio Tavares I e em laranja ao sítio Travessão do Rio Vermelho.

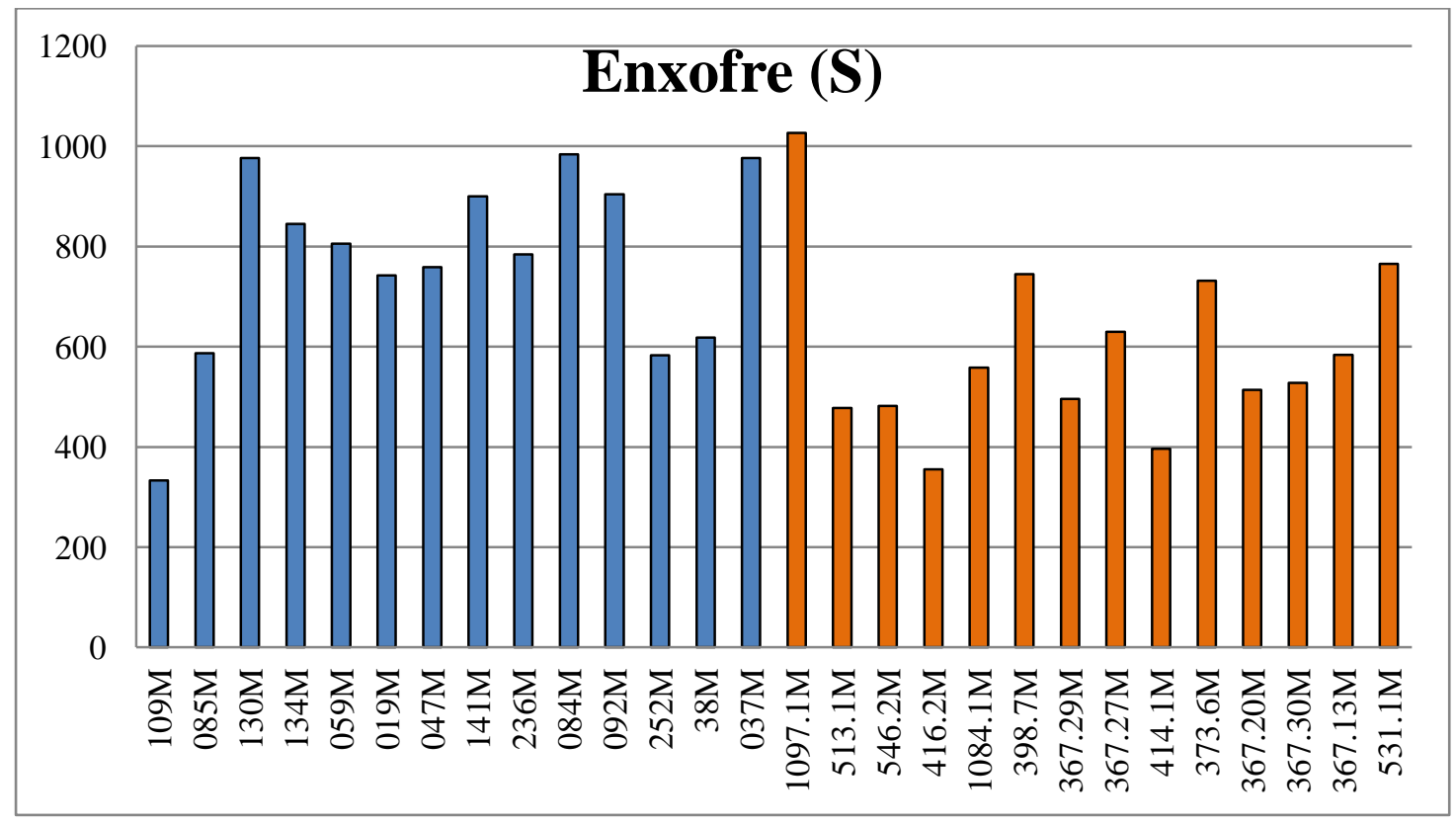

Figura 101. Gráfico representando a área calculada do pico para o elemento químico enxofre no núcleo das amostras. As barras em azul correspondem ao sítio Lagoinha do Rio Tavares I e em laranja ao sítio Travessão do Rio Vermelho.

Há uma certa homogeneidade no que concerne ao elemento químico enxofre (S) entre as amostras do sítio RT (Figura 101), em contrapartida, as amostras do TRV encontram-se bastante heterogêneas na presença desse elemento.

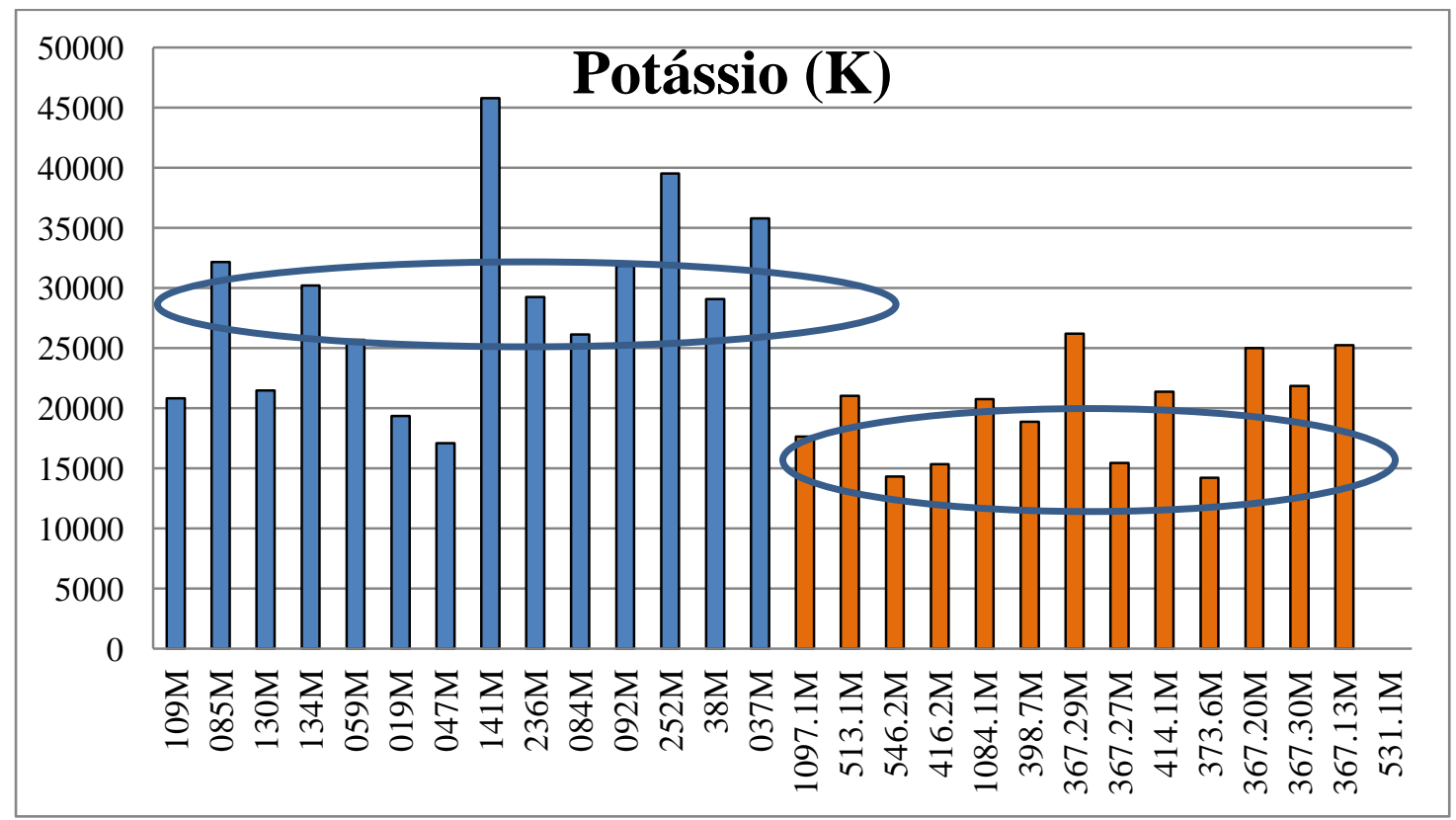

Figura 102. Gráfico representando a área calculada do pico para o elemento químico potássio no núcleo 
das amostras. As barras em azul correspondem ao sítio Lagoinha do Rio Tavares I e em laranja ao sítio Travessão do Rio Vermelho.

Existe uma variação para o elemento químico potássio $(\mathrm{K})$, também presente nos núcleos das pastas e em menor quantidade que $\mathrm{Al}$ e $\mathrm{Si}$, conforme observado na Figura 102. De modo geral, há dois grupos: um mais homogêneo com as amostras do TRV (com menos Potássio); e outro mais heterogêneo com as amostras do RT (com maior presença do elemento).

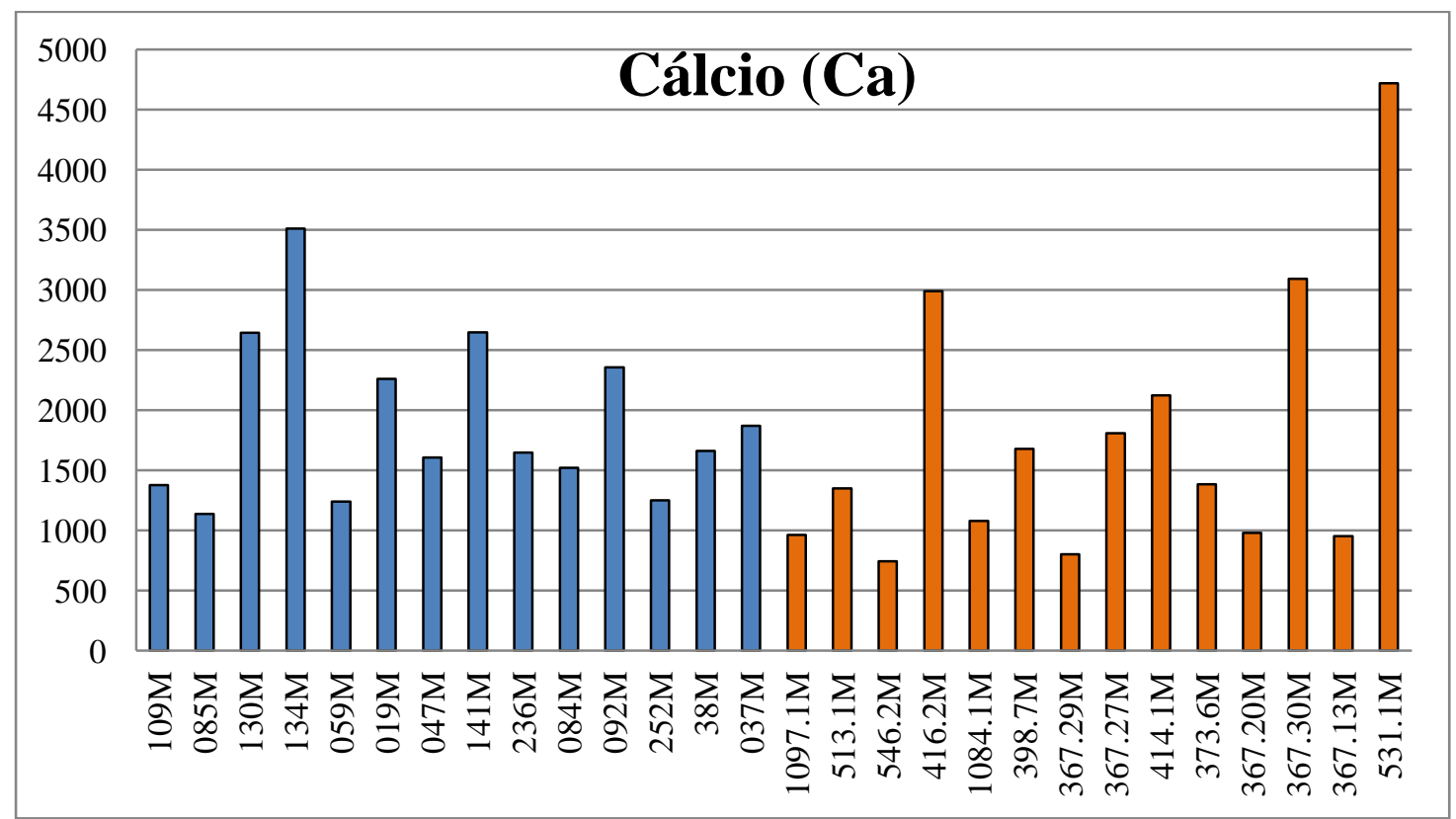

Figura 103. Gráfico representando a área calculada do pico para o elemento químico cálcio no núcleo das amostras. As barras em azul correspondem ao sítio Lagoinha do Rio Tavares I e em laranja ao sítio Travessão do Rio Vermelho.

Já com o elemento químico cálcio (Ca) (Figura 103), encontramos variação entre as amostras e parece haver três agrupamentos: picos maiores (3500 a 5000 de área), médios (1500 a 3499 de área) e menores (de zero a 1499 de área). Nos picos maiores estão duas amostras, uma de cada sítio: RT.I.1.64.134 (RT) e 531.1 (TRV). Uma pesquisa publicada por Ikeoka et.al. (2010) sobre fragmentos cerâmicos do sambaqui da Bacanga (MA) demonstrou que esses vestígios possuíam em sua composição os elementos $\mathrm{Fe}, \mathrm{Ca}, \mathrm{Sr}, \mathrm{Zr}, \mathrm{Mn}$, Ti e Zn (IKEOKA et.al., 2010, P.65) e a interpretação que é feita é de que o Ca do depósito, associado à decomposição das conchas do sambaqui, teria aderido ao material cerâmico. Na mesma linha de raciocínio, o Ca presente nas amostras aqui analisadas pode estar aderido à superfície da cerâmica e ser pós-deposicional em virtude das conchas existentes nos depósitos, ou ser devido ao uso das vasilhas, uma vez que as quantidades maiores de Ca estão nas faces dos fragmentos. O $\mathrm{Ca}$ ser proveniente dos depósitos é consistente com o que foi 
documentado na escavação arqueológica do TRV: presença de conchas em boa parte da área $\mathrm{B}$, sendo que bastante próximo às três quadras selecionadas para análise havia outras três possíveis estruturas de combustão com conchas em seu interior e conchas esparsas em todo o sítio arqueológico. No sítio RT não foram descritas conchas no depósito, mas ambos os sítios possuem quantidades similares de Ca. Existe uma variabilidade, então, ou a quantidade de conchas nos depósitos é desigual, ou, é mais provável que esse $\mathrm{Ca}$ seja em grande parte proveniente do uso de vasilhas para processamento de alimentos, nesse caso, em função no ambiente litorâneo, processamento de animais com ossos.

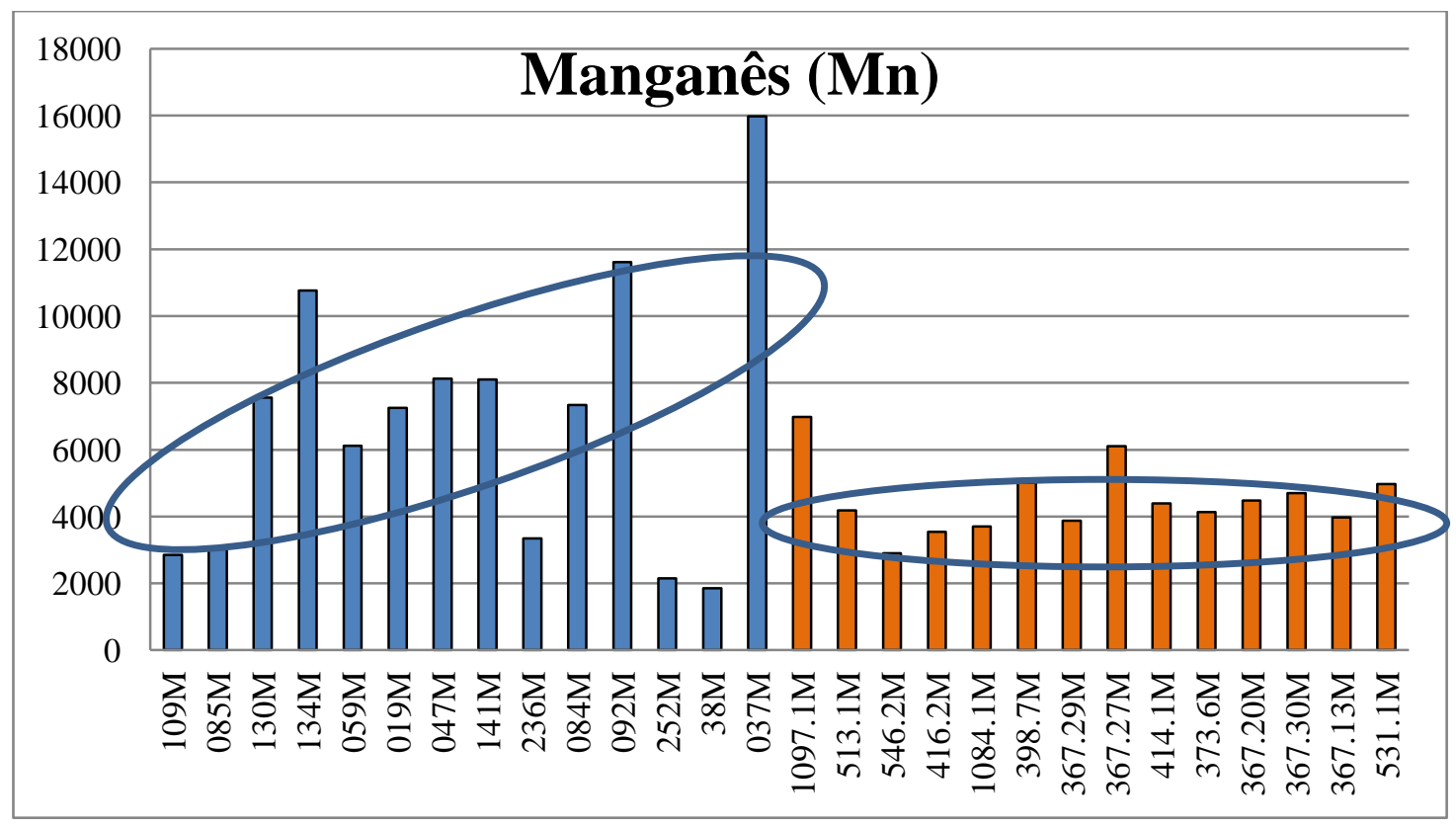

Figura 104. Gráfico representando a área calculada do pico para o elemento químico manganês no núcleo das amostras. As barras em azul correspondem ao sítio Lagoinha do Rio Tavares I e em laranja ao sítio Travessão do Rio Vermelho.

Já o manganês $(\mathrm{Mn})$ apresenta boa separação entre as amostras, menos presente nas amostras do TRV e de forma homogênea (Figura 104). Nas amostras do TRV, observa-se homogeneidade maior, porém as amostras de RT representam conter mais Mn. Esse elemento também está presente em outros resultados de análises de XRF, como em Ikeoka et.al. (2010) e Appoloni et.al (2001), interpretado pelos autores como presente nas fontes de argila. Crê-se que, para as coleções TRV e RT, o manganês, além de estar presente nas fontes de matéria-prima em níveis diferentes (pois além da variabilidade entre ambas as coleções observada nas medidas dos núcleos, há 
variabilidade interna em cada uma delas) encontra-se mais abundante nas faces dos fragmentos, o que indica que o manganês está fortemente relacionado ao manganês dos depósitos em que estavam os fragmentos cerâmicos arqueológicos.

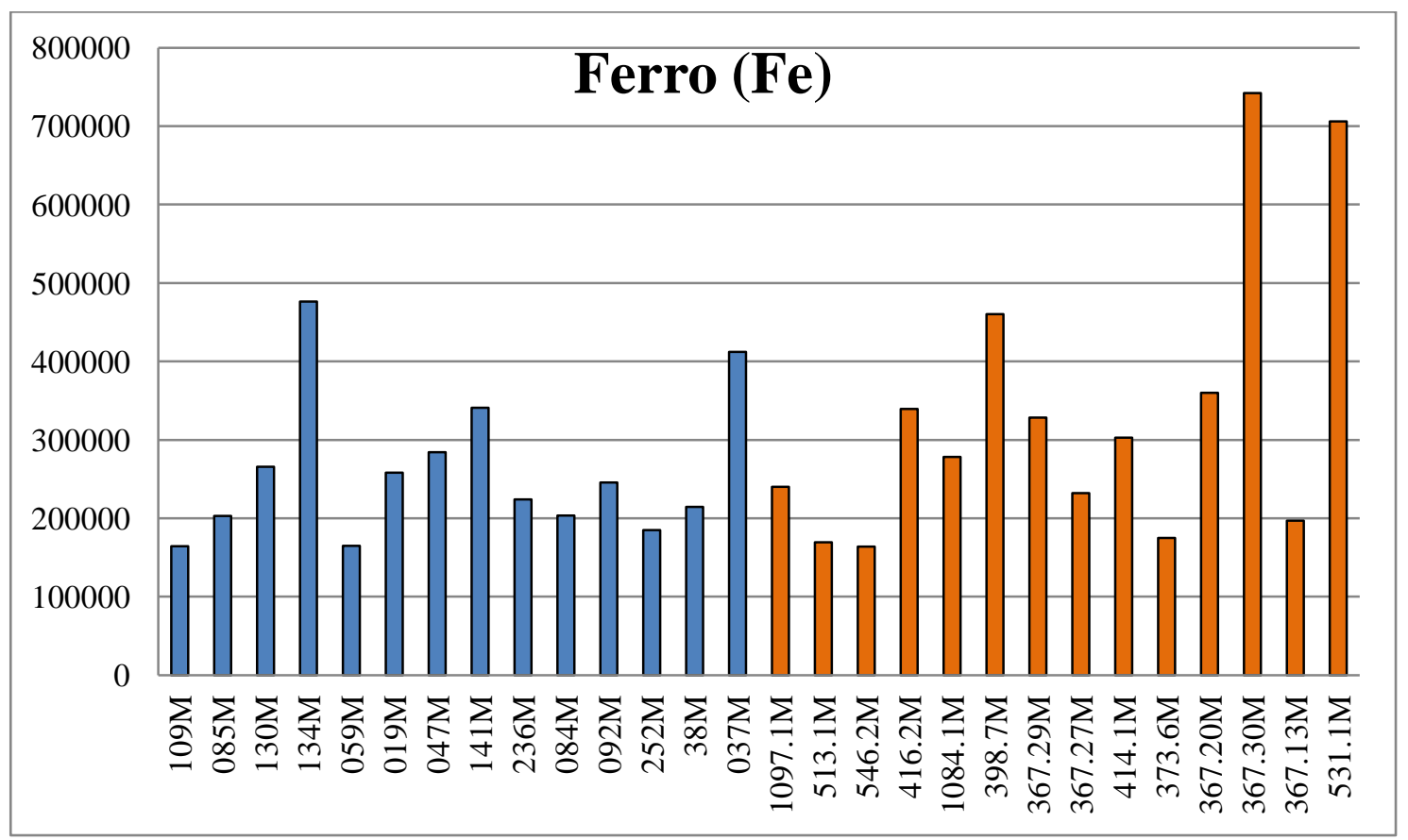

Figura 105. Gráfico representando a área calculada do pico para o elemento químico ferro nas amostras. As barras em azul correspondem ao sítio Lagoinha do Rio Tavares I e em laranja ao sítio Travessão do Rio Vermelho.

O Ferro (Fe), ao primeiro olhar na Figura 105, encontra-se em maior quantidade em três amostras do TRV e em duas algumas amostras do RT. Como já observado na apresentação dos resultados para cada coleção, o Fe está em maior quantidade nas pastas de ambas as coleções que em suas faces. E, a quantidade de $\mathrm{Fe}$ nos núcleos das amostras do TRV apresenta-se mais heterogênea, ao contrário daquelas em RT. A amostra 367.30 (TRV) trata-se de uma base classificada macrovisualmente em conjunto de pasta laranja B (conjunto 3). A amostra TRV.531.1 também foi classificada/agrupada na pasta laranja $\mathrm{B}$, lembrando que há amostras no gráfico da Figura 105 representando os três tipos de pastas laranja observadas nas coleções (pastas laranja A, B e C). As pastas laranja A macrovisualmente apresentam coloração de fato alaranjada; as pastas laranja B apresentam aspecto avermelhado; e as pastas laranja C apresentam aspecto em tom de marrom. Essas diferenças estão documentadas a partir das colorações representadas pelo Munsell. Observando físico-quimicamente parece haver certa distinção entre essas colorações de pasta associada à presença de Fe. Pouca 
diferença é observada entre as amostras de pasta laranja A e C, considerando que uma grande quantidade de Fe está associado à coloração mais "avermelhada" da pasta. Aqueles fragmentos de pasta laranja A estão apresentados no gráfico como os picos em 416.2, 1084.1 (TRV) (mesmo este estando com queima redutora), 398.7, 367.29, 367.20. As demais amostras de TRV são representadas macrovisualmente por pasta laranja C, ou branca, TRV.1097.1. Esta última amostra (TRV.1097.1, de pasta branca) apresentou valores similares de ferro que as pastas laranja $\mathrm{C}$, mesmo sendo esperado que apresentasse valores bastante inferiores de Fe. RT também apresenta grandes quantidades de Fe mesmo que a coloração avermelhada não esteja expressa macrovisualmente na pasta. Isso demonstra que as colorações das coleções não dependem totalmente da quantidade de Fe na matéria-prima e, por consequência, nas pastas cerâmicas. Essa quantidade influencia mas não denomina a coloração sozinha. Isso quer dizer que as análises reafirmam que a coloração observada macrovisualmente depende das fontes de matéria-prima da pasta, mas também de sua queima.

Ainda que a eficiência do equipamento de medição seja desigual para os elementos (possui alta eficiência para o ferro e baixa para alumínio e silício por exemplo) (MOTA, 2017, P.69), ao comparar os gráficos sobre as medidas do ferro somente, é possível estabelecer inferências; o que não quer dizer que haja mais ferro que alumínio ou silício nas pastas, pois na prática ocorre o contrário. O ferro também poderia ser proveniente da ação antrópica, se houverem óxidos de ferro e adicionados à pasta cerâmica. No entanto, ainda que tenhamos identificados poucos antiplásticos de óxidos de ferro, os resultados demonstram que há uma variabilidade grande de fontes de argila utilizadas nas pastas (assim como os dados do silício e alumínio demonstram. 


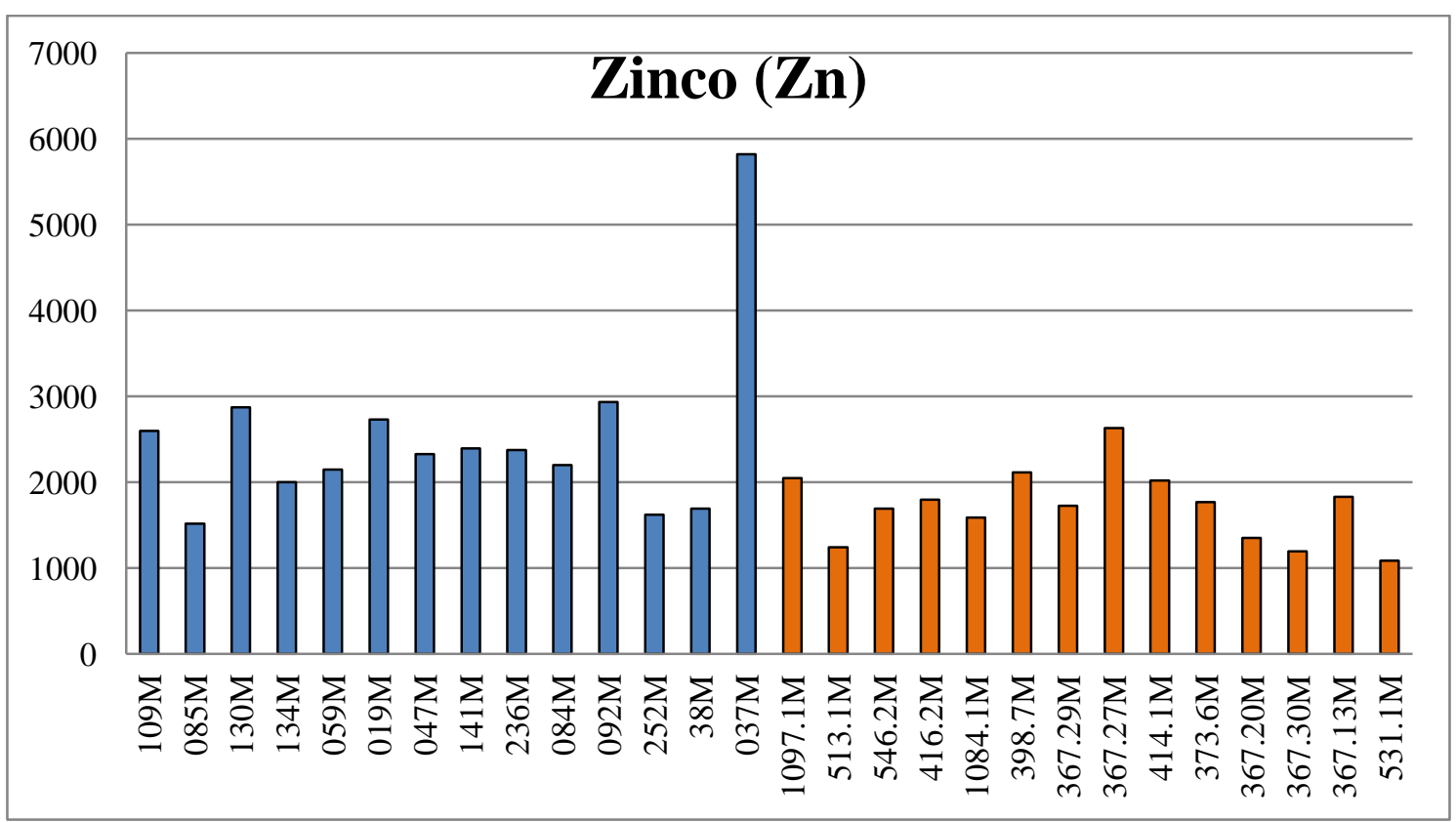

Figura 106. Gráfico representando a área calculada do pico para o elemento químico zinco no núcleo das amostras. As barras em azul correspondem ao sítio Lagoinha do Rio Tavares I e em laranja ao sítio Travessão do Rio Vermelho.

Já com relação ao zinco (Zn) na Figura 106, os picos demonstram-se bem homogêneos, a não ser pela amostra 037 (RT), a qual, pelo mesmo motivo com o Ti apresenta esse pico elevado. A medida foi feita em cima de corretivo (material de papelaria) utilizado para a base da numeração da peça.

Já, no que se refere ao elemento estrôncio (Sr), o encontramos em maior quantidade nas amostras do RT (Figura 107). 


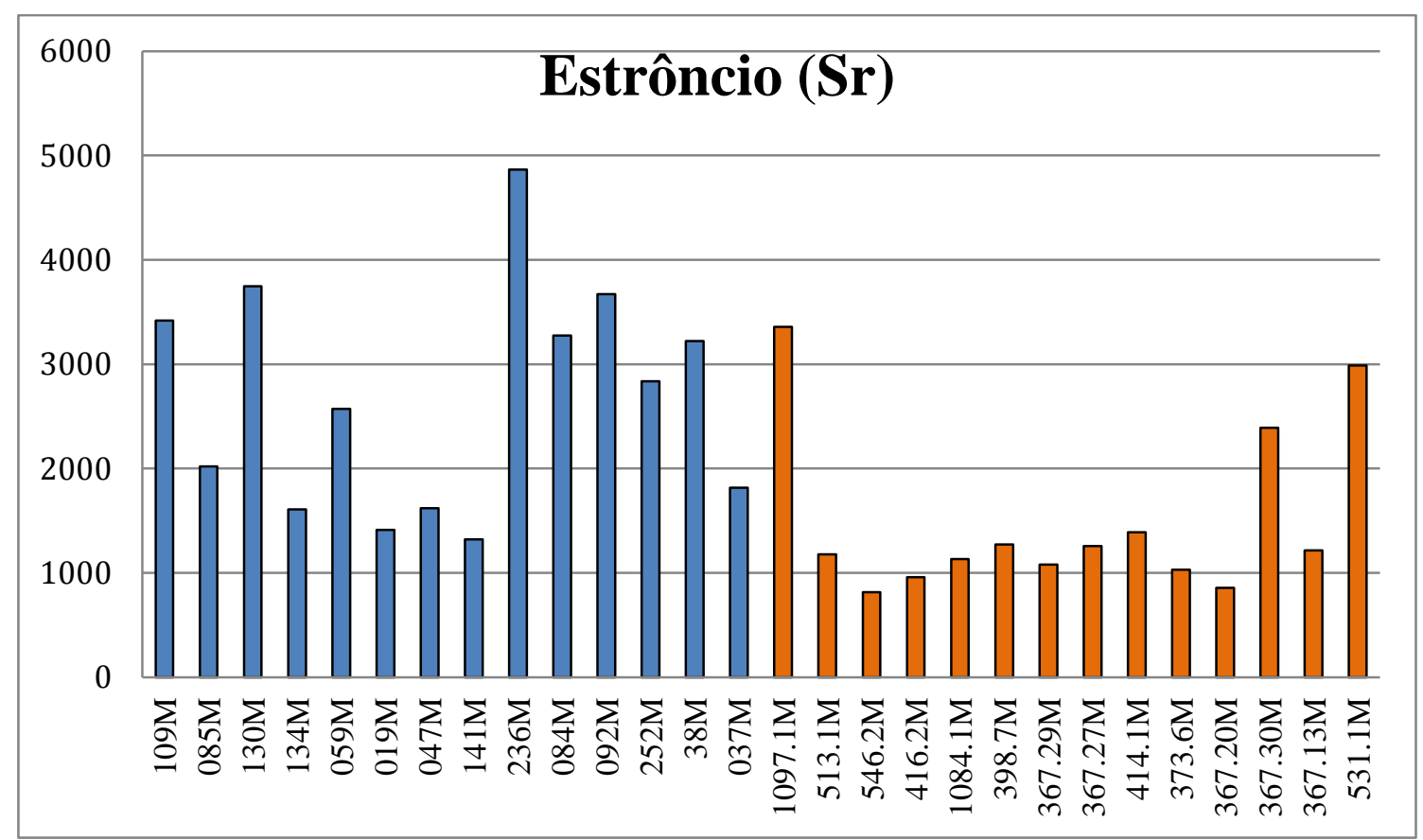

Figura 107. Gráfico representando a área calculada do pico para o elemento químico estrôncio no núcleo das amostras. As barras em azul correspondem ao sítio Lagoinha do Rio Tavares I e em laranja ao sítio Travessão do Rio Vermelho.

As medidas dos núcleos das pastas indicam que há uma separação dos conjuntos de cerâmicas dos sítios RT e TRV com relação aos elementos químicos manganês $(\mathrm{Mn})$, potássio $(\mathrm{K})$ e fósforo $(\mathrm{P})$. Essa diferenciação pode corresponder com diferenças no local de captação da argila para a produção da pasta cerâmica. Observamos também variações individuais com relação aos elementos ferro $(\mathrm{Fe})$, cálcio (Ca), zinco ( $\mathrm{Zn}$ ), e enxofre (S). Ainda, os elementos Sr, P, K, S, Ti, Mn, Sr apresentam alguns picos maiores em $\mathrm{RT}$, enquanto que $\mathrm{Fe}$ e $\mathrm{Ca}$ aparecem com picos maiores em TRV. No entanto, importante evidenciar que o que medimos não se trata do sedimento do sítio arqueológico, tampouco da argila pura que compôs a pasta que analisamos. As medidas representam o produto final da coordenação entre matéria-prima (argila e antiplásticos) organizada e confeccionada a partir de distintas escolhas para formar a vasilha cerâmica, somado a todos os processos pós-deposicionais que atingiram o material após seu descarte no sítio arqueológico. Nas medições desses pontos, o detector captou a superfície do ponto (pode ser que com algum material de sedimento do sítio incrustado, uma vez que os materiais foram limpos a seco).

No próximo tópico, parte-se para explorar os resultados (em forma de histogramas) das medidas das faces interna e externa das mesmas amostras. 


\subsubsection{Faces interna e externa dos fragmentos}

Nas Figuras 108 a 117, são apresentados os resultados da comparação entre as faces interna e externa em ambas as coleções. São apresentadas pranchas, cada uma contendo dois gráficos: o primeiro com os resultados das faces da coleção RT e o segundo com os resultados da coleção TRV. Para cada gráfico, as barras em vermelho referem-se às medidas das faces internas; as barras em verde referem-se às medidas das faces externas. Uma especial atenção para a amostra e RT, 037 que nos gráficos dos núcleos das pastas já observamos uma situação específica seus pontos de medição internos não foram utilizados devido à contaminação por material utilizado para a base da numeração da peça; sendo assim, para essa peça observamos no gráfico apenas seu pico referente à face externa. 


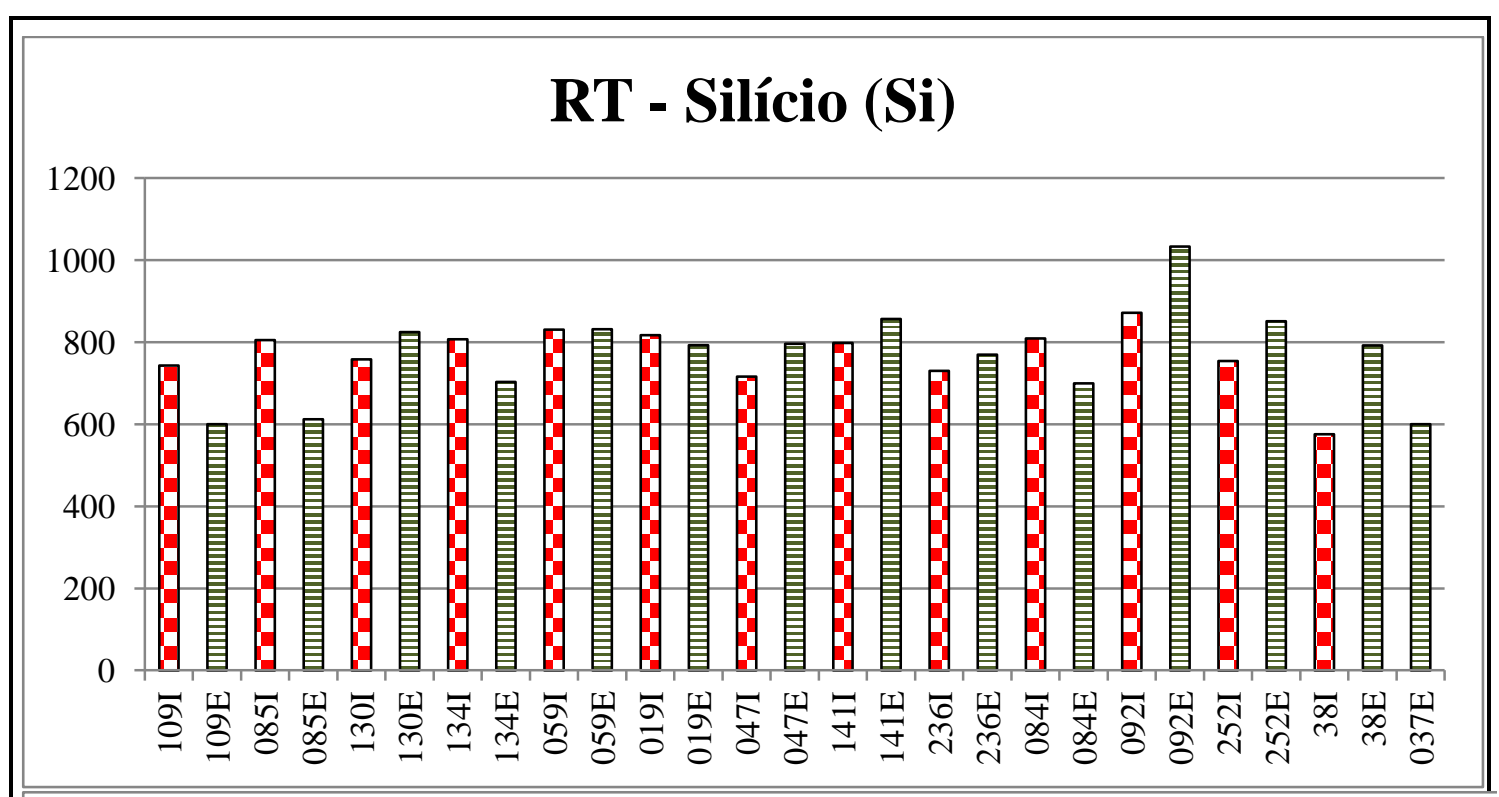

\section{TRV - Silício (Si)}

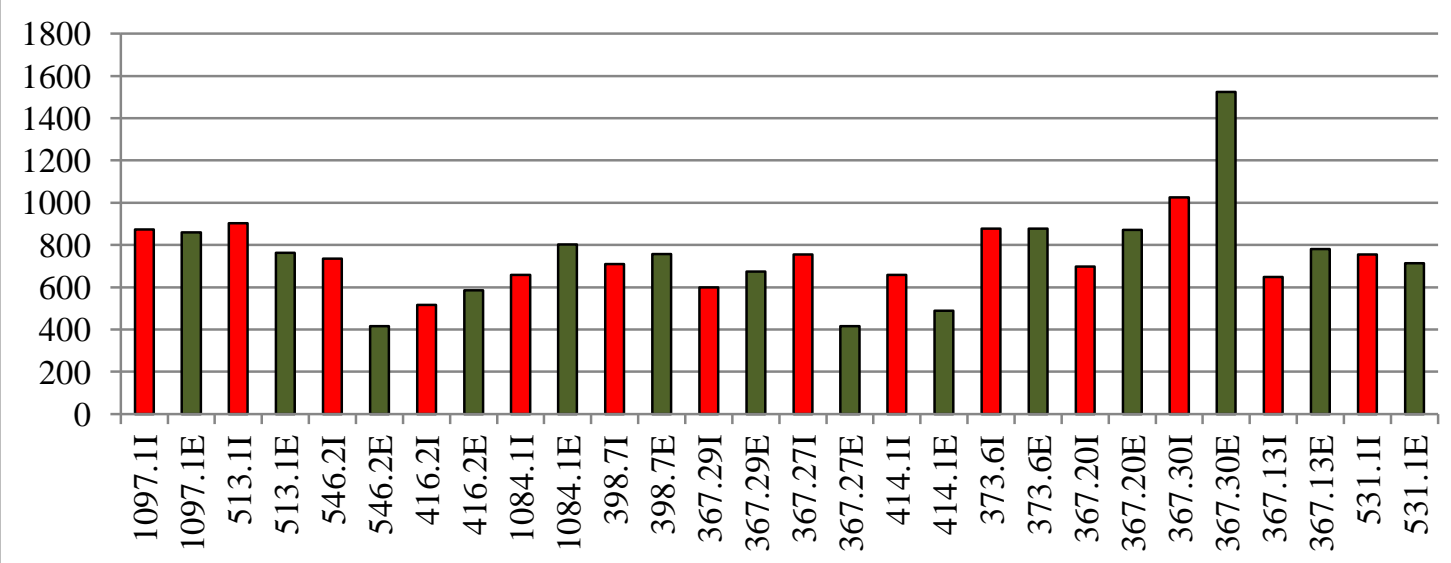

Figura 108. Gráficos representando a área calculada do pico para o elemento químico silício nas faces internas (vermelho) e externas (verde) das amostras. As barras sólidas no gráfico inferior pertencem ao sítio Travessão do Rio vermelho e as barras no gráfico superior ao sítio Lagoinha do Rio Tavares I.

O silício ( $\mathrm{Si}$ ) (composição básica da argila junto ao alumínio), na Figura 106, encontra-se homogêneo em ambas as coleções e em menor quantidade que nas medidas dos núcleos, a não ser por um pico alto em 367.30E (TRV), podendo ser devido a resquícios do sedimento do sítio na face medida (ainda que a curadoria tenha sido feita, mas sem o uso de água, podendo ter permanecido aderido grãos de sedimento arenoso). 


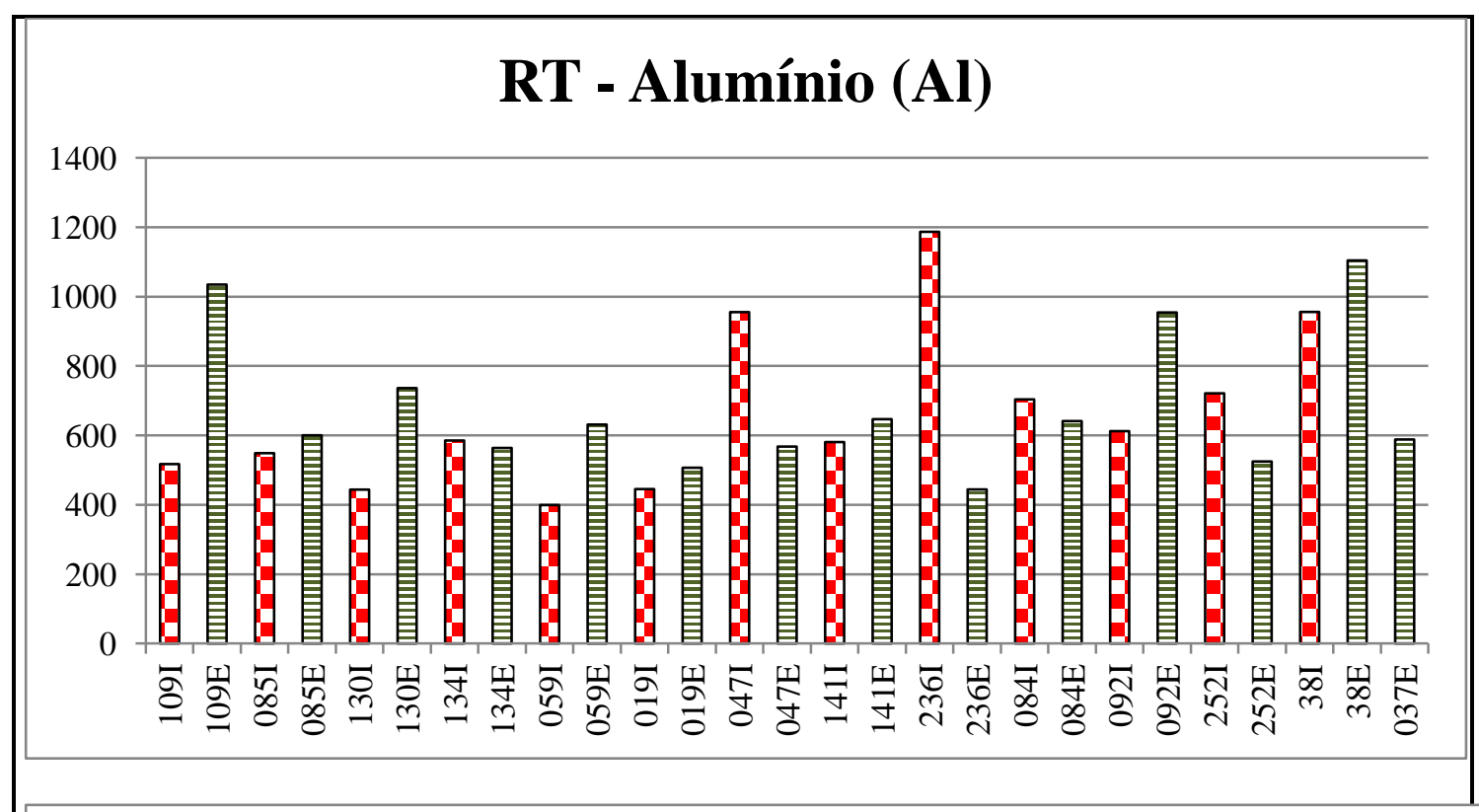

\section{TRV - Alumínio (Al)}

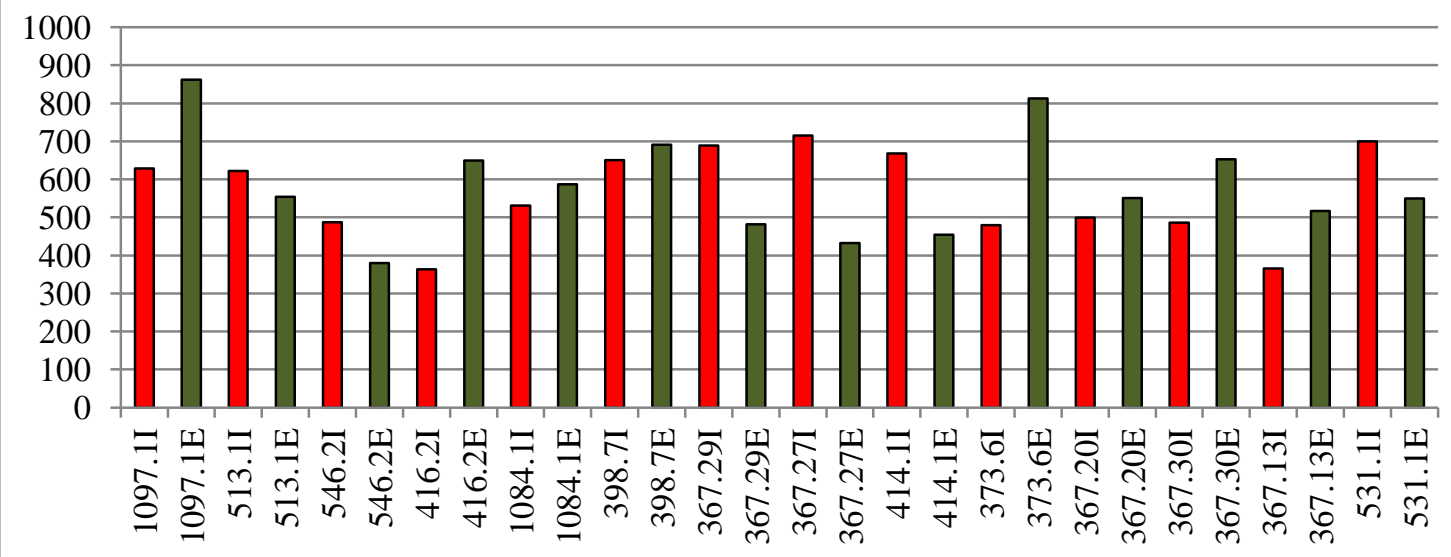

Figura 109. Gráficos representando a área calculada do pico para o elemento químico alumínio nas faces internas (vermelho) e externas (verde) das amostras. As barras sólidas no gráfico inferior pertencem ao sítio Travessão do Rio vermelho e as barras no gráfico superior ao sítio Lagoinha do Rio Tavares I.

O alumínio (Al) (Figura 109) está presente nas faces interna e externa de forma indiscriminada, assim como nas medidas dos núcleos das pastas vistas anteriormente, uma vez que faz parte da pasta cerâmica junto ao silício. Embora o Al esteja em muito maior quantidade nos núcleos (indicando ser das matérias-primas das pastas), é detectado nas faces da pasta cerâmica, e sugere ter quantidade captada um pouco maior em RT que em TRV. As variações nos dois gráficos (especialmente no 
gráfico de RT, com heterogeneidade maior) indicam variabilidade de fontes de matériaprima.

Já, com relação ao fósforo (P) na Figura 110, encontra-se com picos maiores nas amostras do sítio RT: 084I, 084E, 092E, 38I, 037E. Assim como nas medidas dos núcleos das pastas, há maior quantidade nas amostras de RT, da mesma forma como nos núcleos/pastas, ou seja, são formados dois grupos distintos. O fósforo, como já discutido quando apresentados os resultados para os núcleos dos fragmentos, está muito maior quantidade nas faces internas e externas (de forma homogênea) e não se compreende ainda com exatidão se seria proveniente do uso das vasilhas (DUMA, 1972) ou mesmo se de aspectos pós-deposicionais (DUNNELL \& HUNT, 1990). Fato é que o P está na pasta cerâmica (portanto, na matéria-prima), mas a maior quantidade nas faces sugere provir também do processamento de alimentos nas vasilhas e de aspectos dos depósitos em que se encontravam os vestígios. E, se há maior quantidade de fósforo nos núcleos e faces de RT que em TRV, esse dado sugere que há mais fósforo nas matérias-primas coletadas para a produção das vasilhas de RT. 


\section{RT - Fósforo (P)}

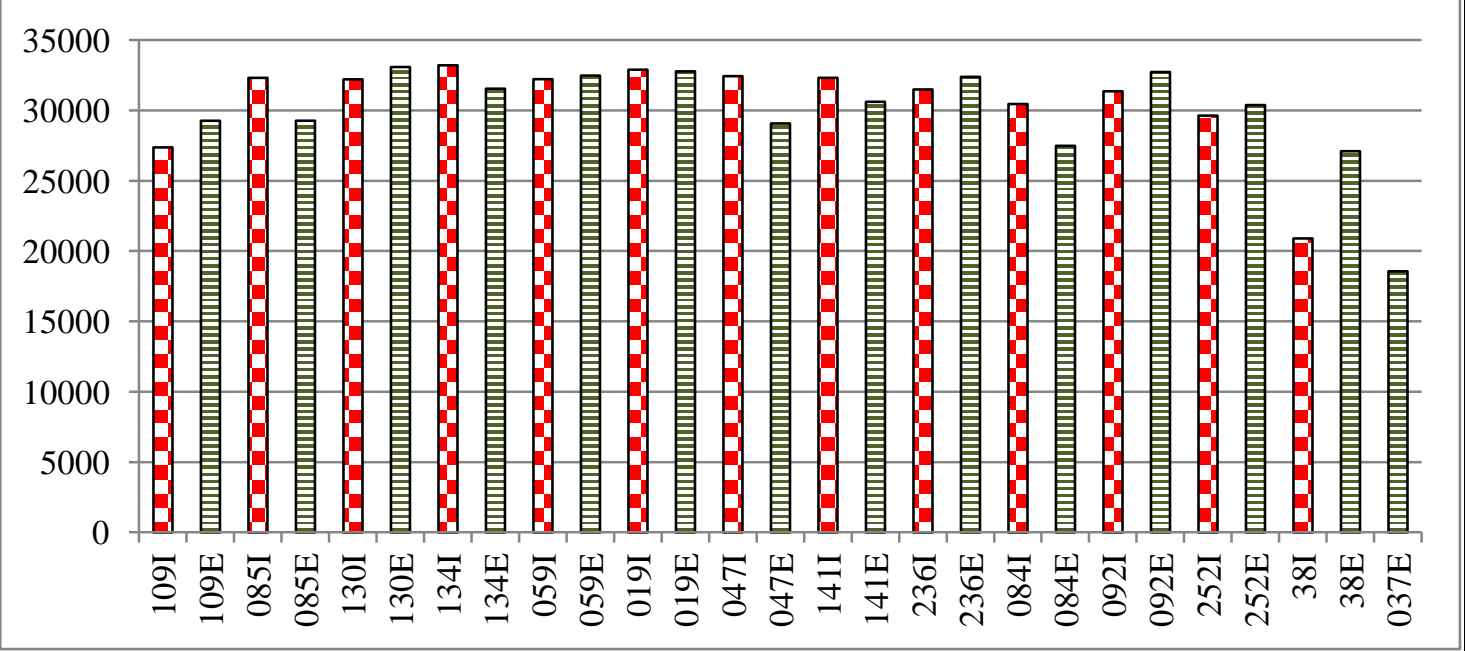

\section{TRV - Fósforo (P)}

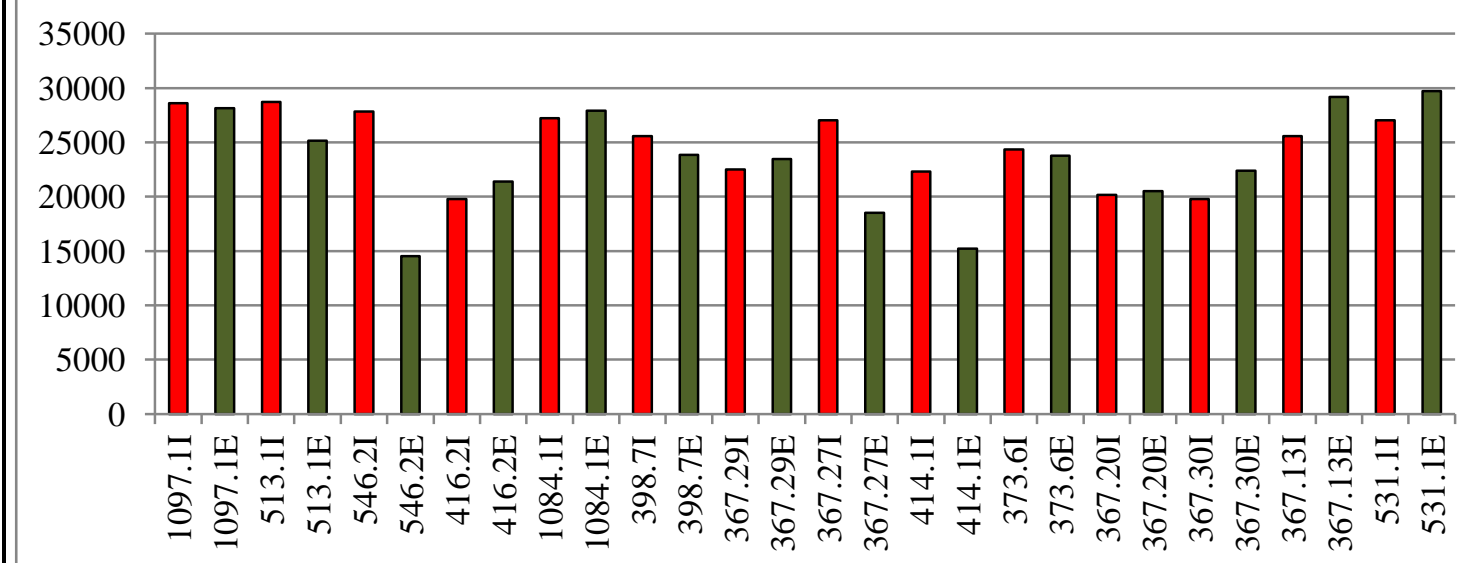

Figura 110. Gráficos representando a área calculada do pico para o elemento químico fósforo nas faces internas (vermelho) e externas (verde) das amostras. As barras sólidas no gráfico inferior pertencem ao sítio Travessão do Rio vermelho e as barras no gráfico superior ao sitio Lagoinha do Rio Tavares I.

O enxofre (S) (Figura 111) aparece em picos maiores em mais amostras de RT e está possivelmente vinculado à presença de matéria orgânica. Ocorre nos núcleos dos fragmentos, mas em maior quantidade nas faces. Não há um padrão de proporções entre faces interna e externa. Ou seja, há variabilidade, portanto, no uso de materiais orgânicos das vasilhas e/ou na presença de S nos depósitos. 


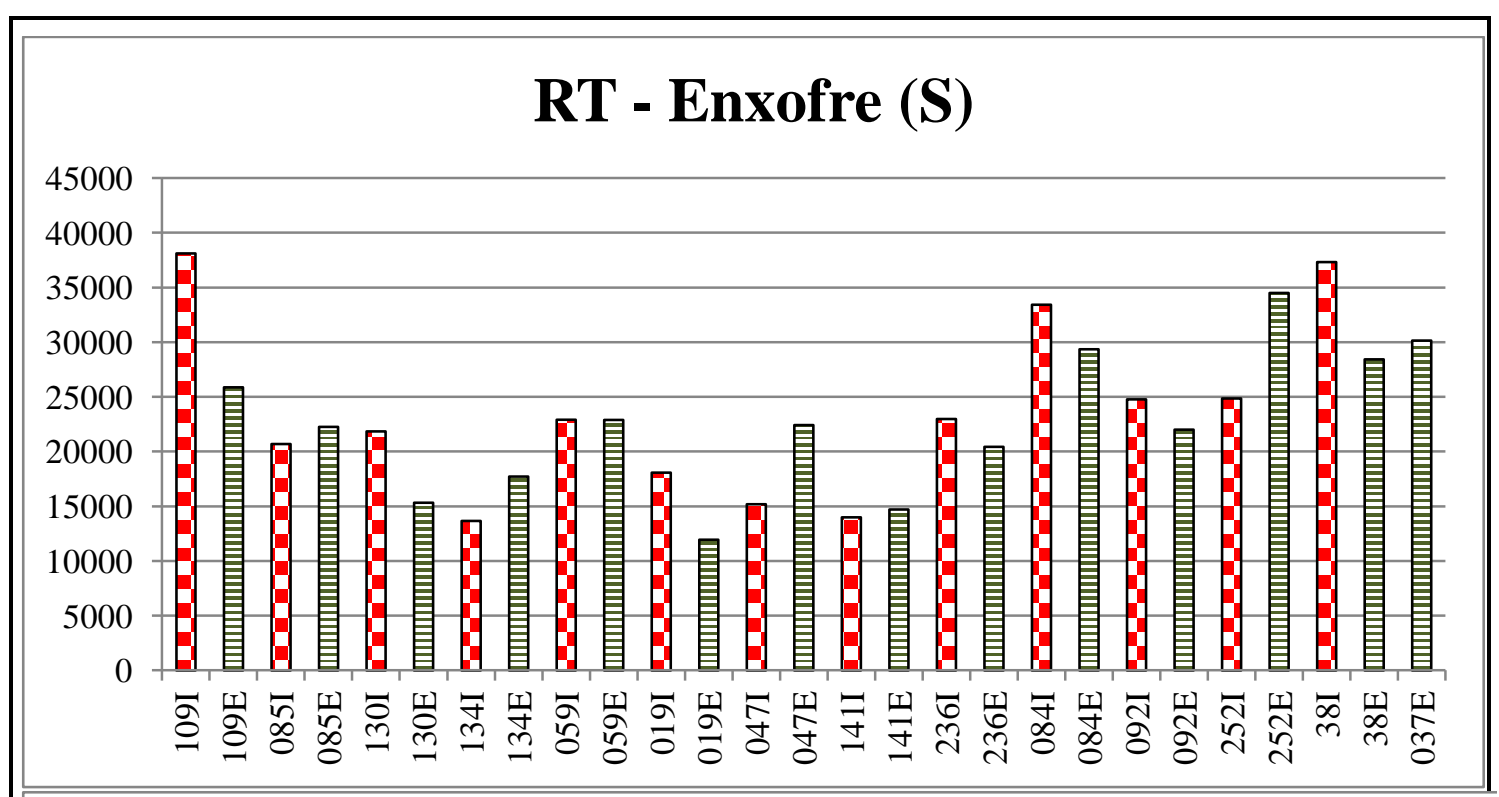

\section{TRV - Enxofre (S)}

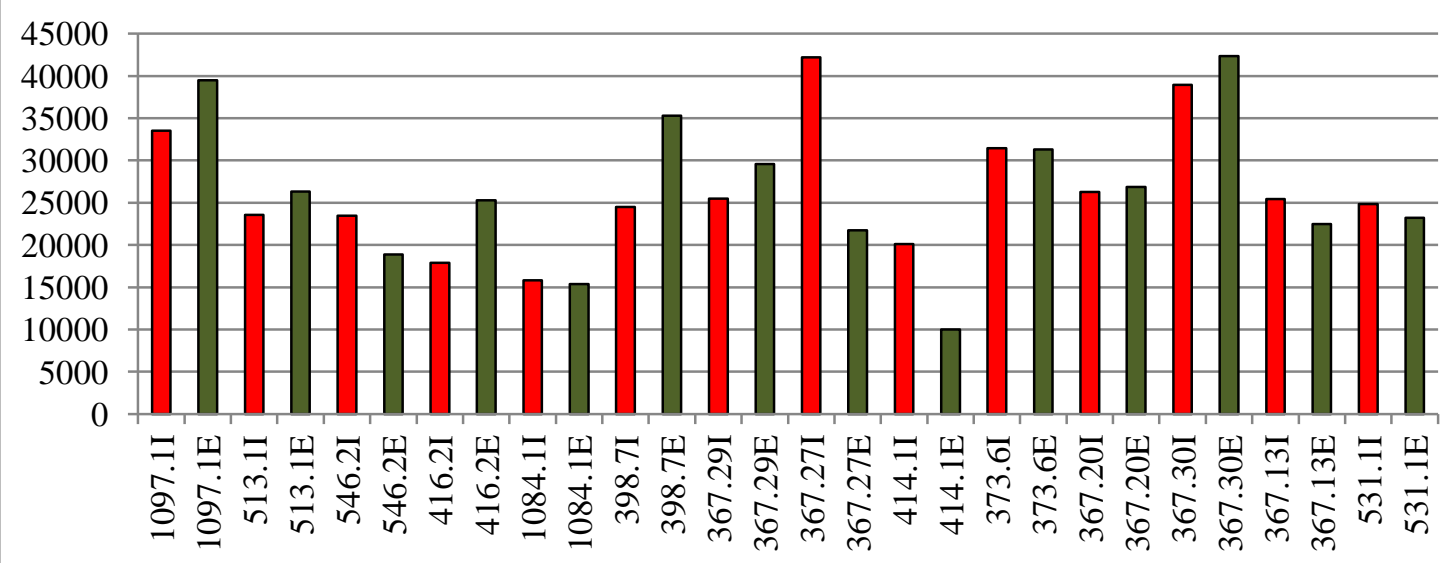

Figura 111. Gráficos representando a área calculada do pico para o elemento químico enxofre nas faces internas (vermelho) e externas (verde) das amostras. As barras sólidas no gráfico inferior pertencem ao sítio Travessão do Rio vermelho e as barras no gráfico superior ao sitio Lagoinha do Rio Tavares I.

Com relação ao potássio (K) (Figura 112), este se mostra de maneira bastante homogênea e similar em ambas as coleções, com um pico destoante em uma amostra de RT (109E). Esse elemento é mais abundante nos núcleos que nas faces dos fragmentos, assim como o ferro $(\mathrm{Fe})$. 


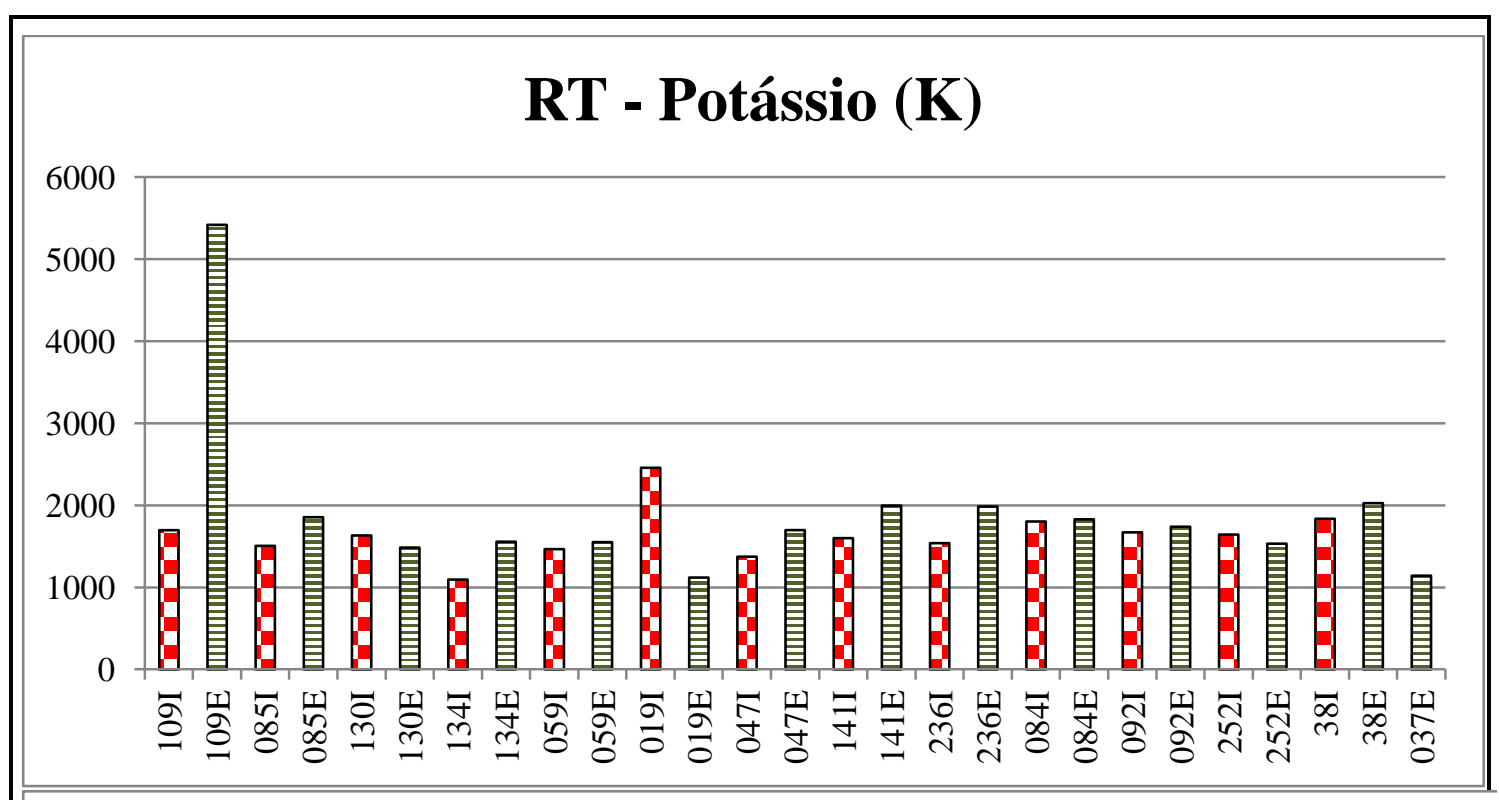

\section{TRV - Potássio (K)}

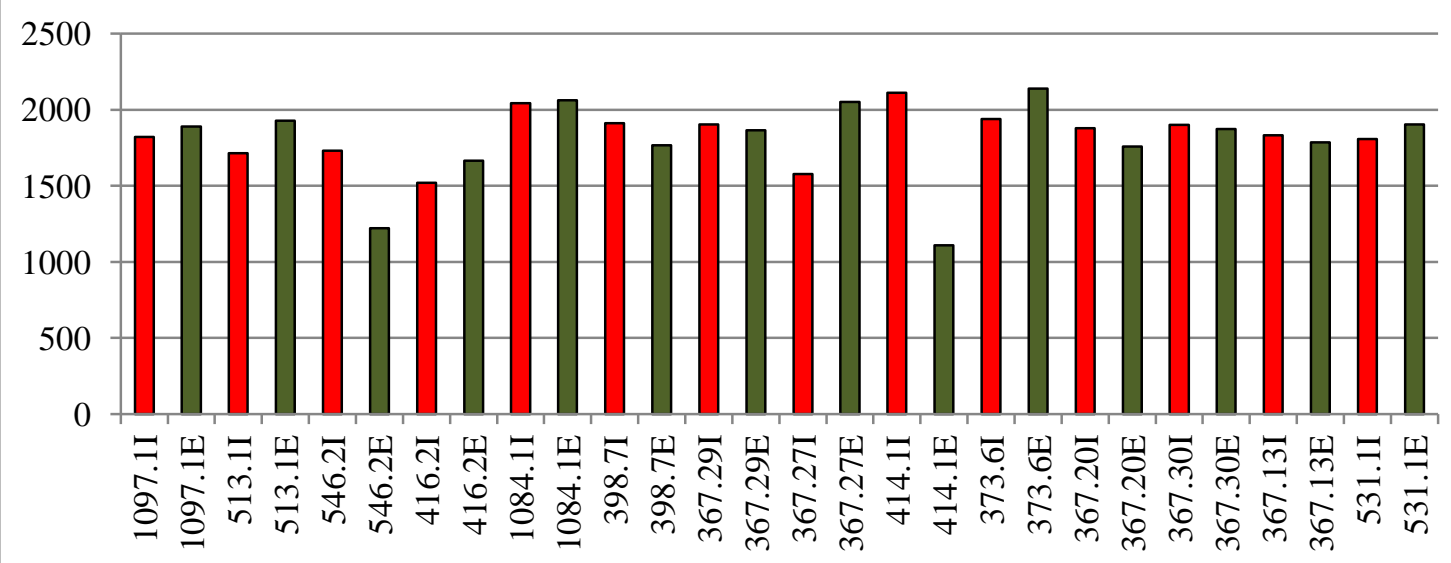

Figura 112. Gráficos representando a área calculada do pico para o elemento químico potássio nas faces internas (vermelho) e externas (verde) das amostras. As barras sólidas no gráfico inferior pertencem ao sítio Travessão do Rio vermelho e as barras no gráfico superior ao sitio Lagoinha do Rio Tavares I.

O cálcio (Ca) é encontrado de forma homogênea em ambas as coleções e em maior quantidade nas faces que nos núcleos dos fragmentos. Como já discutido com a Figura 113 que demonstra a presença do Ca nos núcleos dos fragmentos cerâmicos, o Ca está presente na pasta, mas seu número muito maior nas faces indica que, muito provável, tenham sido processados nas vasilhas alimentos ricos desse elemento, como ossos ou conchas. Outra hipótese é a de o Ca seja proveniente dos depósitos em que se encontravam os vestígios. Segue o histograma na Figura 113: 


\section{RT - Cálcio (Ca)}

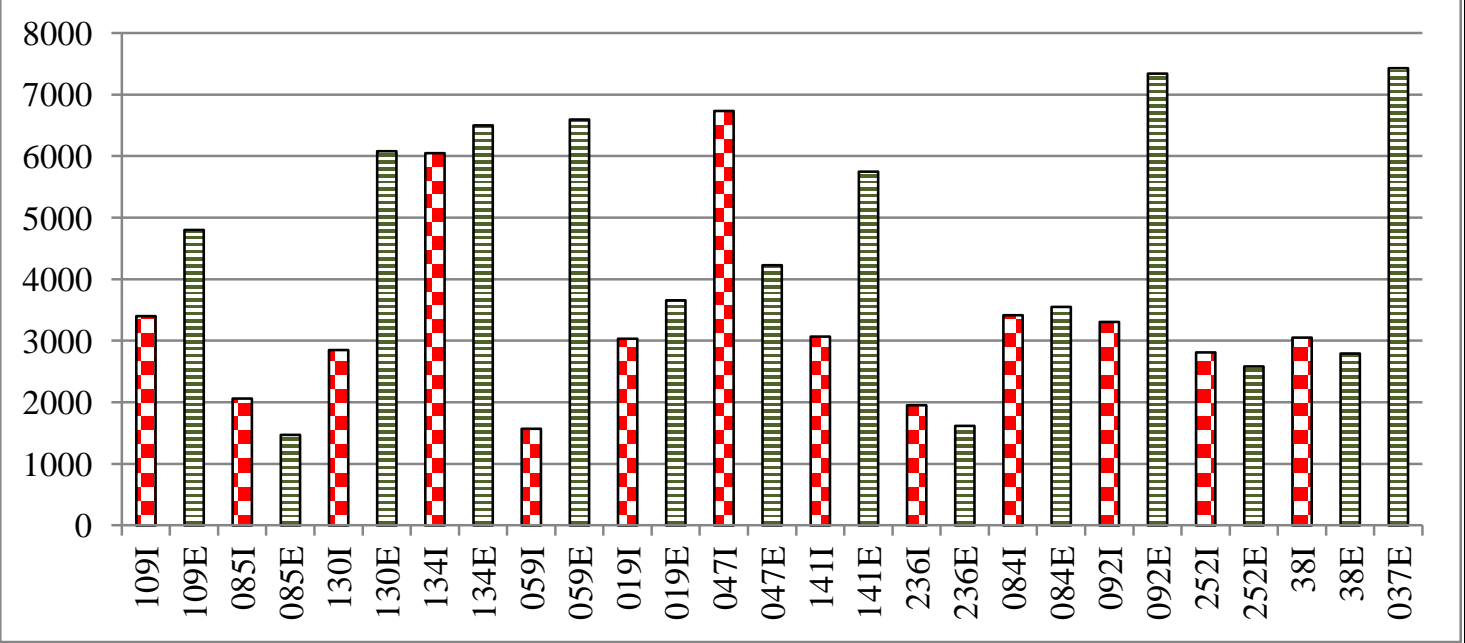

\section{TRV - Cálcio (Ca)}

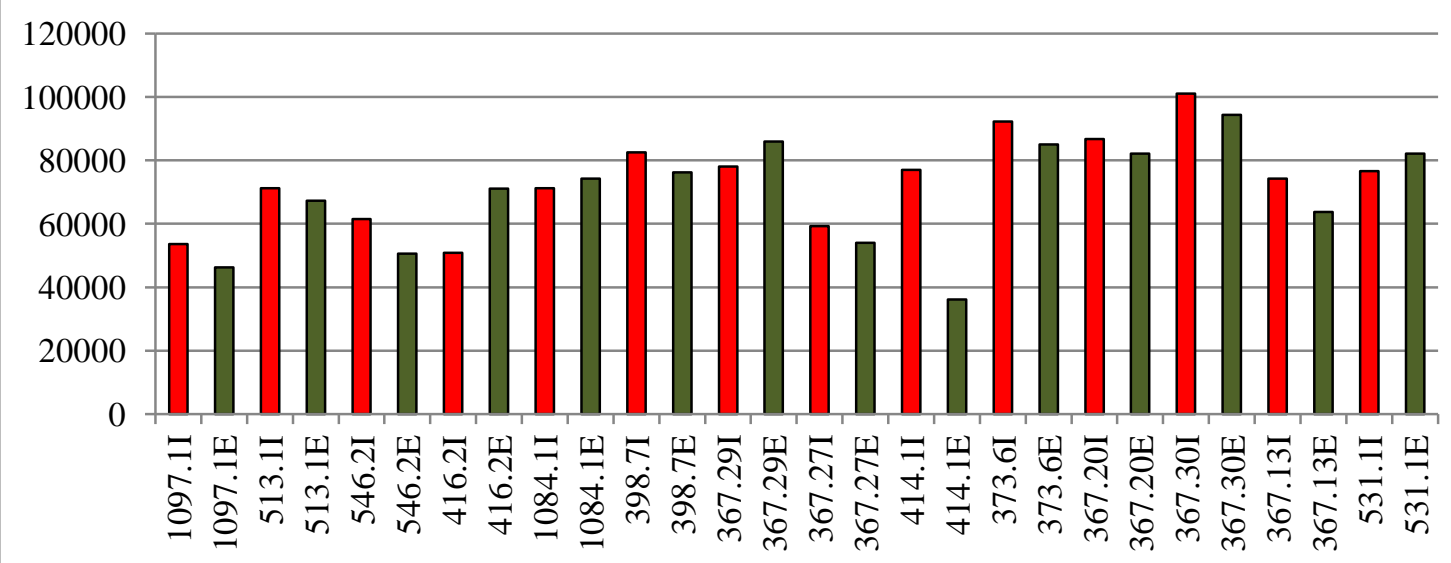

Figura 113. Gráficos representando a área calculada do pico para o elemento químico cálcio nas faces internas (vermelho) e externas (verde) das amostras. As barras sólidas no gráfico inferior pertencem ao sítio Travessão do Rio vermelho e as barras no gráfico superior ao sitio Lagoinha do Rio Tavares I. 


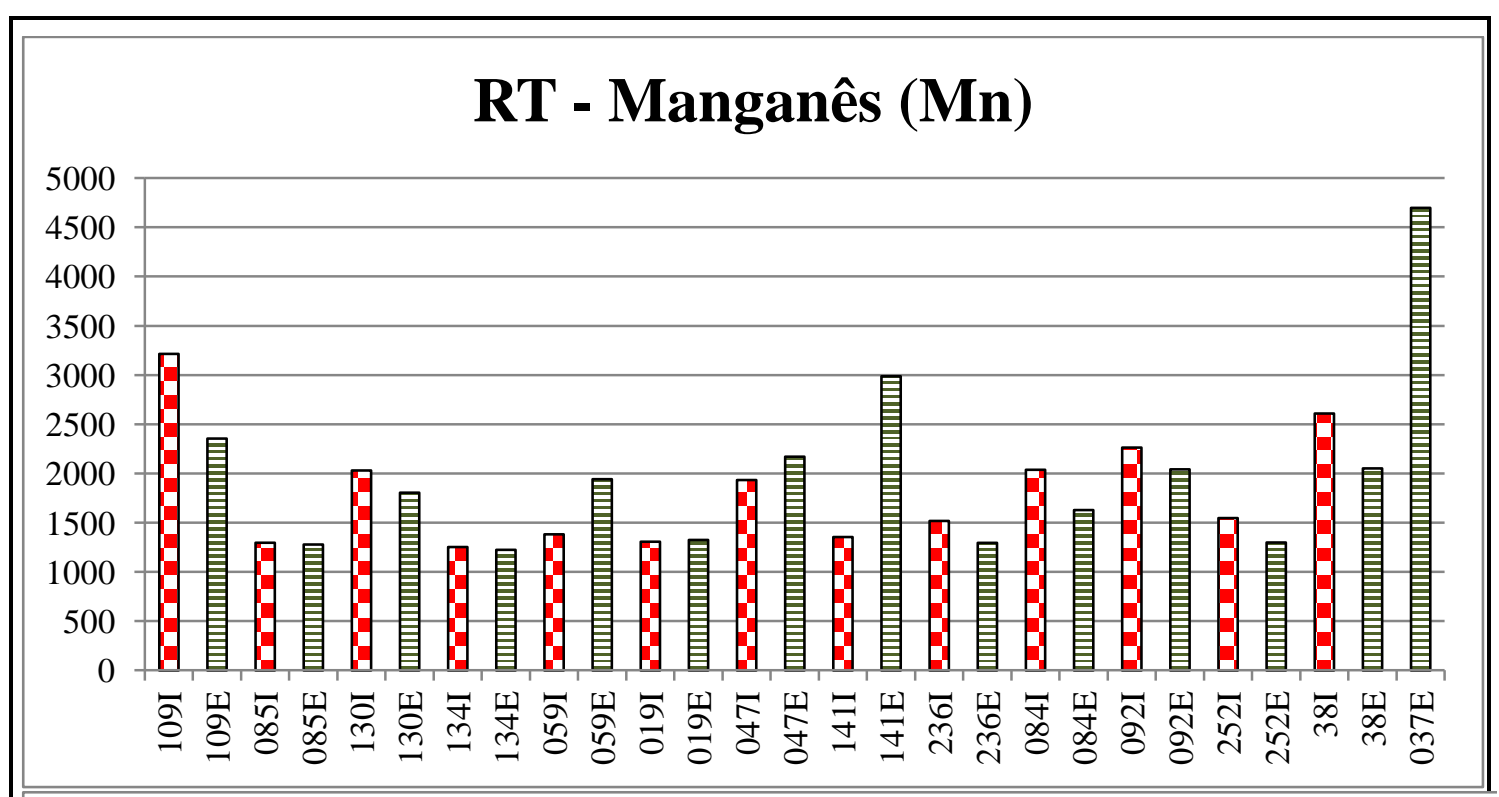

\section{TRV - Manganês (Mn)}

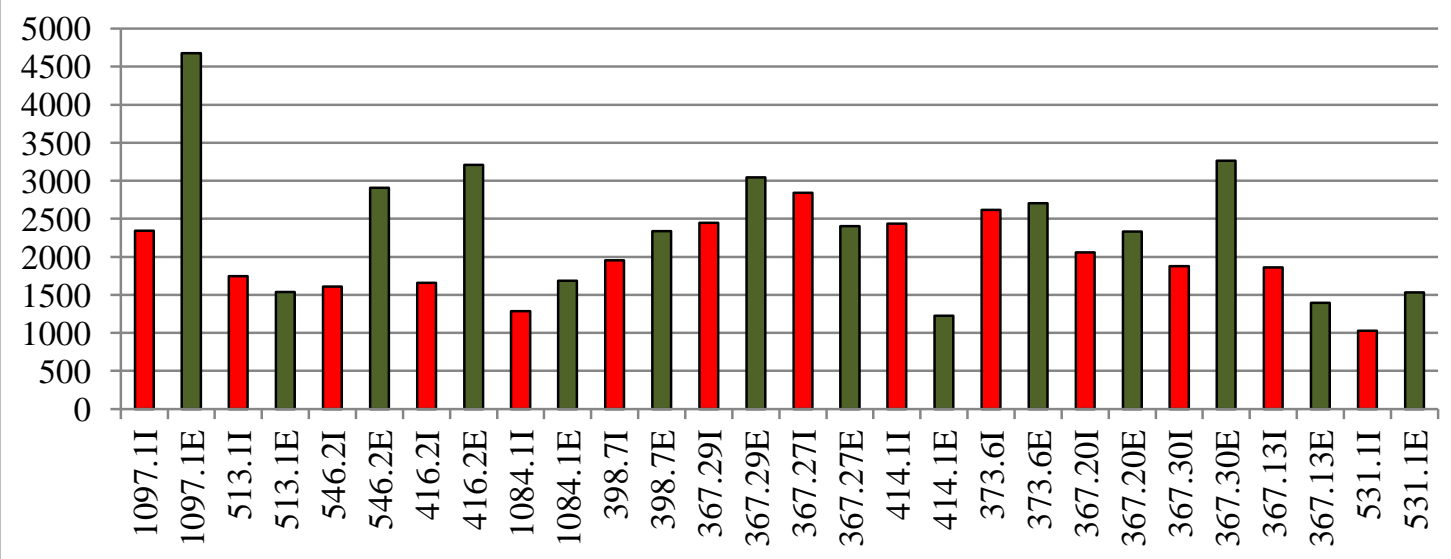

Figura 114. Gráficos representando a área calculada do pico para o elemento químico manganês nas faces internas (vermelho) e externas (verde) das amostras. As barras sólidas no gráfico inferior pertencem ao sítio Travessão do Rio vermelho e as barras no gráfico superior ao sitio Lagoinha do Rio Tavares I.

O manganês (Mn) (Figura 114), apesar de bastante heterogêneo em ambas as coleções nas faces dos fragmentos, possui faixa de valores similares (1000 a 4500 de área) em ambas. O Mn encontra-se em quantidade muito mais alta nas faces em relação aos núcleos, e nos núcleos, há presença maior desse elemento na coleção RT, indicando mais Mn nas argilas utilizadas em RT. Mas, nas faces analisadas, não há tal distinção entre as coleções e há presença maior de Mn nas mesmas. Isso significa que esse elemento está presente de forma variável nos depósitos de ambos os sítios arqueológicos. 


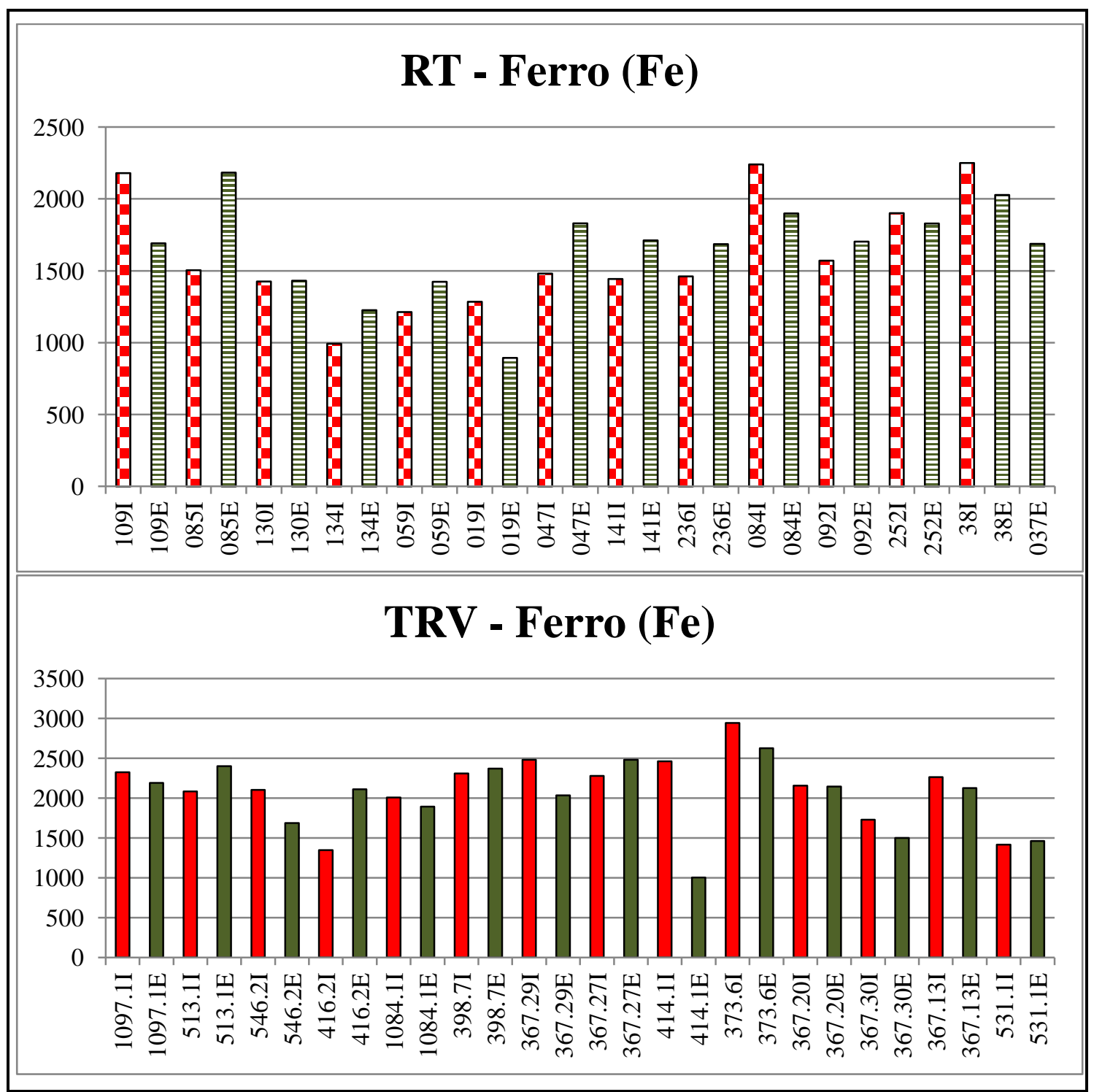

Figura 115. Gráficos representando a área calculada do pico para o elemento químico ferro nas faces internas (vermelho) e externas (verde) das amostras. As barras sólidas no gráfico inferior pertencem ao sítio Travessão do Rio vermelho e as barras no gráfico superior ao sitio Lagoinha do Rio Tavares I.

Referente ao elemento ferro (Fe) (Figura 115), é bastante evidente a variabilidade, mas a faixa de valores é similar em ambas as coleções (500 a 3000 de área). O Fe, ainda que apareça nas faces dos fragmentos, é extremamente maior nos núcleos (na ordem de 100.000 de área), indicando provir das fontes de matérias-primas. 


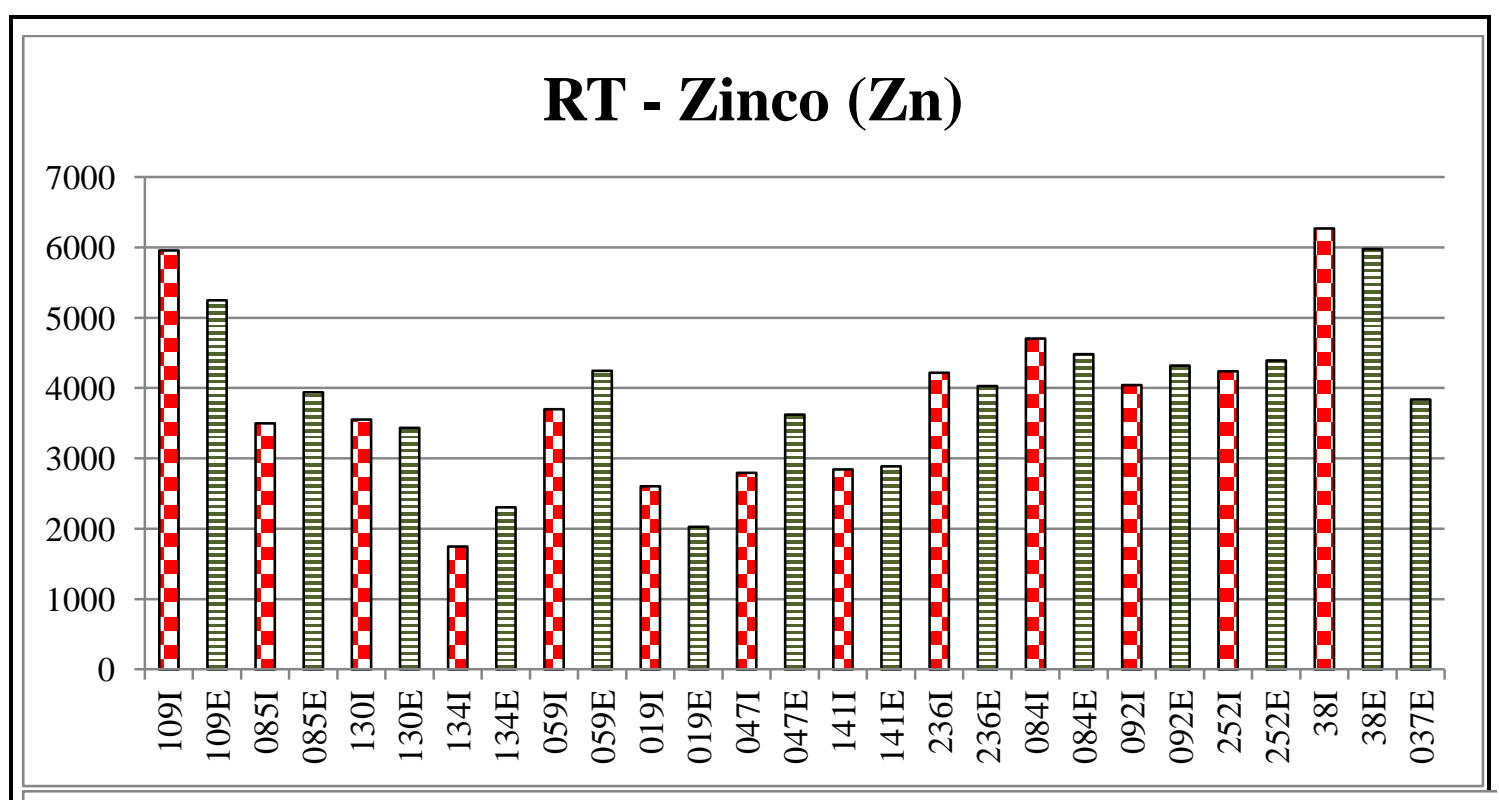

\section{TRV - Zinco (Zn)}

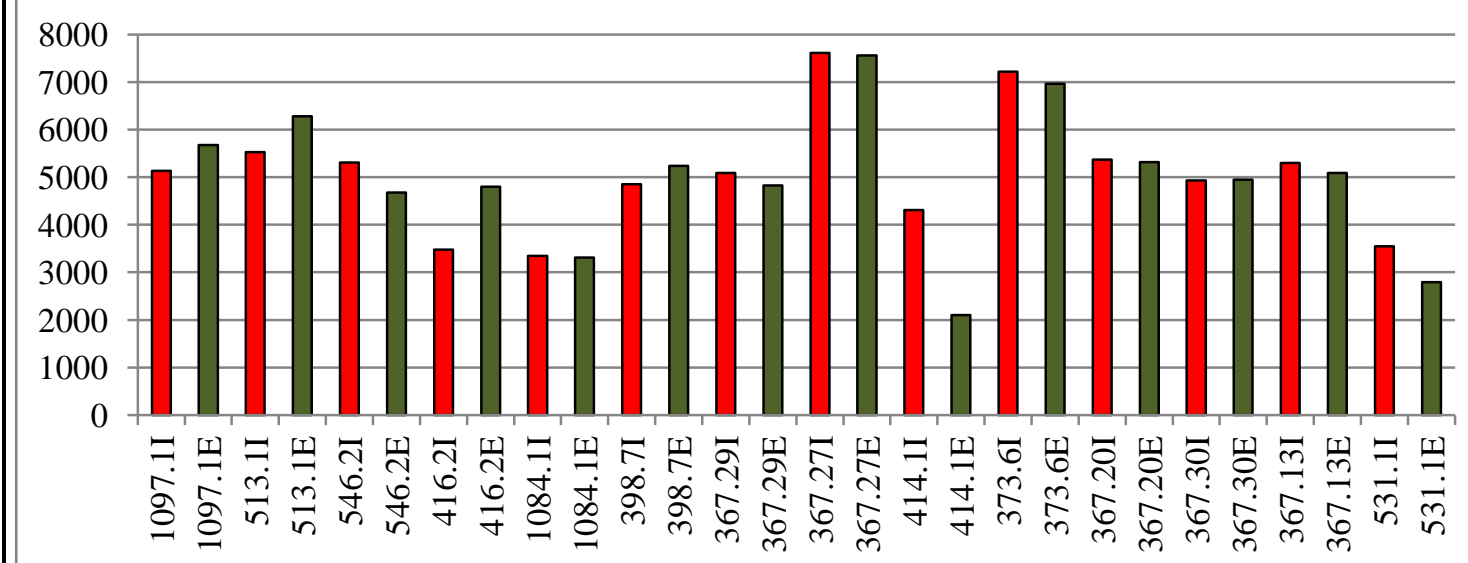

Figura 116. Gráficos representando a área calculada do pico para o elemento químico zinco nas faces internas (vermelho) e externas (verde) das amostras. As barras sólidas no gráfico inferior pertencem ao sítio Travessão do Rio vermelho e as barras no gráfico superior ao sitio Lagoinha do Rio Tavares I.

Com relação ao zinco (Zn) (Figura 116), esse elemento é mais abundante nas faces dos fragmentos que nos núcleos, evidenciando ser provenientes de impregnação pós-deposicional nos depósitos de onde as coleções foram retiradas. 


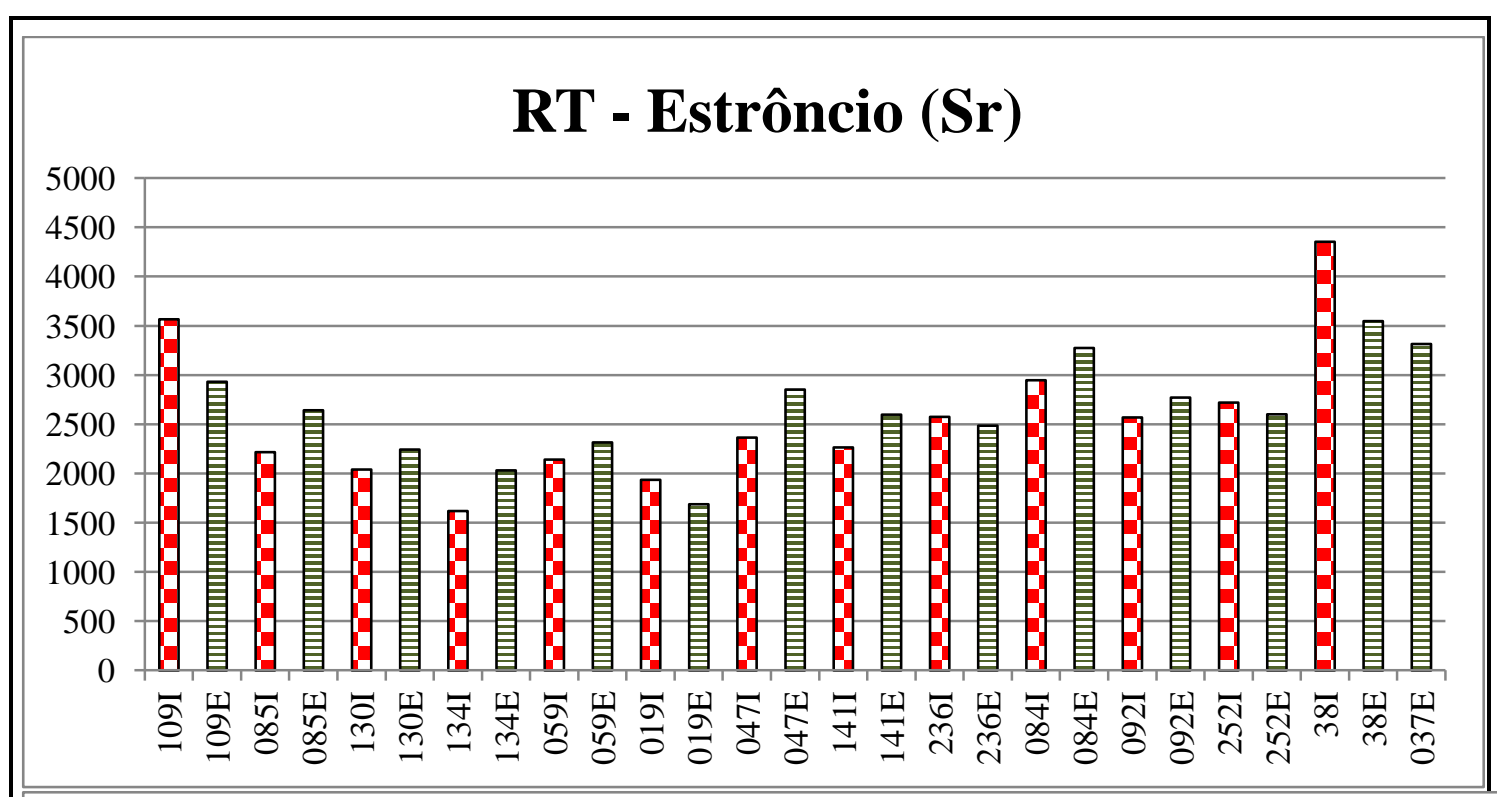

\section{TRV - Estrôncio (Sr)}

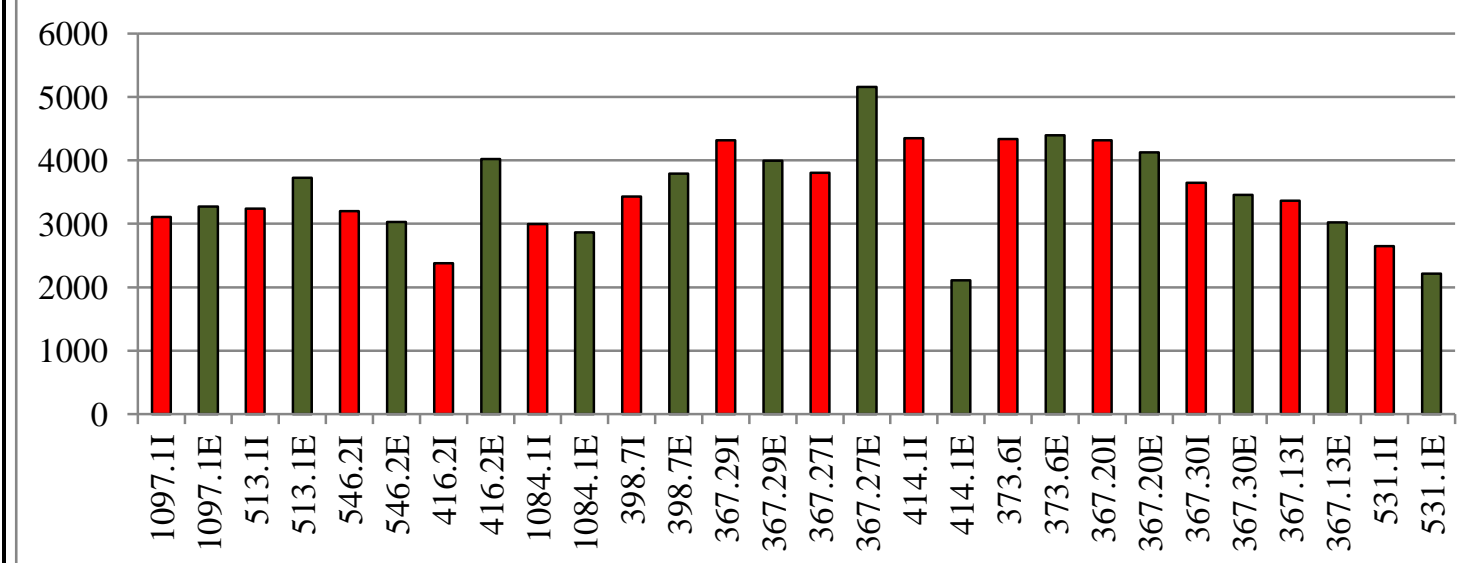

Figura 117. Gráficos representando a área calculada do pico para o elemento químico estrôncio nas faces das amostras. As barras sólidas no gráfico inferior pertencem ao sítio Travessão do Rio vermelho e as barras no gráfico superior ao sitio Lagoinha do Rio Tavares I.

O elemento estrôncio ( $\mathrm{Sr}$ ) aparece vinculado ao Fe nas amostras de TRV: 367.30 E 531.1 (Figura 117), ou seja, as amostras que tem ferro alto/baixo também possuem estrôncio alto/baixo. Esse elemento também, como o zinco ( $\mathrm{Zn}$ ), é mais abundante nas faces dos fragmentos que nos núcleos, indicando ser proveniente em grande parte dos depósitos dos quais as coleções fora retiradas.

Portanto, as medidas das faces dos fragmentos, embora não tenha nos dado diferenciações e inferências entre as faces internas e externas, reforçou aqueles elementos que não estão tão presentes nas pastas cerâmicas, mas são presentes em 
virtude do uso e manipulação das vasilhas e nos falam também sobre ações pósdeposicionais nos sítios arqueológicos.

\subsection{Sobre as coleções}

Ambas as coleções apresentaram uma variabilidade grande internamente e entre as mesmas. Mas, o que essa variabilidade reflete? Qual o papel e o que podemos inferir desses fragmentos analisados nos sítios arqueológicos? Como podemos interpretar essa variabilidade artefatual cerâmica e os sítios arqueológicos das coleções estudadas?

Chilton (CHILTON, 1998, P.132) descreve que, por muito tempo, no nordeste da América do Norte, a cerâmica foi trabalhada de forma a serem construídas tipologias estilísticas rígidas para inferir etnicidade e cronologia; e com o tempo essas tipologias tornaram-se o fim em si mesmas. Pouca atenção foi dada ao universo de variedade de escolhas disponíveis aos ceramistas durante a produção cerâmica e seu uso e, segundo ela, certamente, o nível com que são isolados aspectos da cultura material determina os padrões de comportamento que somos capazes de ver, ou seja, a forma que olhamos para o material e os classificamos revela os padrões de comportamento que somos capazes de apreender.

De forma similar, dadas as trajetórias de pesquisa distintas, as pesquisas em Arqueologia Guarani foram limitadas por muito tempo à análise cerâmica seguindo os padrões conhecidos e tão difundidos (de identificação de forma e função diretamente por exemplo). Essa era a finalidade de grande parte em leituras e releituras das publicações pronapianas (década de 1960) e mesmo de um engessamento na leitura de La Salvia \& Brochado (1989). Isso posto que a maior parte dos sítios Guarani conhecidos é identificada através da cerâmica de tradição tupiGuarani. Após a crítica representada por Noelli (1993), especialmente, e Soares (2004), Landa (1995), por exemplo, novos trabalhos surgiram. Ainda assim, existe uma dificuldade mesmo nos trabalhos atuais que envolvem análise cerâmica Guarani em se extrapolar os padrões, buscar as particularidades que, como menciona Chilton (1998), estão nos contextos tecnológicos e sociais do uso e manufatura da cerâmica. Trata-se de um desafio 
perfeitamente implementável e com muitas possibilidades de expectativas. Aqui, o material analisado também é cerâmico, tradicional na Arqueologia Guarani, mas o intuito foi implementar uma articulação entre análises macro e arqueométricas, a partir da análise tecnológica de atributos aliada à fluorescência de raios-x.

Enquanto que, para grande parte dos contextos etnográficos brasileiros não há tantas referências etnohistóricas e etnológicas, para os falantes Tupi, principalmente de línguas Tupi-Guarani, há muitas dessas referências. Há a necessidade de avançar e explorar essas fontes para confrontar com a Arqueologia na busca de estudos mais inter e multidisciplinares. Ainda assim, faltam referências etnográficas para a produção cerâmica Guarani, as quais devem ser buscadas, bem como na etnoArqueologia e na arqueometria.

Dessa forma, como visto em toda a explanação das análises macroscópicas, a ficha de análise e as apresentações dos resultados buscaram seguir o processo de produção da vasilha: desde a escolha das matérias-primas (argila e antiplástico), sua manipulação e o processo de dar forma a vasilha, a queima e os tratamentos de superfície aplicados, além de marcas de uso. E os resultados macroscóipicos e arqueométricos mostraram variabilidade bastante grande de materiais utilizados nas coleções analisadas (e, por consequência, nos sítios arqueológicos correspondentes) podendo deixar bem claro onde se aproximam e onde se diferem. É possível, então, realizar a comparação entre ambas as coleções, buscando suas particularidades na estrutura e prescritividade da cultura Guarani.

Para a colecão TRV, foram vislumbradas mais paredes (92.12\%) - igual ocorreu com a coleção RT-, sem cachimbo/petanguá, ou alças que pudessem remeter que a coleção possua algum retrato do período do contato europeu. Portanto, isso somado ao fato de que não foi encontrado nenhum tratamento de superfície que remeta a contato europeu nos diz que, apesar de o sítio TRV ser datado do século XVI (ou seja, do contato europeu na Ilha de Santa Catarina por viajantes como visto nos relatos etnográficos), a coleção não possui registro desse contato. Isso não quer dizer que contatos entre essas diferentes populações não tenham ocorrido; esses contatos devem ter sido muito breves (como as etnografias e etnohistórias trazem) que formas da cultura europeia não foram incorporadas na cultura material Guarani. $O$ mesmo ocorreu com a coleção RT, sem ocorrência de vestígios associados à ocupação europeia, 
ainda que não se tenha o conhecimento de datações do sítio arqueológico. A coleção TRV é basicamente roletada/acordelada (já esperado pela na bibliografia cerâmica Guarani), com base moldada.

Com relação ao antiplástico encontrado no material cerâmico, $75 \%$ é antiplástico mineral em todos os tamanhos (sendo $92.68 \%$ antiplástico mineral em toda a coleção) e caco moído, carvão e óxidos estão em $7.32 \%$ da coleção e sempre associados ao antiplástico mineral. Aqui, importante enfatizar que a busca e processamento de matéria-prima influi na variabilidade da pasta conforme discutido por Arnold (2000), ainda que o antiplástico mineral seja aquele base na coleção. E a pasta é chave para nossa discussão que será explorada mais adiante. Com relação às queimas das vasilhas, os dados obtidos levam a compreender que, no geral, o ambiente não proporcionou queimas homogêneas, favorecendo um cozimento maior nas partes externas das vasilhas, diferente da pasta em sua parte interna. As queimas foram realizadas em ambientes abertos, sem controle da temperatura e oxigênio, como ocorrem amplamente pelos grupos pré-coloniais no Brasil. Os tratamentos plásticos predominantes são a associação entre alisamento (face interna), corrugado e ungulado (faces externas predominantes), seguido de alisamento (faces internas) e ungulado (faces externas) associados, e alisamento, ungulado e acanalado, e alisamento e escovado. São todos tratamentos comuns da literatura cerâmica Guarani (LA SALVIA \& BROCHADO, 1989), sendo o alisamento interno excelente para uma vasilha conter alimentos e demais produtos. O alisamento externo e os acabamentos ásperos favorecem a capacidade térmica, aumentam a resistência ao choque térmico e reduzem o lascamento térmico (CHILTON, 1998), favorecendo a ida ao fogo dessas vasilhas (juntamente com a ação do antiplástico mineral na pasta, bom condutor térmico). Acabamentos ásperos nas faces externas das vasilhas também facilitam seu manuseio, não escorregando de mãos e suportes com facilidade. Se essas características favorecem a ida do recipiente ao fogo, isso quer dizer que o cozimento de alimentos é facilitado, uma vez que o calor se mantem na vasilhae é transportado de forma mais rápida pelas paredes. Lembrando que toda vasilha é alisada internamente e externamente, ou para receber outro tratamento ou não. Também, essas escolhas certamente se devem aos demais aspectos sócio-culturais da vida Guarani e escolhas da ceramista devido a aspectos práticos de uso, de melhor performance ou não de uma vasilha segundo seu fim, segundo crenças e escolhas sociais. 
Ainda que o tratamento cromático represente um universo bem menor dos tratamentos observados, existe também uma variabilidade em seu uso, sendo o principal, o enegrecimento/brunidura, a técnica monocrômica (somente pintura nas faces internas), bicrômica nas faces internas, engobo vermelho e engobo branco em todas as faces internas. Isso demonstra que a coleção TRV possui vasilhas, muito provavelmente, utilizados para servir e armazenar também, além da maioria das vasilhas que vão ao fogo (com tratamento plástico). Ou seja, a coleção TRV possui um conjunto de vasilhas com diferentes funções (cozinhar, servir e armazenar), mesmo que as vasilhas de cozinhar sejam predominantes. Ainda, $66.67 \%$ da coleção possui pasta laranja $\mathrm{C}$, seguido de laranja $\mathrm{B}$, laranja A e branca. Há uma variabilidade visual de cor das pastas (em 4 tipos) com preferência da pasta laranja $\mathrm{C}$ e, microscopicamente, essa variabilidade se mostra bastante grande também. Na análise por XRF também ficou constatado que a coloração observada de forma macrovisual não depende somente da composição química da matéria-prima que forma a pasta, mas de sua interação com a queima. A pasta laranja C é escolhida em TRV para levar a maior parte dos tratamentos alisado, corrugado e ungulado; os tratamentos de superfície identificados nas pastas laranja C (em TRV) e branca (em RT) também estão nas demais pastas, ou seja, não há uma diferenciação de tipos de vasilhas para determinada cor de pasta dentro de cada coleção; mas há essa diferenciação entre as coleções. A pasta laranja C em TRV também apresenta todas as faixas de espessura (da menor à maior), o que significa em sua grande parte, as vasilhas possuem a mesma faixa de espessura e não há uma relação direta entre espessura da peça e escolha da pasta pelos ceramistas Guarani que produziram a coleção. O mesmo ocorre em RT.

A maior parte das bordas é irrestritiva e um terço delas é restritiva (uma questão de tamanho da amostra e de sua fragmentação orientando a compreensão dos ângulos das bordas). Mesmo que a coleção analisada possua poucas bordas, é possível indicar através dessas informações produzidas que a coleção possui vasilhas utilizados para cozinhar e servir (fortalecendo a interpretação levantada até aqui), visto que vasilhas restritivas são utilizadas para funções de armazenagem no geral, pois restringem o acesso a seu interior. A única base encontrada, plana, também é tradicional na literatura cerâmica Guarani.

Os oito conjuntos observados se agrupam em termos de semelhança das seguintes variáveis: cor da pasta, tratamento de superfície e espessura. Observa-se aí, 
que essa divisão macroscópica já ressalta a pasta, essencial em nossa discussão, os tratamentos de superfície e espessura dos fragmentos que são características-chave de nossa interpretação. Essa forma de agrupar vai ao encontro do que Chilton (1998) propõe para uma análise que deve buscar a variabilidade de técnicas e tratamentos de superfície e lida com a avaliação de vasilhas enquanto olha fragmentos.

Ocorre na coleção, também, a predominância de espessuras de peças de 6 a $11 \mathrm{~mm}$, mais presentes são peças de $7 \mathrm{~mm}$. O tamanho das vasilhas pode se referir a quantas pessoas alimentam, assim como vasilhas mais finas estão mais aptos a irem ao fogo sem quebrar (CHILTON, 1998, P.151), e essa última afirmação fortalece a ideia de que as vasilhas na coleção TRV iam ao fogo. Essa informação das espessuras das peças, associada ao diâmetro e espelhamento projetado das bordas oferece uma dimensão da vasilha. Ainda assim, há uma grande variabilidade de espessuras de 3 a $20 \mathrm{~mm}$ que deve ser considerada, ou seja, há a presença de vasilhas pequenas a grandes. Nesta coleção, ainda, foram observáveis diâmetros projetados de 10 a $48 \mathrm{~cm}$, portanto, uma variedade grande de vasilhas pequenas a grandes, com ênfase em vasilhas médias que predominam 22 e $48 \mathrm{~cm}$, com espessuras de 6 a $15 \mathrm{~mm}$, ou seja, essas vasilhas possuem alta capacidade de aquecimento (somado ao antiplástico mineral) e de baixa a média resistência ao impacto (ainda que o antiplástico mineral esteja em medida equilibrada para não favorecer quebras). Como visto, a associação entre espessura das peças, diâmetro projetado das bordas (diâmetro projetado da abertura das vasilhas) e espelhamentos (favorecendo a visualização da dimensão da vasilha) nos revela mais sobre a dimensão das vasilhas, confirmando e complementando o que já vem sendo proposto e que junto à presença de marcas de fuligem nos fragmentos (de distintas espessuras e tratamentos plásticos de superfície), revela: a coleção é formada por vasilhas de pequenas a grandes, vasilhas de ir ao fogo, de servir e armazenar, com ênfase em vasilhas médias de ir ao fogo e excelentes para irem ao fogo, mas de baixa a média resistência ao impacto (apesar das vasilhas pequenas e médias, e dos tratamentos de superfície ásperos no exterior das vasilhas, fáceis de manusear), não podendo ter sido transportada muito.

Ainda que não sejam vasilhas grandes demasiadamente na maioria, a densidade de material em tão pequena área de escavação corrobora as interpretações feitas a partir da análise cerâmica macroscópica que, ou há um adensamento populacional considerável no sítio, não se tratando de um sítio acampamento dentro do 
teko 'á, por exemplo, ou se trata de uma área de descarte dentro de uma aldeia. Milheira (MILHEIRA, 2008), por exemplo, se valeu de associações advindas de dados arqueológicos e etnográficos para demonstrar sua proposta de adensamento populacional para os sítios arqueológicos às margens da Laguna dos Patos e sudoeste da serra no estado do Rio Grande do Sul. Se observamos os dados gerados das análises cerâmica para o sítio TRV, somado à presença de três possíveis estruturas de combustão com material conchífero, pouquíssimo material lítico presente (ou seja, não se trata de um sítio arqueológico de produção de material lítico onde a atuação deste seja primordial) e ao sedimento escuro, característico da presença de ocupações humanas, levam a pensar que a área escavada do sítio TRV se trata de uma área de atividade específica dentro da aldeia, uma área de atividade feminina.

Mais um dado corrobora essa interpretação, pois seria possível pensar que a parte escavada do sítio TRV seja uma estrutura de habitação. Mas a disposição dos materiais cerâmicos não favorece, visto que não há remontagem de material nas unidades analisadas (sendo os vestígios em configuração mais espalhada, a não ser pelo fundo de vasilha fragmentado in situ). Pode ser devido a um abandono da habitação, por ter ocorrido uma mudança e reordenamento nos vestígios que ficaram. Mas, além disso, os estudos recentes de áreas de refugo secundário em culturas Guarani são difusos e escassos, mas essas áreas de refugo secundário possíveis de identificar. Há que se avançar na identificação desse tipo de área de atividade para que não se prevaleça a antiga ideia de que o lixo era deixado dentro das habitações. Havia limpeza e organização que envolvia o tratamento do lixo (MILHEIRA, 2014). Ainda assim, esta não seria uma área de refugo secundário, uma vez que não há outros componentes do "lixo", como ossos de fauna, material lítico em abundância ou lentes de carvão indicando queima sucessiva do lixo (SCHIFFER, [1972] 1995). Novamente, Milheira (2014) realiza um levantamento bastante consistente em termos de vestígios materiais e relatos etnográficos sobre áreas de descarte e lixeira (ou áreas de refugo secundário). Aborda um tema que é tratado tangencialmente na Arqueologia Guarani e diz ser necessário melhor refinamento para encontrar essas áreas de descarte, pois são muito diversas. O autor usa exemplos etnográficos para demonstrar a frequência dessas estruturas de descarte nos sítios arqueológicos.

Ainda, a área escavada no sítio TRV não foi considerada área de fabricação das vasilhas (apesar da presença de estruturas de combustão) visto que não foram 
encontrados elementos típicos de sítios que representam essas áreas, como bolotas de argila, trempe/ytácuru (Noelli, 1993, P.234), ou roletes avulsos. Ainda assim, é importante considerar que todas essas inferências são feitas a partir dos dados produzidos, uma vez que o TRV não foi delimitado, tampouco foram buscadas outras áreas de atividades no sítio de forma a compreender mais amplamente a aldeia escavada durante a etapa de campo. Até o momento também não foram realizadas análises microarqueológicas como para a identificação de microvestígios - amidos, fitólitos e ácidos graxos - nas vasilhas analisadas por exemplo, o que, sem dúvidas, trará uma visão bastante aprofundada do uso das vasilhas.

Pensa-se, portanto, que a área escavada do sítio de onde provem a coleção analisada seja área de atividade da aldeia, voltada à vida em comunidade, especialmente uma área mais feminina, na qual as mulheres tomam conta da cena (LANDA, 1995; LÉVI-STRAUSS, 1986). Essa área de atividade no sítio TRV muito provavelmente tratou-se de área de processamento de alimentos nas vasilhas produzidas, dadas as características das vasilhas estudadas e demais elementos da escavação descritos (aspectos do sedimento arqueológico e possíveis estruturas de combustão). A produção cerâmica nas sociedades pré-coloniais no Brasil é feminina (LIMA, 1987) e, especialmente, a produção cerâmica Tupi, de forma geral, também o é. A pesquisa de Landa (1995) é uma pesquisa emblemática nos estudos em Arqueologia Guarani e vem sendo muito utilizada nos estudos de gênero na Arqueologia, uma vez que ela aborda como objeto de estudo a mulher nas sociedades Guarani pré-coloniais e as atividades realizadas por elas nesses meios. A autora trabalhou especificamente com pesquisa etnográfica profunda e a partir de documentos históricos, como os dicionários de Antônio Ruiz de Montoya, a produção de cronistas, viajantes e missionários dos séculos XVI e XVII e as cartas ânuas dos jesuítas. São atividades das mulheres, segundo Landa:

"A ela [a mulher Guarani] cabia especialmente, o serviço doméstico, todo o processamento alimentar, as tarefas da roça, confeccionar a cerâmica, fiar e tecer. O homem caçava, pescava, trabalhava a madeira, confeccionava a cestaria, preparava o terreno para o plantio, plantava a mandioca e colhia o milho, fazia os cachimbos" (LANDA, 1995, P.26)

Portanto, a mulher estava em muitas atividades na vida da aldeia, mas duas atividades em que atuavam exclusivamente mulheres eram na produção cerâmica e na tecelagem. Com relação à produção cerâmica, essa seria uma das mais importantes 
segundo Landa, pois as vasilhas cerâmicas tinham a forma apropriada para cumprirem várias funções nas demais expressões da vida da mulher Guarani e do restante do grupo:

"Serviam para carregar água, preparar o alimento e bebidas, armazenar as farinhas, processar os produtos provindos das diferentes técnicas de captação de recursos. Para as pessoas mais importantes do grupo, serviam de urna funerária. Portanto, a cerâmica não estava somente na vida das mulheres, mas na organização social do grupo.”(LANDA, 1995, P.41)

E, portanto, na produção cerâmica, eram responsáveis por todas as etapas (menos pela confecção dos cachimbos como visto em excerto do trabalho de Landa): captação das matéria-primas (feita em expedições em grupo), a limpeza da argila (a sua manipulação para a retirada de impurezas, feita no local de produção cerâmica), a construção das vasilhas em si, a secagem (em locais abrigados de intempéries, nas habitações ou estruturas anexas), a queima (após a secagem, em local abrigado do vento, não em habitações ou próximo a elas, em local próximo com madeira suficiente para proceder à cocção), e tratamentos cromáticos finais (LANDA, 1995, P.p.45-48). Posteriormente, o processamento do milho, da mandioca, do feijão, da batata (tão importantes que também eram instrumentos técnicos de aprendizagem da língua e que requeriam por parte das mulheres uma organização rigorosa e complexidade de procedimentos), de assados, fervidos, farinhas e bebidas também cabia a elas (LANDA, 1995, P.p.68-122). E, com relação às convenções sociais existentes no grupo para a partilha do alimento, são divididas em três formas: 1- as refeições cotidianas da família nuclear sem diferenciação de grupos; 2- as refeições cotidianas da família extensa com divisão de grupos; 3- as refeições coletivas com caráter festivo (entre membros da aldeia, entre membros de outras aldeias, entre membros de vários teko'ás) (LANDA, 1995, P.122).

Sobre o sedimento escuro que caracteriza os sítios, não se trata de manchas pretas circulares ou elípticas da bibliografia tradicional. As manchas pretas da bibliografia tradicional indicam que seriam estruturas de habitação / casas / ou okas. Mesmo que existam as três possíveis estruturas de combustão e essas serem possíveis em habitações tanto da família nuclear como da família extensa. Milheira (MILHEIRA, 2010, P.p.144-145) faz um compilado do que Noelli (1993) e Assis (1996) versam sobre as casas ou okas, sugerindo uma série de métodos de construção, materiais e formas do registro arqueológico após o colapso das casas. A mancha de terra 
preta evidenciaria a habitação Guarani segundo Pallestrini (1978), Noelli (1993), Assis (1996), Carle (2002) e Soares (2005). Essa ideia, segundo a investigação de Milheira, pode ser elucidada nas pesquisas no interior do estado de São Paulo, na região do Projeto Paranapanema. Sobre a evidenciação das áreas habitacionais do sítio Prassévichus em Itaberá - SP, Pallestrini e Morais (1984), comentam que:
“(...) as manchas de terra preta correspondem ao que restou de antigas casas: com o abandono e subsequente queda de madeirame de sustentação e da cobertura vegetal, ficou no solo uma mancha enegrecida, rica em carbono residual e outros elementos resultantes das atividades humanas" (PALLESTRINI \& MORAIS, 1984, P.160).

Conforme o esclarecimento de Noelli (1993), essas manchas seriam contextos bem definidos e, além de serem unidades habitacionais, podem ser unidades funcionais da aldeia, como estruturas anexas para processar alimentos, lazer, depositar e manufaturar objetos. A documentação etnohistórica também mostraria isso, sugerindo uma diversidade funcional não captada em termos arqueológicos ainda. As manchas com seu formato circular (quando a estrutura cai no sentido vertical, caindo o telhado sobre o piso) ou elíptico (quando a estrutura colapsa para um dos lados, num movimento horizontal) seriam então o resultado do colapso das casas. Com esta discussão e com base nos dados etnohistóricos e etnográficos, Noelli (1993) supõe que casas com formato elíptico não existiriam na cultura Guarani, apenas casas circulares Porém, Milheira adverte que, como pesquisadores, é necessário estarmos atentos de que essas manchas não adquirem os formatos pressupostos por vezes, como sua própria pesquisa de campo demonstrou. Portanto, é evidente que há que se refinar métodos de campo para averiguar essas possibilidades tendo em vista os questionamentos que a Arqueologia Guarani levanta.

$\mathrm{Na}$ coleção RT, assim como em TRV, a maior parte dos fragmentos se constitui de parede (63.25\%), uma questão amostral já explanada; há também uma trempe/ytácuru presente na literatura sobre os Guarani (NOELLI, 1993, P.234) representando apoio da fase de produção de vasilhas e de uso, serve de apoio as vasilhas na superfície ou mesmo em fogueiras. Há bordas e paredes com inflexão (além de fragmentos maiores em comparação às duas coleções) e reforços não observados na coleção TRV. Ao observar a presença de bordas e paredes com inflexão e reforços na coleção RT, compreende-se que a mesma deve possuir vasilhas de tamanhos 
maiores comparados a TRV, pois esses recursos e estruturas como inflexão e reforços são utilizados para uma maior sustentação da massa da vasilha. A técnica mais utilizada é o roletado/acordelado e o moldado (para as bases). É ela que possibilita a estruturação de vasilhas pequenas a grandes. Também não ocorre nessa coleção, nenhuma identificação de material de contato europeu. Não foi identificada técnica torneada de fabricação, assim como em TRV. Por isso, se o sítio for datado do período do contato assim como TRV (pois não se conhece datações absolutas para o sítio arqueológico da coleção RT), não possui nenhuma característica material desse momento. Mas, possui mais bordas e bases que em TRV ( 47 bordas e 2 bases contra 12 bordas e 1 base para TRV) o que também representa uma questão amostral como em TRV (devido as vasilhas possuírem mais área de parede que de borda e base), mas é um número muito maior que em TRV, muito provavelmente que em razão da dispersão dos fragmentos nos sítios e mesmo do tipo de coleta feita na escavação.

Também aqui, como em TRV, predomina o antiplástico mineral, em seguida minerais e caco moído e, por fim, minerais e carvão. Há uma variabilidade em questão de composição da pasta nesse sentido, mas sempre predominando o antiplástico mineral abundante na região e, acredita-se, que não somente por isso, mas devido a sua performance nas vasilhas. $O$ tamanho dos antiplásticos minerais revela muito sobre a manipulação dos mesmos (aqui divididos em três tamanhos). Nenhum deles contem antiplástico mineral demasiado, tampouco antiplástico mineral grande (mineral A) de forma a fazer quebrar as vasilhas, pois tendem a ser mais frágeis que as vasilhas de antiplástico orgânico não observados nesta análise. Isso porque as quebras observadas estão nos roletes sempre. Os antiplásticos minerais em tamanho grande (mineral A) aparecem em ambas as coleções associados sempre aos antiplásticos minerais $\mathrm{B}$ e/ou $\mathrm{C}$ (tamanhos médio e pequeno respectivamente) e em muito menor quantidade que estes últimos. Considerando isso, acredita-se que ocorriam quebras em função do uso desse antiplástico, mas não de forma extensiva (as quebras estão nas junções dos roletes e não necessariamente em áreas de maior concentração de antiplástico mineral A). Então, olhando apenas para o antiplástico mineral, pode-se dizer que as vasilhas poderiam ir ao fogo por possuírem boa capacidade de condutividade térmica e não se tratavam de vasilhas que seriam muito transportados. Mas, com a avaliação sobre tratamentos de superfície, verifica-se que essas vasilhas, não necessariamente por possuírem antiplásticos minerais bons 
condutores térmicos, eram utilizados ao fogo em sua grande parte. Crê-se que eram utilizados para servir e armazenar alimentos e produtos.

Nessa coleção, há o predomínio de dois tipos de queima: ou totalmente oxidante, ou totalmente redutora, o que significa que não há um controle homogêneo da atmosfera circundante no momento da queima das vasilhas desidratados, ou seja, a queima é feita a céu aberto como a coleção TRV, apesar dos seus resultados serem diferentes. Há uma variedade de formas de bordas e de lábios, mas sem nenhuma relação direta entre elas, tampouco relação entre espessura da peça e espessura do lábio, a não ser que as espessuras dos lábios são menores que a espessura do restante da peça, e quanto maior a espessura do lábio, maior a espessura da peça e o diâmetro da borda projetado, algo extremamente comum nas literaturas cerâmicas.

Ainda, segundo Chilton (CHILTON, 1998, P.154), os tratamentos de superfície podem afetar profundamente a performance de uma vasilha (Schiffer et al., 1994). Com relação ao tratamento plástico, neste predomina o alisamento (essencialmente em ambas as faces), isso porque as peças recebem tratamento cromático na sequência. Aparecem em menor número corrugado, ungulado e acanalado, sempre com alisamento interno. Isso significa que a coleção é formada, principalmente por materiais com tratamento cromático (vasilhas de servir e armazenar, visto que esses tratamentos auxiliam nessas funções, diminuindo a porosidade das vasilhas), ainda assim, com uma variedade de tratamentos plásticos (também bastante conhecidos na cerâmica Guarani). Uma vez que a coleção é formada em sua grande parte por fragmentos com tratamento cromático, os engobos vermelho e branco são os mais evidentes (de 102 peças, 52 possuem somente engobos). Ainda assim, são observáveis fragmentos monocrômicos, bicrômicos, enegrecimento e o que parece ser tipo de "resina" em menor quantidade. A grande parte desses tratamentos é observada nas faces internas dos fragmentos. Ocorrem nas faces externas, mas chama a atenção a presença desses tratamentos nas faces internas. Ou seja, essas vasilhas, muito pouco provávelmente, iam ao fogo. Os engobos, especialmente, são excelentes para tirar a porosidade dos recipientes, favorecendo o armazenamento de líquidos e alimentos pastosos, por exemplo, ainda que a maior parte das vasilhas possua bordas irrestritivas. Vasilhas restritivas e verticais são mais associadas ao processamento ou armazenamento de líquidos, portanto, estas são poucas na coleção. As bases identificadas são planas, como em TRV. 
$\mathrm{Na}$ coleção foram identificadas as cinco cores de pasta presentes na ficha, sendo mais presentes, em sequência: branca, laranja C, laranja A, laranja B e cinza/preta, o que quer dizer que há, no mínimo, cinco variáveis de pasta formadas, havendo uma variabilidade de fontes de coleta de matéria-prima somado à diversidade e resultados provocados pela queima a céu aberto. Porém, há a preferência pela pasta branca. A pasta branca é escolhida para levar o alisamento que dá base ao tratamento cromático na coleção RT, sendo em sua maior parte vasilhas para servir e armazenar. Os tratamentos de superfície identificados nas pastas laranja C (em TRV) e branca (em RT) também estão nas demais pastas, ou seja, não há uma diferenciação de tipos de vasilhas para determinada cor de pasta dentro de cada coleção; mas há essa diferenciação entre as coleções.

Nove agrupamentos de conjuntos foram identificados segundo cor de pasta, espessura e tratamentos de superfície das peças, e os espelhamentos levaram em conta o posicionamento da borda e seu diâmetro projetado (na ficha de análise) (diâmetro de abertura). Os espelhamentos, junto às espessuras das peças (a maior parte das espessuras dos fragmentos é de $7 \mathrm{~mm}$, mas essa faixa vai de 1 a 23mm) e diâmetro projetado levam a crer que a coleção possui muitas vasilhas médias a grandes (diferente de TRV). Nessa coleção, o desgaste acentuado é a marca de uso mais encontrada, e esse desgaste acredita-se estar mais associado a ações pós-deposicionais no sítio arqueológico. Portanto, predominam vasilhas médias a grandes com diâmetros de 16 a $56 \mathrm{~cm}$, com maior ênfase em diâmetros de 20, 54 e $56 \mathrm{~cm}$ e espessuras de 6 a $18 \mathrm{~mm}$, ou seja, com menor capacidade de aquecimento e alta resistência ao impacto apesar de possuir antiplástico mineral que favorece a quebra mas favorece a condutividade térmica. $\mathrm{Ou}$ seja, teríamos aqui vasilhas de tamanhos pequeno a grande, com ênfase nos médios e grandes (dado estruturas de parede e reforços, espessuras e diâmetros compatíveis visualizados nos espelhamentos), vasilhas com tratamento plástico e cromáticos bons para irem ao fogo devido ao amplo uso do antiplástico mineral e tratamento áspero no seu exterior, mas na sua grande maioria provavelmente não iam ao fogo, devido a serem vasilhas com demasiado tratamento cromático se comparados à coleção TRV, bons para servir e armazenar (pois os tratamentos cromáticos, especialmente, engobos diminuem a porosidade das vasilhas). As espessuras médias a grandes somadas ao tratamento alisado e cromático nas superfícies não favorecem o uso ao fogo das vasilhas (ARNOLD, 2000, P.154). Vasilhas mais finas estão mais aptas a irem ao fogo sem 
quebrar (CHILTON, 1998, P.151), e as espessuras em RT são maiores que em TRV. Nessa coleção, a fuligem proveniente do uso das vasilhas no fogo foi pouquíssimo observada, sendo o desgaste acentuado devido a características pós-deposicionais, a marca mais evidente corroborando a interpretação. As análises de XRF nesse sentido corroboram a evidenciação de que as vasilhas contiveram matéria orgânica em virtude da presença do elemento químico fósforo (P) nas faces das vasilhas, também acontecendo na coleção TRV. Não eram vasilhas muito transportadas dados suas dimensões médias a grandes e o uso do antiplástico mineral (apesar da espessura das vasilhas contrabalancear essa característica) e a sua grande maioria possuir aspecto alisado externamente, o que dificulta o manuseio (nesse aspecto, diferente da coleção TRV).

Importante salientar que, ao avaliar se as vasilhas analisados iam ao fogo ou não, não é feita uma distinção entre o que é "utilitário" ou "ritual", uma vez que não seja crível que haja essa distinção para os Guarani. O próprio uso de grandes vasilhas nos enterramentos secundários Guarani é evidência de que não existe essa separação. Ambas as coleções demonstram que as ceramistas possuíam um grande domínio empírico sobre a produção cerâmica segundo seu uso final, dada a forma como foram conjugadas as características físico-químicas dos materiais utilizados e sua performance final. O que vem sendo observado até então é que tudo o que aparece nas coleções é de domínio conhecido para a cerâmica Guarani, mas a diferenciação das coleções vem na conjuntura de uso e coordenação dessas categorias e, principalmente, na composição da pasta. A pasta é a chave.

Somado a essa conjuntura expressa pelo material cerâmico analisado, há a presença de um sepultamento humano secundário em urna que não pode ser identificado por possuir apenas um osso longo conforme Noelli (1993, P.108) propõe identificar. O autor propõe identificar, ao menos, se o sepultamento é masculino ou feminino, dadas as condições sempre difíceis e debilitadas dos poucos sepultamentos Guarani encontrados e estudados. Há materiais líticos na mesma área de onde provem o material analisado, contudo, ainda não se compreende qual sua associação com o material cerâmico. A vasilha utilizado como urna não foi analisado por se encontrar em exposição no MArquE, mas apresenta características bastante distintas do restante coleção uma vez que não possui pinturas ou engobos, apenas tratamento plástico corrugado e alisado em pasta laranja C (ANEXO 09). Sobre os sepultamentos humanos 
secundários, Noelli (1993, P.p.101-104) descreve poder haver duas formas: dentro ou fora da habitação. No caso de sepultamentos secundários, Noelli retoma Jolís (JOLÍS, 1972, P.256 apud NOELLI, 1993, P.104) que afirma que os sepultamentos humanos secundários fora das habitações localizavam-se nos contornos dos assentamentos. Observa-se, portanto, que essa área de atividade de sepultamento dentro do sítio é uma área de atividade dentro de uma aldeia (apesar da baixa densidade de material se comparado à coleção TRV), visto que os sepultamentos humanos são parte da vida coletiva Guarani (MILHEIRA, 2010).

Também, como em TRV, o sedimento escuro descrito na documentação primária remete a um sedimento de sítio arqueológico com alta atividade humana, sedimento esse encontrado ao longo de boa parte do sítio arqueológico delimitado (não somente na área de escavação realizada na década de 1960). Não foram delimitadas manchas escuras circulares ou elípticas que pudessem caracterizar registros de okas e cabanas, tampouco nessa etapa de pesquisa foram realizadas intervenções de forma a identificar outras áreas de atividade humana dentro do sítio. Novamente, como em TRV, essa é uma área de atividade pública, voltada à vida em comunidade. Apesar de ter sido encontrado na coleção um trempe/ytácuru, o que seria uma evidência de local de fabricação pelas oleiras, o trempe/ytácuru pode não ser exclusivo desses locais de atividade; e, devido ao sepultamento humano secundário e demais vasilhas, acredita-se tratar de local de sepultamento dos mortos, dentro do amundá, ou melhor, local de sepultamento de uma pessoa dentro do amundá. Não é possível falar, como foi em TRV, que esse espaço trata-se de uma espaço especificamente feminino, visto que apesar da presença cerâmica e da provável manipulação de alimentos nele (identificação do elemento químico fósforo nos recipientes cerâmicos) indicarem a predominância feminina, encontra-se o único sepultamento presente no mesmo contexto. E, não se conhece bibliograficamente que o espaço e momento de enterramento de um morto Guarani esteja vinculado especificamente a um ou outro grupo específico da comunidade. Sobre o sepultamento, também não está claro se faz parte do mesmo período do material cerâmico no sítio e se esses elementos estão no mesmo contexto, dada a documentação escrita primária não abranger tais observações de interpretação estratigráfica durante a escavação. Por isso, por enquanto, é possível afirmar com cautela que essa se tratava de uma área de atividade na qual o material cerâmico é central - com vasilhas cerâmicas predominantemente para guardar e servir 
alimentos / materiais orgânicos (até o sepultamento é secundário em vasilha cerâmico) com um sepultamento humano nos limites do assentamento. Trata-se de uma área de servir alimentos e bebidas nos limites do assentamento, muito provavelmente em momento específico da cultura Guarani associado ao sepultamento humano.

Essas interpretações vão ao encontro do que se avançou e se compreende sobre a organização territorial Guarani a partir dos trabalhos referência de Noelli (1993), Assis (1996) e Soares (1997) (MILHEIRA, 2010). Essa organização se dá através da articulação entre diferentes dimensões espaciais. A casa (oka) é onde reside a família nuclear e a família extensa ou teýy. Seria na casa organizadas as relações de parentesco mais próximas, onde dormem, onde são tratados os doentes, onde se guardam pertences e alimentos. Cada família nuclear tem sua fogueira na casa. Garlet (1997) e Assis (1996) sugerem que a casa seja um espaço de convívio particularizado e que as ações cotidianas mais frequentes sejam praticadas no ambiente externo da casa. Essa informação é bastante coerente para interpretar o sítio TRV. Fora da casa, no ambiente da aldeia, se dá o preparo de comidas, o conversar em grupos, fabricação de instrumentos, dormir à rede e à sombra, jogar, beber. De forma semelhante, Moi (2007), com um trabalho de campo etnográfico entre os grupos Xerente, também teria sugerido que a casa seja um espaço particular e que o cotidiano indígena é mais voltado ao espaço da aldeia em si. O autor (MILHEIRA, 2010 P.p.143-144) também faz um compilado bastante interessante de relatos etnográficos de Cabeza de Vaca e do Padre Jerônimo Rodrigues sobre as casas nas aldeias e sua densidade.

Sobre o amundá, que seria o espaço da aldeia, outras facetas da vida aldeã se desenvolvem. Fenômeno de aprendizado oralizado das crianças (MELIÁ, 1979 apud MILHEIRA, 2010, P.p.146-147), o espaço das relações entre as famílias, da produção dos alimentos e da sua distribuição. Da produção das panelas de barro, onde as oleiras se juntam. Vivência dos homens nos jogos e parlamentações, também onde se encontram os mortos, onde se vinga a morte dos parentes através dos rituais de antropofagia. É o espaço da vida coletiva que articula várias gerações. As aldeias são pouco discutidas na literatura arqueológica, conforme Milheira (MILHEIRA, 2010) pois são difíceis de se mapear. E no geral é abordada apenas através do micro-espaço da casa. Segundo por causa dos relatos dos cronistas (já no período da decadência das comunidades) que relatam aldeias formadas por uma ou duas casas. Mas, sabe-se de aldeias com centenas de indivíduos e áreas com muitas aldeias densamente ocupadas, 
que permitem abordar a temática de maneira bem distinta. Milheira cita ainda exemplos em Staden (1557), Cabeza de Vaca (1999) e Rodrigues (1605-1607). Segundo Schaden (SCHADEN, 1974 apud MILHEIRA, 2010, P.147), não haveria conglomerados compactos de habitações nas aldeias Guarani, consistiriam em casas isoladas, mais ou menos distantes umas das outras, espalhando-se pelas clareiras abertas na floresta. Em geral, não é possível determinar um "centro" da aldeia, a não ser que se considere como tal a habitação de ñanderú, chefe religioso, ou o oyguatsú, casa de festas religiosas (MILHEIRA, 2010). A coleção RT certamente esteve presente em área de atividade nos limites do amundá, representando um momento da vida coletiva em que estavam dispostos alimentos e bebidas.

As aldeias Guarani estudadas por Milheira (MILHEIRA, 2010, P.148) não possuem formato circular como sugerem as xilogravuras das aldeias Tupinambá publicadas por Staden 2007[1557]. Milheira sugere as casas estarem alinhadas e, em alguns casos, conforme os aldeamentos atuais das reservas indígenas Mbyá Guarani do Estado do Rio Grande do Sul (GARLET, 2007), dos Ñandeva-Guarani do Mato Grosso do Sul (LANDA, 2005). Este tipo de estudo etnoarqueológico é um novo passo a ser realizado para o futuro das pesquisas em Arqueologia Guarani na ilha de Florianópolis. Ao pensar as aldeias nesse teko'á Guarani na ilha, questionamentos também surgem sobre se as aldeias foram ocupadas permanentemente até seu abandono final, ou se eram abandonadas e reocupadas anos mais tarde. Noelli (MILHEIRA, 2010, P.p.150-151) corrobora a ideia de que as aldeias eram ocupadas ao longo de 3 a 5 anos e depois abandonadas, podendo ser reocupadas anos mais tarde. Para adentrar também neste tipo de discussão para a região delimitada, alguns próximos passos são estudos em microestratigrafia em ambos os sítios arqueológicos, e realização de datações radiocarbônicas no sítio arqueológico RT. Para o sítio TRV, já se sabe que houve um período de ocupação de aproximadamente cem anos, no entanto, não se sabe com que intervalos de tempo ou se permanentemente (o que seria pouco provável levando em consideração a literatura etnográfica). Para buscar elucidar a questão, a microestratigrafia seria muito eficaz.

Outra forma de aprofundar essa pesquisa será a busca pelas fontes de matérias-primas (argila e antiplástico) captadas para a produção do material cerâmico analisado e que certamente irá ajudar a compor o cenário da ocupação Guarani na Ilha, irá ajudar na compreensão de como funcionava o teko'á, aprofundando as discussões 
sobre território (após levantamento sistemático em campo buscando compreender sistemas de assentamento). Complementarmente, análises petrográficas do material cerâmico também auxiliarão a compreender a composição da pasta cerâmica, bem como análises de XRF de matérias-primas das possíveis fontes utilizadas poderão ser comparadas às pastas encontradas nos sítios arqueológicos, como já mencionado anteriormente. Dessa forma, é possível identificar muitas possibilidades e frentes de análises e estudos a serem realizados com a temática e materiais aqui propostos na busca de compor uma história indígena Guarani de longa duração no litoral central catarinense.

E, conforme visto, a análise das duas coleções suscitou direções e também questionamentos. Outros tópicos de pesquisa a serem buscados são, por exemplo: pensar a variabilidade observada da pastas trata-se de escolhas de matéria-prima disponíveis e/ou estilo; ou, se ambas as produções forem contemporâneas (uma vez que não possuímos datações para a coleção RT), como ocorria o domínio ou compartilhamento do território e fontes de matérias-primas pelos ceramistas? As diferenças observadas também podem ser devidas ao distanciamento de tempo e espaço observáveis entre os sítios arqueológicos? E, por fim, como permanecer visualizando a fluidez na cultura Guarani e as particularidades perante a estrutura de longa duração dessa cultura?

\section{As análises por XRF demonstraram explicitamente a variabilidade da} composição química dos vestígios cerâmicos analisados, tanto entre as coleções, como em cada coleção. As variações de silício ( $\mathrm{Si}$ ) e alumínio (Al), base das argilas, são aquelas que mais demonstram essa variabilidade, uma vez que nenhuma medida é igual à outra. Isso remete a compreender que há uma variedade de fontes de matériaprima utilizada para a fabricação das vasilhas em cada coleção.

Sobre a composição das argilas que formam as pastas cerâmicas, Shepard afirma que os componentes predominantes da argila são a sílica, o alumínio e a água, mas também podem estar presentes ferro e terra alcalina (SHEPARD, 1965, P.6):

"Clay is difficult to define precisely because the term has been applied to a variety of materials differing in both origin and composition. It is broadly defined as a fine-grained chemical components are silica, alumina, and water; frequently it alsocontains appreciable amounts of iron, alkalies, and alkaline 
earths. The term 'clay', however, has been applied to materials that have some but not all of these properties. It has also been used as a particle-size designation for the smallest fraction of soil.”(SHEPARD, 1965, P.6)

Silva (2000) afirma que a seleção da argila mais adequada pelo ceramista leva em consideração tanto aspectos geográficos - de disponibilidade de matéria-prima, quanto aspectos culturais - como o tratamento que se pretende dar àquela argila até a forma final da vasilha a ser obtida; neste sentido, os ceramistas não coletam sua matéria-prima aleatoriamente, mas sim selecionam uma determinada porção de um único depósito que lhes parece mais homogênea. A partir dessas afirmações de Silva et.al. (2004), é possível pensar o que seria uma boa argila para as Guarani? Aos poucos, esse tipo de questionamento levanta pontos a serem debatidos e deixa bons direcionamentos para o futuro da pesquisa. Arnold faz uma discussão mais aprofundada sobre os aspectos de busca por fontes de argila que será tratada mais adiante.

Foi identificado que os elementos $\mathrm{Si}$, Al, seguidos de ferro (Fe) e potássio (K) em ambas as coleções são elementos mais abundantes nos núcleos dos fragmentos que nas faces, ou seja, nas pastas. Mas, também são identificados nas faces. Os elementos fósforo (P), enxofre (S) e cálcio (Ca) estão em maior abundância nas faces dos fragmentos, ainda que estejam na composição das pastas. O zinco $(\mathrm{Zn})$ e o estrôncio ( $\mathrm{Sr}$ ) na coleção RT aparecem de forma similar nos núcleos e faces; na coleção TRV, o Zn e o Sr estão mais abundantes nas faces. E, por fim, na coleção TRV, o manganês (Mn) está em proporções semelhantes nos núcleos e faces, enquanto que na coleção RT, encontra-se em maior quantidade nas faces. Todos os elementos avaliados nesse trabalho estão distribuídos nos núcleos e faces dos fragmentos, como já dito, e de forma bastante heterogênea de forma geral, reiterando a variabilidade macroscopicamente observada, mas agora em nível composicional. Outro aspecto muito interessante é que os elementos presentes nas faces não estão ordenados mais na face interna ou externa em comparação um ao outro.

Portanto, é importante retomar os resultados e interpretações formadas até então: o Si nos núcleos das coleções encontra-se de forma bem heterogênea e em altas quantidades, enquanto que nas faces, em ambos os sítios, aparece de forma mais homogênea entre as amostras, com alguns picos maiores possivelmente em decorrência de resquícios do sedimento do sítio aderido nos materiais (ainda que após serem higienizados a seco). $\mathrm{O} \mathrm{Al}$, junto ao $\mathrm{Si}$, forma a base das argilas e, portanto, em maior 
quantidade nos núcleos dos fragmentos que nas faces, mais no núcleo da coleção RT em comparação com TRV. Ou seja, temos as argilas que formam as pastas dos fragmentos selecionados para representarem as coleções analisadas e que, dentro de variabilidade apresentada em cada coleção, é possível observar que a coleção RT possui mais alumínio em sua base se comparada a coleção TRV. Isso, devido aos traços geológicos existentes nas fontes de matéria-prima utilizadas.

Os demais elementos em maior quantidade nos núcleos que nas faces (maior quantidade após os elementos base) são o $\mathrm{Fe}$ e o $\mathrm{K}$. O Fe está de forma mais heterogênea (ou seja, variabilidade maior) nos núcleos da coleção TRV, mas em valores bastante similares na coleção RT. Os maiores e mais variáveis picos de Fe na coleção TRV são aqueles de fragmentos de cor de pasta laranjas A e B (e, portanto, mais avermelhados), enquanto que os maiores picos em RT não se demonstram de forma mais avermelhada macrovisualmente nas pastas. Esses dados físico-químicos reforçam que a coloração observada nas pastas depende de dois aspectos: não somente da composição química das mesmas, mas dos tipos de queima das vasilhas. Nas faces, é encontrado em quantidades similares em ambas as coleções, ainda que essas quantidades sejam heterogêneas de uma amostra a outra. Já o K aparece mais homogêneo e em menos quantidade em TRV que em RT (este tem mais potássio em comparação a TRV). Nas faces, ele também é encontrado, mas de forma mais homogênea e em valores similares em ambas as coleções.

\section{O elemento $P$, também encontrado nos núcleos, está em maior parte nas} faces, junto ao S, Ca e Ti, o que significa que são provenientes dos usos das vasilhas (que deixam resquícios físico-químicos) e/ou de ações pós-deposicionais que atuaram sobre os vestígios nos depósitos arqueológicos, não sendo possível definir qual das duas opções melhor se encaixa na interpretação nesse momento. De qualquer forma, é evidente que há mais $\mathrm{P}$ nos núcleos e faces de RT que em TRV - há mais fósforo nas matérias-primas coletadas para a produção das vasilhas de RT e que o uso e processamento de materiais orgânicos tenha sido maior/ tenha aderido mais em RT que em TRV, e mesmo que o depósito em que se encontrava a coleção RT possui mais $\mathrm{P}$ que o depósito da coleção TRV. A inferência a partir da análise macroscópica de da coleção RT de que, em sua grande parte, a coleção não era levada ao fogo, e a observação de que a presença de material orgânico nela é alta são complementares visto que, muito provavelmente, devido às vasilhas não terem ido ao fogo, favoreceram a 
preservação dos materiais orgânicos. $\mathrm{O} \mathrm{S}$ também está vinculado à presença de matéria orgânica, tanto do uso das vasilhas quando da presença de $\mathrm{S}$ nos depósitos arqueológicos e está em maior quantidade nas faces e núcleos na coleção RT que na coleção TRV. O Ca, mesmo presente nos núcleos (portanto na argila utilizada para a fabricação das pastas, visto que as coleções não possuem antiplásticos ricos desse elemento, como antiplástico de conchas por exemplo), aparece heterogeneamente nas faces das amostras de ambas as coleções, indicando que muito provavelmente as vasilhas processaram materiais orgânicos ricos de cálcio, como conchas de moluscos. Outra hipótese menos provável, mas igualmente válida é de que o Ca seja proveniente dos depósitos em que se encontravam os vestígios (mesmo que não sejam descritas conchas durante a escavação arqueológica do sítio Lagoinha do Rio Tavares I).

O Mn separa bastante as amostras, especialmente, ambas as coleções, visto que se encontra em quantidades similares nos núcleos e faces da coleção TRV e está menos presente em TRV (de forma mais homogênea). Isso remete às fontes de argila em RT terem mais Mn que as fontes utilizadas para a produção das vasilhas em TRV. Nas faces, estão em quantidades similares, significando que está presente de forma variável nos depósitos de ambos os sítios arqueológicos. O Zn está presente também nos depósitos de onde os vestígios cerâmicos foram extraídos e o $\mathrm{Sr}$ nos núcleos está mais presente na coleção RT (esta possui mais Sr nas sua matéria-primas que em TRV). Nas faces da coleção TRV, o Sr está vinculado ao elemento Fe, e por sua alta quantidade nas faces de ambas as coleções, também está associado aos depósitos arqueológicos de ambas. Sendo assim, não foram diferenciados elementos mais presentes nas faces internas ou externas, mas sim, entre núcleos e faces de modo geral, o que influencia dizer que, além, dentro da variabilidade observada, as pastas de RT são mais ricas em Al, K, P, S, Mn e Sr que as pastas em TRV; e que as faces, portanto, o meio de depósito ou uso das vasilhas na coleção RT apresentou mais $\mathrm{P}$ e $\mathrm{S}$ que a coleção TRV. Os valores de $\mathrm{Si}, \mathrm{Fe}, \mathrm{Ca}, \mathrm{Zn}, \mathrm{Mn}$ (nas faces apenas) e Sr (nas faces apenas) são similares em ambas as coleções.

Reitera-se que as análises de XRF proporcionam um excelente confronto com relação ao que foi analisado macrovisualmente. Por exemplo, com relação à coloração das pastas e à presença do elemento Fe em alta quantidade na composição das amostras; deram também importantes passos a avançar discussões como usos das vasilhas (a presença do $\mathrm{P}, \mathrm{Ca}$ e $\mathrm{S}$ são exemplares para tal) e depósitos arqueológicos 
ainda que, para avaliações mais profundas, sejam necessários diferentes tipos de análises futuras como análises de microvestígios e análises de sedimentos dos sítios arqueológicos e de argilas de possíveis fontes de matérias-primas. No entanto, grande parte dos resultados está voltada para a composição das pastas observadas nas coleções, explicitamente muito mais plurais que a classificação dada pela ficha de análise tecnológica utilizando cinco cores de pasta aglutinadoras, mas que revelam cores muito mais abrangentes como já sugerido na correspondência com o código Munsell e variabilidade muito mais extensa demonstrada nos gráficos de análises de núcleos por XRF.

Dean Arnold (ARNOLD, 2000), por exemplo, levantou e discutiu muitas inferências realizadas sobre as pastas cerâmicas a partir de sua pesquisa etnoarqueológica e arqueométrica, especificamente a partir da ativação neutrônica (INAA). No seu trabalho publicado no ano 2000, o autor questionou se a uniformidade da pasta realmente reflete padrões e se seria o resultado de um intenso nível de especialização na produção cerâmica entre os ceramistas, afirmação comum na literatura arqueológica e difundida por Rice $(1981$; 1991) e Costin (1991) por exemplo (ARNOLD, 2000, P.334):

"More recently, the amount of paste variability has been seen as an indicator of different types of production organization. Ethnoarchaeological data from Mexico, Peru, and Guatemala suggest that a variety of environmental, technological, and social factors influence paste variability. These factors are important in all production contexts and complicate inferences drawn about production organization in antiquity. As a consequence, social and economic inferences derived from ancient ceramic pastes need to be understood in relation to numerous other factors such as natural variability of the ceramic raw materials, their procurement, and their use in paste preparation..”(ARNOLD, 2000, P.333)

O autor esclarece e pontua todos os processos envolvidos na produção da pasta cerâmica e sua variabilidade. E, nesse sentido, nos auxilia a compreender a complexidade e a variabilidade dos dados obtidos até então: são resultado de uma série de fatores ambientais e escolhas antrópicas ao longo do tempo e do espaço por ceramistas. Observamos nos gráficos trabalhados que as pastas dos dois sítios arqueológicos são diferentes entre si, são heterogêneas, e são diferentes. Os picos de alumínio (Al) e silício (Si) nos núcleos das pastas das amostras de ambos os sítios se 


\title{
diferem, ou seja, indicam que as argilas captadas para a formação dos materiais
} cerâmicos encontrados em cada um dos sítios têm origem distinta dentro da Ilha.

Ou seja, além da variabilidade observada macroscopicamente, existe uma variabilidade em termos de composição química. Essa composição também separa os materiais cerâmicos de ambos os sítios (assim como cor da pasta, antiplástico e tratamentos de superfície separam as coleções macroscopicamente).

Segundo os pressupostos colocados na citação de Arnold a seguir, o controle das elites de uma comunidade pelas fontes de matéria-prima é tido como reflexo de especialização na produção cerâmica segundo a literatura cerâmica mais tradicional:

\begin{abstract}
"By definition, the initial transition from non-specialized to specialized production occurs when potters first begin producing pots for distribution outside of their own households. Second, increased skill and routinization may lead to a highly efficient technology and result in standardization. Third, the state or other empowered elite may take control of production in some cases and restrict access to resources. A restricted resource base presumably means reduced chemical and mineralogical variability in ceramic raw materials in comparison with nonelite-controlled resources, and this change results in pastes with greater homogeneity." (ARNOLD, 2000, P.334).
\end{abstract}

Mas, é justamente isso que Arnold (2000) descontrói e vem a superar interpretações. O que ele encontra é que há alguns fatores que afetam a variabilidade das pastas, e o primeiro deles é a variabilidade natural inerente nas argilas (ARNOLD, 1971, 1972b; BISHOP, 1980; BISHOP et al., 1982; POOL, 1992), afetada pela geologia local. Em segundo, ocorrem as variáveis de busca ou "procurement variables" que incluem: 1- a percepção dos ceramistas sobre a matéria-prima (argila), 2- a experimentação dessas fontes, 3- padrões de assentamento (se a geologia de onde estão localizadas as aldeias e assentamentos sé variável), 4- questões energéticas (aqui, a quantidade de energia necessária para obter a matéria-prima é muito relevante), 5padrões de relação com a terra ou "land tenure patterns", 6- fatores religiosos (ARNOLD, 1971; RICE, 1987), 7- intenção de uso (o uso de uma ou outra argila e antiplásticos varia conforme o uso), 8- forma e tamanho do pote, 9- mudança nas fontes (naturais e por ação humana devido a sua procura), 10- processos ambientais e mudança de fontes (sendo a erosão a principal) (ARNOLD, 1975b, 1985; KOLB, 1997), 11- a 
propriedade da terra e a mudança de fontes de matérias-primas e, por fim, 12- a exaustão de fontes e mudança de recursos.

O terceiro fator que altera a variabilidade das pastas seriam as variáveis de preparação da pasta: 1- a alteração física de matérias-primas (através do esmagamento, triagem, levigação,..), uma vez que são essas técnicas, muitas vezes combinadas, que alteram os tamanhos das partículas e têm profundo efeito na sua variabilidade química e mineralógica (ARNOLD, 1985; BLACKMAN, 1992); 2- as receitas de pastas, ou seja, a mistura das matérias-primas para formar a pasta, que devem ser flexíveis o suficiente para ajustar variação de propriedades físicas das matérias-primas para produzir vasilhas satisfatórias); 3- o efeito de moldar tecnologias (muitas técnica são usadas para formar vasilhas); mudanças ao longo do tempo nas "receitas" de pastas, primeiro porque as matérias-primas mudam e os ceramistas precisam ajustar as receitas, segundo porque as fontes são esgotáveis e inacessíveis e novas fontes são usadas, e finalmente por outras questões; e, 4- estilo e variabilidade da pasta.

Sobre mudança de organização, restrição de recursos e controle de produção, Arnold (2000, P.358) argumenta que nos casos em que estudou, ao contrário das expectativas sobre hipóteses de especialização, o aumento na escala de produção cerâmica resultou em expansão no lugar de restrição de matérias-primas cerâmicas, uma vez que não é possível controlar a produção, mas o acesso dos ceramistas à argila por exemplo. Ou seja, essa variabilidade das pastas encontrada em ambas as coleções (TRV e RT) advém de diversas variáveis naturais e sociais misturadas e organizadas de forma a trazer como produto final vasilhas cerâmicas e não uma falta de especialização na produção.

Essa variabilidade na pasta de ambas as coleções tem, portanto, origem nas fontes de matérias-primas, dentre uma das variáveis principais. O rótulo "cor da pasta", por exemplo, envolve algo maior por detrás para sua compreensão: as variáveis colocadas por Arnold (2000). Podemos imaginar que as diferentes comunidades ceramistas tinham fontes de matéria-prima distintas na Ilha? Ao menos, sabe-se que duas fontes distintas foram usadas a partir das análises realizadas nas coleções TRV e RT. Essas fontes mudam de acordo com o tempo e com seu esgotamento. Como ocorria essa seleção? As cores de argilas escolhidas têm algum significado para os Guarani? Há diferenças nas coleções e nos lugares. Há diferenças no tempo? Com relação estas 
últimas perguntas, difícil mapear visto que ainda não temos dados suficientes para a região para datar e analisar todos os contextos; no entanto, já começa-se a avançar nessa discussão para a região com esta pesquisa.

Todos os argumentos de Arnold (2000) levam a compreender que a composição da pasta arqueológica deve ser vista como uma representação dinâmica das formas como ceramistas manipulam fontes de matéria-prima para produzir específicos tipos de vasilhas, usando a tecnologia disponível. O modelo de limite de fontes de matéria-prima cerâmica sugere que fontes de argila e tempero/antiplástico ocorrem em áreas bem definidas geograficamente que circunscrevem as causas naturais da variabilidade da pasta (ARNOLD, 1980, 1981, 1991; ARNOLD et al., 1991). Seus estudos sugerem que a área de coleta de matéria-prima não seria superior a um raio a 4 km (ARNOLD, 2000, P.363). Possíveis passos para avançar na compreensão da pasta cerâmica das duas coleções analisadas e dar continuidade na temática de pesquisa é a busca por fontes de matérias-primas em mapeamento e a busca em campo (em escalas plausíveis), análises petrográficas e microscópicas, aprofundamento das análises de fluorescência, assim como pesquisa etnográfica e etnoarqueológica bem elaboradas.

Aprofundando um pouco ainda a discussão sobre a produção cerâmica, e com relação à escala de produção? Poderíamos falar de uma indústria doméstica ou produção doméstica para os Guarani que produziram o material que compõe a coleção TRV? Ao falar em indústria doméstica ou produção doméstica, utiliza-se aqui a definição de Arnold (2000) que refere-se ao tamanho da produção cerâmica e local onde ela é realizada no geral; o que é diferente de dizer de "cerâmica doméstica" (uso doméstico), por exemplo, cujo conceito não é utilizado neste trabalho. Portanto, existe uma alta densidade de material cerâmico mesmo se comparado a coleção RT. E, sobre essa temática, Chilton (1998) argumenta, baseada em Arnold (2000), que a produção doméstica (ou household production) é dominada exclusivamente pelos membros domésticos para seu consumo (ARNOLD, 1985, P.225 apud CHILTON, 1998, P.157). Assim, ceramistas domésticos precisam direcionar pouco tempo à manufatura cerâmica (ARNOLD, 1991). Seriam evidências dessa escala de produção: a falta de frequência de atividade, o baixo número de atores envolvidos na produção e a falta de controle sobre acesso a recursos (RICE, 1991). Do outro lado, há a forma de "indústria doméstica" ou household industry (VAN DER LEEUW, 1984, P.722; ALLEN, 1992). Ela é caracterizada por uma produção em tempo direcionado para o uso do grupo. Nessa 
forma, mais pessoas estão envolvidas na sequência de produção (ARNOLD, 1985). As maiores diferenças entre ambos os tipos de produção são que, na indústria doméstica, a produção ocorre com frequência maior; há um aumento na quantidade de produção e, por consequência, há um investimento maior no trabalho (ARNOLD, 1991, P.92). A produção se torna mais regular e, arqueologicamente falando, esse crescimento gera densidades cerâmicas maiores (ARNOLD, 1991, P. 93). Segundo Chilton, Arnold (1985) afirmaria que a indústria doméstica seria mais característica e relacionada com o aumento da população, quando há uma demanda maior na produção cerâmica. Importante salientar que quando Arnold propões os termos "produção doméstica" e "indústria doméstica", não falamos de distinção entre o que é utilitário ou ritual, mas fala-se em escalas de produção, fala-se de baixa e alta escalas de produção.

Portanto, em posse dessas informações, torna-se um tanto complicado definir qual a forma de produção cerâmica utilizada para a produção das coleções analisadas baseado nas definições de Arnold que provêm de suas experiências de pesquisa com grupos das Américas do Norte e Central. Porém, poder-se-ia interpretar que a produção em TRV é maior comparando ambas as coleções, baseado na densidade de material, mas ainda assim seria uma produção doméstica. Por consequência, RT também seria marcado por uma indústria doméstica. Isso porque, segundo Landa (1995, P.52), as ceramistas se reuniam em local de atividade específico na aldeia para a produção, e quando havia uma demanda de produção maior em momentos específicos como a vinda de pessoas de demais aldeias, as mulheres eram reunidas para a produção de mais vasilhas. Ou seja, não havia uma produção grande contínua, visto que havia a produção para as habitações das famílias e produção para grupos maiores, e quando era necessário aumentar a produção em virtude de momentos específicos, reforçava-se a confecção com mulheres sendo deslocadas de outras atividades para a confecção cerâmica. Também não existem outras densidades a comparar, mas sabe-se pelas datações que, embora houvesse grandes aldeias no sul da ilha, as datas da coleção TRV remontam ao período do contato, portanto, de declínio populacional não só para os Guarani. Declínio este ora descrito como "fuga ao interior" (MILHEIRA, 2010), ora não mencionado. Essa interpretação é reforçada pela maior presença de vasilhas de tamanho mediano na coleção TRV. Segundo trabalho mais recente de Arnold (2000, P.363), sem mais estudos da relação entre variabilidade da pasta e as variáveis (geológica, social e comportamental) da 
seleção de matéria-prima, aprovisionamento e preparação da pasta em contextos etnoarqueológicos, o uso de dados da pasta para inferir organização de produção entre a comunidade de ceramistas é prematura. A composição da pasta, segundo ela, sugere apenas fornecer informação sobre contexto geológico e localização geográfica de comunidades ceramistas do que informação sobre organização de produção. A variabilidade da pasta está relacionada principalmente à variabilidade de materiais disponíveis aos ceramistas, a forma com que esses materiais são selecionados e processados para formar a pasta e a disponibilidade de matéria-prima que muda com o tempo (ARNOLD, 1980, 1981, 1991, 1992; BISHOP et al., 1982). A variabilidade observada deve ser analisada diacrônica e sincronicamente para continuar perseguindo inferências no nível da comunidade.

\subsection{Sobre os Lugares e o contexto regional Guarani: Construindo uma Arqueologia do Lugar}

Para construir essa história indígena de longa duração Guarani no litoral central catarinense, foram usadas a Etnologia, Etnohistória e Arqueologia em discussão e confronto, havendo ainda muitas possibilidades de abordagens a serem tratadas. Essas populações estavam preferindo as várzeas e desembocaduras de rios mais expressivos na região (exemplo, rio Massiambu no sul da parte continental), e praias mais protegidas das intempéries, regiões mais planas e próximas a grandes cursos de água doce (rios e lagoas, como a Lagoinha do Rio Tavares I no bairro Rio Tavares, sul de Florianópolis).

Segundo sua ficha de registro no projeto Florianópolis Arqueológica (em ANEXO 03), o sítio TRV encontra-se entre cordão de dunas, em planície eólica, em regime deposicional, portanto solo arenoso, cujo corpo d'água mais próximo é o Rio Vermelho, distante $570 \mathrm{~m}$ do sítio na Bacia da Lagoa da Conceição. Portanto, é um local abrigado dos fortes ventos que vêm do mar da praia do Moçambique, com rio, mar a leste e laguna a oeste próximos que proveriam recursos para essas populações. Essa área de atividade está em planície flúvio-aluvial, em regime deposicional, sendo o corpo d'água mais próximo, a Lagoinha do Rio Tavares I, distante 320 m, com o Rio Tavares próximo, na bacia do Morro das Pedras. Novamente, aqui, assim como com o sítio 
TRV, o sítio RT possui corpos d'água abundantes ao seu redor, provendo recursos para as populações. Trata-se de uma área de planície extensa propícia à captação de recursos, sendo notória na etnografia pela presença de aldeias Guarani (Riberaco, Tíqua, Tameubre, Trinoga e Aboçapeau) mencionadas por Oviedo e Valdés no século XVI.

Além disso, essas populações ocuparam uma ilha através da navegação, mantendo intensas atividades conhecidas pelos sítios arqueológicos e suas coleções cerâmicas (coleções TRV, RT - ambas analisadas neste trabalho-, coleção Carlos Berenhauser, por exemplo). Não se conhece ainda por quanto tempo as populações Guarani estiveram na região , uma vez que a datação mais recente é aquela do sítio TRV (290ะ30 A.P, datação bastante similar com aquela do sítio arqueológico Poço Grande, litoral norte) e as mais antigas, dos sítios Porto do Rio vermelho I (910 A.D./C14) e Tapera (1400+-70 A.D./C14). Estas últimas datações se referem a sambaqui que apresentou poucos fragmentos cerâmicos da tradição tupiGuarani. Estes tipos de contextos (cerâmicas Guarani encontradas em sambaquis) ainda precisam ser melhor elucidadas para a região. Mas somente ao analisarmos essas datações e materiais cerâmicos associados, a presença de etnografias e registros escritos demonstrando a presença Guarani no período do contato europeu e a presença indígena Guarani na atualidade, é possível reiterarmos a longa duração Guarani no litoral central catarinense.

As datações dos sítios em Florianópolis também se encontram de acordo com os modelos de expansão e movimentação Guarani mais recentes, como o de Bonomo et.al. (2014), sendo que essas populações teriam ocupado o litoral sul catarinense e teriam ido também em direção à região central do litoral catarinense (movimento sul-norte). Torna-se difícil aprofundar as reflexões visto que este é o primeiro trabalho que busca compreender essa ocupação no litoral central.

Há agora duas coleções cerâmicas analisadas provenientes de dois sítios arqueológicos na Ilha: um sítio na região nordeste da Ilha (Travessão do Rio Vermelho, TRV), e outro na região sul (Lagoinha do Rio Tavares I, ou RT), de onde provem grande parte dos registros etnográficos sobre os carijó/Guarani na Ilha (esta última muito habitada atualmente, e aquela vem crescendo em população nos últimos anos, uma vez que são umas das poucas regiões planas da Ilha). E, esses sítios arqueológicos, como visto, apresentam funções distintas. Ainda que não existam, também, dados suficientes produzidos para identificarmos com exatidão os teko'á, guará, amundá e teii 
da região, supõe-se que tenha existido um grande teko'á na região sul da Ilha e outro da região sul continental, uma vez que, segundo Noelli (1993) e Milheira (2010) os teko'ás eram divididos por grandes barreiras naturais, ou seja, a própria região aquática entre Ilha e continente seria tal divisa, ou mesmo divisa entre diferentes guará. O sítio TRV teria participado desse grande teko'á no sul da Ilha? Difícil extrapolar as interpretações sem datações para os sítios da região. Também, torna-se complicado falar de padrão de assentamento e detalhar um território Guarani como proposto por Zedeño (ZEDEÑO, 1997). Outro forte argumento está em que ambientes de ilhas geralmente geram contextos bastante específicos de organização social. Porém, os dados trabalhados possibilitam discutir sobre lugares e lugares significativos (inseridos nos teko'ás).

Os Guarani possuem seu grande território no sul da América do Sul, pelo qual circulam em constante movimento (inclusive cultural). Mas, para eles, os lugares são significativos como demonstra amplamente Darella (2004) em sua pesquisa entre os Mbya Guarani do litoral catarinense. Para eles, o teko'á é o lugar de viver o modo de ser Guarani (ou tekó) (DARELLA, 2004, P.78; NOELLI, 1993). Darella (2004) traz alguns relatos de indígenas Mbya sobre o teko'á enquanto lugar de vivências:

"Lugar 'onde acontece o trabalho, a vida, a tradição. Onde podemos fazer nossa tradição acontecer. (...) Tekoa é tudo'. Deve ser o mercado, a farmácia (Timóteo de Oliveira). / Lugar do fogo (tata), pois 'índio Guarani tem que viver junto do fogo. (...) No nosso sistema de dia e de noite sem fogo não pode ficar. Tem que ser junto do fogo e água' (Francisco Timóteo Kirimaco, em 2003). 'Tataypy (assentos de fogueiras) é a expressão tradicional usada para denominar um tekoa' (Ciccarone, 2001:237). / Tekoa deve ser o local 'para viver nossa cultura com liberdade (...). Sempre os mais velhos falam assim: "não somos os donos da terra porque a terra nos criou através dos alimentos, de remédios e muito mais coisas. Então, a terra é dona de nós...(...) Então a terra é muito superior a nós' (...) (Leonardo da Silva Gonçalvez, em 2000)." (DARELLA, 2004, P.79)

Então, é possível falar de uma Arqueologia do Lugar Guarani? O que seria um lugar significativo nesse contexto de ocupação Guarani na Ilha?

Tendo em mente como o movimento de Arqueologia do Lugar se desenrolou e qual seu objetivo, como podemos pensar em lugares significativos para o contexto estudado dos sítios arqueológicos TRV e RT? Como falar de lugar Guarani nesses contextos? Os sítios arqueológicos TRV e RT certamente fizeram parte de um 
teko'á (ainda que o impacto do contato tenha modificado muitas relações e o desenvolvimento das comunidades indígenas na América). Como os materiais cerâmicos analisados entram nessa discussão? O sítio TRV foi um lugar de manipulação cerâmica e alimentícia, lugar especialmente feminino como visto (LANDA, 1995). Foi um locus de manipulação de alimento, da vida coletiva, para o coletivo e na aldeia e no teko'á.. O alimento e o compartilhamento em comunidade estão presentes nesse sítio arqueológico, também o fogo (nesse caso, três fogos ou estruturas de combustão), essencial na cultura Guarani. O fogo faz parte, inclusive do mito de criação entre os Mbyá (Guarani presentes no litoral catarinense) sendo sua aquisição e domesticação relacionados diretamente ao advento da vida breve (DARELLA, 2004, P.16; LITAIFF, 1999, P.298). A cerâmica marca esse lugar de experiências sociais compartilhadas, esse lugar significativo, que além de ser um lugar físico, também é social. Ao menos é a cerâmica, majoritariamente, que chegou ao presente, ao registro arqueológico, e através dela acessamos possibilidades de interpretação sobre o passado. A cerâmica da coleção TRV apresentou grande pluralidade com ênfase na preparação de alimentos e bebidas ao fogo, ou seja, alia-se o material cerâmico ao fogo em um locus que marca o modo de vida Guarani, uma vez que a preparação do alimento pelas mulheres é sinônimo de manter ñande rekó diante do constante movimento e expansão em seu grande território no sul da América do Sul.

“(...) o cozimento dos alimentos só é realizável com a existência do fogo para transformar o que é cru em apto para o consumo, ou, cozido. I A mulher Guarani, plantando, manejando o ambiente, processando os alimentos retirados da roça como os provenientes de outras técnicas de captação de recursos alimentares, e sendo responsável por manter o fogo sempre aceso - para aquecimento e transformação do alimento - reúne em si algumas das variáveis que a tornam uma mediadora eficaz e única na cultura Guarani.(...).” (LANDA, 1995, P.110)

"As panelas Guarani confeccionadas pelas mulheres eram fundamentais para a manutenção do modo de ser do grupo, pois o processamento dos alimentos e o cozimento dos mesmos eram fundamentais como atividades cotidianas das mulheres." (LANDA, 1995, P.49).

No sítio arqueológico RT, foi observado também um lugar compartilhamento da vida coletiva. Um lugar que contem uma cerâmica não tão própria a ir ao fogo, mas para servir alimentos e bebidas, e um sepultamento humano. Um locus em que foram dispostos os alimentos e bebidas prontos nos limites do assentamento 
muito provavelmente em virtude do sepultamento humano. Como os Guarani tratam os mortos? Quais os significados desses lugares para os Guarani? Como lidam com a morte e antepassados? Esse lugar envolve todos da comunidade? Ambos os sítios arqueológicos representam lugares da vida em comunidade, da vida na aldeia, cada um com atividades distintas. Mas nos dois lugares (alimentação e morte), a cerâmica está presente. A questão ritual permeia todos os aspectos de vida Guarani. Então, qual o significado da cerâmica para essas populações? A cerâmica também representaria um lugar significativo? Qual o significado das fontes de matéria-prima cerâmica? Acreditase que a cerâmica esteve presente em muitos lugares significativos da vida Guarani e através da qual podemos acessá-los. Tão emblemática que marcou lugares Guarani ao longo de toda a América do Sul e aqui na região delimitada diferencia-se fortemente da cerâmica proveniente de grupos Jê. Essas questões perpassam lugares e tempos distintos que possuem seu impacto na construção de significados em virtude da historicidade dos processos com que se lida na ciência arqueológica. Exemplo disso é o impacto causado pelo contato europeu nas estratégias de movimentação Guarani pelo grande território. É evidente, com esses questionamentos, que há muita pesquisa a ser realizada em torno de etnologias, etnohistórias, etnoArqueologia, em torno de mapeamentos e pesquisas geomorfológicas e microarqueológicas para continuar perseguindo o objetivo de construção de uma Arqueologia do Lugar Guarani no litoral central catarinense e mais ainda, a construção de uma história indígena Guarani na região. Trata-se de uma tarefa plenamente possível e implementável.

As etnografias e registros escritos estudados dos anos 1500 e 1600 explicitam a presença Guarani na região, mas bastante desestruturada, sendo frequente nos relatos a descrição de "fugas" das populações "carijó"/Guarani ao interior, da sua amizade com os portugueses, da localização de aldeias nas regiões sul da Ilha de Santa Catarina e sul do litoral central (onde encontramos muitos sítios arqueológicos com essa ocupação). Uma vez que não era a preocupação desses europeus compreender como era o modo de vida dessas populações e compreender sua cultura, a partir desses relatos não podemos avançar na discussão sobre "lugares significativos Guarani", a não ser pela ênfase que os relatos trazem nas regiões em que essas populações estão descritas (como já mencionado) e pela toponímia herdeira dessa presença Guarani de longa duração na região. 
Outro importante ponto a ser refletido é sobre a toponímia Guarani. Ela marca os lugares importantes e significativos, conforme visto com os nomes das aldeias do século XVI no sul da Ilha vistos e explorados no tópico 2.3: aboçapecau (barro do porto do rio dos patos) e jurumerim ("boca pequena" se referindo ao estreito de terra que liga a parte continental do litoral central e a Ilha de Santa Catarina). Ou seja, os nomes dados aos lugares são emblemáticos na cultura. Outros muitos exemplos são encontrados na emblemática obra Tesoro de la Lengua Guarani de padre Ruiz de Montoya (1639).

Assim, como dizem Bowser e Zedeño (BOWSER, ZEDEÑO, 2009, P.p.1314), a Arqueologia é a única ciência social que desconecta de seu assunto para estudálo, e o desafio colocado para implementar a Arqueologia do lugar é integrar coerentemente significados de análises objetivos e subjetivos para reconstruir lugares antigos e interpretar seus significados. Os trabalhos realizados até então com essa perspectiva ressaltam a necessidade de abraçar a diversidade teórica e múltiplas linhas de evidência para desenvolver uma compreensão de significância dos lugares arqueológicos. Sem reduzir o conceito para encaixar na natureza fragmentada da Arqueologia, os autores ancoram seus argumentos no registro material de experiências, atividades, significados e metáforas na presença do passado na sociedade contemporânea. O lugar para Whitridge (WHITRIDGE, 2004, P.243) ocupa um espaço entre cultura e natureza, o ideal e material, o individual e o social, e auxilia a mover-nos entre essas polaridades, sendo que a construção de lugares significativos não é um processo oposto ao domínio simbólico e prático do espaço, mas um aspecto dele. Uma Arqueologia do lugar, segundo ele, implica em uma Arqueologia do imaginário. Dessa forma, essa abordagem permite um trabalho multidisciplinar de interpretação do registro (vai do mundo natural ao social), e busca não sacrificar nenhum discurso.

Assim, foi possível iniciar uma construção sobre o que são os lugares significativos Guarani a partir do registro arqueológico, que deve ser desenvolvida com o aprofundamento das pesquisas e novos questionamentos acerca do contexto Guarani na região e no sul da América do Sul. 


\section{CONSIDERAÇÕES FINAIS}

Essa dissertação de mestrado perseguiu seu objetivo de contribuir para a construção de uma história indígena Guarani de longa duração no sul do Brasil através de análises tecnológicas e químicas de coleções cerâmicas Guarani de contextos arqueológicos localizados na Ilha de Santa Catarina. Esse objetivo foi vislumbrado somente com abordagem inter e multidisciplinar, seja através das etnografias e etnohistórias, das análises macroscópicas de cunho tecnológico, as análises arqueométricas por fluorescência de raios-x e através de um aparato teórico cujas interpretações possibilitaram ultrapassar o que se conhecia para a região e construir uma interpretação de forma mais fluida. Foi produzido conhecimento sobre a presença Guarani na Ilha de Santa Catarina através da análise de material cerâmico de pelo menos quinhentos anos deixado por essas populações; esse conhecimento é inédito para a região do litoral central catarinense, assim como os tipos de análises realizadas também o são (tecnológica e arqueométrica); foi proposta uma nova forma de vislumbrar a presença Guarani no litoral central catarinense: através de uma história de longa duração Guarani; bem como através da proposição de lugares significativos Guarani a partir do registro arqueológico.

Entretanto, mais do que afirmações e interpretações, há ainda muitos questionamentos levantados pelas próprias análises e formas de olhar os dados produzidos. A própria abordagem de "lugar" abre muitas possibilidades de problemáticas e muitas possibilidades de continuação da pesquisa.

As particularidades (perante a estrutura) almejadas só continuarão a ser alcançadas se múltiplas formas de abordar o material forem usadas de forma coordenada e com bagagem teórica compatível. Por exemplo, a análise de fragmentos e de conjuntos (a partir de atributos), bem como as análises de XRF, mostraram-se essenciais nesse ínterim para perpassar interpretações conhecidas de forma tecnológica e propor ações futuras. O uso das etnografias e etnohistórias abriram caminho às propostas de interpretação de "lugares significativos" Guarani junto ao registro arqueológico, bem como trouxeram expectativas de futuros trabalhos colaborativos juntamente a um trabalho mais profundo de mapeamento. A própria forma de compreender a análise cerâmica como o modo de fazer por trás do objeto suscita mais trabalhos 
interdisciplinares para compreendermos os modos de vida e interação com o meio na construção dos lugares significativos para essas populações nos contextos que viveram. Portanto, ainda que se tenha enfatizado coleções da Ilha de Santa Catarina (Florianópolis), o litoral central possui grande potencial como um todo para serem debatidas em conjunto as propostas aqui deixadas nas discussões dos resultados. 


\section{REFERÊNCIAS}

Florianópolis Arqueológica. Relatório Parcial, Portaria N.37 de 19 de agosto de 2013. Processo 01510.001749/2013-18. Atividades de Intervenção no sítio arqueológico Travessão do Rio Vermelho. Etapa 1, novembro/2013 a março/20014. Projeto financiado pelo CNPQ (Processo 406314/2012-8) e pelo IPHAN (termo de cooperação técnica IPHAN-UFSC). / Laboratório de Estudos Interdisciplinares em Arqueologia, Universidade Federal de Santa Catarina.

Etnohistória, História Indígena e Educação. Ed. Palotti, Porto Alegre, RS, 2012.

Mapa etno-histórico de Curt Nimuendaju / IBGE. Fundação Nacional Pró-memória, IBGE, Rio de Janeiro, 1981.

Parque Estadual do Tabuleiro: aspectos culturais e sociais. Volume I. UFSC FATMA, 1976.

APPOLONI, C.R, F.R. ESPINOZA P.H.A. QUIÑONES, A.O. ARAGÃO, L.M. DOS SANTOS,. P.F. DA SILVA e V.F BARBIERI. Filho do Nascimento and M.M. Coimbra,. EDXRF study of Tupi-Guarani archaeological ceramics, In: Radiation Physics and Chemistry, 61, 2001. P.p. 711-712.

ARNOLD, D.E. Does the Standardization of Ceramic Pastes Really Mean Specialization? In: Journal of Archaeological Method and Theory, v.7, issue 4. Plenum Publishing Corporation, 2000. P.p.333-375.

ARNOLD, D. E. Ethnomineralogy of Ticul, Yucat'an potters: Etics and emics. In: American Antiquity, 36, 1971. P.p.20-40.

ARNOLD, D. E. Principles of paste analysis: A preliminary formulation. In: Journal of the Steward Anthropological Society, 6(1), 1975b. P.p.33-47.

ARNOLD, D. E. Localized exchange: An ethnoarchaeological perspective. In: Fry, R. (ed.), Models and Methods in Regional Exchange, SAA Papers No. 1, Society for American Archaeology, Washington, DC, 1980. P.p. 147-150.

ARNOLD, D. E. A model for the identification of non-local ceramic distribution: A view from the present. In: Howard, H., and Morris, E. L. (eds.), Production and 
Distribution: A Ceramic Viewpoint, BAR International Series 120, British Archeological Reports, Oxford, 1981. P.p. 31-44.

ARNOLD, D. E. Ceramic Theory and Cultural Process. Cambridge University Press, Cambridge, 1985.

ARNOLD, D. E. Ethnoarchaeology and investigations of ceramic production and exchange: Can we go beyond cautionary tales? In: Bishop, R. L., and Lange, F.W. (eds.), The Legacy of Anna O. Shepard, University Press of Colorado, Boulder, 1991. P.p. 321-345.

Arnold, D. E., Neff, H., and Bishop, R. L. Compositional analysis and sources of pottery: An ethnoarchaeological approach. In: American Anthropologist, 93, 1991. P.p.70-90.

BERGER, Paulo. Ilha de Santa Catarina: relatos de viajantes estrangeiros nos séculos XVIII e XIX. $4^{\text {a }}$. ed. rev. Florianópolis, SC: Ed. da UFSC: Lunardelli, 1996;

BANDEIRA, Dione da Rocha. Ceramistas pré-coloniais da Baia da Babitonga, SC: Arqueologia e etnicidade. São Paulo: Unicamp, 2004. Tese (Doutorado) apresentada ao Programa de Pós-Graduação em História.

BARRETO, Cristina. A construção de um passado pré-colonial: uma breve história da Arqueologia no Brasil. In: Revista USP, 1999-2000. N.44.

BHABHA, H. O local da cultura. Belo Horizonte: EduUFMG, 1999. BONOMO, M., et al., A model for the Guaraní expansion in the La Plata Basin and litoral zone or southern Brazil.In: Quaternary International (2014), http://dx.doi.org/10.1016/j.quaint.2014.10.050.

BONOMO, M., et al., A model for the Guaraní expansion in the La Plata Basin and litoral zone or southern Brazil. In: Quaternary International, 2015. Disponível em: http://dx.doi.org/10.1016/j.quaint.2014.10.050.

BONOMO, M.; CAPDEPONT, I.; MATARRESE, A. Alcances en el estudio de colecciones. Los materiales arqueológicos del delta del río Paraná depositados en el Museo de La Plata (Argentina). In: Arqueología Suramericana / Arqueologia Sulamericana 5, 1, ene/jan 2009. P.p.68-101. 
BRAUDEL, Fernand. História e Ciências Sociais. A longa duração. In Annales E.S.C, n.4, out.-dez 1958, Débatset Combats, 1992.

BINFORD, Lewis. Em busca do passado. Lisboa. Publicações Europa-América. 1983.

BOURDIEU, P. Estruturas, Habitus e Prática. In:Bourdieu, P. A economia das trocas simbólicas. São Paulo, Perspectiva, 2011 [1967]. 361p.

BOURDIEU, P. O poder simbólico.Rio de Janeiro: Bertrand Brasil, 2003.

BOWSER, Brenda J. Prologue: Toward na Archaeology of Place. In: Journal of Arcaheological Method and Theory, v.11, n.1, 2004.

BOWSER, Brenda; ZEDEÑO, María N. The Archaeology of Meaningful Places. Bibliovault OAI Repository, the University of Chicago Press, 2009.

BROCHADO, José Proenza. A Expansão dos Tupi e da cerâmica da tradição policrômica amazônica. In: Dédalo, São Paulo, v.27, 1989.

BRIGHENTI, Clóvis. Povos indígenas em Santa Catarina. In: Notzold, A., Rosa, H. e Bringmann, S. (orgs.) Etnohistória, História Indígena e Educação. Ed. Palotti, Porto Alegre, RS, 2012.

BROCHADO, José P. What did the Tupinambá cook in their vessels? A humble contribution to ethnographic analogy.In: Revista de Arqueologia,6:40-88, 1991.

BROCHADO, J.P.; MONTICELLI, G. Regras práticas na reconstrução gráfica das vasilhas de cerâmica Guarani a partir dos fragmentos. In: Estudos Ibero-Americanos. PUCRS, v.XX, n.2, dez. 1994. P.p.107-118.

BROCHADO, J.; MONTICELLI, G.; NEUMANN, E. Analogia Etnográfica na reconstrução gráfica das Vasilhas Guarani Arqueológicas. In: Veritas, 35(140), p.727$743,1990$.

BUENO, Lucas de Melo Reis. Florianópolis Arqueológica. Projeto de pesquisa, CNPq/IPHAN, Florianópolis, Santa Catarina, 2012. 38p.

BUENO, L., BOND, L., MENDES, R., OPPITZ, G., PEREIRA, T., BATISTA, J., BEE, B. Florianópolis Arqueológica. Relatório Final, CNPq/IPHAN, Florianópolis, Santa Catarina, 2014. 120p. 
CASTAÑEDA, Quetzil E. 2008 The "Ethnographic Turn" in Archaeology. Research positioning and reflexivity in ethnographic archaeologies. In: 2008 Ethnographic Archaeologies: reflections on stakeholders and archeological practices, edited by Q. E. Castañeda and C. N. Matthews, pp. 25-61. Altamira Press, Plymouth.

CAVALCANTE, T.L.V. Etno-história e história indígena: questões sobre conceitos, métodos e relevância da Pesquisa. In: História (São Paulo), v.30, n.1, p.349-371, jan/jun 2011.

CARBONERA, M.; APPOLONI, C.R.; SANTOS, G.H. Materiais pictóricos da cerâmica Guarani do alto Uruguai a partir de medidas de fluorescência de raios X. In: Revista do Museu de Arqueologia e Etnologia, 28, 2017. P.p.133-144.

CAVALCANTE, T.L.V. Etno-história e história indígena: questões sobre conceitos, métodos e relevância da Pesquisa. In: História (São Paulo), v.30, n.1, p.349-371, jan/jun 2011.

CHILTON, E. The cultural origins of technical choice: unraveling Algonquian and Iroquian ceramic traditions in the northeast. In: M. Stark (Ed.). The Archaeology of Social Boundaries. Smithsonian Institution Press. Washington/London. 1998. PP.132160.

COLWELL-CHANTHAPHONH, C. The archaeologist as a world citizen. In: L. Mekell (Ed.). Cosmopolitan Archaeologies. Durham/London, Duke University Press. 140-165. 2009.

CORRÊA, Ângelo Alves. Longuedurée: história indígena e Arqueologia. In: Cienc. Cult., São Paulo, v. 65, n. 2, Junho 2013. P.27. Disponível em: $<$ http://cienciaecultura.bvs.br/scielo.php?script=sci_arttext\&pid=S000967252013000200011\&lng=en\&nrm=iso>. Acesso em: 17Nov. 2014.

CORRÊA, Ângelo Alves. Datações na bibliografia arqueológica brasileira a partir dos sítios Tupi. In: Cadernos do Lepaarq. V.XIV, n.27, 2017. P.p.380-406. ISSN 23168412.

DARELlA, Maria Dorothea Post. Ore Roipota Yvi Porã - Nós queremos terra boa. Territorialização Guarani no Litoral de Santa Catarina - Brasil. (Tese de Doutorado) PUC-SP: São Paulo, 2004.DIAS, Adriana S. Um projeto para a Arqueologia Brasileira: 
breve histórico da implementação do PRONAPA. In: Revista do CEPA, 19(22), 1995. P.p.25-39.

DIAS, Adriana. Sistemas de Assentamento e Estilo Tecnológico: uma proposta interpretativa para a ocupação pré-colonial do alto Vale do Rio dos Sinos, Rio Grande do Sul. Tese de doutorado. Universidade de São Paulo, São Paulo, 2003.

DIAS, Adriana. Um projeto para a Arqueologia Brasileira: breve histórico da implementação do PRONAPA. In: Revista do CEPA, 19 (22) 1995. P.p.25-39.

DUMA, G. Phosphate contente of ancient pots as indication of use. In: Currently Anthropology, 13, P.p.127-130.

DUNNELL, R.C.; HUNT, T.L. Elemental composition and inference of ceramic vessel function. In: Current Anthropology, 31, 1990. P.p.330-336.

EBLE, Alroino B; REIS, Maria José. Patrimônio Pré-histórico. In: Parque da Serra do Tabuleiro - Aspectos culturais e sociais. Volume I. Universidade Federal de Santa Catarina: UFSC - FATMA, 1976. P.p.08-44.

EREMITES DE OLIVEIRA, Jorge. Sobre os conceitos de etnohistória e história indígena: uma discussão ainda necessária. In: ANPUH - XXI Simpósio Nacional de História - João Pessoa, 2003.

FERREIRA, Lucio. Vestigios de Civilização: O Instituto Histórico e Geográfico Brasileiro e a Construção da Arqueologia Imperial (1838-1870). In: Revista de História Regional, 1999. 4(1), P.p. 9-36.

FOSSARI, Teresa Domitila. A população pré-colomial Jê na paisagem da Ilha de Santa Catarina. (Tese de Doutorado) Universidade Federal de Santa Catarina: Florianópolis, 2004.

GIDDENS, Anthony. The constitution of society: outline of the theory of structuration. Berkeley: University of California Press, 1984.

HAMILAKIS, Y. Archaeological ethnography: a multitemporal meeting ground for archaeology and anthropology. In: Annual Review of Anthropology, 2011. P.p.399-414.

HODDER, I. Reading the past. Cambridge: Cambridge University Press, 1986. 
HODDER, I. The decoration of containers: an ethnographic and historical study. In: LONGRACE, W. A. (Ed.). Ceramic ethnoarchaeology. Tucson: University of Arizona Press, 1991.

IKEOKA, R.A.; APPOLONI, C.R.; PARREIRA, P.S.; LOPES, F.; BANDEIRA, A.M. Análise de fragmentos cerâmicos do sambaqui do Bacanga (MA) através da técnica de fluorescência de raios X por dispersão de energia (ED-XRF). In: La arqueometría en Argentina y Latinoamerica, 2010. P.p.61-66.

INGOLD, Tim. Perception of the Environment: Essays in livelihood, dwelling and skill. London: Routledge, 2001b.

LA SALVIA, Fernando. Cerâmica Guarani./ Fernando La Salvia e José Proença Brochado (orgs.). Porto Alegre: Posenato Arte e Cultura, 1989.

LANDA, Beatriz dos Santos. A mulher Guarani: atividades e cultura material. Dissertação de mestrado, PUC-RS, Porto Alegre, Rio Grande do Sul, 1995.

LAROQUE, L; MACHADO, N.; JASPER, A.; ZANON, L. Etnohistória como abordagem interdisciplinar no estudo de populações indígenas Guarani. In: Bol.Geogr., Maringá, v.33, n.33, P.p.168-183, set.-dez., 2015.

LÉVI-STRAUSS, Claude. A oleira ciumenta. Editora Brasiliense, São Paulo, 1986.

LIMA, Tânia Andrade. Cerâmica Indígena Brasileira. In: RIBEIRO, Darcy (Editor). Suma Etnológica Brasileira. Edição atualizada do Handbookof South AmericaIndians. Rio de Janeiro: Vozes, 1987. P.p.173-229.

LINO, Jaisson Teixeira. Arqueologia Guarani na Bacia Hidrográfica do Rio Araranguá, Santa Catarina. Dissertação, UFRGS/RS, Porto Alegre, 2007.

LOHN, Reinaldo Lindolfo. O náufrago e o sonho: Aleixo Garcia e o imaginário da conquista. In: BRANCHER, Ana e AREND, Sílvia M. F.(org.) História de Santa Catarina. Séculos XVI a XIX. Florianópolis, UFSC, 2004.

MACHADO, Juliana Salles. História (s) Indígena (s) e a prática arqueológica colaborativa. In: Revista de Arqueologia, v.26, n.1, 2013. P.p. 72-85. 
MACHADO, Juliana Salles. Montículos Artificiais na Amazônia Central: um estudo de caso do sítio Hatahara./ Dissertação de mestrado. São Paulo: USP, 2005.

MACHADO, Juliana S. O potencial interpretativo das análises tecnológicas: um exemplo amazônico. In: Revista do Museu de Arqueologia e Etnologia, São Paulo, 1516: 87-111, 2005-2006.

MACHADO, Juliana S. Os significados dos sistemas tecnológicos: classificando e interpretando o vestígio cerâmico. In: Arqueología Suramericana / Arqueologia SulAmericana, 3,1, enero/janeiro, 2007. P.p.62-83.

MELIÁ, Bartomeu; SAUL, Marcos Vinicios de Almeida; MURARO, Valmir Francisco. O Guarani: uma bibliografia etnológica. Santo Angelo: FUNDAMES, 1987.

MELLO, Amílcar D’Avila de. Expedições: Santa Catarina na Era dos Descobrimentos Geográficos. Florianópolis: Expressão, 2005. Volume I. ISBN: 85-87887-02-5.

MELLO, Amílcar D’Avila de. Expedições: Santa Catarina na Era dos Descobrimentos Geográficos. Florianópolis: Expressão, 2005. Volume II. ISBN: 85-87887-02-5.

MILHEIRA, Rafael Guedes. Arqueologia Guarani no litoral sul-catarinense: história e território. São Paulo: USP, 2010.

MILHEIRA, R.G; APPOLONI, C.A; PARREIRA, P.C. Arqueometria em cerâmicas Guarani no sul do Brasil: um estudo de caso. In: Revista do Museu de Arqueologia e Etnologia. São Paulo, 2009. P.p.355-364.

MILHEIRA, R.G.; FARIAS, D.S.E.; ALVES, L. Perfil tipológico da indústria cerâmica Guarani da região sul de Santa Catarina. In: Revista Tempos Acadêmicos, Dossiê Arqueologia Pré-histórica, n.11, 2013, P.p.210-233. ISSN 2178-0811.

MILHEIRA, R.G. Um modelo de ocupação regional Guarani no sul do Brasil. In: Revista do Museu de Arqueologia e Etnologia, São Paulo, 18: 19-46, 2008.

MILHEIRA, R.G. Áreas de descarte em sítios arqueológicos Guarani: o caso das lixeiras. In: Revista do Museu de Arqueologia e Etnologia, São Paulo, 24: 3-23, 2014. 
MONTEIRO, John M. Os Guarani e a História do Brasil Meridional: séculos XVIXVII. In: CUNHA, M. (org.) História dos Índios no Brasil. São Paulo: Cia das Letras, 1992.

MONTICELLI, Gislene. O céu é o limite: como extrapolar as normas rígidas da cerâmica Guarani. In: Boletim Museu Paraense Emílio Goeldi, Ciências Humanas, Belém, v.2, n.1. PP.105-115, jan-abr.2007.

MONTOYA, Antonio Ruiz de. Tesoro de la lengua guaraní. Juan Sanzhez: Madrid, 1639,830 p.

MOTA, Duane P. C. O material da cultura: análises arqueométricas da cerâmica arqueológica da T.I. Koatinemo, Pará. Dissertação de mestrado, Universidade de São Paulo (USP): São Paulo, 2017.

MÜLLER, Isabela da Silva. A interdisciplinaridade em História: apontamentos para as interpretações dos primeiros contatos europeus com os Guarani no litoral central do estado de Santa Catarina. In: Revista Santa Catarina em História - Florianópolis UFSC - Brasil ISSN 1984-3968, v.8, n.1, 2014. P.p.178-191. Disponível em: http://www.nexos.ufsc.br/index.php/sceh/article/view/709.

MÜLLER, Isabela da Silva. Arqueologia Guarani no Litoral Central de Santa Catarina: estudo de caso do sítio TRV. Trabalho de Conclusão de Curso de curso de Graduação em História. Universidade Federal de Santa Catarina: Florianópolis, 2015.

NASCIMENTO-DIAS, Bruno L. do.; OLIVEIRA, Davi F.; ANJOS, Marcelino J. A utilização e a relevância multidisciplinar da fluorescência de raios-x. In: Revista Brasileira de Ensino de Física, vol.39, n.4, e4308, 2017.

NEUMANN, Mariana Araújo. Distribuição das marcas de uso e especificidades funcionais para a cerâmica Guarani pré-colonial. In: Revista de Arqueologia, v.24, n.1, jul. 2011. P.p.52-65. ISSN 0102-0420.

NOELLI, Francisco S. A ocupação humana na região sul do Brasil: Arqueologia, debates e perspectivas. In: Revista USP 44(2), 1999/2000. 
NOELLI, Francisco S. O espaço dos Guarani: a construção do mapa arqueológico no Brasil, Paraguai, Argentina e Uruguai. In: Arqueologia Guarani no litoral Sul do Brasil/ Rafael Guedes Milheira, Gustavo Peretti Wagner (orgs.). Curitiba: Appris, 2014.

NOELLI, Francisco S. Por uma revisão das hipóteses sobre os centros de origem e rotas de expansão pré-históricas dos Tupi. In: Estudos Ibero-Americanos. PUCRS, v.XX, n.1, 1994.

NOELLI, Francisco S. Sem Tekhoá não há Tekó (em busca de um modelo etnoarqueológico da subsistência e da aldeia Guarani aplicado a uma área de domínio no delta do Jacuí-RS). Dissertação, PUC/RS, Porto Alegre, 1993.

NOELLI, F.S.; MILHEIRA, R.G.; WAGNER, G.P. Tabela de sítios Guarani do litoral sul do Brasil. In: Arqueologia Guarani no Litoral Sul do Brasil / Milheira, R.G., Wagner, G.P (orgs.). - Curitiba: Appris, 2014.

NOELLI, Francisco S. Os Jê do Brasil meridional e a antiguidade da agricultura: elementos da linguística, Arqueologia e etnografia. In: Estudos Ibero-Americanos, Rio Grande do Sul, v. 22, n. 1, 1996. P.p.13-26.

NOELLI, Francisco S. O mapa arqueológico dos povos Jê no sul do Brasil. In: TOMMASINO, K.; MOTA, L.; NOELLI, F. S. (Org.). Novas contribuições aos estudos interdisciplinares dos Kaingang. Londrina: EDUEL, 2004. P.p. 19-55.

NOELLI, Francisco S. La distribución geográfica de las evidencias arqueológicas Guarani. In: Revista de Indias, 64 (230), 2004. P.p 17-34.

NOELLI, Francisco S. Rethinking stereotypes and the history of research on Jê populations in South Brazil: An interdisciplinary point of view. IN: FUNARI, O.; ZARANKIN, A.; STOVEL, E. (eds). Global Archaeological Theory Contextual Voices and Contemporary Thoughts, New York: Springer, 2005. P.p.167-190.

OLIVEIRA, Kelly de. Estudando a cerâmica pintada da tradição TupiGuarani: a coleção Itapiranga, Santa Catarina. Porto Alegre: PUCRS, 2008.

ORTON, C., TYERS, P., VINCE, A. Pottery in Archaeology.Cambridge University Press, 1993. 
PALMA DE HARO, Martim Afonso (org). Ilha de Santa Catarina: relatos de viajantes estrangeiros nos século XVIII e XIX. Florianópolis, SC: Assembleia Legislativa do Estado de Santa Catarina, 1979.

PERRONE-MOISES, Leyla.Vinte luas: viagem de Palmier de Gonneville ao Brasil, 1503-1505. São Paulo, SP: Companhia das Letras, 1992.

PIAZZA, Walter F. Nota preliminar sobre o Programa Nacional de Pesquisas Arqueológicas no Estado de Santa Catarina. In: PRONAPA, São Paulo, 1967.

PIAZZA, Walter F. O sítio arqueológico do Rio Tavares (Santa Catarina).[SEPARATA]. In: PRONAPA, São Paulo, 1965.

PIAZZA, Walter F. Nota preliminar sobre o Programa Nacional de Pesquisas Arqueológicas no Estado de Santa Catarina. In: PRONAPA, São Paulo, 1967.

POLITIS, Gustavo G. Nukak: Ethnoarchaeology of an Amazonian People. Left Coast Press, Walnut Creek, CA, USA, 2007.

POLITIS, Gustavo G. Acerca de la etnoarqueología em América del Sur. In: Horizontes Antropológicos, Porto Alegre, ano 8, n.18. P.p.61-91, dez. 2002.

PYBURN, K.A. Developing archaeology. In: P.G. Gould e K.A. Pyburn (Eds). Collision or Collaboration. Springer, 2016. Pp. 189-200.

REIS, Maria J.; FOSSARI, Teresa D. Arquelogia e preservação do patrimônio cultural: a contribuição do Pe. João Alfredo Rohr. In: Cadernos do CEOM - Ano 22, n. 30 Políticas públicas: memórias e experiências.

REIS, Maria J.; FOSSARI, Teresa D. Arquelogia e preservação do patrimônio cultural: a contribuição do Pe. João Alfredo Rohr. In: Cadernos do CEOM - Ano 22, n. 30 Políticas públicas: memórias e experiências.

RICE, John D. O idioma Tembé (Tupi-Guarani). Journal de la Societé des Américanistes, 26(1): 109-180, 1934.

RICE, Prudence M. On the origins of pottery. In: Journal os Archaeological Method and Theory, v.6, n.1, 1999. P.p.1-54. 
ROBRAHN-GONZÁLES, Érica. Arqueologia em perspectiva: 150 anos de prática e reflexão no estudo de nosso passado. In: Revista USP, 1999/2000. N.44.

ROGGE, Jairo H. As teorias adaptacionistas e o estudo de grupos horticultores - a tradição tupi-Guarani no médio Jacuí. In: Anais da $8^{a}$ Reunião Científica da SAB, Porto legre, EDIPUCRS, n.1, v.02: 245-254.

ROHR, J. A. Sítios arqueológicos de Santa Catarina. In: Anais do Museu de Antropologia, Museu Universitário, UFSC, Florianópolis, n. 17, 1984. P.p.77-168.

SAHLINS, Marshall. Estrutura e História. In. Ilhas de História. Rio de Janeiro, Zahar Editores, 1989. Cap. 5. P.p.172-194.

SALVADOR, Angela Sabrine do Nascimento. Entre escritos e vasilhas cerâmicas: o indígena na sociedade colonial da Ilha de Santa Catarina (séculos XVIII e XIX). Dissertação (mestrado) em História, UFSC, 2017.

SAID, E. Orientalismo: o Oriente como invenção do Ocidente. São Paulo: Companhia de Bolso, [1978] 2007.

SANTOS, Sílvio Coelho dos. Nova História de Santa Catarina. Florianópolis: Ed. Da UFSC, 2004, $5^{\mathrm{a}}$ ed.

SCABORA, Victoria. Ceramistas na Serra do Tabuleiro: um estudo tecnológico do saber-fazer pré-colonial Guarani. In: Machado, Juliana et al. Territorialidades Ameríndias no Alto Vale do Itajaí, Santa Catarina. Relatório I. Premio Elisabete Anderle 2017/FCC: Universidade Federal de Santa Catarina, janeiro 2019.

SCHIFFER, M.B. Archaeological Context and Systemic Context. In: Michael Schiffer. Behavioral Ar-chaeology. First Principles. Foundations of archaeological Inquiry. [1972]1995. pp.25-34.

SCHMITZ, Pedro I. A cerâmica Guarani da Ilha de Santa Catarina. In: Pesquisas, Antrpologia. São Leopoldo: Instituto Anchietano de Pesquisas, N.3, 1959.

SCHMITZ, Pedro I. João Alfredo Rohr - um jesuíta em tempos d transição. In: Pesquisas, Antropologia. São Leopoldo : Instituto Anchietano de Pesquisas, N.67, 2009. 
SHEPARD, A. O. Ceramics for the archaeologist. Washington, Carnegie Institute of Washington, 1956 [1985].

SILLIMAN, S. Between the longue durée and the short purée: postcolonial archaeologies of indigemous history in colonial North America. In:M.Oland, S.M. Hart e L. Frink (Eds). Decolonizing Indigenous Histories.Exploring Prehistoric/Colonial Transitions in Archaeology. Tucson: The University of Arizon Press, 2012. Pp.113-131.

SILVA, F.A; NOELLI, F.S. Arqueologia e Linguística: construindo as trajetórias histórico-culturais dos povos Tupí. In: Crítica e Sociedade: revista de cultura política. Uberlância, v.7, n.1, 2017. P.p.55-87.

SILVA, F.S.; APPOLONI, C.R.; QUIÑONES, F.R.E.; SANTOS, A.O.; SILVA, L.M.; BARBIEN, P.F.; FILHO, V.F.N. A arqueometria e a análise de artefatos cerâmicos: um estudo de fragmentos cerâmicos etnográficos e arqueológicos por fluorescência de Raios X (EDXRF) e transmissão Gama. In: Revista de Arqueologia, 17, 2004. P.p.4161.

SOARES, André Luis. Contribuição à Arqueologia Guarani: estudo do sítio Röpke. São Paulo: USP, 2004.

STUART, Barbara H. Analytical Techniques in Material Conservation. John Wiley \& Sons, 2007.

SKIBO, J., SCHIFFER, M.B. Understanding artifact variability and change: a behavioral framework. In: M.B. Schiffer (Ed.) Anthropological Perspectives on technology. Albuquerque, University of New Mexico Press, p. 39-150, 2001.

WHITRIDGE, Peter. Landscapes, Houses, Bodies, Things: "Place" and the Arcaheology of Inuit Imaginaries. In: Journal of Archaeological Method and Theory, v.11, n.2, Recent Advances in the Archaeology of Place, Part 2 (Jun., 2004), P.p.213250.

ZEDEÑO, M.N.; BOWSER, B. The archaeology of meaningful places. In:

ZEDEÑO, María Nieves. Landscapes, Land Use, and the History of Territory Formation: An Example from the Puebloan Southwest. In: Journal of Archaeological 
Method and Theory. Plenum Press, v.4, n.1, new York and London. P.p.67-103, march 1997. 


\section{ANEXO 01}

\begin{tabular}{|c|c|c|c|c|c|}
\hline \multicolumn{6}{|c|}{ Sítios Arqueológicos da Região da Serra do Tabuleiro* } \\
\hline \multicolumn{6}{|c|}{ Referência: Parque Estadual do Tabuleiro: aspectos culturais e sociais. Volume I. UFSC - FATMA, 1976.} \\
\hline № & Nome & Tipo & Descrição Sumária & Localização & Bibliografia \\
\hline 1 & SC PEST 01 & Sambaqui & $\begin{array}{l}\text { Presença de anomalocardia, dimensões 60X40X1m. Proprietário } \\
\text { do terreno Brich Wesphal. }\end{array}$ & Casqueiro, no município de Palhoça. & Eble \& Reis, 1976 \\
\hline 2 & SC PEST 02 & $\begin{array}{l}\text { Mancha } \\
\text { Preta }\end{array}$ & $\begin{array}{l}\text { Encontrados materiais lítico e conchas. Dimensões 20X30m. } \\
\text { Proprietário do terreno Luiz Henrique Batistotti. }\end{array}$ & $\begin{array}{l}\text { Estrada do Beijarô (Km } 212 \text { - BR 101), } \\
\text { Localidade do Casqueiro, Município de } \\
\text { Palhoça. }\end{array}$ & Eble \& Reis, 1976 \\
\hline 3 & SC PEST 03 & Sambaqui & $\begin{array}{c}\text { Dimensões 50X50m. Proprietário do terreno Luiz Henrique } \\
\text { Batistotti. }\end{array}$ & $\begin{array}{l}\text { Estrada do Beijarõ, Localidade do Beijarô, } \\
\text { Município de Palhoça. }\end{array}$ & Eble \& Reis, 1976 \\
\hline 4 & SC PEST 04 & $\begin{array}{l}\text { Mancha } \\
\text { Preta }\end{array}$ & $\begin{array}{l}\text { Com material cerâmico. Dimensões de 20X20m. Proprietário do } \\
\text { terreno Sabino Joaquim da Silveira. }\end{array}$ & $\begin{array}{l}\text { Localidade da Pinheira, Município de } \\
\text { Palhoça. }\end{array}$ & Eble \& Reis, 1976 \\
\hline 5 & SC PEST 05 & Sambaqui & $\begin{array}{c}\text { Presença de material arqueológico dos tipos lítico, conchas e } \\
\text { material ósseo humano. Dimensões de } 10 \times 10 \times 3 \mathrm{~m} \text {. Proprietário do } \\
\text { terreno Bento Carioni. }\end{array}$ & $\begin{array}{l}\text { Localidade da Pinheira, Município de } \\
\text { Palhoça. }\end{array}$ & Eble \& Reis, 1976 \\
\hline 6 & SC PEST 06 & $\begin{array}{l}\text { Mancha } \\
\text { Preta }\end{array}$ & $\begin{array}{l}\text { Presença de material cerâmico e lítico. Dimensões de 15X20m. } \\
\text { Proprietário do terreno Ildefonso Vieira. }\end{array}$ & $\begin{array}{l}\text { Sede do Distrito, Localidade da Gamboa, } \\
\text { Município Paulo Lopes. }\end{array}$ & Eble \& Reis, 1976 \\
\hline 7 & SC PEST 07 & $\begin{array}{l}\text { Mancha } \\
\text { Preta }\end{array}$ & Presença de material lítico e cerâmico. Dimensões de 20X30m. & $\begin{array}{l}\text { Dunas da Gamboa - Encantada, Localidade } \\
\text { de Gamboa, Município Paulo Lopes. }\end{array}$ & Eble \& Reis, 1976 \\
\hline 8 & SC PEST 08 & $\begin{array}{l}\text { Mancha } \\
\text { Preta }\end{array}$ & $\begin{array}{c}\text { Sem presença de material. Dimensões de } 10 \times 15 \mathrm{~m} \text {. Proprietário do } \\
\text { terreno Nestor Martins de Matos. }\end{array}$ & $\begin{array}{l}\text { Praia da Pinheira, Localidade do Canto da } \\
\text { Praia de Baixo, Município de Palhoça. }\end{array}$ & Eble \& Reis, 1976 \\
\hline
\end{tabular}




\begin{tabular}{|c|c|c|c|c|c|}
\hline 9 & SC PEST 09 & $\begin{array}{l}\text { Mancha } \\
\text { Preta }\end{array}$ & $\begin{array}{c}\text { Presença de material lítico. Com dimensões de 10X20m. } \\
\text { Proprietário Pedro Paulo Goedert. }\end{array}$ & $\begin{array}{c}\text { Localidade da Vargem do Braço, Município } \\
\text { de Santo Amaro. }\end{array}$ & Eble \& Reis, 1976 \\
\hline 10 & SC PEST 10 & $\begin{array}{l}\text { Casa } \\
\text { subterrânea } \\
\text { e montículos }\end{array}$ & $\begin{array}{l}\text { Não há presença de material arqueológico. Dimensões de } \\
\text { 100X100m. Proprietária do terreno Brasilpinho S/A. }\end{array}$ & $\begin{array}{l}\text { Horto Florestal - Brasilpinho, Localidade } \\
\text { Massiambu, Município de Palhoça. }\end{array}$ & Eble \& Reis, 1976 \\
\hline 11 & SC PEST 11 & $\begin{array}{l}\text { Mancha } \\
\text { Preta }\end{array}$ & $\begin{array}{l}\text { Presença de material arqueológico lítico e cerâmico. Dimensões de } \\
\text { 100X100m. Proprietário do terreno Saturnino Araujo dos Santos. }\end{array}$ & $\begin{array}{l}\text { Porto, Localidade Albardão, Município de } \\
\text { Palhoça }\end{array}$ & Eble \& Reis, 1976 \\
\hline 12 & SC PEST 12 & Sambaqui & $\begin{array}{l}\text { Presença de ostrea, com material lítico e conhas e dimensões de } \\
\text { 30X20m. Propriedade do sítio: Quirino José da Silva. }\end{array}$ & $\begin{array}{l}\text { Roça, Localidade Albardão, Município de } \\
\text { Palhoça }\end{array}$ & Eble \& Reis, 1976 \\
\hline 13 & SC PEST 13 & Sambaqui & $\begin{array}{l}\text { Presença de Anomalocardia brasiliensis, de dimensões 20X20X4m. } \\
\text { Apresenta material lítico e conchas. Proprietário do terreno } \\
\text { Manoel José do Nascimento. }\end{array}$ & $\begin{array}{c}\text { Roça, Localidade Três Barras, Município } \\
\text { Palhoça }\end{array}$ & Eble \& Reis, 1976 \\
\hline 14 & SC PEST 14 & Sambaqui & $\begin{array}{l}\text { Presença de Anomalocardia brasiliensis, material lítico e conchas, } \\
\text { de dimensões 20X30X3m. Proprietário do terreno Manoel José do } \\
\text { Nascimento. }\end{array}$ & $\begin{array}{c}\text { Roça, Localidade Três Barras, Município } \\
\text { Palhoça }\end{array}$ & Eble \& Reis, 1976 \\
\hline 15 & SC PEST 15 & Sambaqui & $\begin{array}{l}\text { Presença de Anomalocardia brasiliensis, material lítico e conchas, } \\
\text { de dimensões 20X30X3m. Proprietário do terreno Manoel José do } \\
\text { Nascimento. }\end{array}$ & $\begin{array}{c}\text { Roça, Localidade Três Barras, Município } \\
\text { Palhoça }\end{array}$ & Eble \& Reis, 1976 \\
\hline 16 & SC PEST 16 & $\begin{array}{l}\text { Mancha } \\
\text { Preta }\end{array}$ & $\begin{array}{l}\text { Presença de material cerâmico. Dimensões de 100X30m. } \\
\text { Proprietário do terreno Nestor Cesário dos Santos. }\end{array}$ & $\begin{array}{l}\text { Porto, Localidade Albardão, Município de } \\
\text { Palhoça }\end{array}$ & Eble \& Reis, 1976 \\
\hline 17 & SC PEST 17 & $\begin{array}{l}\text { Mancha } \\
\text { Preta }\end{array}$ & $\begin{array}{l}\text { Presença de material lítico e cerâmico. Dimensões de 20X20m. } \\
\text { Proprietário do terreno Amadeu Antonio Moisés. }\end{array}$ & $\begin{array}{l}\text { Areias de Paulo Lopes, Localidade da Costa } \\
\text { do Morro, Município de Paulo Lopes. }\end{array}$ & Eble \& Reis, 1976 \\
\hline 18 & SC PEST 18 & $\begin{array}{l}\text { Mancha } \\
\text { Preta }\end{array}$ & $\begin{array}{l}\text { Presença de material cerâmico. Dimensões de } 20 \times 20 \mathrm{~m} \text {. } \\
\text { Proprietário do terreno Baldino Borges. }\end{array}$ & $\begin{array}{l}\text { Penha, Localidade Penha, Município de } \\
\text { Imbituba }\end{array}$ & Eble \& Reis, 1976 \\
\hline 19 & SC PEST 19 & $\begin{array}{l}\text { Mancha } \\
\text { Preta }\end{array}$ & $\begin{array}{l}\text { Presença de material lítico e cerâmico. Dimensões de 20X20m. } \\
\text { Proprietário do terreno Eugeniano Baldino Borges. }\end{array}$ & $\begin{array}{l}\text { Penha, Localidade Penha, Município de } \\
\qquad \text { Imbituba }\end{array}$ & Eble \& Reis, 1976 \\
\hline
\end{tabular}




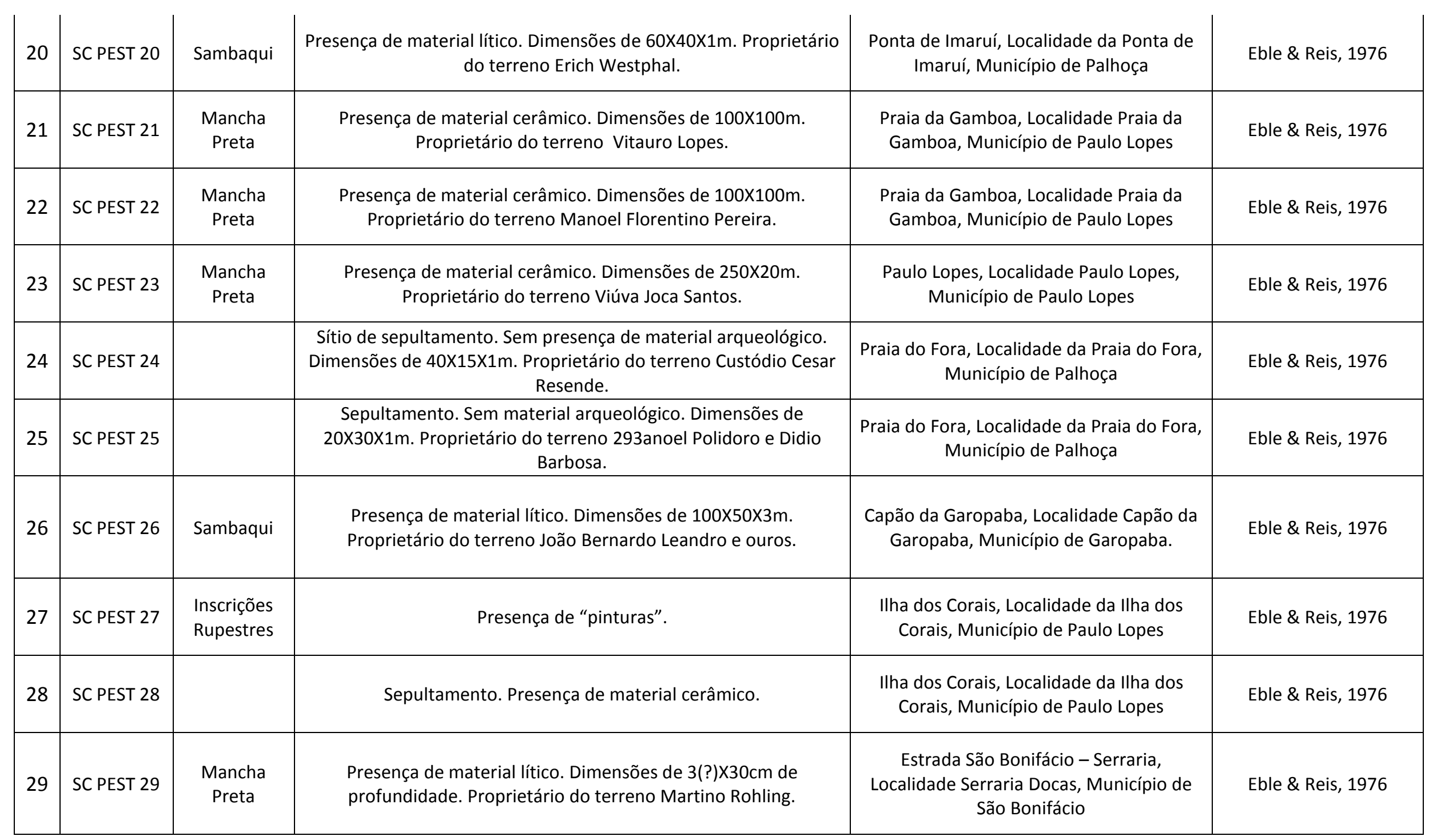




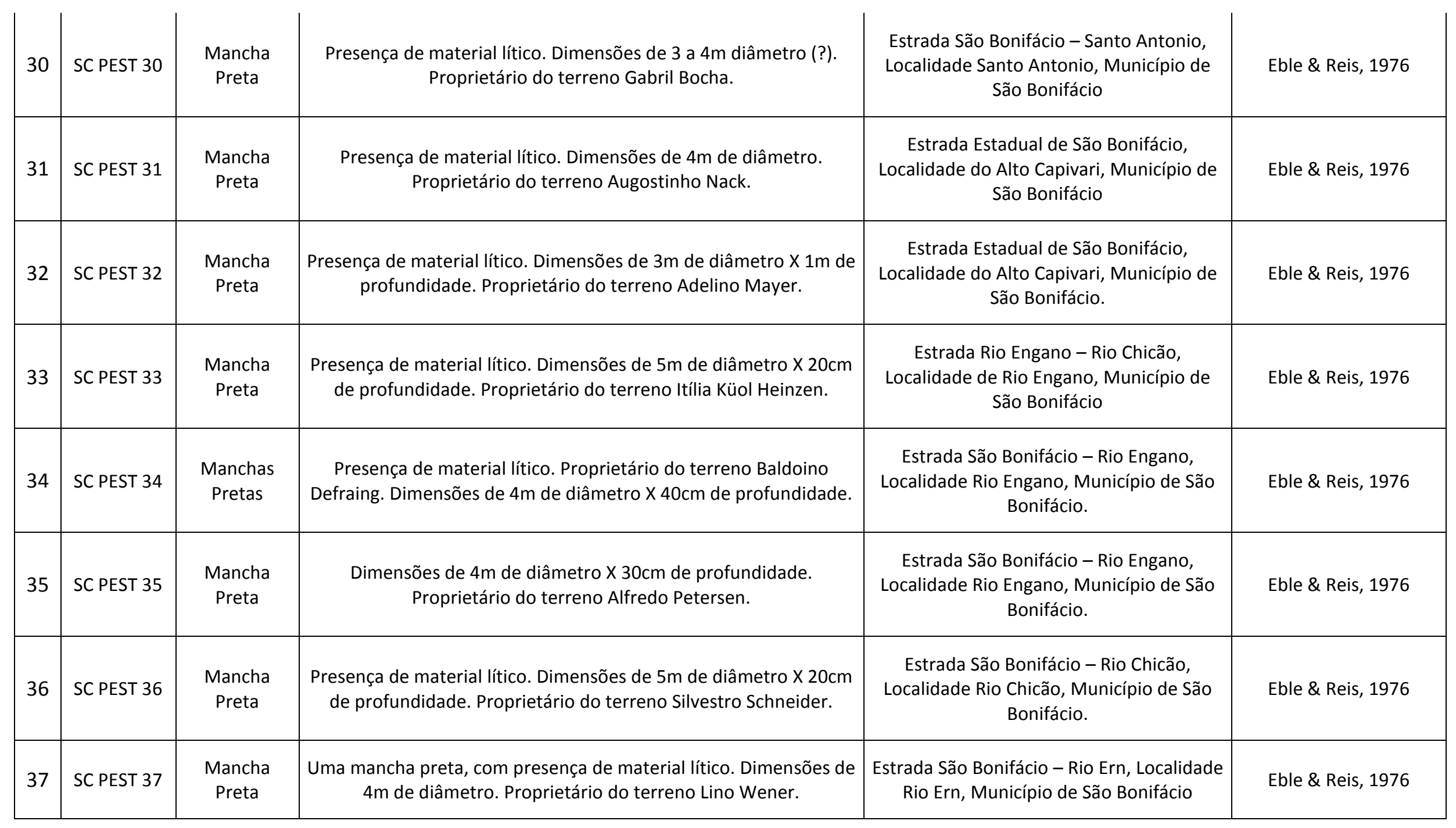




\begin{tabular}{|c|c|c|c|c|c|}
\hline 39 & SC PEST 39 & $\begin{array}{l}\text { Mancha } \\
\text { Preta }\end{array}$ & $\begin{array}{l}\text { Presença de material lítico, com dimensões de } 4 \mathrm{~m} \text { de diâmetro. } \\
\text { Proprietário do terreno Guilherme Berkenbrook. }\end{array}$ & $\begin{array}{l}\text { Estrada Rio Ern - São Martinho, Localidade } \\
\text { Rio Ern, Município de São Bonifácio. }\end{array}$ & Eble \& Reis, 1976 \\
\hline 40 & SC PEST 40 & $\begin{array}{l}\text { Mancha } \\
\text { Preta }\end{array}$ & $\begin{array}{l}\text { Presença de material lítico, com dimensões de } 60 \mathrm{~cm} \text { de } \\
\text { profundidade. Proprietário do terreno João Rohling. }\end{array}$ & $\begin{array}{l}\text { Rio Theiss - São Bonifácio, Localidade de } \\
\text { Rio Theiss, Município de São Bonifácio. }\end{array}$ & Eble \& Reis, 1976 \\
\hline 42 & SC PEST 42 & $\begin{array}{l}\text { Mancha } \\
\text { Preta }\end{array}$ & $\begin{array}{l}\text { Presença de materiais líticos. Dimensões de } 60 \mathrm{~cm} \text { de } \\
\text { profundidade. Proprietário do terreno Armando Petry. }\end{array}$ & $\begin{array}{l}\text { Rio Theiss, Localidade de Rio Theiss, } \\
\text { Município de São Bonifácio. }\end{array}$ & Eble \& Reis, 1976 \\
\hline 43 & SC PEST 43 & $\begin{array}{l}\text { Mancha } \\
\text { Preta }\end{array}$ & $\begin{array}{c}\text { Presença de materiais líticos. Proprietário do terreno Alberto } \\
\text { Rohling. }\end{array}$ & $\begin{array}{l}\text { Bloemer - São Bonifácio, Localidade Rio } \\
\text { Bloemer, Município de São Bonifácio. }\end{array}$ & Eble \& Reis, 1976 \\
\hline 45 & SC PEST 45 & $\begin{array}{c}\text { Mancha } \\
\text { Preta }\end{array}$ & $\begin{array}{l}\text { Presença de material lítico e cerâmico. Dimensão de } 200 \text { metros } \\
\text { quadrados. Proprietário do terreno Marcos Sehnem. }\end{array}$ & $\begin{array}{c}\text { Barra do Rio Sete - São Bonifácio, } \\
\text { Localidade Rio Sete, Município de São } \\
\text { Bonifácio }\end{array}$ & Eble \& Reis, 1976 \\
\hline 46 & SC PEST 46 & $\begin{array}{l}\text { Mancha } \\
\text { Preta }\end{array}$ & $\begin{array}{c}\text { Presença de material lítico. Dimensão de } 500 \text { metros quadrados. } \\
\text { Proprietário Marcos Sehnem. }\end{array}$ & $\begin{array}{c}\text { Barra do Rio Sete - São Bonifácio, } \\
\text { Localidade Rio Sete, Município de São } \\
\text { Bonifácio }\end{array}$ & Eble \& Reis, 1976 \\
\hline
\end{tabular}




\begin{tabular}{|c|c|c|c|c|c|}
\hline 49 & SC PEST 49 & $\begin{array}{l}\text { Manchas } \\
\text { Pretas }\end{array}$ & $\begin{array}{c}\text { Não há a presença de material arqueológico. Dimensões de } 300 \\
\text { metros quadrados. }\end{array}$ & $\begin{array}{c}\text { Rua São Martinho - Imaruí, Localidade } \\
\text { Vargem do Cedro, Município de São } \\
\text { Martinho. }\end{array}$ & Eble \& Reis, 1976 \\
\hline 50 & SC PEST 50 & $\begin{array}{l}\text { Mancha } \\
\text { Preta }\end{array}$ & $\begin{array}{c}\text { Presença de material lítico. Dimensões de } 3 \text { a 4m de diâmetro. } \\
\text { Proprietário do terreno Simão Sehuem. }\end{array}$ & $\begin{array}{l}\text { Desvio da Estrada São Martinho, } \\
\text { Localidade da Vargem do Cedro, Município } \\
\text { de São Martinho }\end{array}$ & Eble \& Reis, 1976 \\
\hline 51 & SC PEST 51 & $\begin{array}{l}\text { Mancha } \\
\text { Preta }\end{array}$ & $\begin{array}{l}\text { Não há presença de material arqueológico. Dimensões de } 200 \\
\text { metros quadrados. Proprietário do terreno José Hoepers. }\end{array}$ & $\begin{array}{l}\text { Desvio da Estrada São Martinho - Imaruí, } \\
\text { Localidade da Vargem do Cedro, Município } \\
\text { de São Martinho }\end{array}$ & Eble \& Reis, 1976 \\
\hline 53 & SC PEST 53 & $\begin{array}{l}\text { Manchas } \\
\text { Pretas }\end{array}$ & $\begin{array}{l}\text { Presença de material lítico. Dimensões de } 4 \text { a } 5 \text { metros de } \\
\text { diâmetro. Proprietário do terreno José Preech. }\end{array}$ & $\begin{array}{l}\text { Desvio da Estrada de São-Martinho- } \\
\text { Imaruí, Localidade da Vargem do Cedro, } \\
\text { Município de São Martinho. }\end{array}$ & Eble \& Reis, 1976 \\
\hline 54 & SC PEST 54 & & $\begin{array}{c}\text { Não contem materiais arqueológicos. Proprietário do terreno } \\
\text { Balduino Feuser. }\end{array}$ & $\begin{array}{c}\text { Vargem do Cedro - São Martinho, } \\
\text { Localidade de Vargem do Cedro, Município } \\
\text { de São Martinho }\end{array}$ & Eble \& Reis, 1976 \\
\hline
\end{tabular}




\begin{tabular}{|c|c|c|c|c|c|}
\hline 57 & SC PEST 57 & $\begin{array}{l}\text { Mancha } \\
\text { Preta }\end{array}$ & $\begin{array}{l}\text { Presença de4 material lítico. Dimensões de } 60 \text { de diâmetro } \times 50 \mathrm{~cm} \\
\text { de profundidade. Proprietário do terreno Evaldo Westphal. }\end{array}$ & $\begin{array}{l}\text { Alto Rio Poncho - São Bonifácio, } \\
\text { Localidade do Alto Rio Poncho, Município } \\
\text { de São Bonifácio. }\end{array}$ & Eble \& Reis, 1976 \\
\hline 58 & SC PEST 58 & $\begin{array}{l}\text { Mancha } \\
\text { Preta }\end{array}$ & $\begin{array}{l}\text { Presença de material lítico. Dimensões de } 30 \text { de diâmetro X } 30 \mathrm{~cm} \\
\text { de profundidade. Proprietário do terreno Tereza Pepler Assing. }\end{array}$ & $\begin{array}{l}\text { Queçaba (sede), Localidade de Queçaba, } \\
\text { Município de Águas Mornas. }\end{array}$ & Eble \& Reis, 1976 \\
\hline 59 & SC PEST 59 & $\begin{array}{l}\text { Mancha } \\
\text { Preta }\end{array}$ & $\begin{array}{l}\text { Não há presença de material arqueológico. Possui dimensões de } \\
3 \mathrm{~m} \text { de diâmetro } \times 25 \mathrm{~cm} \text { de profundidade. Proprietário do terreno } \\
\text { Balduino Weber. }\end{array}$ & $\begin{array}{l}\text { Queçaba - Rio Cubatão, Localidade de } \\
\text { Queçaba, Município de Águas Mornas }\end{array}$ & Eble \& Reis, 1976 \\
\hline 62 & SC PEST 62 & $\begin{array}{l}\text { Mancha } \\
\text { Preta }\end{array}$ & $\begin{array}{c}\text { Presença de material lítico. Dimensões de } 4 \mathrm{~m} \text { de diâmetro X } 30 \mathrm{~cm} \\
\text { de profundidade. Proprietário do terreno Armandinho Carlos } \\
\text { Hasseg. }\end{array}$ & $\begin{array}{l}\text { Queçaba - Águas Mornas, Localidade de } \\
\text { Queçaba, Município de Águas Mornas. }\end{array}$ & Eble \& Reis, 1976 \\
\hline 63 & SC PEST 63 & $\begin{array}{l}\text { Mancha } \\
\text { Preta }\end{array}$ & $\begin{array}{c}\text { Presença de material lítico. Proprietário do terreno Deonaldo } \\
\text { Germano Mess. }\end{array}$ & $\begin{array}{c}\text { Rio do Cedro - Águas Mornas, Localidade } \\
\text { de Rio do Cedro, Município de Águas } \\
\text { Mornas. }\end{array}$ & Eble \& Reis, 1976 \\
\hline 64 & SC PEST 64 & $\begin{array}{l}\text { Mancha } \\
\text { Preta }\end{array}$ & $\begin{array}{l}\text { Não há presença de material arqueológico. Proprietário do terreno } \\
\text { Lídia Westphal Dofrein. }\end{array}$ & $\begin{array}{l}\text { Rio Engano - Águas Mornas, Localidade do } \\
\text { Rio Engano, Município de Âguas Mornas. }\end{array}$ & Eble \& Reis, 1976 \\
\hline
\end{tabular}




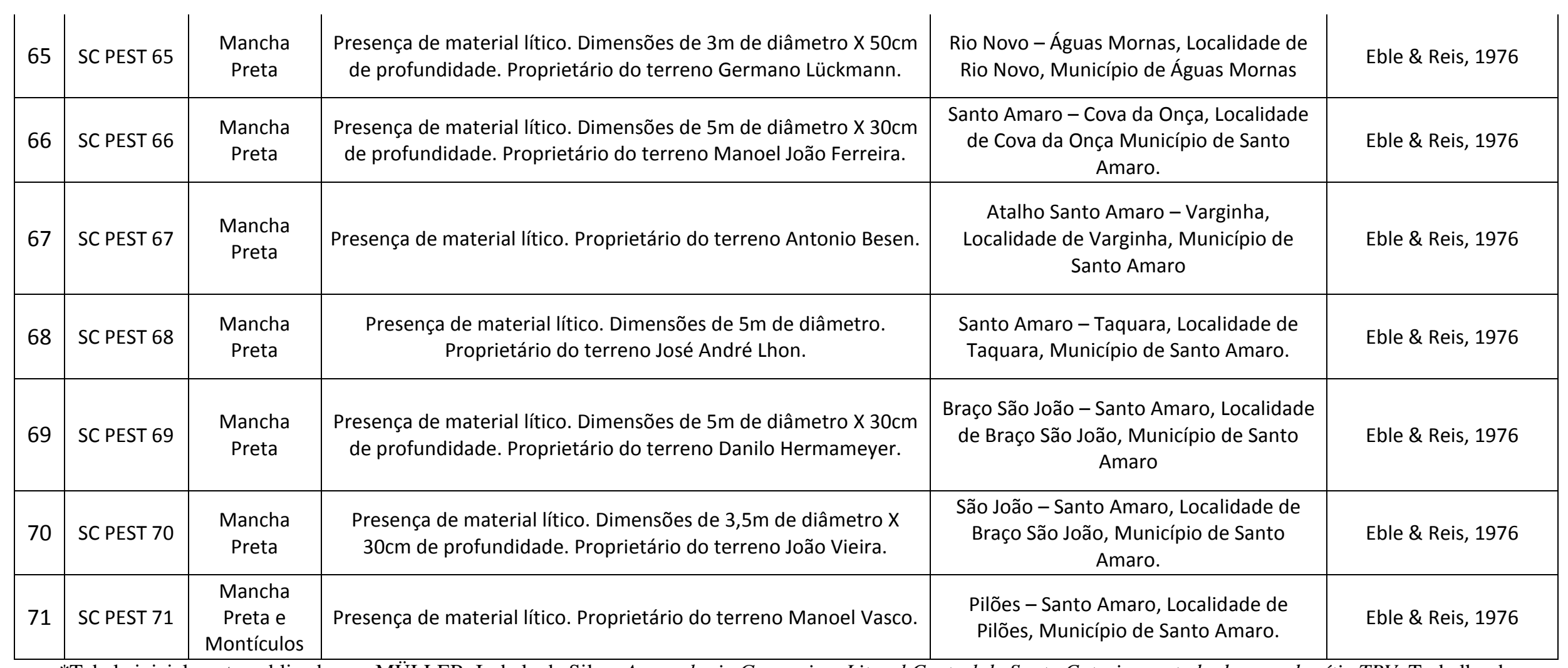

*Tabela inicialmente publicada em: MÜLLER, Isabela da Silva. Arqueologia Guarani no Litoral Central de Santa Catarina: estudo de caso do sítio TRV. Trabalho de

Conclusão de Curso de curso de Graduação em História. Universidade Federal de Santa Catarina: Florianópolis, 2015. 


\section{BETR BETA ANALYTIC INC.}

\section{REPORT OF RADIOCARBON DATING ANALYSES}

\begin{tabular}{lccc}
\hline \multicolumn{1}{c}{ Sample Data } & $\begin{array}{c}\text { Measured } \\
\text { Radiocarbon Age }\end{array}$ & $\begin{array}{c}13 \mathrm{C} / 12 \mathrm{C} \\
\text { Ratio }\end{array}$ & $\begin{array}{c}\text { Conventional } \\
\text { Radiocarbon Age }\left(^{*}\right)\end{array}$ \\
\hline $\begin{array}{l}\text { Beta - 401460 } \\
\text { SAMPLE : TRV463 }\end{array}$ & $380+/-30 \mathrm{BP}$ & $-25.8 \mathrm{o} / \mathrm{oo}$ & $370+/-30 \mathrm{BP}$ \\
ANALYSIS : RadiometricPLUS-Standard delivery & & \\
$\begin{array}{l}\text { MATERIAL/PRETREATMENT : (charred material): acid/alkali/acid } \\
\text { 2 SIGMA CALIBRATION : } \quad \text { Cal AD 1460 to } 1640 \text { (Cal BP 490 to 310) }\end{array}$ &
\end{tabular}

\section{REPORT OF RADIOCARBON DATING ANALYSES}

\begin{tabular}{|c|c|c|c|}
\hline Sample Data & $\begin{array}{c}\text { Measured } \\
\text { Radiocarbon Age }\end{array}$ & $\begin{array}{c}13 \mathrm{C} / 12 \mathrm{C} \\
\text { Ratio }\end{array}$ & $\begin{array}{c}\text { Conventional } \\
\text { Radiocarbon Age }\left(^{*}\right)\end{array}$ \\
\hline $\begin{array}{l}\text { Beta - } 371131 \\
\text { SAMPLE : TRV403 } \\
\text { ANALYSIS : RadiometricPLUS-S } \\
\text { MATERIAL/PRETREATMENT : } \\
\text { 2 SIGMA CALIBRATION : }\end{array}$ & $\begin{array}{l}\qquad 330+/-30 \mathrm{BP} \\
\text { Standard delivery } \\
\text { : (charred material): acid/alkali/acid } \\
\text { Cal AD } 1500 \text { to } 1500 \text { (Cal BP } 450 \text { to } 450 \text { ) } \\
\text { Cal AD } 1620 \text { to } 1660 \text { (Cal BP } 330 \text { to } 290 \text { ) }\end{array}$ & $\begin{array}{l}-27.6 \mathrm{o} / \mathrm{oo} \\
\text { AND Cal AD }\end{array}$ & Cal BP 440 to 350 ) \\
\hline
\end{tabular}

*Datações radiocarbônicas inicialmente publicadas em: MÜLLER, Isabela da Silva. Arqueologia Guarani no Litoral Central de Santa Catarina: estudo de caso do sítio TRV. Trabalho de Conclusão de Curso de curso de Graduação em História. Universidade Federal de Santa Catarina: Florianópolis, 2015. 


\section{ANEXO 03}

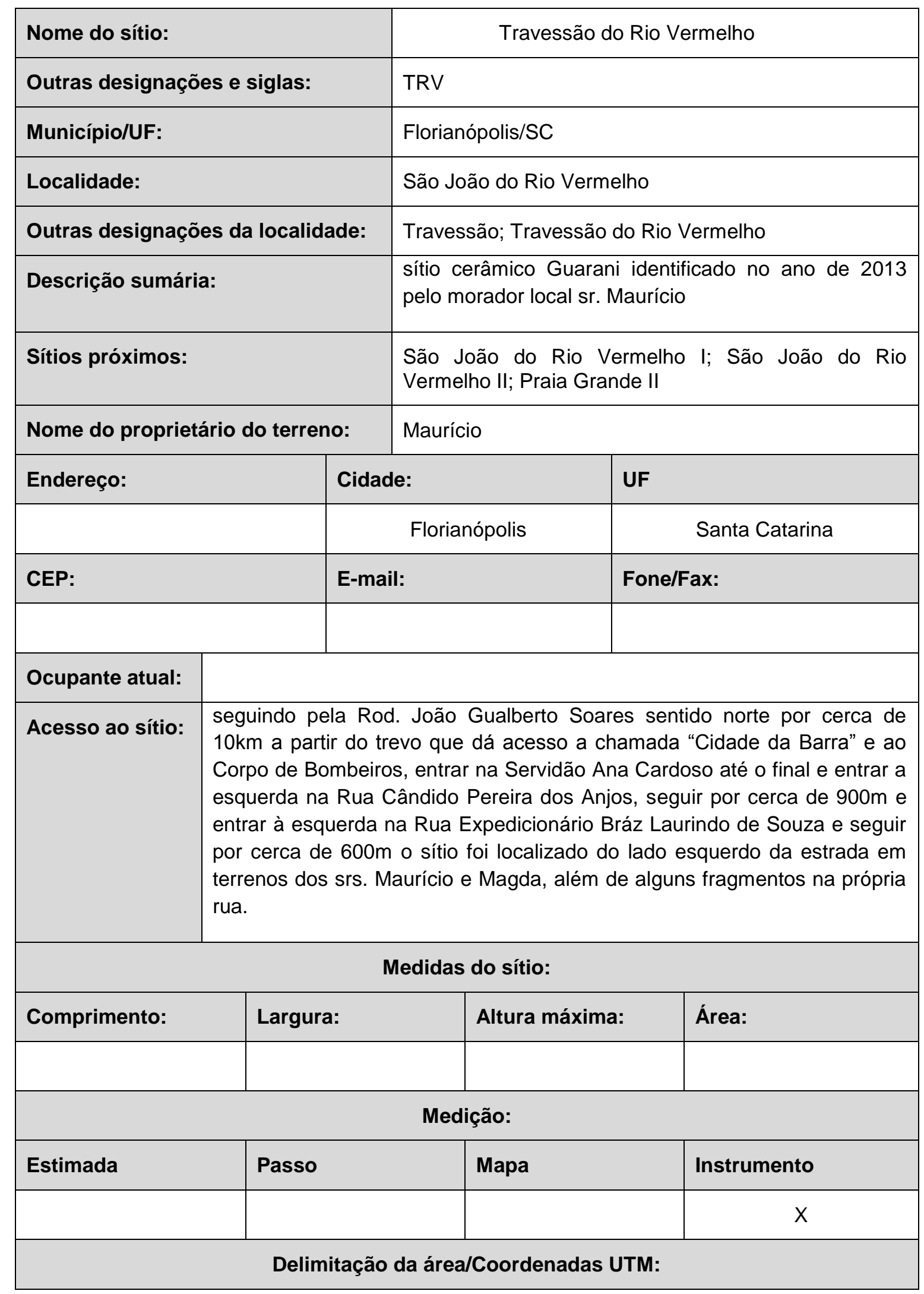




\begin{tabular}{|c|c|c|c|c|c|}
\hline \multicolumn{6}{|c|}{ Ponto central: } \\
\hline \multicolumn{6}{|c|}{756372 / 6957075} \\
\hline \multicolumn{6}{|c|}{ Perímetro: } \\
\hline \multicolumn{4}{|c|}{ DATUM: } & \multicolumn{2}{|c|}{ WGS 84} \\
\hline \multicolumn{6}{|c|}{ Unidade geomorfológica } \\
\hline & \multicolumn{3}{|c|}{ Cordões de Restinga } & $\begin{array}{l}\text { Modelado de } \\
\text { Dissecação }\end{array}$ & Planície Aluvial \\
\hline & \multicolumn{3}{|c|}{$\begin{array}{l}\text { Planície de Maré (ou } \\
\text { planície de } \\
\text { manguezal) }\end{array}$} & Planície de Resting & Planície Eólica \\
\hline & \multicolumn{3}{|c|}{ Planície Fluvial } & $\begin{array}{l}\text { Planície Flúvio- } \\
\text { Aluvial }\end{array}$ & $\begin{array}{l}\text { Planície Flúvio- } \\
\text { Marinha }\end{array}$ \\
\hline & \multicolumn{3}{|c|}{ Planície Lacustre } & Planície Marinha & $\begin{array}{l}\text { Rampa colúvio- } \\
\text { eluvionais }\end{array}$ \\
\hline & \multicolumn{3}{|c|}{ Rampa de dissipação } & $\begin{array}{l}\text { Terraço Marino } \\
\text { Antigo }\end{array}$ & $\begin{array}{l}\text { Terraço Marinho } \\
\text { Recente }\end{array}$ \\
\hline \multicolumn{6}{|c|}{ Compartimento topográfico } \\
\hline$x$ & \multicolumn{3}{|c|}{ Regime deposicional } & Regime erosivo & Regime relictual \\
\hline \multirow{2}{*}{\multicolumn{2}{|c|}{$\begin{array}{l}\text { Altitude: (com } \\
\text { relação ao nível } \\
\text { do mar) }\end{array}$}} & $\begin{array}{l}\text { Ági } \\
\text { pró }\end{array}$ & Ia & Distância: & Bacia: \\
\hline & & \multicolumn{2}{|c|}{ Rio Vermelho } & $570 m$ & $\begin{array}{ll}\text { Lagoa } & \mathrm{da} \\
\text { Conceição } & \end{array}$ \\
\hline \multicolumn{6}{|c|}{ Outras referências de localização: } \\
\hline \multicolumn{6}{|c|}{ Vegetação atual: } \\
\hline \multicolumn{3}{|c|}{$\begin{array}{l}\text { Floresta Pluvial da } \\
\text { encosta Atlântica }\end{array}$} & \multicolumn{2}{|c|}{$\begin{array}{l}\text { Floresta } \\
\text { planícies } \\
\text { quaternárias }\end{array}$} & nguezal \\
\hline Área & Irbanizada & & Dunas & & aias \\
\hline
\end{tabular}




\begin{tabular}{|c|c|c|c|c|c|c|c|c|c|c|}
\hline \multicolumn{11}{|c|}{ Uso atual do terreno: } \\
\hline \multicolumn{2}{|c|}{$\begin{array}{l}\text { Área } \\
\text { edificada }\end{array}$} & \multicolumn{2}{|c|}{ Via pública } & $\begin{array}{l}\text { Refloresta } \\
\text { mento }\end{array}$ & \multicolumn{2}{|c|}{ Pasto } & \multicolumn{2}{|c|}{ Plantio } & $\begin{array}{l}\text { Área não } \\
\text { utilizada }\end{array}$ & Outro: \\
\hline \multicolumn{2}{|c|}{$x$} & & & $x$ & & & & & $x$ & \\
\hline \multicolumn{11}{|c|}{ Propriedade da terra } \\
\hline \multirow{2}{*}{\multicolumn{2}{|c|}{ Área públic }} & & \multicolumn{3}{|c|}{ Área privada } & \multicolumn{3}{|c|}{ Área militar } & \multicolumn{2}{|l|}{ Outra: } \\
\hline & & & \multicolumn{2}{|r|}{$X$} & & & & & & \\
\hline \multicolumn{5}{|c|}{ Proteção legal: } & \multicolumn{6}{|c|}{ Esfera da proteção legal: } \\
\hline \multicolumn{3}{|c|}{$\begin{array}{l}\text { Patrimônio } \\
\text { tombado }\end{array}$} & \multicolumn{2}{|c|}{$\begin{array}{l}\text { Unidade } \\
\text { conservação } \\
\text { ambiental }\end{array}$} & \multicolumn{3}{|c|}{ Municipal } & \multicolumn{2}{|c|}{ Estadual } & Federal \\
\hline \multicolumn{11}{|c|}{ Exposição: } \\
\hline \multicolumn{4}{|c|}{ Céu aberto } & \multicolumn{4}{|c|}{ Abrigo sob rocha } & \multicolumn{3}{|c|}{ Submerso } \\
\hline \multicolumn{4}{|c|}{$\mathrm{x}$} & & & & & & & \\
\hline \multicolumn{11}{|c|}{ Contexto de deposição: } \\
\hline \multicolumn{4}{|c|}{ Em superfície } & \multicolumn{4}{|c|}{ Em profundidade } & \multicolumn{3}{|c|}{ Outra: } \\
\hline & & $x$ & & & & $x$ & & & & \\
\hline & & & & & Tip & de sítio & & & & \\
\hline$x$ & Cerâ & & & & & & & & & \\
\hline$x$ & Gua & & & & & & Itar & & & \\
\hline & Con & ero & & & & & & & & \\
\hline & & rân & Guaran & & $\begin{array}{l}\text { Cor } \\
\text { Itar }\end{array}$ & $\begin{array}{l}\text { cerâmica } \\
\text { ré }\end{array}$ & & & Sem cerâ & âmica \\
\hline & Hist & & & & & & & & & \\
\hline & Lític & & & & & & & & & \\
\hline & $\begin{array}{l}\text { Amo } \\
\text { polic }\end{array}$ & $\begin{array}{l}\text { lor- } \\
\text { fixc }\end{array}$ & & $\begin{array}{l}\text { Vestígio } \\
\text { lascados }\end{array}$ & & & $\begin{array}{l}\text { Vest } \\
\text { polic }\end{array}$ & & & Dutro \\
\hline & & & Tipos & s de Modific & açã & (Amolad & r-Pol & dor $f$ & & \\
\hline & Baci & $e p$ & ento cố & ôncava & & & $\mathrm{Bac}$ & de & limento cônc & ava-convexa \\
\hline
\end{tabular}




\begin{tabular}{|l|l|l|l|l|l|}
\hline \multicolumn{5}{|c|}{ Suporte (Amolador-Polidor Fixo) } \\
\hline \multicolumn{5}{|l|}{ Sulco } \\
\hline & Bloco/Matacão & Dique & & Laje \\
\hline & Representação Rupestre & Caracterização \\
\hline \multicolumn{5}{|c|}{} \\
\hline & Gravura & & Conjunto de gravuras & & Conjunto de suporte \\
\hline
\end{tabular}


12. ANEXO 04

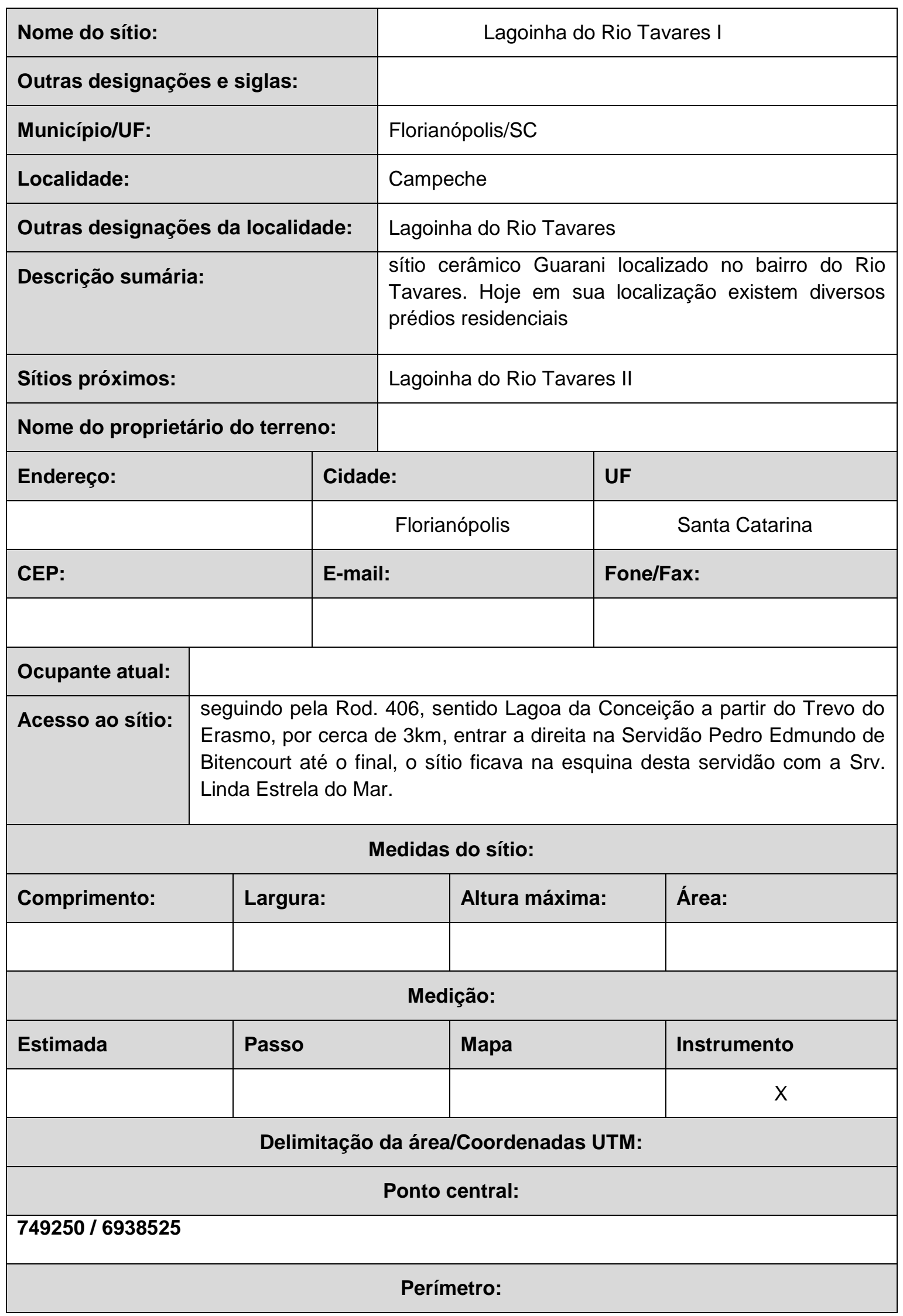




\begin{tabular}{|c|c|c|c|c|c|c|c|c|c|c|}
\hline \multicolumn{6}{|c|}{ DATUM: } & \multicolumn{5}{|c|}{ WGS 84} \\
\hline \multicolumn{11}{|c|}{ Unidade geomorfológica } \\
\hline & \multicolumn{5}{|c|}{ Cordões de Restinga } & \multicolumn{3}{|c|}{$\begin{array}{l}\text { Modelado de } \\
\text { Dissecação }\end{array}$} & \multicolumn{2}{|c|}{ Planície Aluvial } \\
\hline & \multicolumn{4}{|c|}{$\begin{array}{l}\text { Planície de Maré (ou } \\
\text { planície de } \\
\text { manguezal) }\end{array}$} & & \multicolumn{3}{|c|}{ Planície de Restinga } & \multicolumn{2}{|c|}{ Planície Eólica } \\
\hline & \multicolumn{4}{|c|}{ Planície Fluvial } & $x$ & \multicolumn{3}{|c|}{$\begin{array}{l}\text { Planície Flúvio- } \\
\text { Aluvial }\end{array}$} & \multicolumn{2}{|c|}{$\begin{array}{l}\text { Planície Flúvio- } \\
\text { Marinha }\end{array}$} \\
\hline & \multicolumn{4}{|c|}{ Planície Lacustre } & & \multicolumn{3}{|c|}{ Planície Marinha } & \multicolumn{2}{|c|}{$\begin{array}{l}\text { Rampa colúvio- } \\
\text { eluvionais }\end{array}$} \\
\hline & \multicolumn{4}{|c|}{ Rampa de dissipação } & & \multicolumn{3}{|c|}{$\begin{array}{l}\text { Terraço Marino } \\
\text { Antigo }\end{array}$} & \multicolumn{2}{|c|}{$\begin{array}{l}\text { Terraço Marinho } \\
\text { Recente }\end{array}$} \\
\hline \multicolumn{11}{|c|}{ Compartimento topográfico } \\
\hline$x$ & \multicolumn{4}{|c|}{ Regime deposicional } & & \multicolumn{3}{|c|}{ Regime erosivo } & \multicolumn{2}{|c|}{ Regime relictual } \\
\hline \multirow{2}{*}{\multicolumn{3}{|c|}{$\begin{array}{l}\text { Altitude: (com } \\
\text { relação ao nível } \\
\text { do mar) }\end{array}$}} & \multicolumn{3}{|c|}{$\begin{array}{l}\text { Água mais } \\
\text { próxima: }\end{array}$} & \multicolumn{2}{|c|}{ Distância: } & Rio: & \multicolumn{2}{|c|}{ Bacia: } \\
\hline & & & \multicolumn{3}{|c|}{$\begin{array}{l}\text { Lagoinha do Rio } \\
\text { Tavares }\end{array}$} & \multicolumn{2}{|l|}{$320 m$} & Rio Tavares & \multicolumn{2}{|c|}{ Morro das Pedras } \\
\hline \multicolumn{11}{|c|}{ Outras referências de localização: } \\
\hline \multicolumn{11}{|c|}{ Vegetação atual: } \\
\hline \multicolumn{4}{|c|}{$\begin{array}{l}\text { Floresta Pluvial da } \\
\text { encosta Atlântica }\end{array}$} & $\begin{array}{l}\text { Flor } \\
\text { plar } \\
\text { qua }\end{array}$ & $\begin{array}{l}\text { sta } \\
\text { ícies } \\
\text { ernárias }\end{array}$ & das & Rest & & Mangueza & \\
\hline Área & Irban & & & Dun & & & Cos & & Praias & \\
\hline$x$ & & & & & & & & & & \\
\hline & & & & & Us & 0 atual & I do te & & & \\
\hline $\begin{array}{l}\text { Área } \\
\text { edifi }\end{array}$ & da & Via & púb & lica & $\begin{array}{l}\text { Reflorest } \\
\text { mento }\end{array}$ & & asto & Planti & $\begin{array}{l}\text { Área não } \\
\text { utilizada }\end{array}$ & Outro: \\
\hline & K & & & & & & & & & \\
\hline
\end{tabular}




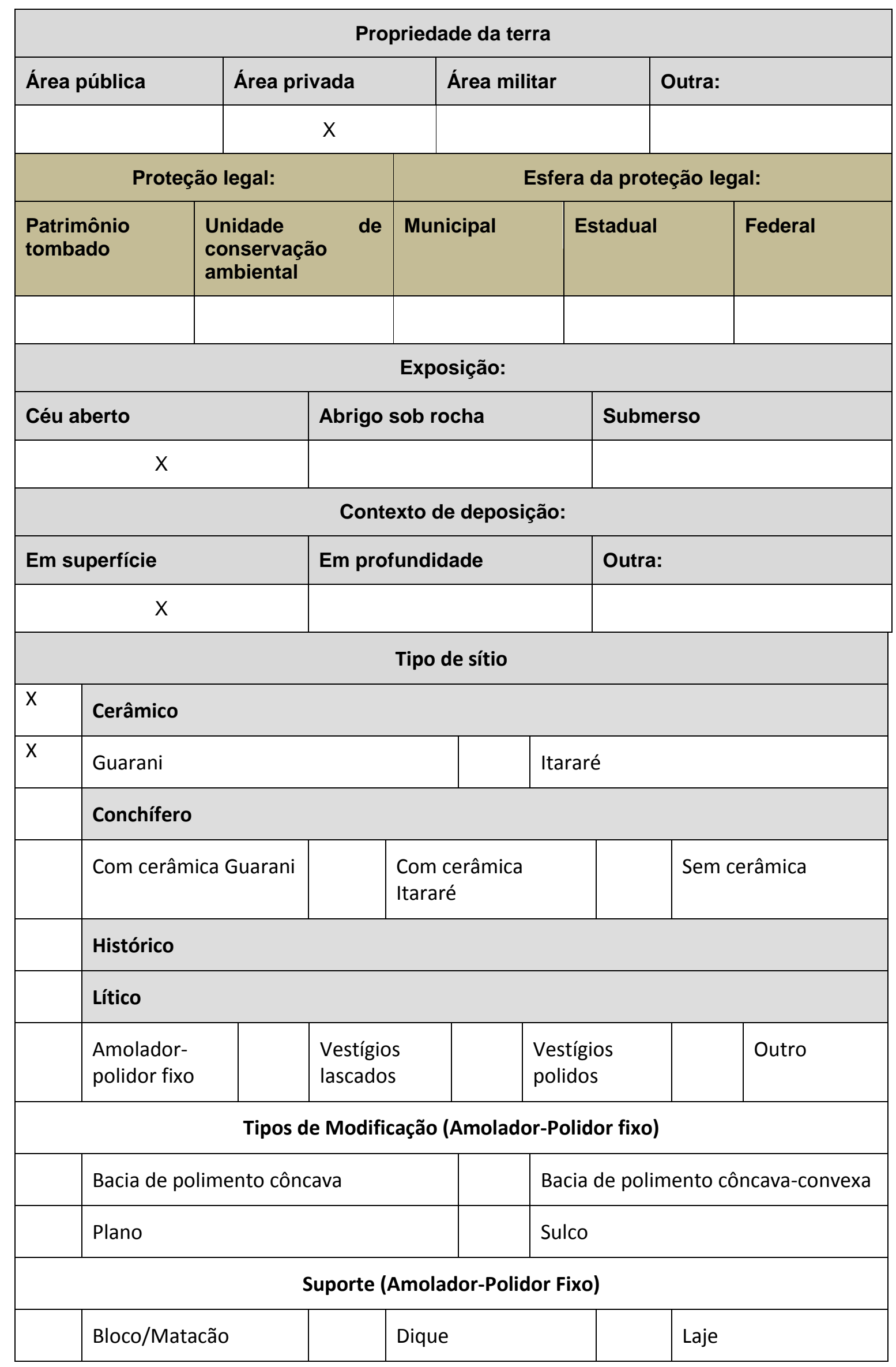




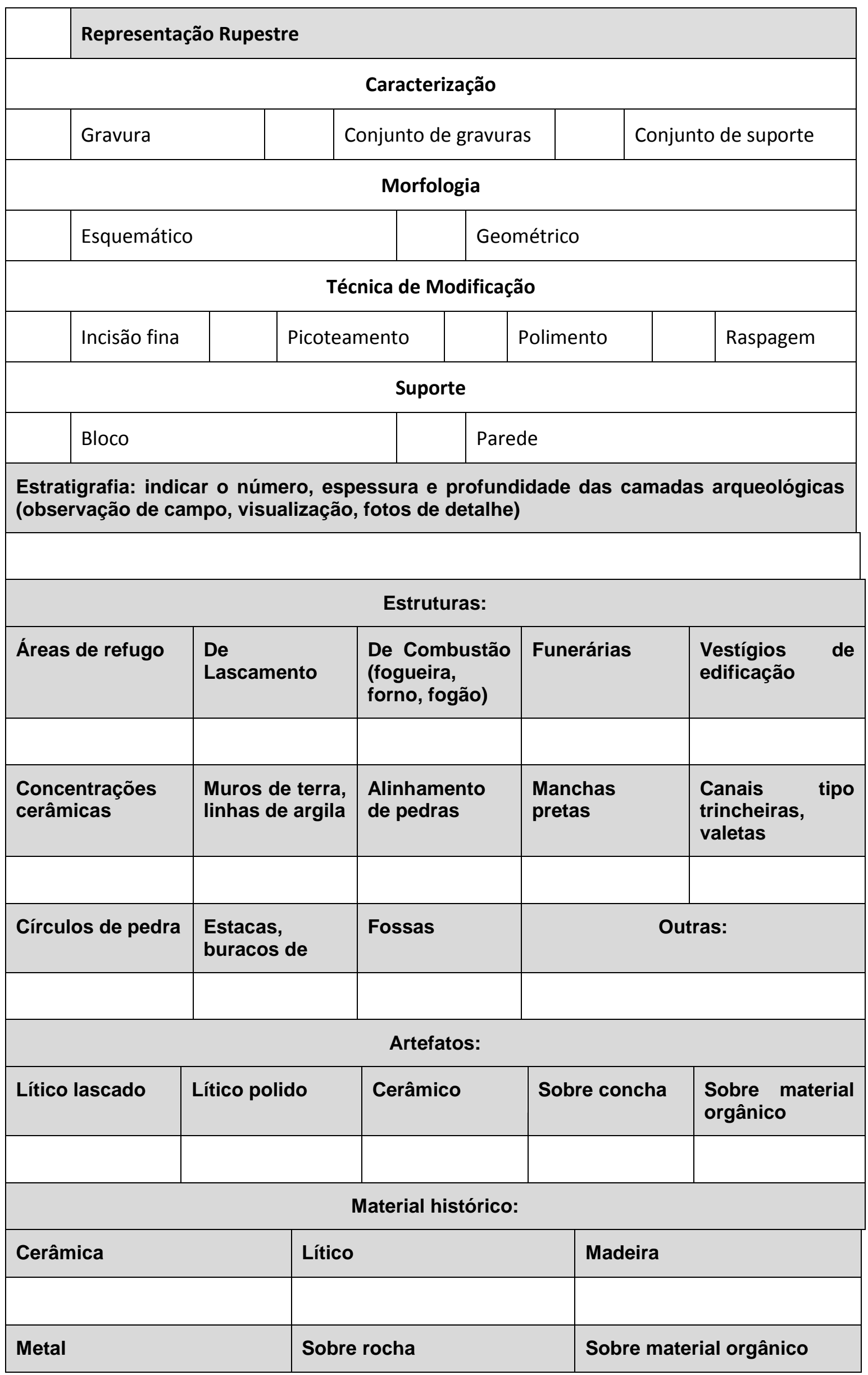




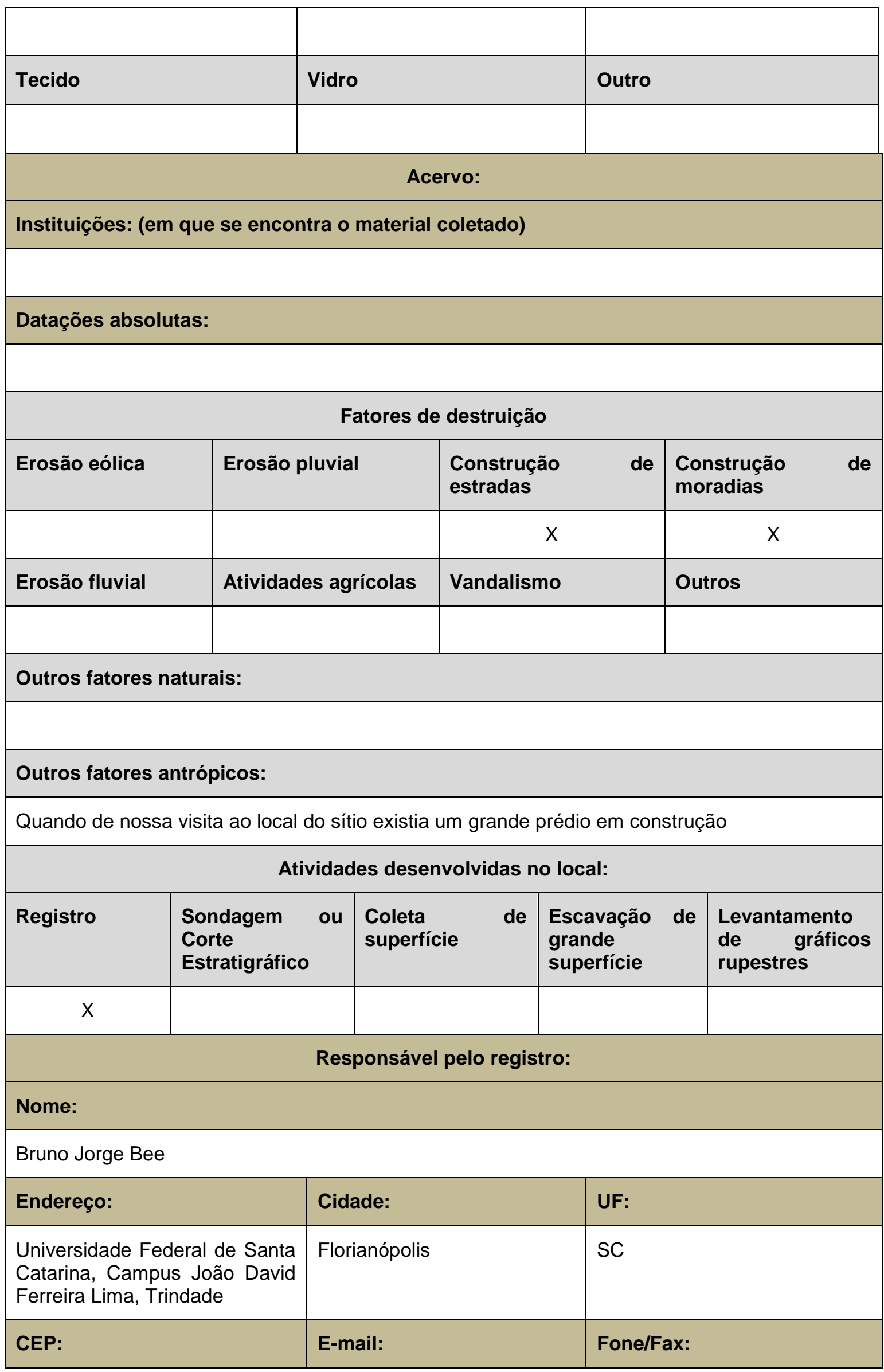




\begin{tabular}{|c|c|c|c|c|c|}
\hline \multicolumn{2}{|l|}{$88040-900$} & \multicolumn{2}{|c|}{ leiArqueologia@gmail.com } & \multicolumn{2}{|l|}{$483721-4134$} \\
\hline \multicolumn{6}{|c|}{ Nome do projeto: } \\
\hline \multicolumn{6}{|c|}{ Florianópolis Arqueológica } \\
\hline \multicolumn{6}{|c|}{ Nome da instituição: } \\
\hline \multicolumn{6}{|c|}{ Laboratório de Estudos Interdisciplinares em Arqueologia } \\
\hline \multicolumn{2}{|l|}{ Endereço: } & \multicolumn{2}{|l|}{ Cidade: } & \multicolumn{2}{|l|}{ UF: } \\
\hline \multicolumn{2}{|c|}{$\begin{array}{l}\text { Universidade Federal de Santa } \\
\text { Catarina, Campus João David } \\
\text { Ferreira Lima, Trindade }\end{array}$} & \multicolumn{2}{|l|}{ Florianópolis } & \multicolumn{2}{|l|}{ SC } \\
\hline \multicolumn{2}{|l|}{ CEP: } & \multicolumn{2}{|l|}{ E-mail: } & \multicolumn{2}{|l|}{ Fone/Fax: } \\
\hline \multicolumn{2}{|l|}{$88040-900$} & \multicolumn{2}{|c|}{ leiArqueologia@gmail.com } & \multicolumn{2}{|l|}{$483721-4134$} \\
\hline \multicolumn{6}{|c|}{ Documentação produzida: (quantidade) } \\
\hline $\begin{array}{l}\text { Mapa com } \\
\text { sítio plotado: }\end{array}$ & Croqui: & $\begin{array}{l}\text { Planta baixa } \\
\text { do sítio: }\end{array}$ & $\begin{array}{l}\text { Planta baixa } \\
\text { dos locais } \\
\text { afetados: }\end{array}$ & $\begin{array}{l}\text { Planta baixa } \\
\text { de } \\
\text { estruturas: }\end{array}$ & $\begin{array}{l}\text { Perfil } \\
\text { estratigráfico: }\end{array}$ \\
\hline \multicolumn{6}{|l|}{$\mathrm{X}$} \\
\hline \multirow[t]{2}{*}{$\begin{array}{l}\text { Perfil } \\
\text { topográfico: }\end{array}$} & Foto aérea: & $\begin{array}{l}\text { Foto } \\
\text { colorida: }\end{array}$ & $\begin{array}{l}\text { Foto preto e } \\
\text { branco: }\end{array}$ & $\begin{array}{l}\text { Reprografia } \\
\text { de imagem: }\end{array}$ & $\begin{array}{l}\text { Imagem de } \\
\text { satélite: }\end{array}$ \\
\hline & & $\mathrm{X}$ & & & \\
\hline $\begin{array}{l}\text { Cópia total } \\
\text { de arte } \\
\text { rupestre: }\end{array}$ & $\begin{array}{l}\text { Cópia } \\
\text { parcial de } \\
\text { arte } \\
\text { rupestre: }\end{array}$ & $\begin{array}{l}\text { llustração } \\
\text { do material: }\end{array}$ & $\begin{array}{l}\text { Caderneta } \\
\text { de campo: }\end{array}$ & Vídeo/filme: & Outra: \\
\hline \multicolumn{6}{|c|}{$\begin{array}{l}\text { Quantidade de imagens anexadas à Ficha de Registro para inclusão no } \\
\text { Banco de Imagens: }\end{array}$} \\
\hline \multicolumn{6}{|l|}{ Bibliografia: } \\
\hline \multicolumn{6}{|l|}{ Observações: } \\
\hline Data: & & Assinatura: & & & \\
\hline
\end{tabular}




\section{ANEXO 05}

\section{GLOSSÁRIO DA FICHA DE ANÁLISE CERÂMICA}

A ficha de análise cerâmica utilizada nessa pesquisa começou a ser formada no ano de 2012 sob a orientação da Profa. Dra. Juliana Salles machado (UFSC) baseada em seu trabalho de mestrado (MACHADO, 2005) e na obra de Fernando La Salvia e José Proença Brochado (LA SALVIA \& BROCHADO , 1989). A ficha foi aperfeiçoada entre 2012 e 2018 com as discussões e demandas provenientes dos participantes e colaboradores do LEIA/UFSC junto às orientações de Machado e, por fim, com as demandas deste trabalho de mestrado especificamente, de seus questionamentos e as necessidades que se apresentaram a partir do andamento das análises e dos questionamentos de profissionais que participaram dessa trajetória no mestrado. Como exemplo das adaptações e rearranjos realizados, estão contribuições da Profa. Dra. Fabíola Silva (MAE/USP) na banca de qualificação do mestrado (em fevereiro de 2018) (estas modificações foram feitas usando como exemplo o trabalho de Gaspar GASPAR, 2014) e das pesquisadoras Carolina Silva e Canela Castro (do Museo de Ciencias Naturales da UNLP, Argentina). Portanto, essa ficha utilizada tem como base a ficha de análise cerâmica utilizada pelo LEIA/UFSC com adaptações da autora para a pesquisa aqui apresentada, como algumas características do trabalho de Gaspar. Portanto, o glossário na sequência da ficha apresentado foi montado pela autora, voltado a esta pesquisa e para a forma como a conduziu.

A ficha passou por algumas modificações, como se vê abaixo. As modificações são apresentadas grifadas em cinza, e nota-se que apenas o atributo de número 23, Atribuição Etnohistórica, não foi trabalhado nesta fase da pesquisa. A pesquisa continua para se encaminhar em um projeto de doutorado, no qual esses estudados devem ser aprofundados. 


\section{A FICHA DE ANÁLISE CERÂMICA (ANTES DA QUALIFICAÇÃO)}

1. Sítio (Sigla)

2. PN - dígito

3. Localização (unidade de escavação)

4. Nível estratigráfico

5. Natureza da Peça

1 - borda

2 - base

3 - parede

4 - inflexão

5 - alça

6 - cachimbo

7 - decoração

6. Argila

1 - cinza

2 - branca

3 - vermelha

4 - laranja 1

5 - laranja 2 (avermelhad0)

6 - laranja 3 (tom de marrom)

7 - marrom escuro

7. Anti-plástico

1 - cariapé

2 - caco moído

3 - mineral 1 (areia grossa)

4 - mineral 2 (areia fina)

5 - hematita

6 - argila

8. Técnica de Manufatura

1 - modelado

2 - acordelado

3 - moldado

4 - torneado

9. Queima

1 - oxidante

2 - redutora

3 - oxidante interna

4 - redutora interna

5 - oxidante interna e externa /

redutora miolo

10. Espessura da peça $(\mathrm{mm})$

11. Espessura da borda (mm)

12. Forma da borda

1 - restritivo

2 - irrestritivo
3 - vertical

4 - ponto de inflexão

13. Forma da base

$$
\begin{aligned}
& 1 \text { - plano } \\
& 2 \text { - côncavo } \\
& 3 \text { - convexo } \\
& 4 \text { - reforçada }
\end{aligned}
$$

14. Tratamento de superfície

1 - alisamento

2 - enegrecimento/ brunidura/

barbotina

3 - resina

4 - polimento

5 - crosta escura

15. Decoração plástica

1 - corrugado

2 - digitado

3 - ungulado

4 - inciso

5 - escovado

6 - acanalado

7 - estampado

8 - ponteado

9- nodulado

10 - exciso

16. Localização da decoração pintada

1 - externa

2 - interna

3 - interna e externa

4 -lábio

17. Decoração pintada

1- monocrômico (pintura)

2 - bicrômico (engobo + pintura)

3 - policrômico

4 - engobo

18. Marca de uso

1 - fuligem

2 - reciclagem

3 - desgaste acentuado

4 - fermentação

19. Categoria etnohistórica

20. Observações 


\section{A FICHA DE ANÁLISE CERÂMICA (APÓS A QUALIFICAÇÃO)}

1. Sítio (Sigla)

2. $\mathrm{PN}$ - dígito

3. Localização (unidade de escavação)

4. Nível estratigráfico

5. Natureza da Peça

1 - borda

2 - base

3 - parede

4 - inflexão

5 - alça

6 - cachimbo

7 - decoração

6. Anti-plástico

1 - cariapé

2 - caco moído

3 - mineral 1 (areia rossa)

4 - mineral 2 (areia fina)

5 - hematita

6 - argila

7. Técnica de Manufatura

1 - modelado

2 - acordelado

3 - moldado

4 - torneado

8. Queima

1 - oxidante

2 - redutora

3 - oxidante interna

4 - redutora interna

5 - oxidante interna e externa /

redutora miolo

9.Configuração do Núcleo

1 -
$2-$
$4-$
$4-$
$6-$

10. Coloração da face externa

11. Coloração da face interna

12. Espessura da peça ( $\mathrm{mm})$

13. Espessura da borda $(\mathrm{mm})$

14. Forma da borda

1 - restritivo

2 - irrestritivo
3 - vertical

4 - ponto de inflexão

15. Forma da base

1 - plano

2 - côncavo

3 - convexo

4 - reforçada

16. Tratamento de superfície

1 - alisamento

2 - enegrecimento/ brunidura/

barbotina

3 - resina

4 - polimento

5 - crosta escura

17. Decoração plástica

1 - corrugado

2 - digitado

3 - ungulado

4 - inciso

5 - escovado

18. Localização da decoração pintada

1 - externa

2 - interna

3 - interna e externa

4 -lábio

19. Decoração pintada

1- monocrômico (pintura)

2 - bicrômico (engobo + pintura)

3 - policrômico

4 - engobo

20. Pasta

1 - cinza

2 - branca

3 - vermelha

4 - laranja 1

5 - laranja 2 (avermelhad0)

6 - laranja 3 (tom de marrom)

7 - marrom escuro

21. Marca de uso

1 - fuligem

2 - reciclagem

3 - desgaste acentuado

4 - fermentação

22. Categoria etnohistórica

23. Observações 


\section{A FICHA DE ANÁLISE CERÂMICA FINAL}

1. Sítio

2. PN - dígito

3. Localização (unidade de escavação)

4. Nível Estratigráfico

5. Natureza da Peça

1 - borda

2 - base

3 - parede

4 - inflexão

5 - alça

6 - cachimbo/petangua

7 - decoração

8 - reforço

9 - bolota de argila ou

trempe/ytácuru

6. Antiplástico

1 - cariapé

2 - caco moído

3 - mineral A (areia grossa)

4 - mineral B (areia média)

5 - mineral C (areia fina)

6 - óxido de ferro

7- argila

8 - carvão

7. Técnica de Manufatura

1 - roletado / acordelado

2 - modelado

3 - moldado

4 - torneado

8. Configuração do Núcleo (indicativo de queima)

1 - (oxidante)

2 - (oxidante interna e externa, e

redutora no núcleo)

3 - (redutora)

4 - (oxidante interna/redutora

externa)

5 - (redutora interna/oxidante

externa)

6 -

9. Coloração da Face Externa

10. Coloração da Face Interna

11. Espessura da Peça (mm)

12. Forma do Lábio

1 - plano

2 - arredondado
3 - apontado

4 - biselado

13. Espessura do Lábio

14. Diâmetro da Borda (cm)

15. Porcentagem da Borda (\%)

16. Forma da Borda

1 - restritivo

2 - irrestritivo

3 - vertical

4 - ponto de inflexão

17. Forma da Base

1 - plano

2 - côncava

3 - convexa

4 - reforçada

18. Tratamento Plástico de Superfície

1 - alisamento

2 - polimento

3 - corrugado

4 - digitado

5 - ungulado

6 - inciso

7 - escovado

8 - acanalado

9 - estampado

10 - ponteado

11 - nodulado

12 - exciso

19. Localização do Tratamento Plástico

1 - face interna

2 - face externa

3 - lábio

4 - face interna e externa

20. Tratamento Cromático de Superfície

1- monocrômico (pintura)

2 - bicrômico (engobo+pint /

pint+pint / engobo+engobo)

3 - policrômico (engob+pint+pint/ 3pints)

4 - engobo vermelho

5 - engobo branco

6- enegrecimento e/ou brunidura

7-resina

21. Localização do Tratamento

Cromático

1 - face interna

2 - face externa 


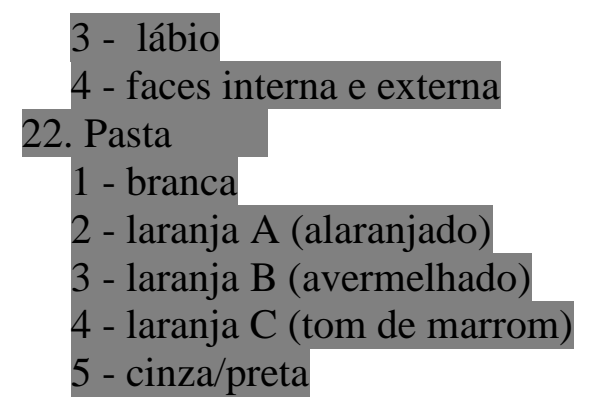

23. Marca de Uso

1 - fuligem

$$
\begin{aligned}
& 2 \text { - reciclagem } \\
& 3 \text { - desgaste acentuado } \\
& 4 \text { - fermentação }
\end{aligned}
$$

24. Atribuição Etnohistórica (não foi atribuída nessa fase da pesquisa)

25.Conjunto Atribuído (pode já ser observável ou não)

26. Observações

Portanto, na sequência é apresentado um Glossário da Ficha de Análise

Cerâmica Final, que vem a explorar cada atributo e categoria utilizada e se apresenta numa ordem que busca vislumbrar a sequência do processo de produção dos objetos cerâmicos. Ainda, vale lembrar que a ficha está destinada à análise de fragmentos, mas não se restringe a estes (podendo ser utilizada para vasilhas inteiras), uma vez que a análise de um fragmento visa contextualizá-lo, na medida do possível, em um objeto maior (a vasilha completa).

1. Sítio: Trata-se de uma variável alfa-numérica e registra o sítio arqueológico do qual a peça foi retirada através da sigla de cadastro do sítio (MACHADO, 2005, P.277) junto ao IPHAN no caso da coleção Travessão do Rio Vermelho (TRV) e de cadastro e numeração do material já contido nos arquivos e peças do MArquE no caso do sítio Lagoinha do Rio Tavares (RT). Assim, os materiais provenientes da coleção TRV possuem nesse atributo a sigla $T R V$ e a coleção RT possui a sigla $R T$.

2. Número de Proveniência / PN - dígito: Também se trata de uma variável alfanumérica e remete ao número de registro do fragmento com dois procedimentos: o padrão e o individual (MACHADO, 2005, P.277). Na coleção TRV, o número padrão é dado por nível artificial e unidade de escavação, ou seja, todo o material coletado no mesmo nível artificial (de $10 \mathrm{~cm}$ ) e unidade de escavação terá o mesmo número de proveniência (número observado na sequência da sigla do sítio). O número individual vem na sequência do anterior, e trata-se de um número único para cada fragmento. Por exemplo, temos $T R V .367 .2$ onde: $T R V$ é a sigla do sítio, 367 é o número padrão para o material coletado no mesmo nível artificial e unidade de escavação e 2 refere-se ao segundo fragmento registrado dentro do mesmo nível e unidade de escavação. $\mathrm{Na}$ coleção RT, temos que I.1.64 é o número padrão para todos os fragmentos (não ocorreu diferenciação entre unidades ou níveis) e o número subsequente não é repetido sob 
nenhuma hipótese e se refere a cada fragmento registrado, ou seja, um número individual. Por exemplo, RT.I.1.64.132 onde $R T$ é a sigla do sítio, I.1.64 é o número padrão para todos os fragmentos e 132 é o $132^{\circ}$ fragmento registrado. Importante mencionar que nem todos os fragmentos da coleção RT se encontravam numerados e para não interferir em nenhuma regra da instituição museológica, foi dado um registro alfa-numérico fictício a cada um desses fragmentos (que representavam uma mínima parte da coleção) em pequena etiqueta guardada junto ao material (que pode ser removida a qualquer momento da coleção). Esse número se diferencial totalmente da numeração do PN aqui referido.

3. Localização (unidade de escavação): variável alfa-numérica que registra a localização e o modo de retirada da peça no interior especificamente para o sítio TRV. Segundo Machado (MACHADO, 2005, P.278):

"Todas as unidades de escavação, sondagens e tradagens recebem um número localizador que está amarrado ao ponto zero, arbitrariamente definido para o mapeamento do sítio, que está por sua vez amarrado às coordenadas geográficas ou UTM."

Assim, N118W131, por exemplo, remete que a unidade de escavação esta localizada a 118 metros ao norte do ponto zero do sítio e a 131 metros a oeste do mesmo ponto. Para o sítio RT não foi encontrada uma correspondência entre cada fragmento e sua proveniência da escavação, por isso esse campo não foi preenchido para essa coleção.

4. Nível estratigráfico: variável alfa-numérica que indica a profundidade da amostra em determinado local a partir da camada artificial a qual ele pertence; e essa profundidade deve estar relacionada a um ponto zero vertical estabelecido independentemente para cada unidade de escavação e amarrado com a topografia geral do sítio a partir de instrumentos (MACHADO, 2005, P.278).

5. Natureza da Peça: trata-se de uma variável também alfa-numérica, constituído de uma lista de variáveis não excludentes, podendo ser utilizados de forma conjugada; as variáveis consistem em formas reconhecíveis nos fragmentos encontrados ou até formas inteiras (MACHADO, 2005, P.279) como os cachimbos. As seguintes categorias estão sob esse atributo: 1 - borda, 2 - base, 3 - parede, 4 - inflexão, 5 - alça, 6 - cachimbo / petangua, 7 - decoração, 8 - reforço, 9 - bolota de argila / trempe/ytácuru (Noelli, 
1993, P.234)e. Sobre a variável inflexão, considera-se o ponto de mudança abrupta ou suave na curvatura da vasilha (MACHADO, 2005, P.285); sobre decoração, considerase algum aplique à vasilha (não comum nessa cerâmica a não ser que tenha influências coloniais, como a alça ressalta). Compreende-se como reforço, camada/camadas de argila utilizadas para dar maior sustentação a determinado ponto na vasilha cerâmica (geralmente em algum ponto de inflexão). Bolotas de argila e trempe nos dão importantes indícios de locais onde foram fabricadas vasilhas, uma vez que bolota de argila não contem antiplástico, trata-se geralmente de um resto do uso da argila para a confecção de vasilhas, e a trempelytácuru e é um pedaço de argila e utilizada para apoiar esses materiais cerâmicos durante o processo de queima por exemplo.

6. Antiplástico: variável alfa-numérica que contempla como variáveis a maior parte dos antiplásticos conhecidos (MACHADO, 2005, P.279) na região sul da América do Sul ou que se conheça a utilização por falantes do tronco linguístico Tupi. Foram evidenciados como antiplástico sempre que sua aparição ocorria em grande quantidade e não apenas isoladamente. Por exemplo, o óxido de ferro ocorre frequentemente nas pastas e, sempre que observado, foi identificado em nota no campo 26.Observações da ficha. Mas somente foi marcado como antiplástico quando não foi observado de forma isolada nos fragmentos. Também é importante enfatizar que as pastas apresentam minerais vindos tanto da argila como matéria-prima quando coletada da natureza como acrescentados intencionalmente (como antiplástico), sendo impossível distinguir quais grãos provêm de um processo ou de outro, uma vez que todos os fragmentos analisados possuem mineral em suas pastas. As variáves utilizadas são: 1 - cariapé, 2 - caco moído, 3 - mineral A (areia grossa), 4 - mineral B (areia média), 5 - mineral C (areia fina), 6 - óxido de ferro, 7 - argila e 8 - carvão. Com relação ao óxido de ferro, não foi feita nenhuma diferenciação com relação a determinar qual tipo em específico se trata, como a hematita, uma vez que são necessários estudos mais aprofundados para tal classificação. E a distinção entre minerais A, B e C se dá por tamanho, sendo que este seguiu uma adaptação da granulometria proposta pelo Código Munsell. A seguir, códigos de identificação de cada antiplástico encontrado na análise (1 - cariapé e 7 argila não foram encontrados nas coleções) e observados através da lupa Leica S9i: 


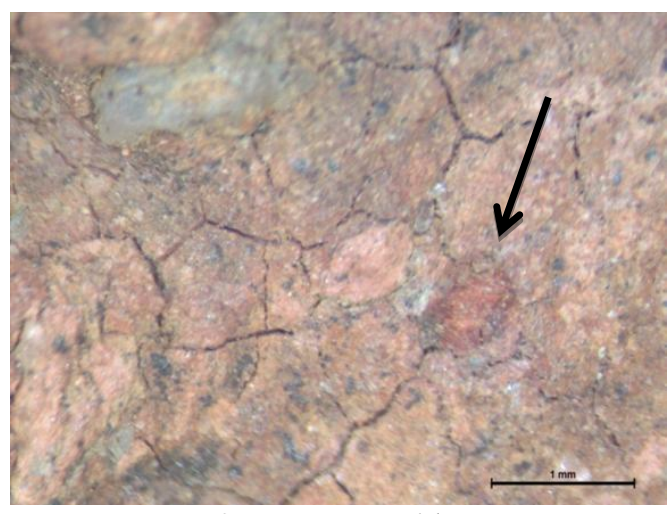

2 - caco moído

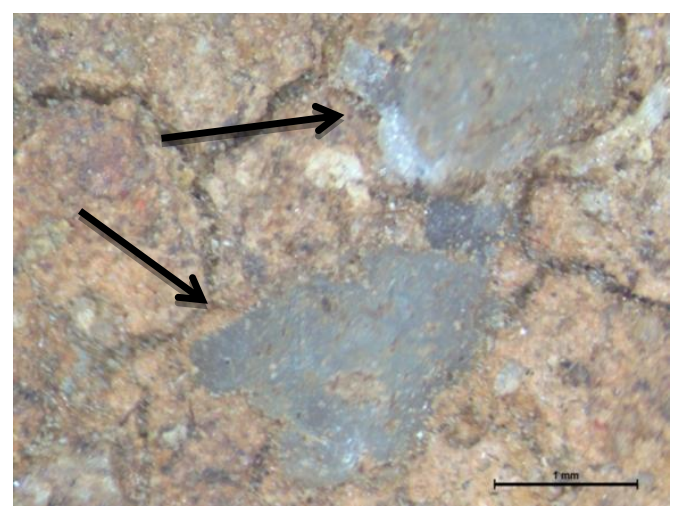

3 - mineral A

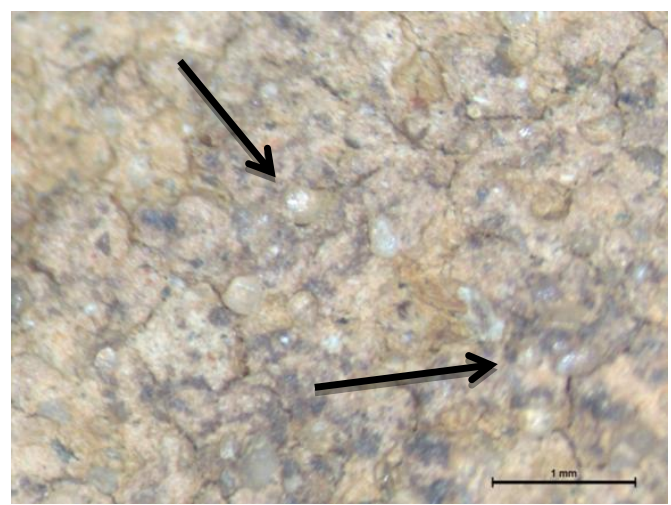

4 e 5 - minerais $\mathrm{B}$ e $\mathrm{C}$

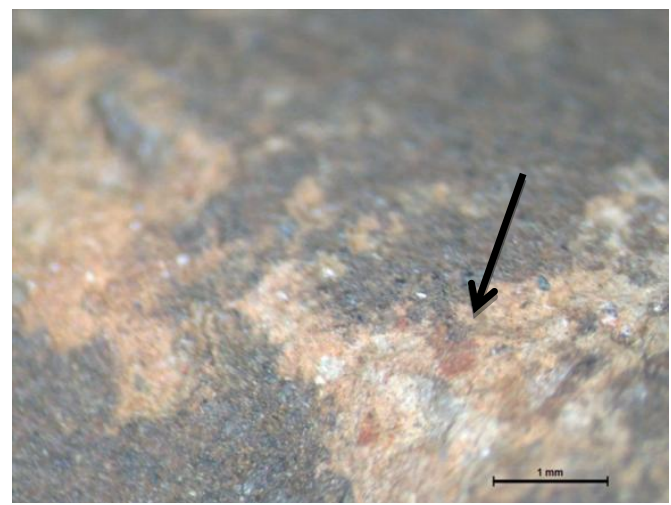

6 - óxido de ferro

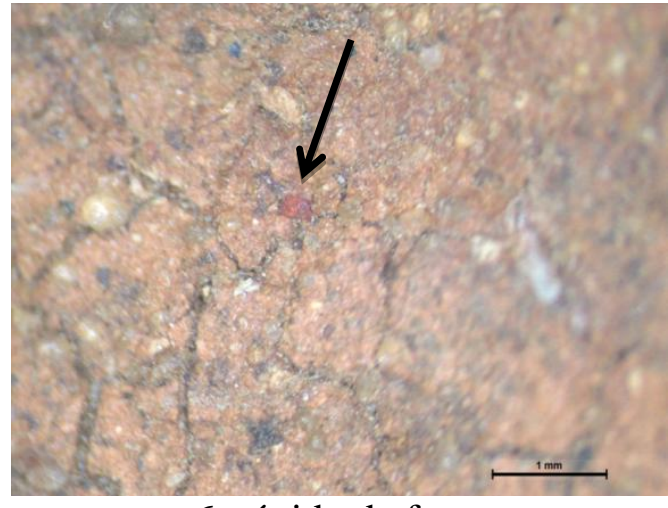

6 - óxido de ferro

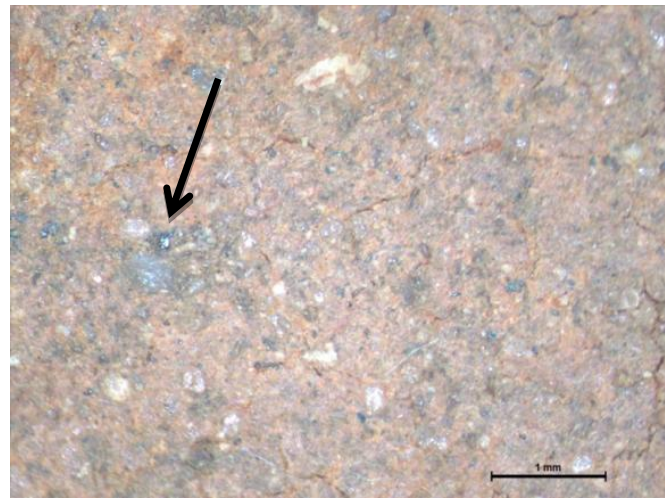

8 - carvão

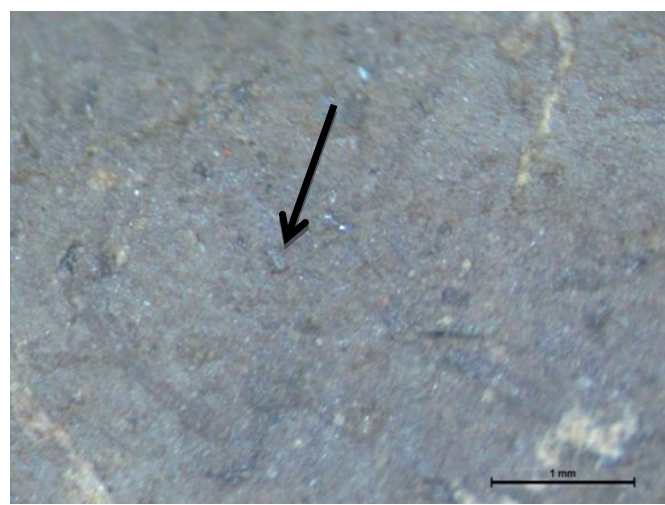

8 - carvão

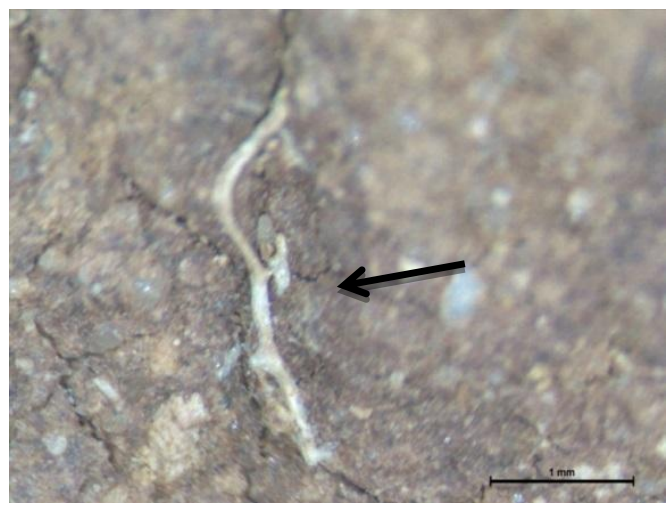

Fibra vegetal identificada que não constitui antiplástico. 
7. Técnica de Manufatura: novamente uma variável alfa-numérica, apresentando quatro variáveis não excludentes e conjugáveis (MACHADO, 2005, P.280): 1 roletado / acordelado, 2 - modelado, 3 - moldado, 4 - torneado. A categoria 4 torneado representa aqui uma influência colonial na cerâmica Guarani, porém não foram encontrados fragmentos que denotem o uso do torno e, portanto, essa influência. Ainda assim, importante estar representada em virtude das datações absolutas registradas de um dos sítios analisados, são contemporâneas às primeiras presenças europeias na região estudada. As marcas de folhas ou de alguma superfície possível de ser identificada na qual foi realizado esse processo de manufatura foram registradas no campo 26.Observações.

8. Configuração do Núcleo (indicativo de queima): trata-se de variável alfa-numérica e se relaciona com outros indicativos de queima, como as colorações das faces dos fragmentos e marcas de queima, conforme Gaspar (GASPAR, 2014, P.43). Refere-se à atmosfera circundante a vasilha no momento da queima das vasilhas (MACHADO, 2005, P.280). Essa categoria baseia-se em Rye (RYE, 1981, P.116 apud GASPAR, 2014):

“(...) o núcleo de Tipo I é claro por inteiro, podendo significar que o ambiente da queima era oxidante ou que não havia material orgânico na pasta; o Tipo 3 é escuro por inteiro, sendo o ambiente e temperatura de queima insuficientes para completar a oxidação e queimar todo o material orgânico da pasta, podendo também ser uma marca de uso ou pósdeposicional; o Tipo 2 tem face interna e externa claras e núcleo escuro; o Tipo 4 tem a face interna clara e a externa escura; o Tipo 5 tem a face interna escura e a externa clara; o Tipo 6 tem alternância entre claro e escuro. Os tipos 2, 45 e 6 seriam variações do 3 e do 1, com diferenças na localização das partes claras e escuras."

Portanto, as variáveis são: 1 - (oxidante), 2 - (oxidante interna e externa, e redutora no núcleo), 3 - (redutora), 4 - (oxidante interna/redutora externa), 5 - (redutora interna/oxidante externa), e 6. Entre parêntesis, são apresentadas as queimas correspondentes aos Tipos apresentados por Rye. Essas queimas correspondentes equivalem à categorização utilizada por Machado (MACHADO, 2005, P.280):

"os atributos desse tópico se referem (...) essa pode ser redutora, se temos falta de oxigênio ou oxidante se temos sobra 
de oxigênio durante o processo de queima. A queima redutora deixa marcas cinza na pasta, enquanto a oxidante tende a deixar marcas mais claras e alaranjadas. Dentre as variáveis listadas encontramos variações de queima que são fruto de atmosferas de queima intermediárias às acima mencionadas."

9. Coloração da Face Externa: junto à variável 8.Configuração do Núcleo, as colorações das faces internas e externas podem revelar o ambiente de queima no momento de manufatura dos objetos cerâmicos e são dadas a partir da comparação com o Código Munsell. Então,

“(...) para padronizar as cores observadas, um dos métodos utilizados é a comparação da cor da cerâmica com as cores do Código Munsell, que organiza as cores de acordo com as variáveis tom, saturação e intensidade, devendo ser medido sempre pela mesma pessoa e na mesma luminosidade, para que a observação não seja tão discrepante" (RICE, 1987, P.343 apud GASPAR, 2015, P.50).

Ambos esses atributos (9.Coloração da Face Externa e 10.Coloração da Face Interna) junto à observação da configuração do núcleo auxilia a inferir a coloração a cor da pasta (22.Pasta). Portanto, no item 22 é feita uma síntese de todas as colorações identificadas no Munsell a partir dos atributos 9 e 10 e agrupados em 5 cores de pasta.

10. Coloração da Face Interna: variável observada com a comparação com o Código Munsell e que segue as mesmas características que o atributo 9.Coloração da Face Externa.

11. Espessura da Peça (mm): trata-se de uma variável numérica aplicável a qualquer fragmento que mede a parte mais espessa do mesmo através de um paquímetro e é dada em milímetros (mm). E "a partir da média da espessura de cerâmicas semelhantes, podemos obter informações de fundamental importância para a caracterização formal de um determinado conjunto cerâmico" (MACHADO, 2005, P;281).

12. Forma do Lábio: variável alfa-numérica que contempla apenas os fragmentos de borda e são excludentes entre si; e aqui foi usado como referência o trabalho de Migliacio adapatado por Gaspar (MIGLIACIO, 2000 apud GASPAR, 2015, P.203). São as seguintes variáveis que compõem essa categoria: 1- plano, 2 - arredondado, 3 apontado e 4 - biselado. 
13. Espessura do Lábio (mm): variável numérica somente aplicável aos fragmentos de bordas, medindo a maior espessura da extremidade do lábio (extremo superior da borda) através de um paquímetro e dada em milímetros $(\mathrm{mm})$. Além disso, conforme Machado também ressalta, essa informação pode apontar padrões formais importantes dentre os diferentes conjuntos cerâmicos (MACHADO, 2005, P.281).

14. Diâmetro da Borda (cm): esse atributo é uma variável numérica dada em centímetro $(\mathrm{cm})$ e restrita apenas às bordas, sendo possível conhecê-la através do uso de um ábaco, tendo em vista que as bocas das vasilhas sejam circulares (BROCHADO et al., 1990, P.728 apud GASPAR, 2015, P.47). Trata-se do diâmetro projetado de abertura das vasilhas a partir dos fragmentos de borda.

15. Porcentagem da Borda (\%): variável numérica restrita às bordas e muito importante mas, muitas vezes, esquecida, porém fácil de ser calculada com o mesmo ábaco no qual é calculado o diâmetro da borda. Refere-se à porcentagem que o fragmento de borda representa em toda a circunferência da boca projetada da vasilha por meio do ábaco. Com essa informação é possível atribuir graus de confiabilidade nas projeções das bordas e seus diâmetros e também provoca refletir o grau de fragmentação das peças (especialmente bordas).

16. Forma da Borda: variável alfa-numérica que contempla apenas os fragmentos de borda. Aqui é

“(...) avaliada a relação entre o diâmetro da peça (projeção do ângulo da parte distal do fragmento de borda) e o diâmetro do lábio (medido através do ábaco). Trata-se basicamente de verificar se esta se encontra na posição restritiva, irrestritiva ou vertical em relação ao corpo do pote. As formas são restritivas quando tiverem o diâmetro da peça maior que o diâmetro do lábio, irrestritiva quando o diâmetro da peça for menor que o diâmetro da borda [e] vertical (...) quando o diâmetro do lábio for igual ao diâmetro do pote." (MACHADO, 2005, P.281).

Portanto, as variáveis desse atributo são: 1 - restritiva, 2 - irrestritiva, 3 vertical, 4 - ponto de inflexão. Este último marca mudanças nos ângulos de contorno. Essas categorias também foram adaptadas das propostas de Machado e La Salvia \& Brochado.

17. Forma da Base: também é uma variável alfa-numérica e trata apenas nos fragmentos de base, sendo que as variáveis são agrupáveis, mas nem todas são 
associáveis entre si (como é o caso das bordas côncavas e convexas, que são excludentes) (MACHADO, 2005, P.281). Como reforça Machado, as diferenças formais são importantes de serem diferenciadas, pois podem organizar diferentes conjuntos cerâmicos e oferecer informações importantes a respeito das funções atreladas a cada especificidade formal (Idem, P.281). As variáveis dessa categoria são: 1 - plano, 2 - côncava, 3 - convexa, 4 - reforçada, e têm como referência os códigos utilizados por La Salvia e Brochado (LA SALVIA \& BROCHADO, 1989, P.120) e Machado (MACHADO, 2005, P.281) para identificar essas formas de bordas e diferenciá-las entre si.

18. Tratamento Plástico de Superfície: variável alfa-numérica que buscou aglutinar as variáveis "acabamento de superfície" e "decoração plástica" que normalmente são observadas nas fichas. Isso em virtude de não considerarmos produtiva uma separação de ambas as categorias baseadas em padrões contemporâneos, por considerarmos que tudo aqui que é feito na superfície das vasilhas pela ceramista seja uma forma de tratamento, sem classificá-lo como "decoração" ou não. Foram considerados tratamentos plásticos de superfície possíveis para a cerâmica Guarani: 1 - alisamento, 2 - polimento, 3 - corrugado, 4 - digitado, 5 - ungulado, 6 - inciso, 7 - escovado, 8 acanalado, 9 - estampado, 10 - ponteado, 11 - nodulado e 12 - exciso. Essas variáveis resultaram da adaptação das obras de Machado e La Salvia e Brochado. Nesta última, são apresentadas uma variedade imensa de formas de corrugados e ungulados, por exemplo (LA SALVIA \& BROCHADO, 1989, P.p.46-57), e que foram aquelas mais presentes nas coleções analisadas. No entanto, optou-se por não tomar todas essas classificações na ficha. Ainda assim, as diferenças observadas nos corrugados e ungulados em questão foi descrita no campo 26. Observações, buscando compreender quais gestos geraram os distintos resultados observados e, portanto, contemplando essa variabilidade (em um trabalho mais metodológico, esses resultados serão explorados no futuro). Sua definição é de fundamental importância para a diferenciação dos diferentes conjuntos cerâmicos; e, também, não serão especificados os motivos gerados a partir das técnicas plásticas (MACHADO, 2005, P.282).

19. Localização do Tratamento Plástico: essa variável, também alfa-numérica, referese à variável anterior (18. Tratamento Plástico de Superfície), à localização do tratamento plástico de superfície no fragmento analisado. Possui, então, as seguintes variáveis: 1 - face interna, 2 - face externa, 3 - lábio e 4 - faces interna e externa. 
20. Tratamento Cromático de Superfície: essa variável alfa-numérica trata as cores aplicadas às superfícies das vasilhas como tratamento e não, especificamente, como decoração; ou seja, não determina a função delas. Contempla os tratamentos que fazem uso da pigmentação (com sobreposições cromáticas ou não); e as variáveis observáveis são bastante genéricas, constatando apenas a existência e a quantidade de cromos utilizados e diferenciando-os através da ausência ou não de sobreposição; porém, nessa categoria não abordadas questões relacionadas aos instrumentos utilizados, estrutura formal dos elementos ou os motivos cromáticos observados (adaptado de MACHADO, 2005, P.283). São as variáveis: 1- monocrômico (pintura), 2 - bicrômico (engobo+pintura / pintura +pintura /engobo+engobo), 3 - policrômico (engobo +pintura +pintura / 3 pinturas), 4 - engobo vermelho, 5 - engobo branco, 6- enegrecimento e/ou brunidura e 7-resina (Idem, P.283). Importante destacar que as variáveis resina e enegrecimento estão neste atributo devido a sua ação de modificar cromaticamente o resultado final das vasilhas. A resina especificamente é bastante difícil de ser identificada (uma vez que é orgânica e sofre decomposição muito rápida em relação à vasilha) e também não há demais trabalhos arqueológicos Guarani que apontem seu uso. A única referência etnográfica ao uso de resina na cerâmica está apontada por La Salvia e Brochado (LA SALVIA \& BROCHADO, 1989, P.98) que retomam Fernão de Cardim (1925) e Gastão de Cruls $(1945,1958)$ para enfatizar o uso da Itaicica como tal. No entanto, foi observado ao longo das análises e discussões no LEIA/UFSC, uma forma de tratamento com aspecto craquelado e que modifica a coloração presente em poucos fragmentos de distintas coleções Guarani no litoral central. Mais estudos são necessários para caracterizar esse tratamento observado (mesmo em formas arqueométricas, que pode gerar excelentes resultados). Aqui, também, não foram trabalhados esmiuçadamente os motivos presentes nos fragmentos pintados conforme propõem La Salvia \& Brochado (Idem, 1989, P.94-110), sendo observados e descritos qualitativamente na categoria 26. Observações. Serão, assim como os corrugados e ungulados na categoria 18. Tratamento Plástico de Superfície, explorados mais a fundo em trabalho mais metodológico no futuro.

Muito importante nesse momento mencionar que esses autores também trazem a classificação de barbotina e banho, sendo barbotina um revestimento superficial de argila mais refinada e aplicado à cerâmica antes da queima; e banho sendo um revestimento superficial, delgado, proveniente de um caldo ou nata de argila 
em suspensão na água e aplicado à superfície cerâmica antes da queima.(LA SALVIA \& BROCHADO, 1989, P.p.17-18). Durante as análises, não foi possível identificá-los ou diferenciá-los, nem de forma macroscópica, como de forma microscópica por enquanto.

21. Localização do Tratamento Cromático: essa variável, também alfa-numérica, refere-se à variável anterior (18. Tratamento Cromático de Superfície), à localização do tratamento cromático de superfície no fragmento analisado. Possui, então, as seguintes variáveis: 1 - face interna, 2 - face externa, 3 - lábio e 4 - faces interna e externa.

22. Cor da Pasta: essa variável alfa-numérica evidencia a cor da pasta, ou seja, não da argila (uma vez que esta se trata da matéria-prima utilizada para a fabricação da vasilha completa que não existe mais) mas do produto da fabricação e utilização da vasilha incompleta (em fragmentos) que sofreu ações pós-deposicionais até o momento de sua retirada do depósito arqueológico e ainda sofre com os mesmos mecanismos mesmo estando em instituição de salvaguarda. Está associada às demais variáveis de determinação de ambiente de queima, como a Configuração do Núcleo e as Colorações das Faces Externas e Internas. Essa variável foi observada visualmente e sem nenhum parâmetro específico como o Código Munsell, ou seja, foi observada apenas comparando cores visualmente agrupáveis nas coleções e foram denominadas de forma bastante simples. Foram encontradas cinco cores: 1 - branca, 2 - laranja A, 3 - laranja B (avermelhado), 4 - laranja C (tom de marrom) e 5 - cinza/preta. Assim, essas cores foram relacionadas às colorações das faces externa e interna observáveis com o parâmetro do Código Munsell e se apresentam da seguinte maneira:

- Pasta branca: 7.5YR 5/1 gray, 7.5YR 6/1 gray, 7.5YR 6/.2 pinkish gray, 7.5YR 6/3 light brown, 7.5YR 6/6 reddish yellow, 7.5YR 7/1 light gray, 7.5YR 7/2 pinkish gray, 7.5YR 7/3 pink, 7.5YR 7/4 pink, 7.5YR 8/1 white, 7.5YR 8/2 pinkish white, 7.5YR 8/3 pink, 7.5YR 6/1 pink.

- Pasta laranja A: 2.5YR 5/5 red, 5YR 5/6 yellowish red, 5YR 4/6 yellowish red, 7.5YR 4/2 brown, 7.5YR 4/3 brown, 7.5YR 4/6 strong brown, 7.5YR 5/4 brown, 7.5YR 5/6 strong brown, 7.5YR 6/4 light brown, 7.5YR 6/3 light brown, 7.5YR 6/4 light brown, 7.5YR 6/6 reddish yellow e 7.5YR 6/6 reddish yellow. 
- Pasta laranja B (tom avermelhado): 5YR 3/3 dark reddish brown, 7.5YR 5/4 brown, 5YR 4/6 yellowish red, 5YR 5/6 yellowish red, 7.5YR 4/4 brown, 7.5YR 4/6 strong brown, 5YR 4/4 reddish brown, 7.5YR 5/8 yellowish red.

- Pasta laranja C (tom de marrom): 10YR 7/2 light gray, 10YR 7/3 pale yellow, 10YR 7/4 pale yellow, 5YR 5/6 yellowish, 5YR 5/8 yellowish red, 7.5YR 2.5/1 black, 7.5YR 3/1 very dark gray, 7.5YR 4/1 dark gray, 7.5YR 4/2 brown, 7.5YR 4/3 brown, 7.5YR 5/4 brown, 7.5YR 6/3 light brown, 7.5YR 6/4 light brown, 7.5YR 7/3 pink, 7.5YR 3/2 dark brown, 7.5YR 3/3 dark brown, 7.5YR 5/6 strong brown, 7.5YR 6/2 pink, 7.5YR 6/6 reddish yellow, 7.5YR 5/3 brown, 7.5YR 4/4 brown, 7.5YR 4/6 strong brown, 7.5YR 5/3 brown, 7.5YR 3/4 dark brown e 7.5YR 5/2 brown.

- Pasta cinza/preta: 7.5YR 3/1 very dark gray, 7.5YR 5/1 gray e 7.5YR 4/1 dark gray.

23. Marca de Uso: variável alfa-numérica que visa lidar com etapas do ciclo de vida do artefato cerâmico após o término do seu processo de manufatura (MACHADO, 2005, P.283), e são elas: 1 - fuligem, 2 - reciclagem, 3 - desgaste acentuado e 4 fermentação. Uma vez que o propósito dessa pesquisa é o processo de manufatura dos artefatos, não foi feita uma análise mais aprofundada com relação a esse atributo, tampouco com relação à tafonomia apresentada nos materiais, temas para os quais há muito interesse e são muito importantes para compor o cenário de análise (será desenvolvido em próxima etapa de trabalho).

24. Atribuição Etnohistórica: atributo que se relaciona diretamente com as categorias conhecidas para a cerâmica Guarani na obra de mesmo nome de Fernando La Salvia e José Proença Brochado (LA SALVIA \& BROCHADO, 1989) baseadas em densa pesquisa etnohistórica de verbetes e expressões em Guarani na tradução para o espanhol da obra do Pe. Antonio Ruiz de Montoya, Vocabulario y Tesoro de la Lengua Guarani Español, Nueva Edición, Viena - Paris, 1876. Ou seja, tratam de características observáveis, segundo os próprio autores. Esse atributo visa registrar segundo categorias etnohistóricas listadas os materiais analisados reconhecidos enquanto pertencentes dessas categorias etnohistóricas e, assim, avançar na interpretação dos mesmos. Especialmente aqui se pode falar em identificar fragmentos cerâmicos provenientes de panelas (yapepó), talhas (cambuchí), pratos (ñae) e outros (LA SALVIA \& BROCHADO, 1989, P.p.125-146). No entanto, o material proveniente especialmente da 
coleção TRV se apresentou demasiadamente fragmentado, limitando o grau de confiabilidade de projeções e, para tal identificação prefere-se a utilização de bordas e bases (mais diagnósticas das formas conhecidas na obra para a cerâmica Guarani). Ainda, nesta etapa de pesquisa, optou-se por não inferir projeções de vasilhas a partir dos fragmentos de bordas mesmo baseado nessa obra de La Salvia e Brochado e, por consequência, os dados produzidos para esse atributos não foram discutidos nesta pesquisa. Um novo estudo em próxima etapa de pesquisa deve tomar esse fôlego com maior cautela e reflexão e à luz de mais considerações deve tomar esse desafio.

25. Conjunto atribuído: variável alfa-numérica que registra

“(...) o resultado qualitativo da somatória das observações realizados no decorrer da acima descrita. A partir da conjunção dessas observações de atributos tecnológicos com os guias de referência da cerâmica da região foram definidos alguns conjuntos cerâmicos(...) a princípio de forma qualitativa, mas posteriormente revistos de maneira quantitativa." (MACHADO, 2005, P.283).

26. Observações: esse último atributo da ficha de análise trata praticamente de uma descrição qualitativa dos aspectos que não foram contemplados na ficha e que, porventura foram vislumbrados no material, assim como trata de todas as informações dos demais campos abordados de forma a repeti-los e enfatizá-los (auxiliando nas análises). Nesse campo também foi possível descrever os tratamentos plásticos e cromáticos observados, bem como marcas específicas de vegetais na pasta (parte do processo de manufatura) e marcas de material orgânico no interior dos fragmentos por exemplo, todas características relacionadas a compreender o processo de produção das vasilhas. 
14. ANEXO 06

CATÁlOGO DO MATERIAL CERÂMICO

ESPELHAMENTO DAS BORDAS E FOTOGRAFIA DAS BASES TRAVESSÃO DO RIO VERMELHO (TRV)

Fotos: Isabela da Silva Müller. Edição: Thiago Umberto Pereira. 
Travessão do Rio Vermelho

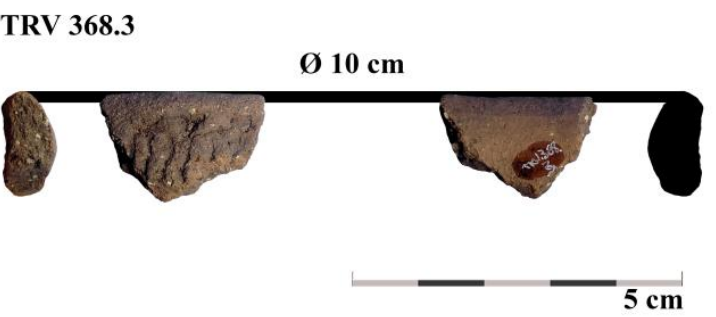

TRV 343.4

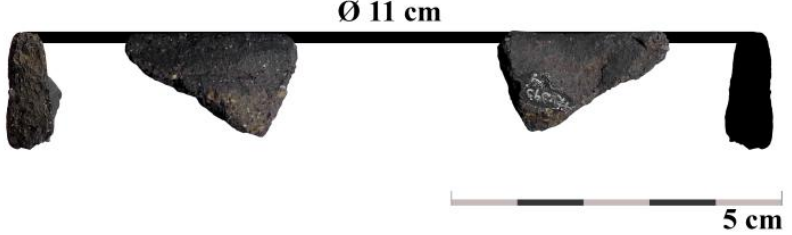

TRV 373.6

Ø $17 \mathrm{~cm}$

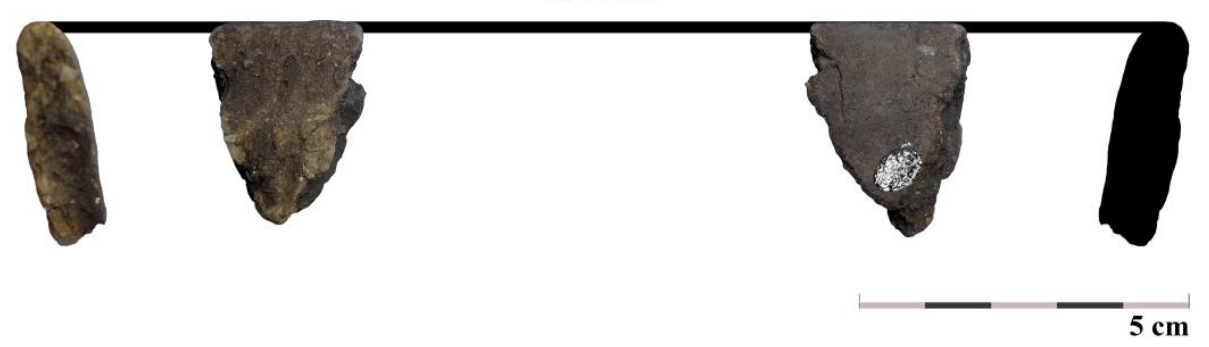

TRV 368.2

Ø $20 \mathrm{~cm}$

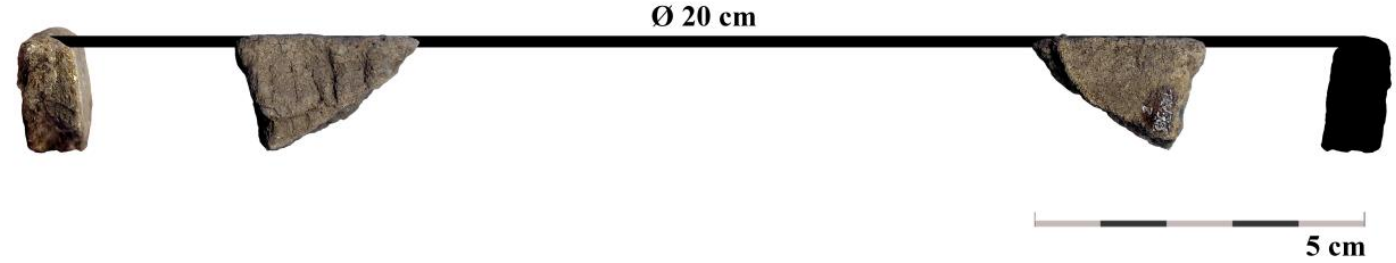

Fotos: Isabela da Silva Müller Edição: Thiago Umberto Pereira 
TRV 344.1

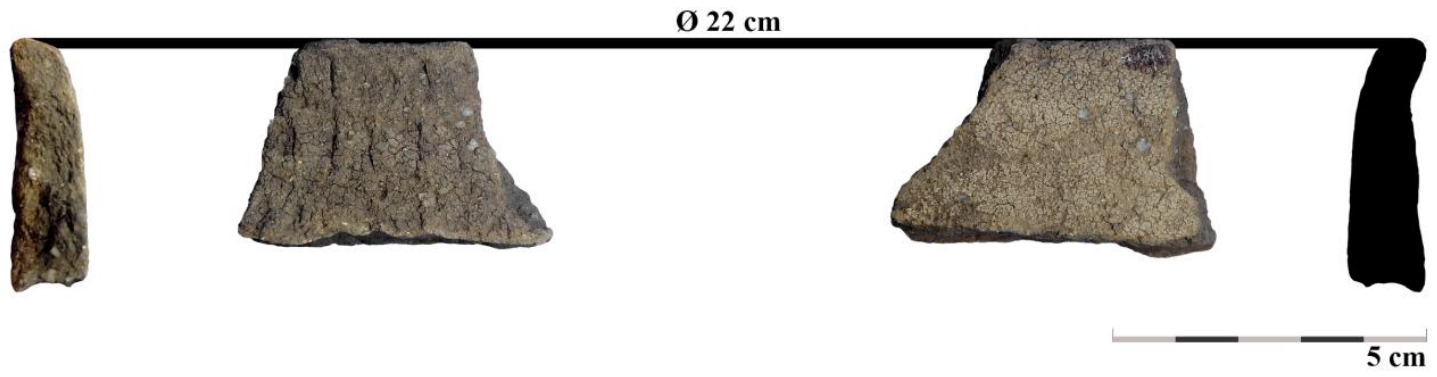

TRV 339.7

Ø $22 \mathrm{~cm}$

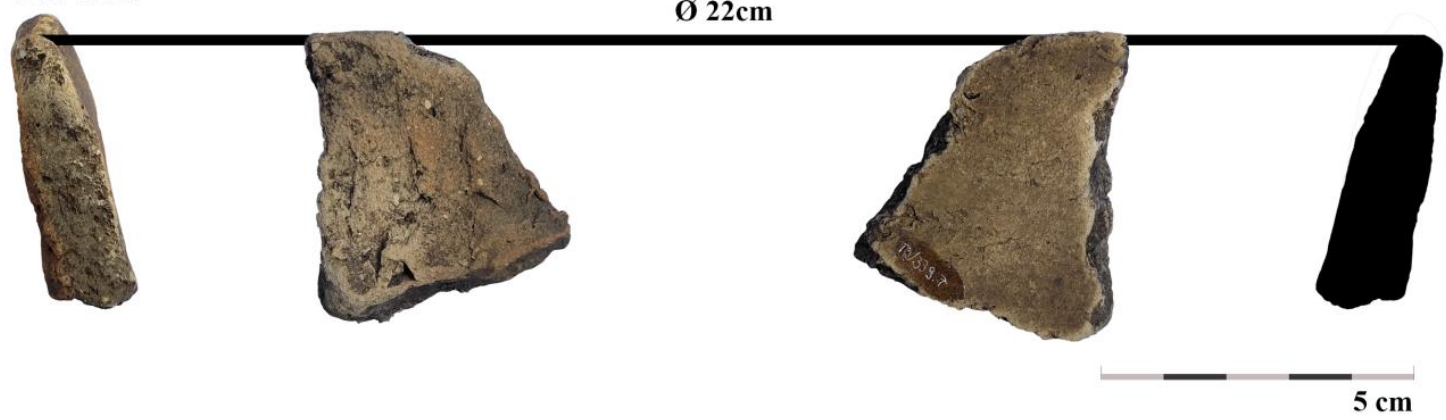

TRV 367.26

Ø $24 \mathrm{~cm}$

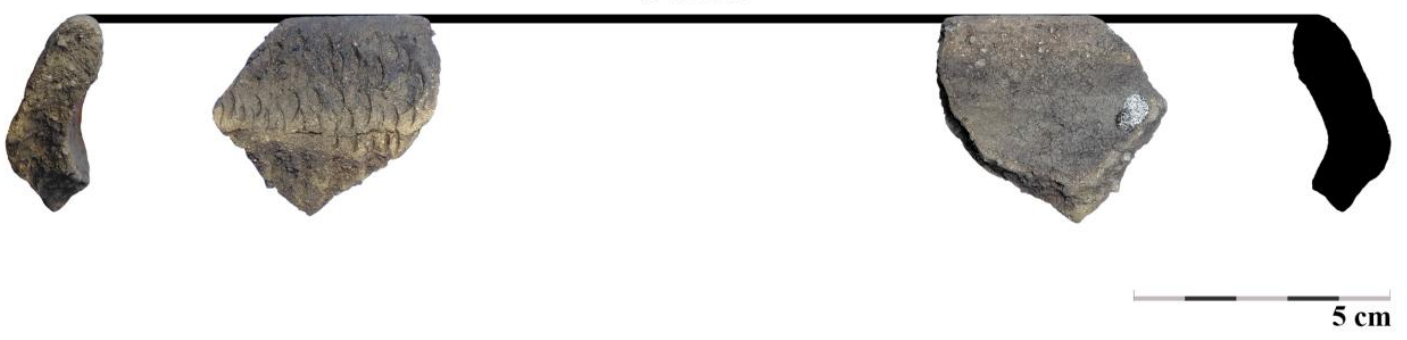

TRV367.18

Ø $30 \mathrm{~cm}$

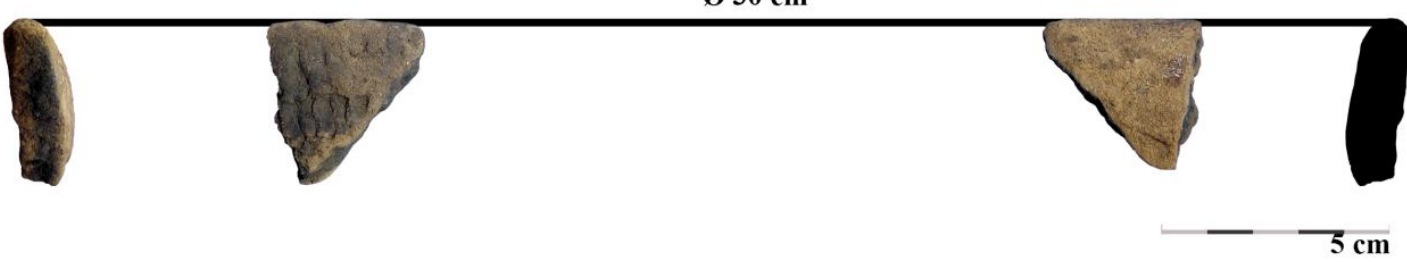

Fotos: Isabela da Silva Müller Edição: Thiago Umberto Pereira 
TRV367.13

Ø $30 \mathrm{~cm}$

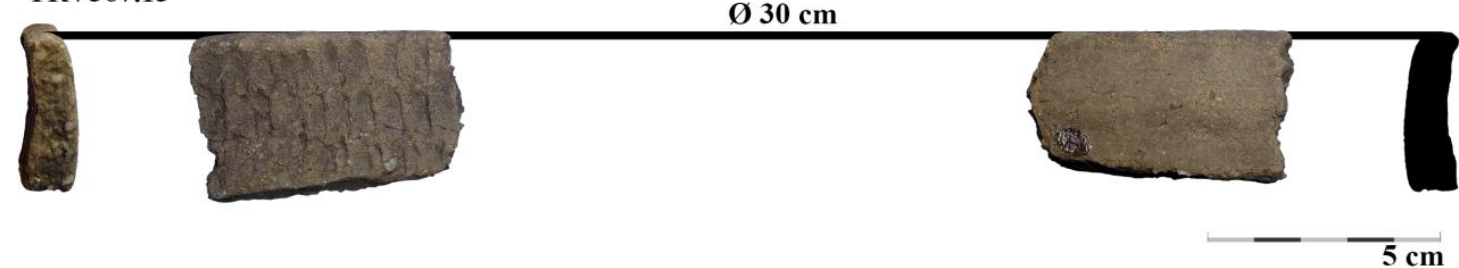

TRV 414.1

Ø $34 \mathrm{~cm}$

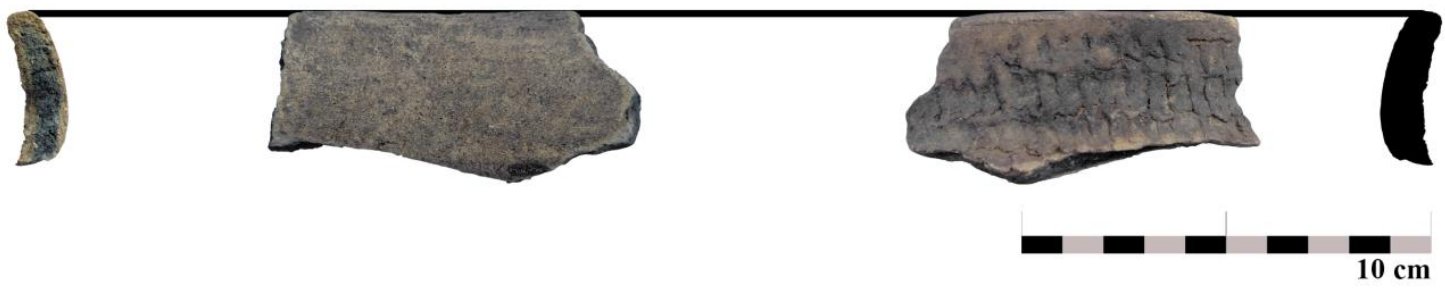

TRV 1084.1 e TRV 1084.2

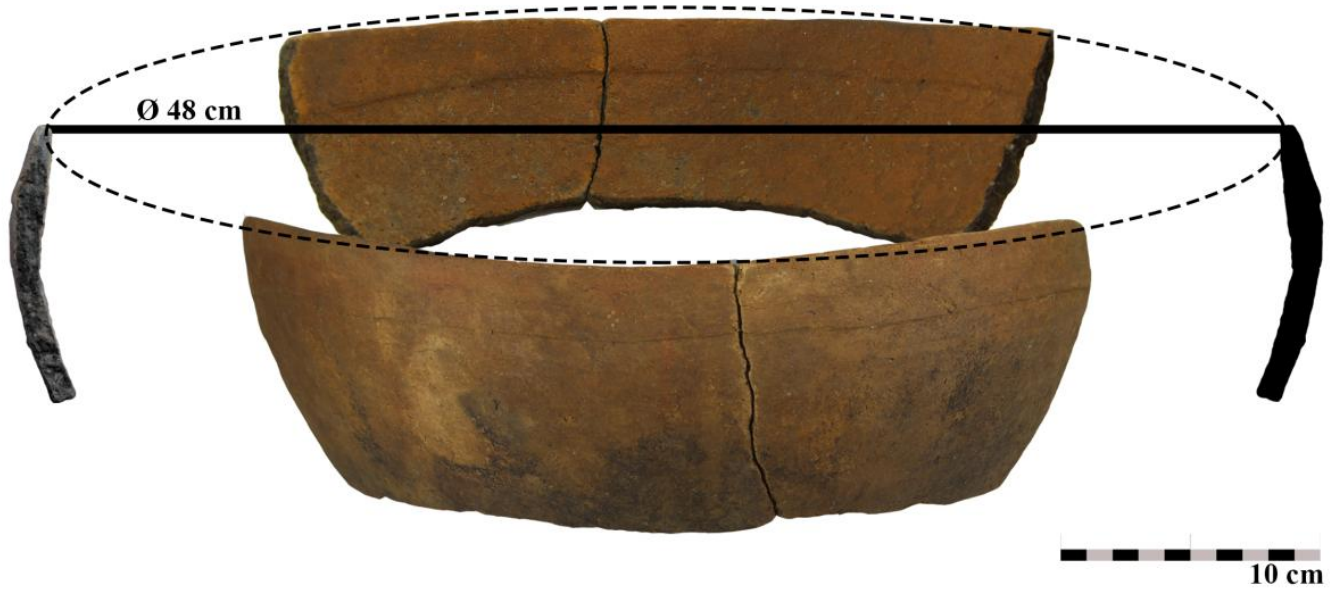

TRV 367.30
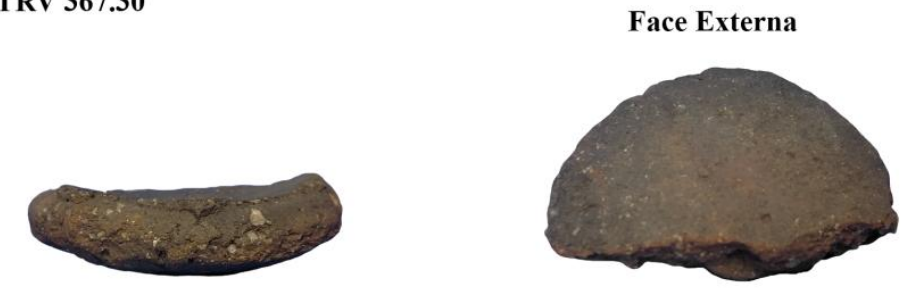

Face Interna
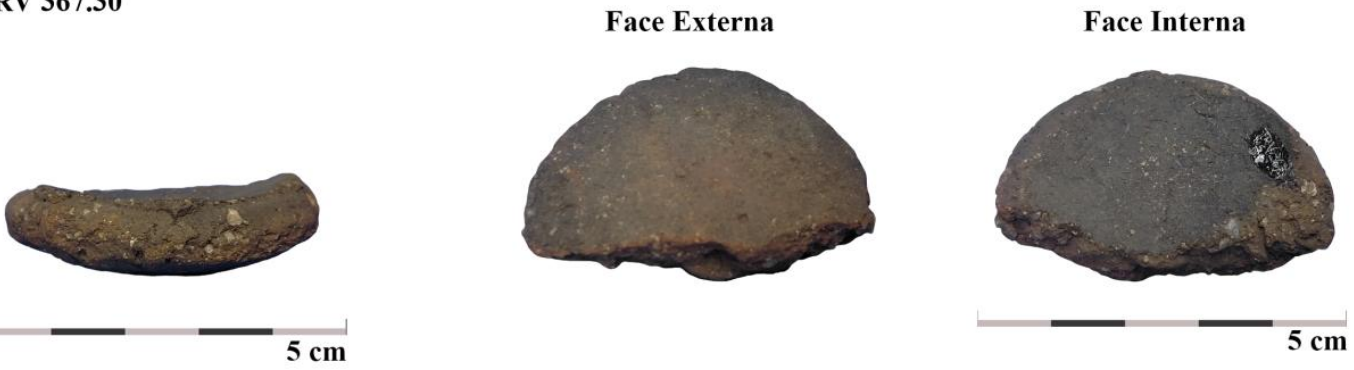

Fotos: Isabela da Silva Müller Edição: Thiago Umberto Pereira 
ESPELHAMENTO DAS BORDAS E FOTOGRAFIA DAS BASES - LAGOINHA DO RIO TAVARES (RT)

Fotos: Isabela da Silva Müller. Edição: Thiago Umberto Pereira. 
Lagoinha do Rio Tavares I

RT I 1.64.037

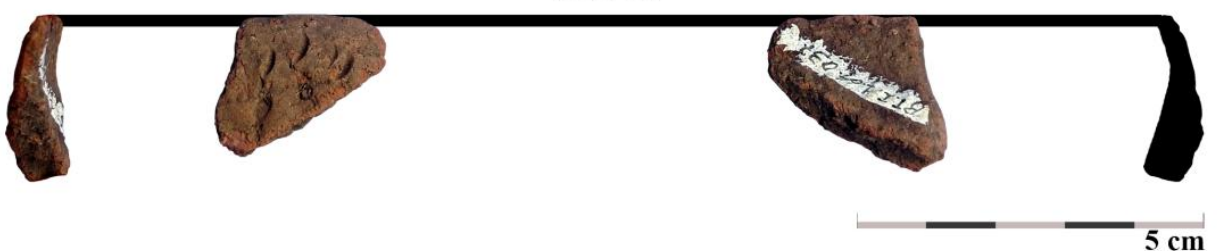

RT.I.1.64.092

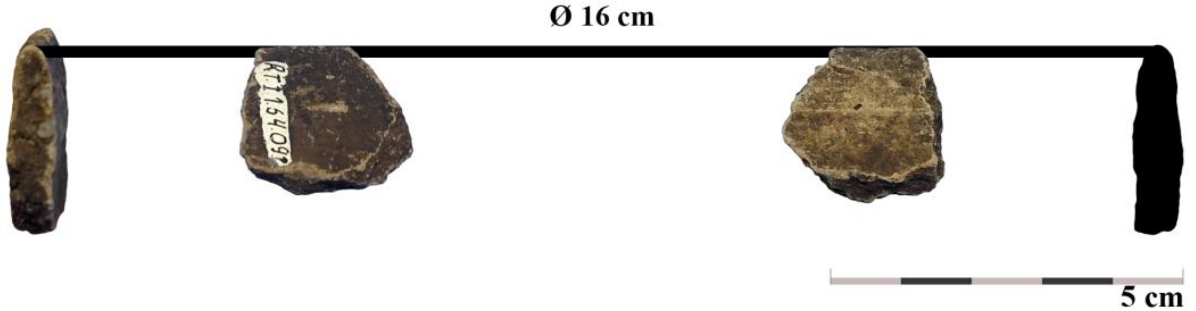

RT.I.1.64.130

Ø $16 \mathrm{~cm}$

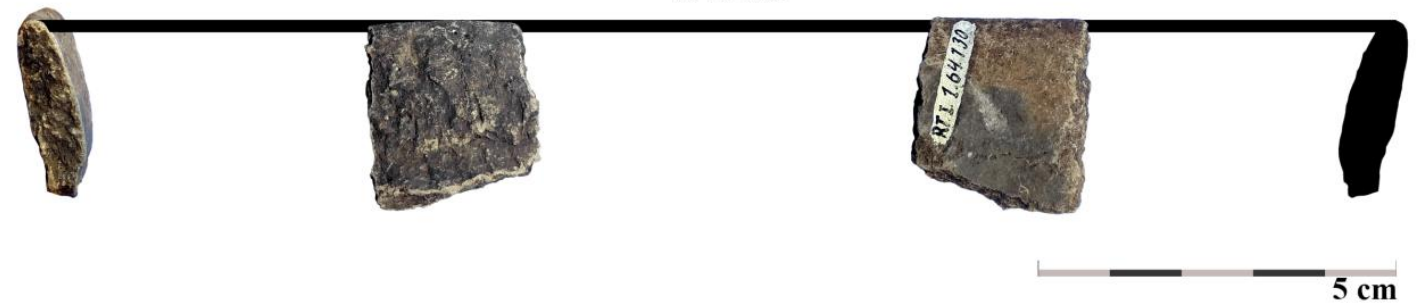

RT.I.1.64.047

Ø $20 \mathrm{~cm}$

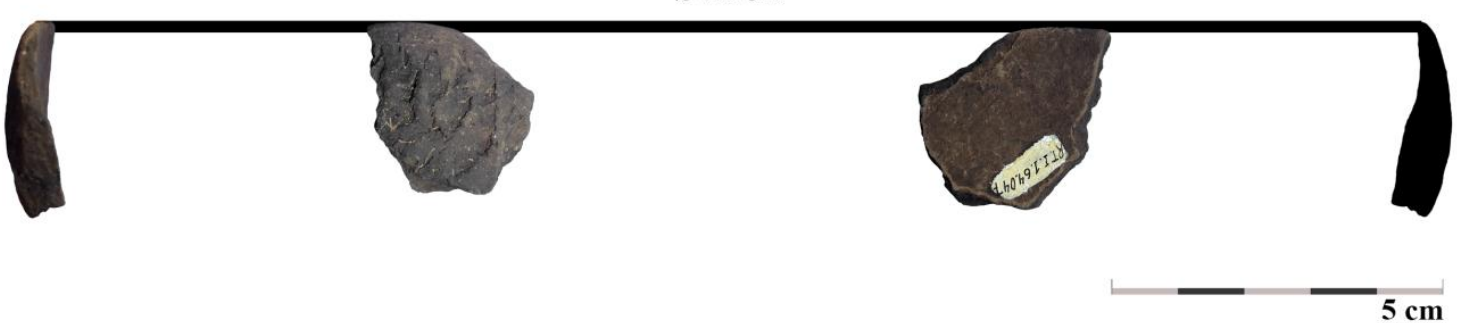

Fotos: Isabela da Silva Müller Edição: Thiago Umberto Pereira 
RT I 1.64.019

Ø $20 \mathrm{~cm}$

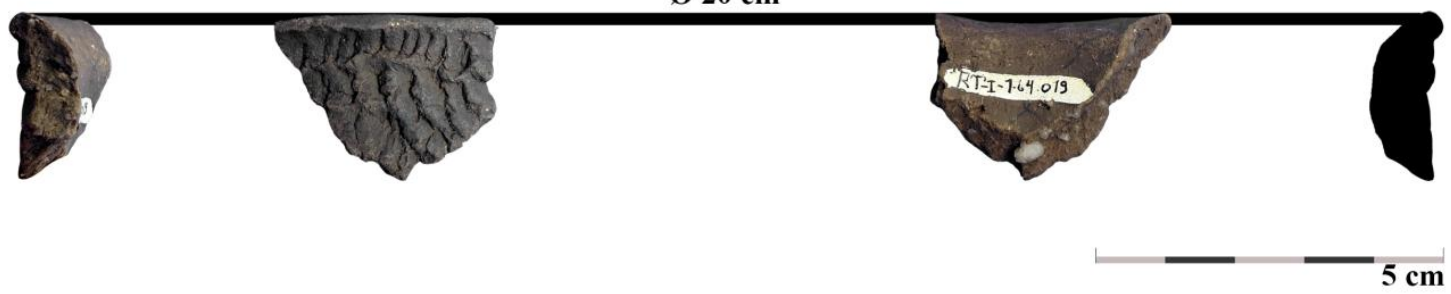

RT.I.1.64.141

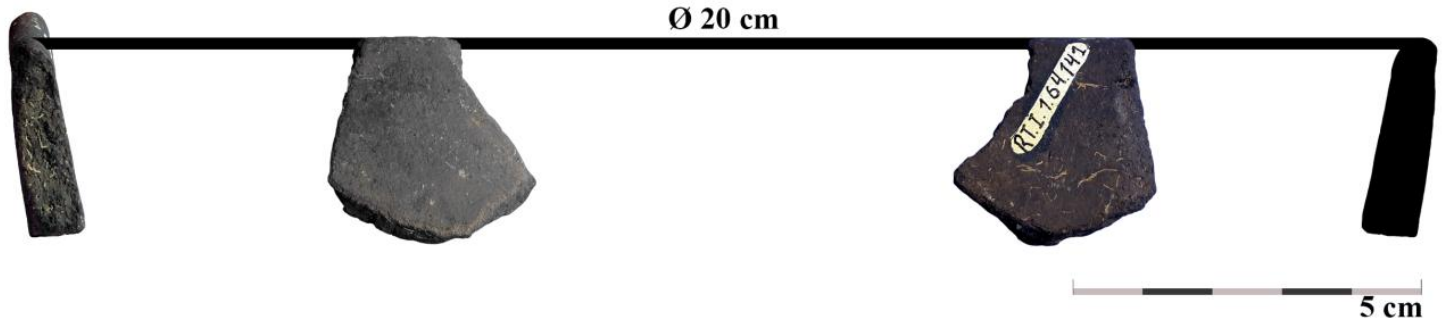

RT.I.1.64.109

Ø $20 \mathrm{~cm}$

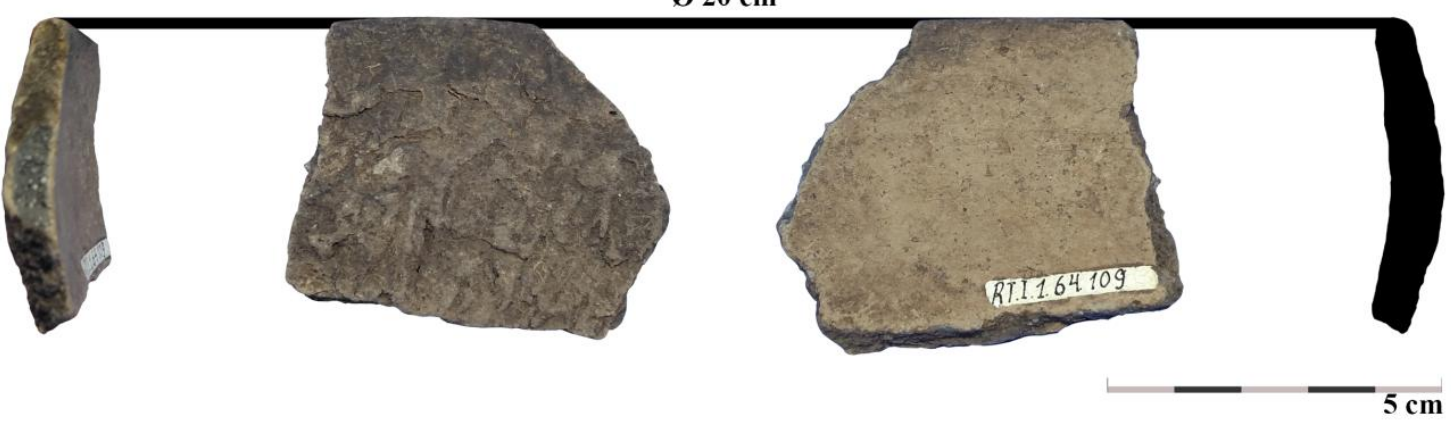

RT.I.1.64.116

$\varnothing 20 \mathrm{~cm}$

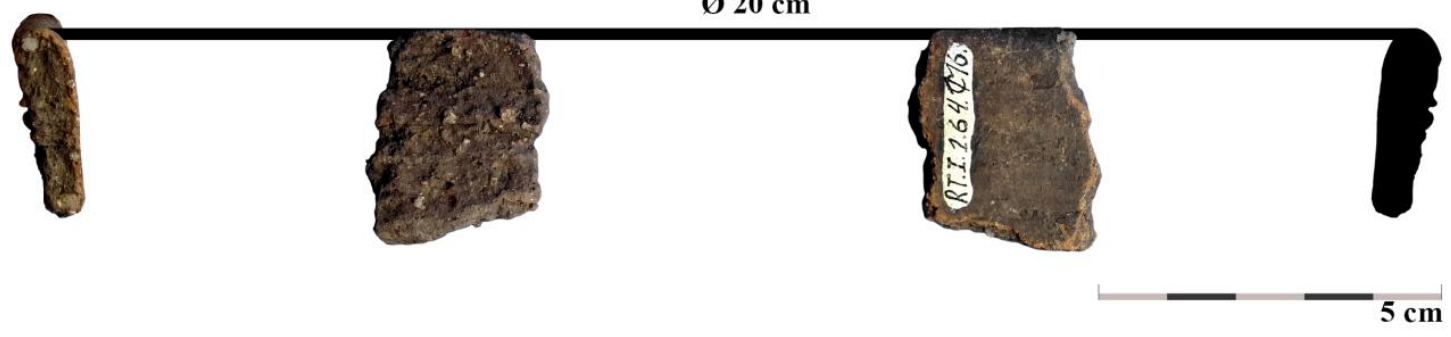

Fotos: Isabela da Silva Müller Edição: Thiago Umberto Pereira 
RT.I.1.64.020

$\varnothing 20 \mathrm{~cm}$

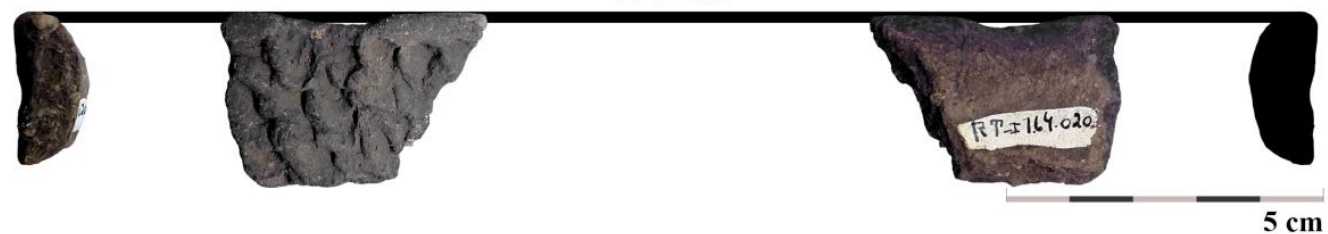

1.1 Ø $20 \mathrm{~cm}$

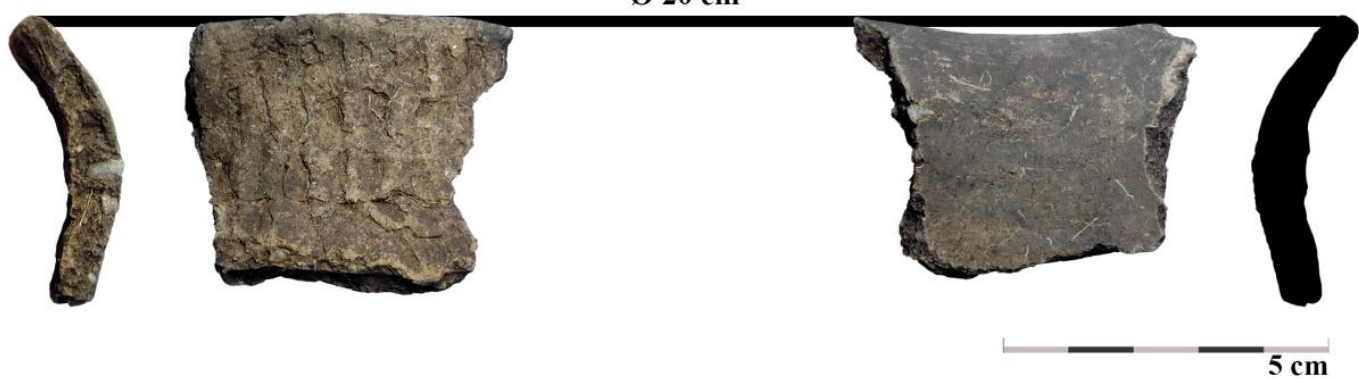

RT.I.1.64.084

Ø $22 \mathrm{~cm}$

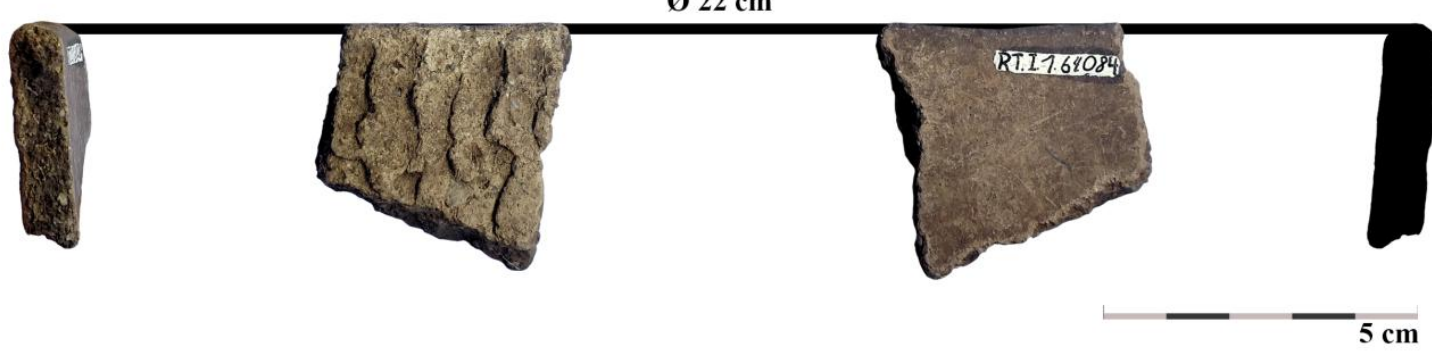

RT.I.1.64.059

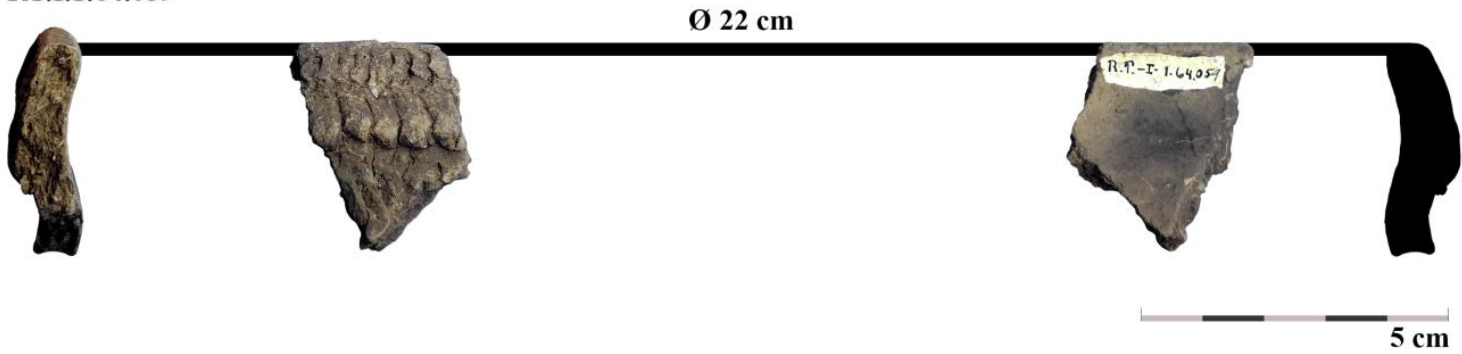

Fotos: Isabela da Silva Müller Edição: Thiago Umberto Pereira 
8.1

Ø $22 \mathrm{~cm}$

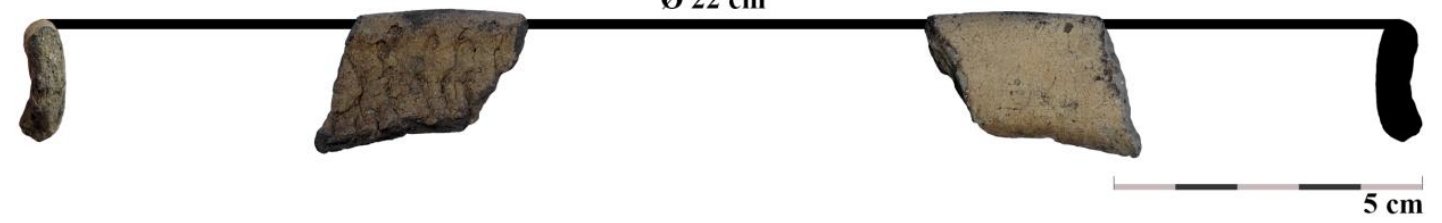

RT I 1.64.004
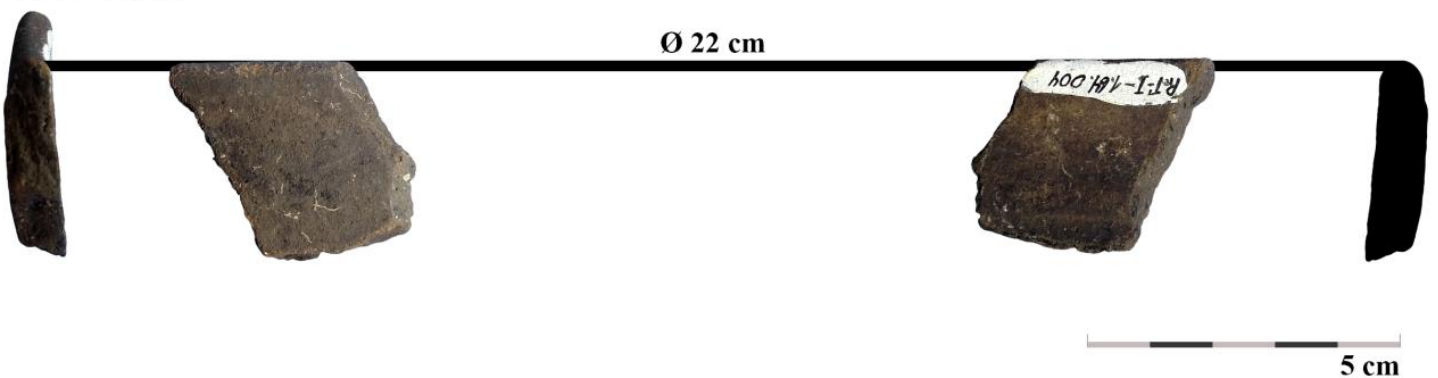

RT.I.1.64.086

Ø $22 \mathrm{~cm}$

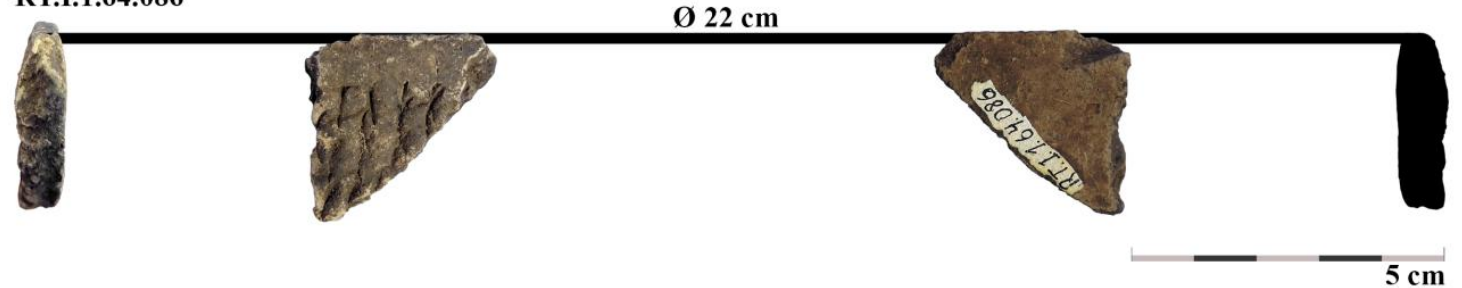

RT.I.1.64.133

Ø $26 \mathrm{~cm}$

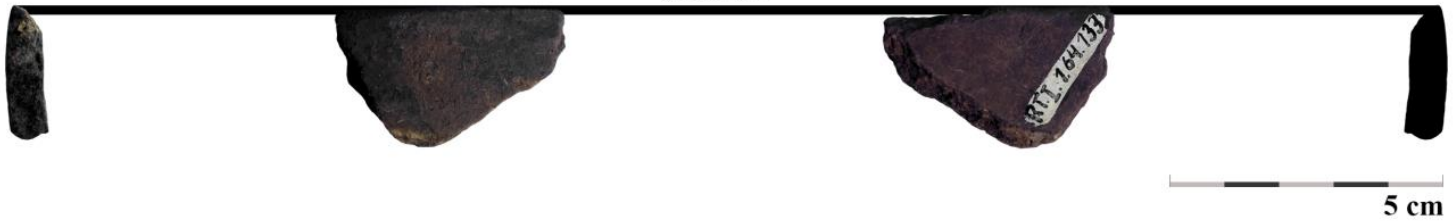

Fotos: Isabela da Silva Müller Edição: Thiago Umberto Pereira 

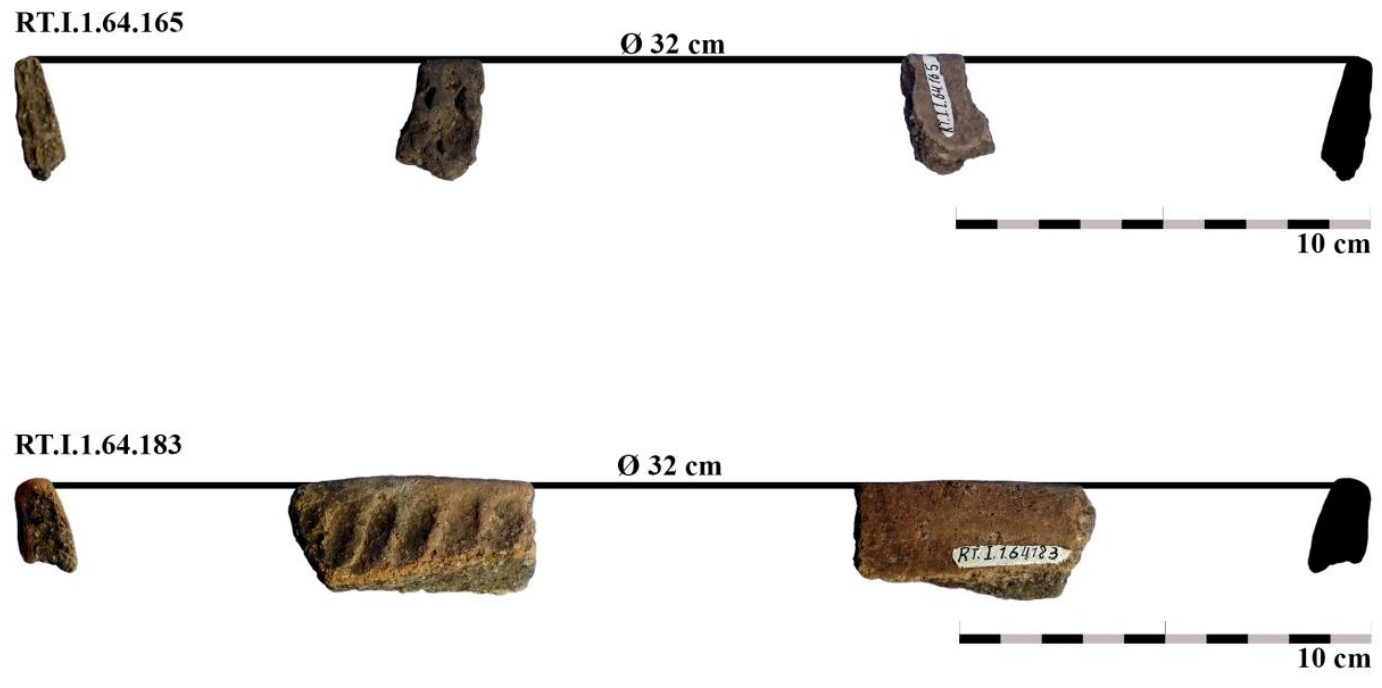

RT.I.1.64.184

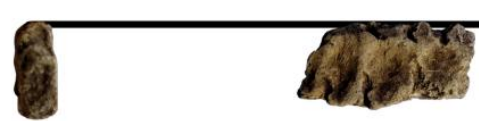

RT.I.1.64.065

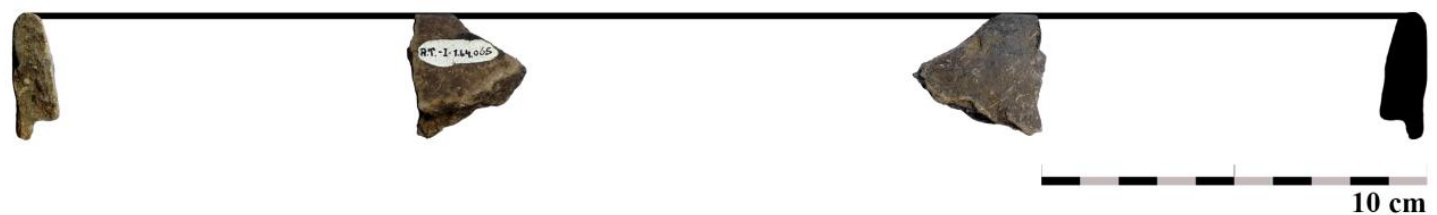

Fotos: Isabela da Silva Müller Edição: Thiago Umberto Pereira 

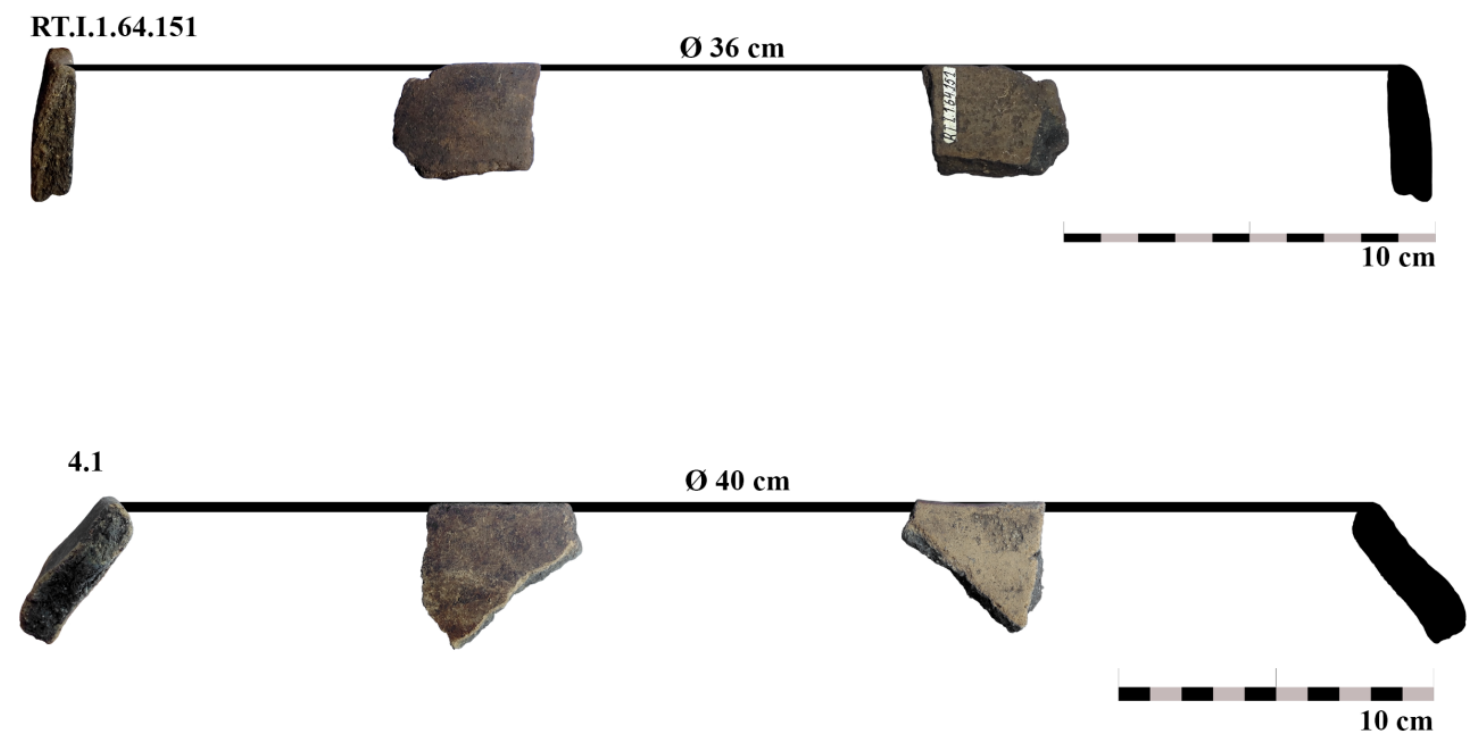

4.2

$\varnothing 40 \mathrm{~cm}$

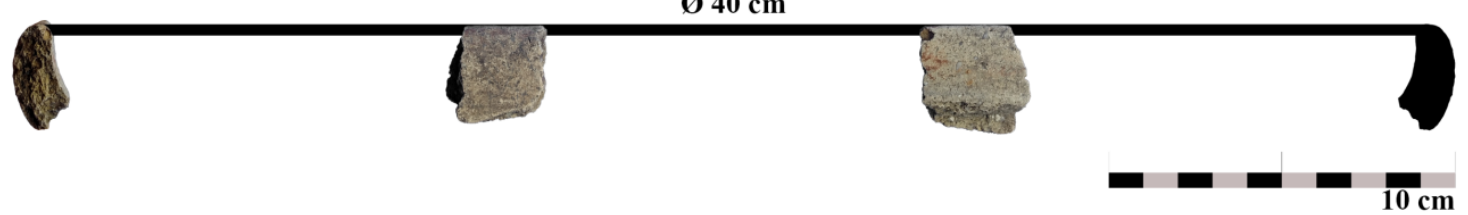

RT.I.1.64.139

Ø $40 \mathrm{~cm}$

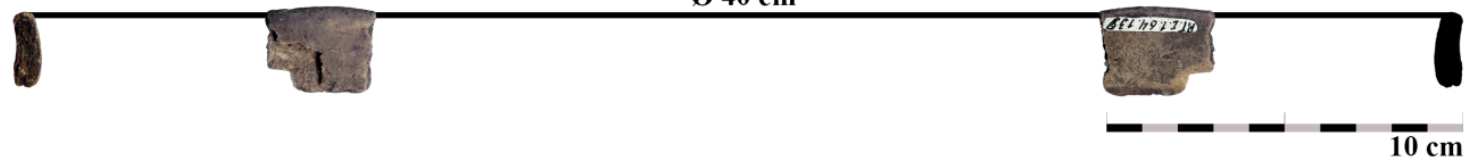

Fotos: Isabela da Silva Müller Edição: Thiago Umberto Pereira 
RT I 1.64.0010

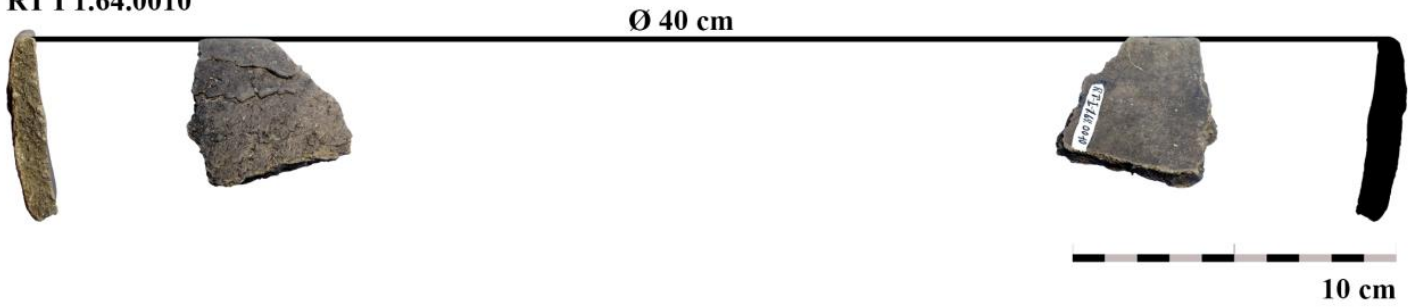

RT.I.1.64.009

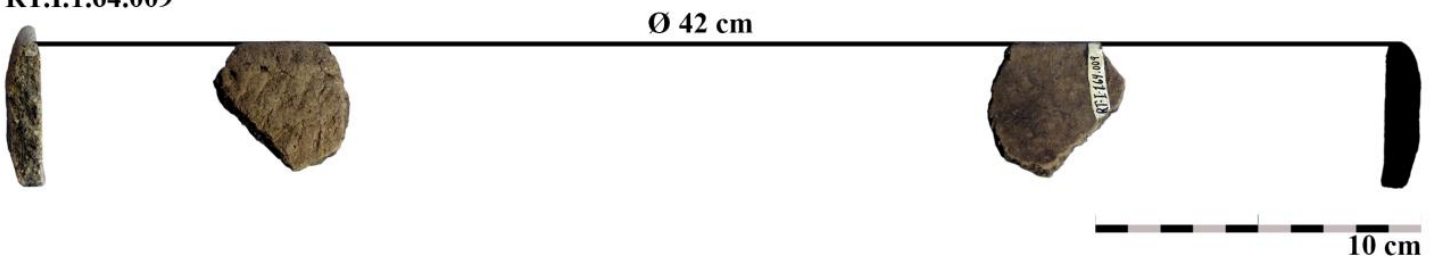

RT.I.1.64.042

Ø $42 \mathrm{~cm}$

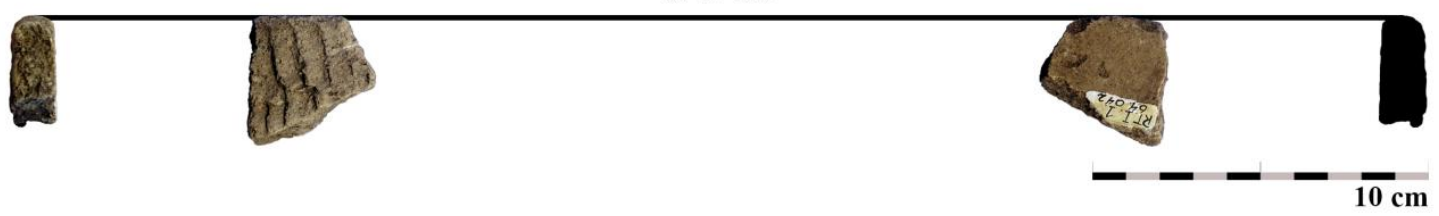

RT.I.1.64.199

$\varnothing 44 \mathrm{~cm}$

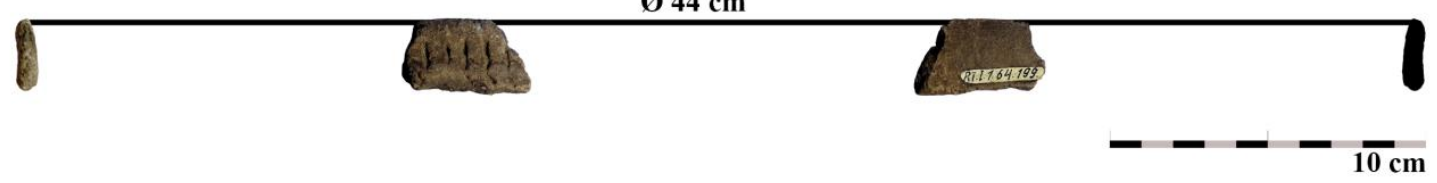

Fotos: Isabela da Silva Müller Edição: Thiago Umberto Pereira 
2.1

Ø $46 \mathrm{~cm}$
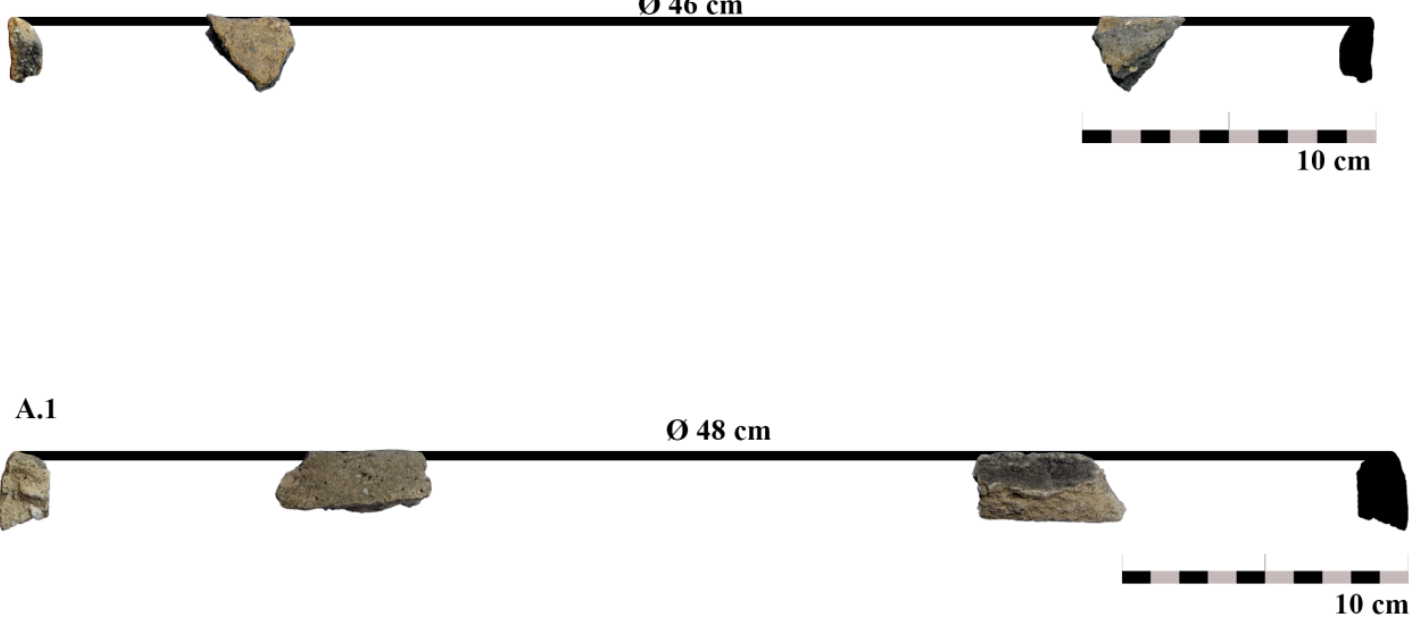

A.2

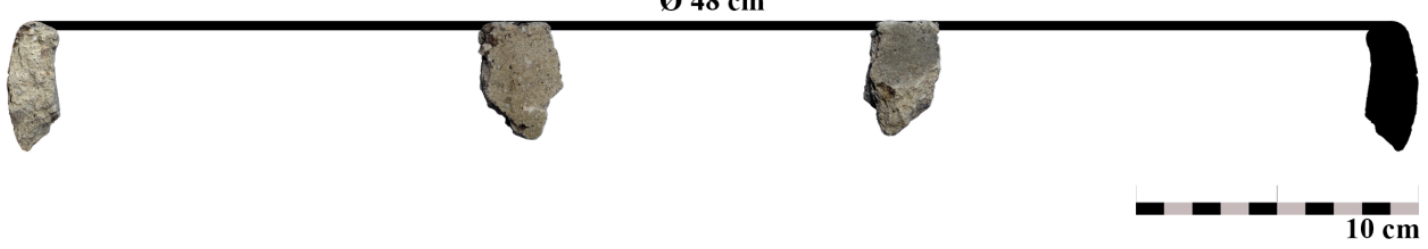

5.1

$\varnothing 50 \mathrm{~cm}$

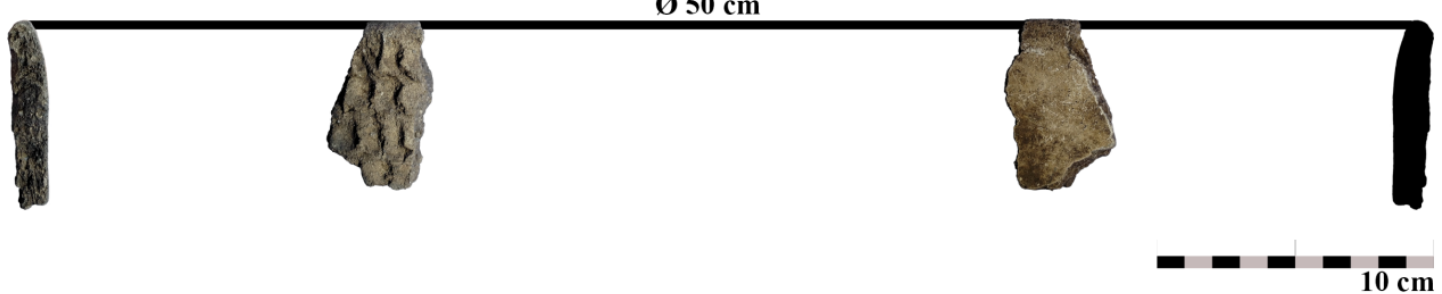

Fotos: Isabela da Silva Müller Edição: Thiago Umberto Pereira 

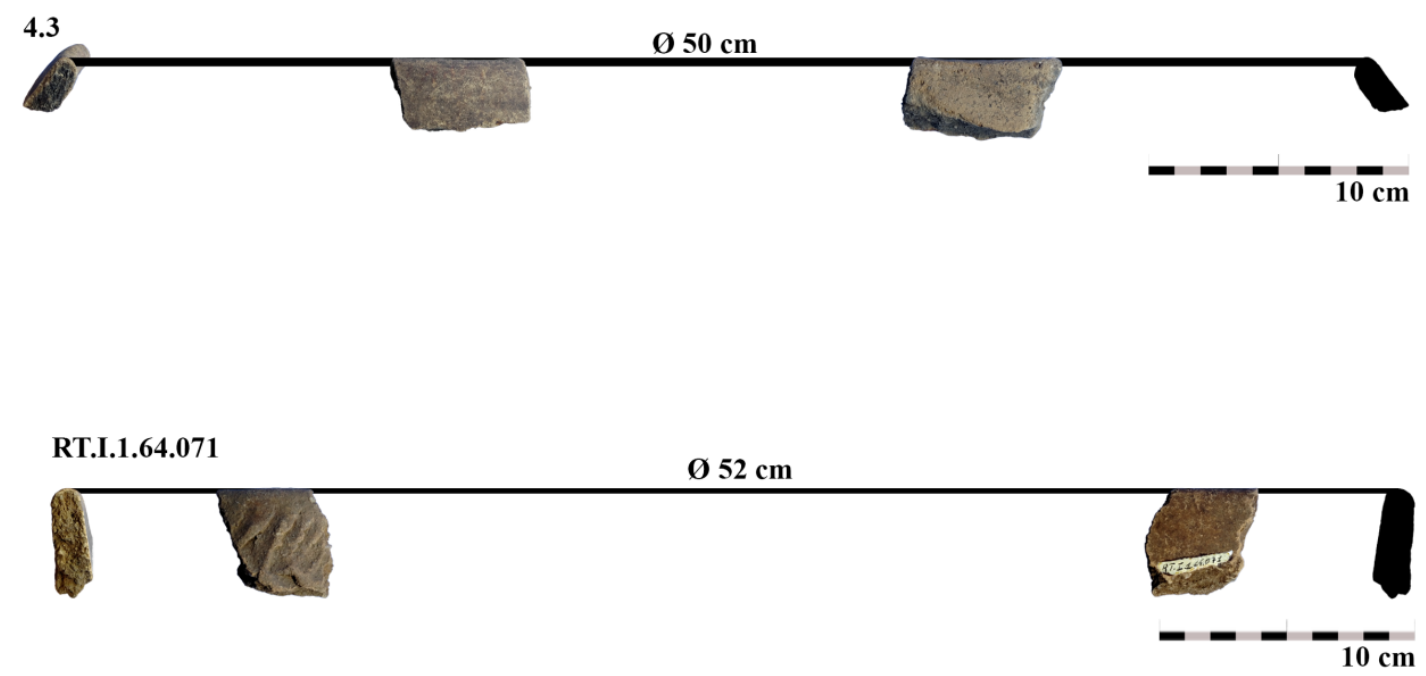

6.1

$\varnothing 52 \mathrm{~cm}$

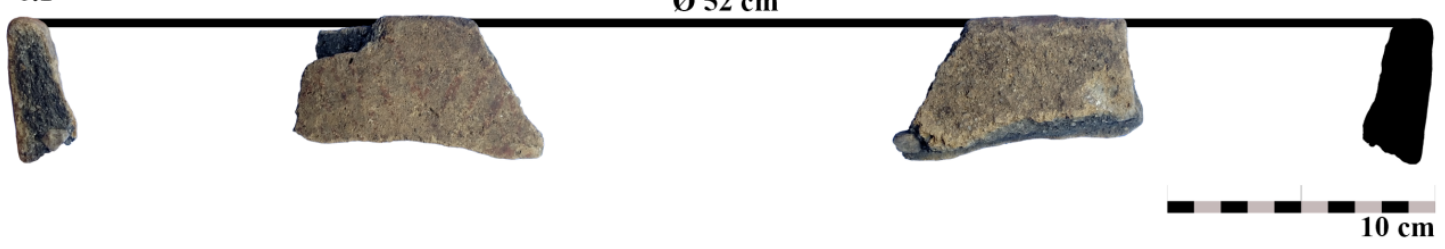

RT.I.1.64.134

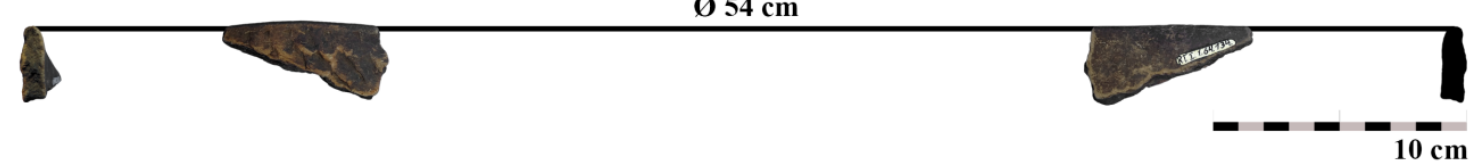

Fotos: Isabela da Silva Müller Edição: Thiago Umberto Pereira 
RT.I.1.64.232, RT.I.1.64.233 e RT.I.1.64.234

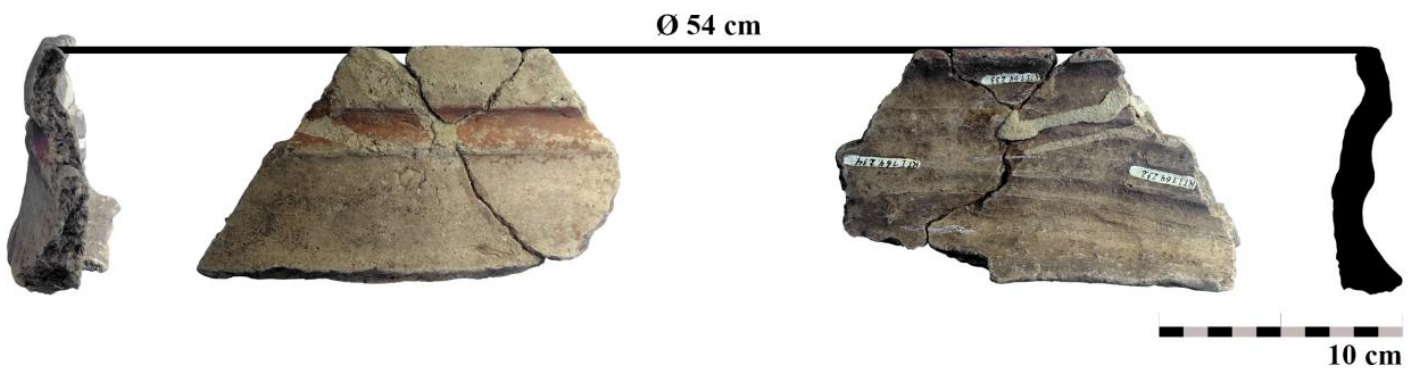

RT.I.1.64.262

$\varnothing 54 \mathrm{~cm}$

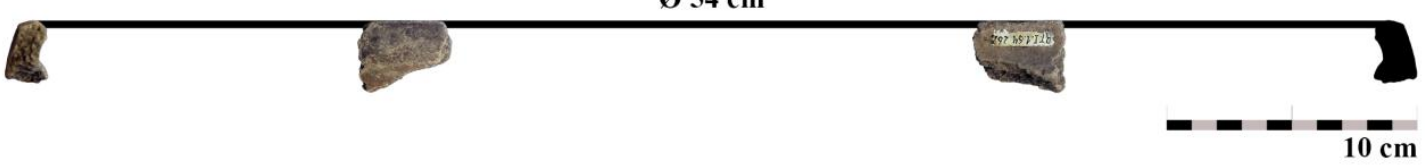

RT.I.1.64.263

Ø $54 \mathrm{~cm}$

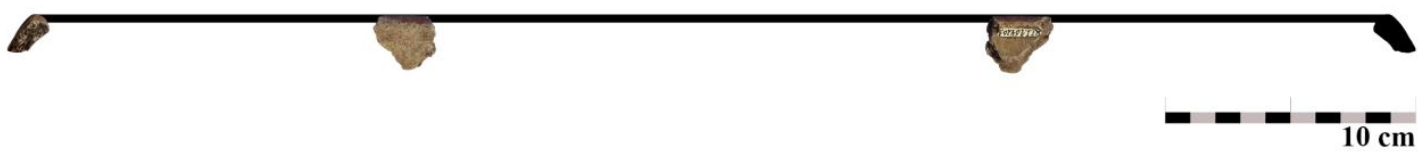

RT.I.1.64.272

$\varnothing 54 \mathrm{~cm}$

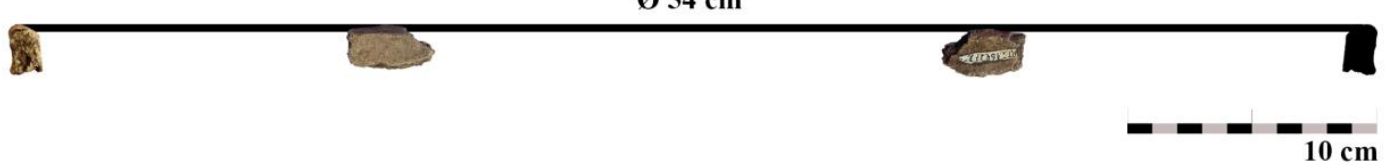

Fotos: Isabela da Silva Müller Edição: Thiago Umberto Pereira 

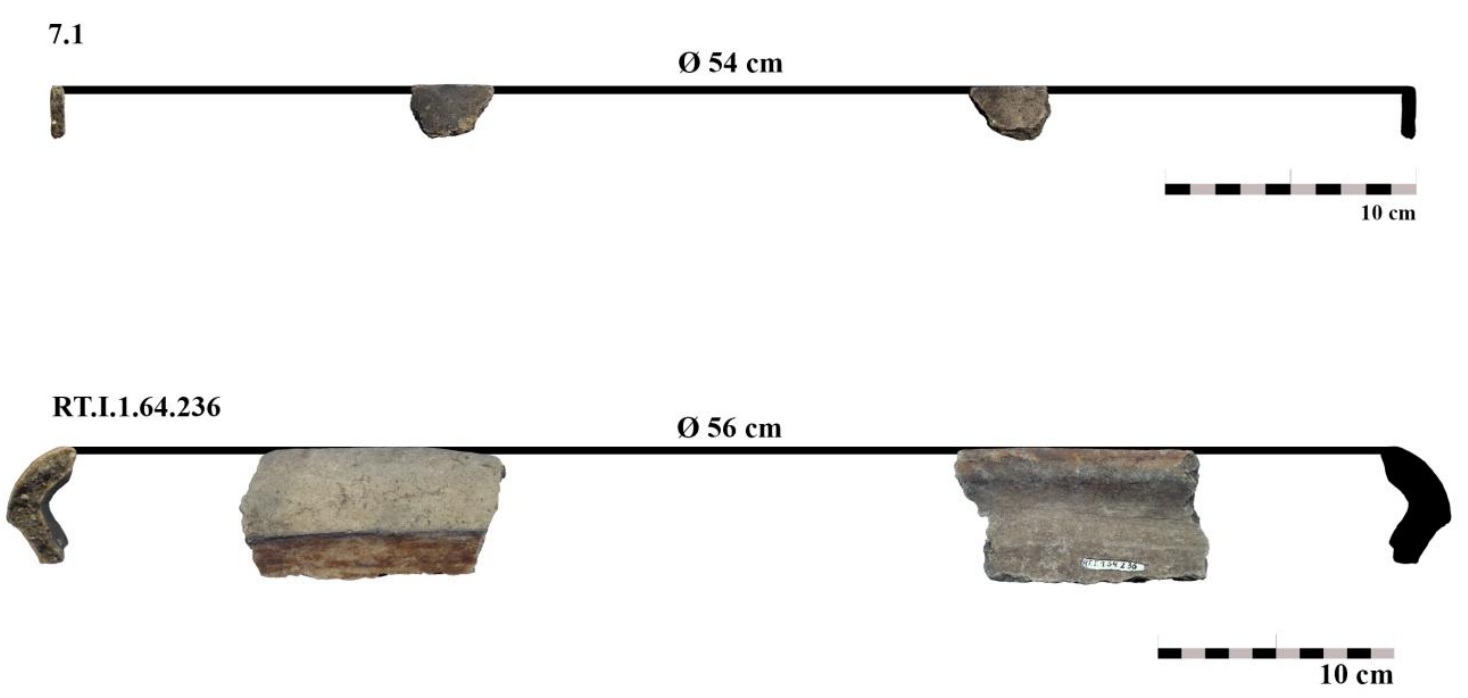

RT.I.1.64.085

$\varnothing 56 \mathrm{~cm}$

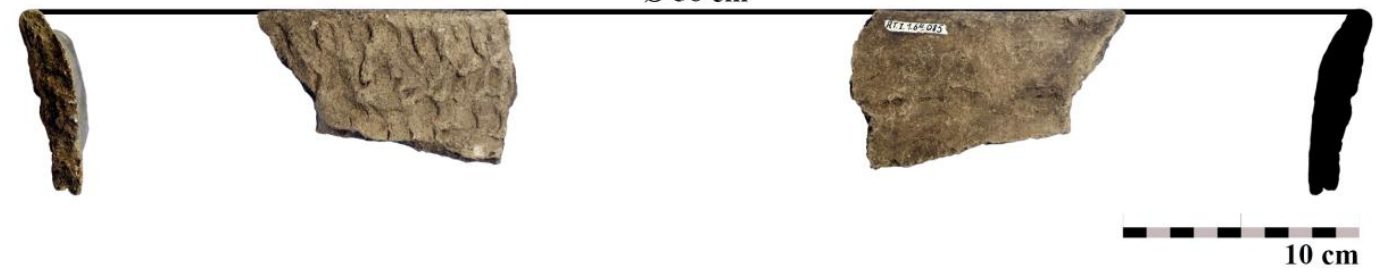

9.1

$\varnothing 56 \mathrm{~cm}$

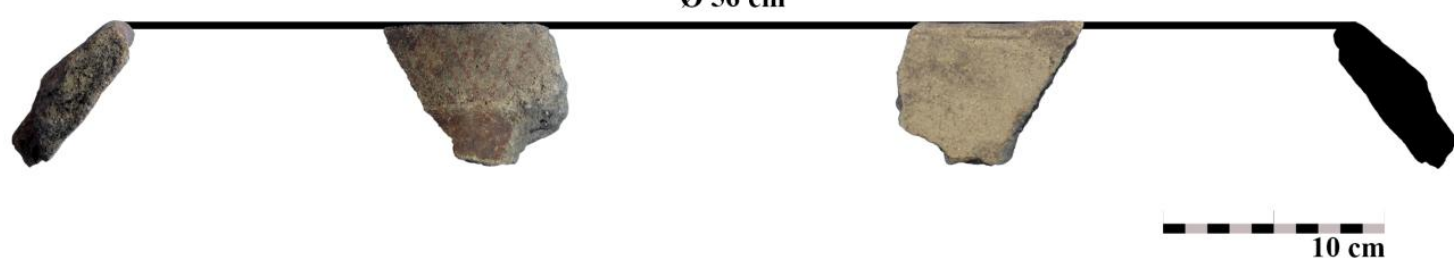

Fotos: Isabela da Silva Müller Edição: Thiago Umberto Pereira 
RT.I.1.64.104

$\varnothing 56 \mathrm{~cm}$

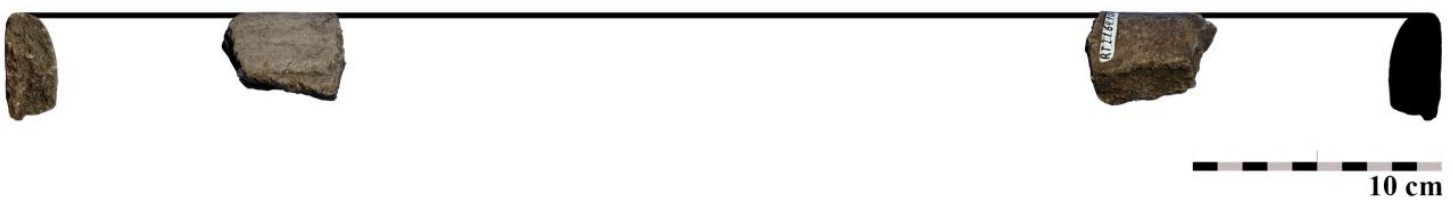

3.1 $\varnothing 56 \mathrm{~cm}$

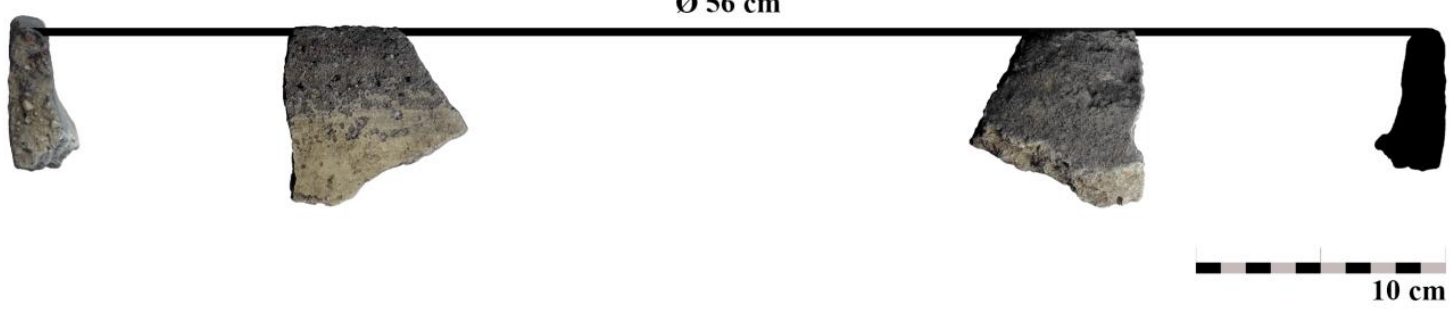

B.1

$\varnothing 56 \mathrm{~cm}$

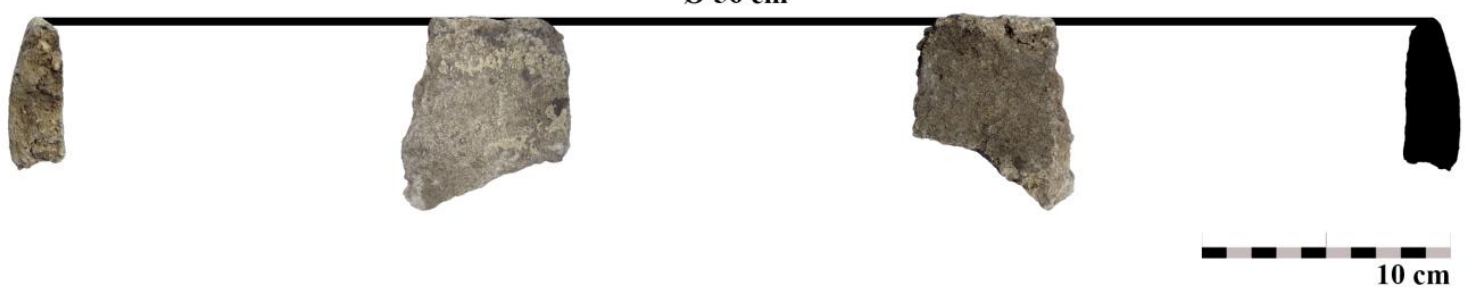

C.1

$\varnothing 56 \mathrm{~cm}$

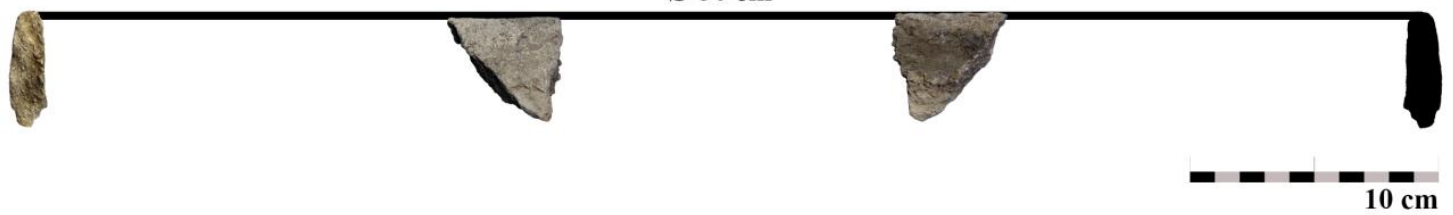

Fotos: Isabela da Silva Müller Edição: Thiago Umberto Pereira 


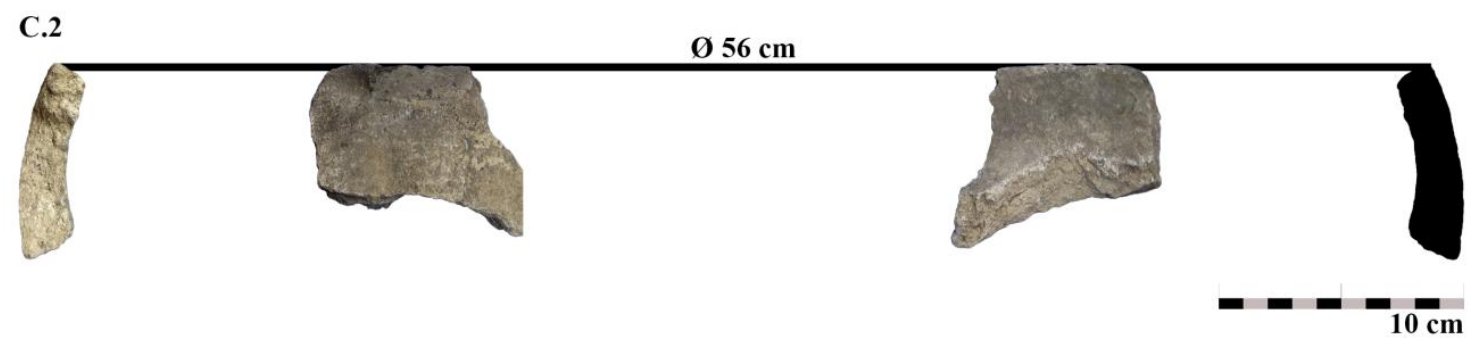

P.1

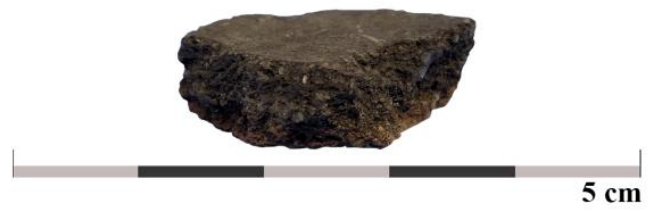

Face Externa

Face Interna
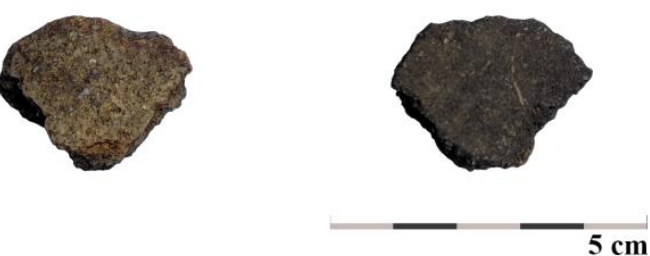

RT.I.1.64.015
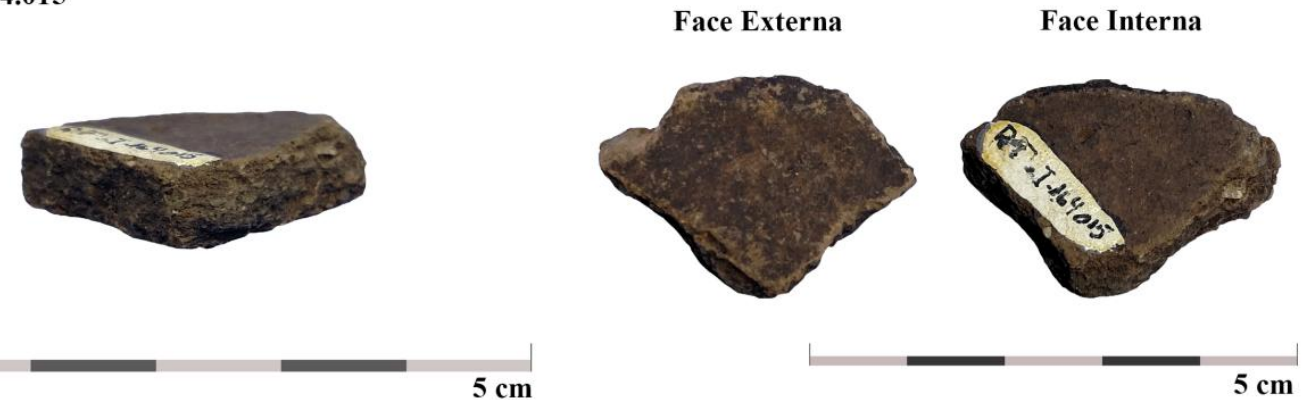

Fotos: Isabela da Silva Müller Edição: Thiago Umberto Pereira 
15. ANEXO 07

\section{CATÁlOGO DO MATERIAL CERÂMICO}

\section{AMOSTRAS ANALISADAS POR FLUORESCÊNCIA DE RAIOS-X (XRF)}

Fotos: Isabela da Silva Müller. Edição: Thiago Umberto Pereira.
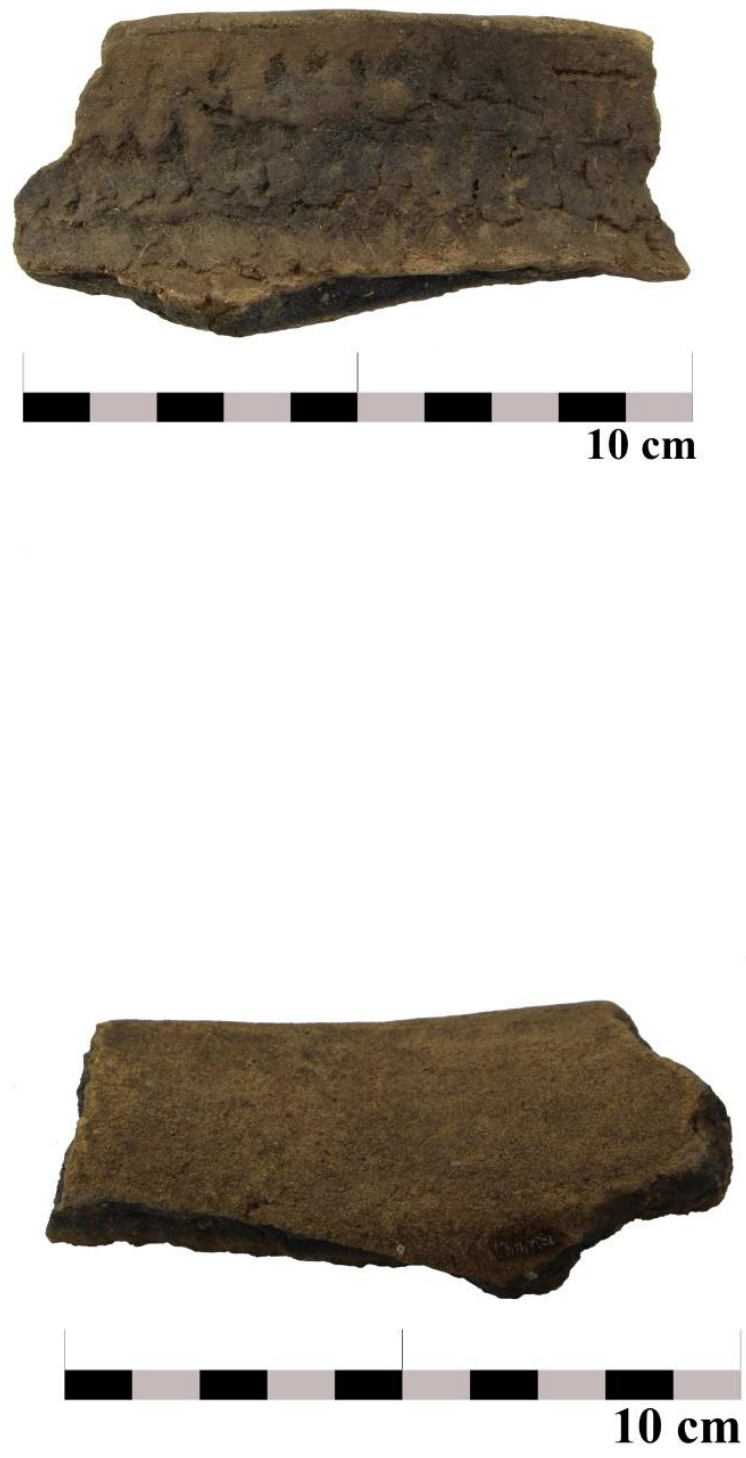

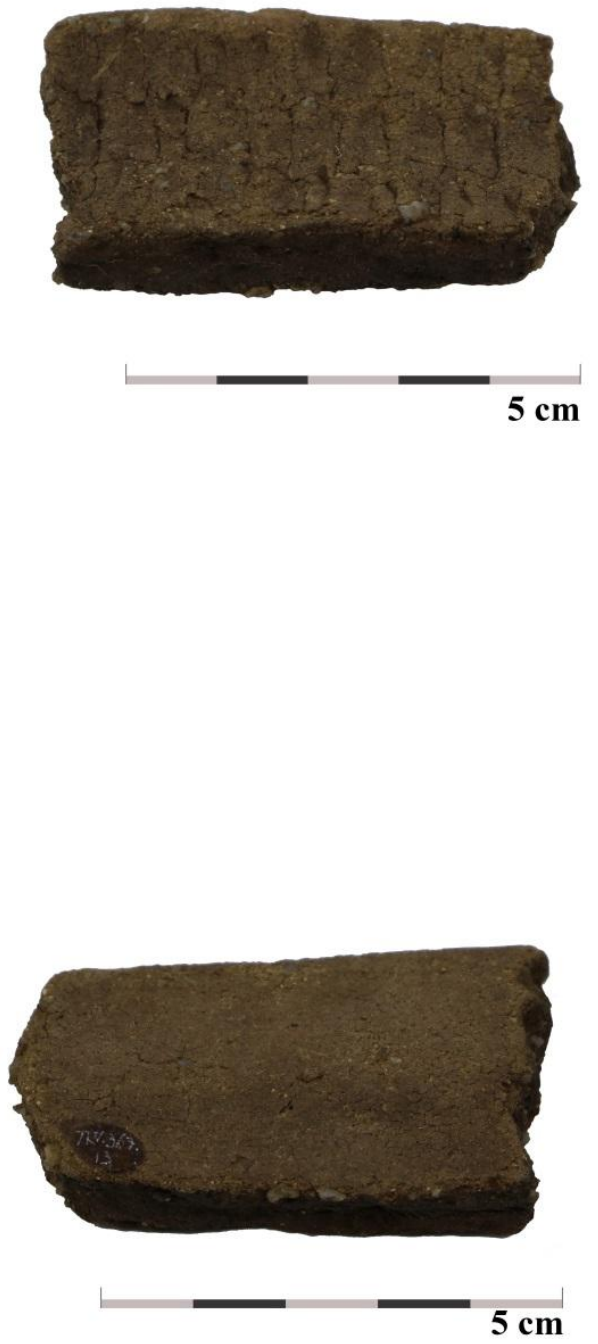

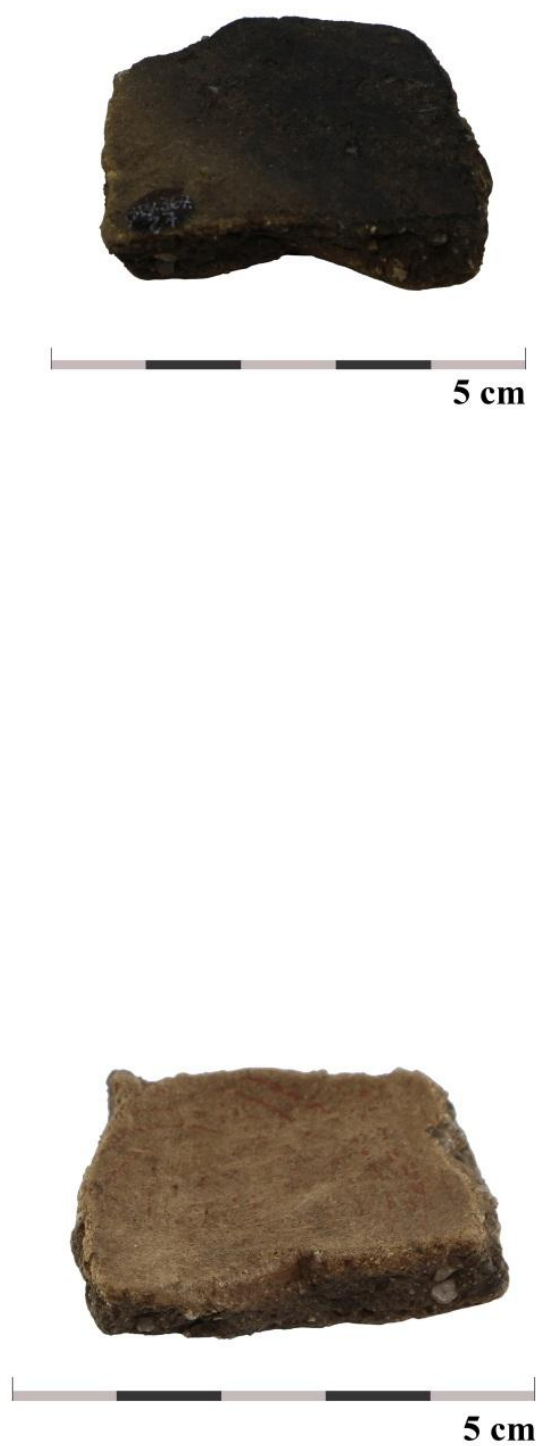

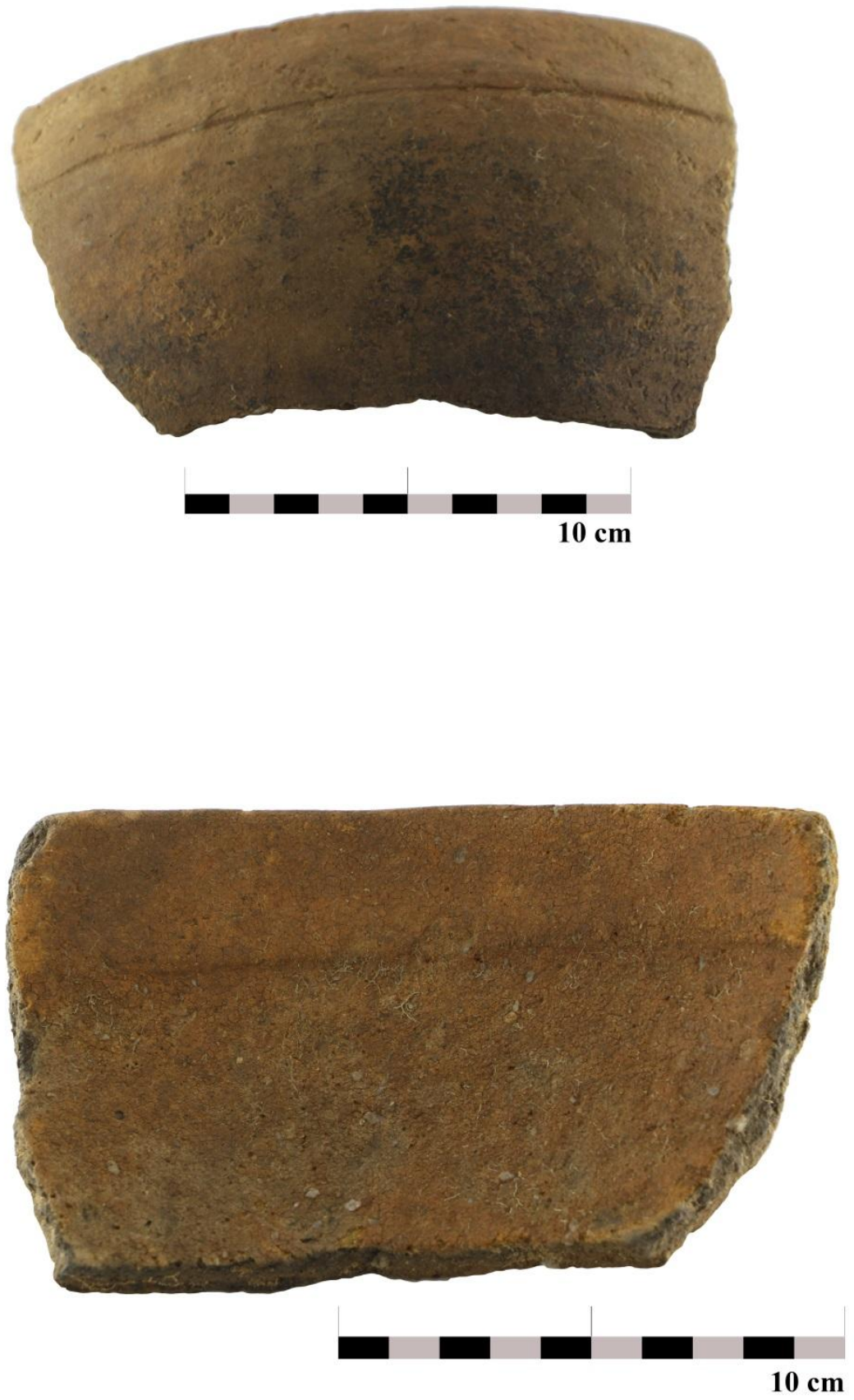

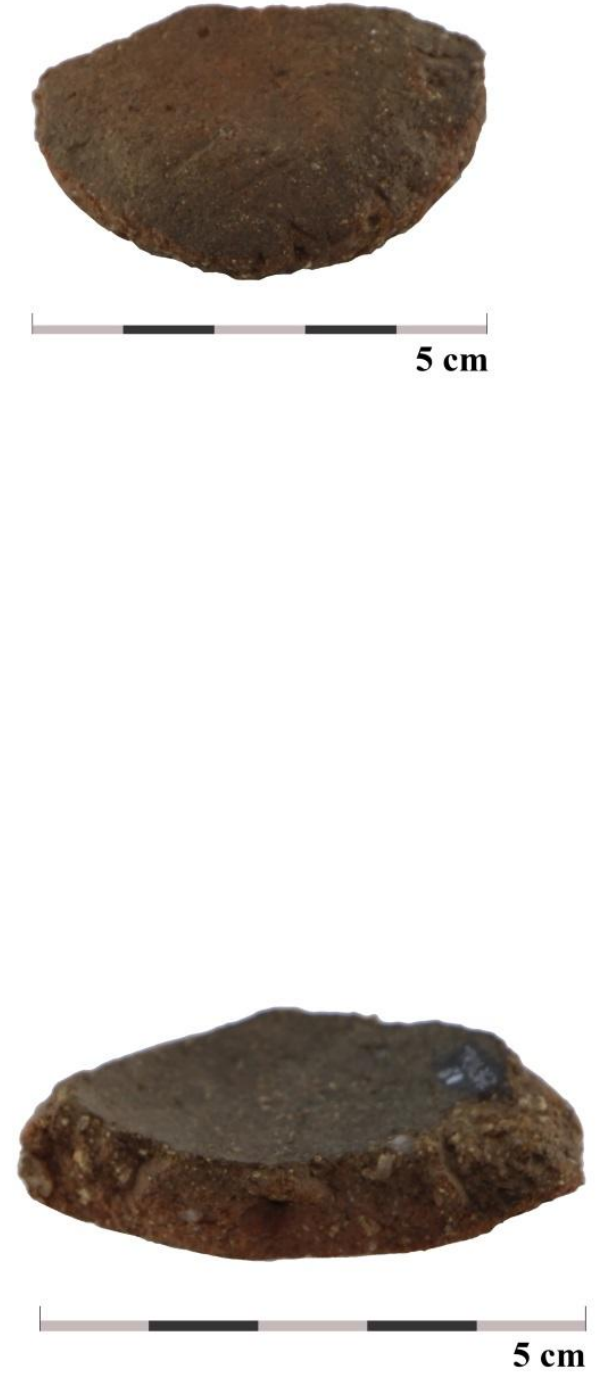


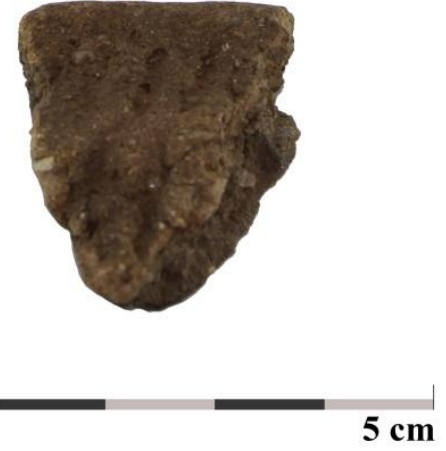



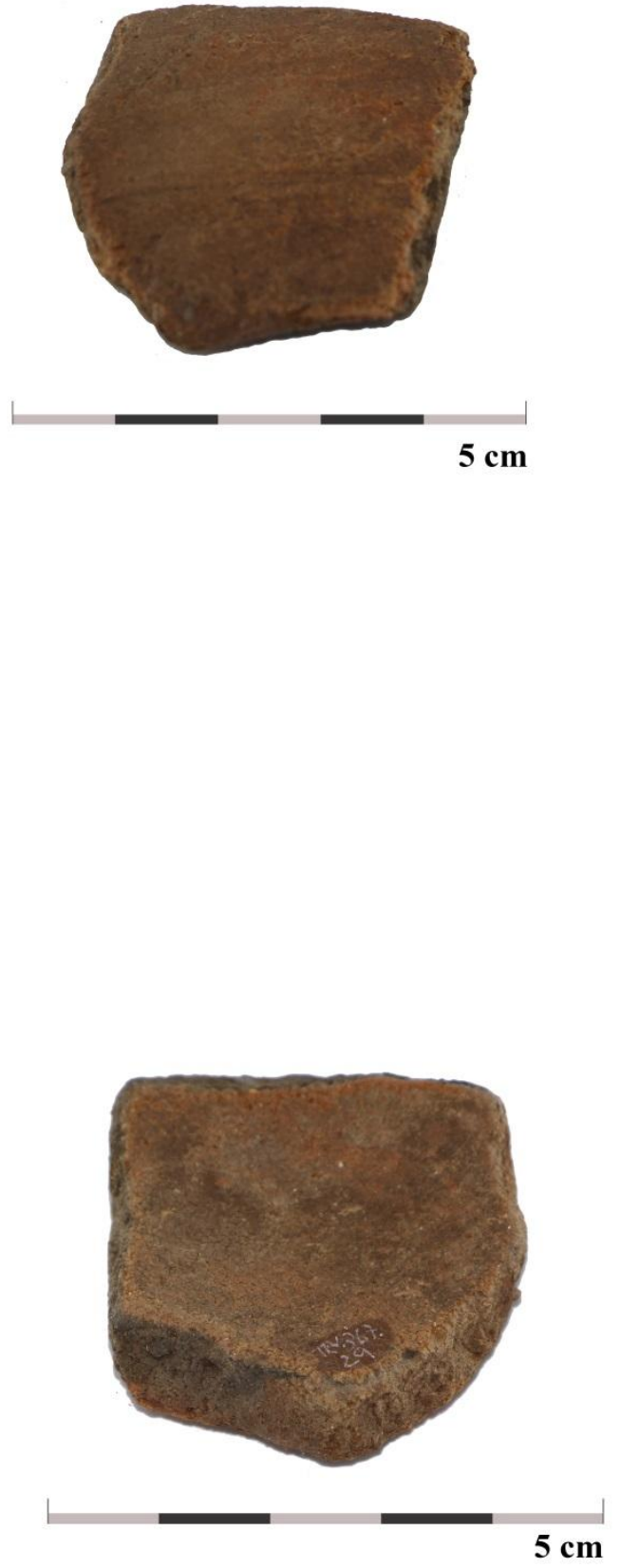

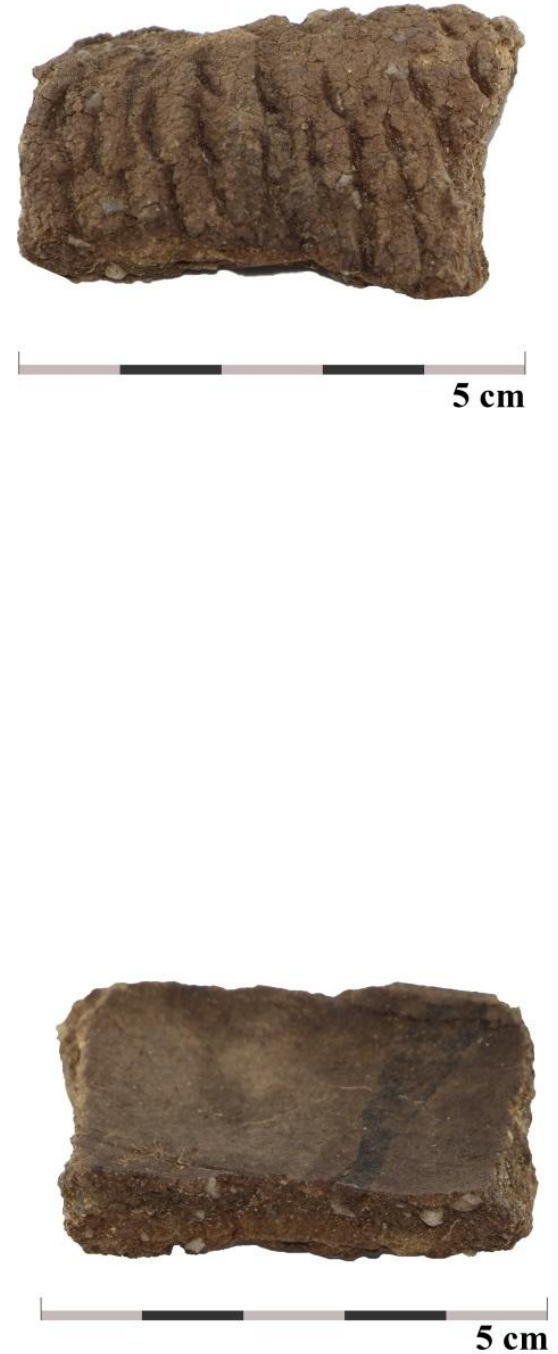


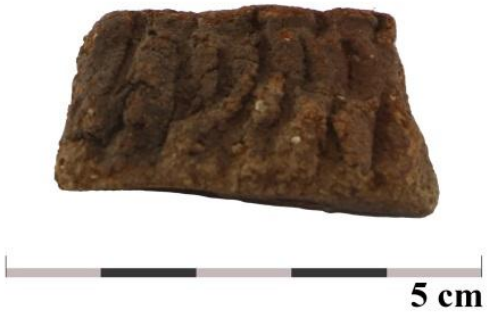



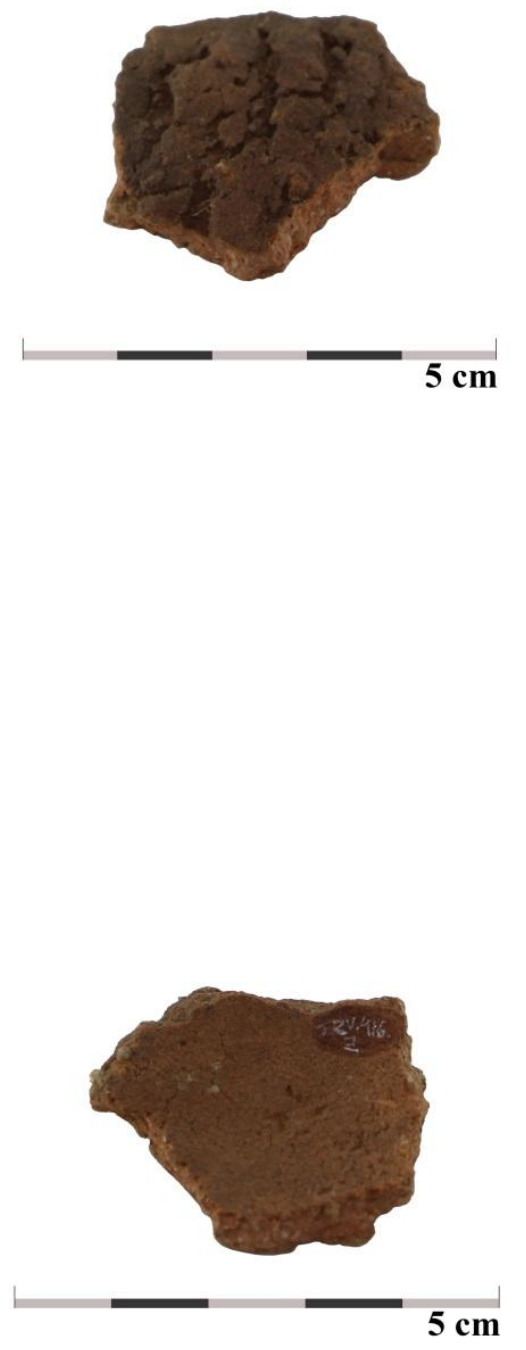

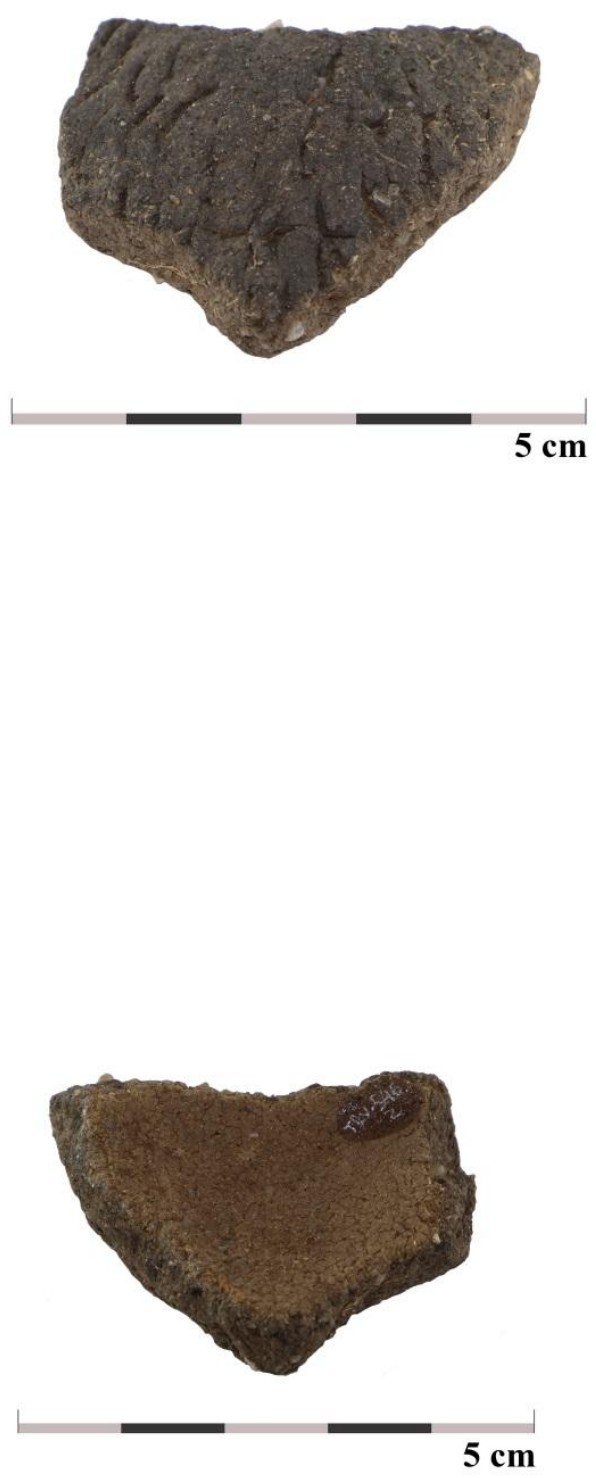

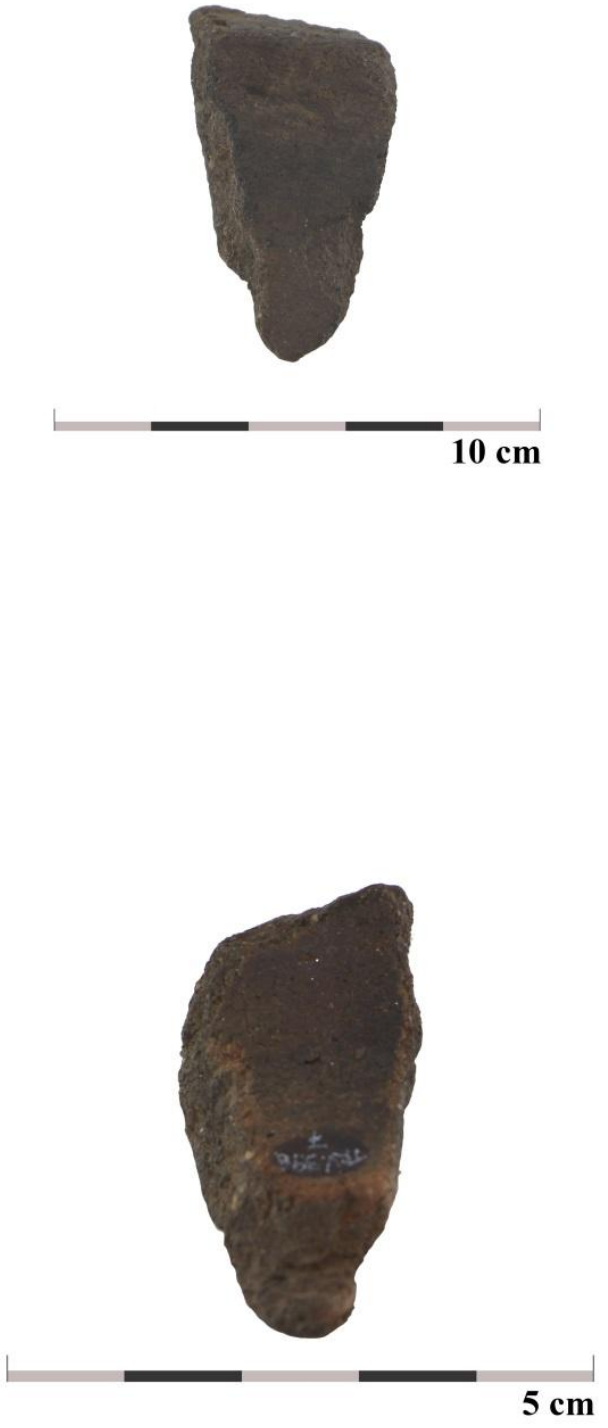

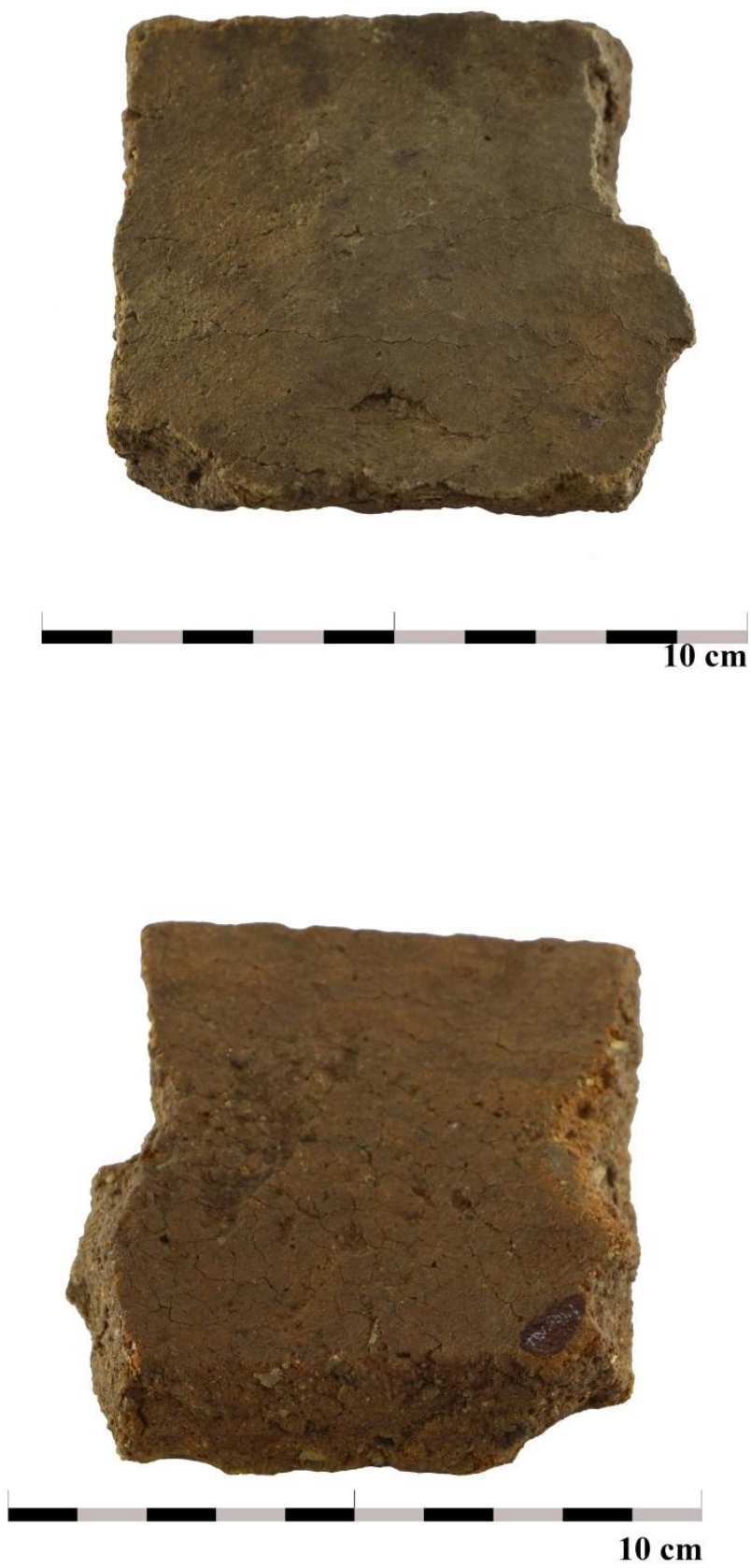

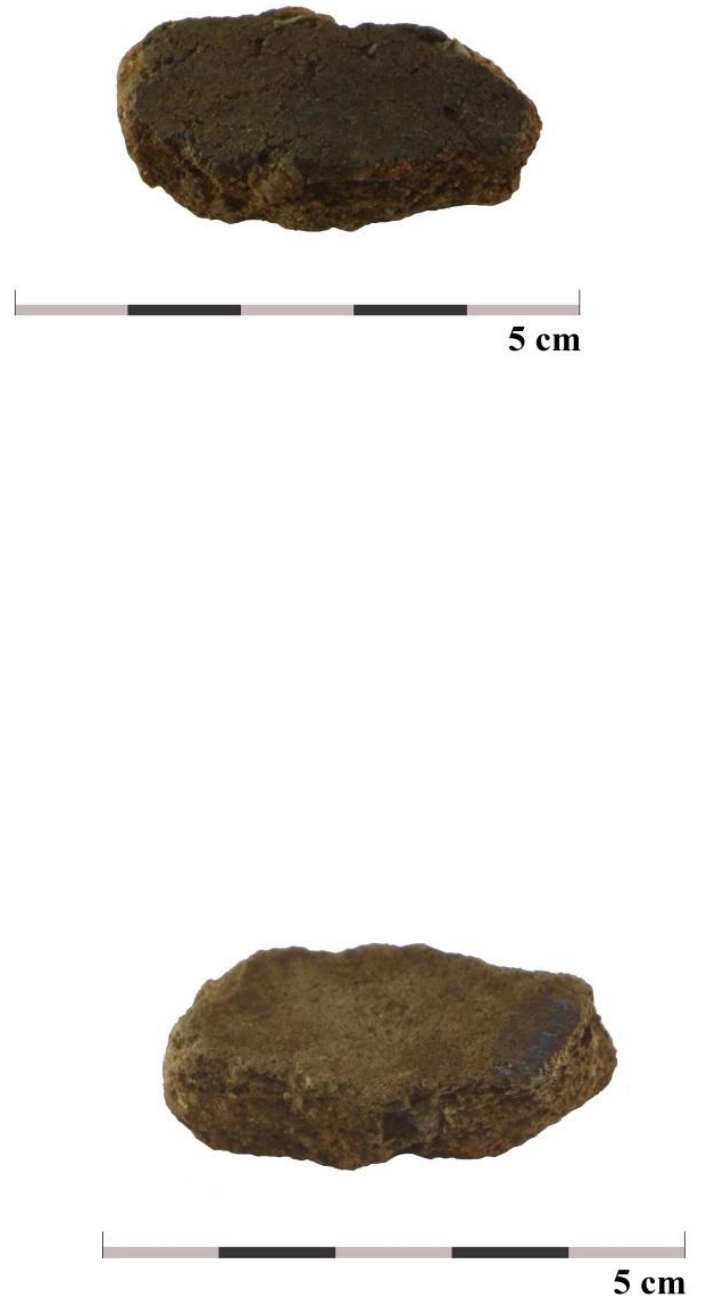

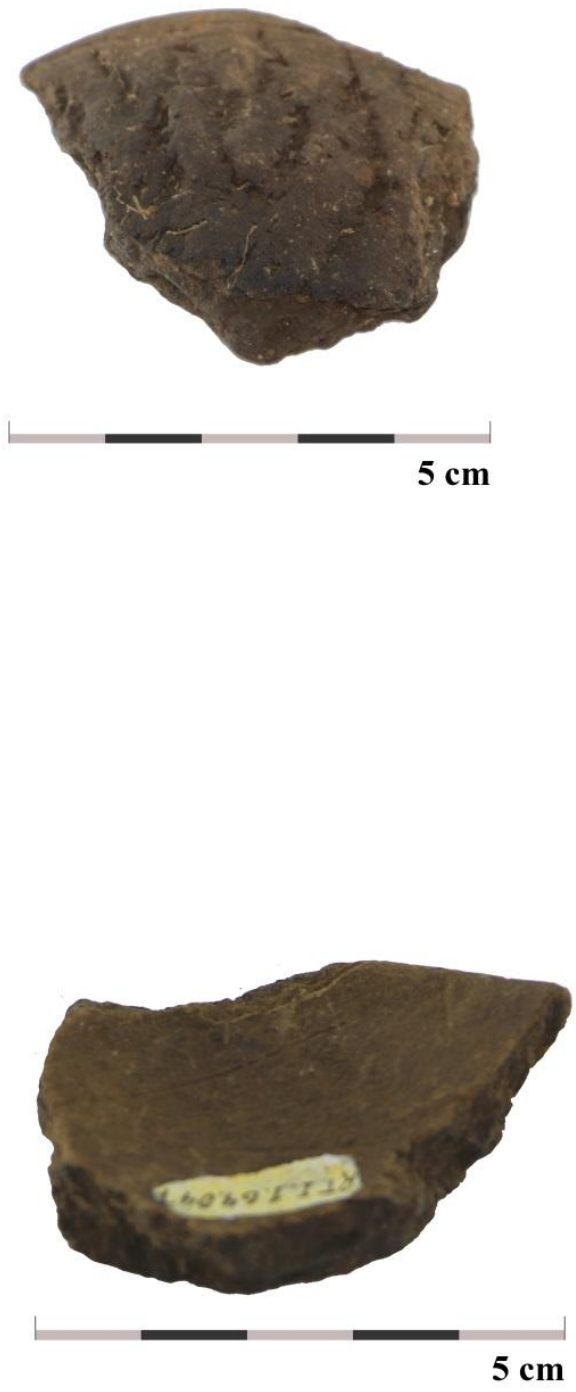

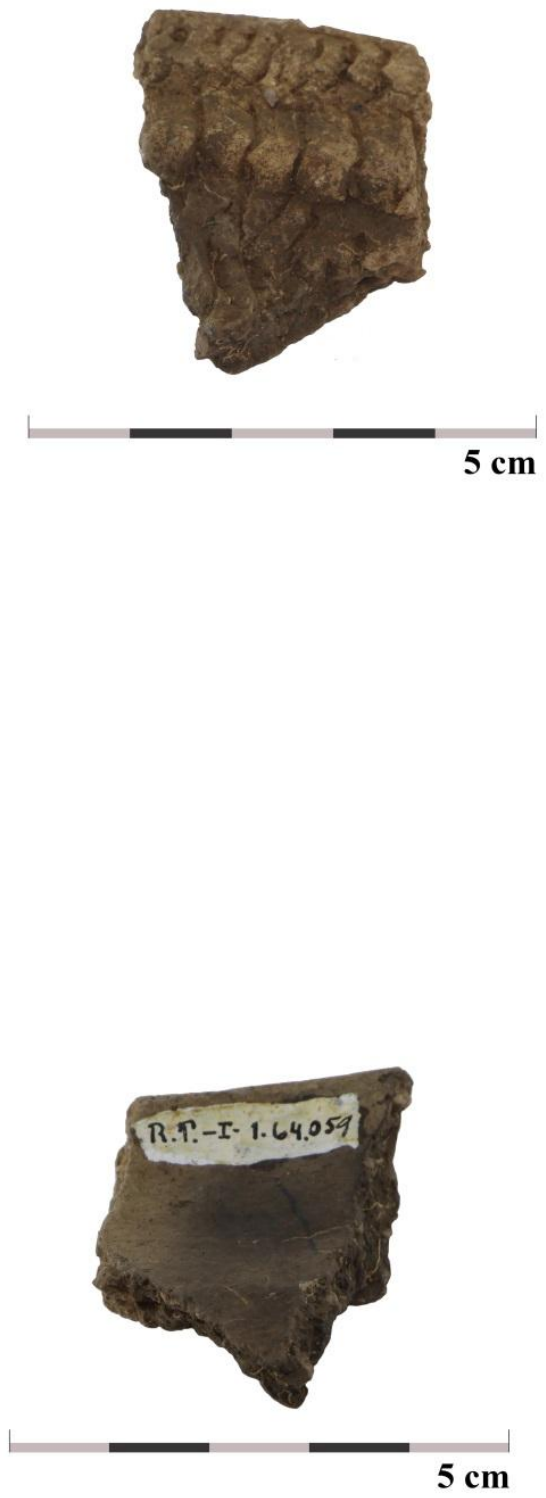

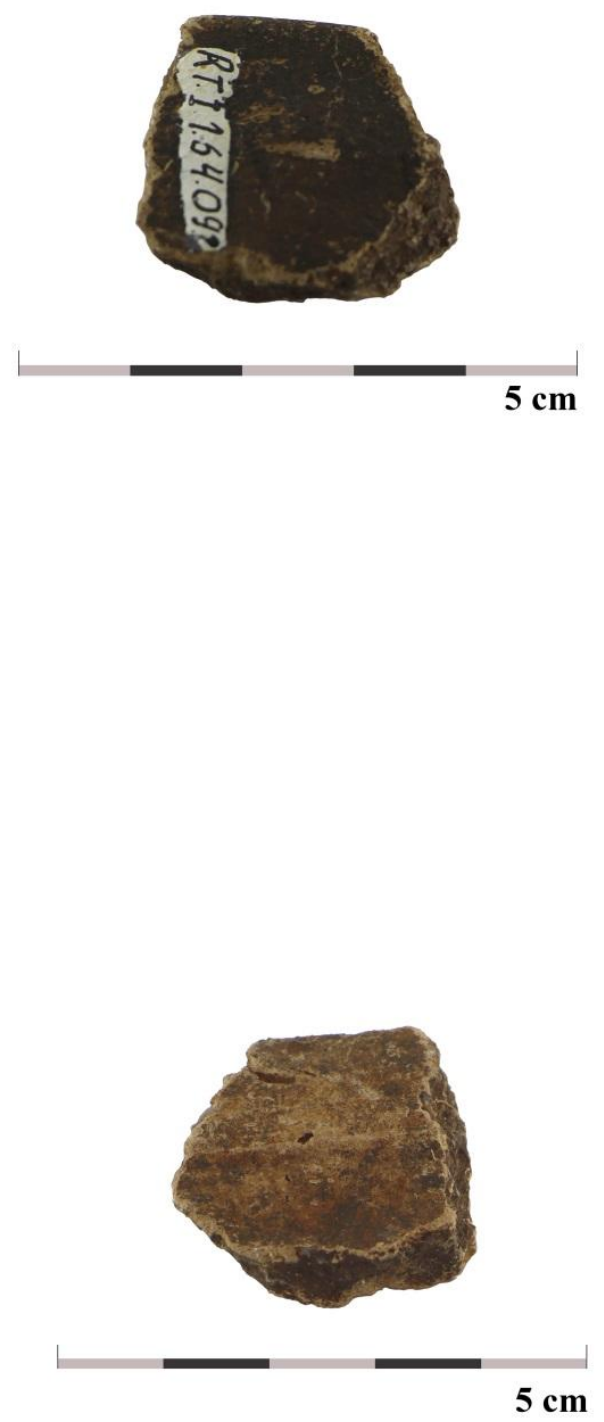

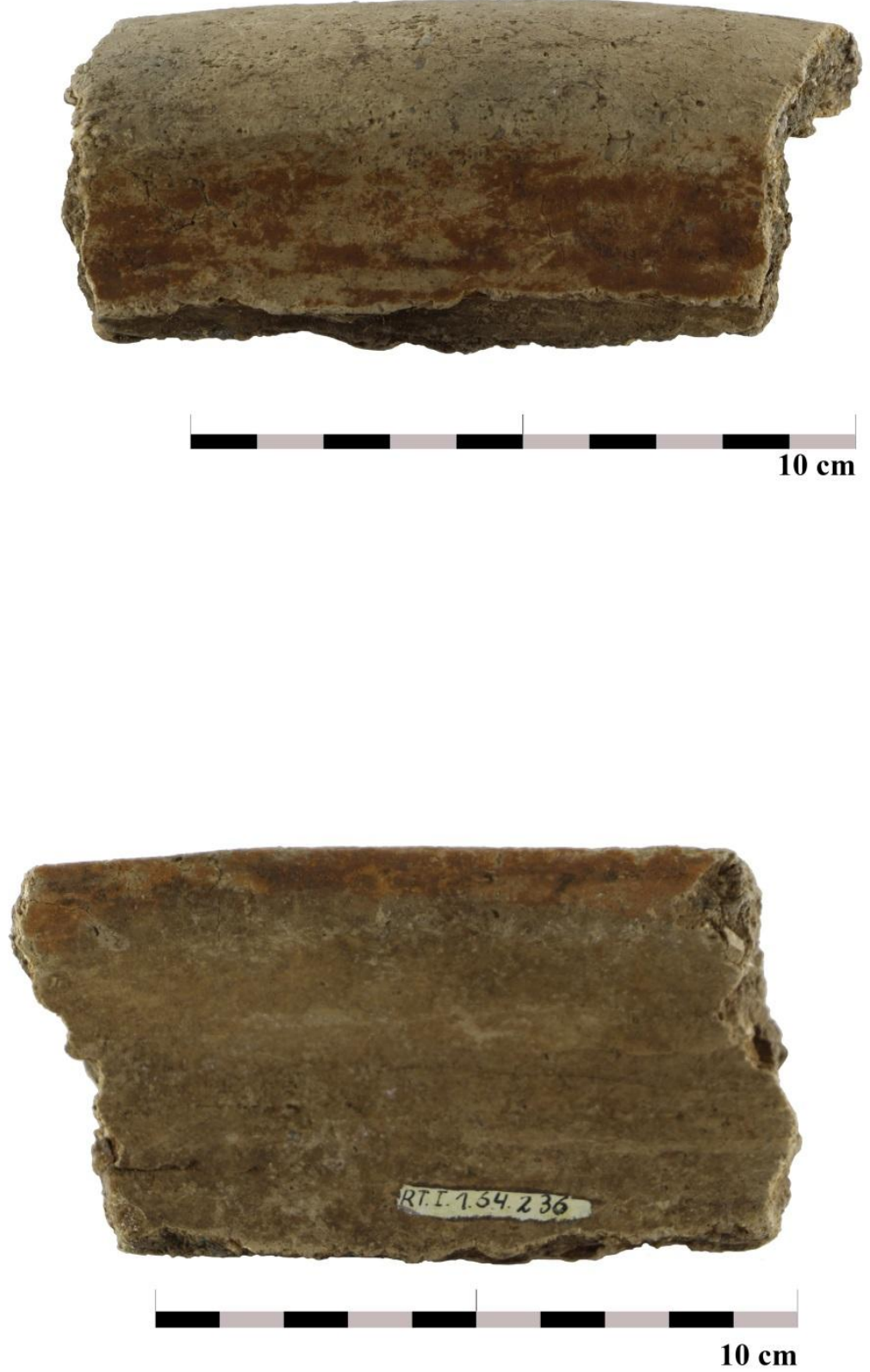

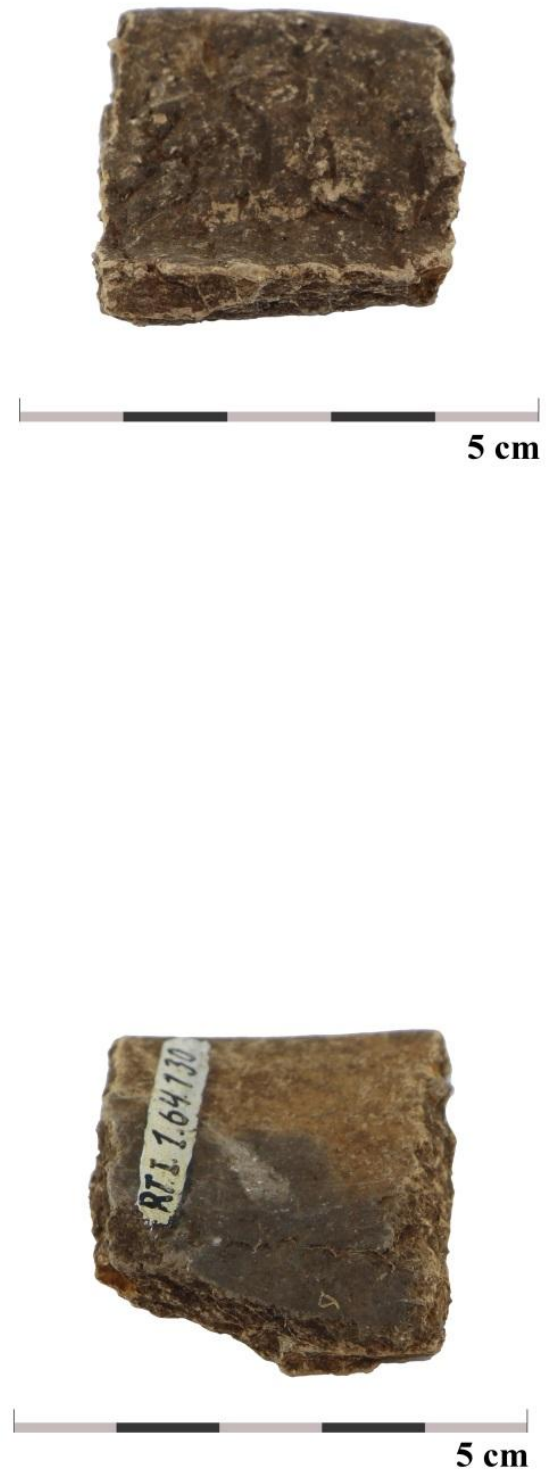

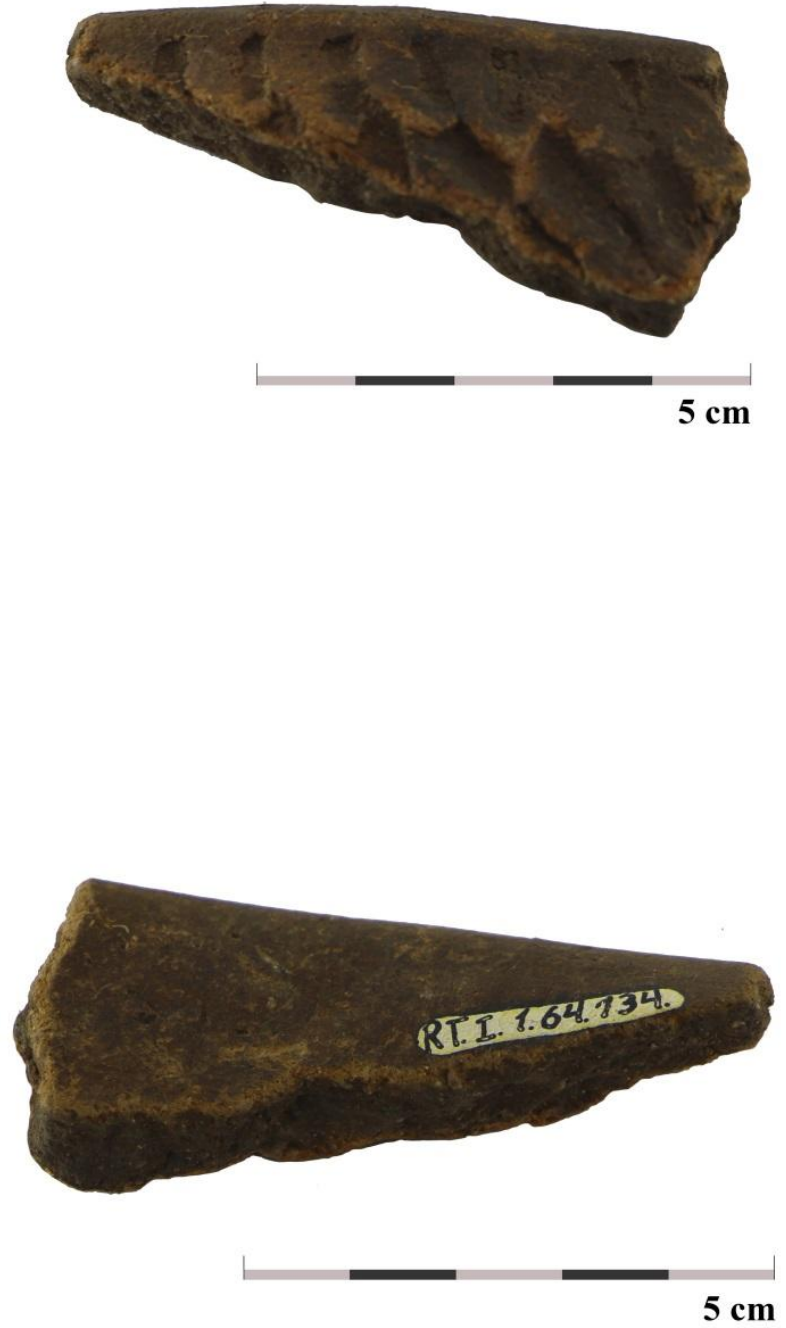

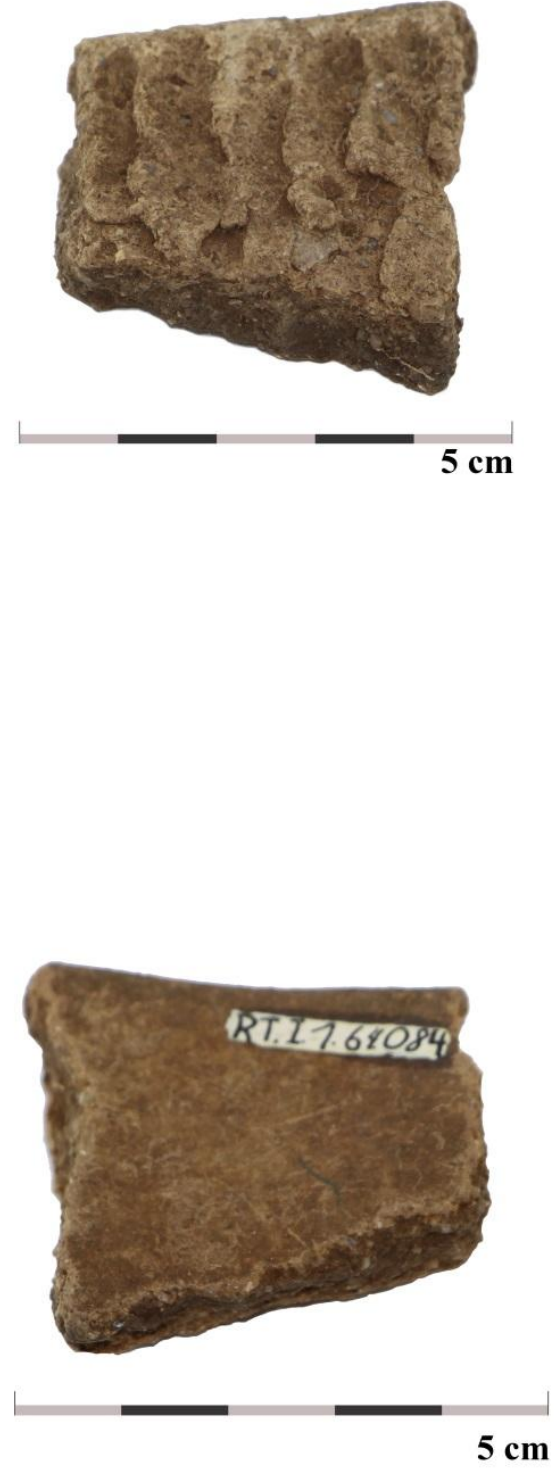

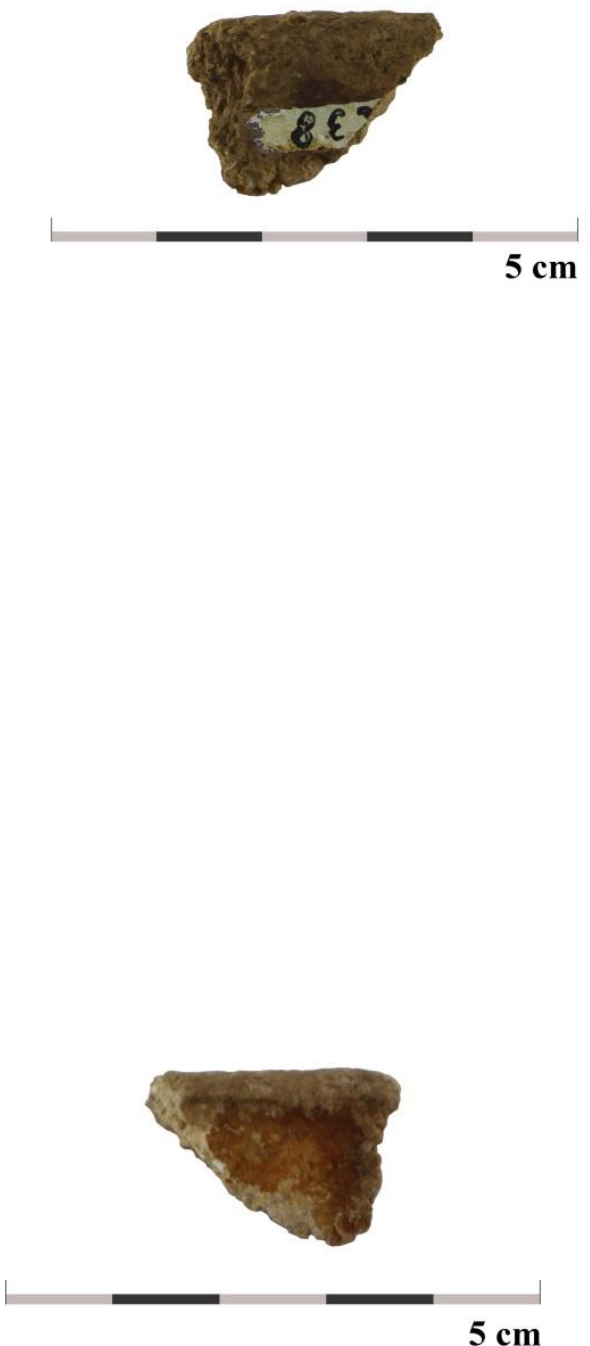

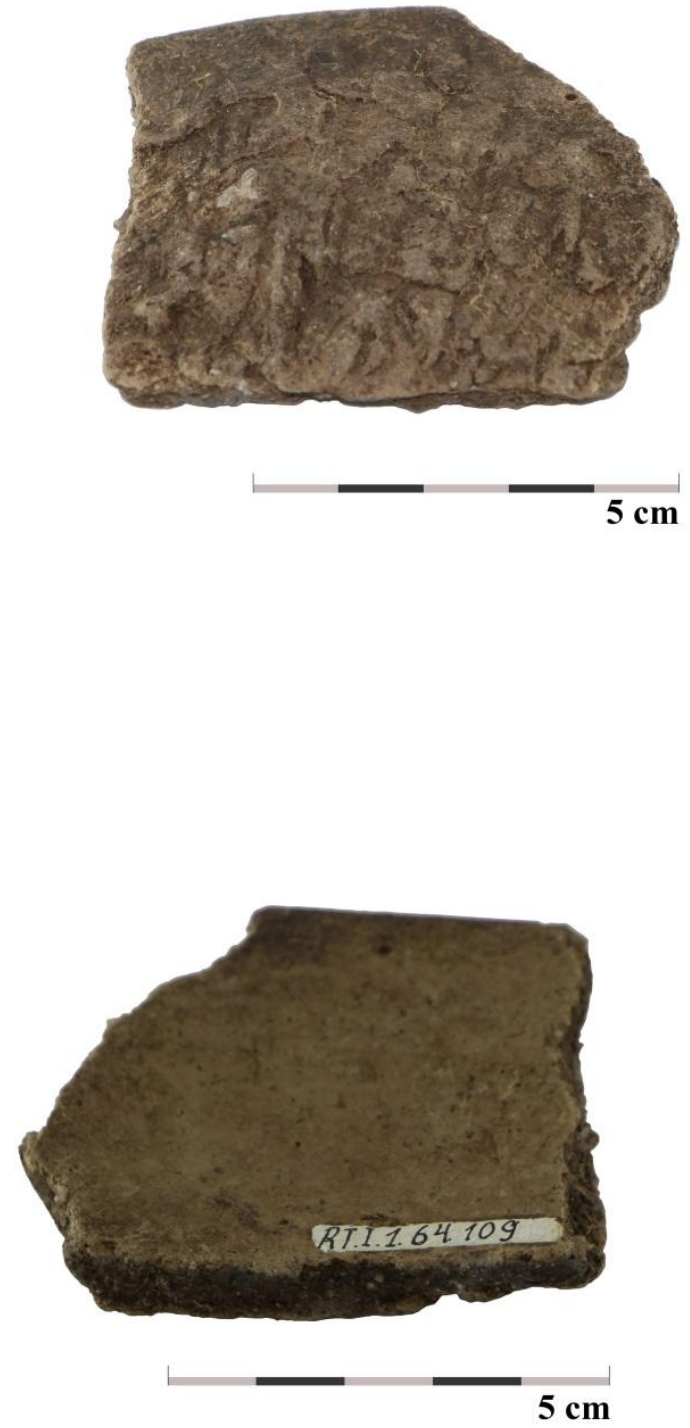


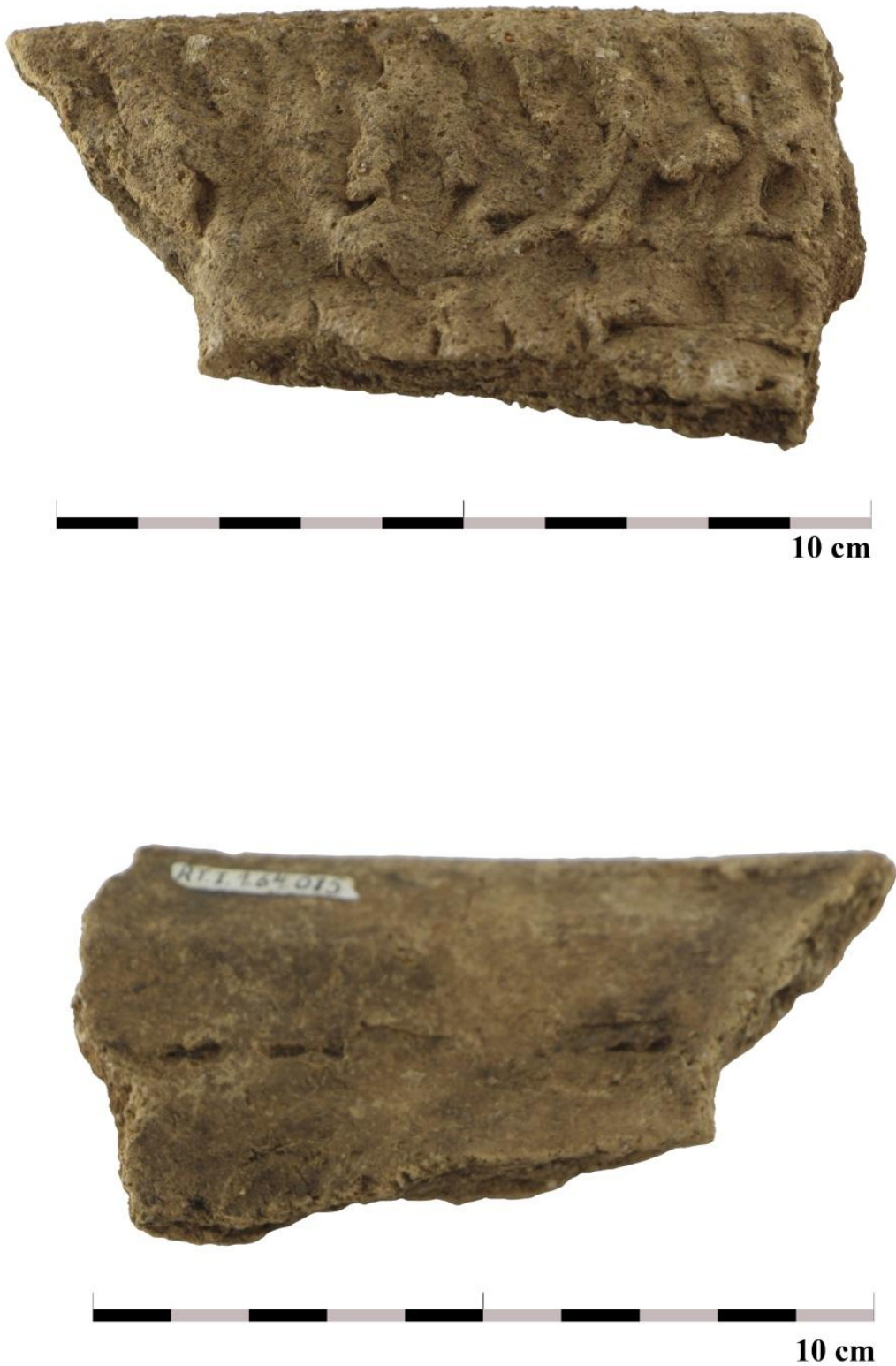

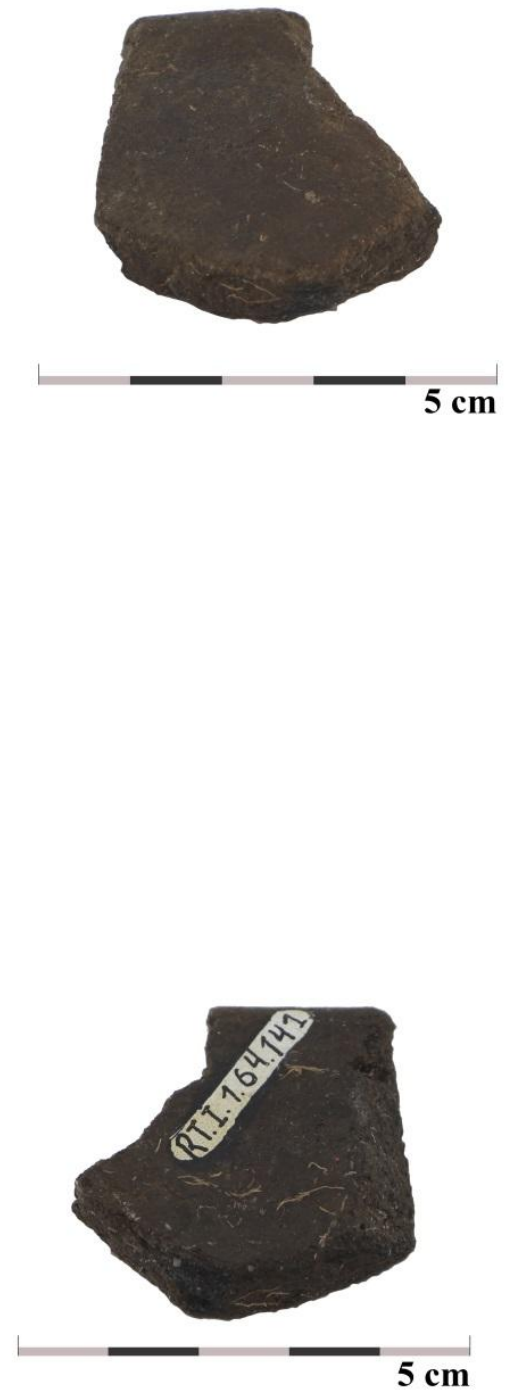

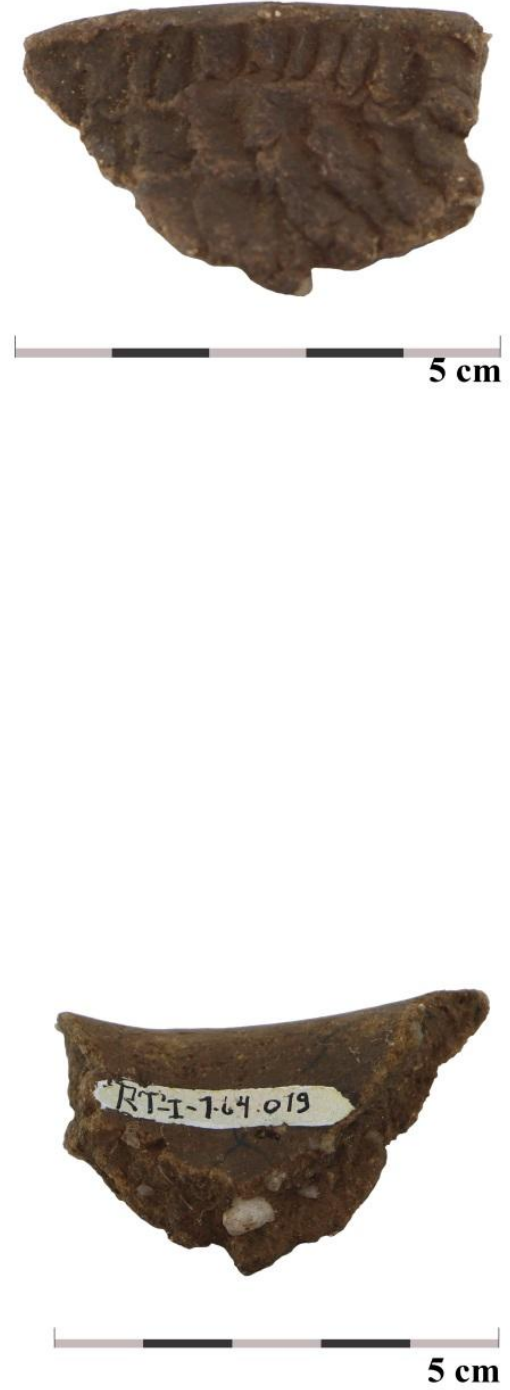

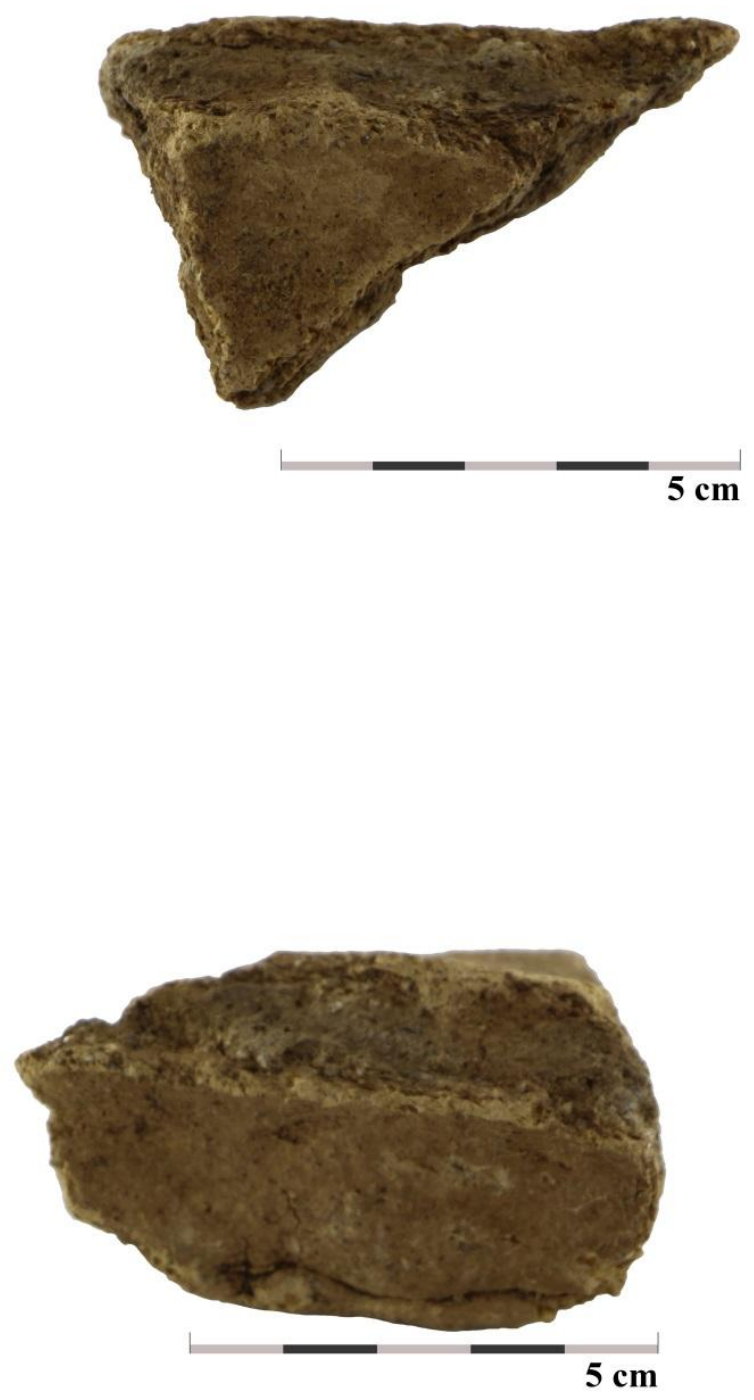


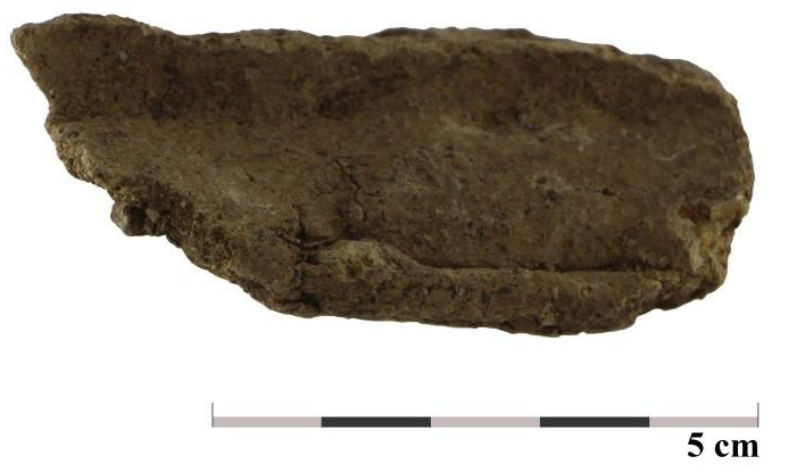

BT. 11.64.252

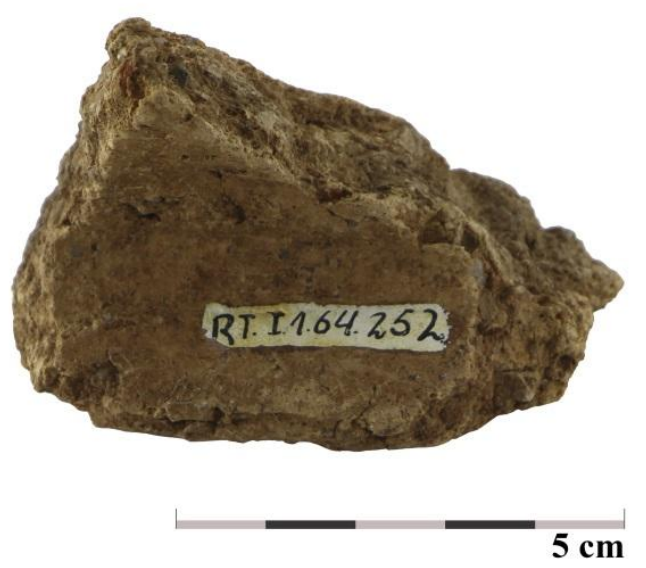



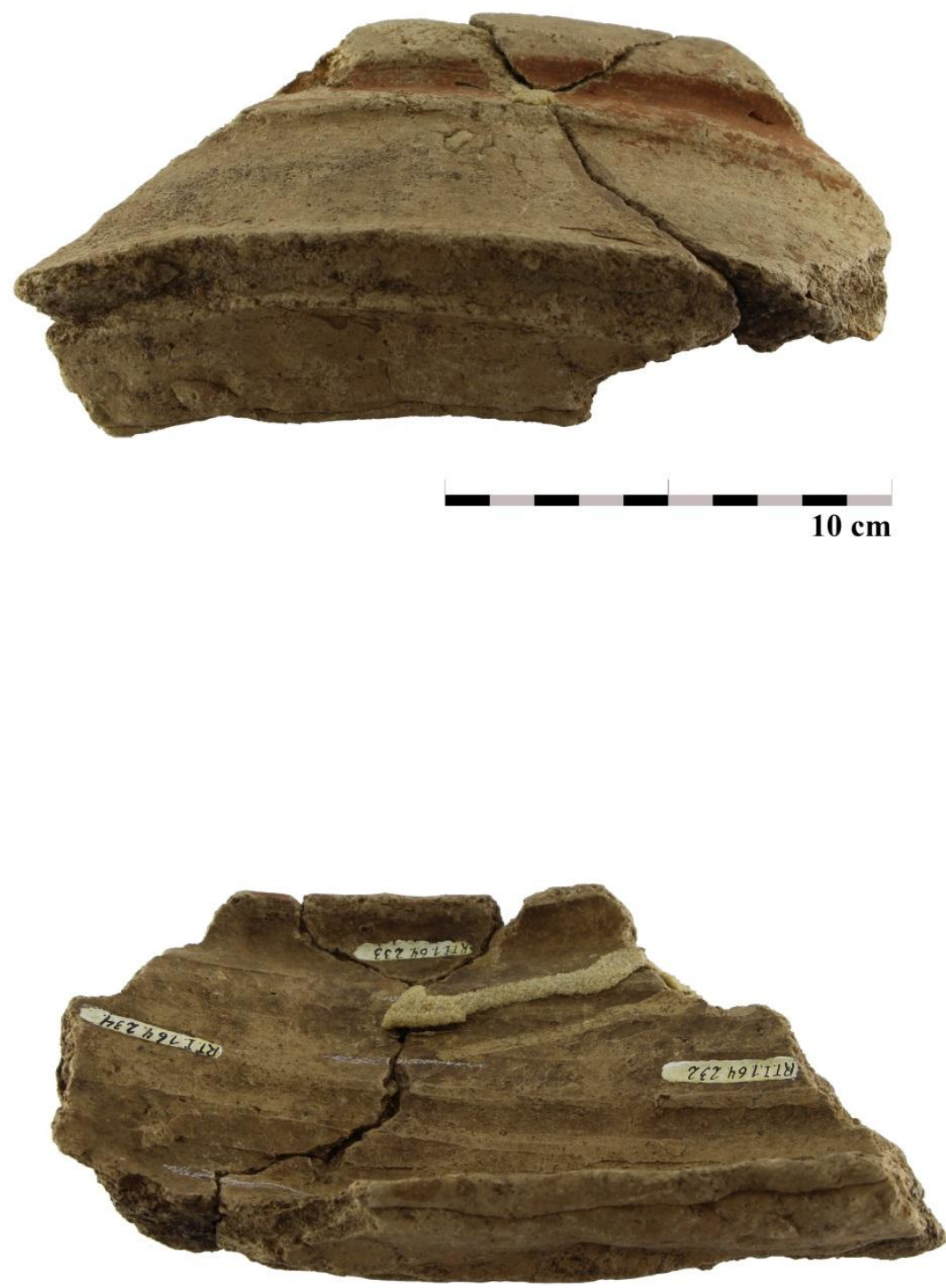

$---\overline{10} \mathrm{~cm}$ 
16. ANEXO 08

RESULTADOS DAS MEDIDAS DE FLUORESCÊNCIA DE RAIOS-X (XRF)

\begin{tabular}{|c|c|c|c|c|c|c|c|c|}
\hline \multicolumn{4}{|c|}{} & \multicolumn{2}{c|}{$\begin{array}{c}\text { RT.I.1.64.109 } \\
\text { FACE INTERNA }\end{array}$} & \multicolumn{2}{c|}{$\begin{array}{c}\text { RT.I.1.64.109 } \\
\text { FACE EXTERA }\end{array}$} & \multicolumn{2}{c|}{$\begin{array}{c}\text { RT.I.1.64.109 } \\
\text { NÚCLEO }\end{array}$} \\
\hline $\begin{array}{c}\text { Elemento } \\
\text { Químico }\end{array}$ & $\mathbf{Z}$ & $\begin{array}{c}\text { Energi } \\
\text { a }\end{array}$ & Área & Área & Área & Área & Área & Ára \\
\hline $\mathrm{Mg}$ & 12 & 1,254 & 0 & 0 & 0 & 0 & -17 & -26 \\
\hline $\mathrm{Al}$ & 13 & 1,487 & 928 & 1792 & 1203 & 472 & 1350 & 1138 \\
\hline $\mathrm{Si}$ & 14 & 1,74 & 13124 & 22256 & 12997 & 9002 & 15182 & 16962 \\
\hline $\mathrm{P}$ & 15 & 2,013 & 275 & 575 & 610 & 102 & 130 & 418 \\
\hline $\mathrm{S}$ & 16 & 2,307 & 359 & 675 & 1299 & 770 & 199 & 467 \\
\hline $\mathrm{Cl}$ & 17 & 2,622 & 758 & 729 & 579 & 622 & 677 & 690 \\
\hline $\mathrm{Ar}$ & 18 & 2,957 & 29825 & 24938 & 27710 & 30843 & 24240 & 23220 \\
\hline $\mathrm{K}$ & 19 & 3,313 & 31036 & 45218 & 31589 & 20187 & 38051 & 31645 \\
\hline $\mathrm{Ca}$ & 20 & 3,691 & 0 & 0 & 5097 & 4100 & 1193 & 1564 \\
\hline $\mathrm{Ti}$ & 22 & 4,509 & 35800 & 55527 & 38416 & 22304 & 24679 & 31048 \\
\hline $\mathrm{Cr}$ & 24 & 5,412 & 1692 & 1705 & 2182 & 8658 & 1285 & 1235 \\
\hline $\mathrm{Mn}$ & 25 & 5,895 & 2386 & 4420 & 7098 & 2509 & 676 & 5029 \\
\hline $\mathrm{Fe}$ & 26 & 6,399 & 141690 & 229205 & 212702 & 110692 & 180368 & 148632 \\
\hline $\mathrm{Cu}$ & 29 & 8,041 & 1445 & 2106 & 2059 & 1449 & 1109 & 2057 \\
\hline $\mathrm{Zn}$ & 30 & 8,631 & 2541 & 3891 & 2860 & 1852 & 3294 & 1899 \\
\hline $\mathrm{Ga}$ & 31 & 9,243 & 1825 & 2536 & 2098 & 1286 & 1660 & 1769 \\
\hline $\mathrm{Br}$ & 35 & 11,908 & 1131 & 1315 & 1534 & 898 & 613 & 1087 \\
\hline $\mathrm{Rb}$ & 37 & 13,375 & 4472 & 7446 & 6627 & 3874 & 6159 & 5557 \\
\hline $\mathrm{Sr}$ & 38 & 14,142 & 2355 & 4200 & 3824 & 2238 & 3560 & 3279 \\
\hline $\mathrm{Y}$ & 39 & 14,932 & 0 & 0 & 0 & 0 & 753 & 773 \\
\hline $\mathrm{Zr}$ & 40 & 15,746 & 4758 & 7598 & 6524 & 3707 & 4886 & 5523 \\
\hline $\mathrm{Ag}$ & 47 & 22,103 & 2666 & 4469 & 3632 & 2234 & 3525 & 3384 \\
\hline $\mathrm{Ba}$ & 0 & 0 & 0 & 0 & 0 & 0 & 0 & 0 \\
\hline $\mathrm{Pb}$ & 0 & 0 & 0 & 0 & 0 & 0 & 0 & 0 \\
\hline $\mathrm{Ni}$ & 0 & 0 & 0 & 0 & 0 & 0 & 0 & 0 \\
\hline $\mathrm{T}$ & $\mathrm{n}$ & & & & & & & \\
\hline
\end{tabular}

Tabela 9. Resultados das medidas de Fluorescência de Raios-X (XRF) para a amostra RT.I.1.64.109 (faces interna, externa e núcleo). 


\begin{tabular}{|c|c|c|c|c|c|c|c|c|}
\hline \multirow[b]{2}{*}{$\begin{array}{c}\text { Elemento } \\
\text { Químico }\end{array}$} & \multirow[b]{2}{*}{$\mathbf{Z}$} & \multirow[b]{2}{*}{ Energia } & \multicolumn{2}{|c|}{$\begin{array}{c}\text { RT.I.1.64.085 } \\
\text { FACE INTERNA }\end{array}$} & \multicolumn{2}{|c|}{$\begin{array}{c}\text { RT.I.1.64.085 } \\
\text { FACE EXTERNA } \\
\end{array}$} & \multicolumn{2}{|c|}{$\begin{array}{c}\text { RT.I.1.64.085 } \\
\text { NÚCLEO }\end{array}$} \\
\hline & & & Área & Área & Área & Área & Área & Área \\
\hline $\mathrm{Mg}$ & 12 & 1,254 & 0 & 0 & 0 & 0 & -89 & -28 \\
\hline $\mathrm{Al}$ & 13 & 1,487 & 661 & 350 & 510 & 680 & 389 & 1543 \\
\hline $\mathrm{Si}$ & 14 & 1,74 & 9023 & 5095 & 12774 & 11214 & 5831 & 19916 \\
\hline $\mathrm{P}$ & 15 & 2,013 & 276 & 480 & 169 & 331 & 388 & 1149 \\
\hline $\mathrm{S}$ & 16 & 2,307 & 514 & 583 & 542 & 658 & 475 & 698 \\
\hline $\mathrm{Cl}$ & 17 & 2,622 & 836 & 775 & 669 & 556 & 761 & 440 \\
\hline $\mathrm{Ar}$ & 18 & 2,957 & 31637 & 33015 & 29058 & 29502 & 29510 & 19035 \\
\hline $\mathrm{K}$ & 19 & 3,313 & 24310 & 17101 & 18544 & 26001 & 15238 & 26430 \\
\hline $\mathrm{Ca}$ & 20 & 3,691 & 714 & 787 & 1986 & 2604 & 696 & 1577 \\
\hline $\mathrm{Ti}$ & 22 & 4,509 & 39289 & 28634 & 26898 & 38187 & 21537 & 46536 \\
\hline $\mathrm{Cr}$ & 24 & 5,412 & 1785 & 1230 & 2227 & 1486 & 1210 & 1423 \\
\hline $\mathrm{Mn}$ & 25 & 5,895 & 1771 & 2356 & 1090 & 1857 & 3207 & 2844 \\
\hline $\mathrm{Fe}$ & 26 & 6,399 & 150678 & 132353 & 149016 & 192605 & 167812 & 238348 \\
\hline $\mathrm{Cu}$ & 29 & 8,041 & 1383 & 950 & 2514 & 1487 & 765 & 1972 \\
\hline $\mathrm{Zn}$ & 30 & 8,631 & 1630 & 966 & 963 & 1597 & 790 & 2246 \\
\hline $\mathrm{Ga}$ & 31 & 9,243 & 1632 & 1378 & 2476 & 1892 & 1308 & 2291 \\
\hline $\mathrm{Br}$ & 35 & 11,908 & 1337 & 1155 & 1631 & 1138 & 1049 & 1449 \\
\hline $\mathrm{Rb}$ & 37 & 13,375 & 3944 & 3057 & 3211 & 4673 & 2839 & 5518 \\
\hline $\mathrm{Sr}$ & 38 & 14,142 & 1752 & 1579 & 2164 & 2134 & 1396 & 2642 \\
\hline $\mathrm{Y}$ & 39 & 14,932 & 0 & 0 & 0 & 0 & 722 & 1009 \\
\hline $\mathrm{Zr}$ & 40 & 15,746 & 4870 & 3836 & 4210 & 6184 & 4955 & 8875 \\
\hline $\mathrm{Ag}$ & 47 & 22,103 & 2496 & 1940 & 2567 & 2720 & 2024 & 4257 \\
\hline $\mathrm{Ba}$ & 0 & 0 & 0 & 0 & 0 & 0 & 0 & 0 \\
\hline $\mathrm{Pb}$ & 0 & 0 & 0 & 0 & 0 & 0 & 0 & 0 \\
\hline $\mathrm{Ni}$ & 0 & 0 & 0 & 0 & 0 & 0 & 0 & 0 \\
\hline
\end{tabular}

Tabela 10. Resultados das medidas de Fluorescência de Raios-X (XRF) para a amostra RT.I.1.64.085 (faces interna, externa e núcleo). 


\begin{tabular}{|c|c|c|c|c|c|c|c|c|}
\hline \multirow[b]{2}{*}{$\begin{array}{l}\text { Elemento } \\
\text { Químico }\end{array}$} & \multirow[b]{2}{*}{$\mathbf{Z}$} & \multirow[b]{2}{*}{ Energia } & \multicolumn{2}{|c|}{$\begin{array}{c}\text { RT.I.1.64.130 } \\
\text { FACE INTERNA }\end{array}$} & \multicolumn{2}{|c|}{$\begin{array}{c}\text { RT.I.1.64.130 } \\
\text { FACE EXTERNA }\end{array}$} & \multicolumn{2}{|c|}{$\begin{array}{c}\text { RT.I.1.64.130 } \\
\text { NÚCLEO }\end{array}$} \\
\hline & & & Área & Área & Área & Área & Área & Área \\
\hline $\mathrm{Mg}$ & 12 & 1,254 & 0 & 0 & 0 & 0 & -2 & -45 \\
\hline $\mathrm{Al}$ & 13 & 1,487 & 573 & 525 & 517 & 324 & 1739 & 1150 \\
\hline $\mathrm{Si}$ & 14 & 1,74 & 7378 & 8137 & 7814 & 3299 & 20440 & 15687 \\
\hline $\mathrm{P}$ & 15 & 2,013 & 259 & 190 & 346 & 163 & 748 & 613 \\
\hline$S$ & 16 & 2,307 & 432 & 455 & 866 & 606 & 981 & 972 \\
\hline $\mathrm{Cl}$ & 17 & 2,622 & 733 & 784 & 798 & 852 & 774 & 749 \\
\hline $\mathrm{Ar}$ & 18 & 2,957 & 32167 & 32271 & 32421 & 33771 & 21884 & 25021 \\
\hline $\mathrm{K}$ & 19 & 3,313 & 20229 & 23490 & 17927 & 12752 & 37643 & 26691 \\
\hline $\mathrm{Ca}$ & 20 & 3,691 & 1084 & 1149 & 2207 & 1109 & 2908 & 2379 \\
\hline $\mathrm{Ti}$ & 22 & 4,509 & 31943 & 33759 & 32122 & 22095 & 47203 & 46369 \\
\hline $\mathrm{Cr}$ & 24 & 5,412 & 1484 & 1784 & 1850 & 1123 & 1684 & 2013 \\
\hline $\mathrm{Mn}$ & 25 & 5,895 & 3007 & 2697 & 6850 & 5316 & 7482 & 7630 \\
\hline $\mathrm{Fe}$ & 26 & 6,399 & 98909 & 95811 & 177767 & 142850 & 283572 & 248109 \\
\hline $\mathrm{Cu}$ & 29 & 8,041 & 1317 & 1671 & 1931 & 629 & 2655 & 1772 \\
\hline $\mathrm{Zn}$ & 30 & 8,631 & 2189 & 1875 & 2357 & 1256 & 2871 & 2869 \\
\hline $\mathrm{Ga}$ & 31 & 9,243 & 1443 & 1410 & 1959 & 905 & 2406 & 1923 \\
\hline $\mathrm{Br}$ & 35 & 11,908 & 902 & 1178 & 1442 & 796 & 1859 & 1853 \\
\hline $\mathrm{Rb}$ & 37 & 13,375 & 3729 & 3380 & 4361 & 2512 & 6352 & 5904 \\
\hline $\mathrm{Sr}$ & 38 & 14,142 & 2681 & 1956 & 1882 & 1376 & 3716 & 3774 \\
\hline $\mathrm{Y}$ & 39 & 14,932 & 0 & 0 & 0 & 0 & 1223 & 1534 \\
\hline $\mathrm{Zr}$ & 40 & 15,746 & 4598 & 4883 & 4717 & 3185 & 9080 & 7813 \\
\hline $\mathrm{Ag}$ & 47 & 22,103 & 2038 & 2045 & 2814 & 1675 & 4667 & 4058 \\
\hline $\mathrm{Ba}$ & 0 & 0 & 0 & 0 & 0 & 0 & 0 & 0 \\
\hline $\mathrm{Pb}$ & 0 & 0 & 0 & 0 & 0 & 0 & 0 & 0 \\
\hline $\mathrm{Ni}$ & 0 & 0 & 0 & 0 & 0 & 0 & 0 & 0 \\
\hline
\end{tabular}

Tabela 11. Resultados das medidas de Fluorescência de Raios-X (XRF) para a amostra RT.I.1.64.130 (faces interna, externa e núcleo). 


\begin{tabular}{|c|c|c|c|c|c|c|c|c|}
\hline & & & $\begin{array}{r}\text { RT.I } \\
\text { FACE } \\
\end{array}$ & $\begin{array}{l}4.134 \\
\text { ERNA }\end{array}$ & $\begin{array}{r}\text { RT.I } \\
\text { FACE } \\
\end{array}$ & $\begin{array}{l}4.134 \\
\text { ERNA } \\
\end{array}$ & $\begin{array}{r}\text { RT.I } \\
\text { NÚ } \\
\end{array}$ & $\begin{array}{l}4.134 \\
\text { EO } \\
\end{array}$ \\
\hline $\begin{array}{l}\text { Elemento } \\
\text { Químico }\end{array}$ & $\mathbf{Z}$ & Energia & Área & Área & Área & Área & Área & Área \\
\hline $\mathrm{Mg}$ & 12 & 1,254 & 0 & 0 & 0 & 0 & -46 & -74 \\
\hline $\mathrm{Al}$ & 13 & 1,487 & 291 & 277 & 348 & 447 & 832 & 1004 \\
\hline $\mathrm{Si}$ & 14 & 1,74 & 4477 & 4079 & 7268 & 7889 & 12698 & 17003 \\
\hline $\mathrm{P}$ & 15 & 2,013 & 215 & 276 & 219 & 276 & 781 & 738 \\
\hline$S$ & 16 & 2,307 & 552 & 618 & 605 & 522 & 893 & 796 \\
\hline $\mathrm{Cl}$ & 17 & 2,622 & 787 & 828 & 689 & 718 & 493 & 559 \\
\hline $\mathrm{Ar}$ & 18 & 2,957 & 33369 & 33072 & 31603 & 31509 & 24435 & 24870 \\
\hline $\mathrm{K}$ & 19 & 3,313 & 14150 & 13200 & 17871 & 17592 & 19564 & 23414 \\
\hline $\mathrm{Ca}$ & 20 & 3,691 & 1757 & 1915 & 2715 & 2576 & 3192 & 3829 \\
\hline $\mathrm{Ti}$ & 22 & 4,509 & 38056 & 35672 & 42788 & 42491 & 57248 & 63880 \\
\hline $\mathrm{Cr}$ & 24 & 5,412 & 1137 & 1056 & 1773 & 1343 & 1873 & 1610 \\
\hline $\mathrm{Mn}$ & 25 & 5,895 & 5888 & 6214 & 6415 & 6590 & 12293 & 9232 \\
\hline $\mathrm{Fe}$ & 26 & 6,399 & 218443 & 265712 & 327326 & 327631 & 511870 & 440779 \\
\hline $\mathrm{Cu}$ & 29 & 8,041 & 1179 & 1017 & 1005 & 1402 & 1652 & 2728 \\
\hline $\mathrm{Zn}$ & 30 & 8,631 & 1100 & 1409 & 1092 & 1360 & 1955 & 2047 \\
\hline $\mathrm{Ga}$ & 31 & 9,243 & 988 & 999 & 1152 & 1302 & 1507 & 1771 \\
\hline $\mathrm{Br}$ & 35 & 11,908 & 915 & 586 & 732 & 704 & 1402 & 1411 \\
\hline $\mathrm{Rb}$ & 37 & 13,375 & 1550 & 1948 & 2367 & 2246 & 3326 & 3815 \\
\hline $\mathrm{Sr}$ & 38 & 14,142 & 701 & 810 & 884 & 827 & 1614 & 1601 \\
\hline $\mathrm{Y}$ & 39 & 14,932 & 0 & 0 & 0 & 0 & 941 & 1010 \\
\hline $\mathrm{Zr}$ & 40 & 15,746 & 7327 & 7134 & 8495 & 7911 & 13866 & 13713 \\
\hline $\mathrm{Ag}$ & 47 & 22,103 & 1610 & 1630 & 1923 & 2143 & 3371 & 3542 \\
\hline $\mathrm{Ba}$ & 0 & 0 & 0 & 0 & 0 & 0 & 0 & 0 \\
\hline $\mathrm{Pb}$ & 0 & 0 & 0 & 0 & 0 & 0 & 0 & 0 \\
\hline $\mathrm{Ni}$ & 0 & 0 & 0 & 0 & 0 & 0 & 0 & 0 \\
\hline
\end{tabular}

Tabela 12. Resultados das medidas de Fluorescência de Raios-X (XRF) para a amostra RT.I.1.64.134 (faces interna, externa e núcleo). 


\begin{tabular}{|c|c|c|c|c|c|c|c|c|}
\hline & & & $\begin{array}{r}\text { RT.I } \\
\text { FACE }\end{array}$ & $\begin{array}{l}4.059 \\
\text { ERNA }\end{array}$ & $\begin{array}{r}\text { RT.I } \\
\text { FACE }\end{array}$ & $\begin{array}{l}4.059 \\
\text { TERNA }\end{array}$ & $\begin{array}{r}\text { RT.I } \\
\text { NÚ }\end{array}$ & $\begin{array}{l}4.059 \\
\text { EO }\end{array}$ \\
\hline $\begin{array}{l}\text { Elemento } \\
\text { Químico }\end{array}$ & $\mathbf{Z}$ & Energia & Área & Área & Área & Área & Área & Área \\
\hline $\mathrm{Mg}$ & 12 & 1,254 & 0 & 0 & 0 & 0 & -34 & -3 \\
\hline $\mathrm{Al}$ & 13 & 1,487 & 483 & 473 & 496 & 557 & 792 & 1154 \\
\hline $\mathrm{Si}$ & 14 & 1,74 & 7765 & 9153 & 6567 & 8043 & 12363 & 15629 \\
\hline $\mathrm{P}$ & 15 & 2,013 & 144 & 162 & 415 & 381 & 490 & 738 \\
\hline $\mathrm{S}$ & 16 & 2,307 & 394 & 404 & 702 & 560 & 801 & 810 \\
\hline $\mathrm{Cl}$ & 17 & 2,622 & 814 & 848 & 854 & 810 & 826 & 654 \\
\hline $\mathrm{Ar}$ & 18 & 2,957 & 32298 & 32166 & 32949 & 32023 & 27688 & 22987 \\
\hline $\mathrm{K}$ & 19 & 3,313 & 21690 & 24161 & 20720 & 25095 & 29413 & 31030 \\
\hline $\mathrm{Ca}$ & 20 & 3,691 & 656 & 706 & 753 & 838 & 1053 & 1429 \\
\hline $\mathrm{Ti}$ & 22 & 4,509 & 29782 & 32211 & 29811 & 31784 & 31795 & 32198 \\
\hline $\mathrm{Cr}$ & 24 & 5,412 & 1449 & 1486 & 1613 & 1493 & 2446 & 1312 \\
\hline $\mathrm{Mn}$ & 25 & 5,895 & 1568 & 1577 & 7330 & 5866 & 6445 & 5791 \\
\hline $\mathrm{Fe}$ & 26 & 6,399 & 105351 & 110254 & 150306 & 145938 & 167645 & 162568 \\
\hline $\mathrm{Cu}$ & 29 & 8,041 & 1497 & 1600 & 1422 & 1267 & 1634 & 2199 \\
\hline $\mathrm{Zn}$ & 30 & 8,631 & 1412 & 1355 & 1794 & 2093 & 2005 & 2288 \\
\hline $\mathrm{Ga}$ & 31 & 9,243 & 1227 & 1201 & 1485 & 1364 & 2827 & 1857 \\
\hline $\mathrm{Br}$ & 35 & 11,908 & 733 & 804 & 1213 & 1238 & 1371 & 1274 \\
\hline $\mathrm{Rb}$ & 37 & 13,375 & 3486 & 3917 & 4258 & 4237 & 5266 & 5486 \\
\hline $\mathrm{Sr}$ & 38 & 14,142 & 1555 & 1693 & 1782 & 2069 & 2471 & 2669 \\
\hline $\mathrm{Y}$ & 39 & 14,932 & 0 & 0 & 0 & 0 & 1176 & 1165 \\
\hline $\mathrm{Zr}$ & 40 & 15,746 & 4012 & 4476 & 4806 & 5188 & 6161 & 5956 \\
\hline $\mathrm{Ag}$ & 47 & 22,103 & 2129 & 2156 & 2348 & 2286 & 3012 & 3469 \\
\hline $\mathrm{Ba}$ & 0 & 0 & 0 & 0 & 0 & 0 & 0 & 0 \\
\hline $\mathrm{Pb}$ & 0 & 0 & 0 & 0 & 0 & 0 & 0 & 0 \\
\hline $\mathrm{Ni}$ & 0 & 0 & 0 & 0 & 0 & 0 & 0 & 0 \\
\hline
\end{tabular}

Tabela 13. Resultados das medidas de Fluorescência de Raios-X (XRF) para a amostra RT.I.1.64.059 (faces interna, externa e núcleo). 


\begin{tabular}{|c|c|c|c|c|c|c|c|c|}
\hline & & & $\begin{array}{r}\text { RT.I } \\
\text { FACE }\end{array}$ & $\begin{array}{l}.019 \\
\text { ERNA }\end{array}$ & $\begin{array}{r}\text { RT.I } \\
\text { FACE }\end{array}$ & $\begin{array}{l}.019 \\
\text { CERNA }\end{array}$ & $\begin{array}{r}\text { RT.I } \\
\text { NÚ }\end{array}$ & $\begin{array}{l}.019 \\
\text { EO }\end{array}$ \\
\hline $\begin{array}{l}\text { Elemento } \\
\text { Químico }\end{array}$ & $\mathbf{Z}$ & Energia & Área & Área & Área & Área & Área & Área \\
\hline $\mathrm{Mg}$ & 12 & 1,254 & 0 & 0 & 0 & 0 & -67 & -18 \\
\hline $\mathrm{Al}$ & 13 & 1,487 & 317 & 455 & 327 & 298 & 993 & 1035 \\
\hline $\mathrm{Si}$ & 14 & 1,74 & 6296 & 7699 & 4101 & 3804 & 14964 & 14742 \\
\hline $\mathrm{P}$ & 15 & 2,013 & 236 & 259 & 199 & 194 & 694 & 608 \\
\hline$S$ & 16 & 2,307 & 403 & 487 & 539 & 474 & 777 & 707 \\
\hline $\mathrm{Cl}$ & 17 & 2,622 & 804 & 831 & 746 & 840 & 647 & 694 \\
\hline $\mathrm{Ar}$ & 18 & 2,957 & 33041 & 32769 & 32303 & 33273 & 27219 & 27489 \\
\hline $\mathrm{K}$ & 19 & 3,313 & 17795 & 18384 & 12590 & 11326 & 24730 & 26665 \\
\hline $\mathrm{Ca}$ & 20 & 3,691 & 1298 & 1409 & 1459 & 1364 & 2464 & 2060 \\
\hline $\mathrm{Ti}$ & 22 & 4,509 & 46970 & 44502 & 38066 & 33207 & 67819 & 65968 \\
\hline $\mathrm{Cr}$ & 24 & 5,412 & 1256 & 3662 & 1273 & 969 & 1416 & 1494 \\
\hline $\mathrm{Mn}$ & 25 & 5,895 & 3007 & 3064 & 3424 & 3896 & 7847 & 6656 \\
\hline $\mathrm{Fe}$ & 26 & 6,399 & 135893 & 131981 & 140675 & 137131 & 271583 & 245178 \\
\hline $\mathrm{Cu}$ & 29 & 8,041 & 1186 & 1014 & 940 & 968 & 1824 & 1637 \\
\hline $\mathrm{Zn}$ & 30 & 8,631 & 1335 & 1282 & 1333 & 1320 & 2820 & 2640 \\
\hline $\mathrm{Ga}$ & 31 & 9,243 & 1380 & 1191 & 851 & 939 & 2258 & 1749 \\
\hline $\mathrm{Br}$ & 35 & 11,908 & 900 & 859 & 613 & 875 & 1585 & 1465 \\
\hline $\mathrm{Rb}$ & 37 & 13,375 & 2560 & 2652 & 2153 & 1905 & 4408 & 4517 \\
\hline $\mathrm{Sr}$ & 38 & 14,142 & 683 & 776 & 637 & 527 & 1441 & 1385 \\
\hline $\mathrm{Y}$ & 39 & 14,932 & 0 & 0 & 0 & 0 & 1606 & 1445 \\
\hline $\mathrm{Zr}$ & 40 & 15,746 & 6863 & 6089 & 6059 & 6161 & 14167 & 11564 \\
\hline $\mathrm{Ag}$ & 47 & 22,103 & 1721 & 2153 & 1684 & 1694 & 3384 & 3423 \\
\hline $\mathrm{Ba}$ & 0 & 0 & 0 & 0 & 0 & 0 & 0 & 0 \\
\hline $\mathrm{Pb}$ & 0 & 0 & 0 & 0 & 0 & 0 & 0 & 0 \\
\hline $\mathrm{Ni}$ & 0 & 0 & 0 & 0 & 0 & 0 & 0 & 0 \\
\hline
\end{tabular}

Tabela 14. Resultados das medidas de Fluorescência de Raios-X (XRF) para a amostra RT.I.1.64.019 (faces interna, externa e núcleo). 


\begin{tabular}{|c|c|c|c|c|c|c|c|c|}
\hline & & & $\begin{array}{r}\text { RT.I } \\
\text { FACE }\end{array}$ & $\begin{array}{l}.047 \\
\text { ERNA }\end{array}$ & $\begin{array}{r}\text { RT.I } \\
\text { FACE }\end{array}$ & $\begin{array}{l}.047 \\
\text { CERNA }\end{array}$ & $\begin{array}{r}\text { RT.I } \\
\text { NU }\end{array}$ & $\begin{array}{l}4.047 \\
\text { EO }\end{array}$ \\
\hline $\begin{array}{l}\text { Elemento } \\
\text { Químico }\end{array}$ & $\mathbf{Z}$ & Energia & Área & Área & Área & Área & Área & Área \\
\hline $\mathrm{Mg}$ & 12 & 1,254 & 0 & 0 & 0 & 0 & -22 & -47 \\
\hline $\mathrm{Al}$ & 13 & 1,487 & 544 & 655 & 974 & 613 & 1483 & 832 \\
\hline $\mathrm{Si}$ & 14 & 1,74 & 6128 & 7452 & 15934 & 10974 & 15516 & 9756 \\
\hline $\mathrm{P}$ & 15 & 2,013 & 416 & 525 & 402 & 332 & 1205 & 833 \\
\hline $\mathrm{S}$ & 16 & 2,307 & 1167 & 743 & 548 & 587 & 832 & 685 \\
\hline $\mathrm{Cl}$ & 17 & 2,622 & 741 & 692 & 726 & 867 & 589 & 794 \\
\hline $\mathrm{Ar}$ & 18 & 2,957 & 32548 & 32345 & 27798 & 30368 & 23361 & 29684 \\
\hline $\mathrm{K}$ & 19 & 3,313 & 14490 & 15914 & 24705 & 20170 & 20970 & 17744 \\
\hline $\mathrm{Ca}$ & 20 & 3,691 & 2647 & 1823 & 1739 & 1450 & 1990 & 1222 \\
\hline $\mathrm{Ti}$ & 22 & 4,509 & 59337 & 64925 & 97177 & 73505 & 82130 & 63866 \\
\hline $\mathrm{Cr}$ & 24 & 5,412 & 1213 & 1538 & 1781 & 1618 & 1523 & 1843 \\
\hline $\mathrm{Mn}$ & 25 & 5,895 & 6286 & 7188 & 4580 & 3881 & 7256 & 8986 \\
\hline $\mathrm{Fe}$ & 26 & 6,399 & 208849 & 234167 & 294893 & 219274 & 301008 & 267429 \\
\hline $\mathrm{Cu}$ & 29 & 8,041 & 1317 & 1419 & 2904 & 2032 & 1889 & 1474 \\
\hline $\mathrm{Zn}$ & 30 & 8,631 & 1814 & 2056 & 2534 & 1810 & 2425 & 2226 \\
\hline $\mathrm{Ga}$ & 31 & 9,243 & 1305 & 1658 & 2027 & 1635 & 2352 & 1979 \\
\hline $\mathrm{Br}$ & 35 & 11,908 & 871 & 1206 & 1543 & 1254 & 1743 & 1490 \\
\hline $\mathrm{Rb}$ & 37 & 13,375 & 2478 & 3116 & 4069 & 3181 & 4085 & 3918 \\
\hline $\mathrm{Sr}$ & 38 & 14,142 & 1099 & 1080 & 1357 & 1316 & 1724 & 1511 \\
\hline $\mathrm{Y}$ & 39 & 14,932 & 0 & 0 & 0 & 0 & 1658 & 1147 \\
\hline $\mathrm{Zr}$ & 40 & 15,746 & 7575 & 9017 & 12001 & 9593 & 12841 & 10110 \\
\hline $\mathrm{Ag}$ & 47 & 22,103 & 2158 & 2574 & 3135 & 2573 & 3736 & 2938 \\
\hline $\mathrm{Ba}$ & 0 & 0 & 0 & 0 & 0 & 0 & 0 & 0 \\
\hline $\mathrm{Pb}$ & 0 & 0 & 0 & 0 & 0 & 0 & 0 & 0 \\
\hline $\mathrm{Ni}$ & 0 & 0 & 0 & 0 & 0 & 0 & 0 & 0 \\
\hline
\end{tabular}

Tabela 15. Resultados das medidas de Fluorescência de Raios-X (XRF) para a amostra RT.I.1.64.047 (faces interna, externa e núcleo). 


\begin{tabular}{|c|c|c|c|c|c|c|c|c|}
\hline & & & $\begin{array}{r}\text { RT.I } \\
\text { FACE }\end{array}$ & $\begin{array}{l}4.141 \\
\text { [ERNA }\end{array}$ & $\begin{array}{r}\text { RT.I } \\
\text { FACE I }\end{array}$ & $\begin{array}{l}.141 \\
\text { ERNA }\end{array}$ & $\begin{array}{r}\text { RT.I } \\
\text { NÚ }\end{array}$ & $\begin{array}{l}4.141 \\
\text { EO }\end{array}$ \\
\hline $\begin{array}{l}\text { Elemento } \\
\text { Químico }\end{array}$ & $\mathbf{Z}$ & Energia & Área & Área & Área & Área & Área & Área \\
\hline $\mathrm{Mg}$ & 12 & 1,254 & 0 & 0 & -93 & 0 & -103 & -48 \\
\hline $\mathrm{Al}$ & 13 & 1,487 & 382 & 915 & 850 & 655 & 1238 & 1306 \\
\hline $\mathrm{Si}$ & 14 & 1,74 & 4290 & 10483 & 11115 & 8870 & 20627 & 18426 \\
\hline $\mathrm{P}$ & 15 & 2,013 & 279 & 487 & 518 & 407 & 837 & 802 \\
\hline $\mathrm{S}$ & 16 & 2,307 & 532 & 629 & 693 & 600 & 820 & 980 \\
\hline $\mathrm{Cl}$ & 17 & 2,622 & 874 & 723 & 909 & 805 & 587 & 614 \\
\hline $\mathrm{Ar}$ & 18 & 2,957 & 33985 & 30670 & 30025 & 31222 & 23774 & 23321 \\
\hline $\mathrm{K}$ & 19 & 3,313 & 11376 & 16632 & 15663 & 13780 & 18519 & 15666 \\
\hline $\mathrm{Ca}$ & 20 & 3,691 & 1523 & 1780 & 1974 & 1962 & 2401 & 2897 \\
\hline $\mathrm{Ti}$ & 22 & 4,509 & 47402 & 74810 & 71114 & 68401 & 93867 & 83590 \\
\hline $\mathrm{Cr}$ & 24 & 5,412 & 1159 & 2044 & 2015 & 1981 & 1832 & 1709 \\
\hline $\mathrm{Mn}$ & 25 & 5,895 & 2771 & 3370 & 6457 & 5045 & 6984 & 9218 \\
\hline $\mathrm{Fe}$ & 26 & 6,399 & 152108 & 233588 & 307137 & 281849 & 336699 & 345621 \\
\hline $\mathrm{Cu}$ & 29 & 8,041 & 1787 & 2850 & 2185 & 1991 & 3277 & 2713 \\
\hline $\mathrm{Zn}$ & 30 & 8,631 & 1057 & 1655 & 3363 & 2615 & 2362 & 2421 \\
\hline $\mathrm{Ga}$ & 31 & 9,243 & 1195 & 1693 & 1792 & 1633 & 2237 & 2164 \\
\hline $\mathrm{Br}$ & 35 & 11,908 & 937 & 1076 & 1121 & 894 & 1788 & 1583 \\
\hline $\mathrm{Rb}$ & 37 & 13,375 & 2315 & 3376 & 3269 & 2510 & 4331 & 4210 \\
\hline $\mathrm{Sr}$ & 38 & 14,142 & 509 & 923 & 865 & 820 & 1357 & 1285 \\
\hline $\mathrm{Y}$ & 39 & 14,932 & 0 & 0 & 1763 & 1814 & 2360 & 2353 \\
\hline $\mathrm{Zr}$ & 40 & 15,746 & 4957 & 7374 & 7939 & 7221 & 10490 & 11390 \\
\hline $\mathrm{Ag}$ & 47 & 22,103 & 1800 & 2732 & 2769 & 2429 & 4030 & 4361 \\
\hline $\mathrm{Ba}$ & 0 & 0 & 0 & 0 & 0 & 0 & 0 & 0 \\
\hline $\mathrm{Pb}$ & 0 & 0 & 0 & 0 & 0 & 0 & 0 & 0 \\
\hline $\mathrm{Ni}$ & 0 & 0 & 0 & 0 & 0 & 0 & 0 & 0 \\
\hline
\end{tabular}

Tabela 16. Resultados das medidas de Fluorescência de Raios-X (XRF) para a amostra RT.I.1.64.141 (faces interna, externa e núcleo). 


\begin{tabular}{|c|c|c|c|c|c|c|c|c|}
\hline & & & $\begin{array}{r}\text { RT.I } \\
\text { FACE }\end{array}$ & $\begin{array}{l}.236 \\
\text { ERNA }\end{array}$ & $\begin{array}{r}\text { RT.I } \\
\text { FACE }\end{array}$ & $\begin{array}{l}4.236 \\
\text { [ERNA }\end{array}$ & $\begin{array}{r}\text { RT.I } \\
\text { NU }\end{array}$ & $\begin{array}{l}4.236 \\
\text { EO }\end{array}$ \\
\hline $\begin{array}{l}\text { Elemento } \\
\text { Químico }\end{array}$ & $\mathbf{Z}$ & Energia & Área & Área & Área & Área & Área & Área \\
\hline $\mathrm{Mg}$ & 12 & 1,254 & -67 & -50 & -89 & -67 & 9 & -53 \\
\hline $\mathrm{Al}$ & 13 & 1,487 & 684 & 666 & 510 & 667 & 1947 & 1387 \\
\hline $\mathrm{Si}$ & 14 & 1,74 & 9613 & 8860 & 7704 & 12139 & 22755 & 14487 \\
\hline $\mathrm{P}$ & 15 & 2,013 & 366 & 324 & 299 & 152 & 432 & 1030 \\
\hline $\mathrm{S}$ & 16 & 2,307 & 1703 & 670 & 531 & 357 & 545 & 1023 \\
\hline $\mathrm{Cl}$ & 17 & 2,622 & 599 & 862 & 715 & 825 & 650 & 761 \\
\hline $\mathrm{Ar}$ & 18 & 2,957 & 30470 & 32531 & 30446 & 34348 & 26196 & 28275 \\
\hline $\mathrm{K}$ & 19 & 3,313 & 23016 & 22970 & 15204 & 25693 & 52680 & 38883 \\
\hline $\mathrm{Ca}$ & 20 & 3,691 & 3373 & 1170 & 1094 & 823 & 1572 & 1727 \\
\hline $\mathrm{Ti}$ & 22 & 4,509 & 31416 & 36273 & 58195 & 38878 & 40236 & 49938 \\
\hline $\mathrm{Cr}$ & 24 & 5,412 & 1483 & 1598 & 2436 & 1538 & 2071 & 1698 \\
\hline $\mathrm{Mn}$ & 25 & 5,895 & 2143 & 1767 & 1687 & 1552 & 2107 & 4573 \\
\hline $\mathrm{Fe}$ & 26 & 6,399 & 146476 & 143514 & 376749 & 118226 & 211290 & 237221 \\
\hline $\mathrm{Cu}$ & 29 & 8,041 & 1224 & 1261 & 1245 & 1273 & 1446 & 1553 \\
\hline $\mathrm{Zn}$ & 30 & 8,631 & 1680 & 1359 & 1124 & 1470 & 3037 & 1707 \\
\hline $\mathrm{Ga}$ & 31 & 9,243 & 1552 & 1372 & 1516 & 1857 & 2858 & 1815 \\
\hline $\mathrm{Br}$ & 35 & 11,908 & 1144 & 896 & 1033 & 908 & 1378 & 1519 \\
\hline $\mathrm{Rb}$ & 37 & 13,375 & 4429 & 4011 & 4011 & 4051 & 7818 & 7715 \\
\hline $\mathrm{Sr}$ & 38 & 14,142 & 2061 & 2098 & 1708 & 1975 & 4393 & 5340 \\
\hline $\mathrm{Y}$ & 39 & 14,932 & 870 & 827 & 437 & 818 & 1420 & 1195 \\
\hline $\mathrm{Zr}$ & 40 & 15,746 & 5279 & 4213 & 4862 & 5272 & 6893 & 7587 \\
\hline $\mathrm{Ag}$ & 47 & 22,103 & 2545 & 2608 & 2274 & 2700 & 4329 & 3654 \\
\hline $\mathrm{Ba}$ & 0 & 0 & 0 & 0 & 0 & 0 & 0 & 0 \\
\hline $\mathrm{Pb}$ & 0 & 0 & 0 & 0 & 0 & 0 & 0 & 0 \\
\hline $\mathrm{Ni}$ & 0 & 0 & 0 & 0 & 0 & 0 & 0 & 0 \\
\hline
\end{tabular}

Tabela 17. Resultados das medidas de Fluorescência de Raios-X (XRF) para a amostra RT.I.1.64.236 (faces interna, externa e núcleo). 


\begin{tabular}{|c|c|c|c|c|c|c|c|c|}
\hline & & & $\begin{array}{r}\text { RT.I. } \\
\text { FACE }\end{array}$ & $\begin{array}{l}.084 \\
\text { ERNA }\end{array}$ & $\begin{array}{r}\text { RT.I } \\
\text { FACE } \\
\end{array}$ & $\begin{array}{l}4.084 \\
\text { ГERNA }\end{array}$ & $\begin{array}{r}\text { RT.I. } \\
\text { NÚ }\end{array}$ & $\begin{array}{l}.084 \\
\text { EO }\end{array}$ \\
\hline $\begin{array}{l}\text { Elemento } \\
\text { Químico }\end{array}$ & $\mathbf{Z}$ & energia & Área & Área & Área & Área & Área & Área \\
\hline $\mathrm{Mg}$ & 12 & 1,254 & -82 & -90 & -69 & -40 & -37 & 34 \\
\hline $\mathrm{Al}$ & 13 & 1,487 & 974 & 852 & 852 & 1025 & 745 & 1404 \\
\hline $\mathrm{Si}$ & 14 & 1,74 & 10861 & 11192 & 12618 & 15915 & 11139 & 20679 \\
\hline $\mathrm{P}$ & 15 & 2,013 & 959 & 452 & 468 & 661 & 851 & 1064 \\
\hline$S$ & 16 & 2,307 & 757 & 650 & 662 & 620 & 971 & 997 \\
\hline $\mathrm{Cl}$ & 17 & 2,622 & 841 & 778 & 679 & 721 & 804 & 749 \\
\hline $\mathrm{Ar}$ & 18 & 2,957 & 30129 & 30803 & 28883 & 26106 & 27602 & 24024 \\
\hline $\mathrm{K}$ & 19 & 3,313 & 33699 & 33179 & 29400 & 29334 & 18682 & 39827 \\
\hline $\mathrm{Ca}$ & 20 & 3,691 & 829 & 754 & 629 & 840 & 1377 & 1664 \\
\hline $\mathrm{Ti}$ & 22 & 4,509 & 43052 & 39114 & 38050 & 39569 & 30368 & 46120 \\
\hline $\mathrm{Cr}$ & 24 & 5,412 & 1910 & 1699 & 1805 & 1857 & 1876 & 1851 \\
\hline $\mathrm{Mn}$ & 25 & 5,895 & 3476 & 3360 & 3167 & 3939 & 8137 & 6536 \\
\hline $\mathrm{Fe}$ & 26 & 6,399 & 163180 & 136679 & 125226 & 132100 & 196362 & 210534 \\
\hline $\mathrm{Cu}$ & 29 & 8,041 & 1830 & 1758 & 1470 & 1568 & 1492 & 2115 \\
\hline $\mathrm{Zn}$ & 30 & 8,631 & 2296 & 1782 & 1626 & 1634 & 2170 & 2227 \\
\hline $\mathrm{Ga}$ & 31 & 9,243 & 2570 & 1912 & 1675 & 2125 & 2206 & 2548 \\
\hline $\mathrm{Br}$ & 35 & 11,908 & 1277 & 1238 & 1380 & 1385 & 1810 & 2212 \\
\hline $\mathrm{Rb}$ & 37 & 13,375 & 5128 & 4285 & 4284 & 4685 & 4797 & 6724 \\
\hline $\mathrm{Sr}$ & 38 & 14,142 & 3132 & 2394 & 2687 & 2650 & 2648 & 3898 \\
\hline $\mathrm{Y}$ & 39 & 14,932 & 689 & 872 & 925 & 805 & 1214 & 1111 \\
\hline $\mathrm{Zr}$ & 40 & 15,746 & 6100 & 5524 & 6291 & 6881 & 8125 & 9686 \\
\hline $\mathrm{Ag}$ & 47 & 22,103 & 3178 & 2719 & 2914 & 3638 & 3557 & 4417 \\
\hline $\mathrm{Ba}$ & 0 & 0 & 0 & 0 & 0 & 0 & 0 & 0 \\
\hline $\mathrm{Pb}$ & 0 & 0 & 0 & 0 & 0 & 0 & 0 & 0 \\
\hline $\mathrm{Ni}$ & 0 & 0 & 0 & 0 & 0 & 0 & 0 & 0 \\
\hline
\end{tabular}

Tabela 18. Resultados das medidas de Fluorescência de Raios-X (XRF) para a amostra RT.I.1.64.084 (faces interna, externa e núcleo). 


\begin{tabular}{|c|c|c|c|c|c|c|c|c|}
\hline & & & $\begin{array}{r}\text { RT.I. } \\
\text { FACE }\end{array}$ & $\begin{array}{l}.092 \\
\text { ERNA }\end{array}$ & $\begin{array}{r}\text { RT.I } \\
\text { FACE I }\end{array}$ & $\begin{array}{l}4.092 \\
\text { IERNA }\end{array}$ & $\begin{array}{r}\text { RT.I } \\
\text { NÚ }\end{array}$ & $\begin{array}{l}4.092 \\
\text { EO }\end{array}$ \\
\hline $\begin{array}{l}\text { Elemento } \\
\text { Químico }\end{array}$ & $\mathbf{Z}$ & energia & Área & Área & Área & Área & Área & Área \\
\hline $\mathrm{Mg}$ & 12 & 1,254 & -68 & -86 & -94 & -112 & -23 & -85 \\
\hline $\mathrm{Al}$ & 13 & 1,487 & 700 & 537 & 598 & 573 & 1111 & 919 \\
\hline $\mathrm{Si}$ & 14 & 1,74 & 11284 & 7129 & 5376 & 7294 & 16419 & 10900 \\
\hline $\mathrm{P}$ & 15 & 2,013 & 246 & 482 & 658 & 442 & 840 & 793 \\
\hline$S$ & 16 & 2,307 & 461 & 763 & 1032 & 876 & 906 & 902 \\
\hline $\mathrm{Cl}$ & 17 & 2,622 & 845 & 899 & 978 & 1089 & 680 & 640 \\
\hline $\mathrm{Ar}$ & 18 & 2,957 & 30506 & 32240 & 33181 & 32300 & 21470 & 25258 \\
\hline $\mathrm{K}$ & 19 & 3,313 & 27551 & 22024 & 20747 & 23293 & 34203 & 18083 \\
\hline $\mathrm{Ca}$ & 20 & 3,691 & 1265 & 1699 & 2481 & 2398 & 2151 & 2561 \\
\hline $\mathrm{Ti}$ & 22 & 4,509 & 39671 & 34144 & 35000 & 37970 & 24706 & 28952 \\
\hline $\mathrm{Cr}$ & 24 & 5,412 & 1767 & 1577 & 1670 & 1811 & 1485 & 2020 \\
\hline $\mathrm{Mn}$ & 25 & 5,895 & 1944 & 4673 & 9744 & 4944 & 10970 & 12255 \\
\hline $\mathrm{Fe}$ & 26 & 6,399 & 102062 & 185464 & 266160 & 179149 & 217644 & 273353 \\
\hline $\mathrm{Cu}$ & 29 & 8,041 & 1865 & 1663 & 1554 & 1772 & 1504 & 1337 \\
\hline $\mathrm{Zn}$ & 30 & 8,631 & 2333 & 2196 & 1916 & 2171 & 3063 & 2802 \\
\hline $\mathrm{Ga}$ & 31 & 9,243 & 1555 & 1588 & 1695 & 1713 & 1815 & 1736 \\
\hline $\mathrm{Br}$ & 35 & 11,908 & 1036 & 1285 & 1386 & 1082 & 1560 & 1502 \\
\hline $\mathrm{Rb}$ & 37 & 13,375 & 4194 & 3896 & 4410 & 4234 & 5710 & 4557 \\
\hline $\mathrm{Sr}$ & 38 & 14,142 & 2210 & 2179 & 2436 & 2095 & 4697 & 2643 \\
\hline $\mathrm{Y}$ & 39 & 14,932 & 978 & 966 & 1060 & 983 & 849 & 725 \\
\hline $\mathrm{Zr}$ & 40 & 15,746 & 6095 & 5887 & 6067 & 6691 & 6541 & 6609 \\
\hline $\mathrm{Ag}$ & 47 & 22,103 & 2629 & 2512 & 2924 & 2621 & 3944 & 3749 \\
\hline $\mathrm{Ba}$ & 0 & 0 & 0 & 0 & 0 & 0 & 0 & 0 \\
\hline $\mathrm{Pb}$ & 0 & 0 & 0 & 0 & 0 & 0 & 0 & 0 \\
\hline $\mathrm{Ni}$ & 0 & 0 & 0 & 0 & 0 & 0 & 0 & 0 \\
\hline
\end{tabular}

Tabela 19. Resultados das medidas de Fluorescência de Raios-X (XRF) para a amostra RT.I.1.64.092 (faces interna, externa e núcleo). 


\begin{tabular}{|c|c|c|c|c|c|c|c|c|}
\hline & & & $\begin{array}{r}\text { RT.I } \\
\text { FACE }\end{array}$ & $\begin{array}{l}4.252 \\
\text { ERNA }\end{array}$ & $\begin{array}{r}\text { RT.I } \\
\text { FACE }\end{array}$ & $\begin{array}{l}4.252 \\
\text { IERNA }\end{array}$ & $\begin{array}{r}\text { RT.I } \\
\text { NÚ }\end{array}$ & $\begin{array}{l}4.252 \\
\text { EO }\end{array}$ \\
\hline $\begin{array}{l}\text { Elemento } \\
\text { Químico }\end{array}$ & $\mathbf{Z}$ & energia & Área & Área & Área & Área & Área & Área \\
\hline $\mathrm{Mg}$ & 12 & 1,254 & -47 & -8 & -51 & -77 & -30 & -53 \\
\hline $\mathrm{Al}$ & 13 & 1,487 & 763 & 720 & 897 & 662 & 1078 & 958 \\
\hline $\mathrm{Si}$ & 14 & 1,74 & 12601 & 11619 & 12593 & 9733 & 16831 & 15938 \\
\hline $\mathrm{P}$ & 15 & 2,013 & 310 & 263 & 204 & 308 & 282 & 325 \\
\hline $\mathrm{S}$ & 16 & 2,307 & 716 & 726 & 465 & 584 & 556 & 610 \\
\hline $\mathrm{Cl}$ & 17 & 2,622 & 778 & 731 & 818 & 885 & 655 & 782 \\
\hline $\mathrm{Ar}$ & 18 & 2,957 & 29023 & 30260 & 30011 & 30769 & 26697 & 25844 \\
\hline $\mathrm{K}$ & 19 & 3,313 & 25073 & 24663 & 34798 & 34230 & 32789 & 30901 \\
\hline $\mathrm{Ca}$ & 20 & 3,691 & 1115 & 1261 & 814 & 776 & 1118 & 1387 \\
\hline $\mathrm{Ti}$ & 22 & 4,509 & 37313 & 40279 & 40628 & 30581 & 46479 & 34304 \\
\hline $\mathrm{Cr}$ & 24 & 5,412 & 1672 & 1618 & 1455 & 1613 & 2048 & 1739 \\
\hline $\mathrm{Mn}$ & 25 & 5,895 & 2894 & 2733 & 1895 & 3276 & 1743 & 2561 \\
\hline $\mathrm{Fe}$ & 26 & 6,399 & 170271 & 171684 & 176716 & 154643 & 212763 & 157292 \\
\hline $\mathrm{Cu}$ & 29 & 8,041 & 1517 & 1326 & 1940 & 1241 & 1784 & 1969 \\
\hline $\mathrm{Zn}$ & 30 & 8,631 & 1607 & 1490 & 1468 & 1133 & 1807 & 1437 \\
\hline $\mathrm{Ga}$ & 31 & 9,243 & 1855 & 1949 & 1919 & 1741 & 2087 & 1892 \\
\hline $\mathrm{Br}$ & 35 & 11,908 & 962 & 1086 & 983 & 960 & 957 & 982 \\
\hline $\mathrm{Rb}$ & 37 & 13,375 & 4511 & 3971 & 4539 & 4251 & 5546 & 5930 \\
\hline $\mathrm{Sr}$ & 38 & 14,142 & 2100 & 2085 & 2212 & 2093 & 2544 & 3126 \\
\hline $\mathrm{Y}$ & 39 & 14,932 & 836 & 739 & 732 & 780 & 1109 & 861 \\
\hline $\mathrm{Zr}$ & 40 & 15,746 & 4938 & 5481 & 5334 & 6002 & 8022 & 5927 \\
\hline $\mathrm{Ag}$ & 47 & 22,103 & 2644 & 2799 & 2769 & 2436 & 3547 & 3570 \\
\hline $\mathrm{Ba}$ & 0 & 0 & 0 & 0 & 0 & 0 & 0 & 0 \\
\hline $\mathrm{Pb}$ & 0 & & 0 & 0 & 0 & 0 & 0 & 0 \\
\hline $\mathrm{Ni}$ & 0 & 0 & 0 & 0 & 0 & 0 & 0 & 0 \\
\hline
\end{tabular}

Tabela 20. Resultados das medidas de Fluorescência de Raios-X (XRF) para a amostra RT.I.1.64.252 (faces interna, externa e núcleo). 


\begin{tabular}{|c|c|c|c|c|c|c|c|c|}
\hline & & & $\begin{array}{r}\text { RT.I } \\
\text { FACE }\end{array}$ & $\begin{array}{l}4.038 \\
\text { ERNA }\end{array}$ & $\begin{array}{r}\text { RT.I. } \\
\text { FACE E }\end{array}$ & $\begin{array}{l}4.038 \\
\text { TERNA }\end{array}$ & $\begin{array}{r}\text { RT.I } \\
\text { NÚ }\end{array}$ & $\begin{array}{l}4.038 \\
\text { EO }\end{array}$ \\
\hline $\begin{array}{l}\text { Elemento } \\
\text { Químico }\end{array}$ & $\mathbf{Z}$ & energia & Área & Área & Área & Área & Área & Área \\
\hline $\mathrm{Mg}$ & 12 & 1,254 & -8 & 21 & -42 & -56 & -1 & -32 \\
\hline $\mathrm{Al}$ & 13 & 1,487 & 1775 & 2410 & 1379 & 1558 & 1936 & 1753 \\
\hline $\mathrm{Si}$ & 14 & 1,74 & 21954 & 23554 & 10005 & 19098 & 20955 & 20365 \\
\hline $\mathrm{P}$ & 15 & 2,013 & 623 & 720 & 314 & 530 & 462 & 277 \\
\hline $\mathrm{S}$ & 16 & 2,307 & 1126 & 785 & 1600 & 608 & 792 & 444 \\
\hline $\mathrm{Cl}$ & 17 & 2,622 & 622 & 530 & 989 & 596 & 668 & 1488 \\
\hline $\mathrm{Ar}$ & 18 & 2,957 & 23183 & 18637 & 29784 & 24436 & 16929 & 21044 \\
\hline $\mathrm{K}$ & 19 & 3,313 & 36236 & 38439 & 24795 & 32094 & 41938 & 37085 \\
\hline $\mathrm{Ca}$ & 20 & 3,691 & 2243 & 1978 & 893 & 1179 & 1806 & 1518 \\
\hline $\mathrm{Ti}$ & 22 & 4,509 & 54690 & 57378 & 37190 & 51822 & 43556 & 28208 \\
\hline $\mathrm{Cr}$ & 24 & 5,412 & 1906 & 1769 & 2217 & 1839 & 1711 & 1637 \\
\hline $\mathrm{Mn}$ & 25 & 5,895 & 2991 & 3117 & 1858 & 3733 & 2483 & 1217 \\
\hline $\mathrm{Fe}$ & 26 & 6,399 & 278300 & 292247 & 417790 & 282007 & 248437 & 180934 \\
\hline $\mathrm{Cu}$ & 29 & 8,041 & 2039 & 1331 & 3612 & 1640 & 943 & 1308 \\
\hline $\mathrm{Zn}$ & 30 & 8,631 & 2663 & 2558 & 2300 & 1806 & 1451 & 1933 \\
\hline $\mathrm{Ga}$ & 31 & 9,243 & 2379 & 2123 & 2019 & 2038 & 2290 & 1763 \\
\hline $\mathrm{Br}$ & 35 & 11,908 & 1597 & 1832 & 1039 & 1367 & 1753 & 1029 \\
\hline $\mathrm{Rb}$ & 37 & 13,375 & 6149 & 6394 & 6104 & 5855 & 6427 & 4758 \\
\hline $\mathrm{Sr}$ & 38 & 14,142 & 2998 & 3425 & 2791 & 2936 & 3786 & 2659 \\
\hline $\mathrm{Y}$ & 39 & 14,932 & 1430 & 1207 & 1119 & 1166 & 1134 & 647 \\
\hline $\mathrm{Zr}$ & 40 & 15,746 & 7660 & 8966 & 7169 & 7765 & 8623 & 4764 \\
\hline $\mathrm{Ag}$ & 47 & 22,103 & 3969 & 4741 & 3256 & 3842 & 4342 & 3429 \\
\hline $\mathrm{Ba}$ & 0 & 0 & 0 & 0 & 0 & 0 & 0 & 0 \\
\hline $\mathrm{Pb}$ & 0 & 0 & 0 & 0 & 0 & 0 & 0 & 0 \\
\hline $\mathrm{Ni}$ & 0 & 0 & 0 & 0 & 0 & 0 & 0 & 0 \\
\hline
\end{tabular}

Tabela 21. Resultados das medidas de Fluorescência de Raios-X (XRF) para a amostra RT.I.1.64.038 (faces interna, externa e núcleo). 


\begin{tabular}{|c|c|c|c|c|c|c|c|c|}
\hline \multirow[b]{2}{*}{$\begin{array}{l}\text { Elemento } \\
\text { Ouímico }\end{array}$} & \multirow[b]{2}{*}{$\mathbf{Z}$} & \multirow[b]{2}{*}{ energia } & \multicolumn{2}{|c|}{$\begin{array}{c}\text { TRV.1097.1 } \\
\text { FACE INTERNA }\end{array}$} & \multicolumn{2}{|c|}{$\begin{array}{c}\text { TRV.1097.1 } \\
\text { FACE EXTERNA }\end{array}$} & \multicolumn{2}{|c|}{$\begin{array}{l}\text { TRV.1097.1 } \\
\text { NÚCLEO }\end{array}$} \\
\hline & & & Área & Área & Área & Área & Área & Área \\
\hline $\mathrm{Mg}$ & 12 & 1,254 & -45 & -61 & -33 & -56 & 27 & -53 \\
\hline $\mathrm{Al}$ & 13 & 1,487 & 1562 & 1452 & 1515 & 1491 & 2070 & 1517 \\
\hline $\mathrm{Si}$ & 14 & 1,74 & 13815 & 12231 & 13627 & 12609 & 22449 & 15393 \\
\hline $\mathrm{P}$ & 15 & 2,013 & 282 & 211 & 217 & 174 & 303 & 250 \\
\hline $\mathrm{S}$ & 16 & 2,307 & 610 & 648 & 822 & 903 & 956 & 1096 \\
\hline $\mathrm{Cl}$ & 17 & 2,622 & 835 & 911 & 834 & 886 & 810 & 565 \\
\hline $\mathrm{Ar}$ & 18 & 2,957 & 28078 & 29153 & 27815 & 28470 & 20609 & 21651 \\
\hline $\mathrm{K}$ & 19 & 3,313 & 34621 & 32404 & 39439 & 39546 & 39390 & 32176 \\
\hline $\mathrm{Ca}$ & 20 & 3,691 & 639 & 883 & 963 & 788 & 1144 & 786 \\
\hline $\mathrm{Ti}$ & 22 & 4,509 & 51623 & 55587 & 48913 & 43670 & 52880 & 30586 \\
\hline $\mathrm{Cr}$ & 24 & 5,412 & 1982 & 1658 & 2009 & 1768 & 1774 & 944 \\
\hline $\mathrm{Mn}$ & 25 & 5,895 & 2951 & 3099 & 8375 & 9599 & 6884 & 7071 \\
\hline $\mathrm{Fe}$ & 26 & 6,399 & 193655 & 190072 & 237096 & 208878 & 277998 & 201940 \\
\hline $\mathrm{Cu}$ & 29 & 8,041 & 1982 & 1474 & 1702 & 2032 & 1543 & 822 \\
\hline $\mathrm{Zn}$ & 30 & 8,631 & 2211 & 2471 & 4840 & 4510 & 2617 & 1473 \\
\hline $\mathrm{Ga}$ & 31 & 9,243 & 2365 & 2281 & 2299 & 2081 & 2637 & 1791 \\
\hline $\mathrm{Br}$ & 35 & 11,908 & 2402 & 2263 & 2138 & 2278 & 3187 & 2180 \\
\hline $\mathrm{Rb}$ & 37 & 13,375 & 5191 & 5077 & 5577 & 5776 & 6477 & 5533 \\
\hline $\mathrm{Sr}$ & 38 & 14,142 & 3059 & 2710 & 2945 & 3313 & 3635 & 3077 \\
\hline $\mathrm{Y}$ & 39 & 14,932 & 827 & 1023 & 855 & 972 & 1390 & 924 \\
\hline $\mathrm{Zr}$ & 40 & 15,746 & 8983 & 8004 & 8145 & 6733 & 11345 & 8781 \\
\hline $\mathrm{Ag}$ & 47 & 22,103 & 3195 & 3023 & 3273 & 3268 & 4539 & 3857 \\
\hline $\mathrm{Ba}$ & 0 & 0 & 0 & 0 & 0 & 0 & 0 & 0 \\
\hline $\mathrm{Pb}$ & 0 & 0 & 0 & 0 & 0 & 0 & 0 & 0 \\
\hline $\mathrm{Ni}$ & 0 & 0 & 0 & 0 & 0 & 0 & 0 & 0 \\
\hline
\end{tabular}

Tabela 22. Resultados das medidas de Fluorescência de Raios-X (XRF) para a amostra TRV.1097.1 (faces interna, externa e núcleo). 


\begin{tabular}{|c|c|c|c|c|c|c|c|c|}
\hline & & & $\begin{array}{r}\text { RT.I } \\
\text { FACE }\end{array}$ & $\begin{array}{l}4.037 \\
\text { [ERNA }\end{array}$ & $\begin{array}{r}\text { RT.I } \\
\text { FACE }\end{array}$ & $\begin{array}{l}4.037 \\
\text { ГERNA }\end{array}$ & $\begin{array}{l}\text { RT.I. } \\
\text { NÚ }\end{array}$ & $\begin{array}{l}4.037 \\
\text { EO }\end{array}$ \\
\hline $\begin{array}{l}\text { Elemento } \\
\text { Químico }\end{array}$ & $\mathbf{Z}$ & energia & Área & Área & Área & Área & Área & Área \\
\hline $\mathrm{Mg}$ & 12 & 1,254 & -75 & -98 & -25 & -64 & -39 & -15 \\
\hline $\mathrm{Al}$ & 13 & 1,487 & 1078 & 266 & 970 & 1575 & 1308 & 1551 \\
\hline $\mathrm{Si}$ & 14 & 1,74 & 10236 & 2529 & 11192 & 16169 & 10751 & 13222 \\
\hline $\mathrm{P}$ & 15 & 2,013 & 822 & 138 & 528 & 876 & 1043 & 937 \\
\hline$S$ & 16 & 2,307 & 1057 & 859 & 458 & 718 & 905 & 1047 \\
\hline $\mathrm{Cl}$ & 17 & 2,622 & 780 & 3250 & 455 & 746 & 635 & 847 \\
\hline $\mathrm{Ar}$ & 18 & 2,957 & 27150 & 17680 & 14385 & 22761 & 23695 & 23927 \\
\hline K & 19 & 3,313 & 28915 & 10951 & 24274 & 36048 & 25090 & 33041 \\
\hline $\mathrm{Ca}$ & 20 & 3,691 & 1774 & 127148 & 1242 & 1675 & 1846 & 1894 \\
\hline $\mathrm{Ti}$ & 22 & 4,509 & 82310 & 355184 & 62523 & 94953 & 66305 & 89867 \\
\hline $\mathrm{Cr}$ & 24 & 5,412 & 1556 & 280 & 849 & 1439 & 1308 & 1473 \\
\hline $\mathrm{Mn}$ & 25 & 5,895 & 13706 & 4242 & 5798 & 9067 & 16269 & 15674 \\
\hline $\mathrm{Fe}$ & 26 & 6,399 & 450221 & 195580 & 307511 & 442715 & 341321 & 483028 \\
\hline $\mathrm{Cu}$ & 29 & 8,041 & 1504 & 2437 & 964 & 1329 & 1517 & 1775 \\
\hline $\mathrm{Zn}$ & 30 & 8,631 & 6001 & 942262 & 3580 & 5818 & 5048 & 6588 \\
\hline $\mathrm{Ga}$ & 31 & 9,243 & 1652 & 4747 & 1279 & 2098 & 1686 & 2041 \\
\hline $\mathrm{Br}$ & 35 & 11,908 & 1764 & 1833 & 1440 & 2198 & 2081 & 2014 \\
\hline $\mathrm{Rb}$ & 37 & 13,375 & 4308 & 3026 & 3138 & 4542 & 4257 & 4957 \\
\hline $\mathrm{Sr}$ & 38 & 14,142 & 1591 & 2309 & 1018 & 1689 & 1559 & 2075 \\
\hline $\mathrm{Y}$ & 39 & 14,932 & 1286 & 2663 & 960 & 1626 & 1096 & 1258 \\
\hline $\mathrm{Zr}$ & 40 & 15,746 & 11639 & 8678 & 9098 & 13385 & 10953 & 13625 \\
\hline $\mathrm{Ag}$ & 47 & 22,103 & 3080 & 3348 & 2608 & 4025 & 3983 & 3909 \\
\hline $\mathrm{Ba}$ & 0 & 0 & 0 & 0 & 0 & 0 & 0 & 0 \\
\hline $\mathrm{Pb}$ & 0 & 0 & 0 & 0 & 0 & 0 & 0 & 0 \\
\hline $\mathrm{Ni}$ & 0 & 0 & 0 & 0 & 0 & 0 & 0 & 0 \\
\hline
\end{tabular}

Tabela 23. Resultados das medidas de Fluorescência de Raios-X (XRF) para a amostra RT.I.1.64.037 (faces interna, externa e núcleo). 


\begin{tabular}{|c|c|c|c|c|c|c|c|c|}
\hline & & & $\begin{array}{r}\text { TR } \\
\text { FACE }\end{array}$ & $\begin{array}{l}13.1 \\
\text { ERNA }\end{array}$ & $\begin{array}{r}\text { TR } \\
\text { FACE }\end{array}$ & $\begin{array}{l}\text { I3.1 } \\
\text { [ERNA }\end{array}$ & $\begin{array}{l}\text { TR } \\
\text { NÚ }\end{array}$ & $\begin{array}{l}3.1 \\
90\end{array}$ \\
\hline $\begin{array}{l}\text { Elemento } \\
\text { Químico }\end{array}$ & $\mathbf{Z}$ & energia & Área & Área & Área & Área & Área & Área \\
\hline $\mathrm{Mg}$ & 12 & 1,254 & 2 & -35 & -21 & -37 & 51 & -17 \\
\hline $\mathrm{Al}$ & 13 & 1,487 & 1124 & 946 & 1091 & 1273 & 1788 & 479 \\
\hline $\mathrm{Si}$ & 14 & 1,74 & 14860 & 11721 & 18308 & 18123 & 25799 & 10415 \\
\hline $\mathrm{P}$ & 15 & 2,013 & 198 & 161 & 152 & 205 & 274 & 64 \\
\hline$S$ & 16 & 2,307 & 530 & 715 & 518 & 591 & 537 & 419 \\
\hline $\mathrm{Cl}$ & 17 & 2,622 & 820 & 986 & 751 & 773 & 514 & 737 \\
\hline $\mathrm{Ar}$ & 18 & 2,957 & 28071 & 29337 & 25408 & 24906 & 18962 & 28839 \\
\hline $\mathrm{K}$ & 19 & 3,313 & 23887 & 23216 & 25552 & 27066 & 25525 & 9755 \\
\hline $\mathrm{Ca}$ & 20 & 3,691 & 1003 & 1354 & 1117 & 1226 & 2113 & 584 \\
\hline $\mathrm{Ti}$ & 22 & 4,509 & 68749 & 73662 & 62902 & 71624 & 63564 & 26247 \\
\hline $\mathrm{Cr}$ & 24 & 5,412 & 1795 & 1635 & 1949 & 1905 & 1851 & 1001 \\
\hline $\mathrm{Mn}$ & 25 & 5,895 & 5414 & 3293 & 5200 & 5049 & 5865 & 2493 \\
\hline $\mathrm{Fe}$ & 26 & 6,399 & 220719 & 221164 & 206249 & 221122 & 238867 & 99894 \\
\hline $\mathrm{Cu}$ & 29 & 8,041 & 2606 & 2303 & 2142 & 1984 & 1716 & 855 \\
\hline $\mathrm{Zn}$ & 30 & 8,631 & 1933 & 1564 & 1647 & 1431 & 1759 & 729 \\
\hline $\mathrm{Ga}$ & 31 & 9,243 & 2177 & 1990 & 2529 & 2272 & 3083 & 3815 \\
\hline $\mathrm{Br}$ & 35 & 11,908 & 1644 & 1565 & 2089 & 2072 & 2837 & 1330 \\
\hline $\mathrm{Rb}$ & 37 & 13,375 & 5827 & 5236 & 5972 & 6587 & 7416 & 2787 \\
\hline $\mathrm{Sr}$ & 38 & 14,142 & 996 & 1053 & 1272 & 1037 & 1647 & 704 \\
\hline $\mathrm{Y}$ & 39 & 14,932 & 1567 & 1637 & 1863 & 1970 & 2025 & 873 \\
\hline $\mathrm{Zr}$ & 40 & 15,746 & 8872 & 8700 & 9893 & 10004 & 11906 & 5173 \\
\hline $\mathrm{Ag}$ & 47 & 22,103 & 3191 & 3287 & 3692 & 3761 & 4707 & 2037 \\
\hline $\mathrm{Ba}$ & 0 & 0 & 0 & 0 & 0 & 0 & 0 & 0 \\
\hline $\mathrm{Pb}$ & 0 & 0 & 0 & 0 & 0 & 0 & 0 & 0 \\
\hline $\mathrm{Ni}$ & 0 & 0 & 0 & 0 & 0 & 0 & 0 & 0 \\
\hline
\end{tabular}

Tabela 24. Resultados das medidas de Fluorescência de Raios-X (XRF) para a amostra TRV.513.1 (faces interna, externa e núcleo). 


\begin{tabular}{|c|c|c|c|c|c|c|c|c|}
\hline & & & $\begin{array}{r}\text { TR } \\
\text { FACE }\end{array}$ & $\begin{array}{l}46.2 \\
\text { CERNA }\end{array}$ & $\begin{array}{r}\text { TR } \\
\text { FACE } \\
\end{array}$ & $\begin{array}{l}6.2 \\
\text { CERNA }\end{array}$ & $\begin{array}{l}\text { TR } \\
\text { NÚ }\end{array}$ & $\begin{array}{l}46.2 \\
\text { EO }\end{array}$ \\
\hline $\begin{array}{l}\text { Elemento } \\
\text { Químico }\end{array}$ & $\mathbf{Z}$ & energia & Área & Área & Área & Área & Área & Área \\
\hline $\mathrm{Mg}$ & 12 & 1,254 & -46 & -25 & 8 & 8 & -53 & -61 \\
\hline $\mathrm{Al}$ & 13 & 1,487 & 871 & 919 & 633 & 1548 & 1529 & 712 \\
\hline $\mathrm{Si}$ & 14 & 1,74 & 16937 & 15717 & 8468 & 25799 & 21320 & 12129 \\
\hline $\mathrm{P}$ & 15 & 2,013 & 50 & 115 & 68 & 156 & 218 & 133 \\
\hline$S$ & 16 & 2,307 & 542 & 432 & 154 & 606 & 526 & 437 \\
\hline $\mathrm{Cl}$ & 17 & 2,622 & 760 & 712 & 182 & 648 & 694 & 771 \\
\hline $\mathrm{Ar}$ & 18 & 2,957 & 27769 & 27887 & 6464 & 22576 & 19644 & 28413 \\
\hline $\mathrm{K}$ & 19 & 3,313 & 21963 & 24979 & 9407 & 28292 & 22508 & 19539 \\
\hline $\mathrm{Ca}$ & 20 & 3,691 & 781 & 869 & 308 & 1225 & 967 & 522 \\
\hline $\mathrm{Ti}$ & 22 & 4,509 & 60722 & 62366 & 25779 & 75288 & 59695 & 48169 \\
\hline $\mathrm{Cr}$ & 24 & 5,412 & 1514 & 1948 & 527 & 1916 & 1951 & 1454 \\
\hline $\mathrm{Mn}$ & 25 & 5,895 & 2361 & 2306 & 1141 & 3917 & 3159 & 2646 \\
\hline $\mathrm{Fe}$ & 26 & 6,399 & 212874 & 203118 & 71820 & 222847 & 185374 & 142661 \\
\hline $\mathrm{Cu}$ & 29 & 8,041 & 2049 & 2041 & 730 & 2087 & 2548 & 1549 \\
\hline $\mathrm{Zn}$ & 30 & 8,631 & 1647 & 1575 & 1004 & 4817 & 1822 & 1565 \\
\hline $\mathrm{Ga}$ & 31 & 9,243 & 2183 & 2027 & 846 & 2527 & 2675 & 1928 \\
\hline $\mathrm{Br}$ & 35 & 11,908 & 1891 & 1542 & 556 & 1628 & 2064 & 1108 \\
\hline $\mathrm{Rb}$ & 37 & 13,375 & 5240 & 5372 & 2350 & 7014 & 5719 & 4626 \\
\hline $\mathrm{Sr}$ & 38 & 14,142 & 914 & 744 & 454 & 1110 & 1013 & 619 \\
\hline $\mathrm{Y}$ & 39 & 14,932 & 1382 & 1180 & 710 & 1862 & 1520 & 979 \\
\hline $\mathrm{Zr}$ & 40 & 15,746 & 8454 & 7699 & 3565 & 10402 & 10956 & 6872 \\
\hline $\mathrm{Ag}$ & 47 & 22,103 & 3368 & 3037 & 1455 & 4603 & 4405 & 2645 \\
\hline $\mathrm{Ba}$ & 0 & 0 & 0 & 0 & 0 & 0 & 0 & 0 \\
\hline $\mathrm{Pb}$ & 0 & 0 & 0 & 0 & 0 & 0 & 0 & 0 \\
\hline $\mathrm{Ni}$ & 0 & 0 & 0 & 0 & 0 & 0 & 0 & 0 \\
\hline
\end{tabular}

Tabela 25. Resultados das medidas de Fluorescência de Raios-X (XRF) para a amostra TRV.546.2 (faces interna, externa e núcleo). 


\begin{tabular}{|c|c|c|c|c|c|c|c|c|}
\hline \multirow[b]{2}{*}{$\begin{array}{l}\text { Elemento } \\
\text { Químico }\end{array}$} & \multirow[b]{2}{*}{$\mathbf{Z}$} & \multirow[b]{2}{*}{ energia } & \multicolumn{2}{|c|}{$\begin{array}{c}\text { TRV.416.2 } \\
\text { FACE INTERNA }\end{array}$} & \multicolumn{2}{|c|}{$\begin{array}{c}\text { TRV.416.2 } \\
\text { FACE EXTERNA }\end{array}$} & \multicolumn{2}{|c|}{$\begin{array}{l}\text { TRV.416.2 } \\
\text { NÚCLEO } \\
\end{array}$} \\
\hline & & & Área & Área & Área & Área & Área & Área \\
\hline $\mathrm{Mg}$ & 12 & 1,254 & -54 & -39 & 15 & -61 & -7 & -13 \\
\hline $\mathrm{Al}$ & 13 & 1,487 & 1050 & 472 & 1686 & 1643 & 1306 & 1251 \\
\hline $\mathrm{Si}$ & 14 & 1,74 & 16404 & 8082 & 22345 & 20100 & 13735 & 13820 \\
\hline $\mathrm{P}$ & 15 & 2,013 & 172 & 62 & 306 & 268 & 222 & 212 \\
\hline $\mathrm{S}$ & 16 & 2,307 & 499 & 228 & 661 & 639 & 273 & 438 \\
\hline $\mathrm{Cl}$ & 17 & 2,622 & 751 & 281 & 646 & 523 & 464 & 514 \\
\hline $\mathrm{Ar}$ & 18 & 2,957 & 26113 & 13424 & 21077 & 21733 & 19866 & 18822 \\
\hline $\mathrm{K}$ & 19 & 3,313 & 23666 & 12084 & 25295 & 25298 & 12753 & 15880 \\
\hline $\mathrm{Ca}$ & 20 & 3,691 & 3042 & 1514 & 4275 & 5575 & 981 & 4998 \\
\hline $\mathrm{Ti}$ & 22 & 4,509 & 67442 & 34167 & 73799 & 68328 & 37606 & 48316 \\
\hline $\mathrm{Cr}$ & 24 & 5,412 & 1990 & 1049 & 1814 & 1517 & 1331 & 1521 \\
\hline $\mathrm{Mn}$ & 25 & 5,895 & 3774 & 2383 & 5776 & 6946 & 1678 & 5394 \\
\hline $\mathrm{Fe}$ & 26 & 6,399 & 437233 & 221659 & 528334 & 522751 & 318635 & 359928 \\
\hline $\mathrm{Cu}$ & 29 & 8,041 & 1870 & 1065 & 1890 & 1330 & 996 & 1125 \\
\hline $\mathrm{Zn}$ & 30 & 8,631 & 2307 & 1005 & 3158 & 3261 & 1346 & 2247 \\
\hline $\mathrm{Ga}$ & 31 & 9,243 & 1768 & 927 & 2244 & 1981 & 1150 & 1480 \\
\hline $\mathrm{Br}$ & 35 & 11,908 & 1364 & 816 & 2084 & 2056 & 652 & 1514 \\
\hline $\mathrm{Rb}$ & 37 & 13,375 & 4655 & 2303 & 4932 & 4670 & 3123 & 3691 \\
\hline $\mathrm{Sr}$ & 38 & 14,142 & 1162 & 435 & 1355 & 1240 & 814 & 1102 \\
\hline$Y$ & 39 & 14,932 & 1182 & 690 & 1364 & 1289 & 1208 & 959 \\
\hline $\mathrm{Zr}$ & 40 & 15,746 & 7912 & 3940 & 9460 & 9057 & 6831 & 7655 \\
\hline $\mathrm{Ag}$ & 47 & 22,103 & 3027 & 1728 & 3944 & 4097 & 3006 & 3615 \\
\hline $\mathrm{Ba}$ & 0 & 0 & 0 & 0 & 0 & 0 & 0 & 0 \\
\hline $\mathrm{Pb}$ & 0 & 0 & 0 & 0 & 0 & 0 & 0 & 0 \\
\hline $\mathrm{Ni}$ & 0 & 0 & 0 & 0 & 0 & 0 & 0 & 0 \\
\hline
\end{tabular}

Tabela 26. Resultados das medidas de Fluorescência de Raios-X (XRF) para a amostra TRV.416.2 (faces interna, externa e núcleo). 


\begin{tabular}{|c|c|c|c|c|c|c|c|c|}
\hline \multirow[b]{2}{*}{$\begin{array}{l}\text { Elemento } \\
\text { Químico }\end{array}$} & \multirow[b]{2}{*}{$\mathbf{Z}$} & \multirow[b]{2}{*}{ energia } & \multicolumn{2}{|c|}{$\begin{array}{c}\text { TRV.1084.1 } \\
\text { FACE INTERNA } \\
\end{array}$} & \multicolumn{2}{|c|}{$\begin{array}{c}\text { TRV.1084.1 } \\
\text { FACE EXTERNA }\end{array}$} & \multicolumn{2}{|c|}{$\begin{array}{c}\text { TRV.1084.1 } \\
\text { NÚCLEO }\end{array}$} \\
\hline & & & Área & Área & Área & Área & Área & Área \\
\hline $\mathrm{Mg}$ & 12 & 1,254 & -75 & 36 & -24 & -85 & -34 & 8 \\
\hline $\mathrm{Al}$ & 13 & 1,487 & 824 & 1041 & 837 & 948 & 879 & 1048 \\
\hline $\mathrm{Si}$ & 14 & 1,74 & 14560 & 16770 & 13527 & 11151 & 14123 & 17313 \\
\hline $\mathrm{P}$ & 15 & 2,013 & 139 & 203 & 134 & 168 & 234 & 170 \\
\hline$S$ & 16 & 2,307 & 454 & 608 & 549 & 626 & 558 & 559 \\
\hline $\mathrm{Cl}$ & 17 & 2,622 & 645 & 671 & 672 & 931 & 709 & 549 \\
\hline $\mathrm{Ar}$ & 18 & 2,957 & 27606 & 26813 & 27583 & 28207 & 25390 & 23526 \\
\hline $\mathrm{K}$ & 19 & 3,313 & 14281 & 17317 & 15308 & 15472 & 12871 & 17835 \\
\hline $\mathrm{Ca}$ & 20 & 3,691 & 1145 & 1355 & 1531 & 1594 & 1106 & 1054 \\
\hline $\mathrm{Ti}$ & 22 & 4,509 & 66037 & 76556 & 76623 & 71887 & 62798 & 56829 \\
\hline $\mathrm{Cr}$ & 24 & 5,412 & 2002 & 2082 & 2129 & 1996 & 2316 & 2061 \\
\hline $\mathrm{Mn}$ & 25 & 5,895 & 3424 & 4150 & 3756 & 4757 & 4217 & 3178 \\
\hline $\mathrm{Fe}$ & 26 & 6,399 & 376955 & 462647 & 416023 & 477812 & 272291 & 283932 \\
\hline $\mathrm{Cu}$ & 29 & 8,041 & 1679 & 1745 & 1814 & 1904 & 2507 & 1423 \\
\hline $\mathrm{Zn}$ & 30 & 8,631 & 1233 & 1344 & 1729 & 1646 & 1931 & 1248 \\
\hline $\mathrm{Ga}$ & 31 & 9,243 & 1873 & 2144 & 2028 & 1755 & 2230 & 2460 \\
\hline $\mathrm{Br}$ & 35 & 11,908 & 1834 & 3101 & 1946 & 2714 & 2798 & 2203 \\
\hline $\mathrm{Rb}$ & 37 & 13,375 & 3135 & 3555 & 3353 & 3273 & 3215 & 4693 \\
\hline $\mathrm{Sr}$ & 38 & 14,142 & 791 & 1155 & 1092 & 900 & 1170 & 1095 \\
\hline $\mathrm{Y}$ & 39 & 14,932 & 1169 & 1263 & 1261 & 1104 & 1134 & 1216 \\
\hline $\mathrm{Zr}$ & 40 & 15,746 & 7559 & 9554 & 7341 & 7831 & 8776 & 8367 \\
\hline $\mathrm{Ag}$ & 47 & 22,103 & 2945 & 3051 & 2818 & 2912 & 3321 & 3678 \\
\hline $\mathrm{Ba}$ & 0 & 0 & 0 & 0 & 0 & 0 & 0 & 0 \\
\hline $\mathrm{Pb}$ & 0 & 0 & 0 & 0 & 0 & 0 & 0 & 0 \\
\hline $\mathrm{Ni}$ & 0 & 0 & 0 & 0 & 0 & 0 & 0 & 0 \\
\hline
\end{tabular}

Tabela 27. Resultados das medidas de Fluorescência de Raios-X (XRF) para a amostra TRV.1084.1 (faces interna, externa e núcleo). 


\begin{tabular}{|c|c|c|c|c|c|c|c|c|}
\hline \multirow[b]{2}{*}{$\begin{array}{l}\text { Elemento } \\
\text { Químico }\end{array}$} & \multirow[b]{2}{*}{$\mathbf{Z}$} & \multirow[b]{2}{*}{ energia } & \multicolumn{2}{|c|}{$\begin{array}{c}\text { TRV.398.7 } \\
\text { FACE INTERNA }\end{array}$} & \multicolumn{2}{|c|}{$\begin{array}{c}\text { TRV.398.7 } \\
\text { FACE EXTERNA }\end{array}$} & \multicolumn{2}{|c|}{$\begin{array}{l}\text { TRV.398.7 } \\
\text { NÚCLEO }\end{array}$} \\
\hline & & & Área & Área & Área & Área & Área & Área \\
\hline $\mathrm{Mg}$ & 12 & 1,254 & -41 & -45 & -63 & -21 & -49 & 25 \\
\hline $\mathrm{Al}$ & 13 & 1,487 & 1307 & 1555 & 1988 & 1501 & 1725 & 1491 \\
\hline $\mathrm{Si}$ & 14 & 1,74 & 18374 & 20687 & 18514 & 19760 & 18582 & 17255 \\
\hline $\mathrm{P}$ & 15 & 2,013 & 199 & 226 & 251 & 221 & 348 & 256 \\
\hline$S$ & 16 & 2,307 & 637 & 664 & 716 & 666 & 765 & 724 \\
\hline $\mathrm{Cl}$ & 17 & 2,622 & 679 & 738 & 716 & 796 & 733 & 708 \\
\hline $\mathrm{Ar}$ & 18 & 2,957 & 25860 & 25264 & 24043 & 23663 & 22504 & 20736 \\
\hline $\mathrm{K}$ & 19 & 3,313 & 23822 & 25199 & 45051 & 25504 & 22582 & 18947 \\
\hline $\mathrm{Ca}$ & 20 & 3,691 & 1624 & 1754 & 1440 & 1936 & 1848 & 1509 \\
\hline $\mathrm{Ti}$ & 22 & 4,509 & 80504 & 84565 & 66607 & 85804 & 77651 & 65930 \\
\hline $\mathrm{Cr}$ & 24 & 5,412 & 1981 & 1843 & 1620 & 1910 & 2169 & 1758 \\
\hline $\mathrm{Mn}$ & 25 & 5,895 & 3629 & 4139 & 5481 & 4879 & 4848 & 5171 \\
\hline $\mathrm{Fe}$ & 26 & 6,399 & 493803 & 519260 & 513167 & 537124 & 489323 & 431715 \\
\hline $\mathrm{Cu}$ & 29 & 8,041 & 2641 & 2775 & 2091 & 2147 & 2157 & 2442 \\
\hline $\mathrm{Zn}$ & 30 & 8,631 & 1786 & 2127 & 2292 & 2382 & 2362 & 1869 \\
\hline $\mathrm{Ga}$ & 31 & 9,243 & 2289 & 2331 & 2573 & 2166 & 2534 & 2119 \\
\hline $\mathrm{Br}$ & 35 & 11,908 & 1956 & 2108 & 2301 & 2046 & 2414 & 2168 \\
\hline $\mathrm{Rb}$ & 37 & 13,375 & 4580 & 5125 & 5490 & 4993 & 5294 & 4543 \\
\hline $\mathrm{Sr}$ & 38 & 14,142 & 1151 & 1132 & 1242 & 1253 & 1288 & 1253 \\
\hline $\mathrm{Y}$ & 39 & 14,932 & 1084 & 1441 & 1503 & 1455 & 1539 & 1329 \\
\hline $\mathrm{Zr}$ & 40 & 15,746 & 8662 & 10695 & 9213 & 9314 & 9505 & 9111 \\
\hline $\mathrm{Ag}$ & 47 & 22,103 & 3380 & 3486 & 3875 & 3712 & 3861 & 3901 \\
\hline $\mathrm{Ba}$ & 0 & 0 & 0 & 0 & 0 & 0 & 0 & 0 \\
\hline $\mathrm{Pb}$ & 0 & 0 & 0 & 0 & 0 & 0 & 0 & 0 \\
\hline $\mathrm{Ni}$ & 0 & 0 & 0 & 0 & 0 & 0 & 0 & 0 \\
\hline
\end{tabular}

Tabela 28. Resultados das medidas de Fluorescência de Raios-X (XRF) para a amostra TRV.398.7 (faces interna, externa e núcleo). 


\begin{tabular}{|c|c|c|c|c|c|c|c|c|}
\hline & & & $\begin{array}{r}\text { TR } \\
\text { FACE }\end{array}$ & $\begin{array}{l}7.29 \\
\text { TERNA }\end{array}$ & $\begin{array}{r}\text { TR } \\
\text { FACE } \\
\end{array}$ & $\begin{array}{l}7.29 \\
\text { CERNA }\end{array}$ & $\begin{array}{l}\text { TRI } \\
\text { NÚ }\end{array}$ & $\begin{array}{l}7.29 \\
\text { EO }\end{array}$ \\
\hline $\begin{array}{l}\text { Elemento } \\
\text { Químico }\end{array}$ & $\mathbf{Z}$ & energia & Área & Área & Área & Área & Área & Área \\
\hline $\mathrm{Mg}$ & 12 & 1,254 & -12 & 22 & -3 & -19 & -15 & 1 \\
\hline $\mathrm{Al}$ & 13 & 1,487 & 1941 & 2466 & 1371 & 1878 & 1076 & 1501 \\
\hline $\mathrm{Si}$ & 14 & 1,74 & 23523 & 17628 & 20012 & 26072 & 12443 & 17975 \\
\hline $\mathrm{P}$ & 15 & 2,013 & 360 & 670 & 214 & 278 & 225 & 300 \\
\hline$S$ & 16 & 2,307 & 533 & 844 & 492 & 472 & 495 & 497 \\
\hline $\mathrm{Cl}$ & 17 & 2,622 & 635 & 562 & 680 & 666 & 570 & 763 \\
\hline $\mathrm{Ar}$ & 18 & 2,957 & 23388 & 21603 & 24727 & 22233 & 21800 & 19602 \\
\hline $\mathrm{K}$ & 19 & 3,313 & 28395 & 22601 & 27140 & 31994 & 16624 & 21133 \\
\hline $\mathrm{Ca}$ & 20 & 3,691 & 1012 & 1503 & 966 & 1514 & 627 & 980 \\
\hline $\mathrm{Ti}$ & 22 & 4,509 & 85717 & 70457 & 82059 & 89743 & 54829 & 68193 \\
\hline $\mathrm{Cr}$ & 24 & 5,412 & 2000 & 1809 & 1823 & 1905 & 1544 & 1846 \\
\hline $\mathrm{Mn}$ & 25 & 5,895 & 3157 & 3392 & 5383 & 4195 & 4718 & 3025 \\
\hline $\mathrm{Fe}$ & 26 & 6,399 & 419909 & 327811 & 526923 & 563424 & 301437 & 355880 \\
\hline $\mathrm{Cu}$ & 29 & 8,041 & 2723 & 2313 & 1683 & 2064 & 1343 & 1969 \\
\hline $\mathrm{Zn}$ & 30 & 8,631 & 2471 & 2421 & 2742 & 3346 & 1298 & 2152 \\
\hline $\mathrm{Ga}$ & 31 & 9,243 & 2536 & 2424 & 1901 & 2168 & 1672 & 2133 \\
\hline $\mathrm{Br}$ & 35 & 11,908 & 2423 & 2873 & 1448 & 1813 & 1816 & 2032 \\
\hline $\mathrm{Rb}$ & 37 & 13,375 & 5299 & 4889 & 4452 & 5201 & 3595 & 4439 \\
\hline $\mathrm{Sr}$ & 38 & 14,142 & 1648 & 1347 & 1155 & 1077 & 1017 & 1141 \\
\hline $\mathrm{Y}$ & 39 & 14,932 & 1806 & 1669 & 1699 & 1502 & 1303 & 1362 \\
\hline $\mathrm{Zr}$ & 40 & 15,746 & 11974 & 11428 & 9015 & 9874 & 8250 & 9445 \\
\hline $\mathrm{Ag}$ & 47 & 22,103 & 4475 & 4155 & 3678 & 4307 & 3335 & 4048 \\
\hline $\mathrm{Ba}$ & 0 & 0 & 0 & 0 & 0 & 0 & 0 & 0 \\
\hline $\mathrm{Pb}$ & 0 & 0 & 0 & 0 & 0 & 0 & 0 & 0 \\
\hline $\mathrm{Ni}$ & 0 & 0 & 0 & 0 & 0 & 0 & 0 & 0 \\
\hline
\end{tabular}

Tabela 29. Resultados das medidas de Fluorescência de Raios-X (XRF) para a amostra TRV.367.29 (faces interna, externa e núcleo). 


\begin{tabular}{|c|c|c|c|c|c|c|c|c|}
\hline & & & $\begin{array}{r}\text { TRV } \\
\text { FACE }\end{array}$ & $\begin{array}{l}7.27 \\
\text { ERNA }\end{array}$ & $\begin{array}{r}\text { TRI } \\
\text { FACE }\end{array}$ & $\begin{array}{l}7.27 \\
\text { ERNA }\end{array}$ & $\begin{array}{l}\text { TRI } \\
\text { NÚ }\end{array}$ & $\begin{array}{l}7.27 \\
\text { EO }\end{array}$ \\
\hline $\begin{array}{l}\text { Elemento } \\
\text { Químico }\end{array}$ & $\mathbf{Z}$ & energia & Área & Área & Área & Área & Área & Área \\
\hline $\mathrm{Mg}$ & 12 & 1,254 & -10 & -69 & 11 & 70 & -4 & 31 \\
\hline $\mathrm{Al}$ & 13 & 1,487 & 1849 & 2076 & 2334 & 2542 & 2000 & 1482 \\
\hline $\mathrm{Si}$ & 14 & 1,74 & 13935 & 15896 & 39259 & 37218 & 24831 & 19170 \\
\hline $\mathrm{P}$ & 15 & 2,013 & 165 & 223 & 210 & 288 & 245 & 192 \\
\hline$S$ & 16 & 2,307 & 621 & 809 & 328 & 538 & 563 & 697 \\
\hline $\mathrm{Cl}$ & 17 & 2,622 & 787 & 724 & 491 & 339 & 574 & 718 \\
\hline $\mathrm{Ar}$ & 18 & 2,957 & 27411 & 26654 & 18819 & 18218 & 19933 & 24171 \\
\hline $\mathrm{K}$ & 19 & 3,313 & 42344 & 42005 & 21551 & 21944 & 24985 & 27390 \\
\hline $\mathrm{Ca}$ & 20 & 3,691 & 1747 & 2267 & 1664 & 1983 & 1715 & 1904 \\
\hline $\mathrm{Ti}$ & 22 & 4,509 & 53976 & 64613 & 53522 & 54383 & 61129 & 72662 \\
\hline $\mathrm{Cr}$ & 24 & 5,412 & 1453 & 1700 & 2494 & 1609 & 1595 & 1789 \\
\hline $\mathrm{Mn}$ & 25 & 5,895 & 3906 & 3890 & 3754 & 2604 & 5663 & 6542 \\
\hline $\mathrm{Fe}$ & 26 & 6,399 & 302221 & 342493 & 212795 & 186750 & 234960 & 228923 \\
\hline $\mathrm{Cu}$ & 29 & 8,041 & 1907 & 2074 & 2357 & 2285 & 2983 & 2121 \\
\hline $\mathrm{Zn}$ & 30 & 8,631 & 2884 & 2802 & 2420 & 2383 & 2692 & 2570 \\
\hline $\mathrm{Ga}$ & 31 & 9,243 & 2040 & 2515 & 2568 & 2393 & 2318 & 2458 \\
\hline $\mathrm{Br}$ & 35 & 11,908 & 1899 & 2136 & 2037 & 1645 & 2023 & 2454 \\
\hline $\mathrm{Rb}$ & 37 & 13,375 & 7492 & 7742 & 8177 & 6945 & 7225 & 7047 \\
\hline $\mathrm{Sr}$ & 38 & 14,142 & 1004 & 1253 & 1395 & 1324 & 1406 & 1104 \\
\hline $\mathrm{Y}$ & 39 & 14,932 & 1482 & 2081 & 2242 & 1968 & 1758 & 2088 \\
\hline $\mathrm{Zr}$ & 40 & 15,746 & 9361 & 10467 & 10781 & 9495 & 9484 & 10357 \\
\hline $\mathrm{Ag}$ & 47 & 22,103 & 3567 & 4040 & 5108 & 5207 & 4814 & 4322 \\
\hline $\mathrm{Ba}$ & 0 & 0 & 0 & 0 & 0 & 0 & 0 & 0 \\
\hline $\mathrm{Pb}$ & 0 & 0 & 0 & 0 & 0 & 0 & 0 & 0 \\
\hline $\mathrm{Ni}$ & 0 & 0 & 0 & 0 & 0 & 0 & 0 & 0 \\
\hline
\end{tabular}

Tabela 30. Resultados das medidas de Fluorescência de Raios-X (XRF) para a amostra TRV.367.27 (faces interna, externa e núcleo). 


\begin{tabular}{|c|c|c|c|c|c|c|c|c|}
\hline & & & $\begin{array}{r}\text { TR } \\
\text { FACE }\end{array}$ & $\begin{array}{l}14.1 \\
\text { ERNA }\end{array}$ & $\begin{array}{r}\text { TR } \\
\text { FACE } \\
\end{array}$ & $\begin{array}{l}4.1 \\
\text { ERNA }\end{array}$ & $\begin{array}{l}\text { TR } \\
\text { NÚ } \\
\end{array}$ & $\begin{array}{l}14.1 \\
\text { EO }\end{array}$ \\
\hline $\begin{array}{l}\text { Elemento } \\
\text { Químico }\end{array}$ & $\mathbf{Z}$ & energia & Área & Área & Área & Área & Área & Área \\
\hline $\mathrm{Mg}$ & 12 & 1,254 & -22 & 5 & -33 & -16 & 44 & -1 \\
\hline $\mathrm{Al}$ & 13 & 1,487 & 1553 & 1637 & 1302 & 142 & 2051 & 1372 \\
\hline $\mathrm{Si}$ & 14 & 1,74 & 27483 & 29163 & 14836 & 1931 & 24746 & 14098 \\
\hline $\mathrm{P}$ & 15 & 2,013 & 221 & 322 & 163 & 9 & 127 & 102 \\
\hline$S$ & 16 & 2,307 & 585 & 752 & 877 & 31 & 267 & 526 \\
\hline $\mathrm{Cl}$ & 17 & 2,622 & 722 & 594 & 899 & 77 & 513 & 637 \\
\hline $\mathrm{Ar}$ & 18 & 2,957 & 22313 & 22277 & 27840 & 2614 & 20134 & 27506 \\
\hline $\mathrm{K}$ & 19 & 3,313 & 19652 & 20557 & 18046 & 1948 & 17013 & 13875 \\
\hline $\mathrm{Ca}$ & 20 & 3,691 & 1988 & 2138 & 1593 & 119 & 2248 & 2000 \\
\hline $\mathrm{Ti}$ & 22 & 4,509 & 78954 & 75212 & 65443 & 6863 & 49839 & 51366 \\
\hline $\mathrm{Cr}$ & 24 & 5,412 & 1821 & 2401 & 2049 & 170 & 1723 & 1964 \\
\hline $\mathrm{Mn}$ & 25 & 5,895 & 5776 & 6800 & 4691 & 507 & 2275 & 6511 \\
\hline $\mathrm{Fe}$ & 26 & 6,399 & 334488 & 383382 & 308380 & 32074 & 311492 & 294589 \\
\hline $\mathrm{Cu}$ & 29 & 8,041 & 2423 & 2337 & 2398 & 246 & 1650 & 1594 \\
\hline $\mathrm{Zn}$ & 30 & 8,631 & 2382 & 2487 & 2186 & 268 & 2304 & 1734 \\
\hline $\mathrm{Ga}$ & 31 & 9,243 & 2592 & 2334 & 1852 & 156 & 2472 & 1681 \\
\hline $\mathrm{Br}$ & 35 & 11,908 & 2185 & 1968 & 1890 & 292 & 773 & 561 \\
\hline $\mathrm{Rb}$ & 37 & 13,375 & 4055 & 4564 & 3767 & 440 & 4475 & 3797 \\
\hline $\mathrm{Sr}$ & 38 & 14,142 & 1389 & 1314 & 1228 & 69 & 1540 & 1241 \\
\hline $\mathrm{Y}$ & 39 & 14,932 & 1493 & 1318 & 1361 & 197 & 1519 & 1291 \\
\hline $\mathrm{Zr}$ & 40 & 15,746 & 9856 & 10270 & 8408 & 818 & 8600 & 7015 \\
\hline $\mathrm{Ag}$ & 47 & 22,103 & 4143 & 4556 & 3763 & 449 & 4445 & 3360 \\
\hline $\mathrm{Ba}$ & 0 & 0 & 0 & 0 & 0 & 0 & 0 & 0 \\
\hline $\mathrm{Pb}$ & 0 & 0 & 0 & 0 & 0 & 0 & 0 & 0 \\
\hline $\mathrm{Ni}$ & 0 & 0 & 0 & 0 & 0 & 0 & 0 & 0 \\
\hline
\end{tabular}

Tabela 31. Resultados das medidas de Fluorescência de Raios-X (XRF) para a amostra TRV.414.1 (faces interna, externa e núcleo). 


\begin{tabular}{|c|c|c|c|c|c|c|c|c|}
\hline & & & $\begin{array}{r}\text { TR } \\
\text { FACE }\end{array}$ & $\begin{array}{l}3.6 \\
\text { ERNA }\end{array}$ & $\begin{array}{r}\text { TR } \\
\text { FACE } \\
\end{array}$ & $\begin{array}{l}73.6 \\
{[\text { ERNA }} \\
\end{array}$ & $\begin{array}{l}\text { TR } \\
\text { NÚ } \\
\end{array}$ & $\begin{array}{l}73.6 \\
\text { EO } \\
\end{array}$ \\
\hline $\begin{array}{l}\text { Elemento } \\
\text { Químico }\end{array}$ & $\mathbf{Z}$ & energia & Área & Área & Área & Área & Área & Área \\
\hline $\mathrm{Mg}$ & 12 & 1,254 & -8 & -15 & 53 & -27 & -43 & -42 \\
\hline $\mathrm{Al}$ & 13 & 1,487 & 1940 & 2034 & 2132 & 1697 & 1292 & 1073 \\
\hline $\mathrm{Si}$ & 14 & 1,74 & 23385 & 25167 & 22954 & 17690 & 15489 & 13401 \\
\hline $\mathrm{P}$ & 15 & 2,013 & 221 & 172 & 194 & 195 & 165 & 171 \\
\hline$S$ & 16 & 2,307 & 537 & 422 & 750 & 875 & 738 & 725 \\
\hline $\mathrm{Cl}$ & 17 & 2,622 & 814 & 940 & 907 & 849 & 780 & 788 \\
\hline $\mathrm{Ar}$ & 18 & 2,957 & 25035 & 23663 & 22487 & 25077 & 26274 & 26571 \\
\hline $\mathrm{K}$ & 19 & 3,313 & 30877 & 31981 & 35113 & 27483 & 26063 & 16684 \\
\hline $\mathrm{Ca}$ & 20 & 3,691 & 1769 & 1752 & 1294 & 1133 & 1750 & 1016 \\
\hline $\mathrm{Ti}$ & 22 & 4,509 & 86656 & 97772 & 90374 & 79716 & 60497 & 43485 \\
\hline $\mathrm{Cr}$ & 24 & 5,412 & 1843 & 2034 & 2017 & 2263 & 1604 & 1739 \\
\hline $\mathrm{Mn}$ & 25 & 5,895 & 2631 & 2196 & 3345 & 3576 & 4365 & 3907 \\
\hline $\mathrm{Fe}$ & 26 & 6,399 & 216414 & 211540 & 228827 & 211656 & 197475 & 152820 \\
\hline $\mathrm{Cu}$ & 29 & 8,041 & 3654 & 3758 & 2512 & 2503 & 2075 & 2860 \\
\hline $\mathrm{Zn}$ & 30 & 8,631 & 2545 & 2691 & 3026 & 2385 & 1965 & 1568 \\
\hline $\mathrm{Ga}$ & 31 & 9,243 & 3108 & 2782 & 2579 & 2671 & 2058 & 2186 \\
\hline $\mathrm{Br}$ & 35 & 11,908 & 2216 & 2181 & 2889 & 2582 & 2558 & 2420 \\
\hline $\mathrm{Rb}$ & 37 & 13,375 & 7069 & 7371 & 7410 & 6524 & 6888 & 5180 \\
\hline $\mathrm{Sr}$ & 38 & 14,142 & 1460 & 1481 & 1424 & 1308 & 1133 & 923 \\
\hline $\mathrm{Y}$ & 39 & 14,932 & 2075 & 2370 & 2595 & 2019 & 1977 & 1597 \\
\hline $\mathrm{Zr}$ & 40 & 15,746 & 10733 & 11615 & 12625 & 9998 & 9660 & 8511 \\
\hline $\mathrm{Ag}$ & 47 & 22,103 & 4269 & 4401 & 4776 & 4022 & 3614 & 3459 \\
\hline $\mathrm{Ba}$ & 0 & 0 & 0 & 0 & 0 & 0 & 0 & 0 \\
\hline $\mathrm{Pb}$ & 0 & 0 & 0 & 0 & 0 & 0 & 0 & 0 \\
\hline $\mathrm{Ni}$ & 0 & 0 & 0 & 0 & 0 & 0 & 0 & 0 \\
\hline
\end{tabular}

Tabela 32. Resultados das medidas de Fluorescência de Raios-X (XRF) para a amostra TRV.373.6 (faces interna, externa e núcleo). 


\begin{tabular}{|c|c|c|c|c|c|c|c|c|}
\hline & & & $\begin{array}{r}\text { TRI } \\
\text { FACE }\end{array}$ & $\begin{array}{l}7.20 \\
\text { ERNA }\end{array}$ & $\begin{array}{r}\text { TRV } \\
\text { FACE I }\end{array}$ & $\begin{array}{l}7.20 \\
\text { [ERNA }\end{array}$ & $\begin{array}{l}\text { TRI } \\
\text { NÚ }\end{array}$ & $\begin{array}{l}7.20 \\
\text { EO }\end{array}$ \\
\hline $\begin{array}{l}\text { Elemento } \\
\text { Químico }\end{array}$ & $\mathbf{Z}$ & energia & Área & Área & Área & Área & Área & Área \\
\hline $\mathrm{Mg}$ & 12 & 1,254 & 21 & -2 & -21 & -41 & -4 & -37 \\
\hline $\mathrm{Al}$ & 13 & 1,487 & 2135 & 1884 & 1708 & 1680 & 1172 & 1031 \\
\hline $\mathrm{Si}$ & 14 & 1,74 & 27515 & 27483 & 22620 & 22861 & 12757 & 12153 \\
\hline $\mathrm{P}$ & 15 & 2,013 & 261 & 193 & 249 & 298 & 222 & 137 \\
\hline $\mathrm{S}$ & 16 & 2,307 & 590 & 408 & 555 & 546 & 542 & 486 \\
\hline $\mathrm{Cl}$ & 17 & 2,622 & 738 & 658 & 801 & 940 & 635 & 746 \\
\hline $\mathrm{Ar}$ & 18 & 2,957 & 19169 & 21182 & 19911 & 21112 & 15879 & 22099 \\
\hline $\mathrm{K}$ & 19 & 3,313 & 25565 & 27011 & 26397 & 27365 & 14218 & 14225 \\
\hline $\mathrm{Ca}$ & 20 & 3,691 & 1796 & 1739 & 1443 & 1354 & 1025 & 937 \\
\hline $\mathrm{Ti}$ & 22 & 4,509 & 84049 & 89433 & 79697 & 84713 & 47256 & 49149 \\
\hline $\mathrm{Cr}$ & 24 & 5,412 & 1836 & 1920 & 1624 & 1890 & 1255 & 1600 \\
\hline $\mathrm{Mn}$ & 25 & 5,895 & 4765 & 4516 & 5790 & 4840 & 5224 & 3732 \\
\hline $\mathrm{Fe}$ & 26 & 6,399 & 537241 & 553335 & 539937 & 573328 & 383483 & 336401 \\
\hline $\mathrm{Cu}$ & 29 & 8,041 & 1642 & 1761 & 1545 & 1793 & 1056 & 1307 \\
\hline $\mathrm{Zn}$ & 30 & 8,631 & 2275 & 1843 & 2481 & 2179 & 1201 & 1502 \\
\hline $\mathrm{Ga}$ & 31 & 9,243 & 2059 & 2253 & 2002 & 2285 & 1462 & 1476 \\
\hline $\mathrm{Br}$ & 35 & 11,908 & 1850 & 1877 & 2033 & 2181 & 1610 & 1259 \\
\hline $\mathrm{Rb}$ & 37 & 13,375 & 5372 & 5377 & 5476 & 5154 & 3589 & 3549 \\
\hline $\mathrm{Sr}$ & 38 & 14,142 & 1379 & 1206 & 1216 & 1266 & 803 & 908 \\
\hline $\mathrm{Y}$ & 39 & 14,932 & 1378 & 1437 & 1580 & 1598 & 1191 & 1152 \\
\hline $\mathrm{Zr}$ & 40 & 15,746 & 10036 & 10730 & 9599 & 10060 & 7938 & 7448 \\
\hline $\mathrm{Ag}$ & 47 & 22,103 & 4211 & 4423 & 4266 & 3991 & 3203 & 3073 \\
\hline $\mathrm{Ba}$ & 0 & 0 & 0 & 0 & 0 & 0 & 0 & 0 \\
\hline $\mathrm{Pb}$ & 0 & 0 & 0 & 0 & 0 & 0 & 0 & 0 \\
\hline $\mathrm{Ni}$ & 0 & 0 & 0 & 0 & 0 & 0 & 0 & 0 \\
\hline
\end{tabular}

Tabela 33. Resultados das medidas de Fluorescência de Raios-X (XRF) para a amostra TRV.367.20 (faces interna, externa e núcleo). 


\begin{tabular}{|c|c|c|c|c|c|c|c|c|}
\hline & & & $\begin{array}{r}\text { TRV } \\
\text { FACE }\end{array}$ & $\begin{array}{l}7.30 \\
\text { ERNA } \\
\end{array}$ & $\begin{array}{r}\text { TR } \\
\text { FACE } \\
\end{array}$ & $\begin{array}{l}67.30 \\
\text { TERNA }\end{array}$ & $\begin{array}{r}\text { TR } \\
\text { NÚ }\end{array}$ & $\begin{array}{l}7.30 \\
\mathrm{EO} \\
\end{array}$ \\
\hline $\begin{array}{l}\text { Elemento } \\
\text { Químico }\end{array}$ & $\mathbf{Z}$ & energia & Área & Área & Área & Área & Área & Área \\
\hline $\mathrm{Mg}$ & 12 & 1,254 & -61 & -51 & -77 & -12 & 24 & -30 \\
\hline $\mathrm{Al}$ & 13 & 1,487 & 2044 & 2042 & 1594 & 1709 & 1940 & 1301 \\
\hline $\mathrm{Si}$ & 14 & 1,74 & 19459 & 22366 & 16294 & 16319 & 19677 & 10117 \\
\hline $\mathrm{P}$ & 15 & 2,013 & 175 & 186 & 232 & 230 & 136 & 193 \\
\hline$S$ & 16 & 2,307 & 495 & 477 & 599 & 706 & 395 & 660 \\
\hline $\mathrm{Cl}$ & 17 & 2,622 & 1014 & 1035 & 1336 & 1712 & 1462 & 930 \\
\hline $\mathrm{Ar}$ & 18 & 2,957 & 20544 & 18986 & 23383 & 21426 & 18064 & 16728 \\
\hline $\mathrm{K}$ & 19 & 3,313 & 40301 & 37565 & 41449 & 43203 & 30907 & 19070 \\
\hline $\mathrm{Ca}$ & 20 & 3,691 & 4712 & 5048 & 5137 & 6052 & 3513 & 2674 \\
\hline $\mathrm{Ti}$ & 22 & 4,509 & 99610 & 102608 & 91146 & 97609 & 67575 & 65832 \\
\hline $\mathrm{Cr}$ & 24 & 5,412 & 1888 & 1911 & 2162 & 1583 & 1919 & 1657 \\
\hline $\mathrm{Mn}$ & 25 & 5,895 & 5248 & 5661 & 11362 & 14608 & 4416 & 4973 \\
\hline $\mathrm{Fe}$ & 26 & 6,399 & 846874 & 853344 & 910055 & 1000445 & 804715 & 680010 \\
\hline $\mathrm{Cu}$ & 29 & 8,041 & 1927 & 2063 & 966 & 1312 & 1266 & 1140 \\
\hline $\mathrm{Zn}$ & 30 & 8,631 & 1816 & 1942 & 2834 & 3699 & 1273 & 1111 \\
\hline $\mathrm{Ga}$ & 31 & 9,243 & 1908 & 1546 & 1605 & 1398 & 1263 & 1049 \\
\hline $\mathrm{Br}$ & 35 & 11,908 & 1011 & 1311 & 1612 & 2048 & 951 & 1315 \\
\hline $\mathrm{Rb}$ & 37 & 13,375 & 5007 & 4865 & 4805 & 5089 & 4561 & 3019 \\
\hline $\mathrm{Sr}$ & 38 & 14,142 & 3155 & 3212 & 2781 & 3083 & 2716 & 2066 \\
\hline $\mathrm{Y}$ & 39 & 14,932 & 672 & 540 & 554 & 906 & 531 & 457 \\
\hline $\mathrm{Zr}$ & 40 & 15,746 & 7467 & 6811 & 6742 & 6823 & 8951 & 5478 \\
\hline $\mathrm{Ag}$ & 47 & 22,103 & 3562 & 3727 & 3455 & 3464 & 3770 & 3143 \\
\hline $\mathrm{Ba}$ & 0 & 0 & 0 & 0 & 0 & 0 & 0 & 0 \\
\hline $\mathrm{Pb}$ & 0 & 0 & 0 & 0 & 0 & 0 & 0 & 0 \\
\hline $\mathrm{Ni}$ & 0 & 0 & 0 & 0 & 0 & 0 & 0 & 0 \\
\hline
\end{tabular}

Tabela 34. Resultados das medidas de Fluorescência de Raios-X (XRF) para a amostra TRV.367.30 (faces interna, externa e núcleo). 


\begin{tabular}{|c|c|c|c|c|c|c|c|c|}
\hline & & & $\begin{array}{r}\text { TRV } \\
\text { FACE }\end{array}$ & $\begin{array}{l}7.13 \\
\text { ERNA }\end{array}$ & $\begin{array}{r}\text { TR } \\
\text { FACE }\end{array}$ & $\begin{array}{l}7.13 \\
\text { CERNA }\end{array}$ & $\begin{array}{l}\text { TRI } \\
\text { NÚ }\end{array}$ & $\begin{array}{l}7.13 \\
\text { EO }\end{array}$ \\
\hline $\begin{array}{l}\text { Elemento } \\
\text { Químico }\end{array}$ & $\mathbf{Z}$ & energia & Área & Área & Área & Área & Área & Área \\
\hline $\mathrm{Mg}$ & 12 & 1,254 & -8 & -109 & -19 & -35 & -16 & -38 \\
\hline $\mathrm{Al}$ & 13 & 1,487 & 1292 & 1121 & 796 & 672 & 879 & 1610 \\
\hline $\mathrm{Si}$ & 14 & 1,74 & 19491 & 17373 & 15158 & 12957 & 13542 & 20971 \\
\hline $\mathrm{P}$ & 15 & 2,013 & 141 & 184 & 204 & 122 & 240 & 216 \\
\hline$S$ & 16 & 2,307 & 308 & 424 & 555 & 479 & 489 & 679 \\
\hline $\mathrm{Cl}$ & 17 & 2,622 & 674 & 621 & 758 & 803 & 702 & 696 \\
\hline $\mathrm{Ar}$ & 18 & 2,957 & 25900 & 25263 & 28569 & 29749 & 24348 & 22243 \\
\hline $\mathrm{K}$ & 19 & 3,313 & 27699 & 23165 & 21535 & 23367 & 19103 & 24595 \\
\hline $\mathrm{Ca}$ & 20 & 3,691 & 892 & 967 & 953 & 850 & 683 & 1222 \\
\hline $\mathrm{Ti}$ & 22 & 4,509 & 71429 & 77139 & 63011 & 64393 & 54040 & 78377 \\
\hline $\mathrm{Cr}$ & 24 & 5,412 & 1761 & 1905 & 1752 & 1821 & 1559 & 1989 \\
\hline $\mathrm{Mn}$ & 25 & 5,895 & 3196 & 3093 & 2907 & 2931 & 3928 & 4011 \\
\hline $\mathrm{Fe}$ & 26 & 6,399 & 171564 & 174261 & 158268 & 158864 & 157499 & 237024 \\
\hline $\mathrm{Cu}$ & 29 & 8,041 & 2105 & 2087 & 2130 & 1987 & 1928 & 2639 \\
\hline $\mathrm{Zn}$ & 30 & 8,631 & 1837 & 1882 & 1522 & 1266 & 1712 & 1945 \\
\hline $\mathrm{Ga}$ & 31 & 9,243 & 2435 & 2092 & 2103 & 2151 & 2113 & 2651 \\
\hline $\mathrm{Br}$ & 35 & 11,908 & 1716 & 1679 & 2031 & 2097 & 2252 & 2685 \\
\hline $\mathrm{Rb}$ & 37 & 13,375 & 5943 & 4658 & 4973 & 5217 & 5330 & 6297 \\
\hline $\mathrm{Sr}$ & 38 & 14,142 & 1267 & 1199 & 989 & 618 & 1099 & 1334 \\
\hline $\mathrm{Y}$ & 39 & 14,932 & 1967 & 1922 & 1816 & 1645 & 1903 & 2230 \\
\hline $\mathrm{Zr}$ & 40 & 15,746 & 8654 & 8705 & 8488 & 8108 & 7978 & 12340 \\
\hline $\mathrm{Ag}$ & 47 & 22,103 & 3412 & 3322 & 3195 & 2846 & 3468 & 4029 \\
\hline $\mathrm{Ba}$ & 0 & 0 & 0 & 0 & 0 & 0 & 0 & 0 \\
\hline $\mathrm{Pb}$ & 0 & 0 & 0 & 0 & 0 & 0 & 0 & 0 \\
\hline $\mathrm{Ni}$ & 0 & 0 & 0 & 0 & 0 & 0 & 0 & 0 \\
\hline
\end{tabular}

Tabela 35. Resultados das medidas de Fluorescência de Raios-X (XRF) para a amostra TRV.367.13 (faces interna, externa e núcleo). 


\begin{tabular}{|c|c|c|c|c|c|c|c|c|}
\hline & & & $\begin{array}{r}\text { TR } \\
\text { FACE } \\
\end{array}$ & $\begin{array}{l}31.1 \\
\text { ERNA }\end{array}$ & $\begin{array}{r}\text { TR } \\
\text { FACE } \\
\end{array}$ & $\begin{array}{l}31.1 \\
\text { [ERNA }\end{array}$ & $\begin{array}{l}\text { TR } \\
\text { NÚ } \\
\end{array}$ & $\begin{array}{l}31.1 \\
\text { EO } \\
\end{array}$ \\
\hline $\begin{array}{l}\text { Elemento } \\
\text { Químico }\end{array}$ & $\mathbf{Z}$ & energia & Área & Área & Área & Área & Área & Área \\
\hline $\mathrm{Mg}$ & 12 & 1,254 & -98 & -14 & -42 & -85 & -78 & -26 \\
\hline $\mathrm{Al}$ & 13 & 1,487 & 1090 & 808 & 1006 & 925 & 685 & 1771 \\
\hline $\mathrm{Si}$ & 14 & 1,74 & 13822 & 9975 & 9292 & 8021 & 7422 & 16624 \\
\hline $\mathrm{P}$ & 15 & 2,013 & 86 & 101 & 73 & 135 & 63 & 236 \\
\hline$S$ & 16 & 2,307 & 525 & 875 & 381 & 718 & 600 & 931 \\
\hline $\mathrm{Cl}$ & 17 & 2,622 & 754 & 756 & 660 & 767 & 788 & 804 \\
\hline $\mathrm{Ar}$ & 18 & 2,957 & 25790 & 28258 & 28779 & 30627 & 29172 & 18132 \\
\hline $\mathrm{K}$ & 19 & 3,313 & 26094 & 23567 & 24552 & 21867 & 16778 & 33677 \\
\hline $\mathrm{Ca}$ & 20 & 3,691 & 4821 & 4480 & 4673 & 4941 & 2889 & 6550 \\
\hline $\mathrm{Ti}$ & 22 & 4,509 & 78785 & 74451 & 74970 & 89314 & 39232 & 115697 \\
\hline $\mathrm{Cr}$ & 24 & 5,412 & 1835 & 1780 & 1924 & 1883 & 2213 & 2125 \\
\hline $\mathrm{Mn}$ & 25 & 5,895 & 4500 & 4354 & 3701 & 3587 & 3000 & 6947 \\
\hline $\mathrm{Fe}$ & 26 & 6,399 & 879129 & 718086 & 700300 & 690338 & 528990 & 882850 \\
\hline $\mathrm{Cu}$ & 29 & 8,041 & 2048 & 1972 & 1164 & 1181 & 1161 & 1429 \\
\hline $\mathrm{Zn}$ & 30 & 8,631 & 1016 & 1045 & 1794 & 1266 & 1140 & 1034 \\
\hline $\mathrm{Ga}$ & 31 & 9,243 & 1524 & 1308 & 1508 & 1412 & 1220 & 1758 \\
\hline $\mathrm{Br}$ & 35 & 11,908 & 980 & 986 & 688 & 1161 & 1464 & 2314 \\
\hline $\mathrm{Rb}$ & 37 & 13,375 & 4138 & 2950 & 2678 & 2914 & 2451 & 4629 \\
\hline $\mathrm{Sr}$ & 38 & 14,142 & 2861 & 2485 & 2453 & 2684 & 2167 & 3809 \\
\hline $\mathrm{Y}$ & 39 & 14,932 & 379 & 550 & 656 & 614 & 743 & 523 \\
\hline $\mathrm{Zr}$ & 40 & 15,746 & 6626 & 6115 & 5366 & 5801 & 4556 & 10038 \\
\hline $\mathrm{Ag}$ & 47 & 22,103 & 3042 & 2258 & 2241 & 2182 & 2331 & 3709 \\
\hline $\mathrm{Ba}$ & 0 & 0 & 0 & 0 & 0 & 0 & 0 & 0 \\
\hline $\mathrm{Pb}$ & 0 & 0 & 0 & 0 & 0 & 0 & 0 & 0 \\
\hline $\mathrm{Ni}$ & 0 & 0 & 0 & 0 & 0 & 0 & 0 & 0 \\
\hline
\end{tabular}

Tabela 36. Resultados das medidas de Fluorescência de Raios-X (XRF) para a amostra TRV.531.1 (faces interna, externa e núcleo). 
17. ANEXO 09

Foto: Isabela da Silva Müller.

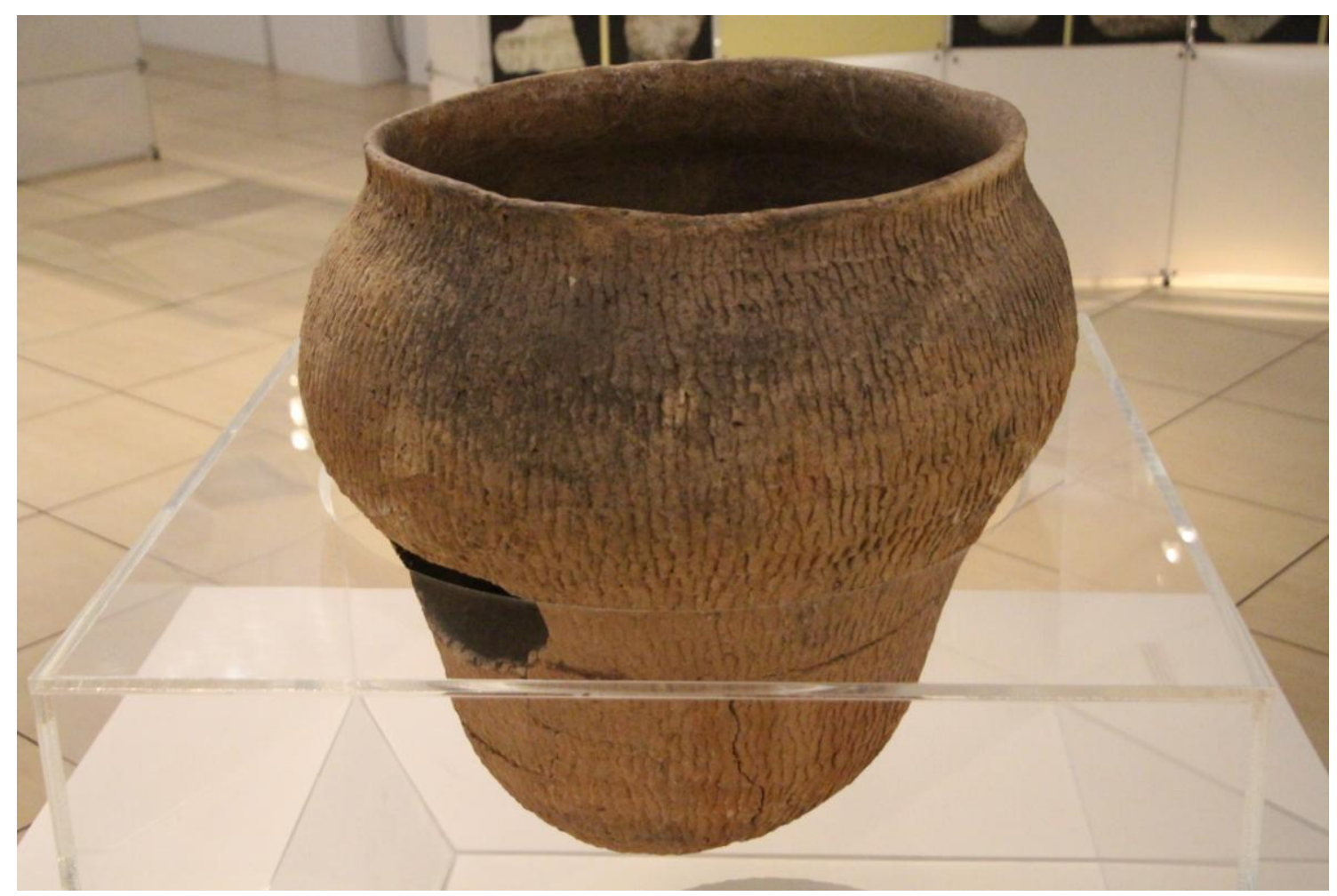

